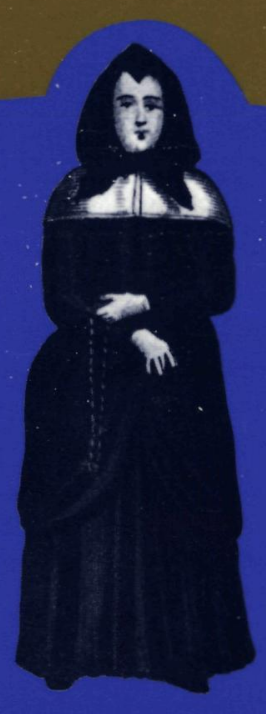

Leven tussen klooster en wereld

Geestelijke maagden in Noord-Nederland

gedurende de zeventiende eeuw 

Geestelijke maagden

Leven tussen klooster en wereld in Noord-Nederland gedurende de zeventiende eeuw 



\title{
Geestelijke maagden \\ Leven tussen klooster en wereld in Noord-Nederland gedurende de zeventiende eeuw
}

Een wetenschappelijke proeve op het gebied van de Letteren

\author{
Proefschrift \\ ter verkrijging van de graad van doctor aan de \\ Katholieke Universiteit Nijmegen, \\ volgens besluit van het College van Decanen \\ in het openbaar te verdedigen op donderdag 30 mei 1996, \\ des namiddags om 3.30 uur precies \\ door \\ MARIT EDIN MONTEIRO \\ geboren te Eibergen
}

Hilversum

Verloren

1996 


\section{Promotores:}

prof. dr. M.G. Spiertz

prof. dr. W.H.M. Jansen

Co-promotor:

dr. A.E.M. Janssen

Leden van de manuscriptcommissie:

prof. dr. P.J.A.N. Rietbergen

dr. J.E.J.M. van Heijst (Theologische Faculteit Tilburg)

prof. dr. P.G.J.M. Raedts

prof. dr. P.J.A. Nissen (Katholieke Universiteit Brabant) 
A word is dead

When it is said,

Some say.

I say it just

Begins to live

That day.

Emily Dickinson 
De publikatie is tot stand gekomen mede dankzij financiele steun van onder meer de Stıchtıng Vobıs, de Radboudstichting, de Mr. Paul de Gruyter Stıchting en het Nuyensfonds.

Afbeelding omslag: Prent van J. de Man, perkament, ingekleurd, ca 1670-1690 Museum Cathanjneconvent, Utrecht (sıgn OKM dp1004I)

Dit proefschrift heeft geen eigen ISBN

het ISBN van de handelseditie 1s: 90-6550-535-0

(C) Uitgever) Verloren, Larenseweg 123, 1221 CL Hilversum tel. $035-6859856$ fax 035-6836557

Omslagontwerp Het Lab / Josée Langen, Arnhem

Typografie Rombus, Hilversum

Druk Wilco, Amersfoort

Brochage Meeuwis, Amsterdam

No part of this book may be reproduced in any form wnthout wntten permisston from the publesher 


\section{Inhoud}

Voorwoord

I Geestelijke maagden verbeeld

Tradities en perspectieven van historisch onderzoek

13

I.I Gemankeerde kloosterlingen of aktieve religieuzen is

Continuïteit in religieuze gedrevenheid 18

Maagdelijkheid en macht $\quad 22$

$\begin{array}{ll}\text { I.2 Religieuze vrouwen } & 24\end{array}$

$\begin{array}{ll}\text { Motieven } & 27\end{array}$

Aanspraak op religieuze status $\quad 29$

Geestelijke personen $\quad 32$

I.3 Religie en sekse in vrouwengeschiedenis van de vroegmodeme tijd 36

'Histoire religieuse' $\quad 37$

Sekse als analysecategorie $\quad 39$

I.4 Probleemstelling en onderzoeksvragen 4I

Identiteitsconstructies $\quad 4$ I

Reformatie en Contrareformatie $\quad 44$

I.5 Bronnen en opzet van deze studie 46

II Dienaressen in de wijngaard des Heren 49

II. I 'Swermen cloppen': aantal en spreiding 51

II.2 'Kloppennesten' en andere woonvormen $\quad 56$

Vergaderingen $\quad 58$

Kleinschalige woonvormen $\quad 60$

Zelfstandig of bij familie $\quad 62$

II.3 Andere organisatievormen 65

Broederschappen 65

Wereldlijke derde orde $\quad 68$

Congregaties $\quad 73$

II.4 Herstel en wederopbouw van de katholieke infrastructuur 75

$\begin{array}{ll}\text { Materiële bijdragen } & 75\end{array}$

Immateriële bijdragen $\quad \mathbf{8 2}$

Betaalde arbeid en liefdewerken $\quad \mathbf{8 2}$ 
$\begin{array}{ll}\text { Zorgtaken } & 86\end{array}$

Onderwijs in de beginselen van het katholieke geloof 88

Gewoon onderwijs 95

II.5 Kloppen als culturele intermediairs 99

$\begin{array}{ll}\text { Confessionalisering } & 103\end{array}$

Informele intermediairs van vrouwelijke kunne 107

II.6 Spanningen in de zielzorg $\quad$ IO9

Trouw aan de parochie $\quad$ IIo

Jansenisme en anti-jansenisme $\quad$ II3

$\begin{array}{ll}\text { Kloppen en rekatholisering } & \text { II } 7\end{array}$

$\begin{array}{ll}\text { II.7 Conclusie } & \text { I20 }\end{array}$

III 'Een waerachtigen staet'?

Geestelijken over de kloppenstaat $\quad$ I22

III. I Kloppenboeken: genre en beperkingen voor onderzoek 123

$\begin{array}{ll}\text { Onderrichtingsboeken en vitae } & 126\end{array}$

$\begin{array}{lr}\text { Aantal, formaat en oplagen } & 128\end{array}$

$\begin{array}{lr}\text { Auteurs } & 132\end{array}$

III.2 Lectuur van geestelijke maagden 133

$\begin{array}{lr}\text { Functie van het lezen } & \text { I34 }\end{array}$

Aanbevolen lectuur $\quad 136$

Wat geestelijke maagden lazen $\quad$ I38

III.3 Geen 'echte' religieuzen I43

$\begin{array}{ll}\text { Staat of geen staat } & \text { I44 }\end{array}$

Buiten mededinging 150

Eeuwig de Zijne? 153

Man noch muur $\quad 155$

III.4 In de wereld, maar niet van de wereld $\quad$ I57

$\begin{array}{ll}\text { Vroeg-christelijk voorbeeld } & 158\end{array}$

Poel des verderfs $\quad$ I59

$\begin{array}{ll}\text { Zelfheiliging in de wereld } & \mathbf{1 6 2}\end{array}$

$\begin{array}{lll}\text { III.5 Vrouwelijke identiteiten } & \text { I67 }\end{array}$

$\begin{array}{ll}\text { Haar plaats weten } & \text { I67 }\end{array}$

Manhaftige maagden $\quad$ I7I

$\begin{array}{lr}\text { Christus' bruiden } & 172\end{array}$

$\begin{array}{ll}\text { Maagdelijke moeders } & 175\end{array}$

III.6 Geestelijke dochters en hun 'vaders' $\quad$ I77

$\begin{array}{ll}\text { Vaders met twee gezichten } & 178\end{array}$

Gods rechtmatige plaatsvervanger $\quad$ I80

$\begin{array}{ll}\text { Overwicht in onderdanigheid } & 184\end{array}$

$\begin{array}{ll}\text { III.7 Identiteit in vroomheid } & \text { I87 }\end{array}$ 
Religieus regime $\quad$ I88

Sacramentele vroomheid $\quad 192$

Penitentiële vroomheid $\quad 196$

Spirituele voorhoede $\quad 199$

$\begin{array}{lll}\text { III.8 Conclusie } & \text { 20I }\end{array}$

IV Geestelijke maagden aan het woord

Gewetensrekeningen als bron voor onderzoek 205

$\begin{array}{ll}\text { IV.I Bezielde vrouwen } & 208\end{array}$

Agnes van Heilsbach (1597-1640) 208

Joanna van Randenraedt (I6ro-1684) 216

$\begin{array}{ll}\text { IV.2 Lotgevallen van de egodocumenten } & 226\end{array}$

Bouwstenen voor een vita $\quad \mathbf{2 2 8}$

Kronieken van 'inwendige gesteldheid' 234

$\begin{array}{ll}\text { IV.3 Zelfportretten volgens bestaande patronen? } & 238\end{array}$

Gewetensonderzoek in theorie $\quad 239$

Gewetensonderzoek in praktijk $\quad 24 \mathrm{I}$

$\begin{array}{ll}\text { IV.4 Tong en pen hoeden } & 244\end{array}$

Weerspannige schrijfsters $\quad \mathbf{2 4 5}$

Schrijven in opdracht $\quad \mathbf{2 4 7}$

IV.5 Kwetsbaar voor de duivel, ontvankelijk voor God 250

Gemakkelijke prooi 25I

Vertrouwd met God 253

Grondslagen voor profetisch gezag 255

IV.6 Weerstanden en dilemma's $\quad 259$

'Vrauwe fantasien' 260

Onverenigbare eisen $\quad \mathbf{2 6 2}$

Retorische oplossingen 265

IV.7 Vrouwenstemmen met goddelijke macht versterkt 270

Onderhandelen $\quad 271$

Bondgenoten $\quad 273$

$\begin{array}{ll}\text { IV.8 Conclusie } & 275\end{array}$

V Godsvrucht en gezag buiten kloostermuren $\quad 279$

V.I 'Onsen minsten staedt'

Geestelijk zelfverstaan $\quad \mathbf{2 8 2}$

'Jezuitinnen' $\quad 284$

Ambivalenties $\quad \mathbf{2 8 8}$

V.2 Geestelijke vaders en moeders $\quad 293$

Geestelijk moederschap $\quad 293$

Gezagsverhoudingen $\quad 295$ 
Vertrouwelingen 30I

$\begin{array}{ll}\text { Taken } & 302\end{array}$

V.3 Moeders en maagden $\quad 305$

$\begin{array}{ll}\text { Vorming } & 306\end{array}$

$\begin{array}{ll}\text { Religieuze vrouwencultuur } & 310\end{array}$

$\begin{array}{lll}\text { V.4 God dienen buiten het klooster } & 3 \text { I4 }\end{array}$

$\begin{array}{ll}\text { Bidden en werken } & 314\end{array}$

$\begin{array}{ll}\text { Loopbaan in goede werken } & 317\end{array}$

Grenzen aan werkzaamheid $\quad 321$

V.5 Lijden en liethebben $\quad 324$

$\begin{array}{ll}\text { Lijdende bruiden } & 325\end{array}$

'Bose natuer' 330

Kostbaarste schat $\quad 333$

$\begin{array}{lll}\text { V.6 Conclusie } & 338\end{array}$

VI Slotbeschouwing $\quad 342$

Bijlagen

I Visitatierapporten I69I-I695 35I

II Lijst van kloppenboeken (I570-1730) 355

III Biogrammen van de auteurs van kloppenboeken $\quad 36 I$

IV Overzicht van de handschriften van Joanna van Randenraedt $\quad 367$

V Overzicht van de handschriften van Agnes van Heilsbach 372

Bronnen en literatuur

Archieven $\quad 373$

$\begin{array}{ll}\text { Gedrukte bronnen en literatuur } & 375\end{array}$

Herkomst van de afbeeldingen $\quad 398$

Summary 400

$\begin{array}{ll}\text { Personenregister } & 409\end{array}$

$\begin{array}{ll}\text { Over de auteur } & 416\end{array}$ 


\section{Voorwoord}

Onder de titel Roeping buiten kloostermuren ging het onderzoeksproject, waarvan deze dissertatie de neerslag vormt, in 1990 van start. Gaandeweg het onderzoek bleek het begrip roeping niet alleen toepasselijk voor geestelijke maagden, de hoofdpersonen van dit boek, maar ook voor de auteur. Wie in de huidige wetenschappelijke conjunctuur aan een promotie-onderzoek in de geesteswetenschappen begint, moet zich waarlijk geroepen voelen. Hoewel soms twijfel aan die roeping rees, behield fascinatie voor het onderwerp van dit onderzoek de overhand, zeker toen ik egodocumenten van twee geestelijke maagden op het spoor kwam. Die vondst betekende een keerpunt en heeft ertoe bijgedragen dat deze studie haar huidige vorm heeft gekregen.

Tijdens alle fases van het onderzoek heb ik mij gesteund en gestimuleerd geweten door een netwerk van deskundigen op allerlei terreinen. Mijn dank geldt in de eerste plaats de promotores, Mathieu Spiertz en Willy Jansen, en de co-promotor, Toon Janssen. $\mathrm{Zij}$ hebben het onderzoek toegewijd en nauwgezet begeleid. Het schrijfproces, dat een haast kloosterlijke afzondering vergde, werd verlicht door het leerzame en inspirerende overleg dat wij op gezette tijden voerden over het boek in wording. Ann Matter (University of Pennsylvania), Anne Schutte en Alison Weber (University of Virginia) hebben de conceptversie van hoofdstuk IV en $\mathrm{V}$ becommentarieerd. Hun opbouwende kritiek heeft mijn gedachtenvorming over autobiografische geschriften van religieuze vrouwen in een stroomversnelling gebracht. Gian Ackermans, Theo Clemens, Agnes Sneller en Gerrit Vanden Bosch ben ik dankbaar voor de zorgvuldigheid waarmee zij (delen van) het manuscript gelezen en van commentaar hebben voorzien. Wil Faessen en Onno Boonstra hebben zich over het cijfermatige deel van het onderzoek gebogen en mij voor onnauwkeurigheden behoed.

Zeer erkentelijk ben ik de archivarissen van verschillende provinciale ordearchieven: pater R. Andela O.F.M., pater W. Bronkhorst O.P., pater Ch. Donker C.ss.R., pater H. Lansinck O.Carm., pater A.K. de Meijer O.S.A. en pater Th. van Eijck S.J.. Aan hun gastvrijheid en belangstelling voor mijn vorderingen bewaar ik bijzondere herinneringen. Ook de medewerkers van de afdeling Kerkelijke Collecties van de Bibliotheek van de Rijksuniversiteit Utrecht, van de Jezuïetencollectie van de Bibliotheek van de Rijksuniversiteit Limburg te Maastricht, en van de Jezuietenbibliotheek Berchmanianum te Nijmegen dank ik voor hun ondersteuning. De bibliothecaris van klooster Soeterbeeck te Deursen, zuster Imelda, gaf bereidwillig enkele zeldzame boeken in bruikleen, die via $R$. van Dijk van het 
Titus Brandsma-Instituut tijdelijk onderdak vonden bij de Bibliotheek van de Katholieke Universiteit Nijmegen. In laatstgenoemde bibliotheek heb ik misschien wel het merendeel van mijn onderzoekstijd doorgebracht en de medewerkers ervan, die onvermoeibaar talloze boeken en tijdschriften gehaald, gebracht en gereserveerd hebben, komt veel dank toe.

Bij de speurtocht naar speciaal voor geestelijke maagden geschreven boeken was M. de Vroede (Katholieke Universiteit Leuven) zeer behulpzaam. In de fase voorafgaand aan het 'echte' schrijven heb ik veel gehad aan gesprekken met Leny van Lieshout en Maria Grever. Anton Schuttelaars deelde ruimhartig zijn kamer en computer met mij, toen ik als wachtgelder in institutioneel opzicht dakloos geworden was. Trees Hesen was de spreekwoordelijke rots in de branding en heeft voorbeeldig gepast op duplicaten van onderzoeksmateriaal, die omwille van de 'risicospreiding' elders ondergebracht moesten worden. Els Peters gaf literatuurverwijzingen op maat. Enkele ingewikkelde taalkundige problemen in de bronnen werden door Geert Dibbets verhelderd. Met een aanstekelijk enthousiasme spoorde Evelyne Verheggen afbeeldingen van kloppen op, die voor een deel in dit boek opgenomen konden worden.

Inhoudelijke en minder inhoudelijke onderzoeksperikelen heb ik de afgelopen jaren kunnen delen met enkele collega's en vrienden. Terwijl wij werkten aan andere boeken kwam het onderwerp 'proefschrift' onveranderlijk ter sprake. Menig idee werd zo geboren, menig probleem opgelost. Gerard Rooijakkers, Joost Rosendaal, Mirjam de Baar en Agnes Sneller dank ik hartelijk voor hun betrokkenheid en steun, die in vorm varieerde van waardevolle literatuur- of bronverwijzingen tot prikkelende gedachtenwisselingen. Op de wijsheid van Gian Ackermans kon ik altijd een beroep doen en dat was een geruststellende gedachte. Gesprekken over onze wederzijdse onderzoeken hebben de wording van dit boek beïnvloed. Mijn bijzondere dank gaat uit naar Marjet Derks en José Eijt. Dankzij hen is mijn denken over de betekenis van religie voor vrouwen verdiept. $Z \mathrm{ij}$ hebben bovendien intens meegeleefd, mij aangevuurd, moed ingesproken en mij met raad en daad terzijde gestaan.

Familie en vrienden hebben ervoor gezorgd dat mijn passie voor dit onderzoek in balans is gebleven met wat het leven verder nog te bieden heeft. Tino Monteiro en Ellen Monteiro-Jansen hebben er nooit aan getwijfeld dat dit boek er zou komen. De ontroerende en intrigerende verhalen van Theresia Monteiro-Sajowetz hebben mijn belangstelling voor andere tijdvakken en onderwerpen levend gehouden. Jolanda Jansen voelde feilloos aan wanneer het weer eens tijd was voor een stevige wandeling of een avondje uit. De 'Italian connection' Rob Roddeman bleef ondanks afstand betrokken en installeerde of repareerde 'hardware' en 'software' wanneer hij in het land was. Jeroen Wienk timmerde het bureau waaraan dit boek tot stand is gekomen. $\mathrm{Zijn}$ onverwoestbare optimisme werkte vaak louterend. Iris Monteiro wist als geen ander hoe zij mij kon steunen en bemoedigen. Meest van allen dank ik Wil Faessen - voor rust en ruimte, voor alle liefde en zorg. 


\section{I \\ Geestelijke maagden verbeeld \\ Tradities en perspectieven van historisch onderzoek}

Op 2 februari 1682, het feest van Maria Lichtmis, vierde Clara Adolfs, I 9 jaar oud, haar geestelijke bruiloft. Bij binnenkomst in de schuilkerk van de augustijnen te Amsterdam aan de Oudezijds Achterburgwal, boven de brouwerij de Burcht, werd zij geflankeerd door de geestelijke maagden Maria Hartman en Maria Boede. De plechtigheid werd geleid door de priester Joannes Uuten Eeckhout. In het bijzijn van de ouders van de geestelijke maagd in spe voltrok hij de inkleding, het ritueel dat Clara van lekevrouw in geestelijke maagd zou veranderen. $\mathrm{Zij}$ ontving bij die gelegenheid een scapulier, sluier, gordel, kroon en ring, die door de priester gezegend waren. Deze attributen symboliseerden kuisheid en verbondenheid met de hemelse Bruidegom. Als Diens aardse plaatsvervanger schoof Uuten Eeckhout haar de ring om de vinger. Clara Adolfs was daarmee een bruid van Christus geworden.'

Anders dan de andere bruiden van Christus, vrouwelijke religieuzen, trokken geestelijke maagden zich niet terug achter kloostermuren. Ongehuwde vrouwen, maar ook weduwen voelden zich tot deze leefwijze aangetrokken. Zij bleven in de wereld die hun, nu ze onvoorwaardelijk hadden gekozen voor het geestelijke leven, onverschillig behoorde te laten.

't $\mathrm{Sijn}$ Gods weldaden di de siele so verheugd

waer bij niet komt te pas al werelts idel vreugd

gedenkt wat God hier geeft, wat loon voor eeuwig spaart

di dit wel inziet, heeft een Hemel op der aardt',

zo dichtte een onbekende amateur-poëet in 1684 ter gelegenheid van een andere geestelijke bruiloft. ${ }^{2}$ Wie aardse genoegens versmaadde, wachtte de vereniging met de hemelse Bruidegom en eeuwige zaligheid in het hiernamaals. Geestelijke maagden behoorden voor de wereld als 'gestorven' te zijn. De donkere, sobere kleding zonder opsmuk die zij droegen, herinnerde hieraan.

Hun ongehuwd religieus bestaan was niet geformaliseerd door de plechtige geloften van armoede, gehoorzaamheid en kuisheid die kloosterlingen aflegden. In de namen die voor deze vrouwen in zwang waren, zijn de elementen maagdelijkheid en vroomheid nadrukkelijk vertegenwoordigd. Benamingen als 'geestelijke maagden'

I PA OSA, De Star, 235. De beschrijving van de ceremonie is gedeeltelijk ontleend aan Stevins, Regel, 87-92.

2 An., 'Lofdicht ter eeren vande Eerbare Deuchtrijke Dochter Jufrou Iacoba van Schuylenborg, op t'aenvaarden van haar Geestelijken Staet den 5 februari 1684', in: RAU, $A O B C$, inv.nr. 1360, Pamfletten en strijdschriften tusschen seculieren en regulieren (I602-1809). Hierbij een nagekomen pak gelegenheidsgedichten voor kerkelijke en wereldlijke personen (I630-1726). 
of 'geestelıke dochters' en hun Latınnse equivalenten 'virgines spintuales', 'filıe spirituales' of 'filiae devotae', die door de clerus werden gebezigd, spreken voor zıch. Weduwen die hun leven voortaan aan God wijdden, werden soms geestelıjke weduwe genoemd, soms ook eenvoudıgweg geestelıjke dochter, klop of kwezel ${ }^{3}$ De begrippen 'kloppen' of 'klopjes' verwijzen vermoedelık eveneens naar maagdelıkhe1d. Het werkwoord 'kloppen' houdt mogelı)k verband met besnıden of castreren; vrouwen die ut godsdienstige overtuiging kuis leefden, 'besneden' zichzelf omwille van het rijk der hemelen en zouden daarom kloppen genoemd worden. ${ }^{4}$ De Rotterdamse pnester Joannes van Heumen leidde 'klopkens' af van 'kloppers', een naam die soms aan novicen werd gegeven die in een klooster wilden intreden. In zijn zesdelige boek Clooster van Sion (I662-I666) noemt hij kloppen ook novicen, namelık voor de geestelı)ke staat in de wereld. ${ }^{5}$ In protestantse knng werd wel de draak gestoken met het begnip klopje ' $O$ ' wat leelıcken naem is dat, klopje', aldus de zeventiende-eeuwse veelschnjver en felle ant1-katholiek Simon de Vries. Mogelı1k inspireerde een van zijn nichten, die klop was, hem tot de anekdote waann De Vnes een geestelijke maagd zelf de oorsprong van het begrip klopje laat verklaren ' om dat wy voor een verkeerde deur klopten' ${ }^{6}$ Volksetymologisch wordt 'kloppen' steevast in verband gebracht met éen van de taken die geestelijke maagden voor hun rekening namen. Na de Reformatre, toen de katholieke eredienst in de Noordelıjke Nederlanden van overheidswege verboden was, waarschuwden geestelı)ke maagden gelovigen voor geheime godsdienstoefeningen door te kloppen op hun deur. Dat hun naam hiervan afgeleıd is, li)kt evenwel onwaarschınlık, want de naam 'kloppen' bestond reeds voór de Reformatıe ?

In de Generaliteitslanden en de Zuıdelı)ke Nederlanden werden geestelı)ke maagden vaak ' $k w e z e l$ ' genoemd ${ }^{8}$ Aanvankelıjk betekende dit woord zoveel als 'vrome vrouw', maar gaandeweg de zeventiende en achttıende eeuw werd het steeds meer een spotnaam voor degenen die in de ogen van hun omgeving overdreven godsdienstig, bigot of zelfs schinnheilig waren. ${ }^{9}$ De anoneme vertaler van de van oorsprong Franstalige levensbeschrijving van Mana Anna du Val de Dampierre verkoos in 1697 bijvoorbeeld 'Quesel' als vertaling voor 'bigot' Behalve voor

3 Vgl De Vroede, 'Kwezels' en 'zusters', 23

4 Klıaen, Etymologrcum Teutonicae linguae (ongepagineerd, zle 'Klop-suster ( ) virgo quae se propter regnum caelorum castravi' Deze zinsnede verwilst naar Mat 19,12 Zie ook Theissing, Over klopjes, 36, Schulte van Kessel, Geest en vlees, 51

5 Van Heumen, Clooster van Sion, V, 'Voorreden' (ongepagineerd)

6 Cupıdo Hymenaeus, Klaer bewys dat alle ende een yder nootsakelick moet trouwen (Utrecht 1682) 17, geciteerd door Baggerman, Een drukkend gewucht, $7 \mathrm{I}$

7 Theissing, Over klopjes, 35-36

8 Voor andere namen die in de Zuidelıke Nederlanden un zwang waren, zie De Vroede, 'Kwezels' en 'zusters', 17

9 Janssens, 'Geestelıke dochters', 336-337, dateert deze ontwikkeling pas rond $1740 \mathrm{Vgl}$ De Vroede, 'Kwezels' en 'zusters', 17-18 Volgens het WNT komt 'kwezel' pas vanaf de negentiende eeuw in zwang voor mannen 
kwezel werd deze Maria Anna uitgemaakt voor 'kruyslijtster, (...) waskeersbrandster' en andere kwalificaties die weinig vleiend bedoeld waren. ${ }^{10} \mathrm{Zelfs}$ protestanten gebruikten 'klop' en 'kwezel' om dissenters of overdreven godvruchtige personen uit eigen gelederen te diskwalificeren. ${ }^{11}$ Voor de vrouwen in kwestie en geestelijken hadden deze namen gedurende de zeventiende eeuw nog geen negatieve bijklank, al gaven zij vaak de voorkeur aan benamingen als geestelijke maagd of geestelijke dochter..$^{12}$

Aangezien de katholieke kerk hun levenswijze niet als religieuze staat erkende, verkeerden tijdgenoten - geestelijken en leken, protestanten en katholieken - vaak in verwarring over de precieze hoedanigheid van geestelijke maagden. De ouders van Lucia Dingnum ( $†$ 1617) wilden bijvoorbeeld niet dat hun dochter geestelijke maagd zou worden, omdat ze nog nooit van die leefwijze hadden gehoord. ${ }^{13}$ Met de aanduiding 'middelen staet', een vroegmodem equivalent voor wat tegenwoordig 'semi-religieus' genoemd wordt, ${ }^{14}$ werd de positie van kloppen naast leken enerzijds en religieuzen anderzijds uitgedrukt. De onduidelijkheid rond hun status werd daarmee echter nog niet opgeheven.

Deze studie beoogt in kaart te brengen welke opvattingen geestelijken en geestelijke maagden huldigden over deze specifieke religieuze leefwijze in de wereld. Vorm en status hiervan lagen niet vast, maar waren voorwerp van onderhandeling tussen geestelijken onderling, alsook tussen hen en kloppen. Onderwerp van dit boek vormt de vraag naar de ontwikkeling van de religieuze identiteit van geestelijke maagden en de betekenis die daar door vrouwen zelf en door de clerus aan werd gehecht. Deze probleemstelling, die verderop in dit hoofdstuk nader wordt toegelicht, bouwt voort op eerder onderzoek naar geestelijke maagden.

\section{I.I Gemankeerde kloosterlingen of aktieve religieuzen}

Tot het verschijnen van de eerste monografie over geestelijke maagden in 1935 was de aandacht voor deze vrouwen in de Nederlandse geschiedschrijving frag-

10 L'Idée d'une vrerge chrestienne, 305: '(...) mangeuse de cructfix, brûleuse de cuerges, bigote, \& (. ) autres semblables noms injuneux'. Voor de Nederlandse vertaling zie Leven Mana Anna du Val de Dampierre, 283 .

II Van Lueburg, 'De recepue', I24; De Baar, “"Ik moet spreken"', 87-88.

12 Theissing, Over klopjes, 36-37 Schulte van Kessel, Geest en vlees, 5I, 201 (noot 1 en 2), idem, 'V1s noch vlees', 171 (noot 9).

13 Graaf, 'Levens', $B B H$ i8 (1893) I15-116.

14 Caussin, Leven Isabella, in. Jacobı, Spreghel der Maeghden Kloppen worden pas recent als sem1religieuzen benoemd, zie bi)voorbeeld Conrad, Zweschen Kloster und Welt, 16 (noot 40), Schulte van Kessel, 'Maagden en moeders', 148; Monteıro, 'Den middelen staet'. De Amenkaanse mediaeviste Carolıne Walker Bynum hanteert voor middeleeuwse religieuze vrouwen, onder wie de begiınen, het begrip 'quasi-religious', zie Fragmentation and redemption. 
mentarisch. Kloppen figureerden in missie-, statie- en visitatieverslagen die werden uitgegeven in drie diocesane periodieken, Bijdragen tot de Geschiedenis van het Bisdom Haarlem (1872-1957), Archief voor de Geschiedenis van het Bisdom Utrecht (1874-1957) en Bossche Bijdragen (1917/18-1970/71)..$^{\text {is }}$ Ook in uitgegeven protestantse kerkeraadshandelingen, plakkaten van gewestelijke overheden of de StatenGeneraal, resoluties van het Hof van Holland en stedelijke verordeningen kwamen zij voor. Deze bronnenuitgaven vormden op hun beurt weer bouwstenen voor publikaties over kloppen.

In hun beschrijving en karakterisering van geestelijke maagden zijn deze uitgegeven bronnen allerminst onproblematisch. $\mathrm{Zij}$ laten eerder iets zien van de beeldvorming over de kloppen dan over hen zelf. Worden zij in protestantse bronnen vaak afgeschilderd als onbeschaamde vrouwen die gereformeerde gelovigen lastig vielen en hun geloofskeuze ter discussie stelden, ${ }^{16}$ in katholieke bronnen staan ze te boek als toegewijde gelovigen die de clerus gewillig steunden. Gezagsdragers van de Nederduits-gereformeerde kerk bleven hameren op de in hun ogen subversieve activiteiten van kloppen, die een bedreiging vormden voor de nieuwe publieke kerk. ${ }^{17}$ Leden van de katholieke geestelijkheid daarentegen moesten in hun verslagen verantwoorden dat er vrouwen betrokken waren bij de zielzorg, die gewoonlijk uitsluitend aan geestelijken was toevertrouwd. Aan de diensten van de maagden mocht niet teveel ruchtbaarheid worden gegeven om verdenkingen ten aanzien van de omgang tussen hen en priesters te vermijien en de protestanten geen aanleiding te geven voor scherpe kritiek. ${ }^{\text {I }}$

In het spoor van de bronnen die tijdgenoten over geestelijke maagden nalieten, ontwikkelden historici verklaringen voor de ontwikkeling van deze kerkrechtelijk niet gefundeerde bestaansvorm, die niet alleen deze leefwijze moesten rechtvaardigen, maar ook de houding die de contemporaine geestelijkheid hier tegenover had ingenomen.${ }^{19}$ Het geschiedverhaal over de katholieke kerk in diaspora vormde hiertoe een bij uitstek geschikt interpretatiekader.

In $158 \mathrm{I}$ werd van overheidswege de katholieke eredienst in de Noordnederlandse gewesten verboden. Gewestelijke plakkaten en stedelijke verordeningen belemmerden priesters in hun ambtsuitoefening en katholieken in hun geloofsbeleving. ${ }^{20}$ Kloosters waren genoodzaakt hun poorten te sluiten of waren tot uitsterven ge-

15 Een karakterisering van deze diocesane periodieken wordt gegeven door Rogier, 'Over de beoefening'; vgl. Post, 'Inleiding', $A A U 75$ (1957) 5. Voor de betekenis van deze penodieken voor de geschiedschrijung over het Nederlands katholicisme, zie Janssen, 'Toewıding', 305-307.

I6 Bijvoorbeeld Van Eeghen, 'De eigendom', 269 (punt 4), geciteerd naar de acta van de kerkeraad van Amsterdam, 5 december 1656.

17 Theissing, Over klopjes, 190.

I8 Vgl. Schulte van Kessel, Geest en vlees, hoofdstuk 3; idem, 'Maagden en moeders', I49.

$19 \mathrm{Vgl}$. Bynum, 'The mysticism', 64 .

20 Een overzıcht van de belangrı)kste verordeningen per gewest biedt Knuttel, De toestand, I. VgI. Rogier, Geschedents, I, 458-460. 
doemd, nu zij geen novicen meer mochten aannemen. De bisschopszetel van het aartsbisdom Utrecht bleef vacant. De Heilige Stoel ging het gebied van de Republiek der Zeven Verenigde Provinciën steeds meer als missiegebied beschouwen. In 1592 werd Sasbout Vosmeer (1548-1614) tot apostolisch vicaris benoemd om in naam van de paus de kerkprovincie te besturen. Vanaf 1622 was de Congregatie van de Propaganda Fide, die ook andere missiegebieden bestuurde, belast met het kerkelijk bestuur van wat sindsdien de Hollandse Zending werd genoemd. ${ }^{21}$

Dit missiegebied kampte tot in het derde decennium van de zeventiende eeuw met een gebrek aan priesters, opgeleid volgens nieuwe, contrareformatorische idealen in de geest van het Concilie van Trente (1545-1563). De infrastructuur van de kerk was goeddeels weggevallen: geen eigen kerkgebouwen of kerkgoederen, gebrekkige voorzieningen op het gebied van geloofsonderwijs, armen- en ziekenzorg. In deze achterstandssituatie, die verscherpt werd door het groeiende besef dat het katholicisme zijn religieuze monopolie had verloren, waren kerk en clerus sterk aangewezen op de steun en inzet van geëngageerde leken. ${ }^{22}$ Tot deze kernleden van de katholieke kerk in diaspora behoorden de geestelijke maagden.

Uit de noodsituatie van de Noordnederlandse katholieke kerk, die hier slechts in zeer kort bestek geschetst kan worden, zijn twee verklaringen voor het ontstaan van de leefwijze van geestelijke maagden te destilleren. De eerste verklaring, door mij kortweg de 'Reformatie-these' genoemd, komt erop neer dat de sluiting van de kloosters tot gevolg had dat vrouwen met een religieuze roeping hun heil buiten de Republiek moesten zoeken, of een bestaansvorm buiten het klooster moesten vinden die plaats bood aan hun godsdienstige inspiratie en energie. Tijdgenoten zagen in de afschaffing van de kloosters al de kiem van het kloppenbestaan. De Franse oratoriaan Pasquier Quesnel (1634-1719), die op beschuldiging van jansenisme zijn vaderland geruime tijd voor de Republiek verruilde en enkele geestelijke maagden onder zijn hoede had, was bijvoorbeeld van oordeel dat het onderscheid tussen de religieuze staat ín en buiten het klooster uitsluitend werd bepaald door de heersende politiek-religieuze verhoudingen ${ }^{23}$ De seculiere priester Adrianus Terlou ( $\dagger$ I696) beschouwde een geestelijke maagd als een bloem, die 'niet elders tusschen de muuren van Clara, Theresia, \&c. maer op 't vlakke veld, op d'Aerde' stond.

'Een Bloemken op het Veldt

Word licht ter neer gevelt',

dichtte hij. ${ }^{24}$ Geestelijke maagden moesten het zonder de bescherming stellen die de volgelingen van Clara, de clarissen, of van Teresa van Avila, de ongeschoeide

2I Spiertz, 'Ambtelijk onbegrip', 6-10.

22 Idem, 'Godsdienstig leven', 348.

23 Tans, 'Van maagden en engelen', 266. Vgl. Theissing, Over klopjes, i3 en Petrus a Matre Dei, Clara Relatio, 89.

24 'Den vertaelder [Adrianus Terlou] aen de Geestelijke Maegden', in: Lindeborn, De Leeder facobs (ongepagineerd). 
karmelitessen, wel genoten. Het gedichtje schetst een scherp contrast tussen de fysieke omgeving binnen en buiten het klooster. De beschutting van het klooster wordt afgezet tegen het open veld dat risico's en gevaren representeert. Dit contrast krijgt door een typografische ingreep - het cursief zetten van de centrale begrippen - extra nadruk. Terlou was blijkbaar de mening toegedaan dat geestelijke maagden een ander religieus bestaan leidden dan kloosterzusters, een kwetsbaarder bestaan dat uit nood geboren was.

De tweede verklaring voor de oorsprong van het kloppenleven is te omschrijven als de 'recruteringsthese'. Sommige auteurs hebben er met nadruk op gewezen dat geestelijke maagden zich uitsluitend in opdracht en onder toezicht van geestelijken van allerlei taken in de zielzorg kweten. ${ }^{25}$ Met andere woorden, priesters mobiliseerden vrouwen, die zich vervolgens over zieken en armen ontfermden, kinderen de beginselen van het katholieke geloof bijbrachten, voor de schuilkerken zorgden, priesters onderdak verschaften en financiële middelen ter ondersteuning van de missiekerk foumeerden. Deze voorstelling van kloppen als gezeglijke helpsters van de clerus ligt, zoals gezegd, al besloten in vele bronnen van katholieke signatuur. De opstellers hiervan lijken te hebben willen onderstrepen dat bestaande hiërarchische verhoudingen tussen priesters en leken, tussen mannen en vrouwen, door de gewijzigde omstandigheden in de Noordnederlandse kerk niet aangetast werden. Waarschijnlijk omdat de latere bezorgers van de bronnen en geschiedschrijvers uit katholieke kring in de regel zelf tot de geestelijke stand behoorden, was het beeld van kloppen als trouwe assistentes zo'n lang leven beschoren. ${ }^{26}$ Geschiedschrijving over het Nederlands katholicisme was lange tijd een clericaal monopolie. En de bovengeschetste hiërarchische verhoudingen tussen de seksen, en tussen clerus en gelovigen, golden tot het interbellum nog onverkort.

Als heldinnen van de schuilkerken en als gehoorzame, maar daadkrachtige verdedigsters van het katholicisme, berokkenden de kloppen het bestaande beeld van de kerk in diaspora en haar gezagsdragers weinig schade. Aangezien zij ingepast werden in een vertoog van vervolging en overleving dat in historische studies over de geschiedenis van het Nederlands katholicisme domineerde, bleven andere mogelijke drijfveren onzichtbaar, totdat de eerste monografie over geestelijke maagden het licht zag.

\section{Continuiteit in religieuze gedrevenheid}

De historica Eugenie Theissing (1892-1970) doorbrak met haar proefschrift Over klopjes en kwezels het clericale monopolie van de geschiedschrijving over het Nederlands katholicisme door zich als vrouwelijke leek te verdiepen in de geestelijke maag-

25 Bijvoorbeeld Van Lommel, 'Pastoors der statie Oud-Ade', 306-307; Van der Loos, 'Kerkelijk Uitgeest', 206.

26 Vgl. Rogier, 'Over de beoefening', 19; Post, 'Inleiding', 5. 
den. Als eerste vrouw en derde student legde zij in 1927 het doctoraal examen in de geschiedenis af aan de in 1923 opgerichte Katholieke Universiteit te Nijmegen. ${ }^{27}$ In 1935 promoveerde zij op de genoemde dissertatie bij G.W. Kernkamp, hoogleraar Algemene en Vaderlandse Geschiedenis aan de Rijksuniversiteit te Utrecht.

Aangezien in de toenmalige historische praktijk weinig plaats ingeruimd was voor vrouwen als subject of object van onderzoek, ${ }^{28}$ dringt zich de vraag op waarom Theissing dit onderwerp voor haar proefschrift koos. Een uitvoerige historiografische analyse is hier niet op haar plaats en evenmin mag de suggestie gewekt worden dat deze vraag met zekerheid beantwoord kan worden. Wel kan vastgesteld worden dat deze studie over kloppen geen uitzondering was. Sinds het einde van de negentiende eeuw, in de context van de vrouwenbeweging van de eerste feministische golf, was er onder Nederlandse historicae een groeiende belangstelling voor religieuze vrouwen in al hun verschijningsvormen: begijnen, zusters van het gemene leven en vrouwelijke religieuzen. Ook de dissertatie van Theissing is een representant van deze historische interesse, waarvan de sporen lange tijd onzichtbaar zijn gebleven. ${ }^{29}$

Aan haar onderzoeksbelangstelling voor geestelijke maagden zou ook een meer persoonlijke reden ten grondslag gelegen kunnen hebben. Eugenie Theissing was lid van De Sleutelbos, een 'vriendschapsverbond' van alleenstaande katholieke academicae die ongehuwde vrouwen beschouwden als een 'derden vrouwenstand', naast gehuwde vrouwen en vrouwelijke religieuzen. ${ }^{3 \circ}$ Vertegenwoordigsters van deze specifieke 'vrouwenstand' onderscheidden zich door hun celibataire leefwijze en economische zelfstandigheid. Anders dan meer grootschalige en toonaangevende vrouwen- en meisjesorganisaties als de RK-Vrouwenbond of De Graal, definieerden de leden van De Sleutelbos de identiteit van de ongehuwde lekevrouw niet in termen van moederschap, geestelijk moederschap of volgens het model van de opofferingsgezinde, maar militante jonge vrouw die zich de bekering van de wereld ten doel stelde. ${ }^{31}$ Volgens hen moesten ongehuwde vrouwen zich, omwille van en in toewijding aan God, maatschappelijk kunnen ontplooien zonder enige religieuze geloften. De overeenkomst met de economisch zelfstandige geestelijke maagden, die de dienst aan God, hun naasten en de kerk als hun levensopgave zagen, is opmerkelijk. ${ }^{32}$

27 'Chronologische lyst', 57.

28 Grever, Stryd tegen de stilte.

29 Derks, e a., 'Res novae', 123-124; Grever, 'De kracht', 230-237.

30 Aerts, 'Op zoek naar konstrukties van vrouwel1,khe1d', 135. Vgl KDC, Archsef De Sleutelbos, inv.nr. 4. De Sleutelbos (1931-1949) was stichting noch vereniging, maar wilde een platform voor katholieke, ongehuwde, afgestudeerde vrouwen zıןn. Gemıddeld telde De Sleutelbos vıftien leden. Theissing bekleedde jarenlang de funcue van secretans

31 'Weet uw weg', II, 16. Aerts, 'Vrouwenstudies als nationaal ballet', 35-36 Vgl. Derks, “"Ik was altud mezelf', en idem en Van Heist, 'De kleur van vakantue en vorming'.

32 Vgl. Aerts, 'Vrouwenstudies als nationaal ballet', 37. 
Het proefschrift van Theissing concentreert zich op het kloppenbestaan in zijn geïnstitutionaliseerde vorm. Daarvoor beschikte zij dankzij de levensbeschrijvingen van de grootste en bekendste kloppengemeenschap in de Republiek, De Hoek te Haarlem, over vele gegevens. Eén van de Haarlemse maagden, Catharina (Trijn) Jans Oly (I585-165I), schreef levensberichten van haar geestelijke zusters die tussen I583 en I65I in De Hoek woonden. Haar handschriften werden tussen I89I en I913 tamelijk onoordeelkundig uitgegeven door J.J. Graaf, ${ }^{33}$ maar vormden niettemin een belangrijke informatiebron over kloppen voor verscheidene historici, onder wie Theissing. ${ }^{34}$

Anders dan andere historici besteedt zij niet enkel aandacht aan de betekenis van kloppen voor het instituut kerk en voor de overleving van het katholicisme, maar heeft zij ook oog voor de geestelijke maagden zelf en hun beweegredenen om een kerkelijk niet gesanctioneerd religieus bestaan te leiden. Natuurlijk vormden de staatkundige en socio-religieuze verhoudingen in de Republiek een belangrijke verklaring voor het ontstaan van wat zij noemde de klopjesstaat. ${ }^{35}$ Maar naar haar mening waren er meer factoren in het spel. Dat er in landen waar de reformatie niet ingevoerd was, naast kloosterlingen ook geestelijke maagden leefden, was daarvoor een belangrijke aanwijzing. ${ }^{36}$ Met deze constatering ontdeed Theissing de kloppen, bedoeld of onbedoeld, van het stempel van een typisch Noordnederlands fenomeen.

De kloppenstaat werd, zo betoogt Theissing, in de zeventiende eeuw gezien als een afzonderlijke religieuze bestaansvorm. Nonnen die ten gevolge van de Reformatie hun kloosters hadden moeten verlaten, zagen in deze leefwijze geen alternatief voor het kloosterleven. Dat verklaart waarom er tenminste in de eerste helft van de zeventiende eeuw in verschillende Noordnederlandse steden drie typen religieuze vrouwengemeenschappen naast elkaar bestonden, namelijk die van voormalige kloosterzusters, van begijnen en van kloppen. ${ }^{37}$ Voor het ontstaan van de kloppenstaat voert Theissing een nieuwe deelverklaring aan. Volgens haar had een zeker autonoom, religieus geïnspireerd streven vrouwen aangezet tot het leiden van een godgewijd leven buiten het klooster. En dit streven kon niet enkel uit de benarde positie van de kerk in de Noordelijke Nederlanden verklaard worden, want in voor de kerk gunstiger tijden hadden vrouwen eveneens gezocht naar andere bestaansvormen dan het klooster. 'Het [klopies]instituut was niets nieuws onder de zon. Altijd al zijn er vrouwen geweest, die in de wereld een meer conscientieus religieus leven hebben willen leiden. ${ }^{3{ }^{3}}$ De laat-middeleeuwse begijnen en zusters van het gemene leven zijn daar voorbeelden van. In leefwijze en (reli-

33 Rogier, 'De cultus van Sint Willibrord', 259 (noot 15); idem, 'Over de beoefening', 12.

34 Graaf, 'Levens'; idem, 'De "vergaderinghe"'.

35 Schulte van Kessel muntte later de omschrijving 'kloppenstaat', Geest en vlees, 62.

36 Theissing, Over klopjes, I3-I4.

37 Ibidem, 33.

38 Tbidem. 
gieuze) intentie vertonen vooral het begijnen- en het kloppenbestaan grote parallellen. Begijnen voorzagen zelf in hun onderhoud of leefden van eigen vermogen, net als kloppen. En vóór de instelling van begijnhoven in de veertiende eeuw leefden zij zelfstandig of in afzonderlijke begijnenhuizen, kleinschalige woonvormen die kloppen eveneens verkozen. ${ }^{39}$ Talrijke vrouwen, ongehuwde en weduwen, voelden zich volgens Theissing aangetrokken tot de kloppenstaat omdat zij deze konden aanpassen aan de eigen sociale en financiële mogelijkheden, alsook aan hun spirituele behoeften. ${ }^{40}$

Haar genuanceerde verklaringen voor de oorsprong van het kloppenbestaan ten spijt, valt het beeld dat Theissing schetst van kloppen nog grotendeels samen met de zeventiende-eeuwse clericale opvattingen die in veel bronnen vervat liggen: volgzame, vrome vrouwen voor wie het behoud van het katholieke geloof boven alles ging. In dat opzicht staat deze historica nadrukkelijk in de traditie van de schuilkerkmentaliteit die geschiedschrijvers vermoedelijk meer beinvloed heeft dan zeventiende-eeuwse katholieken zelf..$^{4 \mathrm{I}}$ Ook zij benadrukt dat geestelijke maagden bij de uitoefening van hun taken voortdurend onder supervisie van mannelijke geestelijken stonden. Degenen die zich niet in gehoorzaamheid en nederigheid onderwierpen aan het clericale gezag, waren laakbaar, zo lijkt Theissing de door zeventiende-eeuwse geestelijken en latere geschiedschrijvers gehuldigde opvattingen onderschreven te hebben. Wél heeft zij oog voor de onduidelijke positie waarin zowel de clerus als de geestelijke maagden zich bevonden in de Hollandse Zending. Onderlinge gezagsverhoudingen werden hier ontegenzeglijk door beïnvloed..$^{42}$

Over het algemeen werd het proefschrift van Theissing beschouwd als een belangrijke bijdrage aan de geschiedenis van het katholicisme in Nederland. ${ }^{43}$ Dat zij evenwel het ontstaan van de kloppenstaat in verband bracht met het begijnenwezen en een continuiteit in religieuze ambities en behoeften van sommige vrouwen aannemelijk maakte, heeft onder latere historici nauwelijks ingang gevonden. Alleen F. van Hoeck S.J. wijst in navolging van Theissing een eenzijdig verband af tussen de Reformatie en het ontstaan van de kloppenstaat. ${ }^{44}$ Anderen benadrukken juist de afschaffing van de kloosters als verklaring. Cornelia W. Roldanus noemt de kloppenstaat 'het eigenaardig hulpinstituut van de kerk' dat 'bij het ontbreken van kloosters' was ontstaan. ${ }^{45}$ L.J. Rogier ziet in de 'spontaan-gegroeide

39 Ibıdem, 5. Ceyssens, 'De congregatie', 12-13, had reeds gewezen op overeenkomsten tussen begijnen en geestelijke maagden.

40 Theissing, Over klopjes, 64-65.

41 Vgl. Fnhhoff, 'De Noordnederlandse oratonanen', 210; zıe ook Dudok van Heel, 'Amsterdamse schuil- of huiskerken?', 6-10.

42 Theissing, Over klopjes, 157-I60.

43 Besprekungen met een overwegend positieve strekking verschenen van de hand van Post, 'Overzicht', [18]-[19]; Van Merlo, recensıe, De B. [M.G. de Boer], 'Een bıjdrage', die Theissing consequent aanduidt met Theissen; Lambermond, recensie.

44 Schets, 165.

45 Zeventrende-eeuruse geestesbloei, 33. 
klopjesgemeenschappen' 'de voornaamste toevlucht van de te allen tijde in een goed-katholieke gemeenschap talrijke kloosterroepingen onder de jongere vrouwen'. De 'staat van klopjes' bood het grote aantal godvruchtige vrouwen zonder religieus emplooi een 'naar's tijds gelegenheid vereenvoudigde en in practische richting omgebogen' religieuze levenswijze. ${ }^{46}$ 'Wie in het vaderland zelf een Godgewijd bestaan wilde leiden, was op het merkwaardig instituut der klopies aangewezen', aldus Pontianus Polman O.F.M.47 Theissings bevinding dat sommige vrouwen andere religieuze bestaanswijzen dan het kloosterleven ambieerden, werd ingepast in een reeds bestaand geschiedverhaal van de ontwikkelingsgang van het Nederlands katholicisme. Hierin zijn vervolging, schuilkerken en strijd om geloofsbehoud kembegrippen en worden geestelijke maagden afgeschilderd als gemankeerde kloosterlingen. Een visie die ook in meer recente studies soms nog weerklinkt. ${ }^{8}$

Doordat Theissing vooral steunde op de levens van de maagden van de Haarlemse kloppenvergadering De Hoek, zijn die geestelijke maagden die zelfstandig leefden en werkten, in haar proefschrift onderbelicht gebleven. Uit haar studie blı)kt dat dagelijks leven, spiritualiteit, werkzaamheden en verhoudingen tussen vrouwen onderling en ten opzichte van geestelijken, strak geregeld waren binnen een dergelijke gemeenschap. Hoe kloppen die buiten een dergelijke vergadering leefden hun bestaan vormgaven, is nog onvoldoende onderzocht.

\section{Maagdelijkheid en macht}

Bijna een halve eeuw na het verschijnen van de dissertatie van Eugenie Theissing heeft Elisja Schulte van Kessel de geestelijke maagden aan een hernieuwd onderzoek onderworpen. In twee artikelen in haar proefschrift Geest en vlees in godsdienst en wetenschap. Vijf opstellen over gezagsconflucten in de I7de eeuw (1980) nuanceert zij de voorstelling van kloppen als gezagsgetrouwe vrouwen. ${ }^{49} \mathrm{Zij}$ betoogt dat de kloppenstaat vrouwen een betekenisvol alternatief bood, in het bijzonder voor het huwelijk. Dankzij deze bestaansvorm konden vrouwen ontsnappen aan de ondergeschikte positie die hun binnen de kerk onder verwijzing naar de scheppingsorde was toebedeeld. Een biografische studie van twee geestelijke maagden, Wenina en Agatha van Heussen, illustreert het bevrijdende karakter van de maagdelijke levensstaat. Hoe omstreden het kloppenbestaan was, blijkt uit de analyse van de rol die kloppen hadden en toebedeeld kregen in de competentiestrijd tussen secu-

46 Rogrer, Geschredents, II, 368-369. Z1e ook Van der Loos, Vaderlandsche kerkgeschiedenis, II, 153-I 54 en Nubel, Mittelalterlache Beginen- und Sozialstedlungen, 295 (noot 504)

47 Katholiek Nederland, I, II I.

48 Zie bujoorbeeld Van Eck, Kunst, twust en devotre, 64-65.

49 Hoofdstuk $\amalg$, 50-88, een herziene versie van Van Kessel-Schulte, 'Wenuna en Agatha van Heussen'; hoofdstuk III, 90-115, eerder verschenen onder de tutel 'Le verginı devote' en in bewerkte vorm later verschenen als ' $V$ is noch vlees'. 
liere en reguliere geestelijken gedurende de zeventiende eeuw in de Hollandse Zending. Evenals Theissing onderkent Schulte van Kessel dat, gezien de buitenlandse parallellen in semi-religieuze bestaansvormen, een eenzijdige causale relatie tussen de Reformatie en de oorsprong van de kloppenstaat onhoudbaar is..$^{\text {so }}$

Schulte van Kessel maakt onderscheid tussen zelfstandige kloppen en geestelijke maagden die deel uitmaakten van een wereldlijke derde orde of een kloppengemeenschap. ${ }^{51}$ Daarnaast scherpt zij door te spreken over 'wereldkloppen' en 'paterskloppen' een soort tweedeling onder geestelijke maagden aan, die berustte op hun loyaliteit aan respectievelijk seculiere en reguliere geestelijken, een verbondenheid die te herleiden was tot verschillende spirituele oriëntaties onder de geestelijkheid..$^{52}$ Door hun lidmaatschap van een wereldlijke derde orde voelden paterskloppen zich vermoedelijk nauw verwant met kloosterzusters. Op grond daarvan zouden zij zich, zo oppert Schulte van Kessel, misschien verheven hebben gevoeld boven de seculiere kloppen, die niet bij een groter religicus verband waren aangesloten. ${ }^{33} \mathrm{Zij}$ vermoedt dat de laatstgenoemden, door haar 'vrije maagden' genoemd, juist belangrijk zijn geweest voor de zielzorg. ${ }^{54}$ Haar eigen studie naar de gezusters Van Heussen, die niet bij een kloppengemeenschap of derde orde waren aangesloten, is helaas weinig illustratief voor die stelling. De bijdrage van Wenina en Agatha van Heussen aan de zielzorg was vooral financieel van aard en vormt een schril contrast met de praktische hand- en spandiensten die andere geestelijke dochters leverden.5s

Sociale en economische verschillen tussen kloppen waren wezenlijk voor de mate en de vorm waarin zij kerk en clerus tot steun konden zijn, aldus Schulte van Kessel. Deze bevinding ontkracht de idee die impliciet uit de studie van Theissing spreekt, dat de kloppenstaat bestaande ongelijkheid in stand en economische positie zou hebben geneutraliseerd en dat bestaande sociale, hiërarchische verhoudingen onder kloppen aan betekenis ingeboet zouden hebben ten gunste van nieuwe rangorden die steunden op andere indicatoren zoals godvruchtigheid of nederigheid. ${ }^{56} \mathrm{Hun}$ financiële draagkracht en nuttige connecties maakten kloppen aantrekkelijk voor de clerus. Meningsverschillen en klachten van geestelijken aangaande de kloppen vonden vaak hun oorsprong in onderlinge wedijver naar de gunst van deze vrouwen. Bovendien kunnen deze strubbelingen niet los gezien worden van de langdurige en telkens weer oplaaiende competentiestrijd tussen de reguliere en seculiere geestelijkheid, die zijn oorsprong onder andere vond in het al dan niet

50 Zie ook Schulte van Kessel, 'Gender and spirit', 49.

51 Idem, Geest en vlees, 52, 57-58.

52 Vgl. Rogier, Geschiedenis, II, 776. Polman, Katholiek Nederland, I, I I5.

53 Schulte van Kessel, Geest en vlees, 104-105.

54 Ibidem, 58.

55 Ibidem, 74.

56 Vgl. Liebowitz, 'Virgins', 135, voor de idee van 'spiritual democracy' die ten grondslag lag aan de stichting van de eerste Ursulinengemeenschap te Brescia. 
erkennen van het gezag van de apostolisch vicaris. Seculieren en regulieren probeerden elkaar over en weer als verantwoordelijke geestelijken te diskwalificeren, onder meer op grond van nauwe contacten met en afhankelijkheid van kloppen. ${ }^{57}$

In haar dissertatie neemt Schulte van Kessel nadrukkelijk stelling ten opzichte van het androcentrische karakter van een geschiedbeoefening en geschiedschrijving, die de betekenis van kloppen 'domweg [hadden] geminimaliseerd of [hen] tot een koddig verschijnsel hadden gedegradeerd'.$^{88}$ Haar aanklacht is geïnspireerd door inzichten uit de vakgebieden vrouwenstudies en vrouwengeschiedenis, die tegen het einde van de jaren zeventig geleidelijk een plek wisten te veroveren in de (universitaire) wetenschapsbeoefening. Binnen deze jonge (sub)disciplines vormden het marxisme en het radicaal feminisme een voedingsbodem voor een theoretisch kader waarin mannen per definitie als onderdrukkers en vrouwen als slachtoffers werden beschouwd. ${ }^{59}$ Dit onderdrukkingsparadigma klinkt ook bij Schulte van Kessel door. Verhoudingen tussen priesters en kloppen worden vanuit een dichotomie geduid, waarin de geestelijken machtiger waren dan de geestelijke maagden, die zich door de keuze voor een maagdelijk bestaan in dienst van God aan deze patriarchale verhoudingen trachtten te ontworstelen.

De wat ongenuanceerde en anachronistische toepassing van de sekse-dichotomie kwam Schulte van Kessel op kritiek te staan..$^{\circ} \mathrm{Al}$ is die kritiek terecht, dat neemt niet weg dat zij toch heeft laten zien dat sekse een fundamentele factor is om de oorsprong en ontwikkeling van de kloppenstaat in de zeventiende eeuw te begrijpen, alsook reacties op deze leefwijze. Met het loslaten van het onderdrukkingsparadigma binnen vrouwengeschiedenis gedurende de jaren tachtig ontstond er meer aandacht voor structuur en werking van machtsverhoudingen tussen mannen en vrouwen. Van deze nieuwe inzichten kon ook het onderzoek naar religieuze vrouwen profiteren.

\section{I.2 Religieuze vrouwen}

Onder invloed van vrouwenstudies - in het bijzonder binnen theologie en geschiedenis - wordt recent systematisch onderzocht of en waarom vrouwen in de zestiende en zeventiende eeuw een religieus bestaan in de wereld hebben geprefereerd boven een leven in kloosterlijke afzondering. Buitenlands onderzoek laat zien dat sommige vrouwen inderdaad zochten naar nieuwe bestaansvormen waarin

57 Vgl. Davis, 'City women and religious change', die voor Frankrijk schetst hoe vrouwen door katholieke en protestantse polemici tijdens de Reformatie op vergelijkbare wijze gebruikt werden om elkaar in diskrediet te brengen.

58 Schulte van Kessel, Geest en vlees, 56; vgl. 183-185.

59 Megens, 'Zicht'; Grever, 'Het verborgen continent'; De Haan, 'Na vijftien jaren'.

60 Frijhoff, 'Pleidool'; Schöffer, recensie. 
zij hun religieuze inspiratie konden uitdragen. Van Italië tot in de Zuidelijke Nederlanden organiseerden groepjes vrouwen zich in kloosterachtige gemeenschappen. ${ }^{65}$ Anders dan vrouwelijke religieuzen leefden en werkten deze religieuze vrouwen ten dele buiten kloostermuren. Hun levenswijzen vertonen parallellen met die van hun laat-middeleeuwse voorgangsters zoals de begijnen, al onderscheidden religieuze vrouwen in de zestiende en zeventiende eeuw zich van hen door hun apostolaire ambitie en hoge organisatiegraad. Analyses van hun initiatieven bieden aanknopingspunten voor onderzoek naar de kloppenstaat.

De opkomst van nieuwe religieuze bestaansvormen hangt ten nauwste samen met de toenemende confessionalisering in de vroegmoderne tijd. Sinds de Reformatie had de katholieke kerk haar godsdienstige monopoliepositie verloren. $\mathrm{Zij}$ moest zichzelf voortaan als confessie begrijpen en profileren om gelovigen te behouden. Terwijl hervormers als Luther en Calvijn de aanval openden op katholieke leerstellingen - de hiërarchie, de heiligenverering en het middelaarschap van priesters - hield de katholieke kerk hier onvoorwaardelijk aan vast. Via een intensief apostolaat moesten deze dogma's onder gelovigen verbreid worden om zich van hun confessionele aanhankelijkheid te verzekeren. Het Concilie van Trente nam daarom maatregelen ter verbetering van de opleiding van de (parochie)geestelijkheid die de gelovigen tot voorbeeld moest zijn. Het Concilie beschouwde predikatie en catechismusonderricht als de voornaamste instrumenten in het proces van geloofsverdediging en -verbreiding. ${ }^{62}$

Vanuit die doelstelling werden verscheidene priestergenootschappen en religieuze mannenorden gesticht: het Oratorium van Philippus Neri, de jezuïeten, de capucijnen, om er enkele te noemen. Er werden ook broederschappen en sodaliteiten in het leven geroepen, die behalve geestelijken ook leken onder hun leden telden. In hun processies en bedevaarten droegen zij de post-Trentse belijdenisvroomheid uit, die het typisch katholieke van leer en cultus als uitgangspunt nam en antiprotestants van karakter was ${ }^{63}$ Verinnerlijking van het geloof, gepaard aan een apostolische levensinstelling, het streven naar religieuze volmaaktheid en charitatieve activiteiten, dat waren idealen waar niet alleen verschillende geledingen van de geestelijkheid, maar ook vele leken zich achter schaarden. ${ }^{64}$

Verscheidene katholieke vrouwen zagen in de verbreiding van hun geloof eveneens een taak voor zichzelf weggelegd. Sterker nog, zij beschouwden het apostolaat als hun roeping. Bij hun pogingen om hieraan gehoor te geven vonden zij echter kerkelijke en maatschappelijke obstakels op hun weg. Belangrijke hinderpalen vormden de kerkelijke richtlijnen voor vrouwelijke religieuzen. Sinds de afkondiging van de bul Periculoso (1298) waren vrouwelijke religieuzen verplicht het slot,

61 Grisar, "“Jesuitinnen"'.

62 Jedin, 'Religiöse Tnebkräfte', 588. Idem, 'Ursprung'.

63 Idem, 'Religiöse Triebkrafte', 592-593; Duhr, 'Confrérie'; Châtellier, L'Europe des dévots.

64 Jedin, 'Ursprung', 456-459. 
ofwel de clausuur, te onderhouden; het was hun verboden het klooster te verlaten, tenzij in geval van brand of een levensbedreigende ziekte. ${ }^{65}$ Deze clausuurverplichting werd door de constitutie Circa Pastoralis (1566) niet alleen van toepassing verklaard op slotzusters die de drie plechtige geloften hadden afgelegd, maar ook op alle andere religieuze vrouwen. In een streven naar een kloosterhervorming, dat voortvloeide uit de besluiten van het Trentse Concilie, werden tertiarissen, begijnen, hospitaalzusters of anderen die een of meer eenvoudige geloften hadden afgelegd en in gemeenschap leefden, door de kerkelijke overheid tot plechtige geloften en de invoering van de clausuur gedwongen. ${ }^{66}$ Gemeenschappen die deze richtlijnen niet eerbiedigden, werden niet direct in hun voortbestaan bedreigd, maar zij mochten geen nieuwe leden meer aannemen.

Deze richtlijnen versmalden de opties voor vrouwen tot 'aut maritus aut murus', een echtgenoot of een (klooster)muur. En wie voor het klooster koos, moest plechtige geloften afleggen en de clausuur eerbiedigen. Nieuwe mannenorden als de jezuijeten daarentegen werden juist vrijgesteld van de gelofte van stabiliteit, die het verblijf in het klooster voorschreef; zij die eenvoudige geloften aflegden, de coadjutores, verkregen bovendien de status van religieuzen. ${ }^{67}$ Een dergelijke erkenning was voor religieuze vrouwen die geen of slechts eenvoudige geloften aflegden, niet weggelegd. De Socièteit van Jezus vormde een belangrijke inspiratiebron voor de opzet en de structuur van nieuwe religieuze vrouwengemeenschappen die in apostolaat en geloofsonderricht schone taken voor zichzelf zagen weggelegd. Het model van deze orde getuigde van een geheel nieuwe conceptie van religieus leven, toegesneden op de eisen des tijds; een conceptie die echter beperkt was tot het religieuze bestaan van mannen en die, wat de Heilige Stoel betreft, de opvattingen

65 Corpus Iurns Canonicı, II, ro53-1054, 'Penculoso, De statu regulanum'; Creusen, 'Clôture', 893-894. Vgl Dolhagaray, 'Clòture'; Lemoune, Le drott des relıgzeux, 24 Als relıgieuzen golden zly, die plechtıge geloften hadden afgelegd Sinds het pontuficaat van Bonifatius VIII (1294-1303) werd er alleen van plechuge geloften gesproken, als deze gepaard gangen met de intrede in een door de Heilige Stoel goedgekeurde orde of met de wijding tot pnester Sleegers, 'Maagdeliskheid', 101-103, schetst de histonsche ontwkkelıng die geleid heeft tot de welhaast onlosmakelıke verbondenheid van het afleggen der geloften en de professie

66 Creusen, 'Clōture', 894-895, en ıdem, 'Les ınstıtuts relıgieux', 57-58. W'1e eenvoudıge geloften aflegde, ontving geen kloosterkleed en hoefde niet van woonplaats te veranderen Wel was men verplicht de dne evangelısche raden - amoede, gehoorzamhe1d en kuisheid - te onderhouden In de bijzondere uirwerkngen verschillen deze geloften echter van de plechuge, hetgeen ook tot uitdrukkung komt in de sanctues op de overtredung van een der geloften Zie 'Gelofte', 'Eenvoudıge geloften' en 'Eeuwige geloften', in Encyclopaedisch kerkelyk woordenboek, 224, I9I en 193. Lemoine, Le droit des religreux, 39-40, stelt dat de consutuue Lubncum vitae genus mannen die eenvoudige gelofte(n) hadden afgelegd en een religieus leven in gemeenschapsverband leidden, eveneens verplichtte tot het afleggen van de plechtige geloften. Vgl. echter Creusen, 'Congregation religieuse', I85 en idem, 'Insatuts religieux', 58

67 Deze voorrechten werden gestrpuleerd door de bul van Gregonus XIII, Ascendente Dominz (1584) Creusen, 'Congtegation religieuse', I85-186; Idem, 'Instututs religieux', 60; Lemoune, Le dront des religreux, 38. Voor de verschillende graden binnen de Societeit van Jezus, zie Andre, 'Opnchting', II. 
van de kerk over vrouwelıjke relıgieuzen in generleı wi)ze wı)zigde. Alleen die vrouwen die een contemplatief bestaan binnen kloostermuren leidden, werden door de kerk als relıgieuzen erkend.

De relıgıeuze energie van vrouwen liet zıch aanvankelıjk nuet gemakkelıjk kanaliseren door het kerkelı)k oppergezag. In de context van de kerk zochten vrouwen werkzaamheden, die niet gekoppeld waren aan de gewilde macht die aan pnesters voorbehouden was, maar die wel meer beantwoordden aan hun behoefte aan maatschappelık engagement en erkennıng dan de gebeden en devoties waarmee de slotzusters bijdroegen aan de verlossing der zielen en de verbreiding van het katholieke geloof. ${ }^{68}$ Vrouwen namen vaak zelf het initıatief tot het opnchten van nieuwe gemeenschappen. In Franknjk waren zlj bıjvoorbeeld al sterk vertegenwoordigd in de katholreke lekenactie die tot ontwikkelıng kwam voordat de Trentse decreten vanaf 1615 door het episcopaat van kracht werden verklaard Terecht bestempelt de Canadese histonca Elizabeth Rapley hun religieus geinspireerd activisme daarom als autonoom. ${ }^{69}$

De werkzaamheden die deze vrouwen tot de hunne rekenden, waren evenwel controversieel Dat gold vooral voor het godsdienstondemcht Ruchtlunen van de apostel Paulus dat vrouwen in hun geloofsgemeente moesten zwljgen (I Kor I4,34, I Tim. 2,II-I2), werden aangegrepen om hun te verbieden anderen te onderwijzen in geloofszaken ${ }^{70} \mathrm{Zwijgzaamheld,} \mathrm{onderdanigheid} \mathrm{en} \mathrm{gehoorzaamheid}$ waren deugden die alle vrouwen behoorden te sieren, ${ }^{71}$ en voor religieus bewogen vrouwen gold in dat opzicht geen uitzondenng. Volgens Rapley onderschreven echter niet alle geestelıken en kerkelıke gezagsdragers dergelıke ideeen klakkeloos. De scheidslinn tussen aanmoediging en oppositie viel beslist niet samen met de scheiding der seksen. Sommige bisschoppen stonden toe dat er binnen de grenzen van hun diocees nieuwe communiteiten werden gesticht die geen of enkel eenvoudige geloften vroegen, en een beperkte of geen clausuur onderhielden. ${ }^{72}$ Een dergeli)ke bisschoppelıke goedkeunng was voldoende voor gemeenschappen die geen nieuwe huizen wilden stichten buiten de grenzen van het eigen diocees en niet de ambitie hadden om als orde erkend te worden ${ }^{73}$

\section{Motzeven}

Apostolaat of dienstbetoon aan de naaste waren niet altıjd de enige driffveren om een actıef-relıgieuze gemeenschap te verkezen boven een slotklooster. Wie een

68 Norberg, 'The Counter Reformanon and women'

69 Rapley, The devotes, 22

70 Ibidem, 72

71 Rotsaer, Tussen Eva en Mana

72 Creusen, 'Instituts religieux', 58, Rapley, The devotes, 28

73 Voor de stıchting van een nieuwe orde was sinds het vierde Lateraans Concile (1215) de goedkeunng van de Heilige Stoel nodig 
religieus leven wilde leiden, maar te zwak was voor het kloosterleven, over onvoldoende middelen beschikte om de bruidschat bij intrede in een klooster te kunnen voldoen, of zich wegens familieverplichtingen niet geheel uit de wereld kon terugtrekken, kon in een nieuwe vrouwengemeenschap eveneens een passend onderkomen vinden. Nieuwe communiteiten konden economisch van betekenis voor vrouwen zijn, doordat zij hier op een eerbare wijze in hun onderdak en levensonderhoud konden voorzien. ${ }^{74}$ En een religieus bestaan bood katholieke vrouwen, vooral uit de hogere klassen, een acceptabel alternatief voor het huwelijk. Een alternatief dat bovendien door geestelijken vanaf de kansel werd aangeprezen, vooral bij gelovigen van de vrouwelijke kunne. ${ }^{75}$ Conform het Trentse standpunt oordeelden clerici dat de maagdelijke staat in zichzelf beter en zaliger was dan het huwelijk. Het huwelijk werd door hen voorgesteld als een gevaarlijke en een in fysiek en psychisch opzicht belastende onderneming. ${ }^{76}$ Dergelijke huwelijksvijandige opvattingen leefden niet alleen onder de geestelijkheid, maar ook onder vrouwen zelf, die in een maagdelijk bestaan gecombineerd met apostolische taken een betere garantie zagen voor hun zieleheil."7

Volgens de Duitse theologe Anne Conrad zochten religieus bezielde vrouwen in de vroegmoderne tijd naar 'Freiräume' binnen de kerk. Het kerkelijk domein dat traditioneel door mannen werd beheerd, was door de nadruk die het Concilie van Trente legde op de door hun wijding bekrachtigde macht van priesters, sterk 'geklerikaliseerd'. Hier trachtten vrouwen zich te emanciperen van mannelijke autoriteiten en aanspraak op autonomie te maken..$^{78}$ In nieuwe gemeenschappen met andere autoriteitsstructuren, waarin mannen geen of slechts een ondergeschikte rol speelden, ziet Conrad een vorm van zelfverwerkelijking, ingegeven door wat zij - zich welbewust van het anachronisme - een 'feministische' grondhouding noemt. ${ }^{79}$ Vroegmoderne religieuze vrouwen zouden een 'ausgeprägtes feministisches Bewußtsein'so hebben gehad en streefden naar een zekere gelijkberechtiging met mannen. Behalve anachronistisch lijkt deze visie op religieuze vrouwen ook wat eenzijdig. Door namelijk enkel op de aspiraties van vrouwen te wijzen, beneemt Conrad het zicht op belangen en idealen die zij deelden met geestelijken en waaraan beide groeperingen, ieder op hun eigen wijze, een bijdrage wilden leveren.

74 De Vroede, 'Kvezels' en 'zusters', 91-99.

75 Storme, 'Die trouwen wult voorsichtelyck', 67-74; Therry, De religieuze beleving, 74-76.

76 Storme, 'Die trouwen walt voorsichtelyck', 74-81.

77 Rapley, The dévotes, 16-20.

78 Voor verbanden russen 'klenkalssering' van het geloof en nieuwe uitdrukkengsvormen van religeuze inspiratie onder vrouwelijke gelovigen in de middeleeuwen en de vroegmoderne tijd, zie Bynum, fesus as mother, I-2I en Schulte van Kessel, 'Maagden en moeders'.

79 Conrad, Zweschen Kloster und Welt, 267-269.

80 Ibidem, 65. 


\section{Aanspraak op religieuze status}

Een contemplatief bestaan in combinatie met liefdewerken deed volgens de $\mathrm{Ge}-$ neefse bisschop Franciscus van Sales (1567-1622) niet onder voor het kloosterleven, maar vertegenwoordigde juist de volmaakte religieuze leefwijze. Met Johanna van Chantal (1572-1647) richtte hij in 1610 de Visitatie van Annecy op, een gemeenschap voor godvruchtige vrouwen die wel een religieuze roeping hadden, maar de strenge kloosterdiscipline niet konden onderhouden wegens hun gezondheid of familieverplichtingen. Een communiteit met eenvoudige geloften en een versoepelde clausuur kwam tegemoet aan deze beletsels. De aartsbisschop van Lyon, Denis-Simon de Marquemont, verzocht de bisschop van Genève in 1616 om de visitandinnen-gemeenschap in Lyon, die het jaar ervoor was gesticht, om te vormen tot een door de paus goedgekeurde orde. Dat betekende dat plechtige geloften en strikte clausuur voortaan vereist zouden zijn. Aanvankelijk verzette Franciscus zich hiertegen. Hij was van oordeel dat de clausuur een betrekkelijk nieuw criterium was voor het religieuze leven, dat bijvoorbeeld onbekend was geweest aan de eerste christenen, wier roeping juist als clausuur fungeerde. Een volmaakt leven behoorde een geestelijke, innerlijke staat te zijn en geen uiterlijke staat. Onvoorwaardelijk vasthouden aan de clausuur zou bovendien betekenen dat vele vrouwen hun religieuze roeping niet konden volgen. Aangezien Marquemont in Frankrijk zó invloedrijk was dat hij verdere uitbreiding van de Visitatie kon dwarsbomen, zwichtte Franciscus voor zijn verzoek. ${ }^{{ }^{81}}$

In de ogen van Marquemont en andere kerkelijke gezagsdragers vonden dergelijke pogingen om de religieuze staat aan te passen geen genade. Hun argumenten illustreren hoezeer de nieuwe religieuze gemeenschappen en hun leden de kerkelijke en maatschappelijke orde doorkruisten. De kloosterhervormingen die de Heilige Stoel had afgekondigd en die erop gericht waren de clausuur te handhaven, dreigden ondermijnd te worden door deze vrouwen, die zichzelf niet alleen als religieuzen zagen maar zich ook als zodanig manifesteerden buiten kloosters. Versoepeling van de clausuur zou de katholieke positie in de interconfessionele polemiek verzwakken; protestanten zouden dan met recht kunnen zeggen dat dergelijke nieuwe gemeenschappen het clausuurgebod eenvoudig omzeilden. Andere fundamentele bezwaren tegen de nieuwe communiteiten waren van juridische aard. Vrouwen die geen plechtige geloften aflegden, zoals de visitandinnen, waren in de zin der wet geen religieuzen. $Z$ ij waren te allen tijde vrij om een huwelijk te sluiten en over hun goederen te beschikken. Daarom werd de intrede in zo'n nieuwe gemeenschap vaak ontmoedigd door familieleden. Met dergelijke juridische bezwaren kwamen kerkelijke gezagsdragers als Marquemont tegemoet aan de eisen die vooraanstaande families stelden aan de wijze waarop hun dochters een religieuze roe- 
ping mochten verwezenlijken. ${ }^{82}$ Lokale maatschappelijke elites bundelden hun krachten op dit punt met de kerkelijke autoriteiten om nieuwe religieuze verenigingen ertoe te bewegen alsnog een goedgekeurde regel en de clausuur aan te nemen.

Ook vrouwengemeenschappen die in de jezuïeten hun voorbeeld zagen, beschouwden zichzelf in strijd met de bestaande kerkelijke definitie als religieuzen. Onder de naam 'jezuitinnen', die oorspronkelijk bedoeld was als scheldnaam, gaan diverse gemeenschappen schuil, die noch onderlung noch met de jezuïeten zodanig formele banden onderhielden dat gesproken kan worden van een vrouwelijke tegenhanger. De jezuïeten wezen pogingen om een vrouwelijke tak van de orde te stichten overigens radicaal af. ${ }^{8_{3}}$ Niettemin traden zij vaak op als biechtvaders en geestelijk leidsmannen van vrouwen die hun religieuze inspiratie in daden wilden omzetten, en stonden hen terzijde bij het concipiëren van regels en constituties. ${ }^{{ }^{4} 4}$ 'Jezuïtinnen' legden wel geloften af, meestal eenvoudige. $\mathrm{Zij}$ aanvaardden geen clausuur, omdat die onverenigbaar was met de werken van barmhartigheid die zij in de wereld uitvoerden. Bovendien maakte hun religieuze, kuise levenswijze in hun ogen het slot overbodig; gebrek aan clausuur en plechtige geloften deed naar hun mening niets af aan hun religieuze identiteit.

Het initiatief van de van oorsprong Engelse Mary Ward (1585-1645) kan gezien worden als de meest verstrekkende poging tot modificatie van het erkende religieuze bestaan van vrouwen in de vroegmoderne tijd, en het verzet ertegen was navenant. Aanvankelijk had Ward een hang naar het strenge kloosterleven ${ }^{{ }^{85}}$ Herhaalde visioenen doordrongen haar echter van het besef naar Gods wil te handelen als zij een gemeenschap naar het model van de Sociëteit van Jezus zou stichten. ${ }^{86}$ Haar stond een nieuwe orde voor ogen die, net als de jezuïeten, rechtstreeks onder het gezag van de paus zou staan. De leden van haar Instituut van de Heilige Maagd Maria, opgericht in 1609 te St.-Omaars, zouden zich bezighouden met meisjesonderwijs, apostolaat onder gelovigen, en de missie in haar geboorteland Engeland, waar de katholieke eredienst verboden was. Deze taken verdroegen geen clausuur. Vrouwen die tot het Instituut toetraden, legden eenvoudige geloften af. Ward streefde ernaar dat zij, in navolging van de jezuieten met eenvoudige geloften, toch tot de religieuzen gerekend zouden worden.

Haar Instituut kreeg in I6I5 de steun de bisschop van St.-Omaars, Jacques Blaes, die zich daarin gesteund wist door het positieve oordeel dat de jezuïet Leonardus Lessius (1554-1623) erover velde. ${ }^{87}$ Volgens deze theoloog getuigde de

82 Evenett, 'The new orders', 290; Liebowitz, 'VIrgins', 139-I40. Vgl. Rapley, The dévotes, 38-39

83 Conrad, Zwuschen Kloster und Welt, 64-65. De orde was in 1547 op verzoek van haar stichter, Ignatius van Loyola, door de paus ook vnigesteld van de zielzorg aan religieuze vrouwen.

84 Gnsar, “Jesuitınnen"', 71-73, Conrad, Zwischen Kloster und Welt, 15-16, vgl 17 (noot 40).

85 Conrad, Zwischen Kloster und Welt, 84-85.

86 Ibidem, 87, Rapley, The dévotes, 28-30.

87 Grisar, 'Das Urtell', 662-666 Aangezıen Lessius' goedkeunng aan strenge jundısche eisen voldeed, 
leefwijze van Ward van een stand van volmaaktheid welke die van een erkende orde niet alleen benaderde, maar in werking en verdienste zelfs geleek. ${ }^{88}$ De erkenning van de Heilige Stoel, die Ward zo vurig wenste, bleef echter uit. ${ }^{89}$ De weerstand tegen het Instituut groeide intussen gestaag. Sommige Engelse seculiere geestelijken zagen de leden ervan als een verlengstuk van de jezuieten, wier invloed in Engeland hun toch reeds een doorn in het oog was. Jezuieten op hun beurt voelden zich ongemakkelijk omdat Ward zich manifesteerde als hun vrouwelijke pendant. $\mathrm{Zij}$ drongen er dan ook op aan dat de vrouwen een andere regel aannamen dan die van de Sociëteit. ${ }^{90}$ Door alle geledingen heen speelde echter het onbehagen over de taakstelling van het Instituut en het religieuze zelfbeeld van de aangesloten leden. De rechtmatigheid van het Instituut werd vanaf 1628 door de Congregatie van de Propaganda Fide onderzocht. Nog datzelfde jaar kwam het tot een veroordeling, die de opheffing van het Instituut inluidde. Als reden werd vooral benadrukt dat de clausuur door Ward niet was ingevoerd, maar een zekere antipathie jegens de jezuïeten speelde eveneens een rol.9"

De formulering van de bul van suppressie, Pastoralis Romani Pontificis (I63I), wijst erop dat Ward zich, naar de mening van de Heilige Stoel, taken had toegeëigend die strijdig waren met wat genoemd werd de vrouwelijke bescheidenheid. Ward en de haren hadden grenzen overschreden: de grenzen van het religieuze bestaan voor vrouwen, alsook de toenmalige sociale conventies voor het vrouwelijk geslacht. Ward zelf was blind noch doof voor deze beperkingen. Naar eigen zeggen had ze geprobeerd zich hieraan te conformeren, zonder evenwel haar overtuiging prijs te geven dat vrouwen net als mannen tot religieuze perfectie en grote daden in staat waren. ${ }^{92} \mathrm{Ze}$ benadrukte dat haar volgelingen ondersteunende taken verrichtten; zij zouden priesters helpen door gelovigen op diensten en preken te attenderen, hun eerbied bij te brengen in de omgang met het sacrale, en hen aan te zetten tot regelmatige biecht en ontvangst van andere sacramenten. ${ }^{93}$ Dat het Instituut tenslotte toch verboden werd, getuigt ervan dat de Heilige Stoel Wards pogingen om zich conformeren aan grenzen die het handelen van vrouwen in religiosis bepaalden, onvoldoende achtte.

1s volgens Gnsar de veronderstelling gerechtvaardigd dat Blaes van ambtswege om een dergelıjk oordeel gevraagd had en daarop zijn open bnef (d.d I 9 maart I6I5) baseerde, waann hu) zich als verantwoordelijke ordinanus uitsprak ten gunste van Ward.

88 Ibidem, 673-674.

89 Conrad, Zwuschen Kloster und Welt, 89, 93

90 Ibidem, 90-9I' de derde en laatste versie van de door Ward opgestelde constituties ( 1620 ) kwam haast woordelı,k overeen met de Formula Institutt, de eerste regel van de Sociëtelt van Jezus uit I54O, die in bewerkte vorm in 1550 door de paus was bevestigd.

91 Gnsar, 'Das erste Verbot', 42 en 1dem 'Der Endkampf, benadrukt dat Francesco Ingoll, de toenmalige secretans van de Congregatie van de Propaganda Fide, die belast was met het onderzoek naar het Instutuut, bekend stond als fel tegenstander van de jezureten.

92 Rapley, The dévotes, 32-33.

93 Conrad, Zusschen Kloster und Welt, 92. 
De opheffing van Wards Instituut vormde het sluitstuk van een periode waarin vrouwen streefden naar een actief religieus bestaan én aanspraak maakten op de religieuze status.94 Onder kerkelijke en maatschappelijke druk ondergingen de visitandinnen en andere gemeenschappen een monastieke transformatie: zij namen alsnog een erkende ordesregel aan en voerden de clausuur in. Zij kregen wel toestemming om hun werkzaamheden - in veel gevallen (godsdienst)onderwijs aan meisjes en vrouwen - voort te zetten binnen de muren van hun klooster. In plaats van actieve religieuzen avant la lettre, werden de leden van de nieuwe gemeenschappen semi-contemplatieven, wier maatschappelijke taak expliciet deel uitmaakte van hun kloosterleven. ${ }^{95}$ Op deze wijze werden hun taken, die inmiddels essentieel waren voor de katholieke hervorming, verzoend met de eisen die de kloosterhervormingen stelden. ${ }^{96}$ Deze medaille had ook een keerzijde die iets optimistischer stemt, want deze inpassing betekende ook impliciete sanctionering. Van relatieve buitenstaanders werden de religieuze vrouwen die tot vrouwelijke religieuzen met een maatschappelijke taak waren omgevormd, insiders in het kerkelijke domein. ${ }^{97}$

\section{Geestelijke personen}

Niet alle gemeenschappen werden tot slotkloosters getransformeerd. Sommige wisten deze aanpassing te vermijden door elke openlijke aanspraak op de religieuze status te laten varen. Vanaf 1630 werden er in Frankrijk allerlei gemeenschappen gesticht die een actief religieus bestaan realiseerden zonder zichzelf religieuzen te noemen. De Filles de la Charité (I633) van Vincentius a Paulo (I58I-I660) vormt hiervan het meest sprekende voorbeeld. Dit genootschap werd in I660 officieel erkend; het was de Filles toegestaan eenvoudige geloften af te leggen, onder een regel in gemeenschap te leven en kleding te dragen, die hen duidelijk van andere leken onderscheidde. Zoals hun stichter verklaarde, waren zij in ieder opzicht behalve in naam religieuzen. Het imago van lekevrouwen stond haaks op de religieuze identiteit die de Filles en hun stichter binnen hun gemeenschap in woorden en daden cultiveerden. ${ }^{98}$

Vergelijkbare communiteiten ontstonden eveneens in de Zuidelijke Nederlanden. De Belgische historicus $M$. de Vroede heeft becijferd dat er circa tachtig van dergelijke gemeenschappen werden gesticht gedurende de zeventiende en achttiende eeuw, in omvang variërend van minder dan tien leden tot meer dan honderd. Tegen het einde van de achttiende eeuw representeerden geestelijke dochters al waren ze dan formeel geen religieuzen - 15,5 à $17,5 \%$ van het totale aantal

94 Gnsar, "Jesuitinnen"', 75-76; Rapley, The dévotes, 34, 4I.

95 Rapley, The dévotes, 48.

96 Ibidem, 50, 72-73.

97 Conrad, Zwrschen Kloster und Welt, 263.

98 Rapley, The dévotes, 85-88, 93. 
vrouwelijke religieuzen. ${ }^{99}$ In de gemeenschappen legden geestelijke dochters zich zowel toe op gebed en meditatie als op werken van liefdadigheid. Algemeen juridisch en kerkrechtelijk hadden deze gemeenschappen de status van verenigingen, en de verschillende namen die ervoor in zwang waren - gemeenschap, genootschap, vereniging, instituut - verhelderen dat er nog geen passende benaming voor andere religieuze gemeenschappen dan kloosters bestond. ${ }^{100}$ Hoewel deze communiteiten geen religieuze status voor zich opeisten, werden ze toch argwanend gadegeslagen door de wereldlijke overheden, die vreesden met nieuwe kloosterstichtingen te maken te hebben die aanspraak zouden kunnen maken op (belasting)vrijstellingen. ${ }^{\text {tos }}$ De meeste gemeenschappen waren zelfstandig en hadden geen onderlinge banden. Volgens De Vroede ondervonden vrouwen in de tweede en derde groeifase van de communiteiten, I650-I 700 en de tweede helft van de achttiende eeuw, steun en stimulans van de parochieclerus. Die wist zich geïnspireerd door de visitandinnen van Franciscus van Sales en Vincentius' Filles. ${ }^{102} \mathrm{De}$ geestelijkheid beschouwde de communiteiten als instrumenten van contrareformatorische kerkelijke strategieën en in de bisdommen leper, Brugge, Doornik en het aartsbisdom Mechelen werd de oprichting ervan zelfs door de kerk gestimuleerd omwille van hun diensten aan de armenscholen. De communiteiten stonden behalve onder de wereldlijke jurisdictie ook onder het gezag en het toezicht van de bisschop.

In deze communiteiten vonden vooral ongehuwde, onbemiddelde vrouwen een zekere mate van bestaanszekerheid, hoewel ook betrekkelijk welvarende vrouwen intraden en enkele communiteiten vooral voor meer bemiddelde vrouwen bedoeld waren. ${ }^{103}$ De gemeenschappen vormden zowel een arbeidseenheid als een religieuze communiteit. De aangesloten geesteliike dochters waren in zondagscholen, dagscholen en werkscholen werkzaam. ${ }^{104}$ Daamaast waren ook zieken- en armenzorg belangrijke arbeidsterreinen. ${ }^{105} \mathrm{Het}$ dagelijks ritme binnen de communiteiten werd bepaald door de werkzaamheden, alsook door de religieuze plichten die waren vastgelegd in een leefregel, zoals het gebed, de meditatie, en soms zelfs ook het bidden der getijden - bij uitstek een kenmerk van kloostergemeenschappen. ${ }^{106}$ Ondanks dit 'geordende' religieuze leven, waren de leden van de communiteiten geen religieuzen, aangezien ze geen clausuur onderhielden en evenmin drie plechtige geloften aflegden. ${ }^{107}$ In veel gevallen werden er wel beloften gedaan, van zui-

99 De Vroede, 'Kwezels' en 'zusters', I18.

$100 \mathrm{Vgl}$. Gnsar, “Jesuitinnen"”.

IoI De Vroede, 'Kwezels' en 'zusters', 219-222; vgl. Rapley, The dévotes, 95.

102 De Vroede, 'Kwezels' en 'zusters', I16-117.

103 Ibidem, I25-I 28.

104 Ibidem, 143-150.

105 Ibidem, 14I-143.

106 Ibidem, 197-20I; vgl. 253.

107 Ibidem, 18I-182. 
verheid alsook van gehoorzaamheid. Dergelijke beloften waren echter niet bindend; men was te allen tijde vrij om de communiteit te verlaten. ${ }^{108}$ De Vroede munt voor deze gemeenschappen de begrippen seculiere communiteiten of wereldlijke verenigingen. ${ }^{109}$

Uit de verschillende regels blijkt dat de leefwijze van de Zuidnederlandse communiteiten sterk georiënteerd was op het monastieke bestaan. En net als bij de Filles de la Charité werd er ook binnen de Zuidnederlandse communiteiten een vocabulaire gebezigd dat ontleend was aan het kloosterleven. Gebeurde dat, zoals De Vroede in navolging van een tijdgenoot van de geestelijke dochters suggereert, bij gebrek aan een beter begrippenapparaat, ${ }^{110}$ of zouden ook andere motieven een rol gespeeld kunnen hebben? Vasthouden aan een seculiere identiteit hield kerkelijke en wereldlijke autoriteiten natuurlijk op een veilige afstand, zo was al gebleken tijdens de consternatie rond de opheffing van het Instituut van Mary Ward. In 1629 werden verscheidene Zuidnederlandse gemeenschappen door de Congregatie van de Propaganda Fide onderzocht op hun banden met Ward en zelfs met opheffing bedreigd. De aartsbisschop van Kamerijk, Franciscus van der Burch, trad evenwel voor hen in het krijt. Hij ontkrachtte de voorstelling dat er enige relatie van deze communiteiten met het Instituut van Ward bestond. Dat zij het slot niet onderhielden, kwam volgens hem omdat zij vrome en geen religieuze gemeenschappen vormden; anders dan Mary Ward wensten deze vrouwen hun lekenstaat te behouden. ${ }^{\text {II }}$

Ware het in de toenmalige historische context geen contradictio in terminis, zo verzucht De Vroede, dan zouden de leden van de Zuidnederlandse communiteiten misschien het beste omschreven kunnen worden als seculiere religieuzen. ${ }^{112}$ Misschien was deze ogenschijnlijke tegenstrijdigheid in de vroegmoderne tijd minder groot dan tot dusver is aangenomen. De regel van de Filles de la congrégation de Notre Dame des Anges te Valenciennes laat zien dat deze vrouwen zich niet tot de religieuze maar tot de maagdelijke staat geroepen voelden. ${ }^{113}$ Een dergelijke roeping werd niet als een wereldlijke, maar juist als een geestelijke roeping beschouwd. Vrouwen die de maagdelijke levensstaat aannamen, werden door anderen gezien

108 Ibidem, I95-196.

109 Vgl. Rapley, The dévotes, die de leden van vergelijkbare Franse gemeenschappen 'filles seculières' noemt.

110 De Vroede, 'Kwezels' en 'zusters', 194.

III Grisar, "Jesuitinnen", 91-97.

112 De Vroede, 'Kevezels' en 'zusters', 209.

113 Isaac, 'Documents inédits', 42; 50: 'C'este congregation est instituee pour servir de retraicte aux filles qui sont appellees de Dieu au célibat et non a religion, affin que, quitant les vanités du monde et la maison de leurs parens, elle puissent en ceste fachon servir plus parfaictement a Dieu en chasteté (...).' Religion betekent in dit verband kloosterstaat (Lat.: religio; Ned.: religie, aldus Binnart, Biglotton amplificatum). Van een roeping tot maagdelijkheid is ook sprake bij de Spaanse tegenhangers van de geestelijke maagden, de beatas. Zie Weber, 'Between ecstacy and exorcism'. Zie verder voor beatas Perry, Gender and disorder, 97-II7. 
als 'geestelijke' personen. De leden van het Keulse Ursula-gezelschap zijn hiervan een voorbeeld.

Het Ursula-gezelschap werd in 1606 opgericht als sodaliteit en in I6I I en I6 I 2 ook als zodanig erkend en onder toezicht gesteld van de Keulse bisschop. Stichteres Ida Schnabels riep hiermee een pendant in het leven van de door de jezuïeten ingestelde Maria-congregaties, die zowel jezuïeten als leken onder hun leden telden. ${ }^{114}$ Vrouwen werden officieel niet toegelaten en evenmin mocht een dergelijke broederschap voor vrouwen opgericht worden. Deze uitsluiting van vrouwen werd door Claudius Aquaviva, die de generale overste van de Sociëteit van Jezus was tussen I58I en I6I5, juridisch gelegitimeerd. ${ }^{115}$ Lidmaatschap van een Mariacongregatie vereiste dat men zich toewijdde aan de Heilige Maagd. Aangezien vrouwen onder de zeggingsmacht van hun vader of echtgenoot stonden, waren zij niet in de positie zichzelf zodanig toe te wijden. Het ontbreken van wettelijk zelfbeschikkingsrecht beperkte zodoende de vormen waarin vrouwen aan het religieuze leven konden participeren. Aan Aquaviva's redenering lag ongetwijfeld het christelijke adagium ten grondslag dat de man als het hoofd van de vrouw beschouwd moet worden (Ef. 5,24; I Kor. II,3). Deze stelregel was echter, zo illustreren de voorbeelden van religieuze vrouwen in het voorafgaande, enigszins aan slijtage onderhevig.

Zagen de leden van broederschappen en sodaliteiten zichzelf vooral als leken in de wereld, de maagden van het Ursula-gezelschap beschouwden zich als geestelijke personen. Hun geestelijke, zelfs clericale zelfbeeld kwam tot uitdrukking in verschillende voorrechten die zij zich hadden toegeëigend en die sinds de late middeleeuwen steevast met de seculiere clerus werden geassocieerd: het celibaat, herkenbare kleding en het recht op een zitplaats in het koor van de kerk. Specifieke liturgische gebruiken, zoals de rituele voetwassing door de overste op Witte Donderdag, onderstreepten deze zelfopvatting. ${ }^{16}$ Hierin werden zij bevestigd door sommige geestelijken die behalve in de genoemde kenmerken ook in de onderwijsactiviteiten van het Ursula-gezelschap, die werden aangemerkt als zielzorg, een parallel zagen met wereldheren. Tijdgenoten bestempelden hun leefwijze als derde, middele, of wereld-geestelijke ('welt-geistliche') stand. ${ }^{117}$

Kerkrechtelijk was het onmogelijk om de leden van het Ursula-gezelschap als geestelijke personen te betitelen. Sinds de vijftiende eeuw golden enkel nog leden van de seculiere en reguliere clerus, per definitie mannen, als geestelijken. Alle

114 Conrad, Zwuschen Kloster und Welt, I05-107; Oorspronkelık werden deze broederschappen ingesteld voor leerlingen en studenten van jezuetencolleges. De eerste sodaliteit werd in i 563 in het jezutetencollege te Rome gestucht Sinds 587 mochten er dankzl) een pauselijke beschikkung (de bul Supema dispositwne ( 1587$)$ ) ook sodaliteiten gesticht worden voor vrome leken.

115 Poncelet, Histoure, II, 327-328 (noot 3); Chàtellier, L'Europe des devots, 3I-32.

II6 Conrad, Zunschen Kloster und Welt, 160, 162-163, 165-167.

II7 Ib1dem, 102. 
vrouwen, religieuzen incluis, waren voor de kerk leken. ${ }^{\text {II }}$ Dat het voor het Ursulagezelschap zelf alsook voor sommige contemporaine waarnemers kennelijk vanzelfsprekend was hen op grond van overeenkomsten met wereldheren toch als 'geestelijk' te definiëren, illustreert treffend de breedte van de kloof tussen het kerkrecht en de receptie of toepassing hiervan in de dagelijkse praktijk.

Voor onderzoek naar religieuze vrouwen in de vroegmoderne tijd is de categorie 'zelfverstaan' of zelfbeeld van belang. Al waren velen van hen in naam geen religieuzen, zij zelf begrepen zich wel als zodanig. Sommige priesters en kerkelijke hoogwaardigheidsbekleders waren de apostolaire aspiraties en het religieuze zelfverstaan van deze vrouwen gunstig gezind. De geestelijkheid kan derhalve niet klakkeloos als onderdrukkende instantie worden aangemerkt. Geestelijken en religieus geïnspireerde vrouwen hadden soms gedeelde belangen, die tot een samenwerking leidden waarvan de betrokken vrouwen zeker ook de vruchten plukten. Zij doorkruisten de door het kerkelijk oppergezag voorgeschreven kenmerken van de religieuze staat, zelfs wanneer zij geen aanspraak maakten op de status van religieuzen. De maagdelijke staat of het celibaat, waarop ook de kerkrechtelijk niet gesanctioneerde kloppenstaat stoelde, lijkt zich - het Ursula-gezelschap en de Filles de la Charité beziend - tot het fundament ontwikkeld te hebben van een voor religieuze vrouwen geheel nieuwe identiteit, die van geestelijke personen.

\section{I.3 Religie en sekse in vrouwengeschiedenis van de vroegmoderne tijd}

Overtuigd door God geroepen te zijn tot allerlei geestelijke en maatschappelijke taken, doorbraken vrouwen her en der in Europa de grenzen die aan hun sekse werden gesteld. Een belangrijke drijfveer hiertoe vormde religie - opgevat als levensbeschouwing of geloofsovertuiging. De betekenis van het katholieke geloof voor vrouwen lijkt paradoxaal. Terwijl het kerkelık leergezag hun een aan mannen ondergeschikte plaats toebedeelde en hen praktisch als onmondigen beschouwde, grepen zij juist hun geloofsovertuiging aan als fundament voor hun identiteit en werkzaamheid. ${ }^{119}$

Deze paradox illustreert treffend dat betekenis en beleving van religie voor gelovigen niet onwrikbaar vastliggen, maar pas vorm krijgen door menselijk handelen. Individuen en groepen (re)produceren door hun eigen handelen culturele praktijken - waaronder religieuze - en maken zich deze eigen. ${ }^{20}$ Deze processen van toeëigening hebben een dynamisch karakter. Dat wil zeggen dat het aan- of overnemen van cultuurvormen gepaard gaat met betekenisveranderingen die het

II8 Ibidem, 162.

119 Vgl. Gilchnst, Gender and matenal culture, I4.

120 Chartier, Cultural hestory, ıdem, 'Le monde', voor Nederland zie Fnjhoff, 'Inleideng', 25-3i. 
gevolg zijn van de betekenispatronen die vigeren in de 'ontvangende' groep. Uiteenlopende individuele en sociale identiteitsaspecten zoals klasse, leeftijd, regionale herkomst of burgerlijke staat, maar ook sekse bepalen hoe individuen of groepen culturele praktijken 'operationaliseren'. ${ }^{121}$

Vooral de variabele sekse blijft ten onrechte vaak onderbelicht in cultuurhistorische analyses. Recentelijk hebben de theologe Annelies van Heijst en de historica Marjet Derks erop gewezen dat vrouwen in het verleden niet zelden van actieve toeëigening en betekenisgeving waren uitgesloten. ${ }^{122}$ Voor onderzoek naar de betekenis van religie voor vrouwen, dat niet een kerkelijk-institutioneel kader als vertrekpunt kiest maar juist de bewogenheid en bezieling van vrouwen zelf, is het concept van toeëigening slechts ten dele bruikbaar. Het verhult namelijk de machtsverhoudingen die noodzakelijkerwijs ontleed moeten worden om spanningsvelden, dilemma's en ambivalenties in historische bronnen en geschiedschrijving tot hun recht te laten komen. Van Heijst en Derks wijzen op het 'meerstemmige' karakter van samenlevingen, die bestaan uit overlappende en elkaar kruisende culturele circuits, waarin groepen en individuen, al naar gelang verschillende identiteitsaspecten, meer of minder invloedriike posities innemen.

Al waren vrouwen doorgaans minder invloedrijk, al waren hun stemmen soms monddood gemaakt, dat betekende nog niet dat zij géén stem hadden in het kapittel. Een stem die zich vaak uitdrukte in termen die bekend en geaccepteerd waren in de kring(en) waar vrouwen deel van uitmaakten of wilden maken. ${ }^{123}$ Religieuze vrouwen kozen begrippen en voorstellingen uit het katholieke, kerkelijke domein om zich uit te drukken, maar veranderden of verdraaiden de betekenis daar soms van. Mary Ward verzekerde kerkelijke gezagsdragers dat haar Instituut niet beoogde om taken voorbehouden aan priesters te annexeren; intussen legden zij en de haren zich toe op het apostolaat en de missie. De Filles de la Charité en hun stichter lieten hun openlijke aanspraak op de religieuze staat varen, maar hun kleding en vocabulaire bemiddelden een geheel andere boodschap. In kleding, taal, symbolen en riten vonden religieuze vrouwen mogelijkheden om de betekenissen van bestaande codes naar hun hand te zetten. ${ }^{124}$

\section{'Histoire religieuse'}

Als subjecten zijn vrouwen lange tijd veronachtzaamd in kerkhistorische studies. De kerk als instituut, haar gezagsdragers, alsook confessionele organisaties op maatschappelijk of politiek terrein waren prominente aandachtsvelden. Vrouwen speelden nauwelijks een rol in deze sferen. Hun domein was vooral de huiselijke

121 Bynum, 'The complexity of symbols'; Monteiro, Rooijakkers en Rosendaal, 'Van hoogaltaar tot tochtportaal'.

122 Van Heijst en Derks, 'Godsvrucht en gender', 25-26.

123 Ibidem, 29-32.

124 Vgl. Pomata, 'De geschiedenis van vrouwen', 92-97. 
kring of de beslotenheid van een religieuze gemeenschap - in de ogen van vele historici weinig belangwekkende onderzoeksterreinen. Dientengevolge werden vrouwen lange tijd genegeerd of alleen voorgesteld in stereotypen van volgzame, trouwe echtgenotes, moeders of religieuzen. ${ }^{125}$ Met de ontwikkeling van nieuwe onderzoeksbenaderingen, in het bijzonder de zogenaamde 'histoire religieuse', is in theorie meer ruimte ontstaan voor onderzoek naar de betekenis van geloof en geloven voor vrouwen. Deze benadering stelt niet de kerk als instituut centraal, maar juist de geloofsgemeenschap bestaande uit gelovigen en geestelijken. ${ }^{126}$ Een fundamenteel principe van de 'histoire religieuse' is het onderscheid tussen de door kerkelijke overheden voorgeschreven orde en de geleefde praktijk van zowel gelovigen als geestelijken. Laatstgenoemden moesten op grond van hun intermediaire positie rekening houden met de eisen die kerkelijke overheid én kerkvolk aan hen stelden. ${ }^{127}$

In de praktijk worden de mogelijkheden, die de 'histoire religieuse'-benadering geschapen heeft om te vragen naar de plaats en waarde die vrouwelijke gelovigen in het verleden toekenden aan religie bij de zingeving en de vormgeving van hun leven, nog maar schoorvoetend benut. Want hoewel de invloed van verschillende identiteitsaspecten (zoals klasse of leeftijd) in het onderzoek werden en worden meegewogen, blijkt het kerkhistorische onderzoeksinstrumentarium vaak theoretisch en conceptueel nog onvoldoende aangescherpt te zijn om de posities van vrouwen in het kerkelijke domein recht te kunnen doen. ${ }^{128}$

Vrouwenstudies, vrouwengeschiedenis in het bijzonder, biedt aanknopingspunten voor een dergelijke aanscherping. Beide vakgebieden beschouwen sekse als een wezenlijk aspect van identiteit, en als zodanig ook als variabele in de analyse van de acceptatie en adaptatie van cultuurvormen, waaronder religie. Door hun onderscheiden maatschappelijke posities hebben mannen en vrouwen historische processen als bijvoorbeeld de Reformatie of de Contrareformatie mogelijk anders ervaren. ${ }^{129}$ Hun deelname aan religieuze praktijken, de wijze waarop zij kerkelijke regelgeving geoperationaliseerd hebben in officiële en officieuze geloofspraktijken, of het belang dat zij toekenden aan religie in hun bestaan, werd beïnvloed door grenzen en verwachtingen die aan hen gesteld werden op grond van hun geslacht. Kerkelijke richtlijnen konden, ook wanneer ze universele aanspraken maakten, in uitwerking en beleving wel degelijk sekse-specifiek zijn. Deze richtlijnen representeren natuurlijk slechts een deel van een historische praktijk; zij geven weer wat wenselijk of noodzakelijk geacht werd. ${ }^{130}$ Aan vrouwen voorgeschreven gedra-

I25 Derks en Van Heijst, 'Katholieke vrouwencultuur'; Derks e.a., 'Res novae'.

126 Frijhoff, 'Van "histoire de l'église"'.

127 Rooijakkers en Van der Zee, 'Van volksgeloof naar religieuze volkscultuur'; Rooijakkers, 'Opereren op het snijpunt'.

128 Vgl. Derks, e.a., 'Res novae'.

129 Zie de verschillende bijdragen in Marshall, Women.

130 Rotsaert, Tussen Eva en Maria, verliest naar mijn idee dit onderscheid tussen voorschrift en praktijk 
gingen en hun feitelijke gedrag konden juist op gespannen voet met elkaar staan, hetgeen aanknopingspunten biedt voor het onderzoek naar de betekenissen van religie.

\section{Sekse als analysecategorie}

Dat de geschiedenis van religie en van de kerk als instituut geen sekse-neutraal onderzoeksterrein is, wordt ook binnen vrouwengeschiedenis pas sinds kort onderkend. ${ }^{131}$ Toen vrouwengeschiedenis in Nederland zich eind jaren zeventig geleidelijk ontwikkelde tot een academisch vakgebied, bestond hierbinnen nog weinig belangstelling voor het thema religie. Zoals gezegd domineerden marxistische en radicaal-feministische uitgangspunten het theoretisch kader van de jonge discipline, en werden kerk en clerus kortweg als onderdrukkende instanties benoemd. In deze optiek was katholieke vrouwen eigenlijk geen andere identiteit toebedacht dan die van machteloze slachtoffers, uitgesloten van de ambtelijke en bestuurlijke structuren van de kerk en onderworpen aan een strenge zedenleer. ${ }^{132}$

Gedurende de jaren tachtig verloor dit onderdrukkingsparadigma aan zeggingskracht, omdat het niet verklaarde hoe machtverschillen tussen de seksen tot stand kwamen en werden gereproduceerd. Er kwam een nieuw onderzoeksscenario tot ontwikkeling dat stoelt op gender of sekse. Sekse wordt in deze studie opgevat als een analytisch begrip, vergelijkbaar met ras of klasse. Het verwijst naar sociaalculturele betekenissen van vrouwelijkheid en mannelijkheid, die worden geconstrueerd en gelegitimeerd op grond van fysieke verschillen tussen mannen en vrouwen. Gebruik van het begrip sekse in plaats van gender lijkt geleidelijk terrein te winnen binnen vrouwenstudies - in het bijzonder binnen vrouwengeschiedenis - in Nederland. Oorspronkelijk werd gender geïntroduceerd om onderscheid te maken tussen culturele constructen en fysieke of biologische gegevenheden. ${ }^{133}$ Inmiddels wordt betwijfeld of een dergelijk onderscheid tussen 'cultuur' en 'natuur' zinvol is, omdat biologische 'feiten' en kenmerken op hun beurt eveneens culturele constructies zijn die in het verleden uiteenlopende betekenissen hebben gehad. ${ }^{134}$

De betekenissen die samenlevingen in verleden en heden geven aan vrouwelijkheid en mannelijkheid, brengen een - meest hiërarchische - ordening aan tussen de seksen. Deze constructies weerspiegelen én legitimeren sociale ordeningen en

te zeer uit het oog. Hoe normstellende bronnen vanuit een sekse-specifieke invalshoek wel vruchtbaar geanalyseerd kunnen worden illustreert Roper, The holy household; zie ook haar " Wille" und "Ehre"', 182 .

131 Bock, 'Women's history', 2I; 'Editorial', 5; Derks, e.a., 'Res novae'.

132 Derks en Van Heijst, 'Katholieke vrouwencultuur', 326-333.

133 Rubin, 'De handel in vrouwen'.

134 Voor het debat binnen vrouwenstudies over de begrippen sekse en gender en hun onderlinge verhouding, zie Brouns, 'Kernconcepten', 30-37. 
machtsverhoudingen tussen mannen en vrouwen. ${ }^{\mathrm{r} 35}$ Sekseverhoudingen in (historische) samenlevingen moeten dan ook primair opgevat worden als een sociaal organisatieprincipe en niet uitsluitend als uitvloeisel van economische of demografische factoren. ${ }^{136}$ Aan de hand van sekse als analytische categorie kunnen veranderende betekenissen van vrouwelijkheid en mannelijkheid in onderscheiden historische periodes en culturen in kaart gebracht worden. ${ }^{137}$ Als zodanig is sekse een fundamenteel instrument voor cultuurhistorisch onderzoek, ${ }^{138}$ waaronder de analyse van de betekenis van geloof en geloofsbeleving.

Niettemin zijn er vraagtekens geplaatst bij de bruikbaarheid van sekse als analytische categorie, in het bijzonder voor vrouwengeschiedenis van de vroegmoderne tijd. Volgens de historica Els Kloek was de ondergeschikte positie van vrouwen toen zó vanzelfsprekend, dat deze op generlei wijze ter discussie stond. ${ }^{139} \mathrm{Zij}$ beschrijft een samenleving waarin asymmetrische machtsverhoudingen tussen mannen en vrouwen onwrikbaar vastlagen. ${ }^{1{ }^{40}}$ Juist omdat rechten en maatschappelijke positie van vrouwen toen nog niet expliciet aan de orde waren, zou sekse voor de vroegmodeme tijd een moeilijk bruikbare analysecategorie zijn. ${ }^{141}$ De reeds genoemde studies van Rapley en Conrad over katholieke religieuze vrouwen, maar ook onderzoek naar de rol van vrouwen in of aan de rand van de protestantse traditie logenstraffen Kloeks stelling. ${ }^{142}$ Definities van vrouwelijkheid, taken en plichten van vrouwen waren in de zestiende en zeventiende eeuw wel degelijk voorwerp van discussie. Vrouwen zelf, maar ook mannen, tornden aan beperkingen die vrouwen traditioneel op grond van hun geslacht waren opgelegd - zij het met wisselend succes.

Sekse laat niet zomaar sporen in de bronnen achter, zoals Kloek veronderstelt, en het is evenmin een neutraal begrip. Het is een historische categorie waarvan de betekenis enkel door grondige historisering en contextualisering vastgesteld kan worden. ${ }^{43}$ Volgens de historicus Thomas Laqueur waren sociale en culturele definities van sekse in de vroegmoderne tijd meer van invloed op de maatschappelijke verhoudingen dan het biologisch geslacht of lichamelijke kenmerken. Noties over mannelijkheid en vrouwelijkheid structureerden de vroegmodeme sociale

135 Scott, 'Gender', 42-45. Aerts, 'Op zoek naar konstrukties van vrouwel,jkheid', introduceerde het begnip 'constructie'. Derks en Van Heıst, 'Katholheke vrouwencultuur', 343-344, prefereren de omschnjung 'configuranes van vrouwelı|kheid', die naar hun mening subuele betekensverschuivingen in identiteitsposities van vrouwen beter kan beschnjven.

136 Scot, 'Women's history', 25.

137 Idem, 'Gender', 32 (noor 7), 45; ze ook Bock, 'Women's history', I I-I5; 1dem, 'Women, gender and dichotomies', 87.

138 Vgl Hunt, 'Introduction', 18-19; Appleby, Hunt en Jacobs, Telling the truth, 226-227

139 Kloek, Wre hy zy

140 Z1e de recensie van Van de Pol; Schwegman, 'Vrouwengeschiedenis'.

141 Kloek, Wie htj $z$ j), 23, 33; vgl idem, 'Introduction', 13

142 Bıvoorbeeld De Baar, 'Van kerk naar sekte' en ıdem, 'Transgressing gender codes'.

$143 \mathrm{Vgl}$. Schwegman, 'Vrouwengeschiedenis', 505. 
orde. ${ }^{144}$ Sekse is voor onderzoek op het terrein van vrouwengeschiedenis van de vroegmoderne tijd daarom zelfs een onmisbare categorie van analyse.

Onderzoek naar de oorsprong en de betekenis van de kloppenstaat dient sekse als analytische categorie zeker als vertrekpunt te nemen, want haast uitsluitend vrouwen voelden zich hiertoe aangetrokken. ${ }^{145}$ Deze staat had voor hen mogelijk een bijzondere en andere betekenis dan voor mannen, die religieuze roeping, maatschappelijke bewogenheid, of een hang naar een celibatair bestaan op verschillende andere, kerkrechtelijk en maatschappelijk geaccepteerde wijzen konden vervullen. Op grond van hun maagdelijke staat namen kloppen tussenposities in, tussen leken enerzijds en religieuzen en geestelijken anderzijds, tussen vrouwen en mannen. Als 'grensgangers' bieden zij zicht op gedragscodes voor beide geslachten en laten zij zien welke gedragingen, gemoedstoestanden of uiterlijke kenmerken tijdgenoten verbonden met vrouwelijkheid en mannelijkheid. ${ }^{146}$ Deze associaties vonden een voedingsbodem in voorstellingen van vrouwelijkheid en mannelijkheid, zoals die door de katholieke geloofs- en zedenleer werden bemiddeld, maar waren in de vroegmodeme tijd geenszins onlosmakelijk verbonden met biologisch geslacht of fysieke eigenschappen. ${ }^{147}$

\section{I.4 Probleemstelling en onderzoeksvragen}

Het vertrouwde, taaie beeld van geestelijke maagden als gemankeerde kloosterlingen die de in nood verkerende katholieke kerk en clerus gewillig terzijde stonden, verhult dat de kloppenstaat herhaaldelijk voorwerp van discussie was. Zodra vrouwen in hun kleding en hun gedrag uiting gaven aan hun intentie vroom te leven in de wereld, was er onenigheid over de waardering van dit streven. In correspondentie, in boeken en, naar we mogen aannemen, ook in persoonlijke gesprekken debatteerden geestelijken over dit onderwerp. Ook geestelijke maagden zelf leverden bijdragen aan de definitie en legitimatie van hun leefwijze. In strijd en in harmonie werden er eisen geformuleerd waaraan dit kerkrechtelijk niet gefundeerde bestaan diende te voldoen. Hierdoor kwam er als het ware een nieuwe identiteit tot ontwikkeling: 'de' geestelijke maagd.

\section{Identiteitsconstructies}

Identiteiten worden veelal voorgesteld als vaststaand, onveranderlijk, reeds bestaand. De historica Joan Scott oordeelt daarentegen dat identiteiten juist in hoge

144 Laqueur, Making sex, 8.

145 Schulte van Kessel, Geest en vlees, 93.

I46 Vgl. Jansen, 'De vele gezıchten van genus', 53-54.

147 Dat geldt eveneens voor de late muddeleeuwen. Zie Bynum, fesus as mother, Kingma, 'Genderbending'. 
mate discursief zijn. ${ }^{14^{9}}$ Als zodanig zijn zij de uitkomst van historische processen die door vertoog aan subjecten een plaats toebedelen en zo hun ervaringen produceren. De doelstelling van historici om menselijke ervaring zichtbaar te maken in de geschiedschrijving schiet volgens Scott tekort, omdat de categorieën die deze ervaring benoemen, hun premissen en hun werking, niet nader onderzocht worden maar als a-historisch worden opgevat. Haar uitgangspunt, dat nauw aansluit bij linguistische theorieën die binnen cultuurgeschiedenis opgeld doen, ${ }^{149}$ is vruchtbaar voor een analyse van de toeschrijving van karakteristieken die categorieën mensen onderscheiden van een veronderstelde, meest onuitgesproken norm. Niet alleen het proces van verschil maken, maar ook de wijze waarop verschillen functioneerden in historische context, dienen voorwerp van onderzoek te zijn. ${ }^{\text {so }}$

Voor de analyse van de identiteit van geestelijke maagden is verschil een centraal begrip. Door de maagdelijke staat te verkiezen onderscheidden kloppen zich van hun seksegenoten. Dit verschil werd uitgedrukt in kleding, gedrag en, tot op zekere hoogte, ook in werkzaamheden. Eigentijdse definities van de kloppenstaat vertrokken vanuit verschillen tussen kloppen en religieuzen enerzijds, en kloppen en gewone lekevrouwen anderzijds. Langs die weg bekrachtigden zij impliciet de bestaande en cultureel geaccepteerde opties van klooster of gezin voor vrouwen. ${ }^{151}$ De tussenpositie van geestelijke maagden werd gedefinieerd door aan te geven wat zij niet behelsde: er waren geen geloften vereist; er bestond geen algemene en kerkelijk goedgekeurde regel; kloppen maakten geen deel uit van een orde. Daarin onderscheidden zij zich het scherpst van vrouwelijke religieuzen. Sinds de dertiende eeuw probeerde het kerkelijk gezag dit onderscheid al streng te bewaken. Wie religieus wilde leven, maar geen kloosterling wilde worden, mocht officieel ook geen enkel kenmerk van het kloosterleven aannemen. Leven in een gemeenschap, het afleggen van (eenvoudige) geloften of het dragen van (uniforme) herkenbare kleding, schond dit voorschrift. Zo eiste het vierde Concilie van Lateranen (I215) het monopolie van het religieuze leven op voor orden die volgens een erkende kloosterregel leefden. ${ }^{152}$ Daarmee werd de basis gelegd voor het verschil tussen religieuzen en degenen die tegenwoordig semi-religieuzen genoemd worden.

Wie er als semi-religieuzen worden beschouwd, wordt bepaald door de kerkelijke definitie van religieuzen. In deze betekeniscontekst verwijst semi-religieus naar een bestaan dat op het kerkelijk erkende religieuze leven lijkt, maar dat niet bestendigd is door de plechtige geloften of een erkende kloosterregel. Met het begrip semi-religieus wordt, haast paradoxaal, impliciet een kerkelijk interpretatiekader gekozen en onderschreven voor groepen die zich niet altijd lieten leiden door kerkelijke begrenzingen van de religieuze staat. Dit blijkt onder andere uit de ge-

148 Scott, 'The evidence'.

149 Chartier, 'Le monde'; Hunt, 'Introduction'; Appleby, Hunt en Jacob, Telling the truth, 198-237.

150 Scott, 'Deconstructie', 96-100.

$151 \mathrm{Vgl}$. Ziegler, Sculpture of compassion, 80-88.

152 Jerrell, The development, I9. 
schiedenis van verschillende religieuze vrouwengemeenschappen in vroegmodern Europa. Hun prioriteit lag veelal bij het leiden van een leven in de geest van het evangelie, al naar gelang de eigen mogelijkheden en de eisen van de tijd. Of kerkelijke erkenning hiervoor in het verschiet lag, was van later zorg. De omschrijving semi-religieus - met haar connotatie van half, tekortschietend, niet volledig religieus - doet onvoldoende recht aan het zelfverstaan van religieuze vrouwen, dat soms religieus, soms geestelijk of clericaal was. De keuze van deze definitie verhult bovendien dat de meningen over wat een religieus bestaan behelsde en wie als religieuzen aangemerkt mochten worden in de vroegmoderne tijd verdeeld waren.

Nog om een andere reden is verschil een fundamenteel concept voor het onderzoek naar de kloppenstaat. Vorm en actieradius van deze staat waren dermate variabel, dat er eigenlijk niet meer over 'de' geestelijke maagden of 'de' kloppenstaat gesproken kan worden. Met de keuze van biechtvaders en geestelijk leidsmannen gaven de 'paters-' en 'wereldkloppen' blijk van een uiteenlopende spirituele oriëntatie. Of een geestelijke maagd in of buiten een kloppenvergadering leefde, was van invloed op haar werkzaamheden en wellicht ook op haar status. Bovendien was het, zo heeft Theissing laten zien, acceptabel dat kloppen al naar gelang hun sociale en economische positie, vorm gaven aan hun leefwijze. De werking van dergelijke verschillen is van belang voor een beter begrip van de betekenis van de kloppenstaat voor vrouwen zelf.

Welke vertogen hebben bijgedragen tot de constructie van de identiteit van geestelijke maagden? Geestelijke maagden hadden hier zelf een belangrijk aandeel in. Door hun werkzaamheden, gedragingen en kleding bakenden zij hun positie af ten opzichte van anderen in de zeventiende-eeuwse samenleving, leken, religieuzen en geestelijken. Deze kenmerken werden ten dele voorgeschreven door de priesters die als hun biechtvader en geestelijk leidsman functioneerden. Onderzoek naar hoe kloppen deze voorschriften volgden of juist aanpasten, kan licht werpen op hun eigen aandeel in de ontwikkeling van de kloppenstaat en de wijze waarop zij deelnamen aan het proces van betekenisgeving.

De bijdragen van geestelijken in dit proces verdienen natuurlijk ook nader onderzoek. Enige differentiatie binnen deze groep is op zijn plaats, omdat de seculieren en de leden van verschillende reguliere orden mogelijk uiteenlopende opvattingen koesterden over de identiteit en de status van geestelijke maagden. Er bestond geen uniforme leefregel met voorschriften ten aanzien van leer en leven van geestelijke maagden. In beginsel bepaalde de biechtvader hoe zijn geestelijke dochter haar kloppenstaat zou concretiseren. Sommige van deze leefregels en gedragsvoorschriften zijn in druk uitgegeven. Hierin zijn denkbeelden van de geestelijkheid over de kloppenstaat gestold. Hun standpunten kwamen natuurlijk ook tot uitdrukking in de persoonlijke, spirituele begeleiding van kloppen, maar zijn als onderdeel van de orale cultuur niet meer te achterhalen. 
De vestiging van een identiteit steunt niet uitsluitend op het zelfbeeld dat een individu of een groep uitdraagt, maar hangt ook af van de perceptie, acceptatie en accomodatie hiervan door de omgeving. ${ }^{153}$ Dat geldt misschien wel in het bijzonder voor degenen, wier leefwijze maatschappelijk noch kerkelijk verankerd was, zoals de kloppen. De perceptie van deze religieuze vrouwen door de buitenwereld staafde die status. Een vrouw werd als klop beschouwd om haar vrome leefwijze. ${ }^{154}$ Haar identiteit stoelde niet alleen op eigen gedrag en leefwijze, maar vooral op de waarneming en benoeming hiervan door anderen. Het functioneren van geestelijke maagden was sterk afhankelijk van de reacties op hun bestaan en werkzaamheid. Vooral de houding van de geestelijkheid was fundamenteel voor de ruimte die geestelijke maagden toebedeeld kregen of zich konden toeëigenen voor hun activiteiten. ${ }^{55}$ Vanuit dat oogpunt wordt de confidentiële relatie tussen biechtvader en geestelijke dochter - een pijler van de kloppenstaat en wezenlijk voor letterlijk haar doen en laten - nader onderzocht.

De dynamiek tussen zelfbeeld en perceptie door anderen, geestelijken en leken, onttrekt zich in het geval van geestelijke maagden vaak aan de waarneming. Dit is hoofdzakelijk het gevolg van een gebrekkig inzicht in het zelfbeeld van kloppen, waarover historisch onderzoek maar bitter weinig heeft weten te achterhalen. De uiterlijke kenmerken (kleding, gedragingen, arbeid) van de identiteit van geestelijke maagden zijn bekend. Maar hoe zagen geestelijke maagden hun positie in verhouding tot 'echte' religieuzen, andere vrouwen of priesters? Was hun zelfbeeld religieus of misschien, net als dat van sommige andere religieuze vrouwen in de vroegmoderne tijd, zelfs geestelijk?

\section{Reformatie en Contrareformatie}

De idealen van de Contrareformatie waren, zoals gezegd, drijfveer en legitimatie voor verscheidene vrouwen en geestelijken om nieuwe religieuze bestaansvormen te ontwikkelen. Vormt de Contrareformatie, naast de Reformatie waarvan het belang al wordt onderkend, niet ook een belangrijk referentiekader voor een onderzoek naar de ontwikkeling van de kloppenstaat? Opmerkelijk genoeg worden geestelijke maagden in de Zuidelijke Nederlanden "een typisch "produkt" van de contrareformatie' genoemd. ${ }^{156}$ En anders dan Schulte van Kessel suggereerde, belemmerde de 'contrareformatorische claustrofilie' - een verwijzing naar de Trentse monastieke hervorming van religieuze vrouwengemeenschappen - hier niet het ontstaan van semi-religieuze of aktieve religieuze leefwijzen, maar riep deze on-

153 Frijhoff, 'Identiteit en identiteitsbesef', 614-615, 623.

$154 \mathrm{Vgl}$. Theissing, Over klopjes, 2-3, die een overeenkomst tussen begijnen en kloppen impliceert in dit verband.

$155 \mathrm{Vgl}$. Scott, 'The evidence', 793.

156 Therry, De religieuze beleving, 75. 
bedoeld juist op. ${ }^{157}$ Het onderscheid tussen de Zuidnederlandse geestelijke dochters en de Noordnederlandse kloppen is volgens sommigen te verwaarlozen. ${ }^{158} \mathrm{Om}$ gekeerd wordt slechts met grote voorzichtigheid op mogelijke overeenkomsten gewezen. ${ }^{159}$

Gezien de lacunes in de katholieke zielzorg en de gebrekkige kerkelijke infrastructuur in de Noordelijke Nederlanden vanaf het einde van de zestiende eeuw, waren hervormingsinitiatieven hier noodzakelijkerwijs kleinschalig en meer toegesneden op de specifieke noden en behoeften van de lokale kerk dan op de concrete Trentse richtlijnen. ${ }^{160}$ Toch tekende een zeker herstel zich af vanaf het derde decennium van de zeventiende eeuw. De toenmalige apostolisch vicaris Philippus Rovenius wist zich bij zijn pastoraal beleid sterk geïnspireerd door Trentse decreten. Vanaf 1633 begon hij de eerste lijnen van een 'rekatholiseringsstrategie' uit te zetten. Hierbij kon hij rekenen op de medewerking van een groeiend aantal priesters die aan de seminaries te Keulen en Leuven een op Trentse leest geschoeide opleiding hadden genoten. ${ }^{161}$ Ook de inzet van geëngageerde leken werd gewaardeerd, onder meer bij het geloofsonderricht, dat zich kenmerkte door een typisch contrareformatorische belijdenisvroomheid die de rooms-katholieke dogmata en geschilpunten met de Nederduits-gereformeerde religie benadrukte. Rovenius hechtte groot belang aan de beoefening van vroomheid in de wereld, hetgeen zijn voorkeur voor lekengemeenschappen, zoals broederschapen, maar ook voor de kloppenstaat verklaart. ${ }^{162}$ Hoewel de Trentse directieven in naar tijd en omstandigheden aangepaste vormen ingang vonden in de Noordelijke Nederlanden, heerste er in katholieke kring onder geestelijken en geëngageerde leken niettemin een mentaal-religieus klımaat, dat gekenmerkt werd door een streven naar interne kerkelijke hervorming en naar afbakening van een eigen, katholieke identiteit. ${ }^{163}$

Dat de invloed van contrareformatorische idealen zich ook binnen de Noordelijke Nederlanden deed gelden, maakt andere perspectieven mogelijk op de oorsprong van de kloppenstaat dan het tot dusverre dominante interpretatiekader van calvinisering en onderdrukking van het katholicisme. Mogelijk werden geestelijke maagden tot inzet geinspireerd door het verlangen de idealen van een doorleefde vroomheid in de wereld in de praktijk te brengen en via actief apostolaat aan anderen door te geven. Niet alleen een streven naar het behoud van de invloed

157 Schulte van Kessel, Geest en vlees, I05.

158 Ceyssens, 'De congregat1e', I2, De Vroede, 'Kwezels' en 'zusters', hoofdstukken I en $\Pi$.

159 Theissung, Over klopjes, 16-17.

160 Spiert, 'Succes en falen', 58.

16I Idem, 'Jansenisme', 154; 1dem, 'De katholıeke geestel1)ke leıders', 5-6 Ook Rogier, Geschiedents, II, o a $37,76,100-108$.

162 Visser, Rovenius, vgl idem, 'De mogelinke invloed', 215.

163 Spiert, 'De katholieke geestelıke leıders', 6. Vgl. Rogier, 'De culus van Sint W/llibrord', 249-250 Fruin, 'De wederopluikıng', 285-286, en Rogier, Geschıedenis, I, 255-256, wi)zen erop dat ook Rovenuus' voorganger Sasbout Vosmeer in belangnjke mate bıjdroeg aan de introductue van het gedachtengoed van Trente 
van het katholicisme, maar ook daadwerkelijke herovering van op de protestanten verloren religieus terrein kan hen ertoe aangezet hebben de kloppenstaat boven de intrede in een klooster te verkiezen. In hun ontplooiing werden zij niet beknot door de kloosterhervormingen, waar elders strak de hand aan werd gehouden. Paradoxaal genoeg schiep het verbod op de katholieke eredienst in de Noordelijke Nederlanden misschien extra ruimte voor de ontwikkeling van de kloppenstaat. ${ }^{164}$ Ruimte die werd benut door vrouwen en door sommige geestelijken, wier welwillende reacties op geestelijke maagden en hun werkzaamheden mogelijk in het licht van de multi-confessionele Noordnederlandse samenleving moeten worden gezien.

\section{I.5 Bronnen en opzet van deze studie}

Om de ontwikkeling en de betekenis van de nieuwe, in de katholieke confessie gegrondveste kloppenstaat te traceren, zijn hoofdzakelijk twee typen bronnen geanalyseerd: enerzijds devotieboeken die speciaal voor geestelijke maagden werden geschreven door seculieren en regulieren, en anderzijds de geschriften van twee geestelijke maagden.

Tot dusver zijn de devotieboeken bedoeld voor kloppen nooit aan een inhoudelijke analyse onderworpen. Theissing heeft geprobeerd uit deze stichtelijke werken gegevens over de dagelijkse praktijk van het kloppenleven af te leiden. Deze werken, voortaan kortweg kloppenboeken genoemd, zijn hier op grond van hun normatieve karakter echter geen betrouwbare graadmeters voor. Wél plaatsen zij ons midden in het zeventiende-eeuwse debat over de vraag of de religieuze leefwijze buiten het klooster een staat vergelijkbaar met de religieuze of de huwelijkse staat was. Aan de hand van de kloppenboeken wordt in kaart gebracht hoe verschillende seculiere en reguliere priesters de leefwijze van geestelijke maagden definieerden, hoe zij hun identiteit en status binnen het kerkelijke domein benoemden, en op welke wijze zij de gezagsverhoudingen tussen deze maagden en hun leidsmannen voorstelden.

Bronnen van de hand van geestelijke maagden zijn, zoals geschriften van vroegmoderne vrouwen in het algemeen, bijzonder schaars. Agnes van Heilsbach (1597I640) en Joanna van Randenraedt ( $1610-1684$ ) hebben egodocumenten nagelaten. Geen van beiden was aangesloten bij een vergadering. $\mathrm{Zij}$ leefden en werkten in Roermond, een stad die net buiten het territorium van de Republiek lag en institutioneel tot de Zuidelijke of Spaanse Nederlanden behoorde. Van de meer dan vierduizend pagina's (autografen en eigentijdse afschriften) overgeleverde notities van beide vrouwen worden vooral de gewetensrekeningen onderzocht. Via deze bijzondere spirituele egodocumenten, die op last van hun biechtvader werden geschreven, kan worden vastgesteld of en hoe deze twee kloppen zich het ideaal van

Dekker, 'Vrouwen', 423. 
de maagdelijke religieuze levensstaat in de wereld, zoals dat door kloppenboeken werd gepropageerd, eigen gemaakt hebben. Bovendien bieden deze bronnen nieuwe gezichtspunten voor de analyse van de verwevenheid van sekse, geloofsovertuiging en identiteit. Deze geschriften laten de spanningen zien die voor vrouwen inherent waren aan de ambitie om God buiten het klooster te dienen; spanningen waar andere geestelijke maagden zich misschien ook mee geconfronteerd zagen. Deze twee maagden zijn uiteraard niet representatief voor de kloppen in of buiten de Republiek. Vorm en invulling van het kloppenbestaan waren, zoals gezegd, dermate individueel en variabel dat de kwestie van representativiteit illusoir is. Toch overstiigen de gewetensrekeningen van Van Heilsbach en Van Randenraedt het unieke en subjectieve ook enigszins, omdat zij als individuen in zekere zin een kruispunt waren van maatschappelijke en persoonlijke omstandigheden. ${ }^{165}$

Deze studie is begrensd naar tijd en ruimte; het temporeel zwaartepunt ligt bij de zeventiende eeuw, soms met uitlopers naar zowel het einde van de zestiende als het begin van de achttiende eeuw; in geografisch opzicht concentreert de studie zich op het grondgebied van het huidige Nederland. Naar zeventiende-eeuwse maatstaven worden daartoe gerekend de Utrechtse kerkprovincie, die samenviel met het territorium van de Republiek der Zeven Verenigde Provinciën, en die delen van de huidige provincies Zeeland, Noord-Brabant en Limburg die bij de Zuidnederlandse bisdommen Brugge, Gent, Antwerpen, 's-Hertogenbosch, Roermond en het prinsbisdom Luik behoorden. In navolging van L.J. Rogier, die zijn nog altijd invloedrijke standaardwerk de titel Geschiedenis van het katholicisme in Noord-Nederland in de r6e en de 17e eeuz meegaf, zal dit gebied voortaan aangeduid worden als Noord-Nederland.

Dit boek is als volgt opgebouwd. In het hierna volgende hoofdstuk worden aantal, spreiding, woonvormen en werkzaamheden van geestelijke maagden in NoordNederland beschreven. Hun materiële en immateriële bijdragen aan het behoud en het herstel van het katholicisme op lokaal niveau, worden eveneens nader beschouwd vanuit de specifieke positie die geestelijke maagden innamen tussen priesters en leken. Hierbij gaat, zoals in de gehele studie, de aandacht vooral uit naar die kloppen die buiten vergaderingen in kleine groepjes of zelfstandig woonden en werkten. Het derde hoofdstuk is gewijd aan een analyse van de kloppenboeken. Het opent met een verkenning van het genre en een poging om vast te stellen in hoeverre dit aftrek vond onder zijn voornaamste doelgroep, geestelijke maagden. Bovenal worden in dit hoofdstuk de idealen geanalyseerd die geestelijken voor ogen stonden ten aanzien van de kloppenstaat. Hun voorstellingen kunnen niet los gezien worden van heersende opvattingen over de wereld, het vrouwelijk geslacht en gezagsverhoudingen tussen de seksen.

165 Vgl. Mossink, 'Naar het leven'; Frijhoff, 'Normeren of waarderen', 18-20. 
In de volgende twee hoofdstukken wordt onderzocht welk aandeel geestelijke maagden zelf hadden in de vormgeving en beleving van de kloppenstaat. De zoektocht naar hun eigen 'stem' op basis van de gewetensrekeningen van Van Heilsbach en Van Randenraedt wordt in twee gedeelten afgelegd. In het vierde hoofdstuk wordt verkend hoe zij meepraatten of tegenspraken via hun gewetensrekeningen. Vorm en inhoud zijn enkel te begrijpen vanuit de verhouding tussen biechtvader en geestelijke dochter. Gewetensrekeningen waren namelijk niet enkel controle-instrumenten waardoor een biechtvader zich op de hoogte stelde van de spirituele ontwikkeling van zijn penitentes. $\mathrm{Zij}$ waren ook media waarmee deze vrouwen zelf konden onderhandelen over hun positie, staat, taken en gezag. Kortom, geschriften waarmee zij hun stem konden laten horen. Een stem die zich weliswaar vaak uitdrukte in voorstellingen van vrouwelijkheid en vroomheid die in katholieke kring algemene geldigheid bezaten, maar die toch ook een geheel eigen geluid liet horen. Wat zij precies te zeggen hadden komt aan de orde in het vijfde hoofdstuk. Hun katholieke geloofsovertuiging, die zij bedreigd zagen door de gevolgen van de Reformatie, vormde zowel een impuls als een legitimatie voor eigen handelen. Hun opvattingen over de status van de kloppenstaat alsook de gezagsverhoudingen ten opzichte van hun leidsmannen en andere geestelijke maagden verduidelijken dat kerkelijke voorschriften en het zelfbeeld van religieuze vrouwen lang niet altijd parallel liepen. De belangrijkste bevindingen worden in de slotbeschouwing samengevat. 


\section{II \\ Dienaressen in de wijngaard des Heren}

In $158 \mathrm{I}$ werd van overheidswege de katholieke eredienst in de Noordnederlandse gewesten verboden. Kerken en kerkelijke goederen werden geconfisqueerd en aangewend voor de nieuwe publieke kerk, de Nederduits-gereformeerde kerk. Sindsdien werden zielzorg, prediking en geloofsonderricht door en voor katholieken min of meer clandestien voortgezet. Er bestonden lokale verschillen in de mate van vrijheid die katholieken werd toegestaan. In het gewest Holland en in steden als Amsterdam en Haarlem konden zij zich bijvoorbeeld wel kerkelijk engageren, mits zij in politiek opzicht geen partij kozen in de Opstand en zich onthielden van publieke geloofsuitingen. Ondanks de cultusonvrijheid was de gewetensvrijheid der katholieken gewaarborgd, doordat zij hun devotie in huiselijke kring mochten voortzetten. Zo werd het recht op gewetensvrijheid, vastgelegd in de Pacificatie van Gent (1576) en de Unie van Utrecht (1579), gewaarborgd zonder dat de bevoorrechte positie van de gereformeerde kerk in gevaar kwam. Deze vorm van gewetensvrijheid beroofde katholieke gelovigen echter van de mogelijkheid sacramenten te ontvangen, waarin de genade Gods werd geschonken, en tastte daarom de wezenlijke kern van hun geloofsbeleving aan. ' Zonder de vrijheid om de sacramenten te mogen ontvangen, bestond er voor katholieken geen gewetensvrijheid, zo oordeelde apostolisch vicaris Philippus Rovenius scherp. ${ }^{2}$

Publieke manifestaties van katholieke geloofsovertuiging zoals de mis, doop- en uitvaartplechtigheden, processies en bedevaarten behoorden tot het verleden. Geestelijken mochten niet langer als zodanig herkenbaar gekleed gaan. Evenmin mochten religieuzen, mannen en vrouwen, zich in het openbaar in hun habijt vertonen. ${ }^{3}$ Vrouwelijke leken kon men echter geen kleding verbieden, laat staan voorschrijven. Zedig in het zwart geklede geestelijke maagden bepaalden zodoende steeds meer het gezicht van de katholieken in diaspora. Hoewel zij geen uniform of habijt droegen, was de tekenwaarde van hun donkere, sobere kleding onmiskenbaar. Al waren kloppen naar de letter van het kerkrecht geen vrouwelijke religieuzen, zij hadden een religieuze uitstraling. Zij verwezen naar de katholieke geloofsgemeenschap en toonden aan dat het katholicisme overleefde. Zij belichaamden voor iedereen zichtbaar de maagdelijke staat, die door protestantse hervormers scherp onder vuur was genomen. Door hun aanwezigheid en kleding alleen al po-

I Nijenhuis, 'Relıgiegeschiedenis I621-1648', 397-399.

2 Rogier, Geschiedenus, II, 73.

3 Plakkaat van 2I november 1584. Groot placaet-boeck, I, 21 I; Wiltens, Kerkelyk Plakaat-Boek, I, 393. 
lemiseerden geestelijke maagden als het ware in levenden lijve met het nieuwe protestantse geloof.

De Hollandse Zending kampte zeker in de eerste decennia van de zeventiende eeuw met een gebrek aan zielzorgers. Daarom moesten de werkzame seculiere en reguliere priesters soms meer dan een parochie bedienen. Als gevolg van het feitelijke verval van de bisschoppelijke hiërarchie werd niet langer over parochies en pastoors gesproken, maar over staties die werden bediend door missionarissen. Vele van de 220 priesters die aan het begin van de zeventiende eeuw werkzaam waren in de Hollandse Zending, trokken anvankelijk zonder vaste woon- of verblijfplaats rond. Voor onderdak, voedsel, financiële middelen en een plaats om te kerken waren zij afhankelijk van katholieke leken. Voorzieningen op het terrein van geloofsonderwijs, armen- en ziekenzorg waren gebrekkig. Deze achterstandssituatie werd verscherpt doordat het katholicisme zijn religieuze monopolie na de Reformatie had verloren. Materiële en immateriële bijdragen van leken, onder wie kloppen, waren niet alleen welkom maar ook noodzakelijk voor het behoud en de confessionele profilering van het katholicisme in Noord-Nederland. Hieraan leverden geestelijke maagden een belangrijke bijdrage door te catechiseren, zieken en armen bij te staan, priesters te huisvesten, en schuilkerken in te richten en te onderhouden.

Het is uitermate moeilijk om vast te stellen hoeveel geestelijke maagden de Noordnederlandse kerk in diaspora gedurende de zeventiende eeuw telde, want zij gaan in de bronnen vaak achter anonieme omschrijvingen schuil. Een voorzichtige schatting van hun aantal en spreiding, die in de eerste paragraaf van dit hoofdstuk wordt gepresenteerd, illustreert dat een aanzienlijk aantal katholieke vrouwen voor de kloppenstaat koos. De tweede en derde paragraaf zijn gewijd aan woonen organisatievormen van geestelijke maagden. Hierdoor ontstaat een beeld van de alledaagse omstandigheden waaronder zij leefden en werkten, alsook van de spanningen die inherent waren aan het leiden van een geestelijk leven in de wereld. Welke werkzaamheden zij hoofdzakelijk verrichtten, wordt in de vierde paragraaf beschreven. Hun aandeel in het confessionaliseringsproces wordt in de vijfde paragraaf nader verkend door een analyse van hun positie tussen geestelijkheid en gelovigen. Deze positie werd mede beïnvloed door verschillende kerk-politieke en spirituele geschillen binnen de Noordnederlandse kerk. Dat geestelijke maagden ondanks hun kerkrechtelijk niet erkende status en hun sekse toch een belangrijke bijdrage leverden aan het behoud en het herstel van het katholicisme bracht op zichzelf al de nodige spanningen teweeg. De arbeidsverhouding tussen de dienaren en de dienaressen in de wijngaard des Heren, die werd gekenmerkt door wederzijdse afhankelijkheid, vertoonde, zo wordt in de slotparagraaf uiteengezet, bij tijd en wijle barsten. 


\section{II.I 'Swermen cloppen': aantal en spreiding}

De vraag hoeveel kloppen er gedurende de zeventiende eeuw in Noord-Nederland waren, is moeilık te beantwoorden. Een eerste complicatie wordt gevormd door de bronnen. In katholieke bronnen is, zoals in het vonge hoofdstuk reeds is opgemerkt, een grote terughoudendheid te bespeuren waar het gaat om geestelijke maagden Concrete aantallen zijn in die bronnen daarom ook schaars. Bronnen van protestantse signatuur vertonen de neiging het getal der kloppen te overdri)ven. De gezagsdragers van de jonge publieke kerk zagen deze vrouwen per definitie als een bedreiging. In classicale en kerkeraadsvergaderingen, maar ook tegenover lokale en gewestelıke besturen fulmineerden predıkanten van de Nederduitsgereformeerde kerk regelmatıg tegen de kloppen die verderfelıke, want katholieke, denkbeelden verspreidden onder de bevolking. Tydens de Grote Vergadenng (1651), waar de miltair-staatkundige en politıek-religieuze verhoudingen sinds de Vrede van Munster (I648) aan de orde werden gesteld, werd hun aantal op maar liefst 20.000 geschat. ${ }^{4}$ Dit getal getuigt van schromelyjke overdriving, die in de gegeven situatie zeker een andere functie had dan het vaststellen van de werkelıke omvang van de groep kloppen. ${ }^{5}$

Behalve dat contemporaine katholieke en protestantse waarnemers net onbevooroordeeld waren, hadden zil ook nog eens te kampen met een definitie-probleem. Want hoe kon men onomstotelık vaststellen dat een vrouw geestelıke maagd was ${ }^{\supset}$ Vaak werd de kleding als indıcator gehanteerd. Kledingvoorschnften in zeventiende-eeuwse kloppenboeken beperken zich tot zwarte, zedige en sobere kleding, zonder enıge opsmuk Maar een dergelıjke dracht was ook gebruıkelı)k voor weduwen of oudere vrouwen, zonder dat daaraan enige religieuze betekenıs verbonden werd. De schaarse zeventuende-eeuwse afbeeldıngen van geestelıke maagden verduidelıken dat specifieke kenmerken als de tipmuts of een brede bef toen nog niet tot hun 'dress-code' behoorden. ${ }^{6}$ Vrouwen die zich niet tot het geestelı)k leven in de wereld hadden bekend, droegen eveneens een dergelı)ke tıpmuts. ${ }^{7}$ De geestelıkke maagden op de tutelpagina van Schoenius' kloppenboek De weg der Suyverheyt van d'Hollantse Maegden (1676) (afb. I) dragen bıjvoorbeeld noch een brede kraag of bef, noch een 'kloppentup'. Afbeeldingen van geestelıjke maagden getooid met tipmuts en brede bef dateren uit de achttiende eeuw. Vaak betreft het beeltenussen op devotieprentjes, hetgeen wisst op een zekere stereotypenng van deze dracht in een mate die voor de zeventrende eeuw niet als zodanig

4 Theissing, Over klopjes, 65-66

5 Overschatting van het aantal religieuze vrouwen buten kloostermuren is ovengens geen typisch Noordnederlands fenomeen In het vroegmodeme Spanje werd het aantal beatas, te vergelıjken met de kloppen, ook vaak schromelık overschat Weber, 'Between ecstacy and exorcism', 224

6 In tegenstelling tot Schulte van Kessel, Geest en vlees, 66, idem, 'Vis noch vlees', 177

7 Ook gehuwde vrouwen werden met tipmuts afgebeeld, zie bıرvoorbeeld twee schildenjen van Pieter de Hooch, weergegeven in Schama, The embarrassment of nchess, 394 en 397 


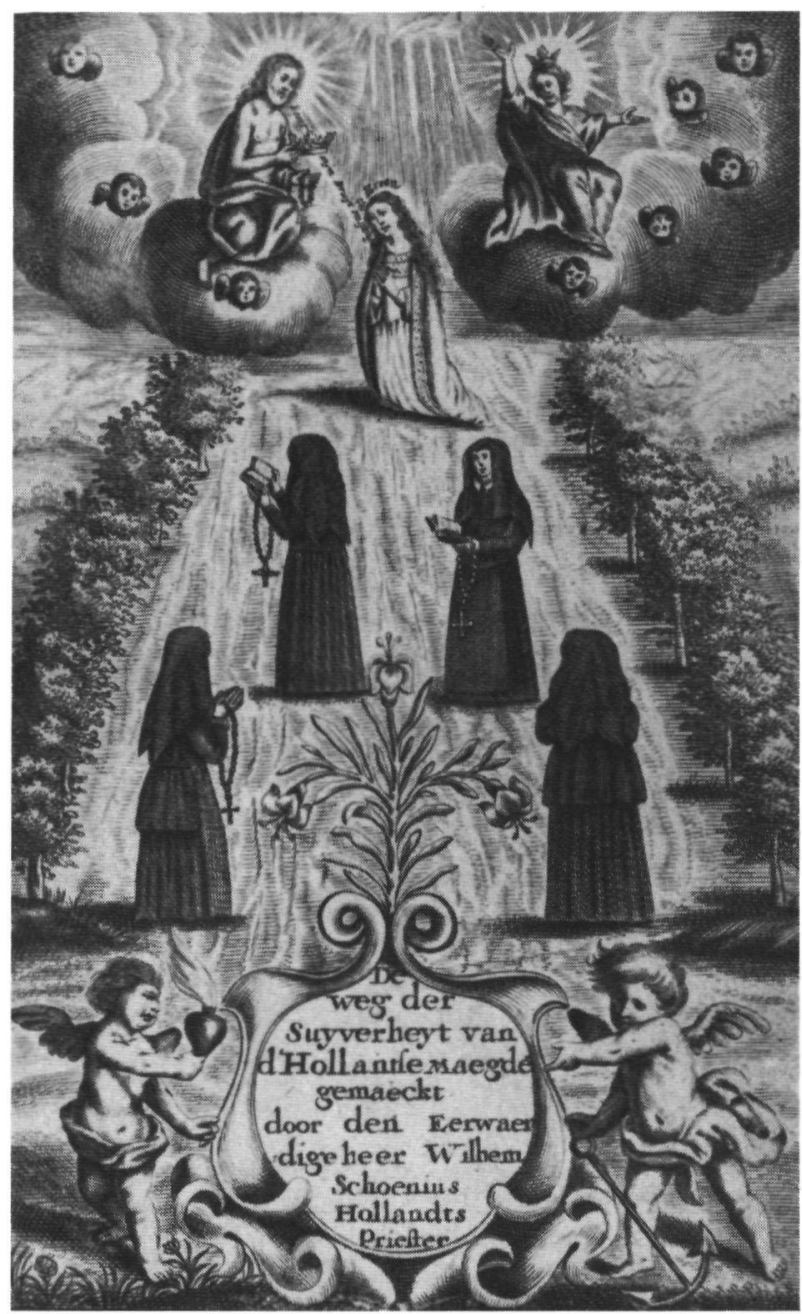

Afb. I De op het titelblad van Willem Schoenius' De weg der Suyverheyt van d'Hollantsche Maegden afgebeelde geestelijke maagden dragen nog niet de tipmuts en brede witte kraag die in de achttiende eeuw als karakteristiek voor kloppen golden.

kan worden vastgesteld. Kleding was daarom geen volledig betrouwbare aanwijzing; zij heeft contemporaine waarnemers soms misschien misleid en verleid tot het uitdelen van het etiket 'klop' waar dit geenszins van toepassing was.

Bronnen die getalsmatige opgaven doen van kloppen moeten vanwege overdrijving, onderschatting en determinatie-problemen met grote voorzichtigheid betracht worden. Een schatting van het aantal kloppen gedurende de zeventiende eeuw is derhalve een netelige aangelegenheid. Tot dusver heeft alleen de historica Elisja Schulte van Kessel zich aan een dergelijke schatting gewaagd. Volgens haar zouden er in de tweede helft van de zeventiende eeuw ongeveer 3500 geestelijke maagden 
geweest zijn. Haar schatting is gebaseerd op een gemiddelde van zeven geestelijke maagden per priester. Met de stijging van het aantal priesters zouden, bij een gelijkblijvend aantal kloppen, de getalsmatige verhoudingen tussen priesters en kloppen veranderd zijn van $1: 7$ tot $1: 5 .{ }^{8}$ Van een gestage stijging van het priestertal gedurende de tweede helft van de zeventiende eeuw was echter, anders dan Schulte van Kessel suggereert, allerminst sprake. Bedroeg het aantal zielzorgers in de Hollandse Zending volgens de opgave van apostolisch vicarissen en nuntii in 1645 nog ca. 440 , in 1668 was dat gestegen tot 508 . Maar in 1701 bedroeg het aantal slechts $466,{ }^{9}$ hetgeen wijst op een geleidelijke daling sinds 1668 .

Een betrouwbaarder schatting kan gemaakt worden aan de hand van visitatierapporten van 94 staties die tussen I69I en I695 werden opgemaakt, wellicht als bouwstenen voor een visitatieverslag in opdracht van toenmalig apostolisch vicaris Petrus Codde (1688-1702). ${ }^{10}$ Op basis van een korte vragenlijst wordt verslag gedaan van de bedienaar van de statie (naam, leeftijd, duur van zijn priesterschap en duur van zijn aanstelling in de huidige statie). Dan volgen opgaven van het aantal communicanten en wanneer het heilig vormsel voor de laatste maal is toegediend in de betreffende statue. Ook moet de verantwoordelijke priester antwoord geven op de vraag hoeveel geestelijke maagden zijn statie telt. Anders dan in andere missie- en visitatieverslagen worden kloppen in dit verslag als een aparte groep vermeld en geteld. Hun uitzonderlijke positie binnen de staties - geen echte leken - wordt daarmee bevestigd.

De visitatierapporten bevatten in hoofdzaak gegevens over Friesland, WestFriesland, Holland en Utrecht (zie bijlage I). Voor Groningen en Zeeland zijn geen gegevens voorhanden en de opgaven voor Overijssel en Gelderland zijn zeer summier. Zeeuws-Vlaanderen, Brabant en Limburg ontbreken in het overzicht, omdat deze territoria kerkrechtelijk tot de Zuidnederlandse bisdommen Brugge, Gent, Antwerpen, 's-Hertogenbosch, Roermond en Luik behoorden. Helaas ontbreken daarom afdoende getalsmatige gegevens om een nauwkeurige schatting voor geheel Noord-Nederland te doen.

Alvorens enige gegevens uit deze visitatierapporten worden gepresenteerd, verdient de betrouwbaarheid ervan enige toelichting. Uit de gegevens is niet op te maken wie de opgave deed. De ronde aantallen communicanten, eindigend op één of meer nullen, wijzen op schattingen. Deze indruk wordt bevestigd door de frequente toevoeging van 'circiter' (circa), alsook door opgaven als ' 800 à 1000'. Duidelijk is wel dat in deze verslagen opgaven van communicanten worden gedaan, en niet van katholieken. ${ }^{\mathrm{II}}$ Tot de communicanten worden katholieken

8 Schulte van Kessel, 'V1s noch vlees', 179. Haar eerdere schatting gedaan in Geest en vlees, 53, tuen kJoppen op iedere pnester, is hiermee herroepen

9 Spiertz, 'De katholieke geestelijke leiders', 20.

Io RAU, $A O B C$, inv.nr. 679, vsitatierapporten I691-I695, opgenomen als bijlage I in dit boek.

II De kwestue communicanten of katholieken staat centraal in het debat naar aanleiding van De Kok, Nederland op de breuklyn Rome-Reformatre Volgens De Kok geeft het missieverslag van Jacobus de la 
van twaalf jaar en ouder gerekend, hetgeen doorgaans neerkomt op circa tweederde van het totale aantal katholieken. Het aantal katholieken zal dus hoger gelegen hebben, al is het in verband met de regionale verschillen in bevolkingsopbouw moeilijk te zeggen hoeveel hoger. ${ }^{\mathbf{1 2}}$ Anders dan de communicantencijfers lijken de opgaven van het aantal kloppen vrij accuraat. Ronde getallen zijn hier eerder uitzondering dan regel; schattingen worden vaak met kleine marges gedaan, bijvoorbeeld 32 à 33 , of 85 à 86 .

Het antwoord op de vraag hoeveel kloppen een statie telt, loopt nogal uiteen. Van de 94 staties die opgave deden of waar onderzoek was ingesteld, maakten er 20 geen melding van kloppen. De wereldheer Zuurhuys geeft bijvoorbeeld expliciet op dat er 'nullas devotas', geen kloppen, zijn in de statie in het Friese Follega die hij bedient. In hoeverre de opgave van de andere staties zonder kloppen accuraat is, valt niet vast te stellen. Voor dit onderzoek is ervan uitgegaan dat geen opgave betekent dat er geen kJoppen waren in de desbetreffende statie. Eén op de vijf staties telde geen kloppen. Meer dan de helft van de staties met kloppen telde er tussen de io en 40 (tabel I).

Tabel I. Verdeling aantal kloppen over staties en gemiddeld aantal kloppen per state rond 1695

\begin{tabular}{rrrrc}
\hline $\begin{array}{l}\text { Aantal kloppen } \\
\text { verdeeld in klassen } \\
\text { (10 als interval) }\end{array}$ & $\begin{array}{l}\text { aantal } \\
\text { kloppen }\end{array}$ & $\begin{array}{l}\text { aantal } \\
\text { statues }\end{array}$ & $\begin{array}{l}\% \\
\text { staties }\end{array}$ & $\begin{array}{l}\text { gemiddeld } \\
\text { aantal kloppen } \\
\text { per statue }\end{array}$ \\
\hline 0 & 0 & 20 & $21,0 \%$ & 0 \\
I-10 & 82 & 21 & $22,5 \%$ & 3,9 \\
II-20 & 293 & 20 & $21 \%$ & 14,7 \\
$21-30$ & 395 & 15 & $16 \%$ & 26,3 \\
$31-40$ & 219 & 6 & $6,5 \%$ & 36,5 \\
$>40$ & 769 & 12 & $12 \%$ & 64 \\
& 1758 & 94 & $100 \%(\mathrm{afg})$ & 18,7 \\
\hline
\end{tabular}

Indien we de gegevens van deze 94 staties beschouwen als een steekproef die enigermate representatief is voor aantal en verdeling van kloppen binnen de Hollandse Zending, dan kan een schatting gemaakt worden van het totale aantal kloppen aan het ende van de zeventiende eeuw. De Hollandse Zending telde rond 1694 circa 250 staties. ${ }^{13}$ Uitgaande van een gemiddeld aantal van 19 kloppen per statie, moet het totale aantal geestelijke maagden ongeveer 4800 bedragen hebben. Als we op grond van deze steekproef aannemen dat een vijfde van deze staties geen kloppen telde, dan lag het gemiddelde kloppental van de staties met kloppen rond

Torre ut 1656 aantallen communicanten per statie op. Dit wordt bestreden in 'Numeneke aspecten' door Van der Woude, Faber en Roessingh, hienn later bugevallen door Spiertz, 'Het aandeel', 149. 12 Regionale verschillen in bevolkungsopbouw en de invloed daarvan op de vaststelling van het aantal katholieken op basis van communicanten-ciffers worden geilustreerd door Spiertz, 'Het aandecl', i 53 13 Vastgesteld aan de hand van de kaart 'Confessionele verhoudingen in 1839 en van de missiestaties in 1700' by Rogier, Geschiedenus 
de 24. De getalsmatige verhouding tussen priesters en kloppen zal tussen r:Io en I:12 gelegen hebben, rekening houdend met het gegeven dat ongeveer $20 \%$ van de zielzorgers geen geestelijke maagden onder de gelovigen telde. ${ }^{14}$

In geheel Noord-Nederland - met inbegrip van die gebieden die kerkelijk gezien tot Zuidnederlandse bisdommen werden gerekend - zal het aantal geestelijke maagden in dit tijdvak de 5000 ruim overschreden hebben. Het aantal katholieken binnen de Hollandse Zending bedroeg in de tweede helft van de zeventiende eeuw circa 300.000. ${ }^{15}$ Binnen de Hollandse Zending representeerden geestelijke maagden gedurende de tweede helft van de zeventiende eeuw I, $6 \%$ van de katholieke populatie. Wanneer het aantal kloppen tegen het einde van die eeuw reeds aan het dalen was, zoals wel is gesuggereerd ${ }^{16}$ dan zou het aantal kloppen in de eerste helft van de zeventiende eeuw nog hoger gelegen hebben. Bij gebrek aan getalsmatige gegevens kan daarover geen uitsluitsel gegeven worden en blijven opmerkingen over stijging of daling van het kloppental gedurende de eeuw tentatief.

De gegevens uit de visitatierapporten zijn op nog enkele andere punten geanalyseerd. Onderzocht is of er een verband bestond tussen het aantal kloppen en de omvang van een statie, uitgedrukt in het aantal communicanten. Tevens is bekeken of het aantal kloppen in een statie werd beïnvloed door het gegeven dat de bedienaar van die statie een seculiere of reguliere priester was. Op grond daarvan zou de aantrekkingskracht van verschillende spirituele oriëntaties binnen de Noordnederlandse katholieke kerk op geestelijke maagden vastgesteld kunnen worden. Het thans beschikbare onderzoeksmateriaal, dat natuurlijk niet systematisch aangelegd is en slechts een beperkt beeld van de Hollandse Zending oproept, laat hierover geen conclusies toe. Evenmin kan een verband worden vastgesteld tussen de leeftijd van de bedienaar en het aantal kloppen. Een dergelijk verband zou uitsluitsel kunnen geven over de vraag of ouderdom en werkervaring van een priester van invloed was op zijn geestelijk leiderschap. Wel kon een zekere samenhang vastgesteld worden tussen de lokatie van een statie - stad of platteland - en het aantal kloppen. Staties zonder of met maximaal tien kloppen kwamen vooral voor op het platteland. Uitzonderlijk grote kloppentallen van vijftig of meer worden vrijwel uitsluitend vermeld in steden met meer dan 20.000 inwoners, zoals Amsterdam, Rotterdam en Utrecht, ${ }^{17}$ al konden enkele priesters in uitgestrekte plattelandsgebie-

14 Uitgaande van een aantal priesters van ca. 470, waarvan in 1701 opgave werd gedaan.

15 Dit aantal wordt door De la Torre genoemd in zijn missieverslag van 1656. Anders dan De Kok, Nederland op de breuklijn Rome-Reformatie, 57, die dit interpreteert als het aantal communicanten, ga ik er, in navolging van 'Numerieke aspecten' en Spiertz, 'Het aandeel', van uit dat het hier een opgave van het aantal katholieken betreft.

I6 Smit, 'Klopjes en klopbroeders', 42-43.

17 De Vries en Van der Woude, Nederland I500-1850, 88-90, bieden gegevens over de ontwikkeling van inwonertallen in Hollandse steden gedurende de zeventiende eeuw. Voor de overige gebieden, Van der Woude, 'Demografische ontwikkeling, I28-139. 
den soms ook op een rijkelijk aantal kloppen een beroep doen. In Dokkum en het omringende gebied bijvoorbeeld, kon pater Joannes van Rode S.J. rekenen op de steun van 60 tot 70 kloppen.

Vooral Utrecht was rijk aan grote kloppengroepen. De Utrechtse seculiere statie St. Gertrudis, geleid door de priester Jacob Cats, telde in 1692 rond de II 5 kloppen; bij de statie Achter de Wal van Joannes Lindeborn, een andere wereldheer, waren 60 geestelijke maagden aangesloten; zijn collega Cornelis Stakenburg, verantwoordelijk voor de statie St. Marie achter Clarenburg, telde 85 of 86 kloppen onder zijn gelovigen. Een andere wereldheer, Johan van Grave, deed opgave van ongeveer 60 kloppen. Ook de Utrechtse staties die bediend werden door regulieren waren 'kloprijk': een jezuïet, die vermeld staat onder de naam Coumscher ${ }^{18}$ kon bogen op 75 kloppen, terwijl de dominicaan De Minnen er 52 of 53 had.

De situatie in Friesland illustreert de grote contrasten ten aanzien van aantallen kloppen. Kon de minderbroeder Steenbicker, die voor Franeker en omliggende dorpen en gehuchten verantwoordelijk was, op de assistentie van 6 kloppen rekenen, zijn Leeuwardense confraters Josephus Kistemaeker en Godefridus van Lent telden respectievelijk 21 à 22 en I2 à 13 kloppen in hun staties. Meer dan een derde van de rond de 120 kloppen die in Leeuwarden woonden, stond onder leiding van wereldheer en aartspriester Willem Foppens. Uitgestrekte plattelandsstaties, zoals de statie Oosterend waartoe 18 of 19 dorpen behoorden, telden soms slechts één klop. De extreme verschillen in aantallen kloppen binnen de 'Missio Frisica' kunnen ten dele verklaard worden door een verbroken continuiteit in de zielzorg in verschillende gebieden. ${ }^{19}$ Toch lijken dergelijke uiteenlopende aantallen binnen de gehele Hollandse Zending eerder regel dan uitzondering te zijn, zonder dat daar op grond van de beschikbare gegevens een sluitende verklaring voor kan worden gegeven.

\section{II.2 'Kloppennesten' en andere woonvormen}

De leef- en woonvormen van kloppen weken af van die van gehuwde vrouwen of kloosterlingen. Hoe een klop haar bestaan kon inrichten, hing mede af van haar financiële en maatschappelijke situatie. Tijdgenoten hebben gewezen op de aanzienlijke en voorname afkomst van kloppen, misschien niet in de laatste plaats om de eerbaarheid van de kloppenstaat te benadrukken. Aan de hand van Trijn Jans

18 Naast de statie die werd bediend door Petrus Strazeele S.J. (1627-I702), was er een tweede, die bediend werd door Philippus van der Straeten (1626-1693) en Phulıpus van Belle (1637-1695). Een jezuiet genaamd Coumscher wordt nergens vermeld; mogelijk betreft het een schuilnaam. PA SJ, Historische handschnftenverzameling, AF 15, Synopsis Chronologica v.d. Missio Batav. S. F. (1592-1688) door Norbertus Aerts (gekopieerd en aangevuld door p. Haakman, naar afschriften van p. van Boxtel (1709) en p. Koedijk (1828)).

19 Spiertz, 'De ontwikkelmgsgang'. 
Oly's necrologieen is vastgesteld dat de maagden die tot 1651 deel uitmaakten van de Haarlemse Hoek overwegend uit de adel en uit kningen van njke kooplieden, hoge ambtenaren, burgenj en gegoede middenstand afkomstıg waren. ${ }^{20}$ Mogelıjk is de sociale samenstelling van De Hoek indicatief voor de geestelıke maagden binnen de grenzen van de Republiek. Voorzichtigheid is echter geboden. Aangezien kloppen in veel bronnen enkel uit de anonimiteit treden als zij geldelıke of matenele bijdragen ter ondersteuning van de missiekerk of clerus leverden, dreigt het beeld te ontstaan dat geestelıjke maagden doorgaans njke vrouwen waren.

Opmerkelıjk is wel dat - voor zover schaarse gegevens hierover conclusies toelaten - kloppen veelal een hoge leeftıd bereıkten. Dat geestelıke maagden ouder werden dan vıftig - met uitschieters van tachtıg en zelfs negentıg jaar - was niet uttzonderlık Gezıen de algemeen lage levensverwachting bij de geboorte, die gemiddeld tussen de 27 en 35 jaar lag, ${ }^{21}$ mag dit frappant heten Natuurlık waren geestelıke maagden en weduwen niet (meer) blootgesteld aan de grootste nsicofactor voor hun geslacht, het kraambed. Desalnettemin wisst de hoge leeftidd op een relatieve welstand, op leefomstandigheden en voedingspatroon die hen minder kwetsbaar maakten voor allerleı exogene doodsoorzaken (vooral besmettelı)ke ziekten en infectreziekten).

Verspreide gegevens uit de tweede helft van de zeventiende en de eerste helft van de achttiende eeuw wizzen op een grotere sociale diversificatie onder kloppen. ${ }^{22}$ Groningse geestelıke maagden, bıjvoorbeeld, waren bij de heffing van een eenmalige belastıng ten behoeve van het herstel van de Martınıkerk in alle behalve de hoogste categoneen vertegenwoordigd De bedragen waarvoor zl) werden aangeslagen, vaneerden van Io stuivers tot 12 gulden en 12 stuivers ${ }^{23}$ De hoogte van het bedrag waarvoor een ieder werd aangeslagen, werd vastgesteld door de stadssecretane, vermoedelıjk werden andere belastungen, gebaseerd op inkomsten en vermogen, hiervoor als nchtlun genomen.

Het is goed mogelıjk dat de eerste kloppen aan het einde van de zestiende en het begin van de zeventiende eeuw vooral uit de hogere middenklasse en de maatschappelıjke elıte afkomstıg waren. ${ }^{24}$ Naast de aantrekkıngskracht van het spintueel ideaal van een geestelık, apostolisch leven in de wereld zouden ook de betrekkelıke persoonlı)ke en matenele zelfstandıgheıd van het kloppenbestaan belangnjke drıffveren geweest kunnen zıjn. Voorbeelden van gezusters die gezamenlıjk voor het religieuze leven in de wereld kozen, illustreren dat familie-achtergrond eveneens een rol kon spelen. ${ }^{25}$ Voor ongehuwde vrouwen uit lagere klassen die in hun

20 Pey, 'De manuscnpten', 152-155

2I De Vnes en Van der Woude, Nederland 1500-1850, 67

22 Vgl Theissing, Over klopjes, I 28-130

23 Doombos, Rooms-katholteke bewonershysten

24 In dat opzicht zou er sprake kunnen zijn van een parallel met de laat-middeleeuwse begionen Zie Grundmann, Relıgose Bewegungen, 188-197, Idem, 'Zur Geschichte', 313-314, 316-317

25 Theissing, Over klopjes, 54-56, zie ook Van Nispen, 'De Hoevense parochie', I 20-127 
eigen inkomsten moesten voorzien, bood de kloppenstaat wellicht een eerbare identiteit. Afhankelijk van persoonlijke, maar ook lokaal-politieke omstandigheden konden kloppen kiezen voor een leven in groepsverband, in familieverband, of voor een zelfstandig bestaan.

\section{Vergaderingen}

Binnen de grenzen van de Republiek kende de kloppenstaat een lage graad van organisatie en institutionalisering. Een belangrijke verklaring voor die kleinschaligheid ligt natuurlijk in de politieke en religieuze verhoudingen in dit gebied. Samenleven in grotere gemeenschappen verhoogde de zichtbaarheid en kon vervolging door wereldlijke overheden uitlokken. Grote leefgemeenschappen van kloppen, de zogeheten vergaderingen, waren daarom schaars; ${ }^{26}$ dit in tegenstelling tot de Zuidelijke Nederlanden, waar geestelijke maagden ongehinderd door politieke omstandigheden gedurende de zeventiende en achttiende eeuw in communiteiten konden leven, die soms meer dan honderd leden telden. ${ }^{27}$ Vermoedelijk leefde nog geen $10 \%$ van de in totaal bijna vijfduizend kloppen binnen de Hollandse Zending in een dergelijke gemeenschap.

Dankzij Oly's necrologieën is bekend dat er in het complex van woningen in de straten rond de Haarlemse Bakenessergracht, dat De Hoek genoemd werd, gedurende de zeventiende eeuw vrijwel permanent tweehonderd maagden leefden. Niet alle aangesloten maagden woonden ook daadwerkelijk in De Hoek. Toen de gemeenschap aan het einde van de zestiende eeuw nog in de opbouwfase verkeerde, konden veel maagden er nog niet gehuisvest worden. Als zogeheten buitenmaagden woonden zij buiten de gemeenschap en soms zelfs buiten de stad. Later, toen de vergadering eenmaal gevestigd was, mochten leden alleen nog om zwaarwegende redenen elders leven, bijvoorbeeld om ouders of andere familieleden te verzorgen. In enkele gevallen bleven vrouwen op bevel van hun priester-overste, die het hoogste gezag binnen de vergadering vertegenwoordigde, elders wonen. Zo gelastte Comelis Arents Lichthert (1522-I613) de boerendochters en geestelijke maagden Dieuwer ( $†$ 1599) en Machtelt Gerrets ( $†$ 1618) uit Grootebroek in hun woonplaats te blijven. 'Om de desolaetheyt ende benautheyt des tijts [waren] daer weinich priesters.' Beide vrouwen namen de taken van priesters ten dele waar; zij 'gaeven onderwijsingen aen de onwetende [en] ook dengeen die buiten het Catolycke geloof waeren', werden door hen bekeerd. ${ }^{28}$

De Hoek vormde in feite een conglomeraat van kleinere, gedeeltelijk zelfstandige gemeenschappen die gemiddeld tien à vijftien leden telden. Op enkele uitzonderingen na waren deze zogeheten particuliere vergaderingen gehuisvest rond de

26 Schulte van Kessel, 'Vis noch vlees', 178.

27 De Vroede, 'Kwezels' en 'zusters'.

28 Graaf, 'Levens', $B B H$ I9 (1894) 310-312. 
Bakenessergracht. Iedere particuliere vergadering kende haar eigen organisatie. $\mathrm{Zij}$ stond onder leiding van een zogeheten particuliere moeder. Die hield toezicht op de naleving van de dagorde en de leefregel binnen de gemeenschap. Moeders delegeerden taken en verantwoordelijkheden aan hun maagden. Sommige maagden waren belast met het huishouden, anderen namen de zorg voor arme en zieke maagden op zich. Daarnaast waren er nog specifieke taken die buiten de particuliere vergaderingen werden uitgevoerd. Eén maagd was bijvoorbeeld verantwoordelijk voor de zorg voor het huishouden van de priester-overste.

Het leven van de maagden van De Hoek stond in het teken van religieuze plichten. Tijdgenoten vergeleken deze vergadering daarom met een klooster. Huishoudelijke en andere taken waren over het algemeen zo georganiseerd, dat zij gebed, meditatie, kerkgang en devotionele praktijken zo min mogelijk doorkruisten. In vergaderingen vonden geestelijke maagden een relatief beschermd godvruchtig milieu voor leven en werken. De leden van een dergelijke gemeenschap stimuleerden elkaar in het ideaal van een zoveel mogelijk teruggetrokken religieus leven. ${ }^{29}$

De Haarlemse Hoek was verreweg de grootste gemeenschap van geestelijke maagden binnen de grenzen van de Republiek. Naast deze vergadering waren er nog enkele andere. ${ }^{3 \circ}$ In Nieuwe Niedorp leefde een kloppengemeenschap volgens de Haarlemse regel. ${ }^{3 \mathrm{x}}$ Aan te nemen valt dat de organisatie hiervan in grote lijnen overeenkwam met die van de Haarlemse Hoek, al zal de vergadering kleinschaliger geweest zijn. In Haarlem zelf bestonden nog twee vergaderingen; één ervan, vlakbij de Hoek in de Koksteeg, was gevestigd in de statie die de kanunnik Augustinus Alstenius Bloemert (1585-1659) in 1636 stuchtte. De maagden van De Hoek noemden deze vergadering de 'cleyne hoeck'. Over de organisatie van deze gemeenschap is niets bekend. Dat geldt ook voor de vergadenngen in Utrecht, Delft en Bergschenhoek. Deze waren in elk geval kleiner dan De Hoek. Onder de duizend zielen voor wie de wereldheer Jan Baptist Stalpart van der Wiele (1579-I630) aan het begin van de zeventiende eeuw in zijn statie St. Hippolytus en St. Ursula te Delft de zorg had, bevond zich ook een 'vergadering vande maechden, die nu in ' $t$ getal waren in de tachtich' ${ }^{32}$ Zijn opvolger Joannes van Beecom ( $\dagger$ I647) zag dit aantal tot honderd groeien. ${ }^{33}$ Tegen het einde van de zeventiende eeuw ontstond er een vergadering van maagden in de Utrechtse statie St. Gertrudis, gelegen in de Mariahoek. Deze statie behoorde sinds 1723 tot de oud-bisschoppelijke clerezie. Het aantal kloppen werd hier geschat op meer dan honderd. Of en hoe zij onderling organiseerd waren, is niet bekend. Het kloppenboek Zedelessen dat Willibrord Kemp ( $\dagger$ I747) schreef voor de maagden in deze statie, die hij zelf bediende, rept

29 Theissing, Over klopjes, 67-68.

30 Ibidem, 56-62.

31 Gonnet, 'De "Vergadennghe"'.

32 'Her levensverhaal van de pnester-dichter Jan Bapust Stalpart van der Wiele door W/lhelmina de Reeck', ingeleid en uitgegeven door Mensinck, Jan Baptust Stalpart van der Witele, 204-205.

33 Hoogland, 'Descriptio status', 207-208 
niet over een vergadering. ${ }^{34}$ Bekend is enkel dat een deel van de kruisgang van St. Marie werd aangekocht als begraafplaats voor de statie, waar tussen 1737 en 1751 ook geestelijke maagden hun laatste rustplaats vonden. ${ }^{35}$ In Bergschenhoek woonden in 1690 tweeëntwintig kloppen..$^{36}$ Negentien van hen leefden samen in twee huizen vlak bij de woning van de priester die de statie bediende. Tenslotte nog een twijfelgeval: in Gorcum werd in 1628 gesproken over een 'Cloppenklooster'. Of het hier een grotere leefgemeenschap betrof is niet bekend. Vermoedelijk was dit de aanduiding voor de schuilkerk die de schout in 1634 ontdekte 'in een achterhouck van dese stadr'. Daar woonden 'eenighe cloppen en een paep'. ${ }^{37}$

\section{Kleinschalige woonvormen}

Het merendeel der geestelijke maagden leefde buiten een vergadering. Geestelijke maagden die het minder breed hadden of zelfs armlastig waren, konden een beroep doen op armenvoorzieningen die geleidelijk weer in opbouw waren in katholieke kring. Van de bewoonsters die tussen 1683 en 1713 leefden op het Hofje van Buytenwech te Gouda stonden er 23 te boek als klop. ${ }^{38}$ In de volksmond heette het hofje daarom ook wel het 'klopjeserf'. Dat geestelijke maagden hier onderdak en andere voorzieningen vonden, paste kennelijk in het armenzorgbeleid van de geestelijken van de seculiere statie De Tol, die sinds 1683 het beheer over het hofje hadden. Onder de bewoonsters die er vóór dat jaar waren komen wonen, worden namelijk geen kloppen vermeld. De bewoonsters van dit hofje, de kloppen incluis, zullen aparte huishoudens gehad hebben. Op een dergelijk hofje konden geestelijke maagden een betrekkelijk besloten leven leiden. Een zekere mate van bescherming en afscherming van de buitenwereld was gewaarborgd door de ligging van het hofje en zijn gedeeltelijke afsluiting door muren en een poort.

Sommige kloppen woonden samen in kleine groepjes geestverwanten. De Amsterdamse kerkeraad klaagde aan het einde van de zeventiende eeuw dat er bij de nieuwbouw van de minderbroederskerk Mozes en Aäron ook woninkjes voor kloppen werden gebouwd, die ten dele zelfs al waren betrokken ${ }^{39}$ In Utrecht werden dergelijke kloppengroepjes ontdekt, toen de vroedschap in 1664 op verzoek van de predikanten der stad besloot tot een onderzoek van verschillende panden die als 'paepse vergaderplaetsen' te boek stonden. ${ }^{40}$ De reeks huiszoekingen in

34 Theissing, Over klopjes, 6r.

35 Kemp hueld in het armenboek bij wie hier was begraven, dus mogelijk werden hier enkel mun- of onvermogende maagden begraven. Lagerwey, 'De Oud-katholieke begraafplaats'.

36 Rogier, 'B1jdragen', $B B H_{42}$ (1926) 298.

37 Van Lommel, 'Bouwstoffen', BBH 6 (1878) I99-200; Huysmans, 'Bijdragen', $221-224$.

38 Smit, Het hofje van Buytenwech, 29. Vgl. Rogier, 'Bıdragen', $B B H_{43}$ (1927) 104. Blıkens een in 1721 gesloten contract tussen het kerkbestuur en de pastoor van Bergschenhoek, was het kerkbestuur verantwoordelık voor het onderhoud van enige 'klopjeshuizen'.

39 Van Eeghen, 'De eigendom', 234-235.

40 Hofman, 'Allerles', I83-187. 
de jaren I664, I665 en I68I die daarvan het gevolg was, had tot doel 'de stouticheden der papisten en derzelver licentieuse vergaderingen' de kop in te drukken. En passant werden echter ook de lokaties in kaart gebracht waar kloppen woonden. Bij de wereldheren Joannes Putkamer en Joannes Lindeborn, 'wonende beyde tesamen achter de Wal bij de Lollestraet', was 'een groot nest kloppen' ontdekt. En op de nieuwe gracht, ten huize van juffrouw Agatha Dierout, waar een priester genaamd Godefridus dienst deed, woonde eveneens 'een goet getal kloppen'. Bij Abraham van Brienen, wereldheer en provicaris van Utrecht, woonachtig in de hoek achter de Mariakerk, waren ook enkele kloppen gevestigd. In Warmond stond een vermoedelijk kleine kloppengroep onder geestelijke leiding van de vooraanstaande wereldheer Henricus van der Graft (I6I I-I694) ${ }^{4 I}$ Al laten bovenstaande beschrijvingen aan duidelijkheid te wensen over, ze verhelderen wel dat organisatie- en leefvormen van geestelijke maagden over het algemeen kleinschalig waren. 'Kloppennesten' zullen in getalsmatig opzicht ver achter gebleven zijn bij de tweehonderd kloppen die de Haarlemse Hoek gedurende de zeventiende eeuw telde. Buiten de Hollandse Zending bestonden eveneens kleinschalige samenlevingsverbanden. In de commanderij van Gemert leefden tussen I662 en 1795 tweehonderd kwezels, zoals kloppen in deze contreien meestal genoemd werden. Veelal woonden zij met z'n vijven in een huis. ${ }^{42}$ De weduwe Meerendonk uit St. Michielsgestel liet in 1699 een onderkomen bouwen, dat in de ogen van de plaatselijke predikant niets anders was dan een klooster. Daar woonde ze met vier of vijf kwezels. ${ }^{43}$

Om de overheden en vooral de Nederduits-gereformeerde predikanten niet te agiteren, deden kloppen er verstandig aan iedere schijn te vermijden dat zij als kloosterlingen een communiteit vormden. Hoezeer overheden en predikanten beducht waren voor samenscholingen van kloppen, moge blijken uit het plakkaat dat op 30 augustus 1641 door de Staten-Generaal werd afgekondigd. Kloppen werd voortaan verboden om met meer dan twee samen te wonen, op straffe van zware geldboetes. ${ }^{44}$ Hoewel de plakkaten tegen kloppen vaak een dode letter bleven - niet in de laatste plaats omdat onduidelijk was op welke gronden een vrouw als klop aangemerkt kon worden - werd dit plakkaat enkele malen aangegrepen om tegen kloppen op te treden. Dat daarvan ook vrouwen het slachtoffer werden voor wie vooral de familieband en niet enkel de kloppenstaat een voomame reden was om samen te wonen, illustreert de verbanning van de Leidse gezusters Van Santhorst. Volgens de plaatselijke schout werden er in hun huis aan de Bredestraat

41 Schulte van Kessel, Geest en viees, 6r.

42 Van Liebergen, 'Waer een paradis', 45.

43 Van Doommalen, 'Accomodatie of confrontatie', 5-6.

44 Groot placaet-boeck, I, 206; Wiltens, Kerkelyk Plakaat-Boek, I, 548. Kloppen die met meer dan twee samenwoonden, kregen vier weken de tijd om te verhuizen. Op de eerste maand waarin men in overtreding was, stond vijftig gulden boete, op de tweede en daarop volgende maanden telkens honderd gulden. Zie ook Theissing, Over klopjes, I91-194. 
paapse diensten gehouden. Daarenboven werden zij beticht van ongeoorloofde samenwoning, want zij woonden met z'n drieēn in plaats van met z'n tweeën. Daarmee hadden ze het plakkaat van I64I overtreden. De zusters brachten daar tegen in dat zij geen kloppen waren en dat zij gedrieën woonden, omdat zij gezusters waren. Ze begrepen helemaal niet waarom zij als kloppen werden aangemerkt, terwijl ze gewone ongehuwde personen waren. Hun verweer mocht niet baten; Hendrina, Machtelt en Hester van Santhorst werden voor een periode van zes jaar uit de stad Leiden verbannen. ${ }^{45}$

\section{Zelfstandig of bij familie}

Veel geestelijke maagden bleven in hun ouderlijk huis wonen of startten een eigen huishouden. Individuele of kleinschalige woonvormen sloten goed aan bij het individuele karakter van de religieuze leefwijze van geestelijke maagden in het algemeen. De kloppenstaat vergde immers geen leven in gemeenschap. Een zekere hang naar onafhankelijkheid kan ook ten grondslag gelegen hebben aan individuele vormen van behuizing van kloppen. Zelfstandig wonende maagden konden doorgaans zelf hun tijd indelen en erop toezien dat huiselijke beslommeringen geen afbreuk deden aan hun religieuze verplichtingen. Maar hoe zat het met kloppen die bij ouders of familie inwoonden? Konden zij in de familiekring, waar het geloof misschien niet de boventoon voerde, aan de eisen van de kloppenstaat voldoen? Geestelijk leidsmannen wisten hoe moeilijk een geestelijk leven in de wereld te realiseren was. Joannes van Neercassel, apostolisch vicaris in de Hollandse Zending van 1663 tot $\mathrm{I} 686$, legde de Brusselse geestelijke maagd Marie-Anne Voeller (1638-1721), voor wie hij als geestelijk leidsman fungeerde, uit dat zowel sociabiliteit als eenzaamheid tot haar religieuze plichten behoorden. Marie-Anne leefde met haar broer Jean-Herman en diens echtgenote samen in hun ouderlijk huis. Aangezien haar verhouding tot haar schoonzus gespannen was, zal dit samenleven niet zonder strubbelingen zijn verlopen. ${ }^{46}$ Neercassel spoorde haar aan haar meditatie thuis te doen en zich pas rond zeven of acht uur 's ochtends naar de kerk te begeven.

'Door het hooren vande Diensten inde kerk, zal UEd. voldoen aende schuldigheyt van met onsen Evennaesten in Gods dienst te communiceren. Door uwe devory inde eenigheijt [eenzaamheid] van uwe kamer, zultge volgen het Exempel van de Maget der Maeghden [Maria] die in haer eenigheyt bad en meest was te vinden. ${ }^{37}$

In de alledaagse praktijk waren allerlei spanningen inherent aan het geestelijk bestaan in de wereld. Dagordes en leefregels, die het leven van geestelijke maagden reguleerden, beschreven gedetailleerd wanneer welke gebeden, meditaties of

45 Hoogland, 'Drie klopjes'; Theissing, Over klopjes, 193-194.

46 Jacques, 'Les Voeller', 164, 179.

$47 \mathrm{RAU}, A O B C$, inv.nr. 605, Neercassel aan Marie-Anne Voeller, 14 november I677. 
devoties gedaan dienden te worden. Met meer profane taken in en buitenshuis hielden zij doorgaans geen rekening. Religieuze plichten en behoeften van geestelijke maagden konden op gespannen voet staan met familiebeslommeringen. Huiselijke verplichtingen verstoorden de aandacht voor God en belemmerden zo geestelijke vooruitgang. De Roermondse geestelijke dochter Joanna van Randenraedt verwoordt enkele hieruit voortvloeiende frustraties. Hoewel zij geen zware huishoudelijke taken hoefde te verrichten, omdat de familie daarvoor dienstboden had, was zij wel vaak belast met de supervisie. Daamaast moest zij allerlei voorkomende klussen - van boodschappen doen tot brieven schrijven - afhandelen. Deze dubbele belasting van bidden en werken mondde soms uit in acute gewetensnood. ${ }^{48}$ Haar familieleden toonden doorgaans weinig begrip voor haar dagorde. Een van haar tantes, die in januari 1643 een bezoek bracht aan Roermond, zadelde haar op met allerlei karweitjes onder het motto: 'Ghy en hebt toch anders niet te doun, ende hebt toch geerne wat werckx'. ${ }^{49}$ Joanna moest van alles voor haar bezorgen of kopen en brieven voorlezen of beantwoorden. Had haar tante geen werk voor haar, dan bedisselde ze dat Joanna maar eens een wandelingetje moest maken. Joanna besefte dat ze hierdoor zaken verzuimde 'die van meer importanci sijn, daer haer L. [zij] geen kennis van en heeft'.

Ook in financieel opzicht werden haar bewegingsruimte en beslissingsbevoegdheid ingeperkt door de zeggenschap die haar ouders over haar uitoefenden. Zelfs toen ze meerderjarig was, bleef zij afhankelijk van een ouderlijke toelage. Soms weigerde haar moeder haar deze te betalen en stopte ze, naar eigen goeddunken, haar dochter enkel nu en dan eens wat toe..$^{50} \mathrm{Al}$ stond klagen over geldgebrek haaks op het armoede-ideaal dat Joanna onderschreef, ze had geld nodig om kleding, papier en schrijfgerei te kopen. En ook haar status als religieuze maagd bracht kosten met zich mee in de sfeer van giften of geld voor materiaal voor paramenten of kerkversieringen. ${ }^{\mathrm{st}}$

$48 \mathrm{~KB}$ Brussel, Handschriften 19070, 152-153vo (22 maart 1645).

49 Ibidem, 9-II (januari 1643). Vermoedelijk betreft het hier een tante van moederszijde, Wilhelma of Wilhelmina van der Meeren, weduwe van Willem de Gryspere (1543/1544-1622), raadsheer van de Geheime Raad. Voor hem zie Brographie Nationale de Belgzque, VI (1884-I885) 390-39I. Vgl. Mosmans, 'Een Limburgsche magistraatsfamilie', 91.

5o Behalve een ouderlijke toelage, kreeg Joanna sinds 1636 ook inkomsten uit een lijfrente, die op haar naam was afgesloten door Charles de Gryspere, een zwager van haar moeder. Zie C.ss.R Roermond, Speczaal Archief A pl. 7, HH ro (afschrift). Ook door haar oom Willem van Randenraedt, kanunnik en officiaal van het bisdom Roermond, werd zij bedacht in zijn testament. Na zijn dood zou zij jaarljiks vijftig gulden Roermonds ontvangen uit het Rumoldus-beneficie. Zie hiervoor RAL, Archief Bisschoppen Roermond, inv.nr. 56 (II,4), Testament Wilhelmus à Randenraedt, 1636 (afschrift). In september 1645 noteerde Van Randenraedt: 'Als ick meuglıck eens wat macht sau krijgen om mijn kintsgedeelte te gebruicken (...)'. Kennelijk was zij nog niet in het bezit gesteld van het erfdeel van haar vader, die in 1643 was overleden. KB Brussel, Handschnften 19070, 256.

5I GAR, Handschnften I A 5, (ongepagineerd; december 1640); KB Brussel, Handschrifien 19070, 307307vo, 3II-3IIvo (november I645). 
Of en hoe een geestelijke maagd actief kon bijdragen aan het apostolaat en allerlei taken in de zielzorg, was in sterke mate afhankelijk van de eisen die haar familie aan haar als dochter of zuster stelde. De Amsterdamse klop Dina Noortdijck (I626-I678) kon of wilde zich pas na het overlijden van haar moeder volledig aan haar roeping wijden. In 1659 verliet zij haar woonplaats om zich elders dienstbaar te maken aan haar mede-gelovigen. Zij verbleef enige tijd in Leeuwarden, Breda, Antwerpen en Enkhuizen, vermoedelijk in opdracht van haar biechtvaders, paters jezuïeten. Tijdens haar afwezigheid onderhield zij per brief het contact met haar familie. Ook in zakelijk opzicht bleef zij nauw met hen verbonden, doordat zij een deel van haar eigen kapitaal had geïnvesteerd in de handelsmaatschappij die haar broer Joost had overgenomen van hun overleden vader. Toen in 1665 door enkele ongelukkige transacties een faillissement dreigde, uitte Dina haar bezorgdheid; niet alleen omdat een zakelijke ondergang eerverlies voor de familie betekende, maar ook omdat persoonlijke financièle schade haar existentie en werk in gevaar kon brengen. Als geestelijke maagd moest zij in haar eigen onderhoud kunnen voorzien en een verlies van de vierduizend gulden die zij in het familiebedrijf had gestoken, kon zij moeilijk lijden..$^{52}$ Ware armoede was voor zelfstandig levende en werkende kloppen, die afhankelijk waren van hun eigen vermogen of werkkracht, een luxe die zij zich vaak niet konden permitteren.

Afhankelijkheid van ouders en verwanten stond soms zelfs een keuze voor de kloppenstaat in de weg. In Nijmegen werd bijvoorbeeld een resolutie ontworpen waarin burgers en ingezetenen der stad expliciet werd verboden hun dochters kloppen te laten worden. ${ }^{53}$ In Oudewater werd een jonge vrouw door tussenkomst van de magistraat gedwongen haar voornemen om klop te worden, te laten varen. De magistraat dwong deze Geertruijt van Ommen terug te keren naar haar moeder Merritge Dammes, 'synde van de Gereformeerde Religie'. Geertruijdt kreeg het consigne zich voortaan te gedragen zoals het een kind betaamt en zich 'tegen de wil van haer moeder geen klop te laten maken, off dat andere mesures sal werden

52 Garrer, 'Dina Noortdyck' De auteur baseert zijn uitspraken over de famlleverhoudingen op bewaard gebleven correspondenue Bij gebrek aan een verwijzing naar deze collecue heb ik geen dezer bneven van en aan Dina Noortdijck zelf kunnen raadplegen.

53 Meler, Domintkaner klooster, 183 en bijlage XIX. Deze ongedateerde resolute wordt door Meijer 'concept van een plakkaat tegen de kloppen' genoemd en op I633 met een vraagteken gedateerd $Z_{1 \jmath n}$ bronverwuzing is gebaseerd op W. van de Poll, Inventars van het oud-rechterlyk archnef der gemeente Nymegen (N1)megen z.). [1890]) 93. Cnmineel Burgemeesters-Protocol, Buj hemieuwde inventansatie (A. Delahaye, Het rechterlyk archzef der stad Nijmegen 1410-18II (Numegen 195I)) zijn de stukken uut het Cnmineel Burgemeesters-Protocol vermoedelıjk ondergebracht by het Rechterl, kke Protocol van de Raad, Cinmunele Zaken. In GAN, ORAN, inv.nr. I69 (II-05-I629 tot 3I-07-I65I) is het door Meijer aangehaalde 'concept-plakkaat' evenwel niet teruggevonden Van Hoeck, De jezureten te Nymegen, IOI102, verwijst voor hezelfde plakkaat naar een stedelıke verordenung van 5 maart 1634. In GAN, $O A N$, inv nr. 96, raadssıgnaten panuan-mei 1634, wordt onder deze datum echter niets over kloppen vermeld 
genomen'. ${ }^{54}$ Dit voorbeeld uit de achttiende eeuw illustreert dat vrouwen jonger dan vijfentwintig, die voor de wet minderjarig waren en onder toezicht van ouders of voogden stonden, niet per definitie vrij waren om voor de kloppenstaat te kiezen. Schakelde Merritge Dammes de magistraat van Oudewater in, andere ouders hebben wellicht hun heil gezocht tot subtielere vormen van dwang, zoals uitsluiting van de familie en onterving.

\section{II.3 Andere organisatievormen}

Voor een godvruchtig, inspirerend milieu waren kloppen die zelfstandig of bij familie woonden afhankelijk van onderlinge contacten en andere organisatievormen. Door het lidmaatschap van een religieuze broederschap of de intrede in een derde orde verzekerden zij zich van het gezelschap van gelijkgezinden. Deze vorm van sociabiliteit was van belang om in een religieus bestaan in de wereld te kunnen volharden. Binnen een broederschap of derde orde vonden geestelijke maagden een passende context voor hun specifieke vroomheid. Een lidmaatschap onderstreepte enerzijds de katholieke collectieve identiteit en anderzijds de godvruchtige, individuele identiteit van een geestelijke maagd.

\section{Broederschappen}

Binnen de door seculiere en reguliere geestelijken opgerichte nieuwe devotiebroederschappen stond een verinnerlijkte, gespiritualiseerde persoonlijke geloofsbeleving centraal. ${ }^{55}$ Religieuze praktijken in broederschapsverband sloten nauw aan bij de geloofsbeleving van kloppen. Regels voor biecht, gewetensonderzoek, communie, vasten en gebed voor broederschapsleden vertoonden overeenkomsten met richtlijnen dienaangaande voor geestelijke maagden, zij het dat frequentie en intensiteit van deze devotionele praktijken onder kloppen misschien doorgaans hoger lagen.

Iedere orde kende gedurende de zeventiende eeuw haar eigen broederschappen. Joannes Lindeborn somt in zijn kloppenboek De Leeder facobs (I670) de verschillende 'godsvruchtige Broederschappen' op, voorzien van hun kenmerkende attributen. Ten eerste de broederschap van de Rozenkrans, ingesteld door de dominicanen, gevolgd door de franciscanen 'met den Gordel', de augustijnen 'met den Riem' en tenslotte de carmelieten 'met den Schapulier'. De seculiere Broederschap der Gratie Gods, met St. Willibrordus en Bonifatius als patronen, was volgens Lindeborn door Sasbout Vosmeer gesticht uit onvrede over de misbruiken die in-

54 Putmans, 'Bijdragen', 237.

55 Vgl. Rooijakkers, Rituele repertoires, 516. Zie ook Wingens, Over de grens, 221-249, die het karakter van bedevaartbroederschappen bespreekt. 
middels in de bestaande broederschappen waren geslopen. Lindeborn gaf de maagden de raad zich niet overal in te laten schrijven, 'want dat sal weinig baten alsoo sy niet terstond deelachtig zijn aen de verdiensten van hun [de broederschappen] alle, (...) als sy maer is ingeschreven'. Niet het lidmaatschap van een of meer broederschappen zou de toegang tot de hemel verzekeren, maar alleen het volbrengen van de wil van God. En een maagd moest zich niet laten verblinden door de vele aflaten, maar haar ogen strak gericht houden op de godvruchtige werken 'waer door sy haer selven (...) bequaem en waerdig make aen de goddelijke Goedertierentheit'. ${ }^{6}$

Heiligenverering vormde de grondslag voor religieuze broederschappen. Via suffragia of 'Maend-Briefkens' werden heiligen als 'maandpatronen' toegewezen aan de broederschapsleden. ${ }^{57}$ Geestelijke maagden onder leiding van jezuïeten kregen tijdens hun maandelijkse eigen preek een maandpatroon..$^{58}$ Het gebruik van maandpatronen werd door Franciscus van Borgia in de Sociëteit van Jezus geïntroduceerd en vond zijn weg daarna naar de broederschappen. Suffragia waren kleine, meestal gedrukte, blaadjes waarop stonden vermeld: de naam van een heilige, de datum waarop die heilige gevierd werd, een specifieke deugd, en een 'sententie' die vaak ontleend was aan de Heilige Schrift of een kerkleraar. ${ }^{59}$ Voorts stond op een suffragium een speciale gebedsintentie, waarbij - handgeschreven - de naam van een persoon was ingevuld. Vaak was een suffragium verlucht met een afbeelding van de betreffende heilige. Volgens Lindeborn berustte de deugd die een klop voor een maand diende te beoefenen, nooit op toeval maar op 'goddelijcke schikking'. En de 'vermaen-briefjes', zoals hij ze met een toepasselijke woordspeling noemt, zouden ieder een lesje leren in de deugd waarin zij het meeste tekort schoot. Maagden moesten hun suffragia ernstig nemen en niet slechts vluchtig lezen, eerbiedig kussen en vervolgens in een boek leggen of achteloos laten slingeren. ${ }^{60}$

Zeventiende-eeuwse ordonnanties en regels van broederschappen ademen de geest van persoonlijke geloofsverinnerlijking, caritas en onderlinge bijstand. Ook de strijd tegen heterodoxie vormde een belangrijke impuls voor vormen van lekenapostolaat binnen broederschappen..$^{61}$ De regels van de Broederschap der Gratie Gods waren sterk gekleurd door de missionaire status van de katholieke kerk binnen de grenzen van de Republiek. Deze broederschap kwam organisatorisch tot volle ontwikkeling onder het vicariaat van Philippus Rovenius. ${ }^{62}$ Volgens

56 Lindebom, De Leeder facobs, 344-345; ook aangehaald door Theissing, Over klopjes, ro5.

57 Lindeborn, $\mathrm{De}$ Leeder Jacobs, 346-350. Het tot dusver verrichte onderzoek naar suffragia spitst zich hoofdzakelijk toe op de Zuidelijke Nederlanden. Zie Thijs, 'Notities'.

58 Post, 'Zes verslagen', 83.

59 Thijs, 'Notities', 562, wijst erop dat niet alleen heiligen, maar ook episodes uit het leven van Jezus of Maria beschreven en afgebeeld kunnen zijn op een suffragium.

60 Lindeborn, De Leeder facobs, 349.

6r Vgl. Duhr, 'Confréries' en Durand, 'Confrérie'. Zie ook Le Bras, 'Les confréries chrétiennes'.

62 Rogier, 'De cultus', waarbij de 'Regulen en ordonantien' van deze broederschap, ontleend aan Rovenius, Het gulden wieroock-vat, als bijlage zijn opgenomen. 
de historicus L.J. Rogier beoogde Rovenius in deze 'gebedenbond der seculieren (...) de bloem der Nederlandse leken met de seculiere clerus onder de apostolisch vicaris [te] verenigen in gebed en offervaardigheid voor het grote missiewerk'. ${ }^{63}$ Leken en geestelijken, mannen en vrouwen konden lid worden van deze broederschap, mits zij veertien jaar of ouder waren. Broederschapsleden moesten, waar zij konden, de gebrekkige kerkelijke infrastructuur proberen te herstellen en in stand houden. Wie in een plaats woonde waar nauwelijks priesters kwamen, werd aangespoord in het eigen huis een bidplaats in te richten, voorzien van een crucifix en een afbeelding van de passie van Christus. De regels schreven ook voor hoe hier in kleine kring de religieuze plichten waargenomen konden worden zonder dat er een mis gevierd werd. Leden werden aangespoord hun huizen open te stellen voor priesters, opdat er 'vergaderinghe' gehouden kon worden. ${ }^{64} \mathrm{De}$ broederschapsleden werd erop gewezen dat catechisatie, ziekenzorg en het geven van aalmoezen voor zieken en armen hun plichten waren. Deze taken rekenden geestelijke maagden, mede op instigatie van hun leidsmannen, eveneens tot de hunne. Wellicht bood een broederschap hun een passend kader om deze barmhartige werken uit te voeren.

Binnen de Broederschap der Gratie Gods vormden geestelijke dochters een aparte categorie. Wanneer de ordonnantiën de leden aanmoedigen om op zonen feestdagen 'de schamele kinderen (...) te leeren lesen, schrijven ende by-sonder de articulen des gheloofs ende onderwijsinghe van de Catechismus' te leren, wordt erbij vermeld dat zowel 'Mans, Vrouwen, ofte gheestelijcke Dochters' hiertoe bekwaam waren. ${ }^{65}$ Ook in broederschappen die geleid werden door reguliere geestelijken, werden de kloppen duidelijk onderscheiden van de andere leden. In ledenlijsten gebeurt dat door toevoegingen als f.d. (filia devota) of g.d. (geestelijke dochter) ${ }^{66}$ Misschien vervulden geestelijke maagden een specifieke rol binnen broederschappen. In een ledenlijst van de Rozenkransbroederschap te Waalwijk bijvoorbeeld staat onder $\mathbf{1 7 3 0}$ dat vanaf dit jaar geestelijke maagden afwisselend de rozenkrans in het openbaar in de kerk begonnen te bidden op zon- en feestdagen, ter verhoging van de godsvrucht. ${ }^{67}$ Het initiatief hiertoe werd genomen door ene Joanna Brekelmans, filia devota. Daarop volgend zijn er, naast de datering vijf november, vier namen van geestelijke dochters aangetekend. Mogelijk beten zij het spits af met het voorbidden van de rozenkrans.

63 Ibidem, 26I.

64 lbidem, 270, art. XII; 272, art. XXIV.

65 Ibidem, 272, art. XXI.

66 Zie bijvoorbeeld PA OP, Namen van de broeders en susters van het Aartsbroederschap van den heyligen Roose-krans van de alderheyligste Maget ende Moeder Godts Maria, tot Amsterdam van het jaar 1638 E'c.. 67 GA Waalwijk, Collectie DTB, Waalwijk XII, ledenregister Broederschap Rozenkrans, 1652-I826 (aanwezig in fotokopie). Met dank aan drs. Joost Rosendaal. 


\section{Wereldlijke derde orde}

Kloppen onder leiding van reguliere geestelijken traden soms in bij een wereldlijke derde orde. Hoeveel geestelijke maagden derde-ordeling of tertiaris waren, is niet te zeggen, omdat niet alle 'paterskloppen' per definitie lid waren van de wereldlijke derde orde. ${ }^{68}$ Van de twintig geestelijke maagden die gedurende de achttiende eeuw binnen de Utrechtse dominicanen-statie De Walsteeg overleden, waren er bijvoorbeeld slechts twee tertiaris. ${ }^{69}$

De wereldlijke derde orde was een van oorsprong middeleeuwse religieuze organisatie voor vrome leken. ${ }^{7}$ Met een eigen regel en bestuur leek zij meer op een kloosterorde dan op een broederschap. De regels en spiritualiteit van de eerste orden vormden de leidraad voor het religieuze leven van de leden van de respectieve derde orden. Derde-ordelingen streefden naar christelijke volmaaktheid uitgedrukt in het volbrengen van Gods wil - volgens een vaststaande en officieel goedgekeurde leefregel. Deze regel leefden zij naar vermogen na; aanpassingen op grond van burgerlijke staat, beroep of andere omstandigheden waren in beginsel mogelijk. Geestelijke maagden die intraden in een derde orde, kregen daarmee tegelijkertijd een vaste leefregel. $\mathrm{Zij}$ die niet intraden moesten het stellen met informele, individuele regels, opgesteld door hun geestelijk leidsmannen. Mogelijk was in de vaste leefregel, en de daarmee gepaard gaande duidelijkheid, voor geestelijke maagden een belangrijk voordeel gelegen. De leefwijze van derdeordelingen was vergelijkbaar met het bestaan van geestelijke maagden. Maar door de intrede in een derde orde maakte men voortaan deel uit van een lekengemeenschap met een erkend religieus karakter. Ook de doelstellingen van de derde orden - zelfheiliging, apostolaat in eigen kring, en caritas - overlapten met de aspiraties van geestelijke maagden.

Wie intrad in de derde orde van St. Norbertus, diende ongehuwd te zijn. Bij intrede werd zonder uitzondering een gelofte van zuiverheid afgelegd. ${ }^{71}$ Vrouwelijke leden van de derde orde van St. Norbertus waren dus per definitie geestelijke maagden, of liever kwezels, ${ }^{72}$ het begrip dat gebezigd werd in Brabant, waar de norbertijnen vooral vertegenwoordigd waren. Ongehuwd zijn was geen voorwaarde voor het lidmaatschap van de derde orde der franciscanen en dominicanen. De franciscaan Mathias Lodewijckx, die de Amsterdamse statie het Boompje bedien-

68 In tegenstelling tor de stelling van Van Hoeck, Schets, I65, ook aangehaald door Rogier, Geschredenis, II, 776 .

69 PA OP, Reginaldus van der Venne, Historische aantekeningen. Nederd. Provincie, kloosters en staties en basdommen (ongedateerd) $\mathrm{KL}$ o-b (negentiende-eeuws afschrift van het register van dopen en huwelijken, waarin een kopıe van de sterfdata van pnesters en geestelijke dochters in de statie sinds I748).

70 Longny, $A$ l'ombre des grands ordres; Auxentius, 'Derde Orde'.

71 Frenken, 'Nog eenige bijzonderheden', I55.

72 Vgl. Thesssing, Over klopjes, 219, bijlage II-g, 'Belofte-formule der St. Norbertus-kwezels'. 
de, maakte consequent onderscheid tussen een geestelijke dochter ('filia spiritualis'), een derde-ordelinge ('tertiaria') en een geestelijke dochter van de derde orde ('filia spirituali[s] tertia Regula S[ancti] P[atri] N[ostri] Francisci'). ${ }^{73}$ Geestelijke dochters vormden binnen deze derde orde wellicht een aparte groep, zoals de geestelijke dochters van de derde orde van St. Franciscus te Tumhout, die verenigd waren in een aparte congregatie. ${ }^{74}$ De leden hiervan kwamen maandelijks bijeen. Dan hoorde men gezamenlijk de mis, gevolgd door een sermoen van de priester-overste, die met 'korte en krachtige vermaeninge der Regels, der deugden en manier des levens' de maagden op hun plichten wees. Hoewel de leden geen gemeenschap vormden, werd toch maandelijks gecollecteerd orn elkaar in geval van nood bij te kunnen staan.

Van kloppen onder leiding van carmelieten wordt ook wel aangenomen dat zij per definitie tot de betreffende wereldlijke derde orde behoorden. ${ }^{75}$ Over hen is nauwelijks iets bekend. Ongeschoeide carmelieten die in Leiden werkzaam waren, namen doorgaans zelf geen kloppen aan, maar namen hen enkel 'over' wanneer hun biechtvader kwam te overlijden. ${ }^{76}$ Aan het begin van de achttiende eeuw verscheen een onderrichtingsboekje getiteld Godtvruchtige Maniere van leven. ${ }^{77}$ Dat was bedoeld voor 'alle Zielen, die buyten het Clooster in den Maegdelijken Staet soecken Godt wel te dienen', in het bijzonder voor 'de Geestelijke Dochters, onder de bestieringe van de Eerw. Paters van d'Ordre der Alderh. Maget Maria des Berghs Carmeli'. Daarin wordt een onderscheid gemaakt tussen 'Regel-Susters' die vermoedelijk lid waren van de derde orde, en degenen die 'buyten den Reghel' het 'Gheestelijcke Dochters-Kleet' aannamen. Intrede in de wereldlijke derde orde was kennelijk niet vanzelfsprekend..$^{78}$

Binnen de Amsterdamse augustijnen-statie De Star vormden de kloppen van de derde orde een onderscheiden groep. Of de ongehuwde staat een voorwaarde was voor de toetreding tot de derde orde van St. Augustinus, is onduidelijk. ${ }^{79}$ Joannes Uuten Eeckhout (1612-1682), sinds 1664 als priester in deze statie werkzaam, en zijn opvolgers Jacobus Willemart (1627-1697) en Ferdinand de Post (1632-I699) maakten korte levensbeschrijvingen van de vijfenzestig geestelijke maagden die tussen 1664 en 1695 hun intrede in de kloppenstaat vierden of in

73 GAA, Archief van de statze en de hulpkerk 't Boompje of H. Franciscus van Assisze te Amsterdam in de Kalverstraat (I628-rgit), inv nr I22, 'Fructus spintuales Fratns Mathiae Lodewicko in Missione Amstelodamensi Anno I662 [1662-1674]'

74 Ceyssens, 'De congregatue'.

75 Van Hoeck, Schets, I65.

76 Frenay, 'Aanteekenıngen', 178,190

77 Zie bıllage II, nr. 10.

$78 \mathrm{Zle}$ ook NCI, Archref van de Carmelieten-pastoor, de sacrista en de kerkmeesters van de parochre van Sint Petrus te Boxmeer, inv nr 4I, Kasboeken van de ontvangsten der kerk van Boxmeer in verband met uttvaart en begrafenissen Tussen 1721 en 1773 wordt het overlyden van zestuen geestelijke maagden vermeld, zonder dat er sprake is van lidmaatschap van de derde orde

79 Merlın, 'Tiers-ordre Augustinien' 
de statie stierven. ${ }^{80}$ Deze beknopte necrologieën illustreren dat geestelijke maagden die niet samenleefden in een vergadering, toch een onderlinge organisatie en band kenden. Deze band werd uitgedrukt door de ceremonie van intrede waarmee behalve de maagdelijke levensstaat ook de opname in de kloppengemeenschap van De Star werd bezegeld. Ook wanneer vrouwen die reeds geestelijke maagd waren zich aansloten bij deze kloppengemeenschap, vond er een speciale viering plaats. Zo werd op I 2 mei I 693 plechtig gevierd dat Margareta Morrenhoven, die al sinds 1682 klop was, tot de maagden van De Star toetrad. ${ }^{81}$

Apostolisch vicaris Joannes van Neercassel keurde het af dat de regulieren geestelijke dochters met veel pracht en praal in hun derde orden opnamen. Hij zag in dergelijk ceremonieel een bedreiging voor de eendracht onder katholieken. Reguliere priesters zouden hun maagden immers overhalen om geen anderen als biechtvaders te gehoorzamen dan leden van die betreffende orde. Dat 'paterskloppen' zich verheven voelden boven andere geestelijke maagden, werkte volgens Neercassel afgunst in de hand. ${ }^{82}$ Bovendien was hij beducht dat dergelı)ke intredeplechtigheden bij protestantse medeburgers en overheden de indruk wekten dat er opnieuw, op verkapte wijze, kloosters werden ingesteld. Deze angst voor groeiende achterdocht van protestantse medeburgers was zeker niet ongegrond. De Nijmeegse kerkeraad toonde zich bijvoorbeeld tijdens zijn vergadering op 25 april I640 bijzonder ontstemd over een intrede-ceremonte van een klop. Met Pinksteren was er in een huis aan de Grotestraat een publieke samenkomst van katholieken geweest. Ter ere van de dochter van de heer des hulzes, 'die sich begaff in der bagijn- of cloppenorden', werd er een plechtige mis gevierd. ${ }^{{ }_{3}}$

In de ogen van de gezagsdragers van de gereformeerde kerk en de wereldlijke overheden hoorden kloppen thuis in de categorie 'geordende personen'. Deze associatie was vermoedelijk te danken aan de verbintenis die sommige kloppen - al dan niet als tertiarissen - aangingen met reguliere pnesters. Weerstand en achterdocht onder protestantse wereldlijke gezagsdragers was en bleef lange tijd groter jegens kloppen onder leiding van regulieren. Werden hun leidsmannen gezien als buitenlandse missionarissen, wier eerste loyaliteit een verre paus en een ordesoverste gold, 'paterskloppen' werden als hun bondgenoten eveneens gewantrouwd. Toen de Staten-Generaal bij plakkaat op 2 I september 1730 besloten dat

80 PA OSA, De Star, 237. Met bızzondere dank aan dr. A K de Meıjer O.S A, die mı op deze bron attendeerde en $\mathrm{m}$ ) zujn transcnpue van de Laujnse tekst ter beschikkung stelde

81 Ibıdem, 237, vgl. ıbıdem, 238, waar de toetreding tot de gemeenschap van Aletha Jans wordt geverd, die kort tevoren 'devota' was geworden in het Klecfse gebied.

82 'Declaravo Repsonsona ad interrogata S. Cong ${ }^{\text {nus }}$ de Propaganda Fude' (anno 1663), in' Brom, 'Neerkassels bestuur', 210

83 GAN, $A N H G N$, inv nr 2, Acta kerkeraad, 25 apnl 1640 Deze passage uit de kerkeraadsnotulen onthult niet wie de mis opdroeg In Nijmegen waren toen vier orden actief jezueten, augustıjnen, dominicanen en minoneten-recollecten. Z1e Gonssen, Stede-atlas van Nymegen, 116. 
voortaan alleen seculieren als zielzorger werden toegelaten, die in de Republiek waren geboren en die door middel van een verklaring blijk moesten geven van hun trouw aan de wereldlijke overheid boven de gehoorzaamheid aan enig kerkelijk gezag ${ }^{84}$ had dat ook consequenties voor kloppen. Sindsdien werd er namelijk een tentatief onderscheid gemaakt tussen geestelijke maagden onder leidıng van een reguliere of een seculiere priester:

'Een soogenaamde geestlı,ke Dogter oft klopie van een waerelds Roomsch Pnester waardoor verstaan word een soodanig een die aan geen orde uitgeattacheert [is] nogte de bekende tna vota gedaan heeft ${ }^{35}$

'Wereldkloppen' golden als 'ongeprofessyde Kloppen', die noch 'Religieusen', noch 'derde Ordens Susters' waren en evenmin 'tot de geestelyken staat' behoorden, maar die zıch enkel 'in Kapsel, Kleding en houding (...) soo gedraagden als eigentlyke Geestelyke'. Geestelijke maagden die bij een derde orde aangesloten waren, werden daarentegen wel 'geprofessyde Kloppen' genoemd. ${ }^{86}$

Het oordeel van deze 'geprofeste kloppen' over de derde orde was vast gunstiger dan dat van apostolisch vicaris Neercassel. Ten eerste bood de derde orde een passend referentiekader om hun streven naar religieuze volmaaktheid gestalte te geven. ${ }^{87}$ En ten tweede kon de ceremonie van intrede, waartegen Neercassel zo gekant was, voor een klop de bevestiging betekenen van haar status als bruld van Christus. Deze geestelijke bruiloft, ook wel 'staatsie' genoemd, markeerde haar uitzonderingspositie ten opzichte van andere leken.

In de Rotterdamse minderbroeder-statie St. Rosalia in de Leeuwenstraat werd de intrede van een neuwe maagd met een plechtige hoogmis gevierd. Vele kaarsen werden geofferd en de kerk werd door geestelijke maagden in spe met allerlei sieraden begiftigd. Toen Catharina van Klut 'Cloppie' werd op Marna Presentatie (21 november) 1759, was op haar kosten de kerk als volgt verlicht met kaarsen:

'Op den hoogen Autaer [een kaars van] 12 pont, bij Onse Liever Vrouw Autaer 7 pont, voor ıder Heijlgen een ponts is 13 pont te samen, nevens de beelden van S. Joseph en $H$ Rosalıa een halff pont dat is 2 [sic] pont Op de commu(nie)bank 3 kaarsen ider van 3 pond, dat is te samen 9 pont, agter op de kroon $I^{1 / 2}$ pont, Op de Sodalittıdt [sic] 5 pont, waer van 4 pont op den Autaer de ander de bruutt kaars, in geheel $49^{1 / 2}$ pont sij heeft het betaelt ${ }^{88}$

84 Groot placaet-boeck, VI, 367-369, Knuttel, De toestand, II, I40-I4I, Polman, Katholiek Nederland, II, 9

85 RAG, Archref van het Bestuur van de Synode van Gelderland, unv nr 215, Stukken betreffende de Roomsche religie en de Roomsche pnesters, kerken en gemeenten in Holland, 1654-1772 Nr. 25 'Advies nopende het testeren van Roomsche pnesters off kloppen met of sonder Octrool)', d.d I oktober 1737

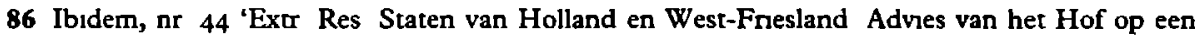
missive van den Raad van Braband, relatf tot haar Hoog Mog Placaet van 14 October 1655, omtrent het testeeren ten behoeve van Pausgezınde Geordende, of Geestelı)ke Armengestıchten, met voorsz Missive Commissonaal'

87 Ceyssens, 'De congregatie', 22.

88 Van Heel, 'Rotterdamse klopjes', 328, die zujn gegevens ontleende aan Naamen van die geSchreven 
Het lidmaatschap van de franciscaanse derde orde kreeg gestalte door twee afzonderlijke plechtigheden, de inkleding en de professie, die gemiddeld een jaar na de inkleding plaatsvond. ${ }^{89}$ Het tussenliggende jaar werd als een proefperiode beschouwd..$^{\circ}$ Voor tertiarissen die voortaan als geestelijke maagd wilden leven, markeerde de inkleding eigenliik hun intrede in de kloppenstaat. De professie daarentegen, is wellicht het beste te vergelijken met het uitspreken van de belofte van zuiverheid, hetgeen geestelijke maagden die geen lid waren van een derde orde weliswaar mochten, maar niet hoefden te doen. ${ }^{91}$

De inkleding in de derde orde van St. Augustinus gold eveneens als intrede in de kloppenstaat voor geestelijke maagden onder leidıng van augustijnen. Deze plechtigheid werd gevierd onder leiding van de priester die de statie bediende. In de Amsterdamse statie De Star, die sinds I67I een schulkerk had op de Oudezijds Achterburgwal ten huize van lakenkoopman Jacob van Loon, ${ }^{92}$ vierden verscheidene vrouwen hun geestelijke bruiloft. Onder hen waren vier dochters van de genoemde Van Loon. Een andere dochter, Mana, de weduwe van Pieter Loyens, stond te boek als weldoenster van de statie. ${ }^{93} \mathrm{De}$ nieuw aan te nemen maagd werd bij binnenkomst in de schuilkerk vergezeld door twee geestelijke maagden. De priester zegende achtereenvolgens attributen die de maagdelijke band met Christus symboliseerden: het scapulier, de sluier, de gordel, de kroon en de ring. Tenslotte werd de nieuwe klop zelf gezegend. ${ }^{94} \mathrm{Na}$ gebed overhandigde de priester scapulier, gordel en kroon ${ }^{95}$ aan de nieuwe maagd. Ring en sluier deed hij haar zelf om, als plaatsvervanger van de hemelse Bruidegom Christus. De ceremonie bevestigde dat de maagd die zojuist ingekleed was, 'de geestelijke staet der Maegden van Onse H. Regel' aanvaard had. De plechtigheid werd voltrokken

zym, in 't vermaart Broeder Schap van het Kaorde, van Hezllgen Vader Francuscus Tot Meerder Eer en glone Godts (1749-1847).

89 Brunvis, 'De statie', I89; PA OFM, Parochie dosszer Ammerzoden, Luber confratemitatum Busc et Ammerz. 1658-1881. Tussen 1720 en 1736 werden zestuen geestelıjke dochters ingekleed in de derde orde van St Franciscus. Twaalf van hen deden hun professie na ongeveer een jaar $Z_{1}$ voor deze bron Van Doornmalen, 'Een opmerkelık franciscaans broederschappenboek'.

90 Dat gold ook voor geestelıke maagden onder leiding van de carmelieten, al dan niet leden van de derde orde. Godtvnuchtuge Manuere, 22-23

91 Vgl. Theissing, Over klopjes, 87-88.

92 Van Eeghen, 'De eigendom', 229, 239-240.

93 PA OSA, De Star, 237.

94 Voor de ceremone van inkledıng zie Stevins, Regel, 87-92 De hier beschreven plechtıgheid komt in grote lijnen overeen met de ceremonue by) untrede in de derde orde van St Dominicus, die wordt beschreven in een handschnft van zeventiende- of achtuende-eeuwse oorsprong. PA OP, Lade Amsterdam, state Het Torentje, Map A (Memone-boeck en oude papieren) Vgl ook de professieplechtughend van geestelıke maagden onder leiding van carmelieten, Godtvnuchtige Mantere, 23-25. 95 Misschuen werd er underdaad een kroonte gebrukt, zoals dat enkele eeuwen later ook gedragen werd door actueve religieuzen bı de ceremonie van professie In de zesuende eeuw droegen Italıanse ursulinen bi) de ceremonie van intrede in de gemeenschap eveneens een kroontje Deze kroning benadrukte hun nieuwe status als godgewyde bruid van Chnstus Zarn, 'Ursula and Cathenne', 261 . 
in het bijzijn van de geestelijke zusters en bevestigde, zoals gezegd, tevens de toetreding van de nieuwe maagd tot de kloppengemeenschap van De Star.

Relicten van de professie zijn zogenaamde professie-formulieren. Het regelboekje voor geestelijke dochters van de derde orde van St. Augustinus bevat een formule van professie, die geestelijke maagden kennelijk moesten (laten) overschrijven en ondertekenen. Hierin was de belofte van maagdelijke zuiverheid opgenomen, die desgewenst voor een nader te specificeren aantal jaren of voor het gehele leven gedaan kon worden. ${ }^{96}$ De nalatenschap van dominicaanse derde-ordelinge en klop Juliana van der Lely uit Leeuwarden bevatte zo'n professie-formulier. Hierin beloofde zij aan de generaal van de orde der predikheren en aan de overste van de domincaanse derde orde in Friesland dat zij voortaan zou leven 'naer den regel ende forme van leven der Broeders ende Susters van deselve Ordre der poenitencie van den $\mathrm{H}$. Dominicus totter doodt toe'. ${ }^{97}$ De minderbroeder Adrianus Fierlinx liet drie geestelijke maagden, die werden opgenomen in de derde orde van St. Franciscus, een formulier tekenen. ${ }^{98}$ Ten overstaan van deze priester, die de Leidse statie H. Hartsteeg bediende, deden Anna Theresa van Rung (27 januari 1676), Aeltgen Jans ( 17 januari 1678 ) en Anna Margaretha Milliert (II november I678) hun professie. Aangezien de handschriften waarin werd ondertekend, afwijken van het schrift waarin de professieformule gesteld was, mogen we aannemen dat deze vrouwen hun professieformulier eigenhandig ondertekenden.

\section{Congregaties}

Naast de derde orde en verschillende broederschappen bestonden er nog andere organisatie-verbanden. De minderbroeder Jacob Tyras (ca. 1593-1638) richtte aan het begin van de zeventiende eeuw een meisjes-congregatie op in Hoorn. Uit de door hem opgestelde leefregels is op te maken dat het om een vereniging van geestelijke maagden ging. De leden kwamen onder leiding van Tyras op gezette tijden bijeen. Op zon- en feestdagen en gedurende de vasten en de advent begaven de meisjes zich dagelijks tussen zes en zeven naar de schuilkerk om daar de kleine getijden van Onze Lieve Vrouw te zingen. Het aantal leden van deze congregatie bedroeg meer dan honderd, van wie er tien à twaalf werden verkozen om de pater bij zijn werkzaamheden in de statie te assisteren. ${ }^{99}$

96 Stevins, Regel, Voorrede (ongepagineerd). Zie ook Godtwruchtige Manvere, 26.

97 Meyer, 'De Dominicanen-statie', 107-ro9

98 PA OFM, Histonsch Archief Letden, 'Memonale alıquorum memorabilium uncipiendo ab anno I676'. Pagina 6vo (van achteraf geteld)-8r, onder de aanhef 'Naemen van die geene die vnjwillıch haere professie hebben ghedaen inde derden regel van onsen H. Vader Franciscus'. Zie ook Sloots, 'De minderbroeders te Leiden', 505

99 Van Heel, 'De staue', 29-30. Voor de regel, zie 76-82, bullage II: 'Maniere van leven voor Imandt die in de werlt geestelıck gelieft te leven om alles naer order te doen'. 
De Sociëteit van Jezus kende in tegenstelling tot de andere regulieren geen wereldlijke derde orde, maar wel de Maria-congregatie. Innerlijke geloofsbeleving, oefening in gebed en meditatie, maar ook apostolaat waren de voomaamste doelstellingen van deze congregaties, die geestelijken en leken onder hun leden telden. ${ }^{100}$ Uit de jaarbrieven aan de provinciaal overste blijkt dat de jezuieten gedurende de zeventiende eeuw nog nieuwe congregaties stichtten in de Hollandse Zending, te weten in Groningen, Gouda, Leiden, Rotterdam, Utrecht, Culemborg, Alkmaar, Haastrecht en Delft. Hoewel vrouwen officieel geen lid konden worden, ${ }^{\text {rol }}$ vermelden de missieverslagen van de jezuieten toch speciale congregaties voor vrouwen in de staties te Groningen (I630), Rotterdam (I630) en Gouda (I66I). ${ }^{102}$ In Alkmaar bestond in 1644 een 'sodalium parthenicorum', een broederschap voor jonge, ongehuwde vrouwen. ${ }^{103}$ Over de religieuze praktijken binnen deze congregaties zijn de jaarbrieven weinig meedeelzaam. Gemeenschappelijke godsdienstoefeningen, de communie, het rozenkransgebed en het bidden van litanieën der heiligen van de Sociëteit op hun feestdagen, alsook dodenwaken en het laten opdragen van missen voor de overledenen zullen tot het vaste programma van de vrouwen- en meisjescongregaties behoord hebben. ${ }^{104}$ Of de leden hiervan ook, net als hun mannelijke tegenhangers, geschoold werden in de religieuze controverse is niet duidelijk. Aan te nemen valt dat sommige geestelijke dochters onder leiding van jezuïeten zich aansloten bij een dergelijke congregatie, maar hoe gebruikelijk of noodzakelijk dat was, is niet meer te achterhalen.

Ook al kende de Societeit van Jezus geen derde orde, de intrede van haar geestelijke maagden in de kloppenstaat werd met vergelijkbare pracht en praal gevierd. Het missieverslag van 1629 vermeldt dat te Leiden enige vrouwen tijdens een ceremonie op het feest van St. Jozef hun wereldse kleding verruilden voor het sobere kleed der kloppen. ${ }^{105}$ Deze ceremonie, waarmee elders - in katholieke steden - gevierd werd dat vrouwen de religieuze staat verkozen, werd hier door de jezuieten geïntroduceerd. ${ }^{106}$ Mogelijk vond dit Leidse voorbeeld navolging in andere jezuïeten-staties. Een geestelijke maagd in spe kreeg een schamel kledingstuk aangereikt, als symbool van haar nieuwe status. Na de viering van de mis werd haar

100 Van Hoeck, Schets, 15I-152.

101 Spiertz, 'Pastorale praktılk', 92-93; vgl. Châtellier, L'Europe des dévots, $31-32$

102 Van Hoeck, Schets, 158-159. Vgl. Conrad, Zwischen Kloster und Welt, 107-108: de stichtung van vrouwencongregaties werd bijvoorbeeld in Freiburg (Zwitserland), Innsbruck, Luzern en Wenen ondersteund. $Z_{1 e}$ voor de sekse-specfieke utslutung van de congregates ook p. 35 van dit boek.

103 PA SJ, Histonsche handschnfienverzameling, doos $148, \mathrm{C} 30$ a, 'Brevis notita Missionis Hollandicae (...)', door Norbertus Aerts, dl. I ( alfabeusch geordend)

104 Dit 'programma' is vermeld in ibıdem, AF 10, Acta Missionts, dl. VIII (I666) 76-77. Vgl. Spiertz, 'Pastorale praku)k', 92-93.

105 PA SJ, Histonsche handschnftenverzameling, AF 5, Acto Missionts, dI III, 498.

106 Ibıdem: 'Additum quod cırca ingredientes relıgionem virgines fien in urbibus Catholıcorum solet, id ad omne a Jesuitus hic esse factitatum.' Religio wordt huer in de betekenis van religieus leven of religreuze orde gebrukt $\mathrm{V} g l_{\mathrm{l}}$ hoofdstuk I (noot I13) van dit boek 
toetreding tot de maagdelijke staat gevierd. Zij werd gekroond als bruid en een jezuïet, die 'paranymphus' wordt genoemd, vriend van de bruidegom, overhandigde haar een brandende kaars. De Acta missionis noemen deze plechtigheid, die herinnert aan een wijding, 'monasticam ritam', een kloosterlijk ritueel. Dit publieke ceremonieel maakte diepe indruk op aanwezige gelovigen, maar was natuurlijk een doorn in het oog van de Leidse magistraat.

\section{II.4 Herstel en wederopbouw van de katholieke infrastructuur}

Op verschillende manieren droegen geestelijke maagden bij tot het herstel en de wederopbouw van de katholieke kerk in Noord-Nederland. Welk aandeel een klop daarin kon hebben, hing af van haar persoonlijke siruatie. Welstandsniveau, woonsituatie en de voorstelling die zij en haar leidsman hadden van een religieus bestaan in de wereld, bepaalden haar inbreng. Wie rijk was, kon zich royaal betonen tegenover de kerk en haar dienaren; wie arm was, had werkkracht te bieden. Wie streefde naar een teruggetrokken, haast contemplatief bestaan, borduurde in rust een antependium; maar wie zich geroepen voelde tot het apostolaat en de zielzorg, trok erop uit om onwetenden te leren en mede-gelovigen bij te staan.

\section{Materiële bijdragen}

Volgens de apostolisch vicaris Philippus Rovenius beschikten geestelijke maagden én over de materiële middelen én over de spirituele capaciteiten om de armen onder de gelovigen voor de katholieke kerk te behouden. In de strijd tussen protestant en katholiek om de gunst van de gelovigen zouden geestelijke maagden hun kerk een belangrijke dienst kunnen bewijzen. Traden ze echter in een klooster buiten de Republiek, dan liepen ze volgens Rovenius het risico hun vermogen te verliezen dat ze anders in vrijheid voor de kerk hadden kunnen aanwenden. ${ }^{107} \mathrm{De}$ wereldheer Willem Schoenius herhaalt Rovenius' stellingen in De weg der Suyverheyt van d'Hollantse Maegden (1676):

'voornamentlijck indien sy niet sonder groot perijkel van haer goet te verliesen, en vyandschap haerder vrienden in een klooster konnen gaen, daer sy van een andere kant haer goederen anders mogen behouwen, en evenwel geen perijkel hebben van haer propoost des suyvere Godvruchtigen levens te verlaten, en andere deugden te oeffenen, met miltheydt tot den armen, die sy door haer middelen en macht tot het Catholijck geloof konnen trecken' (p. 55).

Anders dan Rovenius en Schoenius doen voorkomen, wordt er in geen enkel plakkaat gericht tegen katholieken gerept over een dreigend verlies van bezittingen bij intrede in een buitenlands klooster. ${ }^{108}$ Misschien bedoelden zij in het algemeen 
dat wie de wereld vaarwel zei en het klooster inging, de beschikking over eigen middelen opgaf.

Geestelijke maagden die meerderjarig waren, behielden in beginsel hun eigen vermogen. ${ }^{109}$ Verschillende gewestelijke wereldlijke overheden probeerden de vermogensrechtelijke positie van kloppen scherp te controleren, uit angst voor een opeenhoping van kapitaal in de dode hand. In Utrecht werd op 17 december 1644 een plakkaat van kracht waarin kinderloze weduwen en ongehuwde vrouwen of het nu kloppen waren of niet - werd verboden zelf hun goederen te beheren. ${ }^{\text {Io }}$ Op last van de overheid werd een van de naaste bloedverwanten als beheerder aangewezen. Dit plakkaat werd in 1656 herroepen; voortaan mochten kloppen bij leven wel over hun eigen goederen beschikken, maar mochten zij geen schenkingen doen aan geestelijke personen of unstellingen. In Gelderland moet een vergelıkbaar plakkaat van kracht geweest zijn, want in $\mathrm{I} 739$ richtte Johanna van Maren, 'clop', een verzoek aan het Hof van Gelre en Zutphen om haar aandeel uit twee leengoederen ten zuiden van Ermelo te mogen verkopen om zo in haar onderhoud te kunnen voorzien. ${ }^{11 x}$

Op 14 oktober 1655 verboden de Staten-Generaal het erven en testeren door kloppen. ${ }^{112}$ Vermogensvorming door kloppen via erfenissen of vrije beschikking bij testament werden zo juridısch belemmerd. Op grond van dit plakkaat konden testamenten nietig verklaard worden, al kon dispensatie worden verleend. ${ }^{13}$ Daartoe deed Maria Cathanna van de Braak, 'clop te Wichen in 't Ryk van Nymegen', in ${ }^{773}$ I een verzoek bij de landschap. ${ }^{114} \mathrm{Zij}$ vroeg toestemming om 'in faveur van

14-04-1649 dat ouders en voogden geen kınderen of anderen naar 'Unversiteyten, Collegien of Schoolen der Jesuiten' in het buitenland mochten sturen. Tevens werd bij deze plakkaten verboden om geld ter beschikking te stellen voor kathoireke kerken, gasthuizen of conventen. Groot placaet-boeck, I, 206, Wiltens, Kerkelyk Plakaat-Boek, I, 544-554.

109 Theissing, Over klopjes, 84 Voor regionale en lokale verschullen in jundische status van ongehuwde meerdejange vrouwen en weduwen, ze Fockema Andreae, Bydragen, I, 40-62. De vermogensrechteli)ke positie van de ongehuwde meerdenange vrouwen in het algemeen wordt besproken door MeulmeesterJacobs, 'Het wereldlık recht', i35 Weduwen waren in beginsel mondig en handelıngsbekwaam Uit deze welomschreven identtet verklaart Marshall, The Dutch geniry, 64-67, dat het percentage hertrouwende weduwen in de hogere klassen in de Republick lager lag dan in de omnngende landen.

110 Theissing, Over klopjes, 197.

II RAG, Archref Hof van Gelre en Zutphen, unv nr. 85, 'Register over de Memone- en Resolute Boeken 's Hovens van Gelderland' (alfabetisch repertonum, trefwoord 'Roomschgezinden', 9 mei 1739) Met dank aan drs. Sil van Doommalen

w2 Theissing, Over klopjes, 195-196 Dit plakkaat werd afgekondigd in navolgning van een gelıjkluidende verordening van de Staten van Holland, d d 4 me1 i655.

113 Hiervan zijn achttiende-eeuwse gevallen bekend. Bijvoorbeeld van de Utrechtse geestelıjke dochter Mana Cesanus ( $\dagger_{1768}$ ), die octrool aanvroeg by het Hof van Utrecht om te mogen testeren GAU, $O R K A$, mv nr. 202.

114 RAG, Archief Hof van Gelre en Zutphen, unv.nr. 85, 'Register over de Memone- en Resolutue Boeken 's Hovens van Gelderland' (alfabetisch repertonum, trefwoord 'Roomschgezinden', 8 oktober I731) Mogelıjk was deze klop cen zuster of tante van de toenmalige Wychense pastoor, Hendnck van de(n) Braak Met dank aan drs Sll van Doornmalen voor deze verwijzing en de aanvullende informatue 
haar behoeftige zusterskinderen resideren[de] te Well' te mogen testeren. De landschap vroeg het $H$ of van Gelre en Zutphen om advies. Omdat vrije vererving bij testament in strijd was met de bepalingen over kloppen in de plakkaten tegen de katholieken, bracht het Hof een negatief advies uit. ${ }^{175}$ Ook in de Generaliteitslanden werd strak de hand gehouden aan richtlijnen ten aanzien van het erven en testeren van kloppen. ${ }^{16}$

Doorgaans bleven kloppen ongehinderd erven en testeren en deden zich alleen dan problemen voor wanneer (protestantse) familieleden een eventuele erfbeschikking aanvochten. ${ }^{117}$ Ook wanneer de begunstigden geen kloppen of geestelijken waren, probeerden erfgenamen testamenten van geestelijke maagden te betwisten in geval zij zichzelf benadeeld achtten. ${ }^{118}$ De jurisprudentie ontwikkelde zich vermoedelijk geleidelijk in het voordeel van kloppen, zo bewijst de kwestie rond de erfenis van de reeds genoemde geestelijke dochter Juliana van der Lely uit Leeuwarden. $\mathrm{Zij}$ had een deel van haar goederen vermakkt ten gunste van de rooms-katholieke armen. Erfgenamen vochten haar testament aan op grond van het professie-formulier van de derde regel van St. Dominicus dat Juliana had ondertekend. ${ }^{19}$ Volgens hen was zij daarom een geprofeste religieuze. Het Hof van Friesland boog zich over deze kwestie en kwam, na raadpleging van diverse geestelijken en geestelijke maagden, tot de slotsom dat Van der Lely geen geprofeste zuster, maar een klop was die in de wereld bleef. En als zodanig kon zij vrijelijk over haar geld en goederen beschikken. Opmerkelijk genoeg repte het Friese Hof niet over het plakkaat van I655. Ook het Hof van Holland boog zich aan het begin van de achttiende eeuw nogmaals over de kwestie of kloppen bij testament vrijelijk over hun eigendommen konden beschikken. Zijn oordeel week echter af van dat van Hof van Friesland. In een advies stelde het Hollandse Hof dat geestelijke maagden onder leiding van wereldheren in beginsel vrij waren om hun testament op te maken, terwijl kloppen onder leiding van regulieren daartoe

15 Het Hof berep zich op het Gelderse plakkaat tegen de katholieken van 24 maart I68I Dit herhaalt de bepalıng dat kloppen mogen erven noch testeren, die in eerdere plakkaten (d d. 2 september I64I en 24 julı I65I) al waren afgekondigd en qua strekkıng overeenkomen met het genoemde plakkaat van de Staten-Generaal van 1655 Groot Gelders placaet-boeck, II, 302, 325, 515

$116 Z_{1}$ bijvoorbeeld het proces van Jan Adnaanse de Laure uit Delft, mede als erfgenaam ab untestato van zujn zuster Anthonetta Adnaanse de Laure, in leven geestelıke dochter te Vessem, contra Jan Casparsse de Laure c.s. RANB, Archnef van de Raad van Brabant, Civiele processen, inv.nr. 788, dossier 2487.

117 Theissing, Over klopjes, 198.

118 RAG, Archief van het Bestuur van de Symode van Gelderland, inv.nr. 215, Stukken betreffende de Roomsche religie en de Roomsche pnesters, kerken en gemeenten in Holland, 1654-1772. 'Pleıjt memone in de sake van Anna Mana van der Stoel Imptr. ( ) contra Comels van Persın nom. ux. ged. (Appolonıa van der Veen) (1736)'. Van der Stoel betwist het testament van de geestelıke maagd Mana Pıl, die Appolonia van der Veen begunsugde.

n9 Meijer, 'Dominicanen-statie'. 107-109 
dispensatie moesten aanvragen. ${ }^{\mathrm{ro}}$ Als 'verlengstukken' van wereldheren die op grond van het reeds genoemde plakkaat van 21 september 1730 officieel als zielzorgers waren toegelaten, werd 'wereldkloppen' door de overheid meer vrijheid in de beschikking over hun eigen vermogen toegestaan.

Familiebelangen speelden ook een rol binnen homogeen katholieke families. De ouders van Joanna van Randenraedt wilden voorkomen dat een deel van hun vermogen naar hun dochters biechtvaders, jezuieten, zou verdwijnen. ${ }^{\text {I2I }}$ Door middel van een bepaling in zijn testament wilde Cornelis van Randenraedt ervoor zorgen dat zijn dochter enkel via een door hem aangewezen curator over haar erfdeel kon beschikken. Overleed Joanna, dan zou haar erfdeel aan iemand anders binnen de familie toevallen. Door deze zogeheten 'fidei commis'-bepaling genoot zij enkel het vruchtgebruik van haar erfdeel, waaruit zij geen schenkingen mocht doen. Zo zou het familievermogen intact blijven. ${ }^{122}$ Voordat hij zijn testament in die zin kon laten opmaken, werd Comelis van Randenraedt door de dood verrast in september I643. Joanna's moeder, Livina van der Meeren, overwoog eveneens een 'fidei commis'-bepaling in haar uiterste wilsbeschikking op te nemen, opdat haar erfenis ten goede kwam aan de kinderen van haar zoon Willem Hendrik en niet aan de geestelijke 'familie' van haar dochter. Omdat Joanna haar verzekerde enkel een klein legaat voor de paters jezuïeten te bestemmen voor haar moeders zieleheil, zag Livina van der Meeren hiervan af. ${ }^{123}$ Nader onderzoek in notariële archieven moet uitwijzen of ook andere geestelijke dochters door dergelijke bepalingen belemmerd werden in het erven en vermaken van bezittingen.

Angsten voor de verkwanseling van familiekapitaal door dochters die klop waren geworden, bestonden ook in de Hollandse Zending. Volgens de Goudse seculiere priester Petrus Purmerent lieten vele ouders van geestelijke maagden onder leiding van jezuïeten hun dochters enkel het vruchtgebruik van hun erfdeel. Deden ze dat niet, dan dreigden wettige erfgenamen door kloppen gepasseerd te worden ten gunste van de Sociëteit. Bij leven stonden jezuieten-kloppen volgens Purmerent het vruchtgebruik van hun bezittingen al af aan hun geestelijke vaders. Daardoor bleef er voor henzelf soms nauwelijks voldoende over om van te leven. ${ }^{124}$ Dergelijke waarnemingen werden zeker gekleurd door concurrentie-besef en naijver die de verhoudingen tussen wereldheren en regulieren, in het bijzonder jezuieten,

I20 RAG, Archref van het Bestuur van de Synode van Gelderland, inv.nr. 215, Stukken betreffende de Roomsche religie en de Roomsche pnesters, kerken en gemeenten in Holland, 1654-1772. Nr. 25 'Adves nopende het testeren van Roomsche pnesters off kloppen met of sonder Octrooij', d.d. I oktober 1737 .

I2I KB Brussel, Handschnfien I9504, 24vo-26vo (anno r647).

122 De Blécourt, Kort begnp, 360.

123 KB Brussel, Handschnfien 19504, $26 \mathrm{vo}$.

124 Theissing, Over klopjes, I68-I 69, aangehaald uit N. Broedersen, Quinque tractatus histonc1 de rebus Metropolitanae Ecclestae Ultrajectinae (1729-1763), V, 32. Theissing weerlegt alle knuek van Purmerent overtuigend, behalve de financiele aspecten. 
sinds het begin van de zeventiende eeuw beïnvloedden. Over en weer beschuldigden zij elkaar van inhaligheid. Natuurlijk werden kloppen als potentiële weldoensters hierbij betrokken. ${ }^{25}$

In kloppenboeken wordt vrijmoedig geappelleerd aan de vrijgevigheid van geestelijke maagden. Hun leefwijze permitteerde de beschikking over eigen vermogen en inkomsten, een vrijheid die vrouwen zich volgens sommige geestelijke auteurs niet moesten laten ontnemen. Vrouwen die trouwden, maakten zichzelf, hun geld en goed onderhorig aan een vreemde, aldus de jezuiet Valentinus Bisschop. Geestelijke maagden deden bij het aanvaarden van hun staat dan wel afstand van aardse rijkdommen, dat betekende niet dat deze achter slot en grendel bewaard moesten worden, want 'het ghelt wordt beschimmelt, ende het verliest syn luyster'. ${ }^{126} \mathrm{Het}$ moest voor 'salighe saken' gebruikt worden, waar niet alleen anderen maar ook de geestelijke maagd zelf van zou profiteren:

'Laet de armen ghevoelen dat ghy rijck zijt; die ghebreck lijden, dat die ghewaer worden dat ghy veel landt en zandt hebt: gheeft u patrimonie aen Godt tot woecker, spijst Christum, versoeckt door de ghebeden van vele, dat ghy eens moogt behalen u glorie des Maeghdorns'. ${ }^{27}$

Bisschop somt op in welke volgorde een geestelijke maagd 'haar goet ter eeren Godts' dient uit te delen. Deze lijst wordt aangevoerd door giften ten behoeve van de kerk. Armen die om aalmoezen verzoeken, andere geestelijke dochters en zij die zich bezighouden met de verbreiding van het geloof maar in vrijwillige armoede leven, zijn de volgenden die geldelijk gesteund moeten worden. ${ }^{128}$ Deze formulering sluit giften aan wereldheren uit, die anders dan regulieren geen gelofte van armoede deden. Bisschops oratio pro domo illustreert dat de concurrentieverhouding tussen regulier en seculier wel degelijk óók een financieel karakter had.

De relatieve persoonlijke en materiële autonomie die geestelijke maagden genoten, was ondenkbaar in vrouwenkloosters. Deze omstandigheid vormt zeker één van de factoren die de motivatie van vrouwen om voor een religieus bestaan in de wereld te kiezen, beïnvloed kan hebben. ${ }^{129}$ Geestelijke maagden konden hun eigen vermogen aanwenden voor particuliere of collectieve initiatieven op het gebied van liefdadigheid of patronage. Op deze wijze verwierven zij meer aanzien en invloed binnen het kerkelijk-religieuze domein dan zij als kloosterlingen ooit gekend zouden hebben. Dat is ook de strekking van de aansporingen van Rovenius en Schoenius, die middelen en macht als het ware met elkaar gelijkschakelen.

125 Theissing, Over klopjes, I67-170; Schulte van Kessel, Geest en vlees, hoofdstuk III.

126 Bisschop, Lof der Suyverheydt, II, 275-276.

127 Ibidem, 278. Bisschop steunt op Cyprianus' De disciplina et habitu virginum.

128 Bisschop, Lof der Suyverheydt, II, 282-284.

129 Voor een parallel met Zuidnederlandse begijnen zie Ziegler, Sculpture of compassion, 75. 


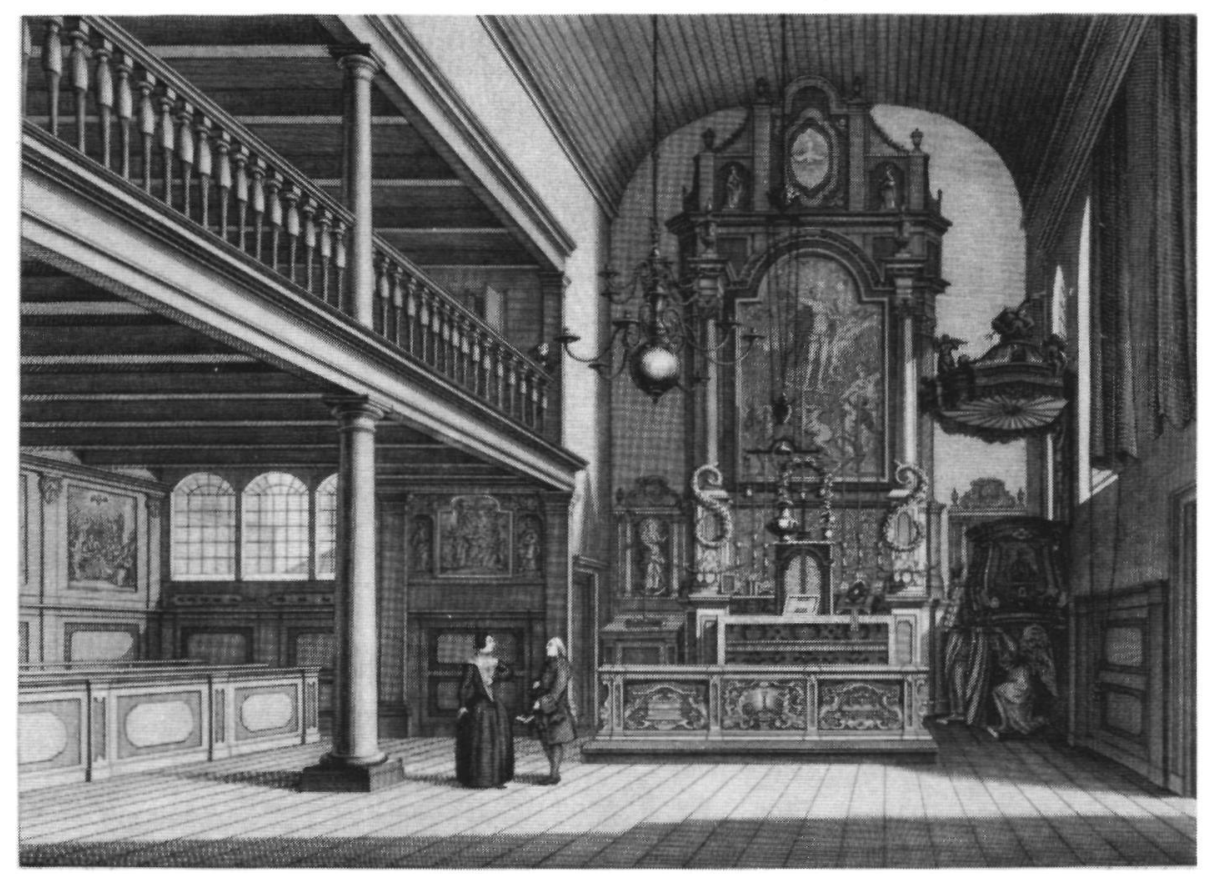

Afb. 2 Interieur van de schuilkerk De Pauw te Amsterdam. Een geestelijke maagd wordt verzocht om een bijdrage door een collectant.

Gulle donaties werden door geestelijken over het algemeen met meer nauwgezetheid gememoreerd dan de werkkracht die vele kloppen ter beschikking van kerk en clerus stelden. Dat arbeid soms minder gewaardeerd werd dan klinkende munt, werd opgemerkt door Joanna van Randenraedt. Zij was zich ervan bewust dat de jezuieten, die als haar leidsmannen fungeerden, haar inbreng vooral naar geldelijke maatstaven maten. Een ware geestelijke dochter van de Sociëteit van Jezus behoorde zich kennelijk niet alleen spiritueel maar ook in geldelijke zin schatplichtig te betonen aan haar geestelijke vaders. Meermaals betuigde Joanna haar spijt dat haar financiële positie schenkingen aan 'haar' orde niet toeliet. Haar ijver in liefdewerken moest vergoeden wat anderen in financiële zin konden bijdragen aan de Sociëteit. ${ }^{130}$

Kloppen die het zich konden veroorloven, deden veelal schenkingen bij bijzondere gelegenheden. De intrede in de kloppenstaat was zo'n gelegenheid bij uitstek. Ook de jubilea van hun intrede werden gevierd en gememoreerd door gulle gaven aan de eigen statie. Sommigen fourneerden werkkapitaal voor staties en leenden forse sommen geld voor de bouw en inrichting van schuilkerken. Vooral uit de achttiende eeuw zijn hier talriike voorbeelden van bekend. Zo verstrekte Euphemia 
van den Idserd, telg uit een aanzienlijk Amsterdams geslacht en geestelijke dochter van de derde regel van St. Dominicus in de Amsterdamse statie 't Torentje, in I72I een royale lening voor de bouw van een nieuw bedehuis. In 1743 tekent Petrus Beckaff, die deze statie toen bediende, in zijn memorieboek aan dat hij haar jaarlijks $3 \%$ procent zal terugbetalen van de 3000 gulden die zij samen met de inmiddels overleden geestelijke dochter Catharina Huysingh heeft voorgeschoten. ${ }^{131}$

Waardevolle altaarsieraden, paramenten, schenkingen en leningen voor de inrichting of het onderhoud van schuilkerken droegen bij aan de vorming en versterking van een collectieve katholieke identiteit. Voor het functioneren en de uitstraling van menige statie in de Hollandse Zending waren de giften en kredieten van geestelijke maagden onmisbaar. ${ }^{132}$ Hun financiele bijdragen waren echter niet altijd vrijblijvend. Sommıge kloppen hadden geheel eigen opvattingen over het eigendomsrecht van het altaarzilver of de kerkelijke gewaden die zij zelf betaald of vervaardigd hadden.

Dat bleek bijvoorbeeld in Gouda, waar in $17 \mathrm{II}$ een conflict tussen priesters en gelovigen van de seculiere staties De Tol en De Braesem ontstond. Van oudsher hadden de vijf Goudse staties hun 'eigen' geestelijke maagden. Dat wees het onderzoek uit dat de raadsheer Sebastiaen Francken in 1643 in opdracht van het Hof van Holland instelde naar 'paepsche stouticheden'. Wereldheer Willem de Swaen van de statie De Tol telde zo'n vijftig à zestig kloppen onder zijn gemeenteleden. Ongeveer dertig kloppen hadden zich aangesloten bij de statie van de minderbroeder Gregorius Simpernel. ${ }^{133}$ Hun financièle bijdragen waren essentieel. Een van Simpernels geestelijke dochters, Anna van Geffen, loste bijvoorbeeld in 1648 een schuld van maar liefst 4000 gulden af, die Simpernel was aangegaan voor de bouw van een kerk annex woonhuis. ${ }^{134}$ In I7II makkte de kersvers benoemde priester van De Braesem, Theodorus Witzenburgh, aanspraak op de pastoorstitel van Sebastianus Verwel van de statie De Tol. Verwel had zijn ambt in 1705 neergelegd maar was op zijn beslissing teruggekomen en weigerde nu het veld te ruimen voor Willem Wannaer, die inmiddels door de apostolisch vicaris Gerard Potcamp benoemd was. De komst van Witzenburgh was aanleiding voor enkele geestelijke dochters om hun leidsman Verwel te verlaten. Eén van hen, Johanna Westerhout, nam bij die gelegenheid vier zilveren kandelaars mee, die eerder door

131 Me1jer, Gedenkboek, 264. PA OP, 'Memone-boeck voor munen opvolgers door Petrus Beckaff O P. pastoor "De Toren" 1731-1764'. In deze schuldbekentenis van 7 oktober 1743 wordt gestıpuleerd dat na het overlyden van Van den Idserd het verschuldıgde bedrag zou worden omgezet in zes missen, dıe jaarlıks voor haar zieleheil zouden worden opgedragen, zoals dat ook gebeurde voor wılen Cathanna Huysingh.

132 Theissing, Over klopjes, I28-131, I38-141.

133 Van Lommel, 'Bouwstoffen', BBH 7 (1879) 350-353 Pater Gregonus Hendnksz Simpernel O F M. had zich zonder toestemming van apostolisch vicans Rovenius in I634 te Gouda gevestigd In I638 droeg de Congregatie van de Propagande Fide Rovenius op om Simpemel pastoorsrechten te verlenen. 134 Van Heel, De minderbroeders te Gouda, II, 30 
haar aan de statie De Tol waren geschonken. Hoewel deze 'diefstal' later weer ongedaan werd gemaakt, spreekt hieruit dat Westerhout kennelijk van mening was dat zij vrijelijk kon blijven beschikken over eenmaal door haar geschonken goederen. ${ }^{135}$

Het verband tussen geestelijke maagden en de financiële toestand van een statie werd ook door geestelijken zelf gelegd. Volgens de Goudse wereldheer Ignatius Walvis, die bekend stond als een fel jansenist, genoten de paters minderbroeders in 1709 meer inkomsten dankzij de aanwas van geestelijke dochters. Aangezien de jezuiet Jacobus Lambrechts het jaar ervoor ten gevolge van jansenistische strubbelingen zijn kerkhuis in de Keizerstraat had moeten sluiten en de stad had moeten verlaten, waren maar liefst veertig geestelijke dochters hun leidsman kwijtgeraakt. Zij gingen over naar de statie der minderbroeders die daarom, volgens Walvis, op meer financiële steun konden rekenen. ${ }^{1{ }^{36}}$

\section{Immateriële bijdragen}

\section{Betaalde arbeid en liefdewerken}

Wie God buiten het klooster diende, maakte lange dagen. Leefregels voor geestelijke maagden ruimen doorgaans geen tijd in voor werken van barmhartigheid, die niettemin een integraal bestanddeel vormden van de kloppenstaat. Een geestelijke maagd behoorde haar tijd vooral te besteden aan gebed, meditatie, het bijwonen van missen, het aanhoren van preken en handwerken. Gelegenheid voor liefdewerken en eventuele inkomstenverwerving was krap bemeten. Wie voor haar kostwinning van loonarbeid afhankelijk was, kon spinnen, naaien, breien, borduren, kantklossen, schoonmaken of turfsteken. Dat nam niet weg dat zij daamaast liefdewerken behoorde te verrichten. Onderdak en onderhoud verschaffen voor priesters, zorg dragen voor schuilkerken, versiering van kerk en altaar, verspreiding van stichtelijke werken en devotionalia, zieken- en armenzorg, alsook (godsdienst)onderwijs werden tot de charitatieve taken gerekend. Verscheidene van deze taken waren half liefdewerk en half loonarbeid. ${ }^{137}$

Door huisvesting van priesters fourneerden bemiddelde geestelijke maagden een basis, van waaruit die dienaren in de wijngaard des Heren konden werken. Zolang priesters niet over een vaste verblijfplaats konden beschikken, waren zij genoodzaakt frequent van logeeradres te veranderen. De jezuïet Adrianus Courten (1577164I) en de wereldheer Volkert Herkinge ( $\dagger$ I662), beiden in Zwolle werkzaam, waren geruime tijd te gast bij Johanna van Oostendorp, weduwe Van Vilsteren. Voor de vrouw des huizes was het geen onverdeeld genoegen deze priesters over de vloer te hebben. De verstandhouding tussen Herkinge en Courten liet namelijk

135 Van Eck, Kunst, twist en devotie, 76-77; zie ook 65, 108.

136 Van Heel, De minderbroeders te Gouda, II, 68-69; Vgl. Van Hoeck, Schets, 64.

137 Theissing, Over klopjes, I3I-I37. 
te wensen over. Laatstgenoemde had enkele boeken, die toebehoorden aan Herlunge, uut het raam gegooid en daarmee andere bewoners van het huis de schrik op het lıf gejaagd. Nu Courten zich onmogelıjk had gemaakt bı) zujn gastvrouw, moest hlj elders zijn kamp opslaan. Daarom droeg hij juffrouw Van Dotecum, 'die een cloppien biy hem geworden was' op om een huis te huren, waar hij zijn intrek nam. Herkunge koos daama het huss van weduwe Van Vilsteren als zl)n vaste residentre. ${ }^{13^{8}}$

Sommuge geestelıke maagden die met apostolisch vicans Joannes van Neercassel correspondeerden, regelden allerleı kwesties voor hem. Iemand als Marie-Anne Voeller kon daarbıj bogen op een invloedrijk sociaal netwerk Haar vader, Léonard Voeller (I596-I675), en haar broer Jean-Herman (I630-1710) vervulden achtereenvolgens de invloednjke functie van secretans van Staat voor Duitse zaken te Brussel. ${ }^{139}$ Mane-Anne was mede daardoor soms in de posine als intermediair voor Neercassel op te treden $Z_{1 j}$ bracht namens hem bneven en boodschappen over aan verscheıdene geestelıken in de Zuidelı)ke Nederlanden, maar ook aan de Brusselse internuntıus, aan wie als pauselı)ke gezant het toezicht op de Hollandse Zending was toevertrouwd. $Z_{1 j}$ bestelde boeken voor hem en vernchtte betalingen uit zijn naam..$^{40}$

Onbemiddelde kloppen konden zıch als dienstmaagd wıden aan de dagelı)kse verzorging van priesters. Binnen de kloppengroep van de Amsterdamse augustınen-statue De Star waren achtereenvolgens Mana van Eck (I608-1702), Margareta van Loon ( $\dagger$ 1664) en Joanna Cloppenborch ( $\dagger$ 1677) verantwoordellyk voor de zorg voor pnesters en sacnstie ${ }^{141}$ De schullkerken die aan geestelijke maagden waren toevertrouwd, boden de geloofsgemeenschap een plaats van samenkomst. Wie als kosteres fungeerde, diende kerk en altaarbenodigdheden schoon te houden, schoon en gesteven linnen op altaar en communiebank te leggen, en te zorgen voor de paramenten. ${ }^{42}$ Kosteressen bekleedden soms een invloedrijke positie binnen de statie, zoals het volgende achttiende-eeuwse voorbeeld illustreert Nicolaas Broedersen, wereldheer van de oud-bisschoppelı)ke clerezıe en pastoor van de kerk van de $\mathrm{H}$ Ursula in Delft, besloot in $\mathbf{7 4 3}$ tot de bouw van een nieuwe kerk Maar niet voordat hij hiertoe overleg had gepleegd met zijn onderpastoor Petrus Brakman, de notabelen der gemeente, en met juffrouw Anna van Loon, geestelıke maagd en kosteres. ${ }^{143}$ Toen Van Loon op 25 maart 1750 haar vjfentwintigjang jubileum als klop vierde, werd er een 'vreugd-gezang' aangeheven, waann zij werd bezongen als 'het puik van onze Maagden', de 'voor 't Maagdenkoor (...) zulk

$13^{8}$ Me1)er, 'Nopende het aartspnesterschap', 22, An , 'Volquerus Herkunge', 280

139 Jacques, 'Les Voeller', I54-I 58

I40 Ibidem, I76-177

I4I PA OSA, De Star, 227, 229-230, 234

142 Theissing, Over klopjes, 134-136

143 Ibıdem, 159 en vgl $I_{42}$ 
prikkelspoor tot Maagdelijke Zeden' betekende. ${ }^{\mathrm{I} 44}$

De beschikbaarhe1d van geestelijke maagden kende ook grenzen. Wereldheer Antonius van der Plaat (1605-1678), pastoor van Oud Ade en aartspriester, verraste een van zijn geestelijke maagden, Maertje Jans of Jannetje Frans, ${ }^{145}$ met de vraag of zij haar kloppenstaat niet wilde verruilen voor het huwelijk. Een kerkmeester uit Zevenhuizen, aan wie Van der Plaat een geducht tegenstander had, had zijn zinnen gezet op deze klop. Hij wilde een gasthuis stichten en uit dien hoofde had hij een vrouw als assistente nodig. In ruil voor 'bemiddeling' bood hij Van der Plaat aan dat hij zich in de toekomst meer coöperatief zou opstellen. Van der Plaat stond perplex, maar bracht het ongebruikelijke 'aanzoek' over. Met de woorden 'Dochter, hier is een zaak voorhanden, waer door gij den hemel kont verdienen' legde hij de geestelijke maagd het verzoek voor. Zich wel bewust van haar plicht om haar biechtvader te gehoorzamen, antwoordde de vrouw: 'Als 't u belieft, vader'. Van der Plaat schrok en legde haar vervolgens uit dat 'dit werk hangt altemaal aan uw vrijen wil' in plaats van aan de zijne. Hij droeg haar op negen dagen te vasten en vervolgens ter communie te gaan om van God de genade te verwerven om in te zien wat ze moest doen. Na die negen dagen verklaarde ze onomwonden 'dat sij bereid was duysendt dooden te willen sterven eerder als haar staat te verlaten'. ${ }^{146}$

Geestelijke maagden droegen waar mogelijk bij aan de opluistering van schuilkerken. Sommigen die met naald en draad zeer bedreven waren, borduurden prachtige paramenten en ornamenten. Enkele bewaard gebleven zeventiende-eeuwse bisschoppelijke gewaden met toebehoren, bestemd voor apostolisch vicarissen Philippus Rovenius en Boudewijn Cats (I662-I663), zijn vermoedelijk vervaardigd door de maagden van de Haarlemse Hoek. ${ }^{147}$ De jezuïet Robertus Seyses stelde in 1704 Geertruid Beijers ervan in kennis dat de satijnen rok en jak, die haar zuster bij haar dood aan de Doesburgse jezuieten-statie had nagelaten, door eenige 'geestelijcke Jufferen en dochters' vermaakt waren tot onder meer een kazuifel, stola en manipel, alsook een antependium. ${ }^{14^{8}}$

$\mathrm{Bij}$ de verspreiding van stichtelijke lectuur en devotionalia onder gelovigen speelden kloppen eveneens een onmiskenbare rol. De Haarlemse maagd Maria Craenhals kocht boeken van voormalıge kloosterzusters op en verkocht ze weer door.

144 An., 'Vreugd-gezang ter eere van Mejuffrouw Anna van Loon (...)', in: RAU, $A O B C$, inv.nr. 1360, Pamfletten en strjudschnften tusschen seculieren en regulieren (I602-1809) Hierbij een nagekomen pak gelegenheidsgedıchten voor kerkelı)ke en wereldlıke personen (1630-1726).

145 Van Lommel, 'Pastoors', 297, 314-315.

146 'Leven van den eerwaardigsten heer Antonn van der Plaat, S.T.L. Pastoor en Aartspnester van Oud Aa, door Joannes Lavalle', uitgegeven un: Van der Wereld, Geschredenis, 89-101, aldaar 98-99

Er is niet vermeld of het hier de uitgave betreft van een handschrift dan wel een eerder gedrukt werk. 147 Theissing, Over klopjes, 134, Caron, "Van de geest"'.

148 PA S], Histonsche handschnftenverzameling, doos I16, C 15 a. 

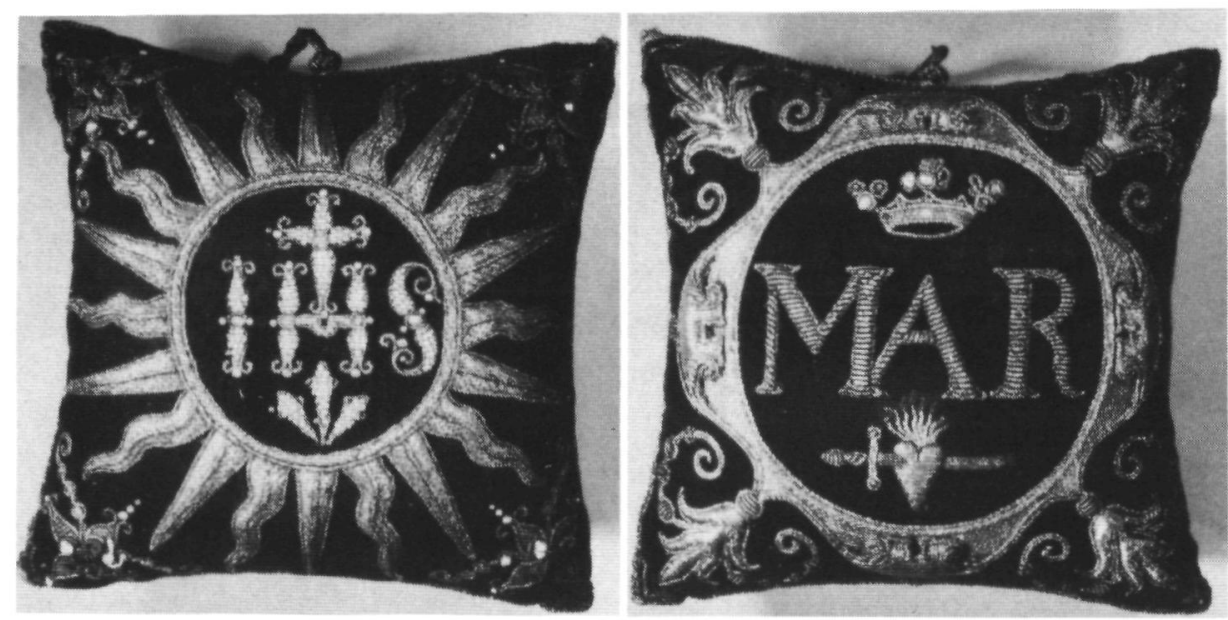

Afb. 3 Speldekussen met Christusmonogram (IHS) en Mariamonogram (MAR), afkomstig van de maagden van De Hoek te Haarlem.

Bovendien restaureerde zij kapotte en afgebladderde beelden, die ze verkocht of weggaf. Tryn Jans Oly noteert dat vrijwel iedere priester in de stad zijn schuilkerk of altaar sierde met door Craenhals herstelde beelden. ${ }^{149}$ Andere Haarlemse maagden vervaardigden en verkochten bid- en devotieprentjes, waarmee ze ten dele ook in hun eigen onderhoud voorzagen. De Amsterdamse geestelijke dochter Hendrina of Hendrickje Kool († I697) handelde sinds 1669 in catholica, voornamelijk boeken, prenten en andere devotionalia. ${ }^{150} \mathrm{Haar}$ winkel en woonhuis lagen aan de Warmoesstraat, 'daar de passer uithangt'; het pand stond bekend als de Vergulde Passer. Zij deelde haar woning korte tijd met een nicht, die eveneens geestelijke dochter was, Claertje Pieters Breevliet ( $\left.\dagger_{\mathrm{I}} 670\right) .{ }^{\mathrm{ISI}}$ Breevliet was een trouw lid van de statie van de wereldheer Willem Schep († I 702). ${ }^{152}$ In haar testament bedacht zij hem met 2000 gulden. ${ }^{153}$ Aan de dertig geestelijke maagden, die de diensten van Schep trouw bijwoonden, vermaakte zij een stichtelijk boek en

149 Theissing, Over klopjes, 134, geciteerd naar Graaf, 'Levens', 35 (1913) 403 e.v.

150 GAA, Notarieel Archief, inv.nr. 5619, nr. 14, notaris J. Commelin, 19 oktober 1697.

151 Filedt Kok, Hinterding en Van der Waals, 'Jan Harmensz. Muller', 352. Zowel Hendrickje als Claertje waren nazaten van de prentenmaker en graveur Jan Muller ( $\dagger_{1628}$ ). Claertje Breevliet was de dochter van Pieter Breevliet en Liesbeth Muller, de zuster van Jan Muller. Hendrickje was vermoedelijk verwant aan de andere zuster van Jan, Maritge, echtgenote van Cornelis Dircksz. Kool, die na de dood van Jan Muller de druk- en verkoopactiviteiten van de Vergulde Passer voortzette.

152 Schep was werkzaam in de statie St. Nicolaas sinds 1655 , tot 1673 als socius en vervolgens tot I693 als pastoor. [Van Heussen], Batavia Sacra, II, 407-408; Van Beek en Hooykaas, Naamlijst, 19. I53 Deze bijdrage was vermoedelijk zeer welkom. De schuilkerk van Schep, De Zwaertvis, gelegen aan de Nieuwezijds Voorburgwal naast de brouwerij de Hooiberg, was uitermate bouwvallig en een prooi voor allerlei ongedierte waardoor de 'deftige luiden' onder de ongeveer zeshonderd gelovigen die deze statie trouw waren, wegbleven. Van Eeghen, 'De eigendom', 230, 258-261. 
een kleine prent, ${ }^{154}$ vermoedelijk afkomstig uit de winkelvoorraad van de Vergulde Passer. Wellicht maakten Breevliet en Kool deel uit van deze kloppengroep. Ongetwijfeld waren beiden zeer devote maagden. In het rijk gestoffeerde woongedeelte van de Vergulde Passer bevonden zich vele schilderijen en beeldjes, onder andere van Onze Lieve Vrouw en Maria Magdalena. Een klein 'sacerdane hout kabinetje met swart ebbenhout ingeleid' met laatjes, dat in de voorkamer stond, bevatte allerlei rozenkransen (paternosters), uitgevoerd in barnsteen, agaath en git. Tevens werden er losse en geregen kralen in bewaard, van zwart git, maar ook gekleurd en 'riekende', waar vermoedelijk rozenkransen van werden gemaakt. Eén kamer, 't kerkje' genoemd, was ingericht voor persoonlijk gebed en meditatie. De ruimte was aangekleed met 'eenige kerkelijke ornemente met sijne misale voorhangels en 't geene voortsz tot den dienst is behoorende'.

Welke boeken Kool precies aan de vrouw of man bracht, is moeilijk vast te stellen, omdat de boedelinventaris van de winkel niet altijd consequent titels vermeldt. In elk geval had zij grote hoeveelheden kerk- en dagheiligingsboeken voorradig, waaronder Rovenius' Gulden Wieroockvat. Daamaast waren er meer algemene handleidingen voor een christelijk leven, zoals bijvoorbeeld Franciscus van Sales' Aenleydinghe tot een devoot leven, dat in de inventaris vermeld staat als 'Onderwijs van Sales'. Ook de Navolging van Christus van Thomas a Kempis had zij op voorraad. Kool bood voorts kloppenboeken aan, te weten De weg der Suyverheyt van d'Hollantse Maegden van Schoenius en de uitgave van het leven van Joanna van Randenraedt. In een aparte ruimte, genaamd het 'winkelkamertje', bewaarde Kool rozenkransen, crucifixen en andere devotionele objecten, bedoeld voor de verkoop. In verschillende kasten werden ' 55 cruisjens fix met haar beeldjens zoo groot als kleen' bewaard, ' 22 swarte houte kandelaars zoo groot als kleen', alsook '50 aarde gepleisterde bloempotjens', die mogelijk bij huisaltaartjes werden gebruikt.

\section{Zorgtaken}

Liefdewerken als zieken- en armenzorg brachten geestelijke maagden in nauw contact met mede-gelovigen. Behalve naastenliefde zal in de ziekenzorg ook de wens om mensen op hun ziek- of sterfbed voor het 'ware' geloof te behouden of te bekeren een belangrijke drijfveer zijn geweest, hetzij van een geestelijke maagd zelf, hetzij van haar geestelijk leidsman. Waar protestantse predikanten hun kudde bijeen trachtten te houden, waren de ziekenbezoeken van een klop natuurlijk een doorn in het oog. De Nijmeegse kerkeraad registreerde in zijn notulen op 24 oktober 1658 de 'stouticheijt sommiger cloppen omtrent het aenspreken en besoecken eenes patients int gasthuijs' ${ }^{155}$ Men oordeelde dat de magistraat zich maar weer eens over deze kwestie moest buigen.

Ook elders probeerden lokale gezagsdragers van de publieke kerk paapse zielzorg

154 Filedt Kok, Hinterding en Van der Waals, 'Jan Harmensz. Muller', 352.

$155 \mathrm{GAN}, A N H G N$, inv.nr. 3. 
aan het ziek- of doodsbed uit te bannen. Martinus Wijbinga, predikant te Hedel, stond Maeijken Arienbroeck bij op haar sterfbed. Hij had de kamer van de stervende vrouw nog niet verlaten of 'de oude quesel, den drost sijn halve suster, met den paep van Ammelroij (...)' makten hun opwachting om zijn werk weer teniet te doen, aldus Wijbinga. ${ }^{156}$ De classis van Woerden klaagde in 1712 tijdens de Synode van Zuid-Holland over een priester, 'de paep van Aerlanderveen', en een klop. ${ }^{157} \mathrm{Zij}$ hadden zich opgedrongen aan een ter dood veroordeelde misdadiger in de heerlijkheid van Vrijenhoven, die ter voorbereiding op zijn straf geestelijk werd bijgestaan door de plaatselijke predikant. Mogelijk bereidden de priester en de klop deze man met rituelen, die de Nederduits-gereformeerde kerk niet als zodanig kende, voor op zijn naderend einde. Stervenden konden hun biecht spreken en vervolgens de communie ontvangen. Vervolgens diende de priester het heilig oliesel toe, waarna hij de pauselijke zegen uitsprak. Tenslotte werden, als de dood nabij was, de gebeden der stervenden uitgesproken. ${ }^{158}$ Of de paap en de klop gelegenheid hadden al deze liturgische handelingen te verrichten, of zich moesten beperken tot de gebeden der stervenden, onthult de bron niet. Het fulmineren van predikanten en gereformeerde kerkelijke instanties tegen dergelijke activiteiten van kloppen, illustreert zowel de schaal waarop deze actıviteiten voorkwamen als de kwetsbaarheid hiervoor van de publieke kerk en haar gezagsdragers.

Kloppen hielden zich ook bezig met armenzorg, al laten protestantse noch katholieke bronnen hier veel over los. Vermoedelijk gaan deze werkzaamheden schuil achter het ongespecificeerde lemma 'paapse stoutigheden' in de acta van kerkeraden, classes en synodes. Apostolisch vicaris Rovenius deed, zoals hierboven geschetst, een appèl op geestelijke maagden om hun middelen en invloed aan te wenden om vooral de armen voor de katholieke kerk te winnen. Zijn oproep kan wellicht geïnterpreteerd worden als een poging om de katholieke armenzorgvoorzieningen, die na de Reformatie teloor waren gegaan, nieuw leven in te blazen. Geestelijke maagden in goeden doen bedachten vaak de armen in hun testament. $\mathrm{Zij}$ werden ook daadwerkelijk ingeschakeld bij het inzamelen en uitdelen van aalmoezen aan katholieke armlastigen. In de Utrechtse statie St. Gertrudıs werden verschillende van hen door de wereldheer Willibrord Kemp als 'armmoeders' aangesteld. Die ontvingen van hem maandelijks een bedrag, waarmee zij de armen

156 RAG, Archref van het bestuur van de Synode van Gelderland, unv.nr 93, Stukken betreffende 'Paepsche Stoutigheden' in de baronie van Hedel en de geschillen aldaar tussen de predikant en de stadhouder en heemraden, 1685-1693 (I omslag) De klop was een halfzuster van de drost Van den Poll. De betreffende episode wordt verhaald in een stuk getuteld 'Paepsche stoungheden van tujd tot tujt bedreven bınnen de Baronıe van Hedel: ende kortelıjk aengeteıkent door Martınus W/jbınga Predıcant derselver steden'

157 RAG, Archief Nederlands Hervormde Clessis Trel, unv.nr 85, afschnften van de Acta van de Synode van Zuid-Holland, 1712 ( 5 julı e.v.) art 12.

158 Hofman, 'Bediening'; 1dem, 'Gebeden der stervenden' 
konden bijstaan. ${ }^{159}$ Ook in Rotterdam werd het armbestuur van de vier katholieke kerken bijgestaan door kloppen, die iedere veertien dagen een bedrag incasseerden ten behoeve van de armlastigen. ${ }^{160}$ Geestelijke maagden ontplooiden zelf ook liefdadige initiatieven. Anna van Loon (1632?-1666), aangesloten bij de kloppengroep van De Star, was bijvoorbeeld arme kinderen zeer toegedaan. $\mathrm{Zij}$ had een grote voorraad kledingstukken aangelegd en wanneer zij een kind naar de kerk zag komen met gescheurde of versleten kleding, dan stak zij het eigenhandig opnieuw in de kleren en stuurde het vervolgens naar huis. ${ }^{161}$

\section{Onderwijs in de beginselen van het katholieke geloof}

In de scholastieke aalmoezenleer, die de theologische basis vormde voor de christelijke naastenliefde, was onwetenden onderwijzen de eerste aalmoes. ${ }^{162}$ De confessionele richtingenstrijd in het tijdperk der reformaties gaf hieraan nog een extra dimensie, want de invloed van de calvinisering deed zich zeker gelden in het onderwijs. Het lager onderwijs, dat van oudsher óók tot doel had kinderen godsdienstige beginselen in te prenten, werd gereformeerd. Niet langer werd de roomskatholieke maar de calvinistische geloofsleer op scholen onderwezen. Kinderen die katholiek gedoopt en opgevoed waren, moesten noodgedwongen protestantse scholen bezoeken en werden verplicht om de protestantse catechisatie en preken bij te wonen. ${ }^{163}$ Doordat kinderen op deze wijze in nauw contact kwamen met het protestantisme, waren katholieke geestelijken bezorgd dat nieuwe generaties voor het 'ware' geloof verloren zouden gaan. Katholiek godsdienstonderwijs verzekerde de overleving van de kerk op langere termijn. Kinderen die eenmaal 'de zuivere waarheden van de kerk' hadden geproefd en in zich hadden opgenomen, zouden niet gemakkelijk meer in verwarring worden gebracht door protestantse schoolmeesters en predikanten. ${ }^{164}$

$\mathrm{Bij}$ het geloofsonderwijs speelden kloppen een belangrijke rol, ${ }^{165}$ al waren zij zeker niet de enigen die zich op dit terrein verdienstelijk maakten. In Friesland werden hiertoe ook gehuwde vrouwen ingeschakeld. ${ }^{66}$ En de minderbroeders in

159 Theissing, Over klopjes, 146, aangehaald uit 'De Oud-Katholıeke kerk van de heilige Gertrudis te Utrecht', De Oud-Katholek 30 (1914) 89.

160 An., 'Katholieke armenverzorging te Rotrerdam', 37, 57.

161 PA OSA, De Star, 229.

162 Conrad, "Katechismusjungfrauen"', 158.

163 Theissing, Over klopjes, 148

164 Petrus a Matre De1, Clara Relatio, 92. Vgl PA SJ, Histonsche handschnftenverzameling, AF 9, Acta Missiones, dl. VII (1663) 445 .

165 Theissing, Over klopjes, Iso Ook in de Zuidelıke Nederlanden vervulden geestelıke maagden een belangrıjke rol bı) het geloofsonderncht, zie De Vroede, 'Kevezels' en 'Zusters', I43-150 en Put, '“Het fundament"'

166 Me1jer, 'Dominicanen-state', 92; Andreae Tiarae Annotationes, 162. Vgl. Hofman, 'Imsum', 148. in I643 was er een plakkaat afgekondigd door de Friese Staten dat kloppen verbood in Fnesland te komen. 
Leıden werden hierbiy terzi)de gestaan door kloppen en tien tot twaalf mannen, die waren opgeleid in de godsdienstleer ${ }^{167}$ De schaarse mannelıke tegenhangers van de kloppen, klopbroeders of kwezelaars geheten, wildden hun krachten eveneens aan de catechisatie ${ }^{168}$ In Utrecht werd in 166 I op negen plaatsen in de stad de catechusmus onderwezen door mannen en maagden die onder leiding van paters jezuleten stonden. ${ }^{169}$ In de Generaliteitslanden waren het voomamelıjk franciscaanse derde-ordelıngen, die toezicht hielden op de catechisantjes. ${ }^{170} \mathrm{Hier}$ hoeft het net noodzakelıjkerwijs om kwezels en kwezelaars te gaan, niet alle leden van de derde orde van St Franciscus legden immers een gelofte van kusheid af

Dit catechiseren was niet zonder gevaar, want wereldlı)ke overheden zagen het als een praktı) $\mathrm{k}$ wartegen opgetreden moest worden. ${ }^{171}$ In de plakkaten van de Staten-Generaal van I64I en 1649 werden kloppen aangewezen als degenen die 'de jonge Jeught ( . ) van den wegh der waerheyt, op verkeerde en tegens Godts Woordt strydende wegen' verleıdden. ${ }^{172}$ De Staten van Utrecht verboden geesteli)ke maagden al in 1639 om catechismusonderricht te geven. ${ }^{173}$ Ook Gelderland vaardigde een dergelık verbod uit in I64I, waann hun tevens werd verboden onderwıss in het algemeen te verzorgen. De verschillende gewestelıjke en lokale verordeningen culmineerden in I64I tenslotte in het plakkaat van de Staten-Generaal waarbij kloppen het recht werd ontzegd iemand in de katholieke leer te onderwizzen of in het vraagstuk der religie te verontrusten ${ }^{174}$ Kloppen die zich hieraan desondanks schuldig maakten, moesten in verschillende steden een boete betalen. ${ }^{175}$ Soms ging het er grimmiger aan toe en werden zil zelfs fysiek bedreigd, godgewıde maagden uit Geertruidenberg werd door 'ketters' toegevoegd dat, als zi) in een nabi) gelegen gehucht geloofsonderncht gaven, ze in het openbaar op de markt gegeseld en vervolgens uit de stad verbannen zouden worden. Het bleef bi) een dreiging, want toen een van de kloppen inderdaad betrapt werd, bleek een boete te volstaan ${ }^{176}$

In de ogen van mede-katholieken werd de betrokkenheld van kloppen bı) het godsdienstonderwils natuurlı k veel gunstiger beoordeeld $\mathrm{Al}$ werd hi) zelf niet door kloppen geassisteerd en zag hil zeker gevaar in de samenwerking met hen in de zielzorg, de karmeliet Petrus a Matre Dei (I6IO-I683) roemde niettemin hun

I67 Sloots, 'De munderbroeders te Leiden', 496-497, 502

168 De Hullu, 'De katholieken te Stompwı)k', I47

169 PA SJ, Histonsche handschnftenverzameling, AF 9, Acta Messiones, dl VII, 316

170 Frenken, 'De Roomsche kerkschuur', 24, vgl Zw1jsen, 'Een jaar kapelaan te Helmond', 88, 95-96

I7I Wiltens, Kerkelyk Plakaat-Boek, I, 544

172 Groot placaet-boeck, I, 206, Wiltens, Kerkelyk Plakaat-Boek, I, 548

173 Theissing, Over klopjes, 190

174 Ibidem, 192

175 In Niymegen bedroeg die boete bijvoorbeeld vıftug goudgulden Raadssignaat van de magistraat, d d 8 maart I660, aangehaald door Meıjer, Dominikaner klooster, 188

176 PA SJ, Historsche handschrftenverzamelng, AF Io, Acta Misstonts, dl VIII (I666) 76 
didactische kwaliteiten. ${ }^{177}$ Tevergeefs had hij mannen ingeschakeld bij de catechisatie. Geestelijke maagden daarentegen wisten de kinderen wel te motiveren door hun welwillendheid. Zeker wierpen de beloningen die de kloppen op gezette tijden gedurende het jaar uitdeelden, ook hun vrucht af. Vol lof is hij over de toewijding van de maagden, die weer en wind trotseerden om in afgelegen dorpen de kinderen van katholieke boeren de beginselen van het katholieke geloof te leren. ${ }^{178}$

Geloofsondericht wordt in de kloppenboeken voorgesteld als een belangrijke vorm van apostolaat, die het eigen zieleheil zou bevorderen. Geestelijke maagden wordt bezworen dat kerk en clerus hieraan grote waarde hechten. Volgens de jezuiet Valentinus Bisschop biedt het catechismusonderricht kloppen zelfs een passend en gelijkwaardig substituut voor de sacramentele taken van priesters, waarvan kloppen op grond van hun geslacht uitgesloten zijn. ${ }^{179}$ Geestelijke maagden konden hun staat en roeping bevestigen door het geven van onderwijs. Daarmee werd het godsdienstonderricht als het ware tot een identiteitskenmerk van de kloppenstaat verheven. Ook protestantse gezaghebbers vonden het catechismusonderricht een kenmerkende bezigheid van geestelijke maagden. Teleurgestelde erfgenamen van de Bossche Adriana Elisabeth Donckers (1679-1760) vochten haar testament aan, omdat zij een klop geweest zou zijn. Op grond van het plakkaat van 1655 zou Donckers dan niet hebben mogen testeren. Behalve haar ongehuwde, kinderloze staat, haar levenswijze en kleding voerden de erfgenamen ook haar onderwijsactiviteiten aan als indicatie voor haar kloppenstaat. Donckers placht namelijk op zondag soms 'publiek' de catechismus te onderrichten, zoals roomse geestelijke dochters dat gewoon waren te doen. ${ }^{\text {180 }}$

Van de in de Hollandse Zending werkzame geestelijkheid documenteerden de paters jezuïeten de bijdragen van kloppen aan het onderwijs het meest uitvoerig. Of dat een aanwijzing is dat zij, anders dan hun collega's, geestelijke maagden nauwer en meer structureel bij het geloofsonderwijs betrokken, is moeilijk te zeggen. De paters beschouwden het catechismusonderricht als minder bevredigend dan het preken, maar niettemin even tijdrovend ${ }^{\mathrm{I}}{ }^{11}$ Misschien was dat één van de redenen waarom zij deze taak ten dele overlieten aan kloppen. ${ }^{182}$ In Amsterdam, Groningen, Nijmegen, het gebied rond Breda, Geertruidenberg en Leiden waren jezuileten-kloppen actief in het geloofsonderwijs. Soms gaven zij uitsluitend meisjes les, zoals bijvoorbeeld in Oudewater. ${ }^{183}$ Niets dan lof wordt hun toegezwaaid door

177 Theissing, Over klopjes, 148-149; Schulte van Kessel, Geest en vlees, 102-103.

178 Petrus a Matre Dei, Clara Relatio, 93.

179 Bisschop, Lof der Suyverheydt, III, 422.

180 Van Sasse van Ysselt, 'Wie viel oudtijds onder de benaming "klopje", 140.

181 PA SJ, Historische handschriftenverzameling, AF 9, Acta Missionis, dl. VII (I663) 445. Zie ook Poncelet, Histoire, II, 299.

182 Vgl. Petrus a Marre Dei, Clara Relatio, 93; Theissing, Over klopjes, 148.

183 PA SJ, Historische handschriftenverzameling, AF Io, Acta Missionis, dl. VIII (I665) 20. 
hun leıdsmannen voor hun onaflaatbare inzet en ıver, hoewel wereldlıjke overheden hun werk soms ernstig bemoeilıkten.

Aangezien het katholıeke geloofsonderncht onder vuur lag van wereldlıke en kerkelıke overheden, moest dit vaak zó georganiseerd worden dat het zo min mogelık in de gaten liep. Waar katholieken bij t1)d en wille scherp werden vervolgd, zoals te Dordrecht en Leiden, werden de catechisanten in kleine groepjes onderwezen. Petrus a Matre Dei verhaalt hoe in deze steden de kunderen door pnesters in groepen van ten hoogste twintg verdeeld werden ${ }^{184}$ Iedere groep kreeg les in een ander (woon)hus, hetzı) van een pnester, hetzı) van een geestelıjke maagd. De missieverslagen van de jezuieten beschnjven hoe in Leiden kunderen omzichtig via een huis, waarn een gewone school was gehuisvest, naar een andere woning werden gebracht waar de catechisatie plaats vond.$^{185}$ De verantwoordelıke paters hielden nauwlettend in de gaten of de onderwissactiviteiten opzien baarden in de omgeving Waar meer vniheid heerste of gekocht werd, kon men minder omzichtig te werk gaan. In Oudewater bijvoorbeeld kon de catechısmus in en buiten de stad betrekkelı1k ongehınderd worden onderncht dankzı) recognıtıe-gelden, betalıngen die katholieken voor korte of langere tijd vnjwaarden van justitiele vervolging wegens het overtreden der plakkaten ${ }^{\text {186 }}$

Over de precieze taakverdelıng van het godsdienstonderwıjs hullen de meeste bronnen zich helaas in stilzwijgen. Vaak laten zij niet meer los dan dat pnesters hierbı) geassisteerd werden door kloppen De wereldheer Bernard Hoogewerff, die Joannes van Heumen bijstond in de Rotterdamse statie St Laurentius en Mana Magdalena in de Oppert, had in 1646 bijvoorbeeld twaalf geestelıke maagden die hem hielpen bij de catechese ${ }^{187}$ Een ondersteunende taak was eveneens weggelegd voor de Roermondse maagd Agnes van Heilsbach. $Z_{1 j}$ werd in haar woonplaats beschouwd als de grondlegster van wat het voorbereidend catechismusonderwi)s genoemd kan worden Van circa 1625 tot 1637 trok deze jezuleten-klop met twee andere maagden langs achteraf-straatjes om kunderen uit voornamelıjk arme gezınnen over te halen godsdienstles te volgen. De lessen werden bi) de vrouwen thuis gegeven, vermoedelı)k om praktısche redenen, want in Roermond, dat behoorde tot de Zuidelı)ke of Spaanse Nederlanden, was geen sprake van geloofsvervolging $\mathrm{Na}$ de les brachten de kloppen deze kunderen naar de kerk, waar een pnester de catechisatıe voortzette. Joanna van Randenraedt, die Agnes' onderwisstaken overnam vanaf 1637 , schnjft dat zij vif jaar lang op zondag 'naer de cristelıcke leerınge' ging, waar ze de vele arme kunderen die niet naar school gingen, 'hilp onderwijessen' ${ }^{\mathrm{r} 8}$ Ook werd er met de kunderen gezongen 'inde cnsteleer' Catechese onder leiding van de jezuieten begon en eindigde vaak

184 Petrus a Matre De1, Clara Relatio, 93

185 Geciteerd door Barten, 'Catechismusonderncht', 24I

186 Van Lommel, 'Relatuo Dekens', 64

187 Theissing, Over klopjes, 59

$188 \mathrm{~KB}$ Brussel, Handschnften 19073 (I), 94 (ongedateerd, vermoedelı)k na 1637) 
met gezang, hetgeen de populariteit van de godsdienstlessen ten goede kwam. ${ }^{189}$ Dat Van Randenraedt na circa 1643 haar apostolaire activiteit verlegde naar geestelijke gesprekken en brieven met andere gelovigen, wijst er misschien op dat een toenemend aantal werkzame priesters in het diocees Roermond de inzet van geestelijke maagden op dit terrein overbodig maakte. ${ }^{190}$

In de Hollandse Zending was het gebrek aan priesters vanaf circa 1638 eveneens minder nijpend. Hulp van kloppen bij het godsdienstonderricht was echter kennelijk nog steeds nodig of wenselijk. ${ }^{\text {'19 }}$ Sommige vrouwen konden betrekkelijk zelfstandig te werk gaan. De Leidse geestelijke maagden, die geprezen worden door Petrus a Matre Dei, waren verantwoordelijk voor het onderwijs aan de jongste kinderen. In totaal namen gemiddeld tweehonderd kinderen deel aan de catechisatie. Priesters kwamen slechts controleren of alles ordelijk verliep en of de kinderen inderdaad vlijtig waren bij het opzeggen van hun lessen. Een groepje Nijmeegse kloppen onder leiding van jezuïeten ging misschien nog onafhankelijker te werk. De catechisatie was in $\mathbf{1 6 2 8}$ aan maagden gedelegeerd, omdat de jezuïeten zelf gevaar liepen door de wereldlijke overheid opgepakt te worden. Om ervoor te zorgen dat de clandestiene religieuze bijeenkomsten hun karakter van viering konden behouden, lieten de paters in deze stad gelovigen stichtelijke teksten zingen op de wijs van drinkliederen, die in en om herbergen populair waren. ${ }^{192}$ Geestelijke liederen gecomponeerd op populaire melodieën waren een door de jezuïeten beproefd didactisch hulpmiddel om gelovigen vertrouwd te maken met de geloofswaarheden. ${ }^{193}$ Misschien oefenden de maagden dergelijke vrome liedjes op profane wijsjes ook met hun catechisanten. Gedurende de jaren zestig trokken kloppen het land van Maas en Waal in om er groepen van driehonderd tot vijfhonderd gelovigen in boerenschuren de beginselen van het geloof te leren; bovendien leidden zij godsdienstige bijeenkomsten bij afwezigheid van een priester. ${ }^{194}$

De in Groningen werkzame jezuïet Ignatius van Meldert ( $\mathrm{I} 662-\mathrm{I} 7 \mathrm{I} 8$ ) stelde een kroniek samen, waarin onder andere de reglementen voor de catechese en de eerste communie van 1701 tot 1718 beschreven worden. ${ }^{195}$ Hieruit valt op te maken

189 Poncelet, Histoure, II, 307-308.

190 Zle hiervoor $V_{4}$ van dit boek.

191 Scheıjndel en Van Hesse, De parochue Woerden, 46-47. Toen de minderbroeder Franciscus van Honsem zijn voorganger Franciscus Cliffius in 1719 opvolgde, kweet hij zich zelf van het geloofsonderncht, een taak die zıjn voorgangers aan een klop hadden overgelaten.

192 PA SJ, Histonsche handschnftenverzameling, AF 5, Acta Misstomis, dl III (I628) 429-43I.

193 Rombauts, Leven en werken, 36-38.

194 Theissing, Over klopjes, I49; PA SJ, Hustorusche handschnftenverzameling, AF 9, Acta Mussionis, dl. VII (I66I) 327-328, 475-476 (I664); AF Io, dl VIII (I665) I9-20

195 GAG, Archief Sint-Martinusparochue, inv.nr. 26, Chronyc- en costuymboeck van den catechismus. Begonst inde kercke der Soc. Jesu in Groening. byder Aa opden sondaghe voor sa tanuani I7os. Deze bron bevat tevens lijsten van catechisanten en communicanten, I70I-1718. Aanvullingen daarop betreffen 1748-1750, 1752 en 1756 Met bıjzondere dank aan drs. Gernt Vanden Bosch, die mij op deze bron attendeerde en $\mathrm{mi}$ ) een gedeeltelıke transcriptie hiervan ter hand stelde Vgl. voor innchting en 
hoe de catechisatie in de statie aan de Aa georganiseerd was en welk aandeel kloppen daarin hadden. Groningse jezuïeten-kloppen waren al vanaf circa 1620 actief in het geloofsonderwijs. ${ }^{196}$ Het is daarom goed mogeliik dat Van Meldert een al langer bestaande praktijk documenteert. Zijn kroniek omvat twee delen, gewijd aan de werkwijze en het verloop van de grote en de kleine catechismus. Bij de grote catechismus, die eens per week op zondagmiddag gehouden werd, vervulden kloppen een assisterende taak. In I7OI namen bijvoorbeeld in totaal 92 kinderen en jongeren deel aan dit onderwijs. Catechisanten werden gestimuleerd door een uitgekiend beloningssysteem. Aan degenen die de geloofsvragen en de bijbehorende antwoorden konden opdreunen, deelden kloppen zogeheten noten uit. De kleur van de noten drukte de prestatie uit.

'De sorghe-hebbende cloptiens sitten, als den Pater staet; ende staen, ofte wandelen, als den Pater sit, dat is onder het antwoorden, herhaelen vande ujtlegginghe etc. om alsoo te gevoeghelijcker de noten te connen uijtdeylen',

aldus Van Meldert. ${ }^{197}$ Tijdens het jaarlijkse mondelinge examen dicteerden kloppen de vragen aan de kinderen, verdeeld in groepen van twaalf. De examenresultaten waren, in combinatie met het aantal en de kleur van de verkregen noten, bepalend voor de rangorde binnen de groep, die eens per jaar werd vastgesteld. Perfectie, maar ook volharding werd beloond met prijzen, die vermoedelijk door kloppen werden vervaardigd. ${ }^{198}$ In elk geval foumeerden zij doorgaans materiaal of middelen voor deze prijzen. ${ }^{199}$

Twee kloppen waren verantwoordelijk voor het bijhouden van de absentie. Binnen een week moest een klop bij de afwezige jongens en een andere klop bij de afwezige meisjes informeren waarom zij verstek hadden laten gaan. ${ }^{200} \mathrm{De}$ voorbereiding van de catechisanten op de eerste communie behoorde ook gedeeltelijk tot de verantwoordelijkheden van de kloppen. ${ }^{201}$ Eerst stoomden zij de kinde-

methode van het catechismusonderncht Poncelet, Historre, II, 307-316.

196 Van Lommel, 'Van de Velde S J, Narratio histonca', 98 In 1664 worden de onderwusacturteiten van geestelı)ke maagden wederom vermeld, zle PA SJ, Histonsche handschrftenverzameling, AF 9, Acta Misstonis, dl. VII (1664) 476. Mogelık leefden deze vrouwen in cen kleine gemeenschap. Doombos, 'Rooms-katholıeke bewonerslısten', $25^{\circ}$ in 1688 wordt er melding gemaakt van 'eenige cloppen bı de A in de gangh', een lokatie die ook wel 't kloester' werd genoemd.

197 Van Meldert, Chronyc-en costuymboeck, 5 vo.

198 Ibıdem, 7vo Ook kloppen onder leıdıng van minderbroeders vervaardigden prjzen voor catech1santen PA OFM, Archreven van de Latynse school te Megen 1645-1967, inv.nr. II-15, rekeningen van schoolgelden van de Rentmeester van de Latınse School, en inv.nr. 16-18, Rekeningen voor de Rentmeester der Laujnse school $1700-1798$.

199 Van Meldert, Chronyc-en costuymboeck, II, waar bjjoorbeeld in verband met de pnjzen aangetekend staat 'Benefactrices Griettuen en Aeltuen Claessens'.

200 Ibidem, 5 vo

201 In 1713 wordt de leeftud waarop de eerste communie werd gedaan, vermeld in de kroniek, lbidem, 52-52vo De twintug communicantjes zı)n gemiddeld dertıen jaar oud Van één van hen is geen leefujd opgegeven De jongste is elf, de oudste achtuen Vier, vif en zeven van hen zijn respectuevelıjk twaalf, dertien en veertien Met dank aan drs. Gernt Vanden Bosch 
ren gedurende veertien dagen klaar, daarna besteedde Van Meldert zelf nog eens acht dagen aan de voorbereiding. Vooral de processie, die vermoedelık plaatsvond binnen de schulkerk waar de eerste communie werd uitgereikt, moest vlekkeloos verlopen. Voor alle zes delen van de processie, met urtzondenng van het slotdeel, droeg een klop zorg. ${ }^{202}$

Tydens de kleıne catechısmus waren kloppen verantwoordelıjk voor de planning en organisatie:

'De manter, opde welcke de catechismus gehouden wordt, de daegen, en ueren, opde welcke de kanderen vergaederen, de verdeılinge vande knderen etc wordt de sorge-hebbende cloptuens vru gelaten ${ }^{303}$

In I70I waren er twee groepen in de kleine catechismus; een van 39 kunderen en een van $27 .^{204}$ Iedere groep werd geleld door een geestell1ke maagd, die werd bijgestaan door een tweede Op dne vaste tijdstippen moesten de kloppen de hun toevertrouwde kınderen naar de kerk begeleıden, waar de pater zich over de kınderen ontfermde. De eerste samenkomst was bedoeld om te bepalen wie naar de grote catechismus mocht. De tweede en derde samenkomst greep de jezuret aan om de kinderen aan te moedigen de catechisatie te hervatten na afloop van de aanstaande vakantre. De pater, 'met sıjnen kerck-tabbaert gecleedt sı)nde', wachtte de kinderen op en overhoorde de vragen en antwoorden. Vervolgens werden er - al naar gelang de prestatie - beloningen uitgedeeld.

Over de vraag of en hoe deze Gronıngse geestelıke maagden werden opgele1d voor hun onderwiss- en assisterende taken, zwilgt Van Melderts kroniek. Uit andere bron valt op te maken dat de jezuneten hun geestelıjke dochters inderdaad opleidden voor het catechismusonderwils. In de Acta misstonts wordt over de Oudewaterse kloppen opgemerkt dat zly 'a nostro instructas' waren, door een jezuiet ter plaatse opgeleid. ${ }^{205}$ Ook de in Leiden werkzame jezuieten schoolden vrouwen, onder wie zeker geestelıke maagden, in het geven van godsdienstonderw1)s ${ }^{206}$

Welke leermiddelen geestelı)ke maagden gebruikten, is met bekend. Voor de Leidse jezureten-statie is vastgesteld dat de paters werkten met de zestrende-eeuwse catechısmus van Petrus Canısıus, kloppen daarentegen gebruıkten waarschı)nlık de catechismus van Rovenius, die meer was toegesneden op de missionaire situatie van de katholieken in een andersgelovige omgeving. ${ }^{207}$ Volgens de afvallige priester

202 Ibidem, 13-14 Vgl Barten, 'Godsdienstonderncht', 242, die oppert dat deze plechtigheid haar oorsprong wellicht vond in de Leidse jezuieten-state

203 Van Meldert, Chronyc- en costuymboeck (II), 3

204 Ibidem, 40-4I

205 Van Lommel, 'Relatio Dekens', 64

206 Barten, 'Carechismusondernchr', 241, 248 Het betreft vrouwen jonger dan zesentwinug jaar, die vooral in de controverse werden geoefend

207 Ibidem, 252-253 Vgl PA SJ, Historssche handschrftenverzameling, AF 9, Acta Missionis, dl VII (1663) 445, waar vermeld wordt dat in Rotterdam de Mechelse catechusmus werd gebrukkt, die kunderen 
Rudolf Franciscus van Groeninghen maakten kloppen bij hun een à twee uur durende catechismuslessen gebruik van 'haer eigene vraegboeckjens' ${ }^{208}$ Of zijn getuigenis, dat vooral bedoeld was om de katholieke kerk die hij de rug had toegekeerd in diskrediet te brengen, geloofwaardig is, moet worden betwijfeld. In elk geval konden dergelijk boekjes tot dusver niet opgespoord worden.

\section{Gewoon onderwijs}

Gewoon onderwijs op primair en secundair niveau was voor sommige kloppen een bron van inkomsten. In zogeheten leer- en winkelscholen leerden zij meisjes breien, naaien, spinnen en allerlei naaldwerken. Dankzl) deze vaardigheden zouden meisjes uit minder bedeelde milieus later zonodig zelf de kost kunnen verdienen. Mogelijk droeg het kloppenonderwijs eveneens bij aan de alfabetisering van meisjes doordat lezen en schrijven deel uitmaakten van het curriculum. In 1588 werd een winkelschool in de Haarlemse kloppenvergadering De Hoek gesticht door de priester-overste Comelis Arents Lichthert. De onderwijzende kloppen legden de leerlingen van dit Maagdenhuis een van geloof doortrokken stramien van leren en werken op, waarin ruimte was voor het kloosterlijk slentium, voor gebeden en het zingen van stichtelijke liedjes. Deze school telde zowel katholieke als nietkatholieke leerlingen. De school was niet gevrijwaard van vervolging, want in 1602 werd er op last van de magistraat door de schout een inval gedaan. De wereldlijke overheld was net zo min geporteerd voor de algemene onderwijsactiviteiten van kloppen als voor hun geloofsonderricht. Ouders van niet-katholieke leerlingen sprongen wel in de bres voor de kloppen bij dreigende vervolging, waardoor het voortbestaan van de school lange tijd verzekerd was. ${ }^{209}$

Natuurlık werden kloppen die leer- en winkelscholen dreven, ervan verdacht kinderen in de beginselen van het geloof te onderwijzen onder het mom hun te leren breien of naaldwerken. ${ }^{20}$ Het voorbeeld van het Haarlemse Maagdenhuis illustreert dat deze verdenking niet geheel ongegrond was. Daarom klaagden kerkeraden, classes en synodes vrijwel onafgebroken over kloppenscholen. Die klachten werden gedeponeerd bij de verschillende lokale en gewestelijke overhe-

uit het hoofd moesten leren. Over de betrokkenhe1d van kloppen bı het onderwijs in de Maasstad wordt dan niet gerept. Voor de grote en kJeune catechismus van Rovenus zie Vregt, 'Over katechismussen', 359-362 De aanpassingen in deze catechismus ten opzichte van de eerste Mechelse catechismus van Lodewi)k Makeblıde S.J worden besproken door Spiertz, 'Godsdiensug leven', 349 . In navolging van de Bossche bisschop Masius nam Rovenuus twee extra lessen op, waarn het pauselıjk pnmaat en het kerkelıjk leergezag uıtdrukkelık werden gestupuleerd. Bıj de behandeling van de vıf geboden der H Kerk gaat hy in op kwesties die specifiek zijn voor katholıeken in de Hollandse Zendıng, zoals onder andere de geldigheid van de doop door een predikant.

208 'Geschiedenis van een afvallige pnester', 242.

209 Theissing, Over klopjes, 150-15I.

210 Van Doommalen, 'Kwezels en kwezelaars', 37, waar een dergelıjke klacht van de schoolmeesters in de classis 's-Hertogenbosch wordt aangehaald Voor vergelıjkbare klachten in Overi)ssel, zie De Hullu, 'Aantekeningen', 47 en Geerdink, Eenige bijdragen, 142 
den, die via schoolverordeningen en schoolreglementen het bestaan van dergelijke ongeoorloofde katholieke bijscholen probeerden in te perken. ${ }^{211}$ In Holland was in I625 een schoolorde aangenomen; oorspronkelijk waren er plannen die ook in andere gewesten te doen invoeren, opdat er op het gebied van het onderwijs voor de gehele Republiek uniforme regelingen golden. ${ }^{22}$ De invoering in andere gewesten bleef evenwel uit en de afzonderlijke gewesten begonnen eigen maatregelen te nemen. In de Generaliteitslanden werd in 1655 een schoolreglement afgekondigd, waarin 'Papen, Monnicken, Mennonieten, Nonnen, Bagijnen, Kloppen, Sectarissen, noch yemant anders, 't zij Man ofte Vrouwe' werd verboden school te houden. ${ }^{253}$ Hierop was het onderwijsreglement dat sinds I68I in Gelderland gold, geïnspireerd, waarin een gelijkluidende bepaling was opgenomen. ${ }^{214}$

Daadwerkelijk optreden van de wereldlijke overheid staat maar zelden gedocumenteerd in de bronnen. In het gewest Utrecht maakten classes en kerkeraden tussen 1634 en 1764 zeven maal melding van kloppenscholen. ${ }^{215}$ De wereldlijke overheid voelde zich maar sporadisch geroepen tegen deze bijscholen op te treden. Alleen de kloppenschool te Wilnis werd in 1634 door de schout verboden. Soortgelijke scholen in Demmerik, De Bilt, Thamen, Harmelen, Cothen en ook de school in Abcoude, gedreven door Gijsje de Clop, konden kennelijk ongehinderd voortbestaan. ${ }^{216}$ Nader onderzoek in Staats-Brabant, in het bijzonder in de classis 'sHertogenbosch, heeft eveneens uitgewezen dat de klachten van lokale protestantse kerkdienaren talrijk waren. Ook hier was het animo onder lokale bestuurders om tegen de gesignaleerde misstanden op te treden echter gering. Lokale bestuurders en het overgrote deel van de bevolking waren immers vaak nog katholiek. ${ }^{217}$ Het leerplan van de meeste kloppenscholen zal het midden gehouden hebben tussen een naai- of breischool enerzijds en een bewaarschool anderzijds. Over het leerlingenaantal delen de bronnen weinig mee, maar vermoedelijk waren de meeste scholen niet groot. ${ }^{218}$ Veel kloppen gaven uitsluitend aan meisjes les. De paters jezuieten, die deze vorm van meisjesonderwijs in verschillende plaatsen gesteund en gestimuleerd hebben, noemen een dergelijk instituut in hun verslagen een 'gynicaeum'. Van een dergelijke school wordt in 1677 te Delft melding gemaakt. ${ }^{219}$ Of

21 De Booy, Weldaet der scholen, 106-109.

212 Ibidem, 27.

213 Groot placaet-boeck, II, 2409. Ook geciteerd door Van Doommalen, 'Kwezels en kwezelaars', 37.

214 Boekholt, Het lager onderwijs, 14-15; De Booij, Weldaet der scholen, 29.

215 De Booij, Weldaet der scholen, 300-304, bijlage 18.

216 Gijsje de Clops school wordt in 1678 vermeld. Mogelijk was dit een kostschool, want in 1722 blijkt er in Abcoude een katholieke kostschool te bestaan. RAG, Archief Nederlands Hervormde Classis Tiel, inv.nr. 87, afschriften Acta synodi Suyd-Hollandiae 1722, art. 19.

217 Van Doommalen, 'Kwezels en kwezelaars', 38-39.

218 De Booy, Weldaet der scholen, I06-107; vgl. Van Doornmalen, 'Kwezels en kwezelaars', 38, die opmerkt dat in de acta van de classis 's-Hertogenbosch slechts eenmaal melding wordt maakt gemaakt van een leerlingental: in 1717 telde de school van een kwezel te Waalwijk 25 leerlingen.

219 Theissing, Over klopjes, 154. 
dit dezelfde kloppenschool is die vóór I630 daar in het leven werd geroepen, is onduidelijk.

De lotgevallen van laatstgenoemde school verhelderen dat sommige kloppen hun eigen scholen niet alleen 'bemanden', maar ook financierden en dat zij daarbij onder toezicht stonden van geestelijken. Maria Bartholomeus, een welgestelde Delftse geestelijke maagd, richtte deze school op in een huis dat haar toebehoorde. ${ }^{220}$ De jezuïet Lodewijk Makeblijde (I565-I630) adviseerde haar om dit pand, dat gelegen was aan de 'Varckmart' en met een poort uitkwam op de Turfmarkt, en de bijbehorende inventaris op naam van een onbemiddelde maagd te zetten. Als de schout een inval deed en de school zou confisqueren, bleven andere bezittingen van Bartholomeus gevrijwaard van inbeslagneming. Ondanks deze vermogensrechtelijke kunstgreep bleef Maria Bartholomeus aangesteld als hoofdmeesteres van de school. De nieuwe eigenares in naam, Anna Jans, werd ondermeesteres. Makeblijde zelf fungeerde als voogd of toezichthouder. Deze taak werd na zijn overlijden overgenomen door zijn opvolger, Roeland de Pottere (15841675). Ondermeesteres Anna Jans accepteerde diens gezag evenwel niet. De onenigheid liep zo hoog op, dat De Pottere en hoofdmeesteres Bartholomeus zich genoodzaakt zagen de school in twee afdelingen te splitsen. Terwiil Jans schoolhield in het voorste en mooiste deel van het huis, nam Bartholomeus met 'haer kiederen [sic]' het achterste gedeelte in gebruik. De splitsing mondde tenslotte uit in een boedelscheiding via een gerechtelijke procedure. Jans dwong af dat zij een deel van de goederen als haar bezit mocht meenemen. Mogelijk deden Bartholomeus en De Pottere die concessie om van deze lastige klop verlost te zijn. Jans betrok een speciaal voor haar ingericht huis op het Begijnhof; of zij ook daar school gehouden heeft, is niet bekend.

De meest bekende kloppenschool was de kostschool te Culemborg, waar meisjes boven de twaalf werden onderwezen. Naast gewone vakken als lezen, schrijven en handwerken, werd er ook Frans en muziek gedoceerd. ${ }^{22 x}$ Het initiatief voor de stichting van deze school ging vermoedelijk uit van de voorname geestelijke dochter Anna Meerhout. Aangenomen wordt dat de school tussen I626 en 1632 werd geopend. Meerhouts initiatief werd in de loop der jaren door de jezuieten overgenomen, die sinds 1628 een vaste statie in Culemborg hadden. ${ }^{222}$ Geheel zonder problemen schijnt dit niet gegaan te zijn; over de kwestie wie zich eigenaar van de school mocht noemen, verschilden de paters van mening met de familie Meerhout. ${ }^{223}$

220 ARAB, Archief fezuëten, Vaamse Provincie, I477, bundel I, nrs. 62-63 [Anoniem getuigenis over de werkzaamheden van de pater Roeland de Pottere in Delft en omstreken, vanaf ca. 1621], 2. Drs. Gerrit Vanden Bosch kwam dit incident op het spoor en voorzag mij van informatie hierover.

221 Theissing, Over klopjes, 152.

222 Van Hoeck, 'De jezuïeten-statie te Culemborg', 65.

223 Theissing, Over klopjes, I53. Vgl. Van Hoeck, 'De jezuieten-statie te Culemborg', 71. 
Naast dergelijke interne problemen, kampte de school ook met de exteme dreiging van vervolging en opheffing, waar de plaatselijke predikanten op aandrongen. De 'seer schadelijcke Cloppenschole binnen Cuijlenburgh' vormde haast een vast agendapunt op de vergaderingen van de Zuid-Hollandse Synode. ${ }^{224}$ Binnen de vrije heerlijkheid van het graafschap Culemborg was de reformatie doorgevoerd, maar lokale kerkelijke gezagsdragers waren allerminst tevreden over het optreden tegen de roomsgezinden. ${ }^{225}$ En de 'ante-Christi Cloppenschool in het midden van ons Lant' bleef een doom in het oog. ${ }^{226}$ Enigszins gênant was dat de school ook niet-katholieke leerlingen trok, die geen strobreed in de weg gelegd kon worden. ${ }^{227}$ Daarom concentreerden kerkeraad en classis zich wellicht vooral op de strijd tegen de kloppen. In I669 deponeerde de Burense classis, waar Culemborg kerkelijk onder ressorteerde, een zoveelste klacht bij de graaf van Culemborg, Henrick Wolraet van Waldeck, over 'het excessiv groot getal der cloppen, die in de huijsen insluijpende, de huijsgesinnen beroeren, en door hare list en bedrog de eenvoudige verleijden en van de Gereformeerde Religie af(..)houden' ${ }^{228}$ De kerkelijke gezagsdragers stelden de graaf voor om 'buijten papen' [priesters van elders], 'buitenkloppen' en katholieke bijscholen te weren. De graaf was van mening dat het aantal kloppen al gedaald was. Hij schatte dat er niet meer dan zeven of acht vrouwen tot die zogeheten 'buitenkloppen' gerekend konden worden; het betrof hier 'juffrouwen van conditien, die lange jaere daer [Culemborg] hadden gewoont, haer selven stil en gerust houdende'. ${ }^{229}$ Van hen hadden de predikanten weinig te vrezen. Maar de plaatselijke officier had de twee priesters ter stede inmiddels aangezegd de overige kloppen te waarschuwen zich van enige godsdienstige opruiing te onthouden. Bovendien bleef een eerdere maatregel van kracht; er mochten geen nieuwe kloppen aangenomen worden. ${ }^{230}$ Of dit alles veel heeft uitgehaald, mag worden betwijfeld: ruim twintig jaar later, in 1693, telde de stad drie wereldheren en één jezuïet. Matthias Tirza, seculier priester, had de leiding over 28 kloppen, terwijl er in de statie van de jezuïet Franciscus Breekevelt maar

224 Van 1574 tot 1624 ressorteerde het graafschap Culemborg onder de classis Gorcum. Na onenigheid over de beroeping van een predikant en de eis van de Gorcumse classis dat de schoolmeesters de nieuwe leerregels, vastgesteld op de synode van Dordrecht (I6I8-1619), zouden ondertekenen, trad Culemborg op gezag van de landsheer, graaf Flons II van Pallandt, in 1624 toe tot de classis Buren. De Jong, De Reformatre, 223-227.

225 Ibidem, passim

226 RAG, Archief Nederlandse Hervormde Classws Tiel, inv.nr. 30, Acta Classis Buranae I657-1691, anno 1659 (9-10 apnl) art 5 .

227 Ibldem, 1657 ( 23 juni) art. 8.

228 Ibıdem, 1669 (8 junt) art. 2.

229 Ibidem, 1669 ( 8 jun) (antwoord van de Ed. heren Raden aan de classis).

230 Op 9 augustus I 663 had de graaf een plakkaat uitgevaardigd waann geestelıke maagden werd verboden van kleding te veranderen, hetgeen neerkwam op een verbod om de kloppenstaat te aanvaarden. Van Hoeck, 'De jezureten-staue te Culemborg', 87 (noot I), 88. 
liefst 49 kloppen geregistreerd werden, ${ }^{231}$ van wie er mogelijk enkele betrokken waren bij de kloppenschool.

In de jaren 1648 en 1649 telde de Culemborgse school ongeveer 40 leerlingen. ${ }^{232}$ Tussen 1673 en 1699 stonden er in totaal 284 leerlingen ingeschreven. De inschrijvingsduur varieerde van een tot zeven jaar. Het 'Cost-Boeck' van de kloppenschool laat zien dat leerlingen overal uit de Republiek en daarbuiten kwamen en voomamelijk uit vooraanstaande families afkomstig waren. ${ }^{233}$ Hoeveel kloppen precies betrokken waren bij het reilen en zeilen van deze school, is niet duidelijk. ${ }^{234}$ Vermoedelijk werd de kloppenschool vóór 1725 opgeheven. ${ }^{235}$

Van een andere kostschool voor meisjes wordt al in 1628 melding gemaakt, en wel te Gouda. Vermoedelijk was deze school kleinschaliger, want ze telde toen dertig leerlingen. Evenals de leerlingenpopulatie van de Culemborgse kostschool waren de leerlingen van de Goudse school van voomame afkomst. Ook zij kwamen van heinde en verre om deze school te kunnen bezoeken. Het onderwijs, waarover inhoudelijk niets bekend is, was in handen van een achttal geestelijke maagden, telgen uit aanzienlijke en zelfs adellijke families. ${ }^{236}$ Deze school was vermoedelijk een langer leven beschoren dan de Culemborgse kostschool, want nog in 1730 wordt er tijdens de Zuid-Hollandse synode geklaagd over een kloppenschool te Gouda. ${ }^{237}$

\section{II.5 Kloppen als culturele intermediairs}

Kloppen namen onder katholieken een aparte positie in. Hoewel zij in kerkrechtelijk opzicht leken waren, beschouwden hun geloofsgenoten hen vaak niet als zodanig. Ook geestelijken onderscheidden deze vrouwen van de ovenge gelovigen. ${ }^{238}$ Tussen $\mathrm{I} 748$ en $\mathrm{r} 800$ overleden twintig geestelijke dochters in de Utrechtse dominicanen-statie De Walsteeg. Hun namen werden vastgelegd op een lijst, die ook de namen bevat van overleden priesters van de Walsteeg, van een vooraanstaande

231 RAU, $A O B C$, unv nr. 679, visıtatierapporten 1691-1695

232 PA SJ, Histonsche handschnftenverzameling, doos $144 \mathrm{C}$ 25, "Culemborg Breve Chronicon sitae ad Leccam flunum, in confinus Geldnae' (verm. Ige-eeuws afschnft).

233 Thym, 'U1t het "Cost Boeck"'.

234 Ibidem, 326, waar wordt gerept over twee à drie.

235 Theissing, Over klopjes, 153

236 Van Lommel, 'Relatio Bauters', 252-253. Theissing, Over klopjes, 153.

237 RAG, Archref Nederlands Hervormde Classes Tiel, inv.nr 91, afschnften Acta synod, Suyd-Hollandiae $173^{\circ}$, art 9.

$238 \mathrm{Z} \mathrm{Z}_{1 \mathrm{e}}$ bijvoorbeeld GAA, Archief van de statze en de hulpkerk 't Boompje of H. Francuscus van Assisze te Amsterdam in de Kalverstraat (J628-r9II), unv $\mathrm{nr}$ 122, 'Fructus spintuales Fratrs Mathuae Lodewıjckx in Missione Amstelodamensi Anno 1662 [1662-1674]' In dit overzicht van dopen, huweli]ken, begrafenıssen, bekenngen en broederschapsleden is een aparte lijst opgenomen van geestelıjke dochters ('fillae spıntuales'). 
weldoener, een man die van het jansenisme was bekeerd, alsook van een priester die elders werkzaam was geweest maar binnen De Walsteeg zijn laatste adem uitblies. Vanuit de optiek van de geestelijke die deze lijst samenstelde, behoorden de geestelijke dochters tot het 'geestelijk' of misschien zelfs 'kerkelijk personeel'. ${ }^{239}$ De uitzonderingspositie van kloppen rustte op een dubbel fundament: de maagdelijke staat enerzijds en de religieuze invulling daarvan onder strakke begeleiding van een geestelijke anderzijds. Deze tweeledige fundering legitimeerde naar de mening van de verschillende geestelijken dat maagden zich toelegden op onderwijs en (semi-)pastorale taken die hen in nauw contact brachten met andere gelovigen. Onder andere politiek-confessionele omstandigheden zouden deze werkzaamheden misschien voomamelijk door geestelijken zijn verricht.

Maagdelijkheid gold in katholieke kringen als beter en zaliger dan het huwelijk, zo was door het Concilie van Trente nogmaals bevestigd. Protestantse hervormers daarentegen erkenden de mogelijkheid van een vrijwillig celibaat wel, maar weigerden dit te zien als een permanente staat die in moreel opzicht superieur zou zijn aan het huwelijk. In hun ogen verdiende het huwelijk als levensstaat de voorkeur boven een ongehuwd bestaan..$^{24}$ Dergelijke opvattingen vonden weerklank onder Noordnederlandse protestanten. Staatsman en literator Constantijn Huygens (1596-1687) vertolkte ze bijvoorbeeld op luchtige, maar niet mis te verstane wijze in een gedicht dat hij in I633 voor de dichter Tesselschade Roemers (I594-I649) schreef. ${ }^{241}$ Dit vers was bedoeld als uitbrander. Huygens beschuldigde haar ervan een jonge vrouw 'tot het geestelick leven' gedreven te hebben. Naar alle waarschijnlijkheid doelde Huygens op de kloppenstaat. ${ }^{242}$ Over de kuisheid, die er het fundament van vormt, maakt hij veel misbaar. Hij vergelijkt de jonge vrouw met een zojuist geschilderd doek en vraagt Tesselschade:

'(...) Rolt ghij se wegh te droogen,

Te schimlen in een hoek (...).,243

Een vrouw die kiest voor een religieus, kuis bestaan onttrekt zich volgens Huygens, die de opvattingen van de hervormer Calvijn echoot, aan de natuurlijke bestemming van haar geslacht. Voortplanting, vrucht dragen, is haar lot. Een geestelijk

239 PA OP, Reginaldus van der Venne, Histonsche aantekeningen. Nederd. Provincie, kloosters en staties en bisdommen (ongedateerd) $\mathrm{KL} \mathrm{o}-\mathrm{b}$. Dit register werd oorspronkelık aangelegd door pater Joannes van Bennekom ( $f$ 1761) en werd door zljn opvolgers voortgezet.

240 Voor de opvatungen van hervormers over het gehuwd en ongehuwd bestaan, zie Kloek, 'De Reformatie'

241 'Aen Joffw. Tesselschade Visscher, drivende een' schoone dochter van Mr. Pieter van Veen, in sijn leven uytnemend schilder, tot het geestelıck leven', geciteerd in Worp, Een onwaerdeerlycke vrouw, 104. Vermoedelı|k bedoelde Huygens Theodora van Veen, de jongste dochter van Pieter van Veen en Jacobmina van Ruyven. Theodora wilde misschien, evenals haar oudere zuster Geertruyt, geestelıke hraagd worden. Tesselschade Roemers, De gedıchten, 63.

242 Zoals Worp reeds heeft geopperd. Een onvaerdeerlycke vrouw, xxxi1.

243 'Aen Joffw. Tesselschade Visscher', vers 7-8, geciteerd in Worp, Een onwaerdeerlycke vrouw, IO4. 


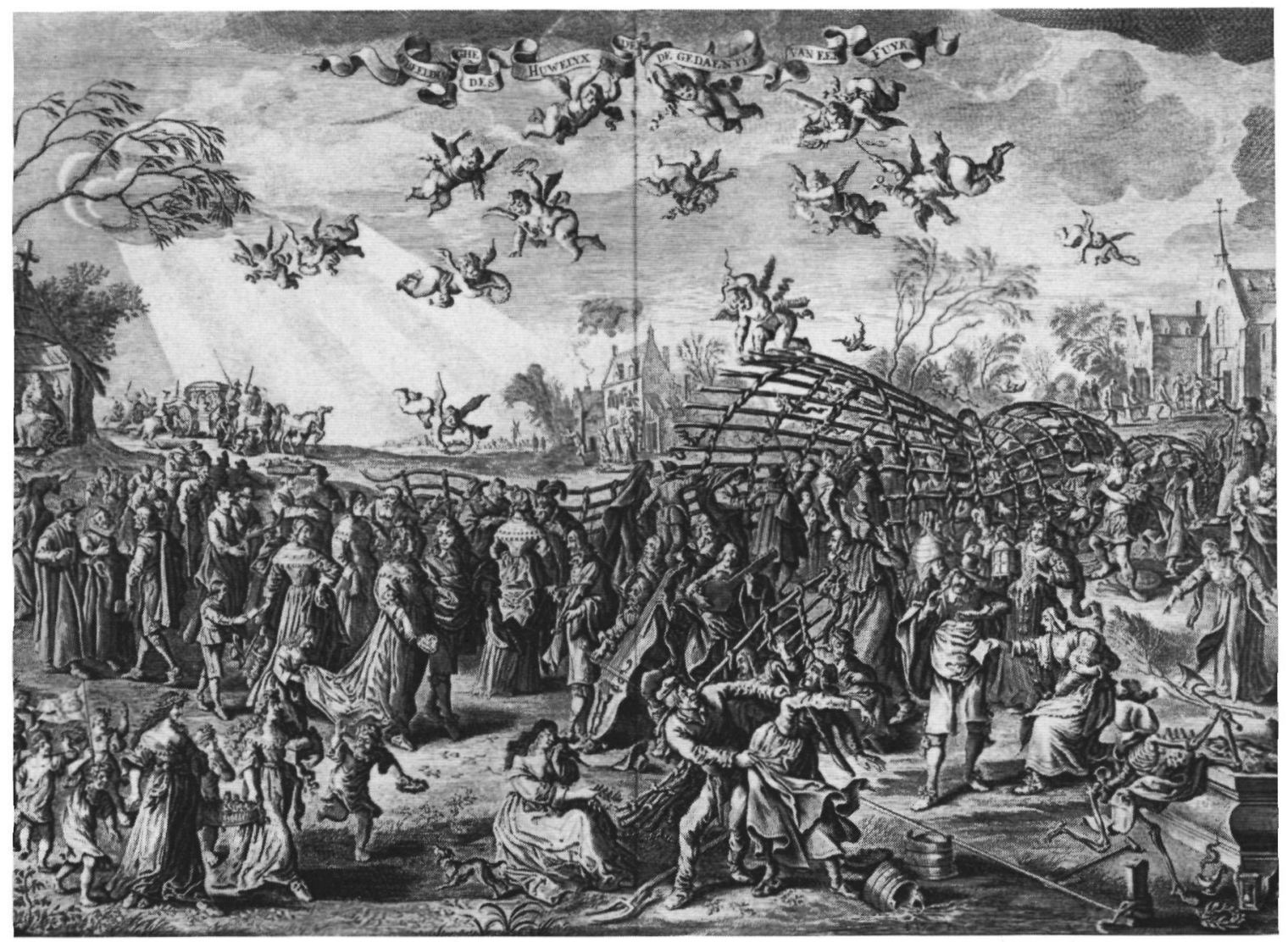

Afb. 4 Deze prent, getiteld 'Huwelijksfuik', is opgenomen in Alle de wercken van facob Cats (1655). Uiterst links bevindt zich een 'Heremijterße, of Klopje'; zij houdt zich enigszins afzijdig en heft haar armen op in een waarschuwend gebaar, ter ondersteuning van haar weeklacht over het huwelijk.

leven is uit den boze, want 'Wie sagh oijt vrucht off vreughd van ongestoken veen'? ${ }^{244}$

In de ogen van protestantse medeburgers waren kloppen misschien wel die betweterige, verzuurde vrouwen, die de raadpensionaris en moralist Jacob Cats (I577-I660) vereeuwigd heeft in zijn Afbeeldinge van 't huwelijck, en 't gheen daer ontrent is, onder de ghedaente van een fuyck. ${ }^{245}$ In deze ironische schets van lasten en plichten van de huwelijkse staat geeft Cats het laatste woord aan een 'Heremijterße, Of Klopje, of yemandt anders, afkeerigh van't Huwelijck zijnde'. Deze figuur wijst op de gevaren en de pijnen van het kraambed, op de lasten van opvoeding en huishouding, en tenslotte op de smarten van het weduwschap. $\mathrm{Zij}$

244 Ibidem, vers I4.

245 Opgenomen in Alle de wercken. 
besluit haar tirade tegen het huwelijk met de aansporing:

'ghy wijfs blijft sonder man, ghy mannen sonder wijf,

Want in een eensaem bedt, daer hoort men geen gekijf .

Onder katholieken genoot maagdelijkheid als levensstaat echter nog groot aanzien. De viering van de intrede in de kloppenstaat getuigt daarvan. Door een plechtige staatsie werden geestelijke maagden als bruiden van Christus afgescheiden van andere leken. Ook wanneer er sprake was van een 'gemankeerd ritueel', wanneer er geen plechtigheid aan te pas kwam of wanneer de ceremonie enkel in zeer kleine kring plaats vond, voltrok zich een statusverandering van 'gewone' lekevrouw tot geestelijke maagd, die voor anderen waarneembaar werd door aanpassingen in kleding en gedrag. Het ritueel van de geestelijke bruiloft of de verandering van kleding bakende hun aparte positie af, waarin zij dichter bij de geestelijkheid kwamen te staan dan andere leken. Deze positie rechtvaardigde dat zij ook 'geestelijke taken' voor hun rekening namen.

Kloppen waren dan wel bruiden van Christus, zij verlieten - in tegenstelling tot kloosterzusters - de wereld niet. Ondanks hun nieuwe staat bleven zij geworteld in hun eigen (geloofs)gemeenschap en kring van familie, verwanten en vrienden. ${ }^{246}$ Hun statusverandering bracht geen abrupte ontworteling met zich mee die wel gepaard ging met de intrede in een klooster. Wie kloosterlinge werd, verbrak de banden met haar naasten, met de wereld en kreeg, los van de persoonlijke achtergrond, een nieuwe sociale identiteit die onder andere tot uitdrukking kwam in een eigen kloosternaam. Wie echter geestelijke maagd werd, kon blijven participeren in netwerken van familie en vrienden en handhaafde de op haar familieidentiteit gebaseerde sociale positie die enkel een nieuwe, namelijk geestelijke, dimensie erbij kreeg. De overgang naar kloppenstaat veroorzaakte zodoende een lagere graad van vervreemding. Ondanks hun gewijzigde status bleven geestelijke maagden binnen hun eigen gemeenschap herkenbaar. Doordat zij geestelijk, maar niet 'wereldvreemd' waren, namen kloppen een intermediaire positie in, tussen leken en geestelijken. Hun verankering in de eigen gemeenschap zorgde wellicht voor een zekere bescherming bij de uitvoering van zorg- en onderwijstaken. Zeker voor de eerste helft van de zeventiende eeuw kan gesteld worden dat de band die kloppen onderhielden met de geloofsgemeenschap waarin zij zelf geworteld waren, meestal hechter was dan die van de bedienaar van een statie, die vaak van elders kwam en in zekere zin een buitenstaander bleef.

Priesters waren zich bewust van de bemiddelende potentie van geestelijke maagden. Dat geestelijken gaandeweg de zeventiende eeuw kloppen bleven inschakelen voor de catechisatie, is een belangrijke indicatie. Zelfs toen het gebrek aan priesters verminderd was, bleef de seculiere en reguliere geestelijkheid een beroep op kloppen doen. Een tweede indicatie voor het besef onder geestelijken van de invloed van kloppen, is het belang dat gehecht werd aan de algemene spirituele vorming $246 \mathrm{Vgl}$. Ziegler, Sculpture of compassion, 75, die een vergelijkbare observatie doet voor de begijnen. 
van geestelijke maagden en het toezicht daarop door hun biechtvaders. ${ }^{247} \mathrm{Om}$ als lichtende voorbeelden te kunnen dienen, moesten levenswandel en geloofsleven van geestelijke maagden onberispelijk zijn. In de verschillende kloppenboeken wordt hier voortdurend op gehamerd en in preken en persoonlijke gesprekken zal er zeker ook de nodige aandacht aan zijn besteed. De jezuïeten lijken zich van deze opleidingstaak met extra zorg gekweten hebben. De visitator van de jezuïetenmissie oordeelde in 1679 en 1690 dat het geestelijk onderricht aan kloppen op verschillende plaatsen tekort schoot. Daar moest verbetering in gebracht worden, hetgeen volgens de visitator waarlijk niet moeilijk hoefde te zijn, als de betrokken maagden maar dagelijks vol toewijding hun geestelijke oefeningen zouden doen. ${ }^{248}$

\section{Confessionalisering}

De politieke situatie en de gebrekkige infrastructuur van de katholieke kerk werkten in de eerste helft van de zeventiende eeuw een proces van geloofsvervreemding onder katholieken in de hand. $\mathrm{Na}$ de wording van de Republiek en het verbod op de openbare uitoefening van de katholieke eredienst stokte de katholieke zielzorg. Er waren onvoldoende zieleherders, die incidenteel en lokaal ook nog eens geplaagd werden door een betrekkelijk agressief vervolgingsbeleid van de wereldlijke overheid. Mankracht en middelen schoten aanvankelijk tekort om de Trentse hervormingsmaatregelen adequaat door te voeren. De geprivilegieerde Nederduitsgereformeerde kerk, die geen volkskerk wilde zijn, voerde een betrekkelijk voorzichtig toelatingsbeleid voor nieuwe lidmaten, aan wie strenge eisen ten aanzien van geloof en leven werden gesteld. ${ }^{249}$ Door al deze ontwikkelingen ontstond er tegen het einde van de zestiende en aan het begin van de zeventiende eeuw als het ware een religieus vacuüm waarin zich een grote groep 'onbeslisten' bevond, die zich nog niet definitief met een geloofsrichting of kerk geaffilieerd had. Sommige van hen kwamen luisteren naar priesters die clandestien religieuze bijeenkomsten leidden. Ook traditionele katholieken, die nauwelijks meer gewend waren de sacramenten te ontvangen, en randkerkelijken woonden deze diensten bij. ${ }^{250}$

Onder leiding van Sasbout Vosmeer, apostolisch vicaris van het aartsbisdom Utrecht van 1592 tot 1614 , werd een begin gemaakt met de reorganisatie van deze kerkprovincie. ${ }^{25 \mathrm{I}} \mathrm{Om}$ althans in de primaire sacramentele en pastorale behoeften van de gelovigen te kunnen voorzien, werd een ambulante zielzorg gestart vanuit Delft en Haarlem, die zich tot centra van de missie ontwikkelden. Beseffend dat

247 Theissing, Over klopjes, IO8-IIO.

248 Ibidem, Io9 (noot 3), geciteerd naar PA SJ, Historische handschriftenverzameling, AF 45, Memoriale der oversten der Hollandse Missie S.J. na de visites van I650 en 167I-I69I (afschrift door A. van Lommel S.J.), 'Memoriale Missum Missione Post Visitationem 2' sept. 1690' (punt 10).

249 Van Deursen, Bavianen en slijkgeuzen.

250 Spiertz, 'Godsdienstig leven', 346.

25I Rogier, Geschiedenis, II, 5-3I. 
het katholicisme een confessie naast andere confessies geworden was, probeerden ongeveer tweehonderd wereldheren en twintig reguliere priesters aan het begin van de zeventiende eeuw, in de geest van de Contrareformatie die hun kerk bezielde, verdere geloofsafval onder hun kudde te voorkomen, en weifelende gelovigen en afvalligen weer de weg naar de katholieke kerk te wijzen. ${ }^{252}$ Hierbij moesten zij niet alleen concurreren met de gereformeerde kerk, maar ook met verscheidene 'secten en gezindheden', die de wereldlijke overheden - vanuit de nagestreefde gewetensvrijheid - meer of minder oogluikend tolereerden: luthersen, remonstranten en doopsgezinden. ${ }^{253}$

Het door Sasbout Vosmeer in gang gezette proces van rekatholisering werd voortgezet door zijn opvolger Philippus Rovenius. Hij was een uitgesproken vertegenwoordiger van hervormingen in Trentse zin. Vanuit een duidelijke belijdenisvroomheid droeg deze apostolisch vicaris bij aan de afbakening van een eigen, katholieke confessionele identiteit, die vorm kreeg door dié elementen te accentueren in de eigen leer en devotionele praktijk, die afweken van andere geloofsrichtingen. ${ }^{254}$ Religieuze pluriformiteit en toenemende confessionalisering werkten dit streven naar herkenbaarheid verder in de hand. ${ }^{25 s}$

Kentering van het proces van ontkerkelijking had vanuit het perspectief van de katholieke geestelijkheid hoogste prioriteit. Degenen die de katholieke kerk trouw waren gebleven of wensten te blijven, moesten onderricht worden in de beginselen van het geloof. Dit was niet alleen nodig omdat de stand van kennis over het geloof onder volwassen katholieken veelal deplorabel was, maar vooral om gelovigen bewust te maken van de essentiēle verschillen tussen hun eigen en andere geloofsrichtingen. De inzet van geestelijke maagden was hierbij vaak onontbeerlijk. $\mathrm{Zij}$ bemiddelden door hun werk en presentie fundamentele kennis over katholieke leerstelligheden. Via de kinderen en anderen die zij onderwezen, zouden de katholieke leer en riten doorsijpelen naar ouders, vrienden, buren. ${ }^{256}$ In Oudewater verzorgden jezuieten-kloppen bijvoorbeeld catechismusonderwijs voor kinderen, maar spoorden zij bovendien ouders en dienstboden tot grotere godsvrucht aan. ${ }^{257}$

Gelovigen die nog slechts een losse band met de moederkerk hadden, moesten in hun eigen omgeving opgezocht worden. Katholieken te Nijmegen die lang van de biecht geabsenteerd hadden, werden bezocht door jezuïeten-kloppen. Deze vrouwen namen ieder verschillende wijken van de stad voor hun rekening om gelovigen hierover aan te spreken. ${ }^{258}$ Lukte het hun iemand tot de biecht te bewegen,

252 Spiertz, 'Godsdienstig leven', 346.

253 Nijenhuis, 'De publıeke kerk'; 1dem, 'Religiegeschredenis I621-1648'.

254 Roger, Geschtedenws, II, 76-77, Iro-II4; Spiert, 'De kathoheke geestelijke leiders', 5-6.

255 Fnjhoff, 'Katholieke toekomstverwachting', 439-442.

256 Barten, 'Catechismusonderricht', 241.

257 PA SJ, Histonsche handschnftenverzameling, AF Io, Acta Missionts, dl. VIII (1665) 20.

$25^{8}$ Ibidem, AF 9, Acta Missınss, dl. VII (I66I) 319-320. Hierbij wordt vermeld dat ook gehuwde vrouwen zich toelegden op het aanspreken van gelovigen over de biecht. 
dan begeleidden zij deze penitent(e) naar de priester, die de biecht afnam. Franciscus l'Hermite S.J., van 1659 tot 1663 werkzaam als priester in Leiden en omstreken, schakelde geestelijke maagden in om op het platteland op zoek te gaan naar potentiële bekeerlingen die, wanneer ze vatbaar bleken voor de katholieke boodschap, door hem werden onderricht en gedoopt. Om ervoor te zorgen dat katholieken immuun bleven voor de verkondiging van het Woord door vertegenwoordigers van andere confessies, was het noodzakelijk ook bij afwezigheid van een priester godsdienstige bijeenkomsten te houden. Vaak namen geestelijke maagden deze taak op zıch en zorgden zo voor een zekere contınuiteit in de zielzorg. ${ }^{259}$ Jutte Costersdochter, bijvoorbeeld, las tot ergernis van haar protestantse medeburgers in Kampen, het volk voor uit katholieke boeken. ${ }^{260}$

In de multuconfessionele Republiek kregen liturgische en paraliturgische rituelen de functie van confessionele identificatiemiddelen. Rituelen gaven vorm en uitdrukking aan een systeem van zingeving op individueel en collectief niveau. ${ }^{261} \mathrm{Zij}$ waren vooral gericht op de verwerving van zaligheid in het hiernamaals, maar kregen in het proces van confessionalisenng een extra dimensie, namelijk het markeren van een confessionele identiteit. ${ }^{262}$ Want wat protestanten afdeden als bijgeloof, kon dienen als middel voor confessionele herkenbaarheid. ${ }^{263}$ Oefening in de katholieke ritus was daarom van essentieel belang. Ook hierbij vervulden kloppen een belangrijke functie, omdat hun catechismusonderncht ook het aanleren behelsde van devotionele praktıken zoals het ochtend- en avondgebed, het dagelijkse gewetensonderzoek en de schuldbelijdenis, gebeden tot de Heilige Maagd en het devotionele vasten op zaterdag. ${ }^{264}$ Deze gebruken konden in kleine kring of volstrekt privé gepraktiseerd worden. Hiermee konden katholieken in het alledaagse leven voor zichzelf en voor anderen onderstrepen bij welke geloofsgemeenschap zij hoorden. ${ }^{265}$

De collectieve katholieke identiteit werd scherp zichtbaar in plechtigheden rond de 'rites de passage', die verschillende levensfasen markeerden en de band met

259 Ibidem, AF Io, Acta Misstonts, dl. VIII (I665) 20. Vgl. Schulte van Kessel, Geest en vlees, 99, die in dit verband opmerkt dat manneli)ke lekenmedewerkers, voor whe Sasbout Vosmeer de funcues van lectores en directores in het leven had geroepen, het al snel hieten afweten Zie voor deze functies Spiert, 'Godsdienstig leven', 348

260 Velthuysen, 'De invoenng', 202.

$261 \mathrm{Vgl} \mathrm{Geert,}$, 'Religion as a cultural system', 123

$262 \mathrm{Vgl} \mathrm{Rooljakkers,} \mathrm{Rutuele} \mathrm{repertorres,} \mathrm{79-80,} 86$.

263 Wingens, Over de grens, $31,252,265$, wisst bujvoorbeeld op het verband tussen de ntuele prakujk van de bedevaart en de ontwikkeling van een katholieke, confessionele identiteit.

264 Barten, 'Godsdienstonderncht', 248 Vgl. PA SJ, Histonsche handschnftenverzameling, AF 6, Acta Missints, dl IV (1630) 16, waar wordt vermeld dat leden van de sodaliteit en godgewijde maagden te Gouda naar schatting dnehonderd kunderen in de beginselen van het geloof en de niten van de kerk ondernchtten

$265 \mathrm{Vgl}$ voor het verband tussen (ntuele) handelingen, indivduele en collectieve identiteit de antropologische studie van Chnstian, Person and God, II. 
de confessionele gemeenschap smeedden. Vooral bij doop- en begrafenisplechtigheden speelden geestelijke maagden een vooraanstaande rol. Het ritueel van de doop impliceerde het wegwassen van de erfzonde. De doop symboliseerde een wedergeboorte van een van erfzonde gereinigde mens in Christus. Met de doop werd men opgenomen in de christelijke gemeenschap; na de doop was men gerechtigd de andere sacramenten te ontvangen. Geestelijke maagden fungeerden vaak als doophefsters, ofwel meters, ook al behoorden zij niet tot de familie of vrienden van de pasgeborene. ${ }^{266}$ Christina Kalckhoven, geestelijke dochter onder leiding van de minderbroeders, trad veelvuldig op als getuige bij dopen en huwelijken in de Amsterdamse statie Mozes en Aäron. ${ }^{267}$ De jezuieten-klop Dina Noortdijck was meermaals getuige bij doopplechtigheden in de statie De Krijtberg te Amsterdam. En toen de bedienaar van deze statie, Petrus Laurentius S.J. (I588I664), in 1654 zijn arm brak, was zij vermoedelijk ook één van degenen die het doopboek tijdelijk bijhield. ${ }^{268}$

Katholieke begrafenisceremonies boden eveneens gelegenheden bij uitstek om, deels in de openbaarheid van kerk of kerkhof, de geloofswaarheden van de eigen confessie in woord en gebaar tot uitdrukking te brengen. En ook hierbij speelden kloppen een belangrijke rol. De katholieke begrafenisgebruiken ontlokten gereformeerde kerkeraden regelmatig klachten gedurende de zeventiende en achttiende eeuw. De hervormers verwierpen het misoffer en het geloof in het vagevuur waar alle zielen loutering ondergingen. De eucharistieviering, de dodenmis, en de liturgische voorbeden voor het zieleheil vormden nu juist de voomaamste bestanddelen van de katholieke begrafenisplechtigheid; tussenkomst van kerk en priester werden hierbij onmisbaar geacht. In de Hollandse Zending moesten de katholieke begrafenisrituelen aangepast worden aan benarde omstandigheden. Het Rituale Contractum, een verkorte versie van het Rituale Romanum (I614) bedoeld voor de 'verdrukte gewesten', dat op gezag van apostolisch vicaris Philippus Rovenius sinds I622 gebruikt mocht worden, kent bijvoorbeeld geen dodenofficie en ook over een requiemmis wordt niet gerept. ${ }^{269}$ Hoewel weinig informatie over begrafenisdiensten beschikbaar is, lijkt het aannemelijk dat, waar de religieus-politieke omstandigheden dat enigszins toelieten, wel een eenvoudige gebedsdienst werd gehouden bij de overledene thuis, in de schuilkerk of aan het graf. ${ }^{270}$ De Nijmeegse classis klaagde in I60I dat er nog op veel plaatsen dergelijke 'lickpredickten', 'praedicaties ofte gebeden' werden gedaan op de kerkhoven bij de graven; een

266 Theissing, Over klopjes, I38. Smit, 'Klopjes en klopbroeders', 54. Gedurende de achrtiende eeuw waren er bijvoorbeeld maar liefst 24 kloppen die in de statie van de oud-bisschoppelijke clerezie te Aalsmeer deze taak op zich namen, vermoedelijk omdat zij door hun werkzaamheden in en om de schuilkerk gemakkelijk beschikbaar waren.

267 Hesse, De Minderbraeders te Amsterdam, 42-43.

268 Garrer, 'Dina Noortdijck', 444.

269 Spiertz, De katholieke liturgie, I, II (vgl. 223-230); I29.

270 Ibidem, 130. 
gebruik dat slechts met grote moeite uit te bannen was. ${ }^{27 x}$

Ook allerlei para-liturgische gebruiken gaven aanstoot aan protestanten: het overluiden van de doden; het versieren van lijken of lijkbaren met baarkleden waar veelal een kruis op afgebeeld stond; het schilderen van een kruis op de lijkkist; het oprichten van kruisen op de graven; het knielen op de graven; het offeren en collecteren voor zielmissen. ${ }^{272} \mathrm{Bij}$ een visitatie van de gemeenten in de Overbetuwe in 1686 constateerden afgevaardigden van de classis Nijmegen te Pannerden en Doomenburg paapse superstitiën, te weten knielen op de graven. ${ }^{273}$ De predikant van Acquoy, Henricus Vos, signaleerde in 1675 nog andere misbruiken: het stoffelijk overschot werd driemaal rond de kerk gedragen, begeleid door een stoet mensen met onbedekte hoofden; er werden drie kruisen op het graf geplaatst en gelovigen knielden aan en op het graf. ${ }^{274}$ Tot grote ergernis van het Nijmeegse consistone was in 1640 de kist van 'seker clopbagin' bedekt met een kleed waarop 'een lang cruijs met de naeme Jesus Maria etc.' afgebeeld stond. ${ }^{275}$ De classis van Leiden fulmineerde in I63I expliciet tegen de 'clopgens en baginen', die zo 'stout [waren] datse op publijcke plaetsen, kercken ende kerckhoven in de bedieninge der dooden haere superstitien met gebeeden ende anderszins niet en ontsien te pleghen'. ${ }^{276}$ Deze kloppen knielden wellicht op het graf om te bidden voor het zieleheil van de overledene, waarbij zij zich bekruisten.

\section{Informele intermediairs van vrouwelijke kunne}

In sociaal en kerkelijk opzicht namen geestelijke maagden een liminele positie in. Enerzijds maakten zij deel uit van het religieus-kerkelijke domein van de geestelijkheid; anderzijds bleven zij geworteld in het seculiere domein. Bij gebrek aan plechtige geloften en volledige afsluiting van de wereld door de intrede in een kloostergemeenschap, was hun sociale status voor tijdgenoten verre van duidelijk. Dat maakte het geestelijke maagden mogelijk om zich telkens tussen het religieuskerkelijke en het wereldlijke domein te bewegen. Deze tussenpositie en de taken die hun werden toebedeeld door hun leidsmannen of die zij uit eigener beweging naar zich toetrokken, vergden een grote sociale wendbaarheid. ${ }^{277}$

'In functie' kwamen kloppen in contact met priesters en leken, kinderen en volwassenen, overtuigde en weifelende katholieken. Om effectief in deze verschil-

271 RAG, Archref van het bestuur van de Class2s Nifmegen, unv.nr I, Acta classis van 28-30 apnl 1601. 272 Rooulakkers, Rutuele repertoures, 459-473, geeft een overzıcht van dergelı)ke 'paapse stoutıgheden' in de Meienj van 's-Hertogenbosch.

273 RAG, Archief van het bestuur van de Classis Nizmegen 1598-I838, inv.nr. 35, Visitatieboek Overbetuwe 1684-1701, Pannerden en Doomenburg, 15 me1 1686.

274 RAG, Archief Nederlands Hervormde Classis Tiel, inv.nr. 30, Acta Classis Buranae 1657-I691, i5-16 juni 1675 , art I5, lid 4.

275 GAN, $A N H G N$, inv nr. 2, Acta kerkeraad, 6 september 1640.

276 Acta Synoden Zuld-Holland, 464-465, art. 74.

$277 \mathrm{Vgl}$. Jansen, 'Het offensief'. 
lende circuits of groepsculturen te kunnen opereren, dienden kloppen over een zekere flexibiliteit in gedragsrepertoires te beschikken. ${ }^{278}$ Anders dan bijvoorbeeld schoolmeesters, pastoors of notarissen, die op grond van hun functie als een culturele tussenpersoon functioneerden binnen verschillende maatschappelijke circuits, konden geestelijke maagden niet bogen op enige formele status. ${ }^{279} \mathrm{De}$ paradoxale positie die culturele bemiddelaars per definitie innamen, ${ }^{280}$ werd in geval van geestelijke maagden versterkt door drie aspecten. Ten eerste was hun positie als geestelijke personen juridisch noch kerkrechtelijk beschernd. Ten tweede lagen hun taken en verantwoordelijkheden niet formeel vast, maar werden deze steeds ad hoc bepaald op gezag van en in overleg met hun geestelijk leidsman. Tenslotte stond de vervulling van bepaalde taken onder zekere spanning, veroorzaakt door de beperkingen die het vrouwelijk geslacht in de vroegmodeme tijd werden gesteld. Deze spanning doet zich met name op het vlak van het geloofsonderwijs gelden.

Zoals gezegd waren sommige geestelijken de mening toegedaan dat kloppen op grond van hun 'vrouwelijke aard' bij uitstek geschikt waren om onwetenden de beginselen van het geloof bij te brengen. Anderen daarentegen hadden daarover zo hun twijfels. Zekere preoccupaties en vooroordelen ten aanzien van de combinatie onderwijs en vrouwelijk geslacht dateren al van vóór de Reformatie. In de synodale statuten van het bisdom Haarlem uit 1564 staat bijvoorbeeld genoteerd dat schoolhoudende vrouwen of begijnen door hun nieuwsgierigheid en onwetendheid het gevaar liepen ketterse of opruiende boeken te gebruiken. Daarom moesten zij onder andere de boeken die zij gebruikten eerst ter goedkeuring voorleggen aan de pastoor. ${ }^{281}$ De kwestie of vrouwen anderen geloofswaarheden bij mochten brengen, kreeg nà de Reformatie natuurlijk een andere dimensie. ${ }^{282}$

De in Leiden werkzame carmeliet Petrus a Matre Dei oordeelde dat de vrouwelijke sekse van kloppen geen hinderpaal vormde. In Noordnederlandse provincies, die besmet waren met 'ketterij', was de nood zó hoog, dat ook vrouwen de jeugd in de beginselen van het geloof mochten onderwijzen. Aangezien zij dit doorgaans deden in particuliere huizen, en niet in de kerk, werd volgens hem Paulus' gebod niet geschonden. Natuurlijk, vrouwen moesten er het zwijgen toe doen in algemene religieuze samenkomsten en evenmin moesten ze het wagen in de kerk het predikambt op zich te nemen of de preekstoel te beklimmen. Maar het gebod van de apostel sloeg volgens de carmeliet niet op vrouwen die kinderen geloofsonderricht gaven in huiselijke kring. Dat verklaarde volgens hem ook waarom de prelaten, die hiervan op de hoogte waren, dit niet alleen toestonden, maar zelfs prezen

$278 \mathrm{Vgl}$. Rooijakkers, 'Opereren op het snijpunt', 246-248.

$279 \mathrm{Vgl}$. Vovellc, 'Culturele tussenpersonen' en Jansen, Women without men, 87.

280 Rooijakkers, Rituele repertoires, 85.

28I [Van Heussen], Batavia Sacra, II, 307 (Statuta synodalia, per Nicolaum, episcopum Harlemensum, edita anno 1564).

282 Vgl. discussies daarover elders in Rapley, The dévotes en Conrad, Zwischen Kloster und Welt. 
en deze 'gewoonte van de Hollandse Missie' goedkeurden. ${ }^{283}$

Nood brak wet, maar discussies bleven. Een Leidse geestelıke maagd, die onder leıding van de paters jezuieten zelfstandig de catechismus onderwees, werd in 1665 het slachtoffer van smaad. ${ }^{284}$ Een nuet met name genoemde reguliere pnester beschuldugde haar ervan dat zuj volgens 'ntu Quakenorum' preekte. $\mathrm{Hu}$ ) vereenzelvigde haar optreden met predikung. Prediking door vrouwen werd toen vooral toegestaan onder de 'quakers', een buitenkerkelı)ke groepenng die George Fox in I649 in het leven had geroepen. ${ }^{285} \mathrm{Z}$ in echtgenote Margaret Fell verdedigde in Women's Speaking fustrfied (1669) het recht van vrouwen om anderen te leren. Naar overtuıging van de 'quakers' maakte de Heilıge Geest geen onderscheid naar sekse en kon $\mathrm{H}_{1}$ zowel mannen als vrouwen inspireren; ook vrouwen konden daarom spreken en preken. In de ogen van de Leidse prester vond het spreken en leren door vrouwen echter geen genade. Hu waarschuwde dat allen, die de gewraakte lessen van de jezuïeten-klop bezochten, een zware zonde begingen. De superior van de 'Missio Hollandica' rapporteerde deze onbezonnen uitspraak bij de provinciaal, gestaafd door een notanele akte waann verschillende getuigen het voorval beschreven.

Niet alleen in eigen gelederen boden de onderwijsactıviteiten van vrouwen stof tot discussie. Nog in een laat achttiende-eeuwse schotschnft werden de kloppen door een anoneme, maar vermoedelık protestantse auteur op de korrel genomen. Dat 'een Vrouwspersoon Klopje genaamt' de catechismus leerde, was 'zekerlyk niet volgens de Leer van de $H$. Apostel Paulus, maar daar schynt men zich weinig aan te kreunen'. Dat het geloofsonderncht aan deze vrouwen was toevertrouwd, had er volgens de anonieme auteur in geresulteerd dat katholıeken de beginselen van hun eigen geloof zo slecht kenden, dat zelfs de gereformeerden de roomse religie beter begrepen ${ }^{286}$

\section{II.6 Spanningen in de zielzorg}

In de loop van de zeventiende eeuw openbaarden zich tegenstellingen onder de in de Hollandse Zending werkzame geestelı)kheid Splıtstof vormde aanvankelıjk de kwestue over het hrerarchisch karakter van de Noordnederlandse katholieke kerk. Dit kerkpolitieke geschil dat seculier en regulier verdeelde, werd verscherpt toen opvattingen over het karakter van de kerk en de pastoraal zich gaandeweg de zeventnende eeuw in uiteenlopende nchtngen ontwikkelden. Deze binnenkerkelıjke spannıngen misten hun urtwerkıng op de kloppen nıet. Omdat geestelı)ke

283 Petrus a Matre De1, Clara Relatio, 94

284 PA SJ, Histonsche handschnfienverzameling AF 10, Acta Missionis, dI VIII (1665) 20-21, geciteerd door Theissing, Over klopjes, 149 (noot 4) Vgl Barten, 'Catechismusonderncht', 249

285 Mack, Vistonary women Wiesner, Women and gender, 206-207

286 Onpartydige Schets, $9 \mathrm{Vgl}$ Clemens, 'De terugdnnging', 3I 
maagden middelen, werkkracht en invloed vertegenwoordigden, wierven seculiere en reguliere geestelijken enerzijds om hun gunst. Anderzijds zetten priesters geestelijke maagden op verschillende manieren in bij hun onderlinge, telkens weer oplaaiende competentiestrijd. Tot drie maal toe vormden kloppen het brandpunt in geschillen tussen seculieren en regulieren ${ }^{287}$ Over en weer beschuldigden zij elkaar van ongepaste omgang met geestelijke maagden, of repten zij over kloppen die de mis dienden, over geestelijken die zich verrijkten door de aalmoezen van kloppen, of die elkaars geestelijke maagden probeerden in te palmen. Deze aantijgingen illustreren dat de geïmproviseerde vormgeving van de kloppenstaat geestelijke maagden en hun leidsmannen kwetsbaar maakte voor uiteenlopende verdachtmakingen. Natuurlijk getuigen deze en andere beschuldigingen eveneens van sterke vooringenomenheid, die menige beschuldiging onwaarachtig maakt. De klachten van de Goudse priester Petrus Purmerent, die al even ter sprake gebracht zijn, zijn daarvan een goed voorbeeld. Volgens hem palmden de jezuïeten via hun geestelijke maagden de dochters van rijke ouders in en haalden hen vervolgens over tot de kloppenstaat. Ze overtuigden deze meisjes ervan dat zij huis en haard moesten verlaten om zich elders als klop te vestigen. En deze nieuwe maagden wijdden zich aan de zorg voor meisjes en schoolgaande jeugd, hetgeen de Sociëteit volgens Purmerent geen windeieren legde. ${ }^{288}$ Taken die kloppen in de Hollandse Zending vervulden, zoals huisvesting, (financiële) ondersteuning en geloofsonderwijs, kwamen door deze en andere beschuldigingen onder spanning te staan.

\section{Trouw aan de parochie}

De kwestie van de kerkelijke hiërarchie speelde reeds vanaf het aantreden van de eerste apostolisch vicaris Sasbout Vosmeer in 1592. Het gebied van de Utrechtse kerkprovincie werd vanaf de oprichting van de Congregatie van de Propaganda Fide in 1622 onder toezicht van deze instantie gesteld. Wat de Heilige Stoel betreft was er niet langer sprake van het aartsbisdom Utrecht, maar van een missiegebied met staties in plaats van parochies. De pastoors, wereldheren die hier werkzaam waren, werden daarmee in feite missionarissen. Niettemin bleven deze priesters zichzelf veelal beschouwen als de bevoegde clerus; missionarissen waren in hun ogen de reguliere geestelijken die vanuit de Zuidelijke Nederlanden noordwaarts werden gestuurd om de kerk in verval mee te helpen herstellen. De regulieren op hun beurt beschouwden juist de wereldheren als missionarissen onder het gezag van de apostolisch vicaris. Zelf betwistten de regulieren, in het bijzonder de jezuieten, dat ook zij onder de jurisdictie van de apostolisch vicaris vielen. $\mathrm{Zij}$ waren immers tot gehoorzaamheid verplicht aan hun ordesoversten en de paus. Als

287 Schulte van Kessel, Geest en vlees, 91-I15.

288 Theissing, Over klopjes, 168-170, aangehaald uit Broedersen, op. cit. (noot 124). 
voorvechters van het centralisatie-streven van de curie, die een grotere zeggenschap binnen alle kerkprovincies ambieerde, botsten de regulieren regelmatig met de apostolisch vicarissen en leden van de seculiere geestelijkheid, die vurig hoopten op een herstel van de bisschoppelijke hiërarchie. Waren de regulieren voorstanders van een ultramontaans kerkmodel, waarin de Romeinse curie vrijwel volledige zeggingsmacht kreeg, hun seculiere tegenstrevers hingen juist een gallicaanse kerkopvatting aan, die nationale kerkprovincies grotere bevoegdheden toestond. Deze wereldheren, onder leiding van het vicariaat van Utrecht en het kapittel van Haarlem, vormden de clerezie die na de definitieve afzetting van apostolisch vicaris Petrus Codde in 1704 en de benoeming van Theodorus de Cock (1650-1720) als zijn opvolger steeds verder verwijderd raakte van Rome. Deze verwijdering mondde uit in een schisma dat zich in 1723 met de afscheiding van de RoomsKatholieke Kerk van de Oud-Bisschoppelijke Clerezie definitief voltrok. ${ }^{289}$

Wereldheren die van mening waren dat het verval van de bisschoppelijke hiërarchie slechts een tijdelijke kwestie was, probeerden geestelijke maagden stringenter aan de parochies te binden. Hoewel er formeel niet langer sprake kon zijn van parochies en pastoors, was apostolisch vicaris Philippus Rovenius van oordeel dat kloppen in eerste instantie hun parochie en pastoor - per definitie een wereldheer - trouw dienden te blijven. Conform de decreten van het Concilie van Trente was hij de mening toegedaan dat gelovigen op zon- en feestdagen de preek in hun eigen parochiekerk dienden bij te wonen. Mogelijke bezwaren van geestelijke maagden als zouden plechtigheden in deze kerken met minder luister worden gevierd dan bij de regulieren, pareerde hij met de aansporing zelf meer bij te dragen aan de versiering en opluistering van de parochiekerken. Hij waarschuwde kloppen dat, ook al hadden zij een regulier als biechtvader, zij daarmee niet ontslagen waren van de verplichtingen die zij tegenover hun parochiekerk hadden. ${ }^{290}$ Daarmee maakte Rovenius de plicht tot trouw die een klop wellicht tegenover een reguliere biechtvader had, ondergeschikt aan haar verplichtingen als parochiaan.

Het lijkt erop alsof geestelijke maagden zich aan deze aansporingen weinig gelegen hebben laten liggen. Hun trouw gold over het algemeen hun biechtvader seculier of regulier - en de statie die hij bediende. Geestelijke maagden investeerden op alle mogelijke manieren in die statie en dat verklaart tot op zekere hoogte hun loyaliteit daaraan. Vertrok een biechtvader naar elders of kwam hij te overlijden, dan kozen zij doorgaans zijn opvolger als nieuwe leidsman. Als insiders in de lokale katholieke gemeenschap konden kloppen deze nieuwkomer - en vaak buitenstaander - juist wegwijs maken. ${ }^{291}$ Het is mogelijk dat naarmate het aanbod van staties van verschillende geestesrichtingen gedurende de zeventiende eeuw groeide, de tolerantiedrempel van sommige maagden evenredig daalde. Bij per-

289 Spiertz, 'Godsdienstig leven ', 344-346; 350-354.

290 Rovenius, Retpublica christanae libn duo, 276-278; Theissing, Over klopjes, 157.

291 Vgl. Theissing, Over klopjes, r36-r 38. 
soonlijke strubbelingen met de biechtvader, of om andere redenen, waren sommigen misschien sneller geneigd van leidsman en statie te veranderen.

Vormgeving en aanzien van de kloppenstaat werden sterk beïnvloed door de spirituele oriëntatie en kerkopvatting van de geestelijke leidsmannen. Waarom een vrouw ervoor koos als klop onder leiding van een wereldheer, franciscaan, jezuiet of augustijn te leven, is moeilijk te achterhalen. Naast spirituele motieven waren er zeker ook andere factoren in het spel, zoals persoonlijk contact. Sybilla van Ingen (1610-I682), telg uit een Overijssels adellijk, maar niet-katholiek geslacht, had haar geboortestreek en familie op jeugdige leeftijd verlaten uit 'liefde voor het katholieke geloof. Zij vertrok naar Amsterdam, waar zij als dienstmeid in haar eigen onderhoud voorzag. Op 5 februari 1647 was zij geestelijke maagd geworden, onder leiding van de wereldheer Henricus Ebbius. Na zijn dood in 1657 werd zijn opvolger Willem Schep haar geestelijk leidsman. Met hem klikte het kennelijk veel minder, want al een jaar later verzocht Van Ingen de paters augustijnen van De Star om in hun kloppengemeenschap opgenomen te worden. ${ }^{292}$ Ook aan het besluit van Maria van Eck lagen misschien persoonlijke motieven ten grondslag om van biechtvader te veranderen. $\mathrm{Zij}$ was oorspronkelijk geestelijke dochter geworden onder leiding van de jezuiet Petrus Laurentius, die de Amsterdamse statie De Krijtberg aan de Singel bediende. In april 1636 verliet zij hem en koos de augustijn Petrus Parmentier (1602-I697), die zich net in Amsterdam had gevestigd, als haar leidsman. ${ }^{293}$

Voor sommige kloppen was het vertrek of overlijden van hun biechtvader aanleiding om een nieuwe leidsman van een andere spirituele richting te zoeken. Adewina en Maria Vis, vermoedelijk elkaars nichten, waren klaarblijkelijk niet bereid met hun leidsman annex broer en neef, Herman Vis, naar Alkmaar te verhuizen. Daarom wilden zij zich graag bij de geestelijke maagden van de augustijnen-statie De Star voegen. ${ }^{294}$ Francisca van der Velst (I608-?), bekeerd uit het lutheranisme, trad als geestelijke dochter toe tot de derde orde van St. Dominicus. $\mathrm{Zij}$ werkte meer dan veertig jaar als dienstmaagd voor Henricus van Merven en Servatius van der Hagen in de Amsterdamse dominicanen-statie Het Stadhuis van Hoorn. Na hun overlijden kwam zij in 1671 naar De Star ${ }^{295}$ Maria van Deventer (1627-?) werd in I66I klop onder leiding van de augustijn Hyacinthus van der Linden (ca. 1600-I669). Toen hij overleed, koos zij een minderbroeder als haar nieuwe biechtvader. Tien jaar later keerde zij evenwel terug naar de augustijnen, misschien wel omdat zij was geprofest in de derde regel van St. Augustinus

292 PA OSA, De Star, 227.

293 Ibidem.

294 Ibidem, 234. Herman Vis S.J. (I64I-173I) - beter bekend onder zijn alias Franciscus van Ens - was tot 1678 werkzaam in Amsterdam. In dat jaar werd hij overgeplaatst naar Alkmaar. PA SJ, Historische handschriftenverzameling, A E 23 f, Herraets, Elenchus Alph. Prov. Fl. Belgium, 164.

295 PA OSA, De Star, 232. 
en bij de augustijnen ook haar belofte van eeuwige zuiverheid had afgelegd. ${ }^{296}$ Natuurlijk oefende een kloppengemeenschap als die van De Star - los van kwesties als spiritualiteit of persoonlijkheid van de biechtvader - de nodige aantrekkingskracht uit op geestelijke maagden. ${ }^{297}$

\section{Jansenisme en anti-jansenisme}

Spanningen tussen jansenisme en anti-jansenisme, die het theologisch denken in Europa sinds 1640 sterk beheersten, verscherpten de polarisatie binnen de Hollandse Zending en lieten ook geestelijke maagden niet onberoerd. Gedurende de eerste fase van het jansenisme, van circa 1640 tot 1660 , stond het genadeprobleem, en dan vooral de verhouding tussen de vrije wil en de goddelijke voorbeschikking, centraal. Cornelius Jansenius (1585-1638), hoogleraar te Leuven en later bisschop van Ieper, wijdde de laatste twintig jaar van zijn leven aan de exegese van de werken van de gezaghebbende kerkvader Augustinus om de genadekwestie te verhelderen. Op grond hiervan was hij onder andere de mening toegedaan dat de voorbestemming van de mens reeds vaststond vóór de voorziene menselijke medewerking. Deze visie stond volledig haaks op zienswijze van de aanhangers van het molinisme, onder wie Leonardus Lessius S.J., die net als zijn ordegenoot Luis Molina (1536-1600) de mening was toegedaan dat de voorbestemming van de mens juist nà de voorziene menselijke medewerking werd beslist. Jansenius' postuum gepubliceerde levenswerk Augustinus (1640) werd door paus Urbanus VIII in de bul In eminenti (1642) veroordeeld. ${ }^{298}$

Aanhangers van het augustinisme, een strenge richting onder katholieke theologen die oordeelde dat God de volledige heerschappij over de mens heeft waarnaar de mens zich volledig moet schikken, liepen het gevaar van jansenisme beschuldigd te worden. Dat gebeurde in I669 onder andere met de apostolisch vicaris Joannes van Neercassel, die sterk onder invloed van de spiritualiteit van Port-Royal stond. Hij ijverde voor een verdieping van het christelijk leven, waarbij de innerlijke geesteshouding belangrijker was dan uiterlijke werken. ${ }^{299}$ Beschuldigingen van minderbroeders aan zijn adres werden weliswaar ontkracht, maar daarmee was er nog geen einde gekomen aan de jansenistische en anti-jansenistische woelingen binnen de Hollandse Zending. ${ }^{300}$

Van geestelijke maagden onder leiding van wereldheren die een meer sobere en rigoristische spiritualiteit en moraal aanhingen, werd een ingetogen geloofsleven verwacht. Neercassel wilde bijvoorbeeld dat de clerus hoge eisen stelde aan het

296 Ibidem, 235.

297 Of de maagden van De Star zelf ook actief nieuwe kloppen wierven, zoals de maagden van de Haarlemse Hoek (Theissing, Over klopjes, 54-56), is niet bekend.

298 Ceyssens, 'Het theologisch denken', 418-438; Spiertz, 'Jansenisme', I44-I52.

299 Spiertz, 'Jansenisme', $152-161$.

300 Idem, 'Anti-jansenisme', 233-244. 
ontvangen van sacramenten als biecht en communie. ${ }^{301}$ In de praktijk konden dergelijk strenge richtlijnen scrupules bij geestelijke maagden veroorzaken. Zo ook bij de Brusselse geestelijke maagd Marie-Anne Voeller, voor wie Neercassel per brief als leidsman fungeerde. Voeller huldigde een zeer pessimistische visie op de menselijke vermogens om God waarlijk te dienen. ${ }^{302} \mathrm{Zij}$ vertrouwde Neercassel per brief toe, dat zij aarzelde over haar biecht en communie. Haar leidsman, die in zijn brieven probeerde haar hang naar spirituele perfectie, penitentie en nederigheid enigszins te matigen, stelde haar gerust:

'UEd. moet niet scrupuleus zyn, raekende hetgene [U] mijn heeft gebicht. UEd. heeft my gebiecht gelyk sy behoorden te doen, dat is met sinceerheyt, en volgens de kennis die sy toen hadde. Derhalven wilt niet langer uyt sulcken scrupel uwe communij uytstellen. Geeft een aelmis [aalmoes] na $U$ welgeval tot penitensy van uyt sulcken scrupel de tafel des Heeren gelaeten te hebben. ${ }^{303}$

Het rigorisme van Van Neercassel uitte zich niet in een voorkeur voor strenge penitenties. Integendeel, deze werden door hem als uitwassen van een overdreven en weinig doorleefde godsvrucht beschouwd. Toen Voeller, die kennelijk kampte met allerlei kwalen, hem geschreven had dat het geknield bidden haar zwaar viel, antwoordde hij dat ze dat dan niet te lang mocht doen; Ignatius bad immers ook zittend. En God vroeg enkel dat zij zich met haar gehele hart aan Hem toewijdde; in welke houding ze bad, was van ondergeschikt belang. ${ }^{304}$

Sommige kloppen lieten zich geen scrupules aanpraten en verzetten zich tegen wat zij zagen als overdreven strengheid van hun biechtvader. De Utrechtse Elizabeth van Schaijk wist kennelijk precies welke wegen zij moest bewandelen om het haar biechtvader Joannes Lindeborn lastig te maken. Zij schreef in ${ }^{6} 687$ de internuntius in Brussel, Giovanni Antonio Davia, dat Lindeborn té streng was in de biechtstoel. Hoewel ze deed wat ze kon om te gehoorzamen, weigerde hij haar absolutie te geven en onthield haar daarmee het sacrament van de biecht; zij dreigde er haast gek van te worden. ${ }^{305}$ Davia zelf was afkerig van alles wat naar rigorisme of jansenisme zweemde en was evenals zijn voorganger Sebastiano Antonio di Tanara een pleitbezorger van de anti-jansenisten. ${ }^{306}$ Davia meende dat de kwestie opgelost moest worden door Petrus Codde, die enige bestuurlijke taken binnen het voormalige aartsbisdom Utrecht waarnam na het overlijden van Neercassel in $\mathrm{r} 686$, in afwachting van de benoeming van een nieuwe apostolisch vicaris. ${ }^{307}$ Codde erkende in zijn repliek dat de strengheid van de clerus in de

301 Idern, 'Godsdienstig leven', 35I.

$302 \mathrm{Vgl}$. Jacques, 'Les Voeller', 179.

303 RAU, $A O B C$, inv.nr. 612, 14 november 1677.

304 Ibidem, 17 augustus 1678 .

305 Dat zij een brief van die strekking geschreven moet hebben, valt op te maken uit een schrijven van internuntius Davia aan Codde, 16 november 1687, in: Polman, Romeinsche Bronnen, III, 112 2-I1 3 (nr. 13I).

306 Jacobs, foan Christian van Erckel, 6I-62.

307 Rogier, Geschiedenis, П, 268-275. Bij ontstentenis van een co-adjutor was de Congregatie van de 
biechtstoel een algemeen probleem vormde, waaraan de nieuw te benoemen apostolisch vicaris aandacht zou moeten besteden. ${ }^{308}$

De kwestie Van Schaijk dreigde uit de hand te lopen, omdat deze maagd het geduld van haar biechtvader zozeer op de proef had gesteld, dat Lindeborn haar ten langen leste maar had voorgesteld dat zij zich bij een andere parochie zou aansluiten. Maar dat was niet wat Van Schaijk wilde. Integendeel, ze bleef hem, de leden van zijn statie en de andere geestelijke maagden kwellen door voortdurend in zijn kerk te verschijnen. Codde vroeg Davia of hij niet toch zijn invloed kon aanwenden in deze aangelegenheid, omdat dat vermoedelijk meer indruk zou maken op deze vrouw. ${ }^{309}$ Davia kaatste de bal echter terug en oordeelde dat de discretie beter gewaarborgd zou zijn wanneer Codde het geschil tot een oplossing bracht. ${ }^{310}$ Vermoedelijk wilde hij zijn vingers niet branden aan dit netelige probleem, waarin latente beschuldigingen van jansenisme sluimerden. Codde zag zich vervolgens geconfronteerd met vooraanstaande leden van Lindeborns statie, die zo langzamerhand ook genoeg kregen van de onrust die Elizabeth van Schaijk voortdurend stookte. $\mathrm{Zij}$ wilden met behulp van de Utrechtse magistraat deze vrouw de toegang tot Lindeborns kerk ontzeggen. ${ }^{311}$ Over de afloop van de kwestie zwijgen de bronnen helaas. Ook de precieze achtergrond van dit geschil tussen geestelijke vader en dochter blijft in nevelen gehuld. Was Lindeborn inderdaad zo streng in de biechtstoel, of koesterde Van Schaijk nog om andere redenen een wrok tegen haar biechtvader? Hoe het ook zij, in de context van jansenistische woelingen kon een aantijging van overmatige strengheid in de biechstoel, geuit aan het juiste adres, een priester in een lastig parket brengen.

Een decennium later werd Petrus Codde zelf het slachtoffer van scherpe beschuldigingen van jansenisme in een vijfendertig pagina's tellend geschrift getiteld Breve Memoriale extractum ex prolixiore de statu ac progressu fansenismi in Hollandia (1697), dat anoniem werd gepubliceerd, maar naar alle waarschijnlijkheid door de jezuïet Franciscus Verbiest (1660-1700) te boek werd gesteld. ${ }^{312}$ Het Breve Memoriale is een beknopte versie van een bredere, nooit gepubliceerde uiteenzetting, het Prolixum Memoriale. Voor de samenstelling hiervan werd gebruik gemaakt van verklaringen, memoranda, brieven, enzovoort, die betrekking hadden op handelingen en denkwijzen die als jansenistisch werden aangemerkt. Op één van deze collecties, de Summarium testimonionum werden twee indices vervaardigd door

Propaganda Fide, in casu de internuntius te Brussel, rechtstreeks verantwoordelık voor het bestuur van de Hollandse Zending. De internuntius had Codde, provicans van Utrecht, de nodige volmachten gegeven voor het aartsbisdom Utrecht. In september 1688 werd Codde benoemd tot apostolisch vicaris.

308 RAU, $A O B C$, inv.nr. 662, Codde aan Davia, 29/19 december 1687.

309 Ibidem, Codde aan Davia, 28 november 1687.

310 Polman, Romeinse bronnen, III, I 19-120 (nr. I42) 19 december 1687.

31I RAU, $A O B C$, inv.nr. 662, Codde aan Davia, 19 december 1687.

312 Voor de wordıngsgeschuedenis en het auteurschap, zie Spıert, 'Achtergronden', 180-207. 
Norbertus Aerts S.J. (1639-1707), die in tegenstelling tot de collectie zelf, in afschrift zijn overgeleverd. ${ }^{33}$

De omgang van de seculiere geestelijkheid met kloppen vormde één van de aandachtspunten in deze indices. Willem van Dalenoort (I658-I738), pastoor te 's-Gravenhage en één van de kopstukken van de clerezie, werd ervan beticht een regel voor zijn geestelijke maagden te hebben geschreven, waaraan ze zich moesten houden, maar waarover ze niet met anderen mochten spreken. ${ }^{314}$ Van Willem Foppens (1634-1699), aartspriester en pastoor te Leeuwarden, werd bericht dat hij leerde dat iedereen, zonder onderscheid des persoons, de Heilige Schrift moest lezen. Zijn geestelijke maagden zouden aan deze aansporing gevolg geven en zelfs over de Schrift disputeren. ${ }^{315}$ De anti-jansenisten waren fel gekant tegen de nieuwlichterij van het lezen van de bijbel in de volkstaal, dat onder andere door Joannes van Neercassel vurig was bepleit. ${ }^{366}$ In hun ogen was het zeer verontrustend dat deze praktijk zich zelfs onder geestelijke maagden verspreidde. ${ }^{37}$ Dat priesters zoals Cornelis Stakenburg (1632/3-1721) geestelijke maagden bij riten betrokken die in de volkstaal werden uitgevoerd, was helemaal aanstootgevend. Stakenburg, wiens statie St. Marie achter Clarenburg ongeveer 85 maagden telde, liet bij begrafenissen kloppen het officie der overledenen in de landstaal bidden, waarbij zij en de dienstdoende priesters elkaar afwisselden. ${ }^{318}$

Ook uit andere, maar nog steeds fel anti-jansenistische hoek, werd kritiek op kloppen onder leiding van rigoristische seculieren geleverd. De minderbroeder Louis Hennepin (1640?-1705?) publiceerde in 1698 La morale pratique du jansénisme, dat qua strekking niet onderdeed voor het Breve Memoriale. Volgens hem verbreidden geestelijke maagden in de Hollanse Zending jansenistische opvartingen via hun onderwijs aan kinderen, die zij onder andere voorhielden dat God dikwijls genade weigerde. ${ }^{39}$ Deze beschuldiging wijst er onomstotelijk op dat de partijen zich terdege bewust waren van de invloed die kloppen door hun taken in onderwijs en zielzorg hadden. Tegelijkertijd lijken deze en de andere bovenstaande aantijgingen te impliceren dat de (vermeende) jansenisten vooral het zwakke geslacht misleidden. Een dergelijke beschuldiging werd expliciet geuit door de Gentse proost

313 PA SJ, Histonsche handschnftenverzameling, AF 2, Index Primus Manuscriptorum Testimonionum et Librorum de Re fansentstica, exhibens singulonum summana, et in quibus Archivn Loculamentzs deposita sint, Index Secundus. Exhibens nomina eonum sacerdotum saeculanum m Misstone Hollandica, de quibus testrmonia, vel informatzones exstant in indice primo: Item; in qutbus urbibus vel pagis Missionzs egennt aliquando vel modo agant. Denique exhtbens dogmata, et praxes ngorosas vel exoticas, aliasve matenas, super quibus informaliones et testimonia lata sunt. Item vana alıa anti-jansenia De Index Secundus vormt een beredeneerd register op de Index Primus

314 Ibidem, Index Primus, 224 (N3); Index Secundus, 433.

315 Ibidem, Index Promus, 59 b; Index Secundus, 437.

316 Spiert, 'Jansenisme', 155.

317 PA SJ, Hestonsche handschnftenverzameling, AF 2, Index Prmmus, 59 b, Index Secundus, 460.

318 Ibidem, Index Promus, so d.; Index Secundus, 467.

319 Rogier, Geschiedenis, II, 308-309. 
Thomas Philippe d'Alsace, de latere aartsbisschop van Mechelen en fel anti-jansenist. Hij schreef een anonieme pater jezuïet in Rome in februari 1703 dat de kwestie rond de inmiddels geschorste Codde zijn aanhangers in de Hollandse Zending in spanning hield. $\mathrm{Zij}$ zouden zich weinig gelegen laten liggen aan de besluiten die de Heilige Stoel in deze kwestie nam en probeerden voortdurend anderen voor hun standpunten te winnen. 'Ils entrainent le sexe [vrouwen, $M M$ ], ignorant au sujet des dévotions, par des pratiques qui sont toutes contraires à la dévotions toujours suivie dans 1 'Église. ${ }^{320}$ Een aantijging, die misschien ook wel tot doel had de jansenisten als capabele zielzorgers te diskwalificeren.

Al geven de bronnen weinig bijzonderheden prijs, de jansenistische strubbelingen grepen hier en daar diep in in de levens van kloppen. Verscheidene jezuïeten-kloppen zagen zich in de nasleep van de afzetting van Codde beroofd van hun leidsmannen die uit verschillende Hollandse steden werden verbannen. ${ }^{321}$ Noodgedwongen moesten zij nieuwe biechtvaders van een andere spirituele richting zoeken, zoals de veertig Goudse maagden, die hun heil bij de minderbroeders ter stede zochten. ${ }^{322}$ Sommige kloppen verdedigden hun geesteliike vaders, zoals Trijntje Cornelisdr. in Naarden. Jansenisten hadden ervoor gezorgd dat de jezuïeten in 1705 hun statie in dit stadje moesten prijsgeven. Al snel kwamen de kerkmeesters er achter dat het kerkzilver was verdwenen. Natuurlijk waren de paters de eerste verdachten, maar die bleken onschuldig. Trijntje Comelisdr. bleek het zilver zolang in bewaring gegeven te hebben bij een zekere Claude Louis de Surmont, heer van Vlooswyck, die aanspraak maakte op het bezit van de schuilkerk. Op voorwaarde dat een jezuiet wederom de statie mocht bedienen, was hij bereid het kerkzilver terug te geven. Toen er in 1709 toch een wereldheer benoemd werd, vond deze bij aankomst de Naardense kerk annex pastorie bezet door de klop Trijntje, die zich intussen ook meester had gemaakt van de boeken die aan de statie toebehoorden. Kennelijk voelde deze geestelijke maagd zich verantwoordelijk voor de statie en achtte zij zich gerechtigd door dergelijke materiële ingrepen de 'machtswisseling' te torpederen. Haar pogingen bleven evenwel vruchteloos. $\mathrm{Na}$ lange onderhandelingen met de kerkmeesters en notabelen der stad, gaf De Surmont zijn aanspraak op de Naardense kerk en haar goederen op. Ook Trijntjes verzet was vermoedelijk gebroken. In I 7II werd in Naarden een wereldheer als zielzorger aangesteld. ${ }^{323}$

\section{Kloppen en rekatholisering}

Verschillen in spiritualiteit en moraal tussen seculieren en regulieren vonden gaandeweg de zeventiende eeuw ook een vertaling in opvattingen over het karakter van

320 Jadin, Le cardinal Thomas Philippe d'Alsace', 87.

321 Van Hoeck, Schets, 267-268.

322 Van Heel, Minderbroeders te Gouda, II, 68-69.

323 Hilhorst, 'Het kerkelijk Gooiland', 277-288. 


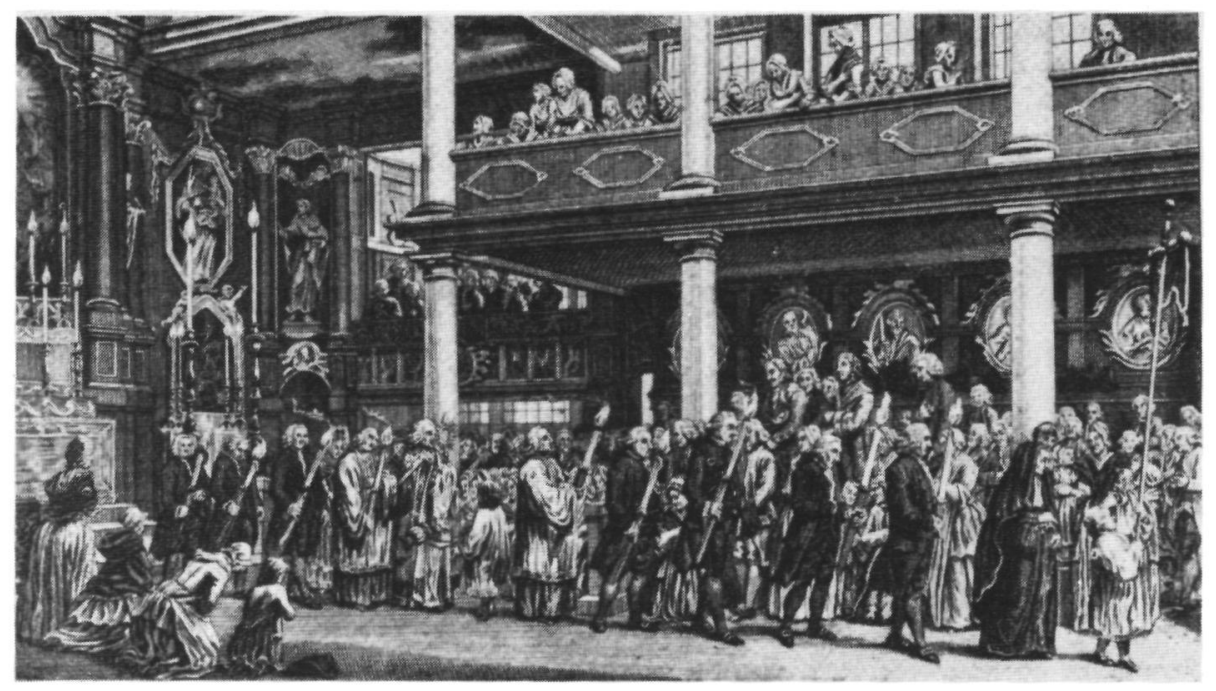

Afb. 5 Sacramentsprocessie binnen de Mozes en Aäronkerk te Amsterdam.

de kerk en de pastoraal. Een meerderheid van de seculiere geestelijkheid stond, in navolging van Neercassel, een sobere kerk voor waarin een strikte sacramentele praktijk werd gehandhaafd. Regulieren daarentegen, streefden over het algemeen naar een brede volkskerk. Ten aanzien van de kerkelijke discipline betrachtten zij een zekere mildheid in biecht en frequentie van communie. De communie werd door hen gezien als een middel tot christelijke volmaaktheid en uit dien hoofde waren zij niet gekant tegen frequent communiceren. Vele seculiere geestelijken daarentegen beschouwden het heilig brood als een soort beloning voor reeds bereikte vroomheid en ontraadden de frequente communie daarom juist. Hun streven naar soberheid werd mede ingegeven door het verlangen de verstandhouding met niet-katholieke landgenoten te verbeteren en een zekere animositeit, opgewekt door roomse rituelen, te verminderen. Deze zorg werd slechts in mindere mate gedeeld door de reguliere geestelijkheid..$^{324}$

Opvattingen over spiritualiteit en moraal beïnvloedden de (re)katholiseringsstrategieën van seculieren en regulieren in de Hollandse Zending. Vooral regulieren eigenden zich elementen toe van religieuze volkscultuur, zoals broederschappen, processies en bedevaarten. $\mathrm{Zij}$ ontwikkelden deze tot middelen van confessionele identificatie. In seculiere kring waakte men voor al te uitbundige en haast mechanische rituelen; niet alleen vanuit een streven naar een waarlijk doorleefd geloof, maar ook om beschuldigingen van protestanten, als zouden katholieken volledig onwetend zijn van spirituele zaken en de sacramenten louter uit gewoonte 
ontvangen, te ontkrachten. ${ }^{35}$ Sommige wereldheren bekntuseerden daarom allerleı praktıken rond helligenverening en aflaten en stelden zich zelf terughoudender op, al betekende dat niet dat zıj zich niet ook van dergelıke confessıonalıseringsstrategieen bedienden. $B$ j hen was veeleer sprake van een dubbele gedragscode: één voor binnen het eigen confessionele verband waarbı) een zekere soberheid en rigornsme werd betracht, en eén voor buiten de eigen geloofskring waann elementen van 'geoffictalıseerde' volksreligiositeit juist een belangri)ke rol speelden ${ }^{326} \mathrm{Te}-$ gen het einde van de zeventiende eeuw werden de effecten van de genoemde verschillen in kerkopvattıng, discipline, spintualiteit en modellen van confessionele identıficatie zichtbaar. In de steden van Holland en Utrecht tekende zich toen een duidelık verloop af van de kerken bediend door wereldheren naar de kerken van de regulieren. ${ }^{327}$

Kloppen fungeerden als het ware als wegwijzers in een katholieke missiekerk met verschillende strategieen van rekatholısenng Het religieus regime dat zij op gezag van hun biechtvaders onderhielden, verned de spintuele onentatie van hun leidsmannen Door de frequentie van biecht en communie, intensiteit van gebed en meditatie - vroomheidspraktı)ken die zıch ten dele in de openbare ruimte van een schulkerk afspeelden - van 'hun' maagden te reguleren, konden die de sacramentele praktı)k van de eigen geestesnchting herkenbaar maken Spoorden francıscanen en jezuieten gelovigen, kloppen incluis, aan tot het veelvuldig ontvangen van de sacramenten, veel wereldheren maanden tot terughoudendhe1d Geestelı)ke maagden vertolkten dergelıke religieuze gedragscodes in hun leefwıze en hun vroomheid en vormden dankzij hun intermediaire positue levende voorbeelden voor andere gelovigen.

Voor zover de lokaal-politieke situatie dat toeliet, werden geestelıke maagden onder leiding van regulieren deelgenoot van een zekere confessionele uitbundigheld Hun leıdsmannen propageerden aflaten, allerle1 vormen van heiligenverenng, bedevaarten en processies. Voor geestelıjke maagden was bij deze praktıjken soms een vooraanstaande rol weggelegd. In de Mozes en Aaronkerk te Amsterdam, bediend door minderbroeders, werden bijvoorbeeld processies binnen het kerkgebouw gehouden. Een laat-achttiende-eeuwse gravure laat zien dat de stoet wordt aangevoerd door de prester die het Heilig Sacrament draagt (afb 5). Hi) wordt op de voet gevolgd door een geestelyke maagd..$^{328}$ Ook de ntuelen rond de intrede in een wereldlı)ke derde orde, waaraan een kerkelı)ke gezagsdrager als Joannes van Neercassel, die hechtte aan soberheld, aanstoot nam, gaven de reguliere geestelıjkheid en hun geestelıke maagden de gelegenhe1d om het karakter van de katholıc1-

325 Idem, 'Jansenısme', 155-161

326 Frijhoff, 'Vraagtekens', 8I-82

327 Spierrz, 'Godsdiensug leven', 353

328 Van Heel en Knipping, Van schuilkerk tot zulkerk, 155, opperen dat dit wellıcht de klop was die beneden in de kerk devotie-artikelen verkocht en tekenen aan dat deze vrouw door zowel de paters als de gelovigen zeer werd geacht 
teit te onderstrepen tegenover het calvinisme dat als sober en kleurloos werd ervaren. ${ }^{329}$

\section{II.7 Conclusie}

Een meerderheid van de meer dan vijfduizend katholieke vrouwen die in NoordNederland een geestelijk bestaan in de wereld leidden, leefde zelfstandig, bij familie of in zeer kleine groepies met geestverwanten. Anders dan maagden die in kloppenvergaderingen woonden, moesten zij passende kaders voor hun vroomheid en barmhartige werken zoeken in broederschappen of een wereldlijke derde orde. Hoe zij hun bestaan als klop gestalte konden geven, hing mede af van hun financiële positie en woonvorm. Ook de voorstelling die een maagd en haar biechtvader hadden over de vormgeving van de kloppenstaat, was van invloed op de taken die zij tot hare mocht rekenen. Direct en indirect zorgden geestelijke maagden voor een zekere continuiteit in de zielzorg en het apostolaat, die ten gevolge van de Reformatie lacunes vertoonden.

Dankzij de sociale verankering in hun lokale geloofsgemeenschap konden kloppen vaak effectief optreden als intermediair tussen leken en geestelijken. Ondanks hun statusverandering - van gewone lekevrouw tot een geestelijke maagd en bruid van Christus - konden zij blijven bogen op bestaande netwerken van familie en vrienden. Hun zeggenschap en aanzien stoelde op hun vergeestelijkte maagdelijke leefwijze. In de ogen van protestantse medeburgers genoot deze bestaansvorm weinig aanzien; integendeel, zij beschouwden een celibatair leven als strijdig met de 'natuurlijke' bestemming van vrouwen. Godgewijde maagden legden in katholieke kring daarentegen nogal wat gewicht in de schaal. Niet enkel op grond van hun maagdelijke staat, maar ook dankzij hun financiële draagkracht, hun daadkracht en de nuttige connecties waarover zij soms beschikten. Door te participeren in belangrijke sociale verbanden als broederschappen, versterkten kloppen mogelijk hun aanzien en invloed in de gemeenschap. Dit kwam hun vermoedelijk van pas bij taken die zij in het geloofsonderwijs en de zielzorg vervulden.

Hun materiële en immateriële bijdragen aan kerk en clerus waren belangrijk voor de katholieke kerk die door de calvinisering vanuit een achterstandspositie bij het confessionaliseringsproces betrokken was. Zichtbaarheid en herkenbaarheid betekenden - hoe paradoxaal ook voor een officieel niet getolereerde confessie als de katholieke - overleving op lange termijn. Patronage in de vorm van royale giften en leningen, en onvermoeibare inzet van kloppen op velerlei terreinen in zielzorg en apostolaat, verzekerden dat het katholicisme zijn uitstraling op lokaal niveau enigszins behield. Kloppen zelf fungeerden door hun bijzondere wijze van kleden en het onmiskenbaar religieuze aura dat om hen heen hing, als levende wegwijzers 
in de missiekerk, waar zich geleidelijk verschillende strategieën van rekatholisering uitkristalliseerden onder seculieren en regulieren. Temidden van allerlei binnenkerkelijke spanningen, van kerkpolitieke en spirituele antagonismen, moesten kloppen zeker over de nodige mentale flexibiliteit beschikken om zichzelf en hun invloed te kunnen handhaven. En dat terwijl zij, zonder enige erkende religieuze status, toch al moesten laveren tussen wereldlijke en kerkelijke circuits.

De geestelijkheid was zich er terdege van bewust dat de inzet en steun van kloppen van eminent belang waren voor het herstel en behoud van het katholicisme in Noord-Nederland. Seculieren én regulieren probeerden bij kloppen in de gunst te komen. Toch was de houding van priesters tegenover deze dienaressen in de wijngaard des Heren op zijn minst ambivalent. Vooral hun materiële en immateriele afhankelijkheid van geestelijke maagden was hier debet aan. Als royale weldoensters of daadkrachtige medewerksters in de zielzorg kregen of maakten kloppen anspraak op een zekere medezeggenschap. En hoewel de kloppenboeken in alle toonaarden waarschuwden voor wat genoemd werd 'heerszucht', waren kloppen in menige statie betrekkelijk invloedrijk. Zeker in de eerste helft van de zeventiende eeuw dreigden de bestaande hiërarchische verhoudingen tussen geestelijken en leken, kloppen incluis, soms verstoord of zelfs omgekeerd te worden. ${ }^{330}$ In deze dreigende inversie ligt de oorzaak van de ambivalente houding van geestelijken ten aanzien van kloppen. Die tweeslachtigheid komt pregnant tot uitdrukking in het volgende hoofdstuk, waarin de ideaalbeelden die geestelijken in kloppenboeken vertolkten, uiteengezet worden. Enerzijds werden geestelijke maagden aangemoedigd zich op alle mogelijke manieren voor hun geloof en kerk in te zetten; anderzijds werden hun activiteiten scherp gecontroleerd en bij tijd en wijle geconformeerd aan de zeventiende-eeuwse normen van betamelijkheid voor leken, maar vooral voor vrouwen. Vrouwelijk engagement in het door mannen gedomineerde kerkelijke domein kende nu eenmaal grenzen. 


\section{III \\ 'Een waerachtighen staet'? \\ Geestelijken over de kloppenstaat}

Ideaalbeelden over vrouwen die hun religieuze roeping buiten de beschutting van dikke kloostermuren trachtten te verwezenlıjken, vonden een vertolknng in kloppenboeken. Er bestond geen algemene regel voor geestelıke maagden. In dit gemis werd ten dele voorzien door kloppenboeken. Hiermee droegen geestelıken bi) tot de vormgeving van een religieuze leefwijze die afweek van de door de kerk erkende kloosterstaat Sommigen moedigden vrouwen explıciet aan om een maagdelık, geestelık bestaan in de wereld te verkezen boven huwelı,k of klooster. Dergelıjke verdedigingen van de geestelı)ke levensstaat buiten het klooster stonden haaks op de besluitvorming van het Conclie van Trente met betrekking tot het religieuze leven van vrouwen Kloppenboek-auteurs omzeilden deze besluiten op verschillende manieren De subversieve implicaties van hun betogen zijn tot dusver nog nauwelı)ks onderkend, evenmın als de sekse-specıfieke ladıng ervan '

Kloppenboeken zijn normatieve bronnen. In dit hoofdstuk wordt geen poging ondernomen om deze bronnen te 'filteren' om te zien hoe de zeventiende-eeuwse werkelıkkheid eruit zag zónder de clencale bril waardoor de kloppenboek-auteurs haar bezagen. Integendeel, het gaat er just om in kaart te brengen hoe de clerus de leefwilze van geestelijke maagden benoemde, hun identiteıt beschreef en de gezagsverhoudingen tussen maagden en hun leıdsmannen voorstelde Aan de hand van kloppenboeken wordt onderzocht welke opvattıngen over vrouwely)kheid en vroomherd, die van invloed waren op vormgeving en status van de kloppenstaat, werden bemiddeld.

Behalve de gedrukte kloppenboeken zijn enkele handschriften met regels en nchtlijnen voor het geestelıjk leven in de wereld bl) het onderzoek betrokken Naast van oorsprong Nederlandstalıge werken zijn ook enkele vertalıngen van buitenlandse kloppenboeken bestudeerd. Werken die verschenen zinn vanaf het einde van de zestiende tot het begin van de achttiende eeuw, zijn onder de loep genomen. Welke kenmerken kloppenboeken vertonen, wordt in de eerste paragraaf kort toegelicht Deze boeken waren vooral voor een vrouwelıjk lezerspubliek bedoeld, maar of vrouwen ze ook lazen, is de vraag Wanneer we de invloed en reikwi)dte van deze categone stıchtelıke werken onder haar voornaamste doelgroep

I Buvoorbeeld niet door Janssens, 'Geestelıke dochters' De Vroede, 'Kwezels' en 'zusters', 28-47, schetst het 'model van een geestelıjke dochter', zoals kloppenboek-auteurs dat hun lezers voorhielden, uitvoeng $\mathrm{H}_{\mathfrak{y}}$ gaat evenwel niet explıciet in op sekse-specifieke en radicale implicaues van hun directueven 
nader willen bepalen, is deze kwestie van belang. Aangezien maar weinig bronnen aanknopingspunten bieden voor de receptie, kunnen in de tweede paragraaf slechts enkele indicaties worden gegeven. Hoe auteurs van kloppenboeken het religieuze bestaan buiten kloostermuren voorstellen, wordt in de derde paragraaf verkend. Vooral over de vraag of deze leefwijze een staat of geen staat was, blijken de geestelijke gemoederen verdeeld.

Betogen over maagdelijkheid en religieus leven in kloppenboeken kunnen niet los worden gezien van het katholieke denken over de menselijke natuur en de wereld. Vigerende definities van zonde en zaligheid vertoonden sekse-specifieke trekken, zo wordt in de vierde paragraaf betoogd. 'Geseksueerde' vertogen van geestelijken over maagdelijkheid en de kloppenstaat worden in de vijfde paragraaf verder uitgediept. Langs deze weg worden denkbeelden over vrouwen en vrouwelijkheid in kaart gebracht, die een ander licht werpen op de warme pleidooien voor de kloppenstaat, die aan vrouwen gericht zijn. Steun en leiding van mannen werden schier onontbeerlijk geacht voor vrouwen, en kloppen (in spe) vormden in dat opzicht geen uitzondering. Voor geestelijke maagden behoorde de biechtvader de voomaamste referentie-persoon te zijn. Deze geestelijke verenigde twee functies in zich, biechtvader en geestelijk leidsman. Deze combinatie dreigde volgens verschillende kloppenboek-auteurs de band tussen priester en geestelijke maagd te vertroebelen. Zeker omdat die band de kern van de identiteit van een geestelijke maagd vormde, zoals in de zesde paragraaf uiteen wordt gezet, waren heldere verhoudingen gewenst. De zevende paragraaf biedt een analyse van het samenstel van regels en richtlijnen in kloppenboeken. Dit regime van vroomheid wordt niet alleen bezien als uitdrukking van een door geestelijken voorgeschreven orde, maar ook als een handelingskader waaraan geestelijke maagden hun identiteit ontleenden. Vroomheid, in de betekenis van een samenstel van devoties, rituelen en charitatieve activiteiten, bood geestelijke maagden een mogelijkheid hun geloof uit te dragen op één van de weinige manieren die vrouwen binnen de katholieke kerk toegestaan was. En vroomheid was volgens de kloppenboeken meer dan een optelsom van religieuze voorschriften; het was een levenswijze, waar op het niveau van individuele en collectieve identiteit een constituerende kracht van uitging.

\section{III.I Kloppenboeken: genre en beperkingen voor onderzoek}

Lectuur voor jonge meisjes en vrouwen in de vroegmoderne tijd droeg over het algemeen een religieus, stichtelijk karakter. ${ }^{2}$ Onder de devotie- en dagheiligingsboeken waarmee de zeventiende-eeuwse markt overspoeld werd, kunnen de stichtelijke werken voor geestelijke maagden als een kleine, aparte groep beschouwd

2 Bij gebrek aan Nederlands onderzoek, zie Moore, The marden's mirror. 
worden. ${ }^{3}$ Als wegwijzers in het religieuze leven passen de kloppenboeken in een traditie van inleidingen tot een goed christelijk leven, die teruggaat tot de Oudheid. Een bekende en wijd verbreide representant van dergelijke inleidingen is Franciscus van Sales' L'Introduction à la vie dévote (1609), waarvan de eerste Nederlandse vertaling in 1616 verscheen, die gedurende de zeventiende eeuw maar liefst 16 herdrukken beleefde. ${ }^{4}$ Dergelijke algemene stichtelijke handleidingen voor ongehuwde en gehuwde gelovigen waren er in overvloed. Ook daaruit konden geestelijke maagden lering trekken voor hun leefwijze. ${ }^{5}$ In doelgroep en specifieke uitwerking van algemeen christelijke idealen onderscheiden kloppenboeken zich echter van dergelijke wegwijzers. Kloppenboeken waren namelijk bij uitstek bedoeld voor ongehuwde jonge vrouwen die op het punt stonden te kiezen voor een levensstaat of inmiddels gekozen hadden voor een godvruchtig bestaan buiten het klooster. In een kloppenboek vonden zij gedragsvoorschriften en richtlijnen voor zo'n bestaan. $^{6}$

Kloppenboeken kunnen worden onderscheiden van andere devotieliteratuur op grond van de titel of het voorwoord. Hierin worden vrouwen die in de wereld een celibatair, geestelijk leven leiden, nadrukkelijk als beoogde - hoewel niet altijd exclusieve - lezersgroep genoemd. Sommige auteurs scharen ook andere religieuze vrouwen, nonnen en begijnen, onder de potentiële lezeressen. ${ }^{7}$ De jezuïet Franciscus de Smidt noemt bovendien geestelijke weduwen expliciet als doelgroep. ${ }^{8}$ Maar niet alleen geestelijke maagden en weduwen konden hun voordeel met deze boeken doen. Ook hun leidsmannen konden hieruit stof en stichtelijke voorbeelden putten voor hun preken, ${ }^{9}$ zeker voor die gedeelten van een preek waarin geestelijke maagden als afzonderlijke groep werden toegesproken. ${ }^{\circ}$ Taal en vorm van sommige kloppenboeken wijzen erop dat niet maagden, maar hun leidsmannen de beoogde lezersgroep vormden. " Weinig maagden zullen het Latijn, de taal van de clerus, voldoende machtig geweest zijn om de Scala facob virginibus Deo cum proposito perpetuae continentiae in seculo famulantibus applicata (1666) van de wereldheer

3 Polman, Katholek Nederland, I, I16, onderscheidt kloppenboeken als een apart genre. Voor het aanbod en nadere classificate van post-Trentse kerk- en dagheiligingsboeken, zie Clemens, $\mathrm{De}$ godsdienstugherd, I, 49-66. Vgl Polman, 'Het geestelıjk leven'

4 Voor de invloed van dit werk in de Nederlanden, zie Dansels, Les rapports.

5 De Vroede, 'Kwezels' en 'zusters', 124.

6 Afgezıen van de thematiek - de geestelıke levensstaat buten het klooster - vertonen kloppenboeken als genre verwantschap met het 'book of virtuous example', een vroegmoderne kruising van het 'book of conduct' met middeleeuwse exempla. Volgens Moore, The mavden's mitror, 86-87, vormden dergelujke boeken het leeuwedeel van de lectuur voor Duitse meisjes in de zestiende en zeventiende eeuw.

7 Van Heumen, Clooster van Sion; Sendbreff, Lumnius, Van d'leven.

8 De Smidt, Van den salighen staet, 'Vermaen (.. )' (ongepagıneerd).

9 Het gebrulk van exempla is volgens Bremond, Le Goff en Schmıtt, L'exemplum, 57, karaktenstiek voor de predikang ten tijde van de Contrareformatie.

10 Rotsaert, Tussen Eva en Mana, 184, verwi)st naar deze preken 'ad status'.

II Vgl. Schulte van Kessel, Geest en vlees, I14 
Joannes Lindeborn te kunnen lezen. De officiële goedkeuring die de provicaris Abraham van Brienen aan dit boek gaf, noemt degenen aan wie de zorg voor geestelijke maagden was toevertrouwd, als lezers. ${ }^{12}$ Daarentegen was de herziene Nederlandse versie, die vier jaar later van dit werk verscheen, ook voor geestelijke maagden zelf bedoeld. ${ }^{33}$ De vorm van sermoenen die Joannes van Heumen voor zijn Clooster van Sion koos, wijst wellicht eveneens in de richting van geestelijken als beoogde lezers.

Ontbreken vermeldingen van kloppen als doelgroep, dan moet gekeken worden of boeken concrete richtlijnen voor gedrag en religieus leven bevatten. Deze gedragsregels zijn geïnspireerd op de drie evangelische raden van armoede, gehoorzaamheid en maagdelijkheid of kuisheid. Die vormen het fundament van alle religieuze levensvormen, in of buiten het klooster. Ook al legden geestelijke maagden geen drie plechtige geloften af - zoals kloosterlingen dat wel deden - zij werden niettemin geacht de evangelische raden naar de geest te volgen. In sommige kloppenboeken zijn de gedragsregels in prescriptieve vorm gesteld, in andere zijn ze juist verpakt in navolgenswaardige voorbeelden.

Kloppenboeken weerspiegelen clericale zorg én regelzucht, want ook het geloftenloos religieus leven van geestelijke maagden behoorde enig houvast te hebben. Daarnaast pogen deze werken, impliciet dan wel expliciet, een rechtvaardiging van de kloppenstaat te geven. Ook al werd deze leefwijze door de kerk niet als staat erkend en ook al mochten zij, die zich hierop toelegden, zich formeel geen religieuzen noemen, de auteurs van de kloppenboeken ijverden ervoor deze bestaanswijze en haar status op enigerlei wijze te verankeren binnen de kerkelijke hiërarchie.

Het apologetisch karakter van een kloppenboek beperkte zich niet altijd tot de verdediging van de kloppenstaat. In De Weg der Suyverheyt van d'Hollantse Maegden probeert de seculier Willem Schoenius zijn gelijk te halen bij de kerkmeesters van de statie Molenbuurt in West-Zaandam. Met hen was hij in 1667 in conflict geraakt naar aanleiding van de kerkgang van kraamvrouwen. Een maand tot veertig dagen na de bevalling mochten vrouwen die een kind gebaard hadden, voor het eerst de kerk weer bezoeken. Met een plechtig ritueel, dat dank aan God uitdrukte voor de ontvangen weldaden en de eerbied van de kerk voor het moederschap symboliseerde, werden zij door de dienstdoende priester plechtig de kerk binnengeleid en als het ware opnieuw in de kerkgemeenschap opgenomen. ${ }^{\text {14 }}$ Schoenius wilde dat vrouwen bij die gelegenheid een aalmoes schonken aan het altaar waarvan hij het beneficie had. ${ }^{15}$ De kerkmeesters verzetten zich daartegen, vermoedelijk uit angst voor inkomstenderving. Schoenius delfde het onderspit en

12 'Approbatio', in: Lindeborm, Scala Jacob (ongepagineerd).

13 Axters, Geschiedenis, IV, 256.

14 Wijnhoven, 'Kerkgang'. Vgl. Dresen, 'Heilig bloed', die erop wijst dat de kerkgang zeker ook als reinigingsritueel na de kraam beschouwd wordt.

15 [Van Heussen], Batavia Sacra, II, 390. 
werd uiteindelijk naar elders overgeplaatst. Via zijn kloppenboek probeerde hij de in zijn ogen rebelse kerkmeesters alsnog een slag toe te brengen. Onder het mom de maagden te leren dat zij volstrekt gehoorzaam moeten zijn, geeft hij deze kerkmeesters een flinke schrobbering door te stellen 'dat alle soodanighe in Hollandt, al roemen sy haer oock Kerck-meesters te zijn' die in opstand komen tegen hun zieleherder, 'van niemandt mogen geabsolveert worden, en gaan verloren als sy sterven'. ${ }^{16}$

\section{Onderrichtingsboeken en vitae}

Kloppenboeken met een duidelijk prescriptief karakter worden regel- of onderrichtingsboeken genoemd. Deze openen doorgaans met een uitgebreide legitimering van het geestelijk leven buiten kloostermuren. ${ }^{17}$ Allereerst wordt de ouderdom van de godgewijde maagdelijke staat gememoreerd. Daartoe maken auteurs een historische excursie naar de vroegste tijden van de christelijke kerk, toen vele vrouwen de maagdelijke staat in de wereld beleefden. De waardigheid van deze levensstaat wordt meestal extra onderstreept door te wijzen op de aanzienlijke afkomst van degenen, die toen en in later tijden deze leefwijze hebben verkozen. Vervolgens worden de vruchten van de godgewijde maagdelijke staat breed uitgemeten. Tenslotte worden concrete regels voor gedrag en geloofsleven van geestelijke maagden vrij minutieus gepresenteerd. Deze nchtlijnen moesten waarborgen dat het buiten het klooster beleefde geestelijke leven ook werkelijk tot deugzaamheid en zaligheid zou leiden. Zij worden vaak geadstrueerd met exempla, korte passages of beschrijvingen van personages uit de bijbel of uit geschriften van de kerkvaders, die als model of symbool worden aangereıkt voor de voorgeschreven deugd of handelwijze. Door het gebruik van exempla tonen de auteurs van dit type kloppenboeken zich schatplichtig aan de kerkvaders, die deze veelvuldig gebrukken. ${ }^{18}$ Met behulp van deze exempla prenten zij hun publiek in dat de voorschriften deel uitmaken van de christelijke traditie en door anderen reeds met vrucht volbracht zijn.

De tweede categorie 'kloppenboeken' wordt gevormd door de vitae of levensbeschrijvingen. Hierin wordt eigenlijk de omgekeerde weg bewandeld. Anders dan in de onderrichtingsboeken, waarin personen en hun geschiedenis een illustratie vormen van het betoog over de geestelijke staat buiten het klooster, staat in een

16 Schoenıus, Weg, 173. Hoewel 'kerck-meesters' taalkundıg gezien betrekking heeft op de geestelıke maagden tot wie Schoenius zich in zi)n boek ncht, blıkt uit het verloop van de tekst dat de auteur niet met de kloppen, maar met de West-Zaandamse kerkmeesters nog een appeltje te schillen had. Laatstgenoemden namen ook aanstoot aan de betreffende passage [Van Heussen], Batavia Sacra, II, 390, zie ook Theissing, Over klopjes, is8

17 Een uizondenng is Musius, Maagde-pligt, dat opent met een lang gedicht, waann de eigenschappen worden genoemd op grond warvan een vrouw zich als 'ware maagd' diskwalıficeert.

18 Bremond, Le Goff en Schmitt, L'exemplum, 48. 
vita het leven van één persoon centraal. Deze figuur vergroot als het ware het geestelijk bestaan in de wereld uit, ${ }^{19}$ afgezet tegen de huwelijkse staat enerzijds en het kloosterleven anderzijds. ${ }^{20}$ Soms lijken de gedrukte levensbeschrijvingen meer prijs te geven van de persoonlijke opvattingen van geestelijke maagden. Deze indruk wordt versterkt wanneer vitae, naar zeggen van hun auteurs, gebaseerd zijn op handschriften van de hoofdpersoon en daarenboven nog doorspekt zijn met citaten. De strekking en vooral presentatie van de levens mogen dan op het eerste gezicht minder prescriptief lijken, ook binnen deze tak van het genre was het de opzet van auteurs om hun lezeressen (en ook lezers) tot een bepaalde leefwijze en geloofsopvatting aan te zetten.

Laatstgenoemde kloppenboeken behoren in zekere zin tot de hagiografie. ${ }^{21} \mathrm{De}$ vrouwelijke figuren die erin worden beschreven, waren naar de letter der kerkwet niet heilig verklaard maar leefden als heiligen. Zij konden wel fungeren als stichtende voorbeelden, maar auteurs moesten de suggestie vermijden dat de hoofdpersonen van hun bocken echte heiligen waren. Daarom opende de auteur van de levens van de Roermondse geestelijke maagden Joanna van Randenraedt en Agnes van Heilsbach met een 'Protestatie vanden schryver': de paus zelf had in 1625 verordonneerd dat 'gheen Boecken, handelende van personen, die met gevoelen van heyligheyt gestorven zijn' het licht zouden zien zónder goedkeuring van de bisschop. In concreto betekende dit dat de vitae van deze (en andere) geestelijke maagden niet 'souden aenveert worden, als eenighe Heyligheyt oft Saligheyt toeschryvende aende persoonen' die door de kerk zalig noch heilig verklaard waren. ${ }^{22}$ De jezuiet Heribertus Rosweydus nam de levens van enkele geestelijke maagden op in zijn boek over heilige maagden in de rubriek 'Sommighe levens ende exempelen van salighe Maeghden, Der welcker Dagh, Naem, oft Canonizatie niet ghevonden en wordt'. Onder andere het leven van de Spaanse geestelijke maagd Luisa de Carvajal y Mendoza is hierin opgenomen; ${ }^{23}$ de vertaling van haar apart geboekstaafde leven kwam in 1649 eveneens op de markt.

Het aloude genre van de heiligenlevens had door de Reformatie schade geleden. De vitae van geestelijke maagden, die tot de kloppenboeken te rekenen zijn, getuigen in zekere zin van de ontwikkelingen die de hagiografie sinds de zestiende eeuw doormaakte. Rond het midden van de zestiende eeuw leefde de katholieke hagiografie weer op - in reactie op protestantse collecties van levens van martelaars en

19 Vgl. Janssens, 'Geestelijke dochters', 3 I 8.

20 Levens van vroeg-christelijke maagden blijven hier buiten beschouwing, aangezien hierin het klooster als optie geen rol speelde.

2I Vitae vertegenwoordigen binnen de hagiografie slechts één van de genres of typen teksten. Von der Nahmer, Die lateinische Heiligenvita, 3.

22 Kort Begryp, 348; Leven ende deughden, 'Protestatie vanden autheur' (ongepagineerd). F.V.O.C.S., Leven Anna de Torres, bevat een 'Protestatio Authoris/Openbare Betuyghenisse des Autheurs' met dezelfde strekking.

23 Rosweydus, Leven der H.H. Maeghden, 537-540. 
heiligen die voor het geloof hadden geleden en gestreden, alsook als uitvloeisel van de hervormingsidealen van de Contrareformatie. Levensbeschrijvingen, zij het van protestantse of van katholieke signatuur, ontwikkelden zich tot een genre waarin de nadruk meer dan in de middeleeuwse hagiografie het geval was, lag op de voorbeeldfunctie van de hoofdpersoon in de strijd om het 'ware' geloof. Auteurs beoogden met de presentatie van toonbeelden van heroïsche zelfopoffering om den gelove hun lezers aan te zetten tot positiebepaling in de geloofsstrijd. ${ }^{24}$

De zeventiende-eeuwse vitae van religieuze vrouwen waren niet alleen bedoeld als aansporingen voor een confessionele, maar ook voor een sociale keuze, namelijk voor een ongehuwd, kuis bestaan. De maagdelijke staat en het celibaat waren net als de heiligenverering onder vuur genomen door de hervormers. Ook in deze kwestie gingen katholieke geestelijken over tot verdediging, waardoor het strijdbare karakter van sommige levensbeschrijvingen verklaard wordt. De keuze voor de maagdelijke staat én die voor het katholieke geloof grepen in sommige levensbeschrijvingen in elkaar. Vrouwelijke hoofdpersonen, die uit religieuze overwegingen onvoorwaardelijk voor de godgewijde maagdelijke staat hadden gekozen, werden ingezet om lezers tot standvastigheid in den gelove te bewegen. ${ }^{25}$ Voor de vitae, maar ook voor de ondernchtingsboeken geldt daarom dat zij niet uitsluitend ter lering van geestelijke maagden of geestelijke leidsmannen zijn geschreven, maar ook deel uitmaakten van de polemiek met de protestanten over heiligheid en maagdelijkheid. ${ }^{26}$ In hun apologetısch karakter resoneerde de protestantse kritiek op de katholieke verheerlijking van de maagdelijkheid.

\section{Aantal, formaat en oplagen}

Op grond van genoemde vorm- en inhoudscriteria - apologie van de maagdelijke staat buiten het klooster, welomschreven lezersgroep en concrete regels voor leven en geloven - zijn voor de penode van 1570 tot 1730 in totaal 34 gedrukte werken als kloppenboeken onderscheiden. ${ }^{27}$ Vóór 1570 zijn, voor zover mij bekend, geen werken verschenen die aan bovengenoemde criteria voldoen. ${ }^{28}$ Kloppenboeken

24 Hieber, Legende.

25 Bijv. De Roa, Leven Sancia Canllo, 170, vgl. het voorwoord van Jacobı, Den Spieghel der Maeghden en de 'dedicatre' van Rosweydus, Leven der H.H. Maeghden.

26 Polman, 'Roomse en antı-roomse stnjdlıteratuur', signaleert dat de religieuze polemiek gedurende de zeventiende eeuw verschoof van het wetenschappelık-theologische domein naar de predikatıe en lectuur die toegankelıjk moest zljn voor gelovigen Ook kloppenboeken geturgen $m .1$ van deze verschuving.

27 Zie Bıllage II. De manuscnpten die qua strekking als kloppenboeken beschouwd mogen worden en bij de analyse betrokken zijn, staan niet in de bıjlage vermeld.

28 De Vroede, 'Kwezels' en 'zusters', betrekt [Joachım van den Putte], Eenen claren spiegel der waerachtugher Chnstelycker maechden (..) (Antwerpen· Gregons de Bonte z j. [1551]) buj zi)n onderzoek Hierin wordt welıswaar de maagdelı)ke staat, maar net explıcıet de maagdelıke staat in de wereld verheerlıkk. Mogelıjk had Van den Putte een andere doelgroep voor ogen. 
werden na 1730 zeker nog herdrukt. Nieuwe titels uit deze periode konden via de Bibliotheca catholica Neerlandica impressa niet opgespoord worden. ${ }^{29}$ Mogelijk kunnen in andere bronnen, zoals bijvoorbeeld oude veilingcatalogi, nog andere kloppenboeken ontdekt worden, die tot dusver onbekend zijn.

Het moge duidelijk zijn dat kloppenboeken een fractie vormen van het totale aanbod van devotielectuur in de zeventiende en het begin van de achttiende eeuw. Het merendeel, namelijk 23, verscheen na 1650; II werken verschenen vóór of in het jaar 1650. Kloppenboeken zagen het licht onder volstrekt uiteenlopende omstandigheden. Aan het einde van de zestiende eeuw was er ten gevolge van de Reformatie een einde gekomen aan het religieuze monopolie van de katholieke kerk. Een proces van confessionalisering tussen katholiek en protestant begon zich af te tekenen en bereikte een hoogtepunt in de eerste helft van de zeventiende eeuw. In de tweede helft van die eeuw werd een zekere consolidatıe bereikt. Binnen de katholieke kerk openbaarden zich echter tegenstellingen, die in de richtingenstrijd rond het jansenisme aan het einde van de zeventende en het begin van de achttiende eeuw tot uitdrukking kwamen. Of en in hoeverre deze ontwikkelingen doorgewerkt hebben in de opvattingen over vrouwelijkheid en vroomheid, zoals die in de kloppenboeken werden vertolkt, zal in het verloop van dit hoofdstuk blijken.

Kloppenboeken verschenen in octavo of duodecimo, kleine formaten die wijzen op hun gebruikskarakter. Eigenaren - of het nu geestelijke maagden zelf of hun leidsmannen waren - waren zuinig op deze lectuur. Bij zijn onderzoek naar kerken dagheiligingsboeken heeft de kerkhıstoricus Theo Clemens reeds opgemerkt dat veel van de bewaard gebleven devotieliteratuur afkomstıg is uit bıbliotheken van vrouwelijke religieuzen. ${ }^{30}$ Dat geldt ook voor kloppenboeken, al zijn deze tegenwoordig toch vooral in de collecties van mannenkloosters, seminaries en pastoorsbibliotheken te vinden. ${ }^{3 \mathrm{I}}$ Met andere woorden, kloppenboeken overleefden in de boekenkasten van leidsmannen van geestelijke maagden en kwamen later, in de negentiende eeuw, ook wel in handen van geestelijke le1dsmannen van actieve vrouwelijke religieuzen. ${ }^{32}$ Het professionele belang dat bezitsters en bezitters

29 Vgl. De Vroede, 'Kwezels' en 'zusters', 32.

30 Clemens, De godsdrenstigherd, I, 43

31 Veel van de door mij onderzochte kloppenboeken zijn te vinden in de Collectue Thomaasse van de biblıotheek van de Ruksuniversiteit Utrecht en de Jezuietencollectie van de bibliotheek van de Rujksunversiteit Limburg te Maastricht In de eerstgenoemde collectie berusten de boeken uit de voormalige studiekloosters der Nederlandse minderbroeders-franciscanen (Alverna, Weert en Venray), alsook de collectues van de voormalige opleidingsinstituten van het aartsbisdom Utrecht (Rusenburg en Dıjnselburg). De Jezuīetencollecue omvat de collecties van twee voormalıge jezuletenopleidingen (de theologische facultert Canisianum te Maastrcht en de filosofische faculteit Berchmanianum te Nijmegen) en van het voormalig groot-seminane Warmond.

32 Jacobus Antonus Heeren (1775-1859), kapelaan van de parochie St Jacob en één van de opnchters van de Dochters van Mana en Joseph, een congregate van hefdezusters te 's-Hertogenbosch (1820), bezat bijvoorbeeld Kon Begrop (1690), de vita van Joanna van Randenraedt, alsook het eerste deel 
hadden bij kloppenboeken, verklaart waarom deze werken betrekkelijk goed bewaard zijn. ${ }^{33}$

Uit de goedkeuringen blijkt dat verreweg de meeste boeken in Antwerpen gekeurd werden en dus in eerste instantie voor verkoop in dat bisdom bestemd waren. Clooster van Sion van Van Heumen en De Leeder facobs van Lindeborn, die door respectievelijk de Rotterdamse uitgever Hendrick de Bruyn en de Amsterdamse uitgever Joachim van Metelen op de markt gebracht werden, hebben een Noordnederlandse keur en zullen vooral voor verspreiding in dat gebied bedoeld zijn geweest. ${ }^{34}$ Boeken met een goedkeuring uit een Zuidnederlands bisdom vonden niettemin hun weg naar het Noorden. De voorraad van de katholieke boekhandelaarster Hendrickje Kool telde bij haar overlijden elf ongebonden exemplaren van Schoenius' De Weg der Suyverheyt van d'Hollantse Maegden, gekeurd in 1676 te Antwerpen, en vier ongebonden en drie gebonden versies van het leven van Joanna van Randenraedt, getiteld Kort Begryp, eveneens te Antwerpen gekeurd in $1689 .{ }^{35}$ Dit geïsoleerde voorbeeld suggereert dat de eenheid binnen het Nederlandse taalgebied maar ten dele werd aangetast door politiek-institutionele barrières. ${ }^{36}$ De verspreiding van dergelijke stichtelijke boeken vanuit de Zuidelijke naar de Noordelijke Nederlanden en omgekeerd verdient daarom nader onderzoek.

Over de oplagen waarin kloppenboeken verschenen, alsook over hun afzet, tasten we in het duister. Onderzoek naar oplages aan de hand van fondslijsten en overgeleverde inventarissen van Zuid- en Noordnederlandse boekverkopers geeft hierover wellicht uitsluitsel. Deze kwestie gaat het bestek van dit boek echter te buiten en blijft daarom voorlopig onbeantwoord. Met enige voorzichtigheid kan de populariteit van kloppenboeken wel geschat worden aan de hand van herdrukken. Elf boeken werden herdrukt. Van Lof van den maegdelijcken staet naemelyck in de werelt van de jezuiet Cornelius Hazart, dat in 1678 voor de eerste maal werd uitgegeven door Michiel Cnobbaert te Antwerpen, verschenen binnen vijftig jaar maar liefst vijf herdrukken. ${ }^{37}$ Hazart, de bekende polemist uit de gelederen der jezuïeten, zet zich in dit boekje af tegen de 'ketterse' protestanten, die de maagdelijkheid als levensstaat belasteren. Wie weigert te erkennen dat de maagdelijke staat in de wereld een echte staat is, krijgt ervan langs. De scherpe, polemische toon en de

van Lof der Suyverheydt (1625) van Valentinus Bisschop S.J. Met dank aan dr. José Eijt.

33 Vgl. Clemens, De godsdienstigheid, I, 43.

34 Dat geldt wellicht ook voor Musius, Maagde-pligt, uitgegeven bij de jansenistische uitgever Hendrik van Rhijn te Delft. Het ontbreken van een bisdomkeur zou er in dit geval op kunnen wijzen dat dit boek voor de Noordnederlandse markt bestemd was. Vgl. Clemens, De godsdienstigheid, I, 27.

35 GAA, Notarieel Archief, inv.nr. 5619, nr. 14, notaris J. Commelin, 19 oktober 1697.

$36 \mathrm{Vgl}$. Clemens, 'Kerkboeken en kerkgeschiedenis'.

$37 B C N I_{14102}$ ([1682]); 14973 (I690); 16473 (1707); 17567 (1718). Janssens, 'Geestelijke dochters', 316 (noot 13), spreekt over zes drukken binnen vijftig jaar. Vgl. De Vroede, 'Kwezels' en 'zusters', 30 (noot I00). 
retorische kracht van zijn betoog doen vermoeden dat vooral priesters hierin stof voor hun sermoenen gevonden hebben. Dit verklaart misschien mede het succes van dit werk.

Het daeghelijcks nieuzve-jaer spieghelken van Philagie (1673) van de jezuïet Adriaan Poirters beleefde vier herdrukken. ${ }^{38}$ Volgens de approbatie in de druk van 1680 zou dit werk zeer 'profijtigh voor alle Godtvruchtighe zielen om daghelijcks den dagh Christelijck en ter saligheyt over te brengen' zijn. Poirters' boekje lijkt niet uitsluitend voor vrouwen, c.q. maagden bedoeld. Toch omschrijft en verheerlijkt hij de maagdelijkheid als staat. $\mathrm{Al}$ is het discutabel of het als kloppenboek aangemerkt kan worden, de strekking van het boek lijkt deze classificatie te rechtvaardigen. De illustraties zullen zeker bijgedragen hebben tot zijn populariteit. En anders dan het boekje van Hazart, wiens betoog voor een belangrijk deel bestaat uit excerpten uit geschriften van vroeg-christelijke auteurs, was het werk van Poirters, die wel de roomse Cats is genoemd, veel toegankelijker dankzij de rijmvorm en gemakkelijker verteerbaar door een behoorlijke dosis humor. ${ }^{39}$

Niet alleen kloppenboeken met een polemische of moreel-didactische strekking mochten zich in een ruime belangstelling verheugen. Ook onvervalste regelboeken als Regel der volmaecktheyt voor alle christene maeghden (I696) of Onderwysingen of maniere van leven voor de geestelycke dochters van het Oratorie (1709) werden opnieuw gedrukt. ${ }^{40}$ Onder de vitae moeten eveneens enkele 'bestsellers' geweest zijn. Het levensverhaal van de zestiende-eeuwse Spaanse geestelijke maagd Sancia Carillo vond bijvoorbeeld weerklank, getuige een herdruk. ${ }^{41}$ En Leven der H.H. Maeghden en Het leven van de heylighe Maghet ende Moeder Godts Maria van Rosweydus beleefden eveneens herdrukken.$^{42}$ Beide werken werden vergezeld van Een cort tractaet vanden Maeghdenlycken Staet, een apologie van de maagdelijke staat in de wereld.

38 $B C N I 13937$ (1680); in 1674 was reeds een vermeerderde herdruk verschenen onder de titel Den Spieghel van Philagie (BCNI 13247), die wederom werd uitgegeven in 1682 (BCNI 14145) en z.j. (BCNI 18635). Zie hiervoor ook Rombauts, Leven en werken, 275-278.

39 Voor een appreciatie van Poirters' betekenis als katholieke dichter, zie Rombauts, Leven en werken en Van Duinkerken, Dichters, 82-83.

40 BCNI 156II (1697); 16795 (1709). Zie voor de herdrukkken van Onderwysingen (...) voor de geestelycke dochters van het Oratorie bijlage II, nr. 23. Een ander regelboek, Instructie, kwam oorspronkelijk in 1703 uit (BCNI 16190), werd herdrukt in 1706 (BCNI 16433) en (vermoedelijk) in 1714, de laatste maal met aanvullingen ( $B C N I$ I7168), waaronder een verkorte versie van het gedicht 'Kort Begryp van't Geestelyck Leven voor alle Geestelycke Dochters', dat ook deel uitmaakt van Ondenuysingen.

4I $B C N I 8270$ (1630), BCNI 9258 (1639).

42 Leven der H.H. Maeghden, BCNI 7729 (1626), 7730 ([1626]); 9701 (1643); I5516 (I696). Het leven vande heylighe Maghet, BCNI 682I (1620), 8149 (1629). 


\section{Auteurs}

Van de 34 kloppenboeken zijn er tien anoniem gepubliceerd. In twee gevallen bleek een jezuïet de auteur. ${ }^{43}$ Achter een ander werk, Onderwijsingen of maniere van leven voor de geestelycke dochters van het Oratorie, gaat vermoedelijk een oratoriaan schuil. ${ }^{44}$ Het leven van Maria Anna du Val de Dampierre (1697), dat uit het Frans vertaald werd, werd door een Franse wereldheer geschreven, Guillaume Leroy. ${ }^{45}$ Godtvruchtige Maniere van leven (...) besonderlijk voor de Geestelijke Dochters, onder de bestieringe van de Eerw. Paters van d'Ordre der Alderh. Maget Maria des Berghs Carmeli (1717) zal door een carmeliet geschreven zijn. Rekenen we de twee anonieme werken die toegeschreven kunnen worden aan een jezuïet mee, dan rijst het aandeel der jezuïeten in de kloppenboek-produktie tot elf. Hiermee waren zij in de meerderheid, zeker wanneer we bedenken dat er nog twee kloppenboeken door jezuïeten in het Nederlands werden vertaald. Uit kringen der seculiere priesters kwamen negen stichtelijke werken voor geestelijke maagden voort, waarvan er één, zoals gezegd, door een oratoriaan werd geschreven. Drie werken werden geschreven door paters carmelieten, twee door dominicanen, en één respectievelijk door een kapucijn en een augustijn. Onder de kloppenboek-schrijvers bevond zich mogelijk een leek, namelijk de Spaanse auteur Ludovicus Munnos. Hij schreef de vita van Luisa de Carvajal y Mendoza, die in I649 vertaald werd door Franciscus de Smidr S.J. Van de overige zes boeken is onduidelijk wie de auteur is, dan wel of het om een seculier of regulier gaat ${ }^{46}$ Opmerkelijk afwezig onder de auteurs zijn de minderbroeders. Wellicht oordeelden zij dat geestelijke maagden voldoende werden geïnformeerd over het geestelijk leven in de wereld door boekjes waarin de leefregel van de franciscaanse derde orde voor leken uiteen werd gezet. ${ }^{47}$

Van enkele auteurs is bekend dat zij vanuit hun pastorale praktijk bekend waren met geestelijke maagden, hetzij in de Noordelijke, hetzij in de Zuidelijke Nederlanden..$^{8}$ Dat geldt voor Valentinus Bisschop S.J., die in Rotterdam een groep geestelijke maagden onder zijn hoede had. Daniël Huysmans S.J. kwam in Roermond in contact met geestelijke dochters, onder wie Joanna van Randenraedt, aan wie hij een levensbeschrijving wijdde. De kapucijn Albertus van den Bosch schreef zijn boek onder andere voor een gemeenschap van geestelijke maagden, die in het Limburgse Horst een teruggetrokken leven leidde volgens de derde orde-regel van St. Franciscus. Joannes Fredericus Lumnius was jarenlang pastoor op het Antwerpse begijnhof. Zijn boek stelt de maagdelijke staat in de wereld centraal en

43 Kort Begryp; Leven ende deughden.

44 Janssens, 'Geestelijke dochters', 327.

45 Zie bijlage II, nr. 18.

46 Dat geldt ook voor F.V.O.C.S., Leven van Anna de Torres. Volgens De Vroede, 'Kwezels' en 'zusters', 35 (noot 135), betreft het F. van de Weyden O.C.S.

47 Voor enkele titels zie Van Adrichem, 'Een lijst'.

48 Bijlage III bevat korte biografische schetsen van de auteurs. 
is behalve voor begijnen bedoeld voor 'alle andere gheestelijcke ende weerlijcke [wereldlijke] maechden Christi'. Op grond daarvan is zijn werk zeker te classificeren als een kloppenboek. ${ }^{49}$ Wellicht was zijn auteurschap mede beïnvloed door dagelijkse voorvallen op het Antwerpse begijnhof. De wereldheer Willibrord Kemp zwaaide de scepter over de kloppenvergadering in de Utrechtse Mariahoek. Fulgentius Stevins, de augustijn die jarenlang de Amsterdamse statie De Posthoorn bediende, had bij het opstellen van zijn regels en voorschriften voor geestelijke maagden mogelijk de groep kloppen voor ogen, die aan de augustijnen-statie De Star was verbonden.

In welke mate de dagelijkse omgang met geestelijke maagden van invloed was op de regelgeving die sommige auteurs te boek stelden, is moeilijk vast te stellen. Het schrijven van een kloppenboek, of het nu een onderrichtingsboek of een vita was, gold wellicht als een vorm van pastorale arbeid. Vóór alles gingen de auteurs van kloppenboeken te rade bij autoriteiten van een geheel ander kaliber: kerkvaders en kerkleraren, vooral uit de vroeg-christelijke periode, die hun pennen reeds beproefd hadden op de merites en de regels van de maagdelijke staat. Uit hun werken konden de zeventiende-eeuwse geestelijken overvloedig putten.

\section{III.2 Lectuur van geestelijke maagden}

Clericale denkbeelden over de leefwijze van geestelijke maagden bereikten hun publiek niet enkel via kloppenboeken, maar ook via preken, persoonlijke gesprekken en via de biecht. Vanuit die wetenschap is de vraag of geestelijke maagden de vooral voor hen bedoelde kloppenboeken werkelijk lazen, minder prangend. Niettemin verdient de lectuur van geestelijke maagden binnen dit hoofdstuk enige aandacht. Want ook al zijn de indicaties voor leesgedrag en lectuur van geestelijke maagden schaars, de vingerwijzingen in de kloppenboeken zetten ons op het spoor van clericale opvattingen over de functie van het lezen in relatie tot lekenvroomheid. Naar de samenhang tussen lezen en geloofsbeleving van vrouwen is in Nederland nog geen onderzoek gedaan. Buitenlandse studies wijzen evenwel uit dat lezen als religieuze oefening grote betekenis had voor vrouwen, zowel in katholieke als in protestantse milieus. ${ }^{50}$

49 Lumnius, Van dleven, 5 , vgl. 3 en 7

50 Moore, 'Erbauungsliteratur'; Becher, 'Religiöse Erfahrung'. Chartier, 'Texts', wijst op processen van betekenisgeving en toeëigening bij lezen. 


\section{Functue van het lezen}

De auteurs van de kloppenboeken li)ken als vanzelfsprekend aan te nemen dat geestelıke maagden konden lezen. ${ }^{51}$ Vnjwel alles wat zi) te berde brachten over de functie van het lezen en gepaste lectuur, was ontleend aan de voorschriften die vroeg-chrstelyje en middeleeuwse godgeleerden hun eigentjdse maagden hadden voorgehouden. Door de zwakheld van hun geslacht - gedemonstreerd door Eva in het paradiss - waren vrouwen, anders dan mannen, zo dacht men, niet in staat het hoofd te bieden aan de gevolgen van kennisverwerving. ${ }^{52}$ Zoals voor alle godvruchtıge lezers gold ook voor kloppen dat alleen het streven naar deugdzaamheid en niet nieuwsgiengheid de dnjfveer van het lezen behoorde te zijn. Tijd en energie die geestelıke maagden in het lezen en studeren mochten investeren, dienden beperkt te zujn. Eén van de vroege boeken, Regel waer duer als een Spieghel, dat vermoedeli1k in 1583 verschenen 1s, spoort maagden aan op zon- en helligedagen stıchtelı)ke 'boecxkens' te lezen. ${ }^{53}$ Volgens latere auteurs moest een half uurtje per dag voldoen, want te veel lezen was niet goed. ${ }^{54}$ Ook in vitae worden geestelıke maagden afgeschilderd als vrouwen die weinig lazen. Mana Anna du Val de Dampierre zou aan twee of dne regels per dag genoeg gehad hebben. Van zichzelf zou zl) gezegd hebben 'dat ze altı)d seer onwetende was gebleven, omdat ze noyt gewenscht hadden om seer verlicht te sıjn, maar alleenlıck om God seer te beminnen (...)'.ss

Godsvrucht en geleerdheid zijn in de kloppenboek-vertogen elkaar uitsluitende categoneen. Honger naar kennis wordt onnodig geacht voor geestelıke maagden, wier leven in het teken van de dienst aan God stond. Apostolisch vicaris Joannes van Neercassel verklaarde de hoofdpiyn en het verminderd gehoor, waarover de geestely)ke maagd Mane-Anne Voeller zich beklaagde, uit haar hang naar een intellectuele vroomheid. Niet het hoofd, maar het hart moest volgens hem bidden. ${ }^{56}$ Zelfs het tegenbeeld dat de levensbeschrijving van de Spaanse geestelıke dochter Luisa de Carvajal y Mendoza biedt, wordt ingezet om lezeressen en lezers ervan te overtuigen dat intellectuele vorming geen hoofdmotief van lezen hoort te ziln. De tijd die Luisa restte naast gebed en andere (religieuze) plichten, besteedde zij aan lezen en studeren. Vanaf haar viftiende begon ze het Nieuwe Testament en andere boeken in het Latijn te begnjpen. Ze kocht Engelse en Latınnse editıes van

5I Rudimentar leesonderwiys zal, naast godsdienstge vorming, het hoofdbestanddeel van het katholiek lager onderwijs zijn geweest dat op clandestene bıjscholen werd gegeven Het niveau hiervan was door gebrek aan overherdssteun en voortdurende angst voor opheffing vermoedelijk lager dan het niveau van het protestantse lager onderwiss, aldus De Booy, 'Volksonderwiss', 267

$52 \mathrm{Vgl} \mathrm{Warner,} \mathrm{De} \mathrm{enige} \mathrm{onder} \mathrm{de} \mathrm{vrouzven,} 224$

53 't'Inhout' (ongepagineerd), kapittel XV

54 Alleen in Regel der volmaecktheyt, 28, wordt tweemaal daags een half uur lezen voorgeschreven

55 Leven Mana Anna du Val de Dampierre, 28

56 Jacques, 'Les Voeller', 178 
Augustinus en Thomas van Aquino, die beiden op schrift 'ketters' hadden bestreden. ${ }^{57}$ Volgens de opdracht in de Nederlandse uitgave van haar vita was haar leven echter eerder 'wonderbaer als naervolghelijck'. ${ }^{58}$ Luisa was weliswaar een schone spiegel voor alle devote juffrouwen, maar moest beslist niet in alles nagevolgd worden.

Lezen betekende leren hoe men de vijand, de duivel en zijn verleidingen, moest weerstaan. Een stichtelijk boek, zo schrijft de jezuiet Valentinus Bisschop, is als een predikant die een zondaar de ellendige staat van zijn ziel doet inzien. ${ }^{59}$ Lezen vormde een compensatie voor 'hooghe studien', waarop een geestelijke maagd zich wegens haar geslacht niet mocht toeleggen. Uit een geestelijk boek leerde zij de maagdelijke staat naar behoren te onderhouden. Al stak een maagd veel op uit de preken, zij mocht het lezen niet opgeven omdat dit de 'krancke memorie' hielp. Bovendien kon een boek de melancholie verdrijven waaraan een klop gezien haar eenzame en teruggetrokken leefwijze best ten prooi kon vallen. Lezen fourneerde voedsel voor haar geest en kon meer vuur en vlam in haar devotie brengen. ${ }^{60}$

Lezen was voor alles een oefening in vroomheid. ${ }^{61}$ Het streven naar vervolmaking en vermeerdering van de eigen deugden diende daarbij voorop te staan. Neercassel beval Adriana Hoynck, één van de maagden met wie hij correspondeerde, het lezen van harte aan. ${ }^{62}$ In eenzaamheid en afzondering konden geestelijke maagden namelijk God zoeken en vinden. ${ }^{63}$ Via het lezen kon een maagd dus ook met haar hemelse Bruidegom communiceren. Lezen was daarenboven een remedie tegen ledigheid, des duivels oorkussen. Wanneer een geestelijke maagd niet bad of werkte, behoorde zij te lezen, aldus de wereldheer Joannes Lindeborn. ${ }^{64}$ Langzaam lezen werd aanbevolen, stukje bij beetje, opdat het gelezene goed doordrong en zou beklijven. Wanneer iemand getroffen werd door 'eenige spreuken, of exempels, of eenige andere lessen, dan is't noodig daer wat op te houden, en ' $t$ selve wel te doorgronden, en opreghtelyck tragten te verstaen, om 't voedsel van de ziel zo veel meer [te] konnen ontfangen'. ${ }^{65}$ Niet alle stichtelijke auteurs waren zo gepor-

57 Munnos, Leven Aloysta de Caravasal, 30, 181-182.

58 Ibidem, opdracht (ongepagineerd). De waarschuwing dat vitae 'ad admirandurn sed non ad imitandum' waren, vormt een vast bestanddeel van het genre van de heligenlevens. Majakowsku, 'Lectro divina', 504; Kueckhefer, Unquiet souls, 12-13.

59 Bisschop, Lof der Suyverheydt, III, 231-242.

$60 \mathrm{Vgl} \mathrm{Becher,} \mathrm{'Religiose} \mathrm{Erfahrung',} \mathrm{318-321.}$

61 Vgl Majkowsk, 'Lecto divina', 503-504 Franciscus van Sales beschouwt het lezen als een geestelı1ke oefenıng gencht op perfecue, evenals Vuncentuus a Paulo die zıjn Fulles de la Chanté daarbı), net als verscheidene kloppenboek-auteurs, voorhoudt dat 'La cunosité est la peste de la vie spintuelle'. 62 RAU, $A O B C$, inv nr. 612, Neerccassel aan Adnana Hoynck, 6 januan 1685.

$63 \mathrm{Vgl}$. Leven Mana Anna du Val de Dampretre, 254-26I

64 Lundebom, De Leeder Jacobs, 218. Hij citeert Bernardus van Clairvaux, die zich aldus tegenover mannelijke religieuzen had geuit.

65 Stevins, Regel, 15. 
teerd voor het lezen door geestelıke maagden. Cornelius Hazart oordeelt in zijn Lof van den maegdelycken staet naemelyck in de werelt dat het beter was te bidden dan te lezen. Een combinatie van bidden en lezen was het meest effectief, wilde men altı)d bıj God zı)n, 'want als wy bıdden, wy spreken met Godt; als wy lesen, Godt spreeckt met ons'. ${ }^{66}$

Gaan we af op haar handgeschreven dagindeling, dan las de Roermondse geesteliyke dochter Joanna van Randenraedt niet busster veel. ${ }^{67}$ Het merendeel van haar tud was gewijd aan gebed en devote oefeningen. Na de middag of 's avonds besteedde ze maximaal een kwartiertje aan lezen. Haar leesgewoonten strookten met de aanwı)zingen in de stıchtelıke handleidingen. Maar er waren ook maagden die in tegenstelling tot die nchtlijnen vol overgave veel stıchtelıjke lectuur verslonden. Enkele maagden van de Haarlemse vergaderng De Hoek waren echte boekenwurmen. Giertgen Frenks ( $\mathrm{I} 6 \mathrm{I} 4 \mathrm{4})$ zat praktisch altud te lezen als men haar opzocht. En Mantgen Isbrants ( $t$ 1649) las dermate veel in geestelyke boeken, dat haar hart vervuld was met hellige lessen. ${ }^{68}$ De levensbenchten van de Haarlemse maagden, geboekstaafd door Trijn Jans Oly, vormen in zekere zin een tegenhanger van de voorschnften in menig kloppenboek, zeker wanneer we bedenken dat Oly deze collectie necrologieen aanlegde met de bedoeling de maagden van De Hoek van navolgenswaardige exempla te voorzien. Veel lezen gold onder sommige kloppen kennelı)k als minder laakbaar dan de kloppenboeken doen vermoeden

\section{Aanbevolen lectuur}

Sommıge kloppenboek-auteurs schrijven gedetalleerd voor wat geestelıke maagden mochten lezen. Bisschop, de jezuiet, rechtvaardıgt zıjn lange lıst van aanbevolen werken onder het motto dat niet alle hout timmerhout 1 s. $^{69} \mathrm{H}_{\mathbf{y}}$ beveelt opmerkelık genoeg slechts eén kloppenboek aan, te weten Rosweydus' Leven der H.H. Maeghden (1626). Bisschops lyst wordt gedomineerd door algemene devoteboeken en handleidıngen tot een christelijk leven' van Franciscus van Sales' Aenleydinghe tot een devoot leven tot ascetische werken van de jezureten Luis de la Puente, Lodewi)k Makeblıde en Robert Bellarminus. Ook de Belydenıssen van Augustınus figureren op de lijst, evenals de sermoenen op het Hooglied van Bernardus van

66 Hazart, Lof, III

67 GAR, Handschnften II B k Onder haar nagelaten geschnften is nog een tweede dagorde, GAR, Handschnften IV, 3 (geen autograaf) Hienn wordt aanbevolen dne maal daags een boek te lezen 's ochtends wanneer men het handwerk onderbreekt, na de middag, eveneens tıjens de onderbreking van het handwerk, mag men een kwartier lezen in 'eenighe gheestlycke histone ( ) met begeerte van haer na te volgen' Tenslotte dient men 's avonds voor het slapen gaan nog een kapittel uit Thomas a Kempis te lezen, waarmee de Navolging van Chnstus is bedoeld

68 Graaf, 'De "vergadennghe"', $B B H 35$ (1913) 410

69 Bisschop, Lof der Suyverheydr, III, 242-244 
Clairvaux. De vitae van Ignatius van Loyola en Teresa van Avila, maar ook die van de middeleeuwse heiligen Catharina van Siena en Lidwina van Schiedam, worden eveneens geschikt geacht. Speciaal voor de vrouwelijke religieuzen onder zijn lezeressen voegde Bisschop nog een viertal boeken toe die handelen over de religieuze staat. Het is natuurlijk niet uitgesloten dat geestelijke maagden juist deze werken ter hand namen. ${ }^{70}$

De wereldheer Willem Schoenius stelde eveneens een lijst van aanbevolen lectuur samen. ${ }^{71}$ Anders dan Bisschop beveelt hij Thomas a Kempis' Navolging van Christus aan, waarin de onthechting van het aardse in een streven naar de vereniging met God benadrukt wordt. Geestelijke maagden moesten zich voortdurend bewust zijn dat deze vereniging het eigenlijke oogmerk van hun bestaan behoorde te zijn, waarop zij zich door terugtrekking uit de wereld, geestelijke oefeningen en de beoefening van deugden adequaat konden preparen. Daarom ook wordt dit werk door andere auteurs en leidsmannen ter lezing aanbevolen. ${ }^{72}$ Levensverhalen van heiligen en religieuzen schitteren in Schoenius' opsomming door afwezigheid. Wat de echte kloppenboeken betreft beperkt ook hij zich tot Rosweydus' werk over maagden in de wereld. De augustijn Fulgentius Stevins schotelt zijn lezerspubliek overwegend werken van en over Augustinus voor. ${ }^{33}$ Daarnaast deden geestelijke maagden er volgens hem goed aan iedere dinsdag enige kapittels uit Thomas a Kempis' Navolging te lezen. Neercassel stond de Brusselse geestelijke maagd Marie-Anne Voeller, voor wie hij meestal per brief als geestelijk leidsman fungeerde, toe haar lezing van Augustinus' De civitate Dei voort te zetten. ${ }^{74}$ Opmerkelijke lectuur voor deze geestelijke maagd, die weliswaar het Latijn machtig was, maar wier sterk op het intellect gerichte vroomheid Neercassel juist wilde temperen.

Anders dan de protestantse kerkgemeenschappen hechtte de katholieke kerk er niet sterk aan dat gelovigen zelfstandig de bijbel lazen. De bemiddeling van Gods woord diende toch vooral door een priester te geschieden. Vermoedelijk maakt de bijbel daarom niet altijd deel uit van de aan kloppen aanbevolen literatuur. Ten aanzien van bijbellezing openbaart zich echter een verschil tussen seculiere en reguliere leidsmannen. Want vooral wereldheren die een meer doorleefde geloofskennis onder gelovigen wilden bewerkstelligen, spoorden in stichtelijke

70 Als één van de werken voor slotzusters noemt Bisschop bijvoorbeeld Rodriguez' Oeffeninghe der volmaecktheyt ende christelijcker deughden (Antwerpen: Cnobbaert 1626-28). Dit werd in 1683 in een oplage van 1500 uitgegeven door de Haarlemse drukker Nicolaas Braau, in samenwerking met de Amsterdamse uitgevers Joachim van Metelen en Johannes Stichter. Met zijn fonds richtte Braau zich onder meer op kopers onder de maagden van de Haarlemse Hoek. Dorren en Verhoeven, 'De twee gezichten', 249, 255-256.

71 Schoenius, Weg, 302-303.

72 Lindeborn, De Leeder facobs, 221. RAU, $A O B C$, inv.nr. 612, Neercassel aan Maria Anna van Wevelinckhoven, 20 april 1684; aan Adriana Hoynck, 6 januari 1685.

73 Stevins, Regel, 13-14.

74 RAU, $A O B C$, inv.nr. 605, 25 februari I678. Jacques, 'Les Voeller', 181-182. 
werken en correspondentie geestelijke maagden aan tot lezing van het Nieuwe Testament. Lindeborn beveelt bijvoorbeeld het Nieuwe Testament aan in zijn Leeder facobs. ${ }^{75}$ Volgens Neercassel, die het lezen van de Heilige Schrift in de volkstaal bepleitte in zijn Tractatus de Lectione scripturarum (1677), ${ }^{76}$ konden geestelijke maagden uit het evangelie leren wat hun christelijke en maagdelijke plichten waren. ${ }^{77}$ Adriana Hoynck stelt hij de heilige Cecilia ten voorbeeld, 'de welcke het Evangelij of het nieuwe testament altooz bij haer droech'. Hoynck moest dagelijks twee hoofdstukken uit het Nieuwe Testament lezen, 'met eerbiedicheijd (...) eerende ook die woorden dewelke U.L. niet wel zal verstaen' ${ }^{78}$

Regulieren blijken een ander standpunt te huldigen, hoewel de beschikbare bronnen op dit punt gebrekkig zijn en mogelijk een vertekend beeld geven. In de stichtelijke levensbeschrijvingen van (middeleeuwse) religieuze vrouwen of vroegmoderne geestelijke maagden, die door jezuïeten werden uitgegeven, zijn geen expliciete verwijzingen naar het Nieuwe Testament te vinden. Op Bisschops lijst ontbreekt de bijbel. Rosweydus geeft in zijn Cort tractaet vanden Maeghdelijken Staet enkele voorbeelden van vroeg-christelijke maagden die het evangelie lazen, zoals Cecilia en Theophila. Instemmend herinnert hij eraan dat de kerkvader Hieronymus ook vermaande tot het lezen van de bijbel. Met zijn keuze van voorbeeld-heiligen lijkt Rosweydus het lezen van het Nieuwe Testament aan te bevelen, maar toch moedigt hij hiertoe niet expliciet aan.

Opvallende afwezigen in de lijsten van aanbevolen werken zijn de kloppenboeken, onderrichtingsboeken én vitae. Hiervoor zijn enkele verklaringen mogelijk. Ten eerste vormden kloppenboeken, zoals gezegd, een minderheid van het totale aanbod van devotielectuur in de zeventiende en het begin van de achttiende eeuw. Ten tweede zijn de lijsten van aanbevolen werken opgenomen in kloppenboeken. Met andere woorden, degene die de lijst doornam, had reeds een kloppenboek ter hand. Een auteur van een kloppenboek zal ervan overtuigd zijn geweest dat geestelijke maagden geen ander werk uit dat genre nodig hadden dan het zijne.

\section{Wat geestelijke maagden lazen}

Kloppenboeken ontbreken opmerkelijk genoeg eveneens in de schaarse bronnen die ons uitsluitsel geven over wat geestelijke maagden daadwerkelijk lazen. De maagden van de Haarlemse Hoek lazen vooral devotieboeken of dagheiligingsboeken. ${ }^{79}$ Bedacht moet worden dat de levensberichten van de Haarlemse maagden

75 Lundeborn, De Leeder facobs, 221.

76 Spiert, 'Jansenısme', 155.

77 Vgl. Gueudre, 'La femme', 57.

78 RAU, $A O B C$, inv.nr. 612, Neercassel aan Adriana Hoynck, 6 januan I685; vgl. idem aan MarieAnne Voeller, I8 augustus I679; aan Mana Anna van Wevelinckhoven, 20 apnl 1684.

79 Zie voor het navolgende Graaf, 'De "vergadennghe"', BBH 35 (1913) 391-393, 405-410; Theissing, Over klopjes, 221-222. 
in het jaar 1651 eindigen en dat het aanbod van kloppenboeken vóór 1650 betrekkelijk gering was. Wellicht groeide met het aanbod ook de populariteit van dit genre onder de maagden van De Hoek in de tweede helft van de zeventiende eeuw. Jannetje Dirks ( $\dagger_{1636}$ ) verslond werken over het lijden van Christus, zoals Bondelken van mirre, en Berch van myrren van de minderbroeder Frans Vervoort ( $\dagger$ 1555), in wiens oeuvre de traditie van de middeleeuwse mystieke en passie-literatuur voortleefde. ${ }^{80}$ Trijn Dircx Wij ( I $62 \mathrm{I}$ ), die lange tijd geestelijke moeder van de vergadering was, las naast legenden en exempelen van heiligen ook de $\mathrm{Na}$ volging van Chrstus en Vervoorts Beghijnken van Mechelen. Ook Trijntje Ariaens ( I 626) las behalve haar getijdenboek eveneens de Navolging. En Grietje Jans Quispel ( $\mathrm{r}_{638}$ ) putte haar geestelijke oefeningen uit werk van de middeleeuwse mystica Geertruid van Helfta $\left(\dagger_{1301 / 2)} .^{81}\right.$ Voor haar dagindeling en een juiste verhouding tussen gebed en werk liet zij zich inspireren door werk van de jezuïet Lodewijk Makeblijde. ${ }^{{ }_{2}}$ Ook de bijbel werd ijverig bestudeerd, evenals de preken van de geestelijke leidsmannen van de vergadering, die werden afgeschreven door geestelijke dochters. ${ }^{83}$

Voor de lectuur van geestelijke dochters buiten de Haarlemse Hoek zijn we aangewezen op bronnen over boekenbezit. Op zichzelf zegt bezit natuurlijk weinig over lezen, maar het geeft een indicatie. Twee boekenlijsten van geestelijke dochters buiten de Republiek die onder leiding van paters jezuïeten stonden, bevestigen ten dele de geringe populariteit van kloppenboeken onder hun primaire doelgroep. De Antwerpse kwezel Josinne Goetbloets ( $\dagger$ 1665) bezat verschillende kloppenboeken: Bisschops driedelige werk Lof der Suyverheydt, het onderrichtingsboek voor jezuïeten-kloppen bij uitstek, Rosweydus' Leven der H.H. Maegden en de stichtelijke levensbeschrijvingen van Luisa de Carvajal y Mendoza en Sancia Carillo. ${ }^{84}$

De boekenlijst van de Roermondse geestelijke maagd Joanna van Randenraedt bevat daarentegen geen enkel kloppenboek. ${ }^{85}$ Daarom is wel getwijfeld of zij inder-

80 De Troeyer, 'Frans Vervoort'.

81 Graaf, 'De “vergadennghe”', $B B H 35$ (1913) 393-394, 405, spreekt over Geertruid van 'Elısben'. Vermoedelı)k wordt bedoeld Het leven vande $H$ Maghet Geenruyt, abdisse tot Eusleben. Theissing, Over klopjes, 221, vermeldt het als Het boeck van S. Geertneydt

82 Vermoedelı,k het dagheiligingsboek Den lusthof der gheestelicke oeffeninghen, dat tussen 1607 en 1635 acht herdrukken beleefde en bijvoorbeeld door Bisschop, Lof der Suyverheydt, III, 243, kloppen ter lezing werd aanbevolen

83 Graaf, 'De "vergadennghe"', $B B H 35$ (1913) 407-410.

84 Baetens, 'De biblıotheek', 222 (nr. 13), 22I (nr. 3); 223 (nr. 28); 224 (nr. 46).

85 Op grond van E.J, Inventarzs, (nr. VII, I) neem ik aan dat het ongineel van deze lijst in I 937 , toen de inventans werd opgernaakt, berustte in het partıculier archief van J. Geradts. De stukken uit dit archief zijn tot op heden niet gevonden Verschueren, 'De boeken', 194-205, heeft deze lijst gepubliceerd. 


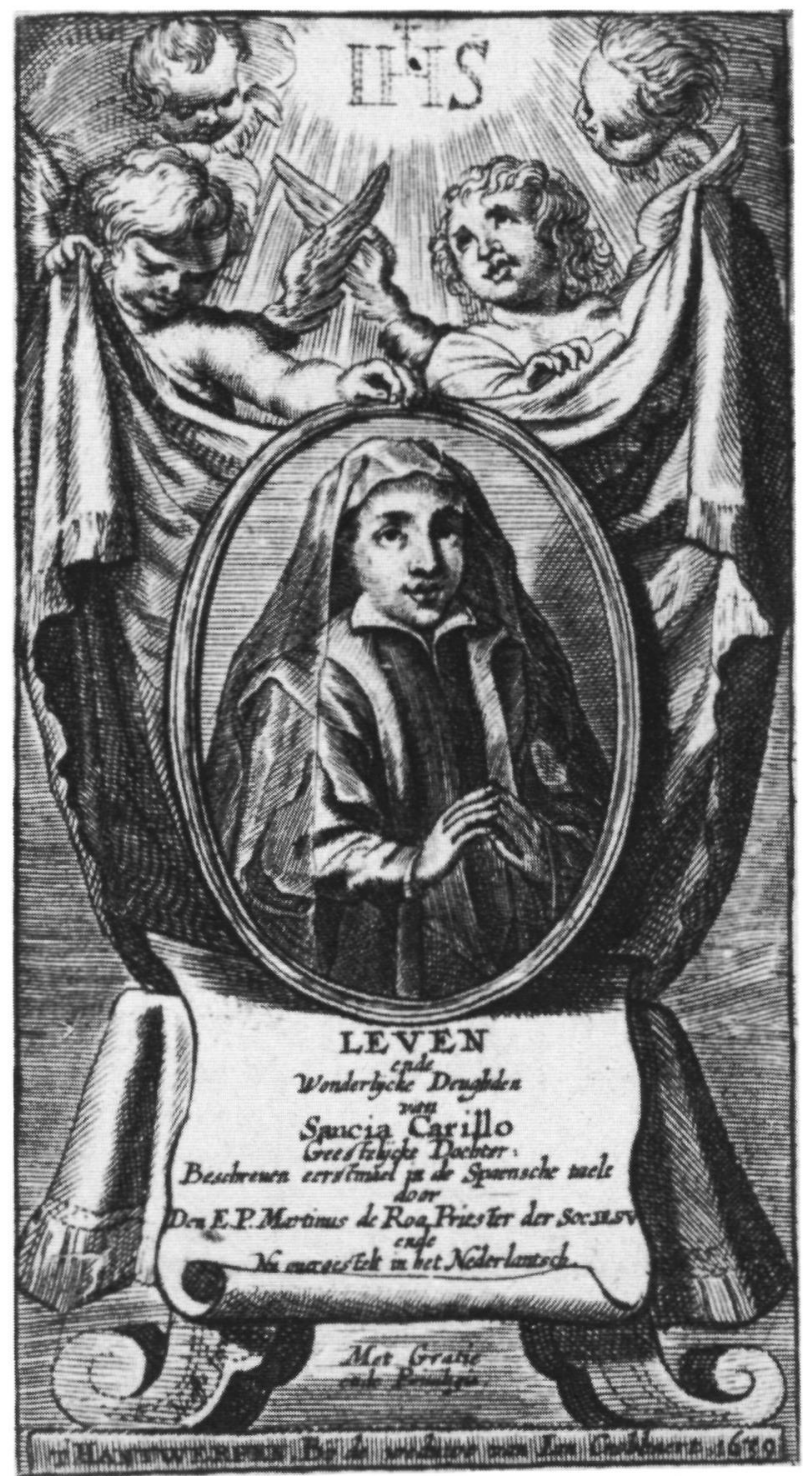

Afb. 6 De Spaanse geestelijke maagd Sancia Carillo, zoals afgebeeld op het titelblad van de $\mathrm{Ne}$ derlandse vertaling van haar vita.

daad de eigenares was van de op de lijst genoemde werken. ${ }^{86}$ Vermoedelijk had Joanna verschillende boeken geërfd van haar vader, alsook van haar oom, kanunnik

86 Verschueren, 'De boeken', 206, 208, acht het aannemelijk dat een deel van de boeken oorspronkelijk van Joanna's vader waren. Joanna heeft het in een brief aan de geestelijke dochter Catharina van den Broeck, inderdaad over boeken van 'monpeer saligers' (GAR, Handschriften, II B c (vermoedelijk 2 augustus 1652). Naar alle waarschijnlijkheid maakte Willem Hendrik van Randenraedt op verzoek van zijn zuster een lijst van het boekenbezit van hun vader, waarmee Joanna een niet nader genoemde Nijmeegse boekverkoper voor koop wilde interesseren. 
en officiaal Willem van Randenraedt ( $\dagger$ I636). Toch zijn er in haar geschriften bewijsplaatsen te vinden voor het gebruik van boeken op de lijst. Zo zocht zij ooit vertroosting in 'Herpius'; ${ }^{87}$ de boekenlijst vermeldt inderdaad Den spiegel der volmaekcheyt $(\ldots)$ van de laat-middeleeuwse mysticus Hendrik Herp $\left(†\right.$ I477) ${ }^{88}$ In een gewetensrekening uit 1649 beschrijft Van Randenraedt dat zij las in het 'geestelijcken bouck welcken was handelende van de $h$. communi' ${ }^{89}$ Deze gewetensrekening staat in het teken van haar verlangen naar dagelijkse communie. Daarom lijkt het aannemelijk dat zij Eligius Ganda's Den eeniegen toevlucht der aerbeijdende ende belaedenen christenen siellen, tot de H. Schrfiuere, ende Oeude Vaders (...) raadpleegde, dat handelt over de frequente communie. ${ }^{90}$ Ook in de Evangelische Peerle, die op de lijst prijkt, ${ }^{91}$ verdiepte Van Randenraedt zich, zo blijkt uit haar spirituele autobiografie. ${ }^{92}$

Haar handschriften verwijzen nog naar andere, niet op de lijst vermelde boeken. ${ }^{93}$ De abdis van de clarissen uit Mechelen leende Joanna werken van de geestelijk leidsman van het Roermondse begijnhof, Pelgrim Pullen. ${ }^{94}$ In de mysticus Pullen (I550-I608) herleefde aan het einde van de zestiende eeuw de traditie van de laat-middeleeuwse Nederlandse mystiek, waarvan Hadewych en Ruusbroec exponenten waren.95 De boekenlijst van Van Randenraedt verraadt een zekere voorkeur voor mystieke werken, die ook reeds in verband met de maagden van de Haarlemse Hoek is opgemerkt. Naast werk van Herp en de reeds genoemde Evangelische Peerle, ${ }^{96}$ bevat de lijst boeken van Tauler en Ruusbroec. Van Randenraedt bezat tevens een exemplaar van het werk van Geertruid van Helfta. Wellicht had het oorspronkelijk toebehoord aan Agnes van Heilsbach, die noteert dat zij dit boek raadpleegde. ${ }^{97}$ Joanna zelf ontleende er, net als de Haarlemse klop Grietje Jans Quispel, geestelijke oefeningen aan.98

87 KB Brussel, Handschnften 19070, 68vo.

88 Verschueren, 'De boeken', 198 (nr I5).

89 GAR, Handschnften I A 2 (ongepagineerd; 26 julı i649)

90 Verschueren, 'De boeken', 195 (nr. 4); vgl. 196 (nr. 5), dat eveneens over de communie gaat, zij het niet de frequente commune.

91 Ibidem, 199 (nr. 19).

92 KB Brussel, Handschnften, 19073 (II), 800, 805.

93 Een werk kon tor dusver net geidenuficeerd worden, namelık het leven van de H. Agatha de la Croux, vermeld in KB Brussel, Handschnften 19070, 344 .

94 GAR, Handschnfien I A 27, bnef d d. 13 november 1659 Niet geadresseerd; vermoedelijk aan Cathanna van den Broeck gencht Vgl. Verschueren, 'De boeken', 205 Voor Pullen en zijn werk zie Reypens, 'Pelgrum Pullen'. De geschriften van Pullen crrculeerden in handschnft en waren vooral verspreid in 's-Hertogenbosch, waar ook de door Joanna geleende exemplaren oorspronkelı)k vandaan kwamen

95 Willaer, Kors en Vekeman, 'De betekenis', 28.

96 Voor het belang van dit werk in de Europese spintualiteitsontwikkeling, zie ibidem, 26-27 en Begheyn, 'De verspreiding', idem, 'Due Evangelusche Peerle'.

97 KB Brussel, Handschrnften 18984, 206 vo.

$98 \mathrm{~KB}$ Brussel, Handschnften 19070, 13. 
Van Randenraedt las ook boeken met een sterk ascetische inslag. Het gulden wieroock-vat van de apostolisch vicaris Philippus Rovenius had ze reeds op jonge leeftijd gelezen. ${ }^{99}$ Dit asceseboek-kerkboek bevat tractaten over het geestelijk leven, preken voor kloosterzusters, allerlei gebeden en wenken voor de dagelijkse meditatie. Of het in grote kring gebruikt werd, wordt wel betwijfeld. ${ }^{100}$ Uit het leven van de Spaanse jezuïet Balthasar Alvarez, dat niet op haar boekenlijst voorkomt, leerde zij oefeningen in zelfverloochening die zij fundamenteel achtte voor haar spirituele ontwikkeling. ${ }^{\text {Ior }}$ Mogelijk putte zij hier ook inspiratie uit voor het geestelijk leiderschap dat zij uitoefende over andere jezuïeten-kloppen in Roermond. ${ }^{102}$ Pater Alvarez had namelijk zijn sporen verdiend als novicenmeester, als overste en als geestelijk leidsman van (religieuze) vrouwen. Door hetgeen zij in het leven van Teresa van Avila las over het lijden van Christus, werd zij bijzonder gesticht. ${ }^{\text {103 }}$ En zij nam ook wel degelijk kloppenboeken door, zoals bijvoorbeeld het leven van de Spaanse geestelijke dochter Sancia Carillo. ${ }^{104}$ Misschien heeft zij ook delen van Rosweydus' Leven der H.H. Maeghden onder ogen gehad. In I683 schrijft zij namelijk dat zij onder andere het leven gelezen heeft van 'St. Christina, die vijf daegen in eenen gloijenden oven had geseetten'. ${ }^{\text {ros }}$ De beproevingen die deze vroeg-christelijke martelares om den gelove moest doorstaan, worden door Rosweydus beschreven, die noteert dat zij 'brandende en blakende vijf daeghen ende vijf nachten achter een sonder eenigh letsel oft hinder' in een oven was opgesloten. ${ }^{106}$

Wellicht had Joanna dit boek geleend van Theodora Portmans ( $\dagger_{1}$ 662), een geestelijke maagd met wie zij regelmatig verkeerde. Portmans was, net als Van Randenraedt, geestelijke dochter onder leiding van de jezuïeten. Tot het overlijden van haar biechtvader Melchior Hulshoudt S.J. in 1652 woonde zij in diens standplaats Nijmegen. Daarna verbleef zij met tussenpozen ook in Antwerpen en Roer-

$99 \mathrm{~KB}$ Brussel, Handschnfien 19073 (I), 32; Kor Begryp, 14.

100 Clemens, De gadsdrenstigherd, I, 7I. Zie verder voor dit werk Visser, Rovenius, 29-34.

I01 GAR, Handschnften II B 1, III; KB Brussel, Handschnften I9073 (I), 148. De titel van dit boek komt net voor op de boekenlijst, maar mogelijk gaat het schul achter een werk dat enkel met de naam van de auteur wordt aangeduid, 'Pater de Poinette'. Verschueren, 'De boeken', 202 (nr. 36), vermoedt dat hrermee pater De Pinell S.J. bedoeld zou kunnen zyn. Waarschınlı)ker is echter dat het gaat om Luis de la Puente, die Leven Balthazar Alvarez publiceerde.

102 GAR, Handschriften II B ,, 11 I.

103 KB Brussel, Handschnften I9073 (II), 327 (anno 1644); Kort Begryp, 61. Mogelijk wordt Teresa's autobıografie bedoeld, waarvan in 1632 een Nederlandse vertalıng verscheen, verzorgd door Elias van S. Teresa O.Carm., onder de tutel Het leven vande $H$. Moeder Teresa van Iesus Fondatersse der baervoetsche Carmeliten ende Carmeliterssen: Door haer selve, mudts bevel haers Overste in't Spaensche beschreven (...) (Gent: Aertssen 1632). Maar wellicht betreft het de vzta van Teresa van de hand van F. de Ribera S.J., die in 1609 en 1620 in een Nederlandse vertaling verscheen. Zie hiervoor DBS VI, I762 en IX, 743-744.

104 KB Brussel, Handschrften 19070, 159 vo.

105 C.ss R. Roermond, Speciaal Archief A pl. 7, HH 8, gewetensrekenıng 1683.

106 Rosweydus, Leven der H.H. Maeghden, 280-292. 
mond. Blijkens haar testament bezat Portmans een 'maeghdeboeck', waarmee mogelijk Rosweydus' Leven der H.H. Maeghden wordt bedoeld. Daarnaast had zij een exemplaar van het leven van Sancia Carillo. ${ }^{107}$ Een 'maeghdeboeck' stond ook bij de Antwerpse geestelijke dochter Joanna van Moock in de kast, met wie Joanna in juli 1645 door haar toenmalige biechtvader Livinus de Clerck S.J. in contact gebracht werd. ${ }^{108}$ Van Moock stond in haar woonplaats Antwerpen bekend als een godvruchtige, fatsoenlijke geestelijke maagd en zakenvrouw, die samen met haar halfzuster Godefrida Buijs een huis in de Prinsstraat bewoonde. ${ }^{109} \mathrm{Het}$ boekenbezit van Portmans en Van Moock wijst op enige invloed van Bisschops aanbevolen lectuur. Wellicht hadden ze zijn kloppenboek gelezen of werden ze hieruit beleerd door hun leidsmannen of andere geestelijke dochters. Het leven van Teresa van Avila en Ignatius van Loyola, warm aanbevolen door Bisschop, waren in het bezit van Portmans en Van Moock. Portmans had bovendien het door Rosweydus vertaalde Tvadersboeck van de kerkvader Hieronymus in huis, naast Van het gheestelyck leven van Alphonsus Rodriguez, dat volgens Bisschop bij uitstek geschikt was voor vrouwelijke religieuzen.

Het aandeel van kloppenboeken in de vorming van geestelijke maagden moet niet overschat worden. Andere lectuur - kerk-, dagheiligings- en devotieboeken - speelde daarbij zeker ook een rol. Over de merites en status van een religieus bestaan konden kloppen daaruit echter minder opsteken.

\section{III.3 Geen 'echte' religieuzen}

Dankzij hun apologetisch karakter vormen kloppenboeken een uitstekende bron om de opvattingen van de clerus over het geestelijk leven buiten het klooster te onderzoeken. In deze stichtelijke werken ontspinnen zich betogen vol voetangels en klemmen. Zelfs een geestelijke dochter betrok stelling in dit debat met een geschnft getiteld Sommige Conszderatien voor dochters die verkiesen met belofte van suyverh[eid] liever inde werelt de volmaecktheyt ende hoochste godsdiensticheyt te betrachten als onder slot van Clooster. ${ }^{10}$ Of de auteur van het handschrift inderdaad

107 PA SJ, Historsche handschnftenverzameling, doos 3 (té grote stukken) C 24 × 4. Testament Theodora Portmans, d d 6 juni 1658.

$108 \mathrm{~KB}$ Brussel, Handschnften 19070, 230. Voor het boekenbezit van Joanna van Moock, zie PA SJ, Histonsche handschnfienverzameling, doos 3 (té grote stukken) C 24 r 4. Testament d.d 29 aprl I673. 109 Duverger, 'De Antwerpse geestelıke dochter', 167-168 In een verklanng van burgemeesters, schepenen en raadsheden van Antwerpen, opgemaakt op verzoek van notans Comelis Doppegieter op I 8 jul1 1659, waann de eerbaarheıd, de lekenstatus en de handelıngsbekwaamheid van geestelıke maagden in het algemeen betoogd wordt, wordt Van Moock genoemd. Over de achtergrond van dit verzoek is niets bekend

110 Jezuretenbibliotheek Berchmanıanum, Nıjmegen, Collecue Canısıanum, sıgn. 5000 A 20. 37 pagina's, met gedateerd (vermoedelıjk ife eeuw). Met dank aan dr R. van Dijk van het Titus Brandsma-Instituut te Nımegen, die mu in de gelegenheid stelde dit handschrift ook op microfiche 
een geestelijke dochter was, is niet met zekerheid vast te stellen. ${ }^{\text {II }}$ Misschien was een geestelijke de auteur. Dit zou dan getuigen van een wel zeer bijzondere strategie om de doelgroep te bereiken.

Eugenie Theissing heeft de vraag al aan de orde gesteld of er volgens seculieren en regulieren een hiërarchie bestond of behoorde te bestaan tussen vrouwelijke religieuzen en geestelijke maagden. ${ }^{\mathrm{x} 2}$ Haar conclusie luidt dat de opvattingen over deze kwestie uiteen liepen, alhoewel sommige geestelijken en kloppenboek-auteurs wel de stelling huldigden dat het religieuze bestaan van geestelijke maagden buiten het klooster een levensstaat was. Welke invloed een dergelijk standpunt had op de levens van vrouwen en religieuze bestaansvormen in de vroegmoderne tuj, is nog onvoldoende afgetast. Kloppenboeken legitimeerden namelijk een altematieve levensvervulling voor vrouwen, die tot dan toe slechts hadden kunnen kiezen uit huwelijk of klooster. Aldus verdedigden zij een nieuwe, eerbare ıdentiteit voor ongehuwde vrouwen. Of deze nieuwe identiteit een wereldlijk of juist een meer religieus of geestelijk karakter droeg, daarover bestond geen eensgezindheid onder de clerus.

\section{Staat of geen staat}

De kerkelijke gezagsdragers in de Hollandse Zending zetten de toon voor de waardering van geestelijke maagden als geëngageerde leken. $Z i j$ hamerden nauwgezet op het onderscheid tussen kloppen en slotzusters of monialen. Ongetwijfeld lag hieraan de intentie ten grondslag geen aanstoot te geven aan het wettige protestantse gezag. ${ }^{113}$ Door hun voorkomen en gedrag hadden geestelitke maagden toch al een onmiskenbaar religieus imago. Gedurende de zeventiende eeuw schaarden wereldlijke overheden de kloppen daarom gemakshalve onder de geestelijken en religieuzen. Aan enig onderscheld tussen 'geordende' en 'ongeordende' personen, dat discussies over geestelijke maagden in katholieke kring kleurde, lieten zij zich weinig gelegen liggen.

In Reipublicae christianae libri duo (1648) stelt apostolisch vicaris Philippus Rovenius ronduit dat geestelijke maagden geen echte religieuzen zijn: 'Hae proprie Religiosae non sunt'. Zijn uiteenzetting over godgewijde maagden in de wereld vormt een aanvulling op de daaraan voorafgaande beschouwing over de kerkelijke staat van relıgieuzen. Hiermee trekt hij een scherpe grens tussen de maagdelijke

te raadplegen.

III Ibıdem, 2-3. De auteur stelt zıch ten doel 'mijn selven ende andere myns gelyck, die inde werelt blyvende de werelt versmaeden, te bevestigen ende couragieren' Volgens de inventans van de Jezuietenbiblıotheek Berchmanianum is de auteur inderdaad een geestelıjke dochter. De strekking van her handschnft wordt als jansenıstısch omschreven Verschillende passages, waarvan hieronder enkele voorbeelden worden gegeven, wizen erop dat een zeker ngonsme de auteur niet vreemd was

112 Theissing, Over klopjes, 13-27.

113 Spiertz, 'De katholıeke geestelıke letders'. 
staat die kloppen onderhouden en de religieuze staat. Geestelijke maagden leefden niet volgens een specifieke regel en legden evenmin plechtige geloften af. Al verkozen zij de maagdelijke staat en deden zij soms een eenvoudige gelofte van zuiverheid, in kerkrechtelijk en algemeen juridisch opzicht waren en bleven zij leken. ${ }^{114}$ God was gelovigen die zich in maagdelijke zuiverheid aan Hem toewijdden dan wel zeer toegedaan, Zijn kerk verleende alleen bijzondere gunsten aan degenen die intraden in een door de paus erkende orde. Wie intreedt in een door de Heilige Stoel goedgekeurde orde en een plechtige gelofte van maagdelijkheid aflegt, komt volgens Rovenius meer lof toe dan degene die in de wereld een dergelijke gelofte doet. "I5 Toch spreekt uit zijn betoog over de status van geestelijke maagden ook waardering, juist omdat zij als leken een vroom leven in de wereld nastreefden. ${ }^{116}$

Ook Joannes van Neercassel ontkent dat geestelijke maagden een aparte stand binnen de kerk vertegenwoordigen. ${ }^{17}$ Net als Rovenius was Neercassel gewoon de kloppen te vermelden nà de religieuzen, maar vóór de leken. ${ }^{18}$ Door hun vaste voornemen de wereld te verzaken voor hun hemelse Bruidegom, onderscheidden kloppen zich van andere leken, maar daarmee was nog niet gezegd dat zij tot de religieuze personen gerekend mochten worden. Tegenover de gezagsdragers van zijn eigen of andere kerken houdt Neercassel vast aan het verschil tussen religieuzen en geestelijke maagden. Maar in zijn persoonlijke correspondentie maakt hij wél toespelingen op de gelijkenis tussen religieuzen en kloppen. Hij vergelijkt de kleine kloppengroep te Warmond onder leiding van zijn intimus Henricus van der Graft, aartspriester van Rijnland en lid van het vicariaat van Utrecht, met de vroeg-christelijke gemeenschap van Hieronymus en Paula. De Warmondse kloppengroep noemt hij bij die gelegenheid 'convent', haar leden zelfs 'Religieusen'. "'9

Gezien zijn opvatting over de status van kloppen, wekt het verbazing dat Neercassel aan de wieg stond van de Scala facob van zijn vertrouweling Lindeborn. Lindeborn betoogt namelijk onomwonden dat de levenswijze van geestelijke maagden een staat is. Soms schakelt hij hen geliik met kloosterlingen, soms acht hij hen zelfs verheven boven slotzusters. ${ }^{120}$ Een vast voomemen om God in maagdelijke zuiverheid in de wereld te dienen, is voldoende om van een staat te spreken die dezelfde verplichtingen met zich meebrengt als de religieuze staat. ${ }^{121}$ Met deze visie schaart Lindeborn zich niet achter Neercassel. Hij betuigt zich juist schatplichtig aan jezuieten, onder wie Valentinus Bisschop en Herman Busenbaum die,

114 Rovenius, Reipublicae christianae libri dus, 264, 276-277.

115 Ibidem, 26r.

116 Visser, 'De mogelijke invloed', 215.

117 Brom, 'Neerkassel's Bestuur', 210.

Ir8 RAU, $A O B C$, inv.nr. 595, Neercassel aan de Heilige Stoel, 29 november 1662.

119 Ibidem, inv.nr. 604, Neercassel aan Pachomius (Henricus van der Graft), 19 februari 1676, aangehaald door Schulte van Kessel, Geest en vlees, 61, 67.

120 Lindeborn, Scala facab, 8.

121 Ibidem, 7, 17, 34. 
voortbordurend op stellingen van Leonardus Lessius, al eerder hadden betoogd dat de leefwijze van geestelijke maagden een staat was. ${ }^{122}$ Lindeborn oogstte scherpe kritiek van een collega seculier, Cornelis Adamsz van Schoonhoven, onder het pseudoniem Bellacuria. Die stelde een bloemlezing van in zijn ogen gewraakte passages uit de Scala facob samen en stuurde deze aan de Congregatie van de Index te Rome, die er in januari 1667 een veroordeling over uitsprak. Lindeborn probeerde zich nog datzelfde jaar tegen Van Schoonhovens aantijgingen te verdedigen met de Spongia oftewel Uitwisch-spons der Tegenspraken. Bellacuria publiceerde vervolgens zijn Spongia contradictionum expressa (I667). ${ }^{\mathrm{I23}}$ Schoonhoven stond te boek als een oproerige priester. Hij was door Rovenius in 1647 ontslagen als bedienaar van een van de Utrechtse staties na een conflict met de Utrechtse provicaris Abraham van Brienen. ${ }^{124}$ Dat laatstgenoemde officièle goedkeuring aan de Scala facob had gehecht, zal zeker een rol hebben gespeeld bij zijn beschuldigingen. ${ }^{\text {125 }}$

Enkele van Van Schoonhovens punten van kritiek vonden gehoor bij de Congregatie van de Index. Behalve van hatelijkheden aan het adres van regulieren die in de Hollandse Zending werkzaam waren, was de kerkelijke overheid te Rome er niet van gediend dat Lindeborns uitgesproken voorkeur voor geestelijke maagden ontspoorde in aanvallen op de wijze waarop kloosterlingen hun staat beleefden. ${ }^{126}$ Deze hele kwestie bracht Neercassel in een buitengewoon lastig parket. Volgens het voorwoord van de Scala facob was dit boek op zijn verzoek tot stand gekomen. Of hij het zelf ingezien heeft, mag betwijfeld worden. Vermoedelijk had hij louter op basis van de goedkeuring van Van Brienen toestemming gegeven voor de uitgave ervan. ${ }^{127}$ Gezien de gespannen verhouding met de reguliere geestelijkheid in de Hollandse Zending, die zıch aan zijn jurisdictie als apostolisch vicaris trachtte te onttrekken, kon hij niet riskeren dat de commotie rond Lindeborns boek uit de hand zou lopen en ook zijn eigen positie zou compromitteren. ${ }^{128}$ Een bijkomende intentie was mischien om Van Schoonhoven, die reeds jaren tegen zijn voormalige collega's queruleerde, ${ }^{129}$ het zwijgen op te leggen. In april 1668

122 Lessius publiceerde onder het pseudoniem Leo Hubertunus het werk De bono statu eorum, qut vovunt et colunt castitatem in saeculo (Keulen Kunckuus 16 I5). Zijn opvatungen worden onder meer vertolkt door de jezulet Hazart, Lof Voor Busenbaums Lulien unter den Dorneren daß sst gottverlobter Fungfrawen und Witwen Welt-getsthcher Standt, zie Conrad, Zuvschen Kloster und Welt, 1 i 2-1 13 . Bisschop noemt de leefwizze van geestelı)ke maagden een 'staet ende officie' in Lof der Suyverheydt, III, 50, 62, 145,395 .

123 Bellacuna, Spongra expressa, 3, aangehaald door Theissing, Over klopjes, 20 (noot 1), die ook hun polemiek uitvoeng weergeeft, met bronvermeldingen (19-26).

124 Post, Romeinsche bronnen, II, 630-63I (nr. 758).

125 Theissing, Over klopjes, 20 (noot I)

126 Buv Lindeborn, Scala facob, 18-19, 176.

127 'Facultas Supenorum', in Lindeborn, Scala facob (ongepagineerd).

128 Spiertz, L'Egluse catholique, 76-79.

$129 \mathrm{Vgl}$ Post, Romeinsche bronnen, II, 630-63I (nr 758) 
wendden zowel hij als Lindeborn zich tot Congregatie van de Propaganda Fide, om te voorkomen dat de $S c a l a$ facob verboden zou worden. ${ }^{13 \circ} \mathrm{Op}$ advies van Neercassel toog Lindeborn persoonlijk naar Rome om zich te verdedigen tegen aanklachten van heterodoxe opvattungen die regulieren in zijn Scala facob meenden te ontwaren. Het laatste woord in de kwestie werd overgelaten aan de Congregatie van de Index. Die dicteerde Lindeborn tot op de letter nauwkeurig welke wijzigingen doorgevoerd moesten worden, wilde de Nederlandse vertaling doorgang kunnen vinden. Lindeborn, die kost wat kost censuur wilde voorkomen, legde deze instructies nog eens aan Neercassel voor. De Congregatie van de Index had de oorspronkelijke tekst van het boek gezuiverd van aanmatigende vergelijkingen tussen kloppen en kloosterlingen, alsook van verdachtmakingen aan het adres van regulieren. Neercassel haalde er nog een laatste angel uit, waarover dadelijk meer. ${ }^{131}$

Lindeborn had leergeld betaald. Hij schrijft in de Nederlandse versie, getiteld De Leeder facobs, dat het geestelijk leven buiten het klooster enkel als staat geldt, wanneer er een belofte van zuiverheid wordt afgelegd. Bedoeld wordt een private belofte of gelofte aan God, zonder enige publieke plechtigheid. ${ }^{132}$ Gaandeweg zijn betoog laat de auteur deze voorwaarde echter weer vallen, want hij verzekert dat maagden die een geestelijke leefwijze buiten het klooster aanvaarden ook zonder die belofte niet vrij zijn om te trouwen. ${ }^{133}$ De gelijkenis van 'den Staet der Klooster en Werelt geestelijke Maegden', die hij had verdedigd en die hem naar eigen zeggen op scherpe kritiek van de Congregatie van de Index was komen te staan, ${ }^{134}$

130 Ibidem, 387-388 (nrs. 463, 464). Voor de repheken van de Congregatie zte 394-395, 399, 400 (nrs. 473, 477, 478, 479).

13I RAU, $A O B C$, inv.nr. 583, ingekomen stukken Joannes van Neercassel, 1667-1668: 'Correctionem Lubn cuı Titulus est Scala Jacob et (...) sic ordinandum statuunt a S. Cong ${ }^{\text {ne }}$ Indicis' (ongedateerd), met een schrijven van Lindeborn, waann staat dat hj de goedkeunng nodig heeft ('deberem habere approbstonem') In strud met de genoemde instructies had Lindeborn twee passages niet gewijugd in de De Leeder Jacobs. Daarom werd voorafgaand aan de opdracht van de vertaler een 'Nota' opgenomen met deze errata, vermoedelık op last van Joannes van Heumen, die ditmaal voor de approbatie tekende 132 Lundeborn, De Leeder facobs, 7. Men bedenke dat 'belofte' in de zeventiende eeuw synoniem was voor 'gelofte'. WNT II-I,2, I739, stelt dat onder belofte onder meer wordt verstaan elke met vnje wil en met voorbedachten rade gedane toezegging aan God of Diens heiligen. Bij intrede in een klooster deed men beloften. De pnvate belofte die een geestelıke maagd aflegde, kan misschien het beste vergeleken worden met een eenvoudige gelofte van zuiverheid. Vgl. Theissing, Over klopjes, 21-22. 133 Lindeborn, De Leeder Jacobs, 66-67.

134 Lundeborn vermeldt deze kntuek in de 'Voorreden' (ongepagineerd) van zijn Leeder. 'En vermits de Heulige vergadenng der Alderutstekenste Heeren Cardinalen van 't Register gants niet bevallen die verschillen waer over men twist met de Religieusen, alsmee de vergelıjkkenıssen tusschen den Staet der Klooster en Werelt geestelıke Maegden Heb oversulks raedsaem geoordeelt het geheele Werk wederom nae te sien (...)'. De betreffende zinsnede komt letterlıjk overeen met de rechtvaardiging die de Congregatie van de Index hem ter correctue van de Scala facob in de pen geeft. RAU, AOBC, inv. nr 583, ingekomen stukken Joannes van Neercassel, I667-I668 'Cumque $S$ Cong ${ }^{\text {n }}$ Em $^{\text {morum }} D^{\text {narum }}$ Cardinalium Indicis controversia (quae cum Regulanbus tractantur, itemque comparationes inter statum Virgines Claustralium et earum quae Deo in seculo famulantur) minime placeant. ideo 


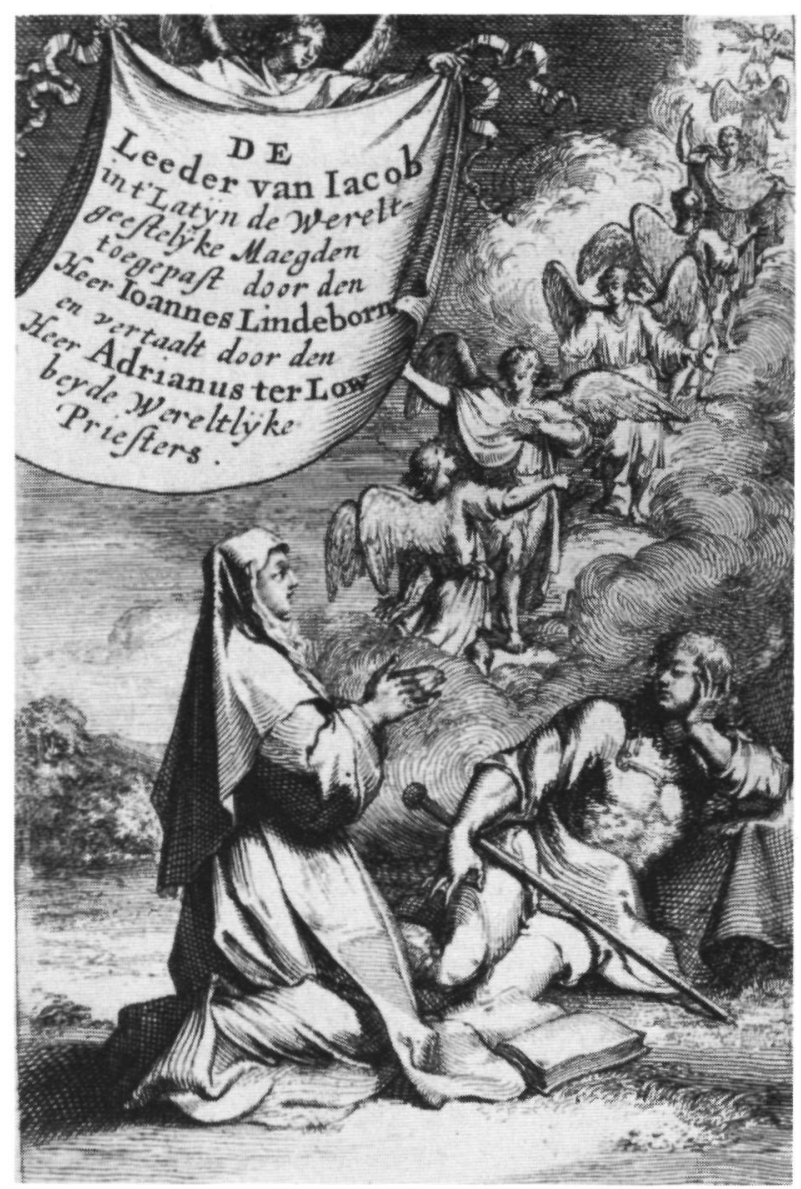

Afb. 7 Verbeelding van de jacobsladder (Gen. 28,12) op het titelblad van Lindeborns kloppenboek.

wilde hij kennelijk niet zomaar loslaten. Op instigatie van Neercassel beschrijft hij de leefwijze van geestelijke maagden in de Nederlandse vertaling echter als 'een afbeelding van staet' binnen de kerk. ${ }^{135}$ Geen staat dus, maar gemodelleerd naar een staat en daarom niet zo 'onbeweeglijck' als de staat der religieuzen, waartoe men niet alleen door gewetensdwang maar ook door de kerkorde verplicht werd en waarvan men in beginsel niet ontslagen kon worden. Dankzij deze ingenieuze redenering kon hij het neologisme 'wereldgeestelijke staat' handhaven zonder de superioriteit van de kerkelijk bevestigde religieuze staat aan te tasten. In zijn visie

consilium coepi totum Opum iterum sub incudem [lezing onzeker] ponendi (...)'.

135 Ibidem, voorgeschreven correctie Scala facob, 12, r. 24 e.v.: 'dico: cum Virginibus nostris a suo proposito resilire fide, quam deo obligarunt, reclamante non liceat, Vitam earum Statum esse in Ecclesia, et quamvis non adeo immobilum ac est matrimonialis et moderna religiose vivendi (...)'. Bij 'Statum' in margine aangetekend door Neercassel: 'Imaginem Status'. 
waren er als het ware twee soorten maagden die niet voor elkaar onderdeden: zij die in een klooster leefden en zij die in de wereld leefden. Laatstgenoemden mochten zich met recht 'in 't getal der Maegden' scharen, die de Bruidegom der maagden reeds prees, die de apostel poogde voort te brengen, en wier lof de kerkvaders oudtijds al hadden gezongen. ${ }^{136}$

Het verschil in status tussen geestelijke maagden en vrouwelijke religieuzen wordt door verschillende auteurs van vitae eveneens scherp in het oog gehouden. Sancia Carillo wijdde zich volgens haar 'biograaf' Martinus de Roa S.J. geheel aan God en verkoos, door een vast voornemen, de maagdelijke staat. Maar haar levenswijze wordt geen staat genoemd. ${ }^{137}$ De Antwerpse geestelijke dochter Anna de Torres heeft evenmin een staat maar een 'manier van leven' gekozen; in deze vita wordt het begrip 'staat' maar mondjesmaat gebezigd. Doordat de auteurs waar mogelijk wijzen op gelijkenissen in de leefwijze van hun hoofdpersonen enerzijds en vrouwelijke religieuzen anderzijds, laten zij impliciet zien dat het bestaan van kloppen qua boetvaardigheid en vroomheid niet onderdoet voor dat van monialen. Soms spreekt er zelfs onverholen kritiek uit beschrijvingen van het kloosterleven. Sancia Carillo wordt een groot medelijden toegedicht met kloosterlingen die 'den hooghen staet ende verdiensten van 't cloosterlijck leven' niet naar waarde schatten. Zij maakten van hun ziel een verblijfplaats voor de duivel in plaats van voor God. ${ }^{138}$

Andere auteurs aarzelden minder om de leefwijze van kloppen als staat te benoemen, hoewel ook zij zich er over het algemeen voor wachtten deze als equivalent van de kloosterstaat te benoemen. De anonieme carmeliet die Godtvruchtige Maniere schreef, heeft het over 'den Geestelijke-Dochters Staet'. Het lijdt naar zijn mening geen twijfel dat deze 'eenen geestelijken, jae Evangelischen Staet' is, die door het voorbeeld en de lering van Jezus Christus wordt bestendigd. Hij geeft toe dat 'Godts-geleerden' onder geestelijke staat de kloosterstaat verstaan. Toch is hij van oordeel dat de 'Staet oft maniere van leven' van geestelijke maagden eveneens tot zaligheid strekt. ${ }^{139}$ De augustijn Fulgentius Stevins spreekt over 'desen Heyligen, en Maegdelycken staet'. Zijn collega Joannes Uuten Eeckhout, die de leiding had over de Amsterdamse kloppen in de statie De Star, heeft het zelfs over de 'status ecclesiasticus', een begrip waarin kerkelijke approbatie besloten lijkt te liggen en dat door Rovenius bijvoorbeeld wordt gereserveerd voor religieuzen. ${ }^{140}$ De jezuiet Comelius Hazart verankert zijn verdediging van de maagdelijke staat in de wereld op polemische wijze in de hoge waardering die er in katholieke kring gehecht wordt aan de maagdelijkheid. Op voorwaarde dat de maagdelijke staat

136 Lindeborn, De Leeder Jacobs, 9. Idem, Scala Yacob, 18. De jezuïet Hazart presenteert in Lof een vergelijkbare redenering.

137 De Roa, Leven Sancia Carillo, 39, 51.

138 Ibidem, 77.

139 Godtunuchtige Maniere, 3-6.

140 PA OSA, De Star, 232. Rovenius, Reipublicae christianae libri duo, 264. 
buiten het klooster met een eeuwige belofte bevestigd wordt, is deze werkelijk een staat, die hoger en volmaakter is dan het huwelijk. ${ }^{141}$ Wie dit bestrijdt, hangt volgens Hazart de ketterse leer van Luther en Calvijn aan en maakt zich schuldig aan een afwijkend standpunt waarvoor eertijds Jovinianus reeds door Ambrosius was veroordeeld. ${ }^{142}$

\section{Buiten mededinging}

Behalve rechtstreekse verdedigingen van de kloppenstaat werden er door geestelijken ook indelingen uitgedacht die geestelijke maagden aan een plaatsje binnen de kerkelijke hiërarchie moesten helpen, te midden van de religieuzen en de geestelijken, zónder met hen te concurreren. Lodewijk Makeblijde S.J. maakt in Den Lusthof der Gheestelicke Oefeningen ( 1607 ), dat kloppen ter lezing werd aanbevolen door Bisschop, een tweedeling tussen de wereldlijke en geestelijke staat. Dit boek is dan wel geen kloppenboek, het betoog is niettemin informatief. Van deze jezuïet is bekend dat hij te Delft de leiding had over een groep geestelijke maagden. ${ }^{143}$ Wie de wereldlijke staat verkiest, is verplicht de geboden van God te onderhouden, aldus Makeblijde. Als wereldlijke staat gelden de huwelijkse, weduwlijke en de ongehuwde staat. Wie daarentegen de geestelijke staat aanvaardt, moet behalve de geboden ook de evangelische raden onderhouden door verschillende geestelijke oefeningen. ${ }^{144}$ Deze verplichting wordt bevestigd door een belofte voor een of meer evangelische raden. De opsomming die Makeblijde geeft van de staten die als geestelijk worden aangemerkt, luidt als volgt:

'den staet der Priesteren, der Diakenen, ende Subdiakenen, der Canonicken, ende Religieusen, ende Maeghden'.

De wereldheer Joannes Van Heumen gaat in zijn kloppenboek Clooster van Sion eveneens uit van een onderscheid tussen 'wereldtsche' en 'geestelijcke' personen. De kloppen worden hier tot de laatste categorie gerekend. ${ }^{145}$ Voor hun geestelijk leven in de wereld vormen de evangelische raden de leidraad. ${ }^{146}$ Dat de zuiverheid zonder mankeren onderhouden moet worden, staat buiten kijf. Maar armoede en gehoorzaamheid, de twee andere evangelische raden, kunnen volgens deze auteur in verschillende gradaties beoefend worden door geestelijke maagden. De anonieme, misschien wel vrouwelijke auteur van Sommighe Consideratien onderschrijft deze stelling. Blijkens haar met stellingen en tegenwerpingen opgebouwd

141 Hazart, Lof, 7-8; vgl. De Smidt, Van den salighen staet, 87-93.

142 In Adversus fovinianum bestreed de bisschop van Milaan, Ambrosius, de 'ketter' Jovinianus, die betwistte dat de maagdelijkheid God welgevalliger was dan het huwelijk. Zie Ranke-Heinemann, Eunuchen voor het hemelrijk, 54-55. Vgl. Brown, The body and society, 359-360.

143 Theissing, Over klopjes, 78, 162.

144 Makeblijde, Lusthof, 527.

145 Van Heumen, Clooster van Sion, III, sermoen 4 en sermoen 8.

146 Ibidem, I, 'Voorreden' (ongepagineerd). 
betoog, was zij geverseerd in de debatten over de maagdelijke staat buiten het klooster. Deze auteur poneert dat de vergrijpen die kloppen begaan tegen de gehoorzaamheid en de armoede, hun minder zwaar aangerekend worden dan religieuzen, omdat zij geen plechtige geloften hebben afgelegd. Zij onderschrijft de rigoristische opvatting dat een moniale die iets doet of nalaat in strijd met deze geloften, een doodzonde begaat. Een geestelijke maagd daarentegen maakt zich enkel schuldig aan een dagelijkse zonde, omdat ze het eigen voomemen om tot volmaaktheid te geraken heeft geschonden. ${ }^{147}$ Deze auteur verbindt daaraan overigens de conclusie dat een geestelijke maagd gemakkelijker in Gods gunst zal blijven, aangezien zij minder gelegenheid heeft om zwaar te zondigen.

Het Clooster van Sion symboliseert volgens zijn auteur Van Heumen de geestelijke staat in de wereld. Wie hierin als novice intreedt, wordt geestelijk. Ditzelfde verschil met verreikende consequenties voor de positie van geestelijke maagden verdedigen de jezuïet Bisschop, de augustijn Stevins en de kapucijn Van den Bosch. ${ }^{18}$ Ook de leefwijze van Joanna van Randenraedt en Agnes van Heilsbach wordt in hun respectieve vitae benoemd als 'gheestelyck' en daarmee scherp onderscheiden van het 'wereldts' leven dat zij vóór hun intrede in de kloppenstaat hebben geleid. Het alsof sommige kloppenboek-auteurs het begrip 'geestelijk' bewust gebruikten om onderscheid te maken tussen 'wereldgeestelijke maagden' enerzijds en kloosterzusters anderzijds. Dergelijke nieuwe classificaties brachten betekenisverschuivingen teweeg van begrippenparen geestelijk en wereldlijk, van geestelijke personen en leken. Doordat zij door priesters als geestelijke personen werden gedefinieerd, onderging de status van geestelijke maagden binnen de geloofsgemeenschap mogelijk een opwaardering. In kerkrechtelijk opzicht waren en bleven zij leken, maar dergelijke scherpslijperij deerde hun tijdgenoten vaak niet.

Andere 'aanpassingen' van de kerkelijke hiërarchie nemen duidelijker afstand van de aanspraak op gelijkheid tussen kloppen en monialen. Hazart postuleert dat de geestelijke staat in de wereld niet gelijk maar wel gelijkwaardig is aan die der kloosterzusters. ${ }^{149}$ De jezuiet Nicolas Caussin benoemt het godgewijde bestaan buiten het klooster als de 'middelen staet'. Mogelijk verwijst hij daarmee bewust naar de benamingen status media of via tertia, die middeleeuwse canonisten gaven aan de leefwijze van begijnen en andere niet-kloosterlijke religieuze vrouwen. ${ }^{150}$ Zeventiende-eeuwse vrouwen die zich noch tot de 'traillie' van het klooster, noch

147 Sommige Consideratien, II-12. In theologisch opzicht is dit standpunt te vergelijken met het onderscheid tussen plechtige geloften, die handelingen in strijd met die geloften ongeldig maken, en eenvoudige geloften, die dergelijke handelingen enkel ongeoorloofd maken. Zie Lemoine, Le monde des religieux, 3-7.

I48 Bisschop, Lof der Suyverheydt, III, 197; Stevins, Regel, 90; Van den Bosch, Het geestelyck verborgen manna, (opdracht; ongepagineerd).

149 Hazart, Lof, 152, I64.

$150 \mathrm{Elm}$, 'Die Stellung der Frau', 14. 
tot het huwelijk aangetrokken voelden, konden zich spiegelen aan Isabella van Frankrijk (1225-1270), de zuster van Lodewijk IX (1214-1270), bijgenaamd de

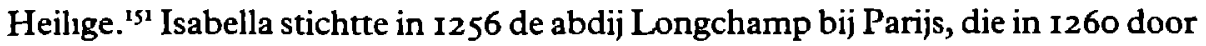
clarissen werd betrokken. Isabella trad niet in maar onderhield de regel die zij, naar verluidt, zelf had opgesteld op eigen gezag. Ze droeg geen habijt en leefde gescheiden van de monialen,

'als die ghedıerten diemen seght eens-deels waetersche, eens-deels aerdsche gedierten te zun, die noch op d'aerde, noch inde Zee blıven, maer leven in eenen middelen staet van leven'. ${ }^{\text {I52 }}$

De geestelijke staat buiten het klooster verschilt volgens Caussin wel degelijk van de kloosterstaat. De bestaande hiërarchie tussen beide leefwijzen is echter niet van invloed op de nagestreefde volmaaktheid. ${ }^{153} \mathrm{Het}$ 'amfibisch' bestaan van Isabella en van hen die haar navolgen is evengoed een 'versekerden staet', wanneer dit door een openbare belofte wordt bevestigd. De auteur laat de hiërarchie tussen de kloosterstaat en de maagdelijke staat in de wereld intact, zonder afbreuk te doen aan de waardigheid van laatstgenoemde leefwijze.

De hiërarchie tussen de kloosterstaat en de kloppenstaat wordt in de betogen van de kloppenboeken grotendeels onverlet gelaten. Sommige auteurs benadrukken de waardigheid van de maagdelijke staat buiten het klooster echter dermate, dat zij aanspraak lijken te maken op een zekere verhevenheid boven de kloosterstaat. ${ }^{154}$ Achter de stelling dat het leven van geestelijke maagden de ultieme navolging van Christus representeert, schuilt mogelijk de pretentie dat kloppen, meer dan andere leken en ook kloosterlingen, een leven in $\mathrm{Zijn}$ geest lesden. Vitae verhalen hoe maagden hun leven modelleren naar de vita apostolica van Jezus. ${ }^{155}$ Behalve een apologetische kracht ging er mogelijk ook een zekere aanmatigende werking van dergelıke redenenngen uit.

Volgens Lindeborn komt het eerstgeboorterecht geestelıke maagden toe; hun leefwijze is ouder - en oorspronkelijker, bedoelt hij misschien te zeggen - dan die van slotzusters. Bij de Congregatie van de Index kon deze stelling echter niet door de beugel. ${ }^{156}$ De jezuïeten Bisschop en Hazart benadrukken dat geestelıjke maag-

15I De Nederlandse vertaling van dit van oorsprong Franstalige levensverhaal is opgenomen in Jacobi, Spreghel der Maeghden Isabella's broer, die regeerde van 1236 tot 1270 , het in 1254 een begi)nhof butten Panjs stichten, waar ongeveer vierhonderd vrouwen een onderkomen vonden Ook elders in zj]n njk nep hij vergelıjkbare instellingen in het leven Daarom werd hij wel spottend 'miserum papelardum regem', armzalige beginenkoning, genoemd Dinzelbacher, 'Rollenverweigerung', 12.

152 Caussin, Leven Isabella, in· Jacob1, Spieghel der Maeghden, 84

153 Ibıdem, 85. In vergelı)kbare bewoordingen verdedıgde de jezuxet Lessius de actieve religieuze leefwijze die Mary Ward trachtte te realiseren. Grisar, 'Das Urtell', 658-706

154 Volgens mededelıng van de jezuret Jacobus (de) Codt aan de Heilige Stoel over de kerkelıke toestand in de Hollandse Zending, werd in de dagelıjkse praktı)k de leefwıze der kloppen hoger gewaardeerd dan die der kloosterlingen Theissing, Over klopjes, I9

155 Byvoorbeeld Munnos, Leven Aloysia de Caravaial, 37.

156 Lindeborn, Scala facob, 8, aangehaald door Theissing, Over klopjes, 20 (noot 3), bekrutuseerd door 
den in de praktijk een belangrijke rol binnen de kerk kunnen vervullen dankzij allerlei liefdewerken en financiële steun. Hazart neemt geestelijke maagden expliciet in bescherming tegen hiërarchische aanspraken van kloosterlingen. Of de belofte van zuiverheid nu in of buiten een klooster werd gedaan, is onbelangrijk. ${ }^{157}$ Waar het om gaat, is de gestelde taak met diepe, wilskrachtige godsvrucht te volbrengen.

Ofschoon zij niets ten nadele van het kloosterleven wil zeggen, huldigt de anonieme auteur van Sommige Consideratien hierover toch een onmiskenbaar negatieve opvatting. Het leven in vrouwenkloosters zou beslist niet zo stichtelijk en vreedzaam zijn als de buitenwacht vaak denkt, en zou soms grote schade aan de bewoonsters berokkenen. Is hier misschien een voormalig kloosterlinge aan het woord? We weten het niet. Hoe het ook $\mathrm{zij}$, de auteur betoogt dat geestelijke maagden, anders dan nonnen, van dergelijke spanningen verschoond blijven en in alle rust hun godvruchtige oefeningen kunnen doen. Voor wie de liefde tot Christus als prikkel tot het geestelijk leven onvoldoende is, die moet misschien maar beter in een klooster intreden, waar een strenge tucht het streven naar volmaaktheid, naar haar zeggen, strakker begeleidt. ${ }^{18}$

\section{Eeuwig de Zijne?}

Illustratief voor de kwestie staat of geen staat zijn de beschrijvingen van de totstandkoming van de geestelijke verbintenis met God en de bindende kracht hiervan. 'Ick ben aen God verlooft, aen mij valt niet te vrijen', zo geeft Adriaan Poirters zijn Philagie in de mond. ${ }^{59}$ Of een geestelijke maagd al dan niet een meer profaan huwelijk mocht sluiten, blijkt een ijkpunt voor de geestelijke staat in verschillende kloppenboeken. Met stellingen dat de leefwijze van een klop dermate door voornemen of belofte verankerd was, dat enige vorm van formele dispensatie nodig was in geval zij wenste te trouwen, scherpt menig kloppenboek-auteur zijn standpunt aan dat haar leefwijze waarlijk een staat is. Voorwaarde voor deze staat is een belofte van zuiverheid. Deze belofte luidt de onverbrekelijke geestelijke verbintenis met de hemelse Bruidegom in. Hoewel een dergelijke belofte gebruikelijk geweest schijnt te zijn, zowel bij kloppen onder leiding van regulieren als seculieren, blijken geestelijken verdeeld waar het gaat om het bindend karakter ervan.

De apostolisch vicarissen Rovenius en Neercassel hadden grote moeite met dergelijke beloften en de daarmee gepaard gaande plechtigheden. Rovenius verbood de clerus uitdrukkelijk om 'vrouwtjes of maagden' ('mulierculas seu virgines') een

Van Schoonhoven Spongia Contradictionum Expressa, 7, io en geschrapt op last van de Congregatie van de Index. RAU, $A O B C$, inv.nr. 583.

157 Hazart, Lof, 149.

158 Sommige consuderatien, 23, 26-28.

159 Po1rters, Het daeghelycks nieuwe-jaer spieghelken, 28. 
belofte van gehoorzaamheld of armoede te laten afleggen. ${ }^{160}$ Tegen een eenvoudige belofte van zuiverheid bestond echter geen bezwaar. Deze vormde in zijn ogen geen beletsel voor een huwelıkk, al zondıgde een geestelıke maagd wanneer zıj in het huwelı)k trad. ${ }^{161}$ Ook Neercassel was er in beginsel fel op tegen dat geestelıke maagden beloften aflegden, ${ }^{162}$ al school er in een persoonlıke belofte van zu1verheid volgens hem geen kwaad. Aan de geestelıke maagd Margareta Petraea houdt hı) voor dat zlj zich 'door beloften van Eeuwige zuyverheyd' aan Chrnstus kan verbinden. ${ }^{163}$ Zo'n belofte stond een eventueel huwelı)k nuet in de weg, ${ }^{164}$ al verrulde een klop natuurlı)k wel haar hemelse Bruıdegom voor een wereldse en was ze daarmee voorgoed geestelyke maagd-af.

Volgens de wereldheren Joannes Lindeborn en Willem Schoenuus daarentegen verbindt een belofte van zuiverheid een maagd juist onlosmakelık aan de hemelse Bruidegom. ${ }^{165}$ Deze belofte representeert een 'geestelıck houwelı)ck met Chnsto' en markeert haar nieuwe levensstaat. Geeft zl) in een later stadium alsnog de voorkeur aan een sterfelijke echtgenoot, dan begaat zlj een grote zonde die haar eigen zaligheid in gevaar brengt De belofte vormt echter geen belemmenng voor een eventueel huwelıj, in dat opzicht stemmen deze auteurs met Rovenıus en Neercassel overeen. ${ }^{166}$ Toch halen zi) instemmend de waarschuwing van de kerkvaders Cypnanus en Basilius aan: wee degene die na een belofte van zuiverheid trouwt, want dat is een overspelıge. Geestelı)ke maagden moeten volgens hen juist een voorbeeld nemen aan verscheidene vroeg-chnsteli)ke martelaressen, die liever hun leven dan hun maagdelıkherd prissgaven. ${ }^{167}$

Opmerkelıjk genoeg secondeert Hazart Rovenıus en Neercassel in hun stellıng dat een geestelı)ke maagd alsnog in het huwelık kan treden. Zıın instemmıng blıkkt echter een retonsche strategie om dat standpunt te ontkrachten en te bewijzen dat de geestelı,ke leefwıjze buiten het klooster wel degelık een onwrikbare staat is Een decennium eerder had de Congregatie van de Index Joannes Lindeborn nog op de vingers getikt, toen die betoogde dat het leven van de 'wereldgeestelı)ke' maagden niet onderdeed voor de religieuze staat of het huweli)k. Hazarts Lof van den maegdelycken staet naemelyck in de werelt heeft van die zijde echter niets te duchten. In zijn interpretatie van de rechtskracht van de belofte van zuiverheid, legt Hazart de maagden verplichtıngen op die geen enkele kerkrechtelıke grond-

I60 'Constitutio', d d 30 junı 1628, aangehaald in [Van Heussen], Batavia Sacra, II, IOI

161 Rovenuus, Retpublucae chrstianae libn duo, 276

$162 \mathrm{RAU}, A O B C$, inv nr 610, Neercassel aan Willem van Dalenoort te Den Haag, 29 me1 1684 De apostolısch vicans schn)ft dat de geestelı)ke maagd Adnana Hoynck, van we deze seculıer kennelı)k de biechtvader was, geen geloften mag afleggen

163 Ibidem, inv nr 612, 6 maart I68I

164 Ibidem, inv nr 609, Neercassel aan Foppens, 28 julı I682

I65 Lundebom, De Leeder facobs, 12-20, 53-54, 64 Schoenıus, Weg, 6 I Z1e ook Sendbreff, 'Vermaninghe tot alle geestelıcke Maechden' (ongepagineerd)

166 Zle ook Bisschop, Lof der Suyverheydt, II, x16

167 Lindebom, De Leeder Facobs, I4-Is en 60, Schoenus, Weg, 61 
slag hebben. Het godgewijde maagdelijke bestaan buiten het klooster, dat berust op een in beginsel onontbindbaar geestelijk huwelijk met de Heer, is een staat net als de religieuze staat of het huwelijk. Volgens deze auteur kan deze geestelijke verbintenis alleen door de hoogste autoriteit binnen de kerk, de paus, ontbonden worden, zoals dat ook gebruikelijk is wanneer een religieus of religieuze het klooster voor een echtverbintenis verruilt. ${ }^{168}$

\section{Man noch muur}

Door vast te houden aan een onderscheid tussen de leefwijze van geestelijke maagden enerzijds, en de religieuze en huwelijkse staat anderzijds, omschrijven de kloppenboeken een nieuwe levensvervulling voor vrouwen. Deze wordt als een herkenbaar alternatief gepresenteerd voor huwelijk en klooster ('aut maritus aut murus'), de opties die vrouwen sinds het Concilie van Trente hadden. Dat vrouwen voor dit alternatief kozen, wordt door geestelijken op verschillende manieren gerechtvaardigd.

De jezuïet Hazart volgt een sekse-specifieke redenering in zijn verdediging van het geestelijk leven buiten kloostermuren voor vrouwen. Dat er zoveel weerstand is tegen vrouwen die in de wereld een belofte van zuiverheid afleggen, begrijpt hij niet. Voor mannen is zo'n belofte geenszins omstreden maar juist lovenswaardig. Wie de kerkelijke wijdingen ontvangt en in de wereld blijft, moet een dergelijke belofte zelfs op last van de kerk afleggen. En dat terwijl mannen door hun 'vryer conversatie, mindere schaemte, ende meerdere occasien' aan grotere gevaren blootstaan dan vrouwen. Waarom, zo vraagt Hazart zich retorisch af, mogen vrouwen dan toch die belofte niet doen? ${ }^{169}$

De wereldheren Rovenius, Lindeborn en Schoenius vestigen de aandacht op ziekte, een zwak gestel of ouderdom, die onoverbrugbare hindernissen betekenen voor iemand met een religieuze roeping en die Franciscus van Sales reeds had aangevoerd bij de stichting van de Visitatie van Annecy. Daamaast noemen zij materiële en familiale motieven. ${ }^{170}$ Sommige vrouwen kunnen de bruidschat, te betalen bij de intrede in een klooster, niet opbrengen. ${ }^{171}$ Anderen zijn thuis onmisbaar, of zijn bang hun aanspraken op geld en goederen in de Republiek te verliezen na

168 Hazart, Lof, 8-11, beroept zich op Lessius' De bono statu, die de belofte tot zuiverheid dermate bindend acht, dat alleen de paus iemand hiervan kon ontslaan. $V_{g l}$. De Smidt, Van den salighen staet, 87-93; Van den Bosch, Het geestelyck verborgen manna, 36-37, maakt hierbij een uitzondering voor maagden die van tevoren hebben afgesproken dat zij van deze belofte door hun biechtvader ontslagen kunnen worden.

169 Hazart, Lof, 148.

170 Rovenius, Reipublicae christianae libri duo, 274; Lindeborn, De Leeder facobs, 8; Schoenius, Weg, 54-57.

171 Dit motief wordt bijvoorbeeld ook vermeld door De Smidt, Van den salighen staet, 'Voorreden tot den Leser' (ongepagineerd). 
intrede in een buitenlands klooster. Deze geestelijken erkennen zowel de religieuze beweegredenen, als de meer profane overwegingen die ten grondslag konden liggen aan de levenswegen die vrouwen insloegen. Ook de politieke en religieuze toestand in de Republiek wordt als argument aangevoerd. Volgens Rovenius zijn vrouwen, die een geestelijk leven in de wereld leiden, vooral te vinden in aan 'ketters' onderworpen gebieden. ${ }^{172}$ De diensten die deze geestelijke maagden de arbeiders in de missie-wijngaard des Heren kunnen bewijzen, zijn van meer praktisch nut dan de gebeden van kloosterzusters in den vreemde, zo kan zijn redenering worden aangevuld. Eenzelfde beeld is te vinden in Munnos' levensbeschrijving van Luisa de Carvajal y Mendoza. $\mathrm{Zij}$ wordt afgeschilderd als voorbeeld voor die vrouwen die Engeland na de godsdienstige omwentelingen, die een einde maakten aan de monastieke traditie in dat land, niet wilden verlaten maar 'aldaer tot de volmaecktheyt [wilden] comen'. ${ }^{73}$

Niet alleen economische of sociale factoren konden een belemmering vormen voor de intrede in het klooster, maar ook individuele karaktereigenschappen. Sommige vrouwen, zo stelt de jezuïet Caussin, zijn té eigenzinnig voor het kloosterleven en worden zeker onvolmaakte religieuzen. ${ }^{174}$ Van religieuzen wordt namelijk een dermate compromisloze gehoorzaamheid verlangd, dat de genade Gods hiertoe onmisbaar is. Roeping speelt in zijn betoog een belangrijke rol, net als in de rechtvaardigingen van andere jezuïeten voor de geestelijke staat buiten kloostermuren. ${ }^{75}$ Volgens Caussins collega Bisschop moet Gods roeping altijd geëerbiedigd worden. Men dient een levensstaat te aanvaarden die met Gods wil strookt en niet één 'die uwe sinnelijckheydt $u$ voorhoudt oft de werelt $u$ raadt'. ${ }^{176}$ In de betogen van verschillende seculiere geestelijken is het concept roeping juist opvallend afwezig; ${ }^{177}$ zij spreken vooral in termen van mogelijkheden, gaven en aanleg. ${ }^{.78}$

Caussin verbindt de keuze van een levensstaat aan ieders individuele capaciteit om zalig te worden. God heeft mensen - dus ook vrouwen - begiftigd met de rede, waardoor zij die staat kunnen kiezen die het meest overeenstemt met hun eigen mogelijkheden en roeping. Als prototype van een vrouw die haar roeping volgt, voert hij de Franse prinses Isabella op. $\mathrm{Zij}$ trotseerde zelfs de paus, die haar ontraadde te kiezen voor de 'middelen staet'. God had haar echter geroepen tot de maagdelijke staat buiten het klooster. En Zijn roeping woog zwaarder dan het ontzag dat ze voor de paus had. De kloosterstaat mag volgens Caussin dan wel

172 Rovenuus, Retpublucae chrstianae libn duo, 274.

173 Munnos, Leven Aloysıa de Caravaial, 254.

174 Caussin, Leven Isabella, in: Jacobı, Spreghel der Maeghden, 40-42.

175 Kort Begryp; Leven ende deughden. De Smidt, Van den salighen staet, 'Voorteden tot den Leser' (ongepagineerd), spreekt over mogelijke ongeschiktheid voor het klooster. Daarenboven waren er vrouwen die 'ghenen sin (.. )' hebben om in een klooster in te treden

176 Bisschop, Lof der Suyverheydt, III, I48-I49.

177 Met uitzondenng van Van Heumen, Clooster van Ston, I, 67-87; III, 172-173.

178 Lindeborn, De Leeder facobs, 8; vgl. Rovenıus, Reipublucae chrstranae libri duo, 274-275. 
de hoogste staat zijn, als men daartoe niet geroepen wordt, dan is het eerder gevaarlijk dan goed om deze staat te verkiezen.

'Daer zijn Jouffrouwen, de welcke inde wereldt een groote volmaecktheydt hebben bekomen, door de wercken van liefde ende Godrvrughugheydt, de welcke by avonture inde Relıgie souden een slap leven gheleydt hebben (...). ${ }^{179}$

Geen vrouw mag, aldus Caussin, gedwongen worden tot de intrede in een klooster. Zonder roeping zal zij deze staat niet goed beleven en het gevaar lopen te zondigen.

Tot grote spijt van de geestelijke maagd Maria Anna du Val de Dampierre, die onder leiding van seculiere priesters stond, gaf God haar geen kloosterroeping. Haar grootste wens om in een klooster in te treden, ging niet in vervulling. Aanvankelijk legde ze, zo lezen we, zich hier niet bij neer. Maar telkens wanneer ze haar verlangen naar het kloosterleven kenbaar probeerde te maken, voelde ze haar tong als het ware bevriezen. En de gedachte aan intreden deed haar schudden en beven. ${ }^{180}$ Gods roeping laat zich niet zomaar negeren, zo luidt de boodschap van deze vita.

\section{III.4 In de wereld, maar niet van de wereld ${ }^{185}$}

De betogen in de kloppenboeken over staat of geen staat maken een spanning voelbaar tussen erkende contemplatieve en nieuwe, meer actieve vormen van religieus leven. Deze spanning heeft alles te maken met het oogmerk van beide leefwijzen, namelijk het streven naar zelfheiliging. Vandaar dat menig kloppenboekauteur zijn publiek op het hart drukt dat religieuze perfectie en de in het hiernamaals volgende zaligheid beslist ook gewaarborgd kunnen worden door het geestelijk leven buiten het klooster. Toch staat deze bewering haaks op het zeventiendeeeuwse concept van zelfheiliging. Het realiseren van een religieuze roeping vergde naar toenmalige maatstaven namelijk een vlucht uit diezelfde wereld. De meest effectieve manier om de wereld te ontvluchten, zo dacht men, was de intrede in het klooster. Aangezien geestelijke maagden de wereld niet verheten, maar hierin juist hun religreuze roeping trachtten te verwezenlijken, zagen kloppenboek-auteurs en andere geestelijken zich genoodzaakt de fundamentele inconsistentie op te lossen tussen deze specifieke leefwijze en vigerende ideeen over zelfheilıging.

179 Caussin, Leven Isabella, in: Jacobı, Spreghel der Maeghden, 23; zıe ook 18-19, 29-34, 49. Eenzelfde redenering in Musius, Maagde-pligt, 2 I

180 Leven Mana Anna du Val de Damprerre, 87-88.

181 Joh. 17, 15-16, waar Jezus zijn Vader vraagt zijn discipelen niet uit de wereld weg te nemen, maar wel voor het kwaad te behoeden, omdat zij net van de wereld zi)n Toespelingen hierop $m$ b.t. geestelıje maagden onder andere in Rovenius, Rezpublicae christianae labn duo, 276 


\section{Vroeg-christelijk voorbeeld}

De tegenstelling tussen de verwezenlijking van zelfheiliging in de wereld en in het klooster kon ten dele opgelost worden door de eerste eeuwen van de kerk in herinnering te roepen. Toen leidden gelovigen immers een vroom bestaan in de wereld. Met toespelingen op de historische parallel tussen zeventiende-eeuwse geestelijke maagden en hun vroeg-christelijke voorgangsters, presenteren jezuieten als Hazart, De Smidt of Caussin, wereldheren als Rovenius, Lindeborn of Neercassel, maar ook de onbekende auteur van Sommighe Constderatien, de geestelijke leefwijze buiten het klooster als een vorm van zelfheiliging, die niet onderdoet voor een vanwege de kerk erkend religieus bestaan. ${ }^{182}$ Teruggrijpen op stichtelijke voorbeelden uit de vroege kerk lag voor deze auteurs allereerst voor de hand, omdat geestelijken en gelovigen toentertijd eveneens te lijden hadden onder geloofsvervolgingen. ${ }^{183}$ Vrouwen als Thecla, Paula, Demetrias en Agnes hadden zich toen, net als geestelijke maagden eeuwen later, onbuigzaam getoond in hun geloof en steun aan de kerk.

$\mathrm{Bij}$ hun verdediging van net-kloosterlijke bestaansvormen lieten zeventiendeeeuwse stichtelijke auteurs niet na erop te wijzen dat er in de eerste eeuwen van de christelijke kerk geen sprake was van een monachale leefwijze. ${ }^{184}$ In de vroege kerk moesten alle gelovigen een vroom, op God gericht leven in de wereld realiseren. Daarin lag nu juist de overeenkomst met vroegmoderne religieuze vrouwen als de kloppen. Deze analogie lijkt evenwel niet alleen voor geestelijke maagden en hun leidsmannen van bijzondere betekenis te zijn geweest. Meer in het algemeen kan namelijk gesteld worden dat een beroep op de vroeg-chnstelijke kerk de in de katholieke kerk zwaar aangezette hièrarchie tussen religieuzen en leken relativeerde. Als zodanig vormde deze diachrone overeenkomst tevens een onèntatiepunt voor de ontwikkeling en legitimering van nieuwe vormen van lekenvroomheid.

Inzet van het betoog van de zeventiende-eeuwse kloppenboek-auteurs lijkt te zijn geweest om de onontkoombare hiërarchie van religieuzen en vroom levende leken te reduceren tot een technisch verschil, dat geen afbreuk deed aan de nagestreefde heiligheid. ${ }^{185}$ Een beroep op de kerkvaders en hun maagdelıke tijdgenotes

182 Spiertz, 'Johannes van Neercassel', 54-65, verklaart Neercassels spintuele onentatie op de vroegchnstelıke kerk ult zıjn opleıding aan het Oratone. Vgl voor Rovenius, Visser, Rovenuus.

183 Natuurlı)k moet de nadruk op de vroeg-chnstelı)ke erfenis ook gezien worden in het licht van de theologische 'herbronning' in het tujdperk van de Reformaties. Jedın, 'Religiose Tnebkrafte', stelt dat de werken van de vroeg-chnstelı)ke kerkvaders en kerkleraren de voomaamste bronnen waren voor de controverse-theologe, waaruit katholieke theologen en geestelıjken putten om de ouderdom van de mis, de transsubstantiatıe-leer, het pnesterambt, het pauselıjke primaat en de ntuelen en heiligenverening te bewijzen

184 Het monachısme als levensvorm ontstond in de tweede helft van de derde eeuw Bartelink, $\mathrm{De}$ bloetende woestijn, 24.

185 Vgl Second, 'L'Emprise', 217-218, over de werkung van het vroeg-chnstely)ke ideaal in het werk van een minder bekende Franse auteur op het vlak van de lekenvroomheid, Philippe d'Angoumols 
zwakte de spanning af die in de eigen tijd inherent was aan het streven naar een vroom bestaan in de wereld en aan de verhouding tussen religieuzen en godvruchtig levende leken. Kloppenboek-auteurs proberen de haast onlosmakelijke band tussen kloosterleven en religieuze volmaaktheid ook voorzichtig losser te maken door de betekenis van de bescherming die kloosters boden, enigszins te bagatelliseren. Verschansing in een klooster biedt volgens hen op zich onvoldoende waarborg voor religieuze volmaaktheid. ${ }^{186} \mathrm{Het}$ besloten paradijs heeft Eva immers niet beschermd, net zo min als de besloten boomgaard Susanna heeft gevrijwaard van de avances van wellustige grijsaards. Zonde en verleiding houden geen halt voor dikke kloostermuren, zo prenten de auteurs de maagden in, al is 'des lichaems maegdelijkheit binnen de paelen van de kloosters, gelijk binnen haer beschanssing, veiliger dan in de Wereld'. Volgens de wereldheer Lindeborn is de 'eenige bewaerster' voor nonnen én kloppen 'de vrees des Heeren' waarmee 'sy, die haer maegdom versekert wil hebben, sich [moest] wapenen (...) in, en buiten 't klooster'. ${ }^{187}$

\section{Poel des verderfs}

Zonden en duivelse verleidingen lagen in de wereld op de loer. In navolging van kerkvaders en kerkleraren schilderen de kloppenboek-auteurs de wereld af als een poel des verderfs. Het is gecompliceerd om de veelvuldige verwijzingen naar deze gezaghebbende werken op juiste waarde te schatten. Vroeg-christelijke opvattingen over menselijke natuur, zonde en wereld werden immers door de zeventiendeeeuwse kloppenboek-auteurs naar hun eigen tijd getransponeerd en ondergingen hierdoor betekenisverschuivingen die enkel door nauwkeurige vergelijkende tekstanalyse te traceren zijn. Een dergelijk onderzoek valt evenwel buiten het bestek van deze studie. Hier wordt daarom volstaan met de constatering dat in de zeventiende-eeuwse kloppenboek-betogen de begrippen 'wereld' en 'werelds' behalve als plaatsaanduiding ook fungeerden als metafoor voor de zondigheid. ${ }^{188}$

Wie heiligheid nastreefde, diende de wereld te ontvluchten. Deze vlucht kon echter slechts gedeeltelijk slagen, omdat de mens de neiging tot zondigen sinds de zondeval in zich droeg. Zonden die als 'dampen, voortkomende uyt de springader die we altujd by ons hebben, en die we van Adam hebben overgeerft, met wiens geest en natuer wy altijd beladen sijn' bedreigden de toenadering tot God. ${ }^{\text {r89 }}$ 'Mijn God, ik ben twee Dochters, de eene een geestelijke, ende de andere een vleeschlijke', vatte Maria Anna du Val de Dampierre de fundamentele oppositie

(† 1638).

I86 Z1e bijvoorbeeld Sommge Conszderatuen, 10-II.

187 Lindeborn, De Leeder Jacobs, Ir.

I88 In belofte-formules bij de intrede in de kloppenstaat wordt het afiweren van de wereld ook uitdrukkelyk genoemd. Zie bijvoorbeeld Theissing, Over klopjes, 216 (bijlage II-c).

189 Leven Mana Anna du Val de Dampierre, 463; vgl Reghel der Volmaecktheyt, 56; Kon Begryp, 163. 
binnen de menselijke natuur samen. $\mathrm{Zij}$ was ervan overtuigd dat enkel de intrede in een klooster haar ervan kon verzekeren dat zij

'alle de gedagten, begeerten, en geneegentheden mag laten varen, die de vleeschlijcke Dochter my souw konnen ingeven: want sy is soo loos, dat ik haer van de geestelijke niet kan onderscheiden, soo weet sy haer met den schijn van deugd en van volmaecktheit te bekleden'. ${ }^{190}$

Dat zij in de wereld moest blijven, omdat God haar geen kloosterroeping had gegeven, zinde deze geestelijke maagd in het geheel niet. De lucht van de wereld was bedorven en wereldse mensen verspreidden volgens haar een vuile stank. Een weinig aanlokkelijk perspectief voor iemand die religieuze volmaaktheid en deugdzaamheid nastreefde.

Zijn predispositie tot zonde kon de mens enkel overstijgen door zich te onttrekken aan datgene wat zijn zinnelijke natuur hem ingaf. Wie een maagdelijk bestaan gewijd aan God verkoos, liet zich als het ware door Hem uit de wereld trekken en oversteeg de eigen menselijke natuur. De strenge leef- en gedragsregels die de kloppenboek-auteurs aanreikten, waren bedoeld om geestelijke maagden te behoeden voor eigen driften en eigenzinnigheid en om hun streven naar religieuze perfectie in goede banen te leiden. ${ }^{191}$ Versterving en penitentie moesten een mentale afsluiting van de wereld bewerkstelligen, die het gebrek aan een fysieke afscheiding zoals kloostermuren zou vergoeden:

'De opsluiting der kloostermaegden moet niet aengesien worden voor een wet ofte schutting, dewelke een strenge wetgever door sijne magt en gesag aen de sielen oplegt: maar wel (...) voor eene wet en eene schutting dewelke mijn hart en mijne siel, om sich aan u [God] toe te heyligen, en om in't toekomende niet als u te soecken ende te beminnen, oplegt aen de wereld, en aen de wereldsche menschen',

aldus Maria Anna du Val de Dampierre, toen zij inmiddels vrede had met een religieus bestaan buiten het klooster. ${ }^{192}$ Eenzelfde dictum als de vroeg-christelijke leidsmannen hun geestelijke dochters hadden voorgehouden, schrijven de zeventiende-eeuwse auteurs hun maagden voor: de omgang met anderen, in het bijzonder 'wereldse' personen, moet beperkt of zelfs vermeden worden; zij moeten liever het stilzwijgen bewaren en zich niets gelegen laten liggen aan geld, goederen en andere bezittingen. Ook de aansporing regelmatig te vasten komt voort uit het streven de banden met het aardse en de verlangens van de menselijke natuur te beperken. De jezuiet Hazart vermaant de maagden, onder verwijzing naar de vroeg-christelijke auteur Fulgentius, dat de hemelse Bruidegom geen lichaam wil dat gewend is aan wellust, maar een lichaam dat getemd is door vasten. ${ }^{193}$ Juist omdat zij hun lichamelijke en geestelijke zuiverheid te midden van allerlei wereldse

190 Leven Mana Anna du Val de Dampierre, 85. De angehaalde passages zijn volgens auteur Leroy aan haar eigen geschriften ontleend.

191 Onderwijsingen (...) voor de geestelyke dochters van het Oratone, 'Voorreden'.

192 Leven Mana Anna du Val de Dampeerre, 48I-482. Eenzelfde redenerung in Schoenius, Weg, 74-75.

193 Hazart, Lof, 98. 
Afb. 8 Een geestelijke maagd wendt zich, geknield voor een (huis)altaar, in gebed tot haar Bruidegom. Het onderschrift van dit bidpentje luidt:

' $O$ Gesus soet mijnen Beminden Laet mijn ziel $u$ altijdt vinden'.

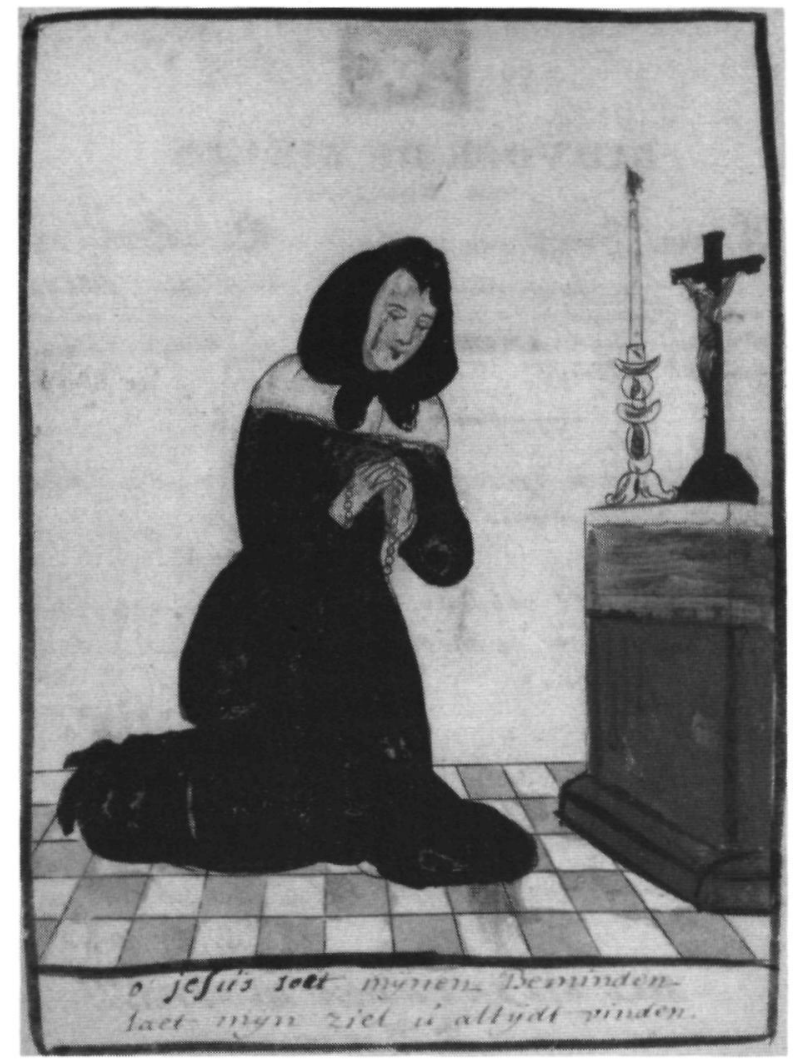

verleidingen bewaarden, zou deze hun misschien wel meer glorie brengen. ${ }^{194}$

Alle christenen zagen zich geconfronteerd met de tegenstrijdige verhouding van de mens tot de wereld, maar voor vrouwen was deze ambivalente relatie extra beladen. Poirters' omschrijving van de wereld als 'snoode vrouw' drukt uit hoezeer vrouwen en vrouwelijkheid in de zeventiende-eeuwse katholieke belevingswereld met zonde en verleiding werden vereenzelvigd. ${ }^{195}$ Sinds de Latijnse kerkvader Ambrosius werd de vrouwelijke sekse nauw geassocieerd met sensualitas, zinnelijkheid en lichamelijkheid. Zijn denkbeelden werkten sterk door in de middeleeuwse scholastiek, die de opleiding van geestelijken in de vroegmoderne tijd nog in hoge mate bepaalde. ${ }^{196}$ Vrouwen zouden 'van nature' in fysiek en moreel opzicht zwakker zijn dan mannen. Hadden vroeg-christelijke auteurs nog gepredikt dat de maagdelijke staat voor vrouwen én mannen aanbevelenswaardig was, in de reprises van hun lofprijzingen in de meeste kloppenboeken valt een sekse-specifieke

194 Van Heumen, Clooster van Sion, I, 'Voorreden'.

195 Poirters, Het daeghelycks nieuwe-jaer spieghelken, 38.

196 Jedin, 'Religiöse Triebkräfte', 562-564. 
dimensie te ontwaren. ${ }^{197}$ De maagdelijke staat wordt daarin gepresenteerd als een probate manier voor vrouwen om de, voor hen in het bijzonder, als gevaarlijk beschouwde verhouding tot de wereld zoveel mogelijk te neutraliseren. Wanneer vrouwen de staat der maagden aannemen, dan verdrijven zij door voortdurende deugdbeoefening 'allen het ghene dat vrouwelijc is', aldus de pastoor van het Antwerpse begijnhof, Lumnius. ${ }^{198}$

Vrouwen die de maagdelijkheid verkozen en een ascetisch bestaan leidden, konden hun 'natuur' overstijgen, daarvan waren verschillende kerkvaders en -leraren al overtuigd. ${ }^{199}$ Kloppenboek-auteurs grijpen hier instemmend op terug, maar zij betuigen zich tevens schatplichtig aan de scholastiek. Zij houden staande dat vrouwen en mannen naar de ziel gelijk zijn, 'even edel ende gheestelijck, even wel en konstich ghemaeckt, na het beeldt ende ghelijckenisse Godts'. ${ }^{200}$ Maar lichamelijk gezien zijn vrouwen toch 'krancker (...), meer teerder ende swacker, ende onedelder'. ${ }^{201}$ Om hun spiritueel potentieel te verwezenlijken, moeten vrouwen zich daarom manhaftig afwenden van de wereld en het vlees, en zich bekeren tot de maagdelijke staat. ${ }^{202}$ De maagdelijke levensstaat - in of buiten het klooster volbracht - dissocieert vrouwen, naar de mening van de kloppenboek-auteurs, van de eigenschappen die met hun sekse in verband worden gebracht. Noties over vrouwelijkheid en mannelijkheid zın in hun betogen niet onlosmakelijk verbonden met vrouwen en mannen. Vrouwen die huwelijk en kinderen versmaden voor de maagdelijke staat, getuigen van 'mannelijke' moed en vasthoudendheid en benaderen mannen in hun 'natuur', die als zodanig superieur geacht wordt aan die van vrouwen.

\section{Zelfherliging in de wereld}

Behalve een poel des verderfs, was de wereld tevens een plaats waar een religieuze roeping verwezenlijkt kon worden door werken van naastenliefde. In de vonge paragraaf is erop gewezen dat sommıge geestelijken impliciet of expliciet meer waardering hadden voor geestelijke maagden dan voor monialen, omdat eerstgenoemden zich op maatschappelijke terreinen dienstbaar maakten. Liefdadige en

197 Bugge, Virginatas, 4, plaatst de oorsprong van de sekse-spectfieke waardenng van de maagdeliskhe1d in de late middeleeuwen Girard de Viltherry, Het leven der maegden, I4, vormt onder de kloppenboeken-auteurs een uızondenng, doordat huj nadrukkel, ,k stelt dat de kerkvaders de maagdelyke staat zowel aan vrouwen als aan mannen aanbevalen.

198 Lumnus, Van dleven, 16

199 Ruether, 'Musogynism', 157-164, Vogt, 'Man worden'; Opıtz, 'Hunger', 60.

200 Bisschop, Lof der Suyverheydt, II, 49.

201 Ibıdem; vgl. De Roa, Leven Sancia Canllo, 170 . Voor de opvattungen over de gelıkenıs naar Gods beeld in ziel en lichaam van mannen en vrouwen, zıe Gōssmann, 'Das Gottes- und Menschenbild', 129

202 Hazart, Lof, 95, vgl De Roa, Leven Sancia Canllo, 40-41, 54-55, waar het streven van deze Spaanse geestelıke dochter verbonden wordt aan 'mannelıke' moed 
andere werkzaamheden bepaalden tot op grote hoogte de identiteit en het aanzien van geestelijke maagden. Maagd zijn alleen is niet genoeg, aldus de kloppenboekauteurs. Dat behaagt God weliswaar, maar het verheugt Hem ook als geestelijke maagden werken en hun arbeid - ook de meer profane - aan Hem opdragen. Met 'stille wercken' als spinnen, kantklossen, tapijtwerk, breien of naaien mogen maagden in hun onderhoud voorzien. ${ }^{203}$ Wat ze ook doen, hun papieren leidsmannen houden hun voor hierbij telkens aan God te blijven denken en zorg te dragen voor hun eigen deugdzaamheid. ${ }^{204}$ Arbeid wordt op deze wijze gespiritualiseerd en tot een vast bestanddeel van de staat der geestelijke dochters gemaakt, dat hun religieuze plichten niet noodzakelijkerwijs doorkruist. ${ }^{205}$

Wie niet hoefde te werken om te leven, kon een religieus gelegitimeerde levenstaak vinden in werken van barmhartigheid, zoals de zorg voor armen, zieken, en ouden. ${ }^{206}$ De wereldheer Van Heumen beschouwt ziekenbezoek als een heilig werk, dat van geestelijke maagden 'Goddelijcke menschen' maakt. ${ }^{207}$ Hun hulp zou gelijk zijn aan de 'hulpe Godts'. Zij konden patiënten leren dat ziekte door God gezonden was en dat genezing afhankelijk was van geduld, inkeer en Zijn genade. De restricties die de kloppenboeken opleggen ten aanzien van de omgang met anderen en het verlaten van eigen huis of kamer, worden versoepeld bij het verrichten van liefdewerken. Natuurlijk kon men zich ook dienstbaar maken door iets fraais te borduren ter ere van het Heilig Sacrament, kandelaren te poetsen of kerklinnen te wassen. Lovenswaardig in de ogen van de auteurs was ook de materiële steun die geestelijke maagden aan de kerk en aan de dienaren in de wijngaard des Heren boden.

Werken voor de kost of voor de kerk wordt voorgespiegeld als een specifieke manier waarop geestelijke maagden Christus konden navolgen. Door te werken onderwierpen geestelijke maagden zich bovendien aan het oordeel dat God over de eerste mens had uitgeproken na de verbanning uit het Paradijs: Adam en zijn nakomelingen zouden voortaan in het zweet huns aanschijns hun brood verdienen. ${ }^{208}$ Het sekse-specifieke karakter van Gods oordeel over Adam (Gen. 3,16) wordt daarbij niet altijd onderkend. Misschien wel omdat het vonnis dat over Eva werd geveld (Gen. 3,19), dat zij en haar geslachtsgenoten voortaan in pijn kinderen zouden baren en dat hun begeerte in het vervolg zou uitgaan naar

203 Bisschop, Lof der Suyverheydt, III, 172. Zie ook Kemp, Zedelessen, 99-100.

204 Bijvoorbeeld Lindeborn, De Leeder facobs, 213-218; Onderwysingen (...) voor de geestelycke dochters van het Oratone, 146-149; Reghel der volmaecktheyt, 62; Kemp, Zedelessen, 103, Poirters, Het daeghelijcks nieuwe-jaer spreghelken, 42-45.

$205 \mathrm{Vgl}$. Therry, De relgieuze beleving, 45-46, die stelt dat arbeid in de vroegmoderne, katholieke samenleving werd beschouwd als boetedoening en vorm van ascese.

206 Gerardi, Spregel van Philotea, 99, maakt de uitvoering van deze taken afhankelijk van de sociaaleconomische status van vrouwen.

207 Clooster van Sion, IV, sermoen 8.

208 Lindeborn, De Leeder facobs, 207-208, F.V.O.C.S., Leven Anna de Torres, 14. Vgl. Reghel der Volmaecktheyt, 22, waar zowel naar Christus als Adam als voorbeeld wordt verwezen. 
hun man, voor kuis levende geestelijke maagden niet toepasselijk was.

Door te werken makten geestelijke maagden zich niet alleen nuttig, maar deden zij ook recht aan de dubbele roeping die aan hun leefwijze ten grondslag lag. De wenselijke verhouding tussen contemplatie en actie wordt traditioneel uitgedrukt aan de hand van de gezusters Maria en Martha, die Jezus in hun huis ontvingen (Luc. I0,4I). Terwijl Martha door het huis redderde om de gast van eten en drinken te voorzien, vlijde Maria zich aan diens voeten om geboeid naar hem te luisteren:

'De twee ghesusters Maria ende Martha moet ghy altijdt by u herberghen, maer so nochtans dese onthalen, dat Martha weet veel te klaghen, als dat ghy met Maria in het ghebedt meer bekommert zijt tot den dienste Godts, dan met haer besich zijt eenich handtwerck te doen tot u gemack, of hulpe van andere. ${ }^{309}$

Niet alle geestelijke maagden konden Maria's zijn, zo geeft Lindeborn toe. Voor het merendeel waren zij Martha's, en dat was goed, 'want geestelijke en lichamelijke arbeid gaen wel t'samen'. ${ }^{210}$ Toch moest het contemplatieve karakter van hun bestaan altijd de overhand hebben boven het actieve. Dat verklaart wellicht waarom de religieuze plichten van geestelijke maagden in de dagordes breed uitgemeten staan, in tegenstelling tot werken van barmhartigheid. ${ }^{211}$

Maria én Martha zijn was niet eenvoudig. In de vita van Anna de Torres wordt benadrukt hoezeer liefdewerken inbreuk plegen op het teruggetrokken leven dat zij nastreefde. Soms boezemden deze haar regelrecht weerzin in. Andere levensbeschrijvingen daarentegen benadrukken juist de vreugde en inspiratie die vrouwen putten uit hun activiteiten voor kerk, clerus en naasten. ${ }^{212}$ De jezuïeten-klop Joanna van Randenraedt wordt bijvoorbeeld voorgesteld als onvermoeibaar in werken van barmhartigheid:

'Want hare Liefde was een werckende Liefde, die alle menschen tot Godt socht te trecken, allen arbeyt tot Godts glorie t'onderstaen, alle goede wercken te doen, hier toe wenschende duysent lichamen, om alle sielen met de selve liefde t'ontsteken. ${ }^{.13}$

Geestelijke maagden konden zich ook dienstbaar maken aan God en hun geloofsgemeenschap door met hun ingetogen, godvruchtige leefwijze model te staan voor anderen. Daarom had God hen juist 'in 't midden der wereldlijken' gelaten, volgens Lindeborn, en niet 'in de omtuinde kloosters'. Kloppen moesten andere

209 Bisschop, Lof der Suyverheydt, III, 4I3. Maria Anna du Val de Dampierre identificeerde zich vanuit een iets andere invalshoek met Martha, zoals blijkt uit haar Leven, 467. Net als Martha was zij onrustig en kon zij haar verstand niet in toom kon houden. Haar streven was nu juist meester te zijn over haar hart en verstand en daartoe had zij Gods genade nodig.

210 Lindeborn, De Leeder facobs, 208.

21I Wel wordt 'handwerk' in de dagordeningen van de meeste kloppenboeken vermeld. Mij schijnt toe dat hiermee vooral werkzaamheden als bron van levensonderhoud bedoeld zijn.

212 Dit contrast tussen Leven Anna de Torres en Leven Sancia Carillo enerzijds en Kort Begryp en Leven ende deughden anderzijds, waarin de levens van respectievelijk Joanna van Randenraedt en Agnes van Heilsbach beschreven staan, is uiteengezet in Monteiro, 'Den middelen staet', 150-153.

213 Kort Begryp, 189. 
gelovigen inspireren tot zorg voor hun eigen zaligheid door voorbeeld en vermaning. ${ }^{214} \mathrm{De}$ - misschien wel vrouwelijke - auteur van het handschrift getiteld Maniere van leven van eene geestelijcke maeght inde weerelt, oppert de gedachte dat geestelijke maagden moeten proberen anderen voor zich in te nemen door een zekere familiariteit, zonder evenwel gezag te verliezen of minachting in te boezemen. ${ }^{215}$

De communis opinio van de kloppenboek-auteurs luidt dat geestelijke maagden zich moesten onthouden van het bekeren van ketters. Dan immers zouden zij debatten moeten aangaan op het theologisch vlak, dat voor vrouwen in de vroegmoderne tijd nog als verboden terrein gold. ${ }^{216}$ Slaan we hier de stichtelijke levensverhalen van verschillende maagden op na, dan blijkt dat zij zich niettemin vol overgave op 'ketterse' dan wel lauwe zielen hebben gestort. De hieruit volgende bekeringen tot een christelijk leven volgens de katholieke leer worden vermeld onder het lemma 'liefdewerken'. Toch zien de auteurs liever dat vrouwen zich van een meer subtiel bekeringsprogramma bedienen, dat de gedragscodes die er voor hun sekse golden, niet schendt. Een geestelijke maagd mocht best proberen 'ketters' in eigen familie, kennissenkring of buurt tot inkeer te brengen door hun devote presentjes te schenken, zoals beeldjes, rozenkransen en vooral geestelijke boekjes over het katholieke geloof. ${ }^{217}$

Onderwijs aan kinderen en meisjes was een terrein waarop geestelijke maagden zich volgens de kloppenboek-auteurs wél mochten ontplooien. De anonieme auteur van Maniere schrijft dat geestelijke maagden zelfs hun eigen gebed mogen onderbreken om kinderen tot gebed, biecht en communie aan te zetten. ${ }^{218}$ Uitgaansrestricties worden ruim geïnterpreteerd voor maagden die onderwijs geven. Vooral auteurs uit de kring der jezuieten stellen het onderwijs aan meisjes voor als de taak bij uitstek waardoor geestelijke maagden hun roeping en staat kunnen verwezenlijken. ${ }^{219}$

214 Lindeborn, De Leeder facobs, 74-76.

215 Ruusbroec-genootschap Antwerpen, sign. 95 (I 100 E 28), Manere van Leven van eene geestelycke maeght inde veerelt, 57 Met dank aan dr. $R$ van Dijk van het Titus Brandsma-Insutuut te Nijmegen, die dit handschnft op microfiche ter beschrkkung stelde. In de Jezwetenbibliotheek Berchmanianum, Nijmegen, Collecue Canisianum, berust eveneens een versie van dit manuscript (sign. $5000 \mathrm{~A}$ il). In dit exemplaar staat op het schutblad vóór de titel Johanna Cathanna Josepha Honı[n]g[a] I685. Wellıcht was zu (één van de) eıgenares(sen) of een kopuiste. Volgens opgave in de inventans is de auteur van dit handschnft een jezuset OP P. 458 identificeert de auteur zich met de geestelı)ke maagden. Het is derhalve niet uitgesloten dat dit manuscnpt door een vrouw, c.q. geestelı)ke dochter is vervaardigd De plaats van oorsprong moet gezıen het taalgebruik en plaatsaanduidıngen in de Zuıdelıke Nederlanden gezocht worden

216 Een regel waar duer als een Spreghel, kapittel XVIII; Munnos, Leven Aloysıa de Caravaıal, 180-18I. 217 Gherard, Spreghel van Phulotea, 98, rol. Vrouwen die in goeden doen waren, mochten dergelıke polemische, stuchtellyke boekjes ook laten drukken.

218 Manere, 76-77

219 Bisschop, Lof der Suyverheydt, III, 413-428. Hazart, Lof, 163, citeert Lessius m b.t. het catechusmusonderwils dat geestelıke dochters aan kunderen geven Kort Begryp, 96; Leven ende deughden, 89-90 
'De sielen bekeeren, die te leren, te helpen aen de deughden, is een groot sacrificie; het is het goddelijckste werck datmen her kan gedoen, (...) een werck der volmaeckte, een werck der Apostelen."220

Deze vorm van apostolaat werd ook gepraktiseerd in de Zuidelijke Nederlanden, waar gemeenschappen van geestelijke dochters zich exclusief op het meisjesonderwijs hadden toegelegd. ${ }^{221}$ In de Hollandse Zending concentreerden kloppen zich, zoals in het vorige hoofdstuk uiteen is gezet, vooral op het elementair geloofsonderricht, aan kinderen én volwassen.

Het gewicht dat in kloppenboeken gehecht wordt aan het onderwijs aan meisjes, moet vooral geplaatst worden in het licht van de confessionele richtingenstrijd in de zestiende en zeventiende eeuw. ${ }^{222}$ Geestelijke maagden leverden met gedegen geloofsonderricht een bijdrage aan de 'inplanting' van het 'ware' geloof op termijn. Later in hun leven zouden de meisjes die zij onderwezen hadden, als moeders de beginselen van het geloof overbrengen op hun eigen kinderen. Voor kloppen zelf zal de overtuiging dat zij door onderwijs meer genade konden verwerven dan door welke geestelijke oefening ook, misschien belangrijker zijn geweest. De jezuïet Bisschop houdt hun voor dat het verzorgen van onderwijs een integraal bestanddeel vormt van hun bestaan en identiteit en rechtvaardigt dat hun een plek gegund wordt temidden van de geestelijke personen. ${ }^{223}$ Want wie een ander in geloof en deugdzaamheid onderwijst, die doet werk van gewijde mannen.

'Hoort ghy dit, O Maghet? 't Welcke u het gheslachte weyghert, dat gheeft u het schoolhouden (...). Hoor 1ck u niet somtıjden clagen, dat ghy een Vrouwe vande nature gheboren zijnde, verboden wordt groote saken te doen, Godt dagelycx sacnficie te offeren, te predicken, de menschen overluydts den wille Godts te leeren. ${ }^{234}$

Wat geestelijke maagden op grond van hun vrouw-zijn verboden was, konden zij in stilte en 'met minder schade' in de beslotenheid van hun eigen huis realiseren door het onderrichten van jonge meisjes. Zo konden zij hun roeping tot maagdelijke volmaaktheid verwezenlijken en de priesterlijke waardigheid, waarvan zij op grond van geslacht waren uitgesloten, door de verdienste van hun werkzaamheden benaderen. Niet alleen een jezuïet als Bisschop onderschrijft deze stelling. Ook de augustijn Fulgentius Stevins beschouwt onderwijs als een eerbaar ambt voor geestelijke maagden, gelijkwaardig aan dat van de 'Leeraers en Priesters'. ${ }^{25}$ En de anonieme auteur van Onderwysingen stelt het onderwijs aan kinderen voor als een vorm van navolging van Christus, die ook vrouwen kunnen praktizeren. ${ }^{226}$

Vgl. Leven Mana Anna du Val de Damplerre, 338-339.

220 Bisschop, Lof der Suyverheydr, III, 414.

221 De Vroede, 'Kwezels' en 'zusters', 162-177; Janssens, 'Geestelijke dochters', 333.

222 Conrad, 'Katechismusjungfrauen', 158.

$223 \mathrm{Vgl}$. Conrad, Zwaschen Kloster und Welt, 149, die uit de regel van het Keulse Ursula-gezelschap opmaakt dat onderwijsactviteiten een 'Konstututivum thres Selbstverstandnisses' uitmaakten.

224 Bisschop, Lof der Suyverheydt, III, 422.

225 Stevins, Regel, 26.

226 Onderwysingen (...) voor de geestelycke dochters van het Oratone, IO-I I. 


\section{III.5 Vrouwelijke identiteiten}

Dat geestelijke maagden anderen onderwezen in de beginselen van de geloofsleer, was geen vanzelfsprekendheid in de toenmalige confessionele context. De apostel Paulus had vrouwen dit immers expliciet verboden. Kloppenboek-auteurs - als geestelijken geschoold in de scholastieke traditie - namen diens leerverbod doorgaans over. Onderrichten vormde het privilege van mannen. Maagden moesten zich ervoor hoeden de rol van leidsman of predikant op zich te nemen, zo wordt in de stichtelijke handleidingen beaamd. ${ }^{227}$ Door onderwijs te verzorgen laadden zij die verdenking soms op zich. Een Leidse jezuieten-klop werd er bijvoorbeeld van beschuldigd, zo kwam in het vorige hoofdstuk al aan de orde, dat zij preekte hoewel ze enkel catechisatie gaf. De rechtvaardigingen die geestelijken aanvoerden voor de onderwijsactiviteiten van vrouwen, illustreren dat geestelijke maagden hiermee een aan hun sekse gestelde grens overschreden. Nood brak dan wel wet, zoals de karmeliet Petrus a Matre Dei in 1658 verkondigde, geloofsonderwijs verzorgd door geestelijke maagden bleef een beladen kwestie. De omzichtige beschrijving van de werkzaamheden van Luisa de Carvajal y Mendoza illustreert dat eveneens. Zij toog naar Engeland om er 'ketters' te bekeren en haar geloofsgenoten, die verstoken waren van zielzorgers en geloofsonderricht, bij te staan. Aangezien zij als vrouw in staat was andere vrouwen in hun eigen huizen te bezoeken zonder al te veel opzien te baren, werden haar activiteiten gebillijkt. Wijze vrouwen als Luisa bewezen de kerk een dienst door hun seksegenoten in het evangelie te onderwijzen, aldus de auteur van haar vita. ${ }^{228}$ Maar hij liet er tegelijkertijd geen misverstand over bestaan, dat geen enkele vrouw uit eigen beweging een dergelijke taak op zich mocht nemen.

\section{Haar plaats weten}

Bronnen als kloppenboeken laten zien hoe wezenlijk voorstellingen van sekse waren voor zeventiende-eeuwers om de wereld om hen heen te begrijpen. Betogen van geestelijken in kloppenboeken getuigen van deze voorstellingen, die niet alleen een afspiegeling vormen van de vroegmoderne maatschappelijke orde, maar daaraan zeker ook een bijdrage hebben geleverd. Deze stichtelijke werken representeren én construeren verschillen tussen mannen en vrouwen, tussen mannelijk en vrouwelijk, en tussen mannelijkheid en vrouwelijkheid. Met behulp van deze verschillen worden gebeurtenissen en verschijnselen in de alledaagse werkelijkheid benoemd. Het onderscheid naar sekse fungeert in dit ordeningsproces als een fundamentele categorie, die betekenis en waarde geeft aan gedragingen, gewoonten en eigen-

227 Maniere, 67. Een regel waer duer als een Spieghel, kapittel XVII.

228 Munnos, Leven Aloysia de Caravaial, 180-184. Zie voor haar opmerkelijke missie-activiteiten Ortega Costa, 'Spanish women in the Reformation', 105-108. 
schappen, die veelal niets uit te staan hebben met fysieke of biologische verschillen.

Katholieke geestelijken stelden het voor als een door God ingestelde orde dat vrouwen een aan mannen ondergeschikte plaats toekwam in het kerkelijke en maatschappelijke domein. Op het punt van de wenselijk geachte gezagsverhoudingen tussen de seksen stemden hun denkbeelden overeen met die van hun protestantse tegenstrevers. ${ }^{229}$ In sommige kloppenboeken vinden we deze opvattingen in onversneden vorm. Vrouwen 'die haer mannen met autoriteyt gebieden', begaan een doodzonde, aldus bijvoorbeeld de wereldheer Willem Schoenus. ${ }^{230}$ De asymmetrische machtsrelaties tussen mannen en vrouwen worden, conform de scholastieke opvattungen over de seksen, gelegitimeerd vanuit de eigenschappen waarmee de leden van beide geslachten van nature begiftigd zouden zijn. Een korte analyse van deze attributen brengt in kaart welke denkbeelden over vrouwelijkheid in katholieke kring opgeld deden in de zeventiende eeuw.

Kerk en samenleving vertoonden allerlei sekse-specifieke markeringen. Aan de ordening van het kerkelijk domein lag bijvoorbeeld een strikte scheıding naar sekse ten grondslag. De bemiddelaar tussen God en gelovige was per definitie een man. Prediking en bediening van de sacramenten werd vrouwen ontzegd; die voorrechten waren aan gewijde mannen voorbehouden. ${ }^{231}$ De bijbel fourneert menig beperkend voorschrift met betrekking tot de rol van vrouwen in de kerk, waarop generatıes geestelijken en kerkelijke autoriteiten zich konden beroepen. In de scheppingsorde - Adam vóór Eva, en Eva uit Adam - zoals verhaald in het tweede scheppingverhaal in het boek Genesis, was een eerste verankering te vinden voor de stellıng dat God wilde dat mannen over vrouwen zouden heersen. ${ }^{232}$ Uitgaande van de natuurfilosofie van Aristoteles verklaarde Thomas van Aquino in de dertiende eeuw de bestaanszin van de vrouw uitsluitend en alleen uit de existentue van de man. Als 'mas occasionatus' - gemankeerde man - zou zij van nature aan de man ondergeschikt zijn. ${ }^{233}$ Bovendien, zo wordt kloppen voorgehouden, rechtvaardigt het gedrag van oermoeder Eva de overtuiging dat vrouwen te allen tijde

229 Voor een overzıcht van de denkbeelden van protestantse hervormers over vrouwen en gezagsverhoudıngen tussen de seksen, zie Kloek, 'De Reformatie'.

230 Schoenius, $\mathrm{Weg}, 172$.

23I U1t de achttiende eeuw zijn enkele preken bekend die werden gehouden door jonge meisjes van een jaar of ten Met een dergelıke preek werd bujvoorbeeld in 1771 een bedevaart naar Kevelaer besloten. Volgens Wingens, Over de grens, 221, werden deze prekende meisjes gezien als reine, onschuldige afspiegelingen van de heilige Maagd Mana Deze vorm van predikng tastte op geen enkele wize het voor vrouwen geldende verbod op (s)preken in de kerk aan

232 Literatuur over de sekse-specifieke aspecten van de bıbel-exegese is njk voorradıg De bıdragen in Braun en Gössmann, Eva, geven verschıllende vroegmoderne visıes weer.

233 Gossmann, 'Das Gottes- und Menschenbild', 131-132 Seculiere pnesters die in de Hollandse Zendıng werkzaam waren en die hun opleiding aan de theologische faculteit van de universiteit van Leuven hadden genoten, waren vertrouwd met de denkbeelden van Thomas van Aquino, alsook met de Arstotelısche natuurfilosofie Zie Jacobs en Smit, Van den Hogenheuvel gekomen, 79-8I en 2I4 
hun meerdere in een man moeten erkennen. Want toen Eva, 'de eerste Maget, in het paradijs hier en daer curieuslijck lanterfantelde ende wandelde, sonder dat Adam bij haer was', kostte het de duivel weinig moeite haar te verleiden. ${ }^{234}$ Daarom wordt Eva ook nog in de zeventiende eeuw afgeschilderd als instrument van de duivel, slachtoffer van haar eigen nieuwsgierigheid, hoogmoed, lichtgelovigheid en zinnelijkheid. ${ }^{235}$ Deze eigenschappen had zij, zo debiteerden geestelijken vanaf de kansel, overgeërfd op haar nakomelingen in de vrouwelijke lijn. ${ }^{236}$

'De natuerlijcke ghenegentheydt', ofwel de toegeeflijkheid ten aanzien van de eigen zinnen, 'dieder ghemeenlijck inde vrouw is', werd gezien als een bedreiging. Niet alleen voor vrouwen zelf, maar ook voor een ieder die met hen in contact kwam. ${ }^{237}$ De pastoor van het Antwerpse begijnhof, Lumnius, waarschuwt zijn collega's uitvoerig voor de verleidingskunsten van vrouwen, onder wie religieuze vrouwen geen uitzondering vormen:

'Alle onbetamelıke kaerschap [vnendschap] van den [kant van] vroukens, is het hly der sonden, ende een fenunuch teyr, waer mede den duyvel die sielen vangt ${ }^{\text {'. }}{ }^{28}$

Verslagen uit de Hollandse Zending ademen eenzelfde angstige, vooringenomen geest. Mogelijke verstoringen van de gezagsverhoudingen tussen de seksen, tussen gewijde en ongewijde macht, maar misschien ook een zekere voorzorg tegen scherpe aanvallen uit protestantse hoek gaven deze angst in. ${ }^{239}$ De carmeliet Petrus a Matre Dei, die de loftrompet steekt van de onderwijswerkzaamheden van geestelijke maagden in de 'ketterse' gebieden, toont zich ook sceptisch. Jonge priesters naar de Hollandse Zending sturen bergt volgens hem een zeker gevaar in zich, onder andere wegens de omgang met kloppen. ${ }^{240}$

Niet alleen deze karmeliet maakte zich hierover zorgen. Bij de wankele gezagsverhoudingen binnen de katholieke geestelijkheid in het Hollandse missiegebied, vormden de betrekkingen tussen geestelijken en maagden een zwakke plek. Seculieren noch regulieren bleven verschoond van allerlei aantijgingen met betrekking

234 Bisschop, Lof der Suyverheydt, III, I5.

235 Gabnel a S Joanne Baptsta O Carm, Het gheestelyck houwelyck, 26-27. Vgl Delumeau, La peur en Occident, 305-345

236 Rotsaert, Tussen Eva en Mana, 65-68. In dit onderzoek naar de betekenis van sekse in het preekvertoog worden untgegeven preken van verscheidene Zuidnederlandse geestel,jken geanalyseerd Naar de preek-cultuur an de Hollandse Zendıng is nog nauwelıks onderzoek gedaan Vele geestelıken die hier gedurende de zeventende eeuw werkzaam waren, hadden hun opleiding genoten aan een seminane in de Zuidelıke Nederlanden Daarom zal de preek-cultuur in de Noordelıke en de Zuidelıke Nederlanden zeker overeenkomsten vertoond hebben, ook al omdat gedrukte prekenbundels uit de Zuidelyke Nederlanden ook in de Hollandse Zending in gebruk waren Cloet, Nissen en Stome, 'Status quaestionis', 202

237 Bisschop, Lof der Suyverheydt, III, 35-36.

238 Lumnius, Van dleven, 227

239 Ozment, When fathers nuled, hoofdstuk I, wijst er bıjvoorbeeld op dat Maarten Luther en zıjn aanhangers katholieke geestelıken ervan beschuldıgden zich in hun hoedanigheid van biechtvader niet zelden onorrbaar te gedragen tegenover vrouwelı)ke penitenten

240 Petrus a Matre De1, Clara Relatuo, 125-1 26, 131, 133. 
tot kloppen; aantijgingen die, zoals inmiddels is aangetoond, vooral berustten op een negatieve beeldvorming. ${ }^{24 I}$ De angst voor ongepaste, zelfs onkuise omgang tussen priesters en kloppen prikkelde niettemin de waakzaamheid van de Romeinse curie, alsook van de gezagsdragers in de Hollandse Zending zelf. De eerste apostolisch vicaris, Sasbout Vosmeer, uit zijn bezorgdheid over de contacten tussen priesters en kloppen in een brief aan zijn broer Tilman in I6I I. Geestelijke maagden zouden te zeer beslag leggen op de clerus en bovenal gevaarlijk zijn in de omgang. Ter adstructie haalt hij de rector van het jezuietencollege te Keulen aan, die zijn medebroeders met de woorden van Franciscus Xaverius vermaande 'dat men met korte woorden en in't openbaar met de vrouwspersoonen moet handelen: want dat het een zeer glibberige zaak is, daar zeer kleine winst en zeer groot gevaar in steekt' ${ }^{242}$ Sasbouts opvolgers drukken priesters in verschillende instructies op het hart vrouwen met uiterste discretie tegemoet te treden, vooral in de biecht. Om opspraak te voorkomen, diende bij vrouwen de biecht in een open ruimte afgenomen worden, binnen een zo kort mogelijk tijdsbestek. ${ }^{243}$

Hoe veronderstelde sekse-specifieke eigenschappen aan vrouwen toegeschreven worden, kan nauwkeurig worden gevolgd in kloppenboeken. In de ogen van de jezuiet Bisschop zijn geestelijke maagden bijvoorbeeld 'van nature armer (...), onstantvastiger en onverstandigher dan een mans persoon, ende daerom meer onderworpen [aan] de ellenden ende perijckelen, die in ' $t$ gheestlijck leven te vinden zijn'. ${ }^{244}$ In deze zinsnede koppelt hij de vrouwelijke sekse aan morele en intellectuele (dis)kwalificaties. Deze koppeling krijgt een hiërarchische dimensie door de vergelijking met de mannelijke sekse, die in dit betoog negatief uitpakt voor vrouwen. Gezien het prescriptieve karakter van dit kloppenboek hebben we hier niet louter met definities van sekse te maken, maar met coderingen of richtlijnen, met geseksueerde markeringen die de zeventiende-eeuwse maatschappelijke verhoudingen onder katholieken beoogden te beinvloeden.

24I Schulte van Kessel, Geest en vlees, hoofdstuk III.

242 [Van Heussen], Batavra Sacra, of Kerkelyke Histone, III, 202-203.

243 'Statutum Illustnssimı ac Reveredıssımı Philıppı Rovenn V A. pro clero', d d 27 september 1618. Geciteerd in [Van Heussen], Batavia Sacra, II, 76-77. In de 'Constitutio Illustrissımı ac Reverendissıms Dominı, D Archiepiscopı Philippensıs, et vicarı apostolıcı per unitas Belgiı Provincias', d d. 30 junı 1628 en 12 december I638, herhaalt Rovenius ziln waarschuwing, geciteerd in ibidem, II, I01, I07. Zachanas de Mez, co-adjutor van apostolisch vicans Jacobus de la Torre (I65I-1662) vermaant geestelıjken niet te lang met vrouwen te spreken in de biecht en bıj hen niet op frequent biechten aan te dringen. Zie zijn 'Brevis informatio, atque instructio a Missionanis in hoc Apostolico vicanata observanda'. Geciteerd in ıbidem II, 47I (art IV, vgl ook art. VIII) Ook Johannes van Neercassel waakte voor een al te gemeenzame omgang van pnesters met vrouwen in de biecht en daarbuiten, zoals blıkt uıt zıjn 'Consututiones servandae a Presbyteris in Foed Belg. laborantıbus', d.d 17 meı 1668, geciteerd in ıbıdem, II, 499 Ook elders waren kerkehıke gezagsdragers ervan doordrongen dat de biecht gelegenherd tot zonde bood. Vooral visueel contact tussen biechtvader en vrouwelıjke pententen poogde men te voorkomen door gedetalleerde instructues voor plaats en wijze van afname van de biecht en door de introductie van de biechtstoel. De Boer, Sinews of discipline, 138-156.

244 Bisschop, Lof der Suyverheydt, III, I 2-13 


\section{Manhaftige maagden}

Al waren de eigenschappen standvastigheid en rationaliteit dan van het predikaat 'mannelijk' voorzien, een en ander betekende niet dat vrouwen hiermee niet begiftigd konden zijn. Afgaande op de kloppenboeken kan vastgesteld worden dat zeventiende-eeuwse geestelijken onderscheid maken tussen biologisch geslacht enerzijds, en sociale eigenschappen van personen anderzijds. Natuurlijk maken mannen op grond van de toenmalige culturele definitie van mannelijkheid in de ogen van hun tijdgenoten meer kans om voor moedig of doortastend door te gaan. Toch kunnen ook mannen eigenschappen en lichaamskenmerken toegedicht kriigen die voor vrouwelijk doorgaan en vaak denigrerend bedoeld zijn. Eén voorbeeld om te illustreren dat nader onderzoek hiernaar de kennis over de betekenis van sekse in zeventiende-eeuwse katholieke context zal verdiepen.

Cornelis van Schoonhoven, de opstandige wereldheer die Joannes Lindeborns $S c a l a$ Jacab veroordeeld probeerde te krijgen door de Congregatie van de Index, maakte zijn superieuren het leven zuur. De strubbelingen tussen hem en zijn collega's dateerden van I643, toen Rovenius de Utrechtste priester Abraham van Brienen aanstelde als verantwoordelijke inzake de armenzorg. Hierover ontstak Van Schoonhoven in woede en brak hij los in een storm van aantijgingen jegens Van Brienen. Daarop werd hij in 1647 uit het pastoorsambt ontzet door de toenmalige nuntius Fabio Chigi. De stortvloed aan beschuldigingen aan het adres van Rovenius, zijn opvolgers De la Torre en De Metz, en wederom Van Brienen, nam daarmee geen einde. In de correspondentie van respectievelijk De la Torre en Joannes van Neercassel met de Brusselse internuntius wordt Van Schoonhoven als toegewijd zielzorger gediskwalificeerd. Met toespelingen op zijn uiterlijk en karakter proberen zij hun negatieve oordeel over deze priester kracht bij te zetten. Van Schoonhoven zou als mannelijk noch vrouwelijk kunnen worden gekarakteriseerd. Androgyn was een betere definitie voor deze priester, die in fysiek opzicht kenmerken vertoonde die eerder met vrouwen dan met mannen werden geassocieerd, zoals een ijle stem, een baardeloze kin en een hoge borst. Daarenboven omschreven beide apostolisch vicarissen hem als ijdel en pedant - eigenschappen die vooral aan vrouwen werden toegedicht. Naar hun oordeel was het allerminst verwonderlijk dat Van Schoonhoven, afgezien van een 'muliercula' (vrouwtje), nauwelijks gelovigen wist te boeien. ${ }^{245}$

Omgekeerd kon vrouwen die zich afwendden van de 'dienst des vleesch ende des wereldts' en de maagdelijke staat verkozen in plaats van het huwelijk, het predikaat 'manhaftig' ten deel vallen. Met de keuze voor een maagdelijk bestaan, omwille van God en in toewijding aan Hem, transcendeerden zij hun natuur, aldus het betoog in de kloppenboeken. Als manhaftige maagden, virago's, zijn zij verzekerd van een grotere gelijkheid met mannen, zoals hun die ook in de heilsorde

245 Post, Romeinsche bronnen, II, 75 (nr. 68); 630-63I (nr. 758). 
wordt gegund. Vrouwen heten net als mannen naar het beeld Gods geschapen en hebben daarom in het hiernamaals evenveel kans op zaligheid en wederopstanding als mannen. Toch wordt dan min of meer als voorwaarde voor deze postmortale equivalentie tussen de seksen gepostuleerd dat vrouwen die eigenschappen waarmee hun sekse ruimer bedacht zou zijn en die hun kwetsbaarder maken voor duivelse verleidingen en zonden, moeten afzweren. ${ }^{246}$

Als we haar levensbeschrijving mogen geloven, dan had de Spaanse geestelijke dochter Sancia Carillo zichzelf boven haar natuur verheven. Men leze hier niet alleen 'menselijke', maar ook 'vrouwelijke natuur'. De jezuïet De Roa beschrijft haar als een jonge vrouw die de duivel overwonnen had en menig man door haar moed zou beschamen. ${ }^{247}$ Want hoe konden mannen zich verontschuldigen voor hun slapheid en lafheid terwiil 'eene jonghe ende teere Maghet met soo groote kloeckmoedigheyt de duyvel overwonnen heeft, haer vleesch t'ondergebracht, ende getriumpheert van eyghen selve'? Sancia is de wellust, de meest geduchte vijand van de zaligheid die in de mensen zelf huist, door strenge penitenties de baas geworden. Wellust en zinnelijkheid zijn, zo zagen we, bij uitstek kwaliteiten waar vrouwen in de vroegmoderne tijd mee vereenzelvigd worden. Haar persistentie en moed in boetvaardigheid worden 'wonderlijk' genoemd, ${ }^{248}$ omdat deze eigenschappen in beginsel als 'mannelijk' gelden. Onder die noemer vlecht De Roa ze ook in zijn betoog: Sancia Carillo streefde de hoogste volmaaktheid na en had daartoe 'den sekeren wegh van mortificatie' verkozen, 'met eene mannelijcke, ja meer als mannelijcke couragie ende standtvastigheydt'. ${ }^{249}$

\section{Christus' bruiden}

Vrouwen die de maagdelijke staat verkiezen boven het huwelijk, volgen Maria en niet Eva na. Maria belichaamt het ideaal dat kloppenboek-auteurs hun maagden voorhielden: wijs en toch nederig zijn, want zonder nederigheid geen wijsheid. In Maria worden twee kwaliteiten verenigd die voor kloppen onmisbaar geacht worden: deemoedige maagdelijkheid en barmhartige moederlijkheid. ${ }^{250}$

Niet iedere ongetrouwde vrouw mag zo maar maagd heten, want niet iedere vrouw heeft haar maagdelijke staat aan God gewijd. Ware maagden hebben niet alleen een ongerept lichaam, maar ook een zuivere ziel. ${ }^{251}$ Daarom worden zij -

246 Bisschop, Lof der Suyverheydt, II, 49.

247 De Roa, Leven Sanca Carllo, voorwoord auteur, gericht aan Don Diego Femandez de Cordova (ongepagineerd).

248 Ibıdem, 55; zie ook 170.

249 Ibidem, 53. Een vergelijkbare redenering volgt Munnos, Leven Aloysia de Caravaral, 6.

250 Vgl. Rotsaert, Tussen Eva en Mana, 73, 78-79. Ook gehuwde en 'gewoon' ongehuwde vrouwen werd vanaf de kansel geraden zich aan Mana te spiegelen.

25I Girard de Vilthierry, Het leven der maegden, 18-19. Vgl. Lumnius, Van dleven, 26 en 212 . Rosweydus, Cort tractaet, 559. 
anders dan hun gehuwde en ongehuwde seksegenoten - beschouwd als dochters van God, koninginnen van de hemel ${ }^{252}$ en allerliefste bruiden van Christus. Het betoog dat de zeventiende-eeuwse jezuiet Heribertus Rosweydus over de verheven status van geestelijke maagden houdt, herinnert aan de stelling van de vroeg-christelijke auteur Methodius. In Symposium noemt hij maagden de wettige bruiden van Christus, terwijl alle andere vrouwen volgens hem enkel concubines zijn. ${ }^{253}$ De vroeg-christelijke auteur Tertullianus heeft vermoedelijk de benaming 'sponsa Christi' geintroduceerd voor elke maagd die zich aan Christus had toegewijd. ${ }^{254}$ Het beeld van de bruid had ook een minder gepersonifieerde en geseksueerde betekenis. In figuurlijke zin verwees het naar de individuele ziel, dan wel de kerk. In de twaalfde-eeuwse Hooglied-commentaren wordt de relatie tussen God en de mens bijvoorbeeld voorgesteld als die tussen brusdegom en bruid. ${ }^{255}$ Maar net als de pleidooien voor de maagdelijkheid wordt ook het bruid-motief door de zeventiende-eeuwse kloppenboek-auteurs van een sekse-specifieke lading voor zien. ${ }^{256}$ Daarmee wordt het in de kloppenboeken tot een identificatiemodel ontwikkeld waaraan ook religieuze vrouwen buiten het klooster zich konden spiegelen. ${ }^{257}$

De intrede in de kloppenstaat - of die nu door een belofte of enkel door een vast voornemen werd bestendigd - betekende de transformatie van een ongehuwde, maagdelijke vrouw in een bruid van Christus. $\mathrm{Zij}$ moest voldoen aan de hoge eisen die de positie van haar koninklijke, hemelse Bruidegom met zich meebracht. En natuurlijk moest zij in Christus, voorgesteld als man, haar heer en meester erkennen. ${ }^{258}$ De zielsverwantschap met haar Bruidegom woog zwaarder dan enige bloedverwantschap. De fundamentele verhouding tussen deze bruid en bruidegom was hierrarchisch. Al uiten de kloppenboek-auteurs zich - in navolging van hun bronnen - doorgaans negatief over het huwelijk als instituut, toch behoren geestelijke maagden zich aan de profane verhoudingen tussen echtelieden te spiegelen waar het hun eigen positie ten opzichte van hun Bruidegom betreft. ${ }^{259}$ Voor Christus' bruiden golden dezelfde zeden die de kerk gepast achtte voor gehuwde lekevrouwen: onvoorwaardelijke trouw en kuisheid tot de dag waarop de echtverbinte-

252 Een epiteton waarmee de maagd aller maagden, Mana, meestal werd getooid.

253 Castell, 'Virgunity', 67 (noot 23).

254 Adnes, 'Marnage et ve chretuenne', 393

255 Ibidem, 388-392. Kingma, De mootste onder de vrouwen, 120-134

256 Neercassel verwi)st in bneven aan verscheidene geestelı\}ke maagden juist naar het meer algemene bruid-begrip dat samenvalt met de ziel.

257 Vandenbroeck, Hooghed, 104, noemt expliciet monialen als bruiden van Chnstus Ook tertianssen, beginen, gasthuiszusters en geestelijke maagden identficeerden zich en werden geıdentıficeerd met bruiden

258 Vgl F V O C S., Leven Anna de Torres, 84, die zich voomam zichzelf als 'een suyvere Bruydt aen eenen Man Chnstus Jesus op te draghen'.

259 Zam, 'Ursula and Catherne', 262, merkt op dat de plechtıgheıd waarmee de geestelıke verbıntenus tussen een maagd en Chnstus bij de ursulmen in de zesnende eeuw tot stand kwam, een verhouding symboliseert die doet denken aan de band tussen echtelieden 


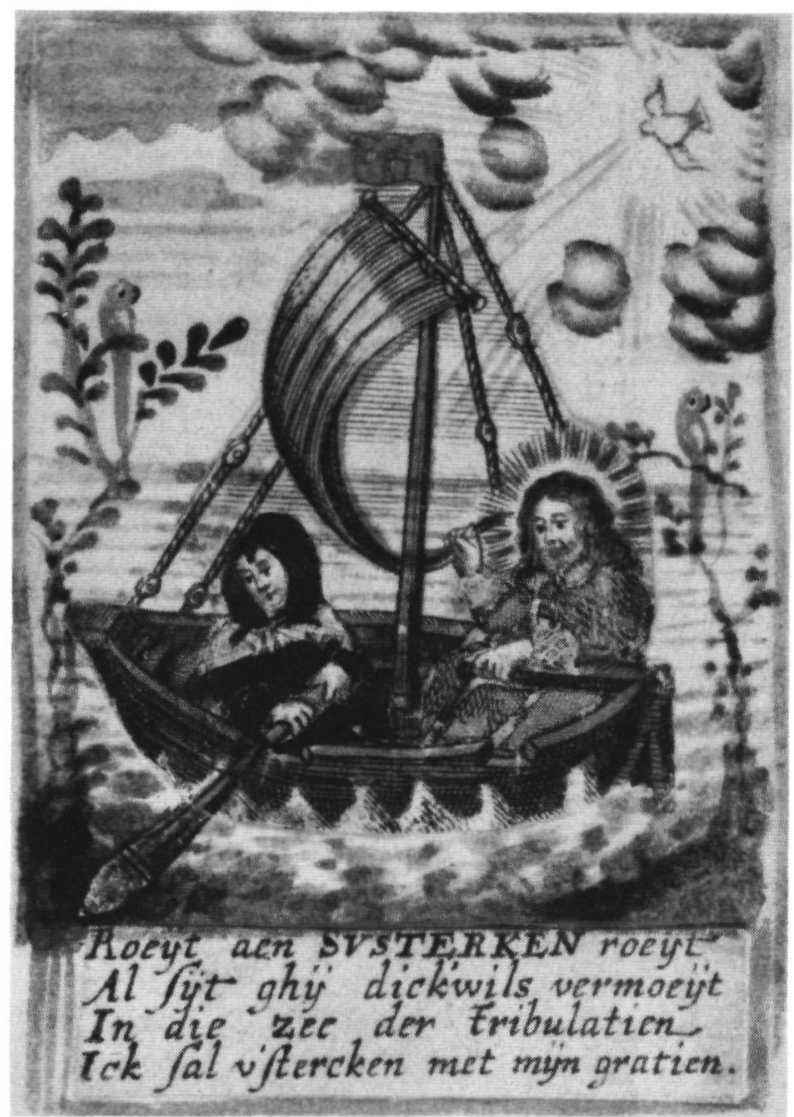

Afb. 9 De mystieke schuit op de zee der beproevingen, met Christus aan het roer en een geestelijke maagd aan de riemen. De voorstelling op dit (laat?-) achttiendeeeuwse bidprentje, die de band tussen bruid en Bruidegom symboliseert, kende nog andere varianten, namelijk met enkel twee religieuze vrouwen aan boord, of met Christus en twee religieuze vrouwen.

Het onderschrift luidt:

'Roeijt aen SUSTERKEN roeijt Al sijt ghij dickwils vermoeijt

In die zee der tribulatien

Ick sal u stercken met mijn gratien'.

nis zich zou voltrekken. Dat gebeurde wanneer een geestelijke maagd stierf. ${ }^{260}$

Wie een geestelijk huwelijk sloot met de hemelse Bruidegom door een belofte van zuiverheid, zag zich voor een levenslange opgave gesteld om de ongerepte staat van haar lichaam en ziel te bewaren. Deze zuiverheid werd gezien als een offer. ${ }^{261}$ 'En hy besit mijn hert, dat hy kocht met syn bloet', zo drukt de jezuïet Poirters het wederkerig karakter van dit offer, in casu het geestelijk bruidschap uit. ${ }^{262}$ Maagdelijkheid wordt in de kloppenboeken niet enkel voorgesteld als een noodzakelijke voorwaarde voor een spirituele verbintenis met Christus, maar ook als een opgave en voortdurende strijd, die in hoge mate de identiteit van deze religieuze

260 Vandenbroeck, Hooglied, 105 ( $\mathrm{afb}$. 95). Vrouwelijke religieuzen en begijnen lieten zich getooid met een bruidskroon op hun sterfbed vereeuwigen, ten teken dat het geestelijk huwelijk dat zij met Christus gesloten hadden, op het punt stond voltrokken te worden.

261 Lindeborn, De Leeder facobs, 56; Hazart, Lof, I5I, citeert Lessius, De bono castitate.

262 Poirters, Het daeghelijcks nieuw-jaer spieghelken, 28. Vgl. ook de vitae van Anna de Torres, Joanna van Randenraedt, Agnes van Heilsbach en Sancia Carillo. 
vrouwen bepaalt. ${ }^{263}$ De beloning voor de onvoorwaardelijke trouw aan de Bruidegom is in de kloppenboek-betogen verknoopt met heilsvoorstellingen, die de verheven positie van geestelijke maagden schragen. Dankzij de genade van hun Bruidegom kunnen de maagdelijke bruiden over eigenschappen beschikken, die als mannelijk gelden en die hen in staat stellen de strijd aan te binden met de duivelse vijand in een streven naar volmaaktheid en zaligheid. Instemmend worden vroegchristelijke autoriteiten als Cyprianus, Athanasius, Augustinus en Ambrosius aangehaald, volgens wie maagden als engelen onbesmet door de wereld passeren. Maagdelijkheid verjaagt dood en hel. Wie haar verkiest, wordt gelijk aan de onsterfelijke en onbederfelijke God. Zo zijn maagden reeds bij leven verzekerd van hun burgerschap in de hemel. ${ }^{264}$

Wie een godgewijd, maagdelijk bestaan verkoos, hoefde niemand anders dan God te gehoorzamen. Maagden hoefden zich, anders dan hun gehuwde seksegenoten, niet te schikken naar meer aardse vormen van gezag. Gehuwde vrouwen moesten in de eerste plaats hun echtgenoten gehoorzamen. Die moesten op hun beurt weer hun meerdere in God de Vader dan wel Zijn zoon erkennen. Maagden mochten deze stap als het ware overslaan. Als bruiden van Christus waren zij enkel aan hun hemelse Bruidegom onderhorig. Omdat zij van nature toch al aan Hem toebehoorden, bood deze gezagsverhouding veel vrijheid. Toch volgt hieruit, aldus het betoog van menige geestelijke auteur, dat zij hun biechtvader, die werd voorgesteld als Christus' of Gods aardse plaatsvervanger, onvoorwaardelijk moesten gehoorzamen. Geheel bevrijd van aardse, mannelijke autoriteit waren zij daarom niet.

\section{Maagdelijke moeders}

Als celibatair levende vrouwen kenden kloppen de lasten van het huwelijk niet of niet meer. Met barensweeën of opvoedingsperikelen hoefden zij zich niet te plagen. Toch mocht de kuise verbintenis met Christus niet onvruchtbaar blijven. Maagden zijn ook moeders, aldus de kloppenboeken. In plaats van kinderen van vlees en bloed, moeten zij 'geestelijke kinderen' ter wereld brengen, die onsterfelijk zijn. Werken van barmhartigheid of onderwijsactiviteiten gelden als passende vruchten van hun geestelijk huwelijk met de hemelse Bruidegom. Ook in hun hoedanigheid van geestelijk raadsvrouw of leidsvrouw worden geestelijke maagden bestempeld als moeders. Wie de scepter zwaaide over een kloppenvergadering was bijvoorbeeld een geestelijke moeder. Maar ook vrije maagden, die buiten een geformaliseerde vergadering leefden, konden zich moeders betonen door andere

263 Lumnius, Van dleven, 16; Girard de Vilthierry, Leven der maegden, 14-15.

264 Lumnius, Van dleven, 21-24; Rosweydus, Cort Tractaet, 549-552; Girard de Vilthierry, Leven der maegden, 9-13. Voor de denkbeelden van de kerkvaders, zie Castelli, 'Virginity'; Radford Ruether, 'Misogynism and virginal feminism'. 
kloppen met raad en daad ter zijde te staan of hen te onderrichten. ${ }^{265}$

Leiderschap van geestelijke maagden over andere geestelijke maagden of vrouwen wordt kloppen als nastrevenswaardig, hoewel uitzonderlijk en niet geheel zonder gevaar, voorgehouden. Angst maakte zich van Joanna van Randenraedt meester, toen zij zichzelf op jonge leeftijd aan de geestelijke leiding van een andere vrouw onderwierp, aldus haar 'biograaf' Daniël Huysmans S.J. ${ }^{266}$ Hiermee onderstreept hij in haar vita, zoals hij dat ook doet in die van haar geestelijk leidsvrouw Agnes van Heilsbach, dat het noodzakelijk was dat deze vrouwen een getrapt leiderschap uitoefenden over haars gelijken. Beiden waren door hun biechtvader, een jezuïet, als geestelijke moeder en 'meesteresse' over andere jezuïeten-kloppen in Roermond aangesteld. Onder zijn supervisie kweten zij zich van die taak. En al laten de gedrukte levens zien dat beide vrouwen eigenmachtig optreden niet vreemd was, toch onderstreept de voorstelling van hun leiderschap de gezagsverhoudingen die Huysmans als auteur wenselijk acht.

De subversieve kracht die besloten ligt in de beschrijving van het geestelijk leiderschap van deze twee vrouwen, moet niet onderschat worden. Kennelijk konden zij door hun biechtvader geautoriseerd worden om religieuze en morele instructies te geven aan andere vrouwen. Niet alleen deze geestelijk leidsman kon zijn gezag aan hen delegeren, maar ook God of Christus. Beide levensbeschrijvingen staan bol van bijzondere, bovennatuurlijke ervaringen van beide vrouwen. Klaarblijkelijk moesten die voorvallen lezeressen en lezers ervan doordringen dat niet alleen priesters uit naam van God of Christus konden spreken en handelen, maar ook vrouwen. Om het waarheidsgehalte van de levens te staven, benadrukt Huysmans dat deze gebaseerd zijn op eigenhandige geschriften van Van Randenraedt en Van Heilsbach. Hoewel er op zijn weergave van deze manuscripten nog wel het een en ander af te dingen valt, zoals in het volgende hoofdstuk nader toegelicht zal worden, kan niet ontkend worden dat de ervaringen en de kennis van beide vrouwen in de vitae gebruikt en gepresenteerd worden als bron van lering. Postuum leverden onderricht en geestelijke leiding aan anderen, die bij leven problematisch konden zijn, vrouwen minder moeilijkheden op.

'Nagtgesigten of visioenen', 'openbaringen' of 'wegrukkinge des geestes' zal de lezer niet aantreffen in zijn levensbeschrijving van Maria Anna du Val de Dampierre, zo waarschuwt auteur Leroy. Dit boek, in Nederlandse vertaling uitgegeven bij de jansenistische uitgever Hendrik van Rhijn te Delft, is eveneens gebaseerd op de 'Schriften en onderregtinge' van de hoofdpersoon zelf. Niet een mystieke band met God, maar haar volstrekt deugdzame levenswijze volgens de grondslagen van het evangelie, vormde de basis van het gezag van deze maagd. ${ }^{267}$ Dat strekte zich

265 Monteiro, "“Ick ben gekomen inde werelt", 79-84.

266 Kon Begryp, 26. Zijn weergave van Van Randenraedts angst strookt met haar cigen voorstelling, die echter meer ambivalent was dan Huysmans doet voorkomen. Zie hiervoor V.3 van dit boek.

267 Leven Maria Anna du Val de Dampierre, 'Voorreden'. 
niet alleen uit over andere vrouwen, maar zelfs over priesters. Was zij niet te spreken over de levenswandel van een ambtsdrager, dan berispte zij hem. Gaf hij geen gehoor aan haar klacht, dan wendde zij zich tot zijn superieuren. Haar huis werd volgens Leroy een soort kweekschool voor priesters die zij financieel en moreel steunde. Nooit echter matigde zij zich aan 'in enigerley manieren bequaem [te zijn] om hun enig licht ofte onderrechting te geven, zich altijd houdende binnen de paelen van de sedigheit en nederigheit, die in de Vrouwspersonen vereyscht worden'. ${ }^{268}$

Haar zeggenschap berustte, net als die van de twee Roermondse maagden, niet op het kerkelijk ambt dat gewijde mannen uitoefenden. Aan absolute deugdzaamheid of goddelijke inspiratie konden deze vrouwen echter een zeker recht van spreken ontlenen, ook tegenover priesters, hun biechtvader incluis. Zo'n claim stond haaks op de verhouding biechtvader-geestelijke dochter, zoals kloppenboeken die voorschrijven. Toch kan deze aanspraak ook gezien worden als een logische consequentie van de stelling in menig kloppenboek, dat een maagd in essentie enkel God gehoorzaamheid verschuldigd was en iedere vorm van meer aardse autoriteit aan deze basale machtsverhouding ondergeschikt mocht maken.

\section{III.6 Geestelijke dochters en hun 'vaders'}

Kloppen waren niet alleen bruiden en moeders, maar ook dochters. Hun geestelijke vader begeleidde hun spirituele ontwikkeling en kon de vormgeving van hun geestelijk leven in de wereld dicteren. Deze priester verenigde doorgaans twee functies in zich, die van biechtvader en die van geestelijk leidsman. De functie van geestelijk leidsman vindt haar oorsprong in het kloostermilieu. ${ }^{269} \mathrm{Als}$ adviseur en vraagbaak vervulde hij een andere rol dan de biechtvader. In het penitentiële systeem van zonde, schuld en boete, moest de biechtvader erop toezien dat door boetedoening de sociale orde binnen de kerk, alsook de morele orde op individueel niveau werd gehandhaafd. Vanaf de hoge middeleeuwen gold het persoonlijke gewetensonderzoek als voorwaarde voor de absolutie in de biecht. De biechtvader was sindsdien niet alleen degene die oordeelde en zonden vergaf, maar hij fungeerde ook als ondervrager die zijn penitenten hun zonden liet belijden. De verhouding penitent-biechtvader veronderstelde openheid. Eenzelfde openheid was ook vereist tegenover een geestelijk leidsman, die men deelgenoot behoorde te maken van de eigen gedachtenwereld. Hem was men eveneens absolute gehoorzaamheid verschuldigd. Hoe en waarom precies, is niet bekend, maar aan de vooravond van de Reformatie vond er een 'fusie' plaats van de functies van biechtvader en geeste-

268 Ibidem, 192-r95.

269 Het navolgende in deze alinea is - tenzij anders aangegeven - gebaseerd op Ranft, 'A key', 9-16. 
lijk leidsman. ${ }^{270}$ Het samengaan van de oorspronkelijk gescheiden functies had belangrijke gevolgen voor met name vrouwelijke penitenten, ${ }^{271}$ onder wie ook kloppen.

\section{Vaders met twee gezichten}

Auteurs van kloppenboeken blijken niet altijd goed uit de voeten te kunnen met de gecombineerde functie biechtvader-leidsman. ${ }^{272}$ De volstrekte openheid die kloppen tegenover een leidsman moesten betrachten, kon immers ontaarden in een al te grote familiariteit van de kant van maagden. Daarom wordt het mede hun verantwoordelijkheid genoemd om hun biechtvader te helpen zijn taken als leidsman en confessarius strikt te scheiden. Biechten en het bespreken van de gewetensrekening, die zij als geestelijke maagd overlegden aan hun leidsman, zijn in de ogen van de jezuiet Gerardi twee aparte zaken. Gaat zij te biecht, dan moet zij zich niet aan haar bıechtvader bekend maken, om langdurige gesprekken tête-àtête te voorkomen. ${ }^{273}$ Ook Lindeborn waarschuwt dat geestelijke maagden geen uitvoerige samenspraken of geestelijke onderrichtingen mogen verwachten in de biechtstoel. Daar was hun biechtvader allereerst rechter en geneesmeester - en geen leidsman, lijkt dan de onuitgesproken toevoeging. ${ }^{274}$ Lange biechtgesprekken of al te vaak biechten werden ontmoedigd. De meeste auteurs bevelen aan eens per week à veertien dagen te biechten. ${ }^{275}$ Voor sommige maagden was dit niet vaak genoeg, zo blijkt uit verschillende vitae. Isabella van Frankrijk placht volgens de

270 Volgens Van Laarhoven, 'Een geschiedenıs van de biechtvader', 380-382, neemt de biechtvader al in de verde eeuw de gedaante aan van geestelıjk leıdsman, en wel binnen de vroege kloosterbeweging Basilius en Cassianus decreteren reeds volstrekte openheid jegens de leidsman. Benedictus van Nursia (480-547), wiens regel de grondslag vormde voor het kloosterleven tot de twaalfde eeuw, introduceerde het biechtgeheim De van oorsprong publieke biecht, die van oudsher het karakter droeg van een openbare zondenbelydenis, boetedoening, vergeving en hermieuwde verzoening met de geloofsgemeenschap, bleef welıswaar bestaan, maar boette aan betekenıs in ten gunste van de pnvébiecht In de pnve-biecht wordt zondenvergeving cen bestanddeel van de geestelijke leiding die de biechtvader als vertrouwensman geeft Bossy, Chrstzanity in the West, 127-128, betoogt daarentegen dat de biechtvader ten tijde van de Contrareformatie vooral een geestelık leidsman werd $\mathrm{H}_{1}$ brengt deze transformatie in verband met veranderingen in functie en vorm van de biecht, die nog meer in het teken kwam te staan van innerlıjke discipline en indiviuele geestelıjke volmaaktheid $Z_{1}$ voor de verpersoonlijking van de verhouding tussen penitenten en biechtvaders, jezureten in het bıjzonder, O'Malley, The first fesuits, 139-140

271 Ranft, 'A key', I7-26.

$272 \mathrm{Vgl}$ De Boer, Sinewus of discipline, die wist op de gecompliceerde en ambivalente positie van de biechtvader in het algemeen als ambtsdrager en vertrouweling $Z_{1 e}$ in dit verband ook O'Malley, The first Jesutts, I40-I4I

273 Gerardi, Spreghel van Phlotea, 31 Maar vgl Maniere, 8I-82, waar de auteur juist waarschuwt voor vertrouwelıkheid butten de biecht.

274 Lindeborn, De Leeder Jacobs, 311

$275 \mathrm{Vgl}$ Reghel der Volmaecktheyt, 78 eens per maand biechten was voldoende, mits geestelı)ke maagden tussentuds hun zonden aan Chnsnus te kennen gaven. 
jezuiet Caussin bıjvoorbeeld dagelıkss te biechten. ${ }^{276}$ Een zeer hoge frequentie, wanneer bedacht wordt dat vele volwassen gelovigen vermoedelık slechts eenmaal per jaar, namelijk in de paastujd, te biecht gingen.

Wellicht probeerden sommige kloppenboek-auteurs met gedragsregels ten aanzien van de biecht en de omgang met de biechtvader annex geestelık leidsman hun collega-geestelıjken te ontlasten van de begeleıding van geestelıjke maagden, die mogelık ten koste ging van de zielzorg aan andere leken. ${ }^{277}$ Maar vermoedelıjk probeerden zij vooral te voorkomen dat het sacrament van de biecht vertroebeld zou worden door de banden, die de verhoudıng van prester en klop, geestelıjke vader en geestelijke dochter, schiepen. Toch werd een dergelıjke vertroebelıng misschien juist in de hand gewerkt door de voorstelling van de ideale gezagsverhoudingen tussen geestelıjke maagden en hun leıdsmannen in kloppenboeken. De clencale auteurs dicteren namelıjk een volstrekte geestelı)ke afhankelı)kheld. Om haar streven naar spintuele perfectie adquaat te kunnen begeleiden, om haar te kunnen troosten in haar verdnet en haar bij te kunnen staan in geestely)ke nood, moest een biechtvader weten wat 'z1n' dochter bewoog. Devoties, emoties, zonden, gedachten, werkzaamheden, niets behoorde een maagd voor haar le1dsman te verbergen Een dergelıjke openhartigheld werd ook verwacht van penitenten die niet voor een geestelıjke leefwijze in de wereld hadden gekozen Maar juist omdat kloppen voor de vormgeving van hun bestaan mede aangewezen waren op de steun en het toezicht van hun biechtvader, kon de plicht tot openheld hun soms zwaar vallen. Dat illustreren bıvoorbeeld de vitae van Joanna van Randenraedt en Agnes van Hellsbach Daann wordt meermalen de weerzin gememoreerd, die z1) hadden om hun brechtvader over goddelijke openbanngen en andere gebeurtenissen te vertellen Door royale aandacht te besteden aan het innerlık verzet van beide vrouwen hamert de jezulet Huysmans, de auteur van deze levens, op de noodzaak van volledige openheid tussen 'vaders' en 'dochters'. Het streven naar een leven dat zou urtmonden in zaligheid, hep gevaar zonder adequate begeleiding van een leidsman. Een vermoedelık laat-zeventiende-eeuwse belofte-formule laat daar geen misverstand over bestaan:

'Ik weet mun God dat mun een leydtsman nodıg is, in de Heılige wegen, die $1 k$ moet in slaen Ik heb nodig een man vol wi)sheyd, afgeruckt van alles, vol van hemelsche begeertens en Heylig van wandel, maeckt sodanıg mijn God wie Geene, die gi) mijn hebt gegeven Geeft mijn God, dat ik hem in alles onderdanig sij ( ) noyt sal ik tegen hem stnbbelen, altıjd voor hem bidden en door een innerlycke Genegentheyt sal ik hem altıjd tragten te wesen tot een troost ()$^{{ }^{3278}}$

Een klop die de maagdelıke leefwıze aanvaardde door een plechug voornemen

276 Caussin, Leven Isabella, in Jacobi, Spreghel der Maeghden, 56

$277 \mathrm{Vgl}$ in dit verband Stevins, Regel, 9, die geestelıke dochters aanspoort niet op zon- en feestdagen te biecht te gaan, omdat ze 'wereldse mensen' dan het biechten beletten, die niet lang aan de biechtstoel konden of wilden wachten

278 Fragment ut een belofte-formule, anoniem RAU, $A O B C$, Collectre Dalennoort, geciteerd door Theissing, Over klopjes en kwezels, 218 , bulage II-f 
of een belofte, was voortaan afhankelijk van haar biechtvader, ook al beloofde zij hem persoonlijk geen gehoorzaamheid. Voor opstandıge maagden heeft de seculier Schoenius geen goed woord over: zij die hun leidsman 'yedt merckelijcks gebieden als of 't haren dienstknecht waer, die sondigen doodelijck tegen het ghebodt Godts ende des Apostels' ${ }^{279}$ Overeenkomstig Gods wil is een geestelijke maagd ondergeschikt aan haar biechtvader, want Hij beschikt 'dat het geen welk onvolmaekter is onderworpen wesen sal onder dat geene welk volmaekter is (...)', aldus Lindeborn. ${ }^{280}$ God was nu eenmaal oneindig volmaakter dan een geestelijke maagd of de priester die haar uit Zijn naam bestierde.

\section{Gods rechtmatige plaatsvervanger}

God geeft een biechtvader aan een geestelijke maagd, die hierom in haar gebed gevraagd heeft, zo stemmen alle kloppenboeken overeen. Deze geestelijke neemt Zijn plaats waar op aarde. ${ }^{281}$ Over de grond van deze aanspraak laten de bronnen zich helaas niet uit. Sinds het vierde Concilie van Lateranen berustte de biechtjurisdictie bij de pastoor van een parochie, die daartoe gevolmachtigd werd door de bisschop van het diocees waaronder zijn parochie ressorteerde. Het Concilie van Trente bevestigde deze bevoegdheid. ${ }^{282}$ De exclusieve biecht-jurisdictie van pastoors was na Trente echter enigszins aan erosie onderhevig, doordat geestelijken, onder wie Franciscus van Sales, betoogden dat penitenten een biechtvader mochten kiezen ${ }^{2{ }^{3}}$ Uitgaande van de gedachte dat een biechtvader door God gezonden was, moedigden kloppenboek-auteurs verandering van biechtvader overigens bepaald niet aan. ${ }^{284}$

Aan te nemen valt dat de status van plaatsvervanger die kloppenboek-auteurs priesters in hun capaciteit van biechtvaders toematen, mede gefundeerd was op de bevoegdheden die zij uit hoofde van hun pnesterambt hadden. In de bediening van de sacramenten - waaronder de biecht - gold een priester strikt genomen

279 Schoenius, Weg, 172

280 Lindeborn, De Leeder Jacobs, 285.

281 In leefregels ontbreken gedetalleerde uiteenzettıngen over de status van de biechtvader meestal. De regel van de kloppenvergadenng van Nieuwe Niedorp, vermoedelık afgeschreven van de regel van De Hoek te Haarlem, rept nuet over Gods plaatsvervanger. De maagden worden enkel aangespoord om hun overste 'naer gewoonte dese lande Vaer [te] noemen, hem behoorlycke eer en respeckt [te] bewi)sen en [te] gehoorsamen in hetgeen het geestelyck leven aengaet'. Gonnet, 'De "Vergaderinghe"', so (capıttel VII, eerste regel) In de regel die de Zuidnederlandse wereldheer Karel-Lodewijk Gnmminck opstelde voor een maagd onder zun leiding, bluft de gezagsverhoudıng en status van hemzelf als biechtvader in het geheel onbesproken Berquin, "Gnmmincks "Regels"'

282 Van Laarhoven, 'Een geschiedents van de biechtvader', 390, 399.

283 Ranft, 'A key', 16-17

284 In tegenstelling tot bijvoorbeeld een algemeen devotieboek als dat van Sucquet, Den wech des eeuwich levens, 77. Hij houdt degenen die voor de maagdelike staat in de wereld hebben gekozen, voor. 'Vraeght oock andere Biecht-vaders raedt in de biechte, als 't u belıeft, ende houdt uwe vnjicheydt'. 
eerder als plaatsvervanger van de bisschop dan als rechtstreekse remplaçant van God. ${ }^{285}$ Aan deze formeel-hiërarchische verhoudingen laten kloppenboek-auteurs, die benadrukken dat de biechtvader als (rechtstreekse) plaatsvervanger van God optreedt, zich echter weinig gelegen liggen. Dat God een geestelijke maagd via de biechtvader regeerde, wordt door de anonieme auteur van het enkel in handschrift overgeleverde kloppenboek Maniere wel op zeer speciale wijze geadstrueerd. Die stelt namelijk dat God zelfs in staat zou zijn door de bek van een ezel een profeet te vermanen tot zaligheid. ${ }^{286}$

Juist omdat zij ervan overtuigd waren dat zij God vertegenwoordigden, was een belofte van gehoorzaamheid aan hen in hun capaciteit van biechtvader voor vele geestelijken onaanvaardbaar. De seculiere clerus streefde over het algemeen gewillige gehoorzaamheid bij geestelijke maagden na, zonder enige belofte. ${ }^{287}$ Maar niet alleen wereldheren verzetten zich tegen een dergelijke gehoorzaamheidsbelofte; voor de door Eugenie Theissing geopperde stelling dat zo'n belofte vooral door paterskloppen vaak gedaan werd, leveren de kloppenboeken uit die kringen in elk geval geen aanwijzingen. ${ }^{288}$ De jezuieten stonden in ieder geval afwijzend tegenover een dergelijke belofte. Volgens de anonieme auteur van Mantere, die vermoedelijk onder jezuïeten of misschien zelfs hun kloppen moet worden gezocht, is een belofte van gehoorzaamheid uit den boze. ${ }^{289}$ Van Agnes van Heilsbach wordt uitdrukkelijk vermeld dat zij een dergelijke belofte niet had gedaan. ${ }^{290}$ Vanuit de overtuiging dat God de maagden regeerde, wordt het optreden van de biechtvader veel scherper herleid tot God als oorsprong van zijn handelen. Onder geen beding mag een klop Gods plaatsvervanger op aarde meer liefhebben dan God zelf. Hij is niet meer dan 'Advocaet en Middelaer' tussen een geestelijke maagd en God, aldus Lindeborn. Aan hem vertrouwt de hemelse Bruidegom Zijn bruiden toe. ${ }^{29 r}$

Ook geestelijken die enkel als leidsman, en niet ook nog als biechtvader fungeer-

285 Schillebeeclox, 'Pnesterschap', 398 I, 3983-3989; Bouman, 'B1echt', 264, stelt dat in de vroegchnstelyke gemeenten de bisschop als hoofd van de geloofsgemeenschap in de biecht optreedt als bemiddelaar die de wederopname van de zondaar in de gemeenschap der gelovigen kan bewerksteilıgen. $\mathrm{H}_{1)}$ kan daartoe ook een pnester als zın plaatsvervanger machugen.

286 Manreve, 41-44 Wellicht is deze passage geinspireerd door Numen 22, 22-34, over de profeet Bileam en zijn ezelın.

287 Theisung, Over klopjes, 79, 110 . Rovenus, Rezpublzcae chnstzanae lzbn duo, 274. De 'Constituqones' van Rovenıus, d.d. 30 junı 1628 en 12 december 1638, herhaald door Neercassel, d.d. 17 me1 1668 , verboden de clerus expliciet dergelı,ke beloften van geestelı)ke maagden te accepteren. [Van Heussen], Batavia Sacra, II, I01, 107, 499. Maar vgl. Tans, 'Van maagden en engelen', 266, die stelt dat de strenge oratonaan Pasquier Quesnel geneigd was het vanzelfsprekend te vinden dat kloppen beloften van armoede en gehoorzaamheid deden aan hun leidsman of zelfs een oudere klop.

288 Theissing, Over klopjes, 78-79.

289 Maniere, 103.

290 Leven ende deughden, 299; Vgl. de algemene handleıding tot een goed, chnstelı)k leven van Sucquet, Den wech des eeuwrch levens, 76 Deze jezuret stelt in zujn bespreking van het geestelıjk leven in de wereld dat een belofte van gehoorzaamheid God zelfs zou mishagen.

291 Lindeborn, De Leeder Facobs, 287. 


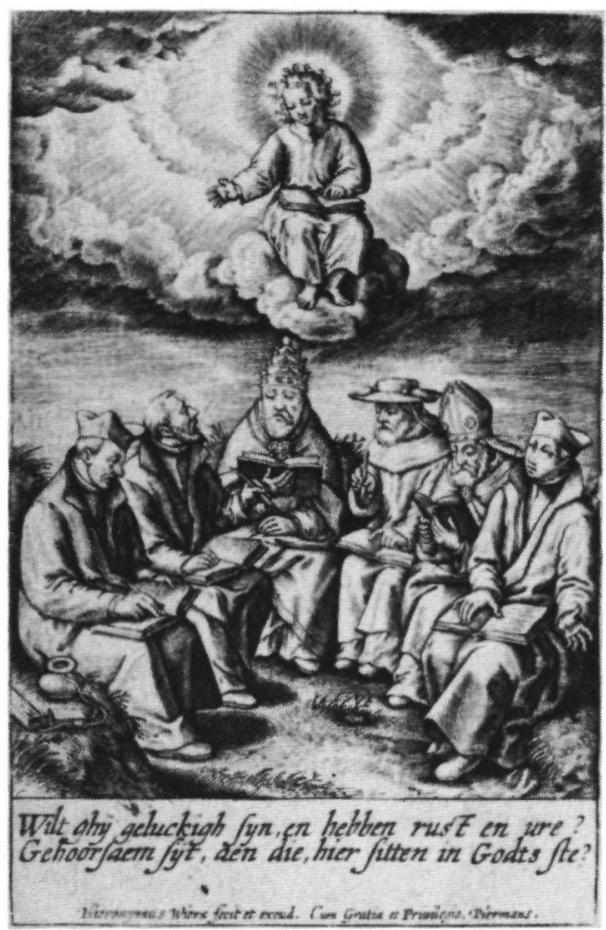

Afb. Io Gods plaatsvervangers op aarde in hun verschillende gedaanten verbeeld. Te oordelen naar hun kleding en attributen staan van links naar rechts afgebeeld: een jezuiet, een theoloog (met toga), een paus, een kardinaal, een bisschop en wederom een jezuïet. Wie gelukkig wil zijn en (gemoeds) rust nastreeft, moet degenen die hier in Gods plaats zitten, gehoorzaam zijn, aldus het onderschrift.

den, beschouwden God als de bron waaruit zij kennis en gezag putten. Joannes van Neercassel zette tegenover de Brusselse geestelijke maagd Marie-Anne Voeller zijn taakopvatting als leidsman als volgt uiteen:

'Tgeen UEd my veropenbaert heeft, doet myn gevoelen dathet Gods genaedige bestiering is, dewelke UEd beweeght heeft om myn tot haeren geestelyken Vader te verkiesen. Dit doet my ook hopen, dathy my soo veel licht en liefde in myn verstand en hart zal geven, als tot sulcks ampt word vereist (...) [en] dat God myn tong of pen zal regeren, wanneer ick die zal gebruijken om UEd vragen te beantwoorden. ${ }^{292}$

Vermoedelijk vanuit de gedachte dat priesters niet meer waren dan Gods uitvoerders, nam Neercassel aanstoot aan een voorschrift in de kloppenregel die een van zijn beschermelingen, de wereldheer Hugo Gael (I655-1720), had opgesteld. Gael stond als priester in de Rotterdamse statie St. Petrus en Paulus. Neercassel wendde zich tot diens moeder, de weduwe Ancilla van Campen, die sinds 1682 de leiding had over een kleine kloppengroep die aan deze statie was verbonden. ${ }^{293}$ Wat Gael precies geschreven of bedoeld heeft, is onbekend. In elk geval was Neercassel bang dat de wijze waarop de gehoorzaamheidsplicht van de maagden aan hun

292 RAU, $A O B C$, inv.nr. 605, Neercassel aan Marie-Anne Voeller, 20 september 1677. Vgl. Reghel der Volmaecktheyt, 78, waar geestelijke dochters worden aangespoord om te bidden dat God hun biechtvader zal verlichten, opdat hij hen goed zal besturen. Zie ook Leven ende deughden, 270.

293 Schulte van Kessel, Geest en vlees, 75. 
biechtvader geformuleerd was, aanstoot zou kunnen geven, 'want quaedaerdige zoude zulcxs konnen uijtleggen als ofte den Biechtvader sich boven de hoogste overigheijd van Gods kerk wilde stellen'.294

Zonder leidsman, die als een stuurman haar schip bestuurde, was een geestelijke maagd tot schipbreuk gedoemd. Deze metafoor, die te herleiden is tot de kerkleraar Athanasius, figureert in menig kloppenboek. ${ }^{295}$ Van een klop werd verwacht dat zij blind voer op het geestelijk kompas van haar biechtvader. $\mathrm{Zij}$ moest haar eigen wil volledig verzaken ten gunste van volstrekte gehoorzaamheid aan en vertrouwen op haar leidsman. ${ }^{296}$ God moest haar daartoe een buigzaam hart geven. ${ }^{297}$ Verzet tegen haar biechtvaders wil werd gezien als regelrechte weerstand tegen God. ${ }^{298}$ Daar stond tegenover dat de biechtvader volgens de kloppenboeken degene was die een geestelıjke maagd in haar voortdurende strijd om religieuze volmaaktheid in de wereld adequaat terzijde kon staan. Als vrouwen werden zij te zwak geacht om deze strijd alleen te voeren. Gods hulp was onontbeerlijk en die werd hun bemiddeld door de biechtvader. ${ }^{299}$ Deze geestelijke kon haar verlossen

'van de dwingelandy van sonde en fauten, die alle hindernissen van zaligheit aen kant make, die haer tot de overwnning der wederspannge dnften mach aenmoedigen, der ziel krankheden en wonden heelen, en uitreiken de terwe der uitverkoornen en den wijn die Maegden baert, met een woordt geseit, uit welkers mondt sy Godts wil en welbehagen verstaen, en wiens hulp en raedgeving sy in al 't gunt [hetgeen] de conscientue betreft gebruken mach', ${ }^{300}$

Biechtvaders worden in kloppenboeken niet alleen voorgesteld als steunpilaren, maar ook als spiegels waaruit geestelijke maagden de graad van hun spirituele perfectie kunnen aflezen. Als hun voornaamste referentiepunt bij de vormgeving en beleving van hun geestelijke staat in de wereld, behoort hij hun gedachten en handelingen te beproeven, te sturen en te corrigeren. ${ }^{301}$ En door voortdurende controle op haar deugdzaamheid bevestigt de biechtvader annex geestelijk leidsman de religieuze identiteit van een geestelijke maagd.

Analyseren we de kloppenboeken op de voorgeschreven houding van geestelijke maagden ten opzichte van hun biechtvaders, dan tekent zich een dubbele bood-

294 RAU, $A O B C$, inv nr. 610, Neercassel aan Ancilla van Campen, I6 september 1684.

295 Maar bıvoorbeeld ook in de geschnften van Joanna van Randenraedt, KB Brussel, Handschrifien 19070, $250 \mathrm{Vgl}$ Bartelink, De bloetende woestın, 80 in de vroeg-christelıke monastieke wereld werd de mens in de wereld al verbeeld als een schip dat geleid diende te worden door het roer der nedengheld.

$296 \mathrm{Vgl}$. GAU, Archief St. Willibrordusparochre, inv nr. 24, 'Gemeene Regel van een Geestelıcke dochter', ongedateerd [vermoedelı,k i 7 e-eeuws], die zelfs opent met het kopje 'Ghehoorsaemhe1]t aen sijn oversten'.

297 Kemp, Zedelessen, 298-299.

298 Maniere, 93.

299 Kemp, Zedelessen, 47. Vgl. Reghel der Volmaecktheyt, 56, waar gesteld wordt dat de mens van zichzelf onbekwaam is om goed te doen en bovendien voortdurend belaagd wordt door onzichtbare 'Duyvels der Hellen'.

300 Lindebom, De Leeder facobs, 285, zie ook 292-293. Zie ook Kort Begryp, 328 en Mamere, too 301 Vgl Schutte, 'Per speculum in enigmate', I89-190 
schap af. Enerzijds mochten deze vrouwen niets voor hun biechtvader verborgen houden en hadden zij voor alles zijn toestemming nodig. Anderzijds werd een al te grote familiariteit en innige band tussen klop en leidman ontmoedigd. De liefde die een geestelijke maagd tot God koesterde, kon afgemeten worden aan de mate van openhartigheid die zij jegens haar biechtvader betrachtte, aldus de auteur van de vita van Joanna van Randenraedt. ${ }^{302}$ Voor niemand vatte zij een grotere genegenheid op dan voor haar biechtvaders. Toch 'maakte Ioanna (...) geen swarigheydt' als één van haar biechtvaders stierf of naar elders verhuisde, vanuit de overtuiging dat dit Gods wil was. ${ }^{303}$ Een dergelijk evenwicht tussen betrokkenheid en afstand tussen 'dochters' en 'vaders' streven ook andere kloppenboek-auteurs na. $\mathrm{Zij}$ hameren er bij geestelijke maagden op vertrouwelijkheden te vermijden en de zuiverheid van hun verhouding tot hun leidsman nauwlettend in de gaten te houden. Kloppen wordt bijvoorbeeld op het hart gedrukt hun biechtvader 'met een effen tronie' weg te sturen, zodra deze iets deed dat de 'heyligheyt van het Priesterdom' dreigde te schenden. ${ }^{304}$

Vanuit dit perspectief krijgt het predikaat 'plaatsvervanger van God' van biechtvaders nog een andere dimensie. Hiermee wordt niet alleen hun gezagspositie ten opzichte van geestelijke maagden tot uitdrukking gebracht, maar deze omschrijving moet ook ongewenst familiarr gedrag van de kant van geestelijke maagden bij voorbaat de kop in drukken. In het bijzijn van God is het vanzelfsprekend dat een geestelijke dochter zich gedraagt als een kind ten opzichte van haar vader, nederig en gehoorzaam. Wie deze basale gedragsregel schendt en haar biechtvader in opspraak brengt, is geen werkelijk godgewijde maagd.

\section{Overwicht in onderdanigheid}

Aan het einde van de vorige paragraaf is er al kort op gezinspeeld dat in plaatsvervanging van God ook een subversief aspect besloten ligt. Sommige kloppenboekauteurs halen dit expliciet voor het voetlicht. Het gezag van de biechtvader als 'stadt-houder Gods' kan ter discussie gesteld worden wanneer deze priester iets gebiedt dat strijdig is met Gods wil, aldus de jezuïet Gerardi. ${ }^{305}$ Wat Gods wil precies was, werd kennelijk aan de perceptie van een geestelijke maagd overgelaten. Zijn wil kennen is volgens sommige kloppenboeken niet het exclusieve voorrecht van gewijde mannen. Vrouwen mogen - moeten zelfs - hun kennis van Gods

302 Kort Begryp, 171.

303 Ibıdem, 226. Dat ze zich nuet alujd voetstoots neerlegde blj een verandering van leıdsman, komt in het laatste hoofdstuk van dit boek nader aan de orde. Vgl. Lindeborn, De Leeder facobs, 308, die maagden aanspoorde om, wanneer hun brechtvader overgeplaatst werd of suerf, bu) zujn opvolger te gaan biechten.

304 Onderuysingen (.) voor de geestelycke dochters van het Oratone, 29; vgl Van den Bosch, Het geestelyck verborgen manna, 29-30.

305 Gerard, Spieghel van Phlotea, 21-22 
wil in stelling brengen tegen geestelijken, die uit hoofde van hun ambt aanspraak mogen maken op het aardse plaatsvervangerschap van God. In de overtuiging dat God haar tot een maagdelijk, kuis bestaan buiten het klooster heeft geroepen, trotseerde Isabella van Frankrijk zelfs paus Innocentius IV. Impliciet geeft de jezuïet Caussin, de auteur van haar vita, te kennen dat de wil van God zelf, kenbaar gemaakt bij monde van een godvruchtige maagd, de zeggenschap van Zijn plaatsvervanger op aarde, in dit geval de paus zelf, kan overstemmen. ${ }^{306}$

Menige maagd had 'ontgeestinghen', 'optooghinghen des gheests', 'revelacien' en 'inspraecken' die haar Gods wil openbaarden, zo blijkt uit verschillende vitae. Hoewel visioenen en inspraken door de kerkelijke overheid in toenemende mate met argwaan werden beoordeeld - zeker wanneer (religieuze) vrouwen de ontvangers ervan waren - maakten dergelijke bovennatuurlijke gebeurtenissen deel uit van het mentale universum dat maagden met hun biechtvaders deelden. ${ }^{307}$ God liet een ongeletterde vrouw als Lidwina van Schiedam delen in Zijn kennis door 'inwendighe verlichtinghe ende wijsheyt'. De zeventiende-eeuwse uitgave van het leven van deze middeleeuwse vrouw beschrijft hoe zij het als haar plicht ziet om, gewapend met deze kennis, anderen te leren en te helpen, onder wie ook kloosterlingen en geestelijken. ${ }^{308}$ Openbaringen en profetieën worden voorgesteld als tekenen van Gods genade, waarvan vrouwen niet uitgesloten zijn. Ook zij kunnen handelen en spreken op Gods gezag. Zijn autoriteit legitimeert zelfs handelingen die voor vrouwen op grond van hun geslacht op zijn minst als dubieus beschouwd worden..$^{309}$ De gewijde autoriteit van priesters kan overstemd worden door het ongewijde gezag van een geestelijke maagd, herleid tot de oorsprong van alle kennis, God.

Uit de beschrijving van de levensloop van Joanna van Randenraedt en Agnes van Heilsbach blijkt dat de keuze tussen gehoorzaamheid aan God of de biechtvader een dilemma kon vormen voor een klop. Op grond van auditieve en visuele ingevingen van God en hun hemelse Bruidegom omzeilden zij soms ge- en verboden van hun leidsmannen. Tengevolge een inspraak van haar Bruidegom kwam Van Randenraedt bijvoorbeeld in de verleiding een gebod van haar biechtvader om niet ter communie te gaan, te negeren. ${ }^{310}$ Het gezag van deze geestelijke werd soms regelrecht bedreigd door hetgeen de hemelse Vader en Zijn Zoon deze twee

306 Caussin, Leven Isabella, in' Jacobı, Spreghel der Maeghden, I5-33.

307 Bell, Holy Anorexıa, 170-178, Bynum, 'The mystıcısm', 77-78, merkt op dat de zestiende-eeuwse protestantse hervormers zuch afzetten tegen de sterk emotioneel geladen affectieve en mystieke vroomheid die vanaf de dertiende eeuw in kringen van lekevrouwen, begijnen, nonnen en tertianssen in de Nederlanden, het Rujnland en Italie tot ontwikkeling kwam en die sinds de viftuende eeuw in bredere knng populanteit genoot Hoewel de argwaan jegens deze vormen van spintualiteit van de zude van de katholieke kerkelıke overheid al vanaf de veertiende eeuw waarneembaar is, werd het wantrouwen ertegen wellıcht gedurende de vroegmodeme tijd geintensiveerd als reacue op protestantse criciti.

308 Brugman, Leven Lydwina, in. Jacobı, Spreghel der Maeghden, 58, 78-82.

309 Ibidem, 108-II 8.

310 Kon Begryp, 330-331. 
vrouwen toonden of lieten horen. Als zodanig worden de visioenen en inspraken ook gepresenteerd in de vitae. Zo wordt beschreven hoe Agnes van Helsbach eens 'zag' dat de handen van de pnester die de communie uitreikte zo zwart waren als roet. ${ }^{311}$ Van God begreep zij dat deze geestelıjke in staat van doodzonde verkeerde en dat hij de genade die God hem wilde verlenen om zıjn leven te beteren, afwees. Een beschnjving als deze lijkt de voorgeschreven gezagsverhoudingen tussen priester en leek, tussen man en vrouw, maar vooral tussen biechtvader en penitente, als het ware om te keren. Zulke bovennatuurlıjke voorvallen doorkrusten de legitieme aanspraak van een priester op het kennen van Gods wil Desalniettemin worden geestelljke maagden in vitae en ondernchtıngsboeken aangespoord om Gods wil rechtstreeks te horen, vooral in het gebed of de meditatie. Ook zonder de bemiddeling van een pnester kunnen zl) volgens de kloppenboek-auteurs van God vernemen waarin zil tekort geschoten ziln of hoe zil hun spirituele streven nog kunnen vervolmaken

Niet alle kloppenboek-auteurs beschnjven bovennatuurlıke verschujnselen echter even welwillend als de jezuret Daniel Huysmans, die tekende voor de levens van Van Randenraedt en Van Heilsbach Zijn ordegenoot Valentınus Bisschop bedıngt in Lof der Suyverheydt dat de beoordeling en duiding van dergelıjke voorvallen enkel en alleen de verantwoordelı)kheid van de biechtvader is. Natuurlyjk is God alom tegenwoordıg, maar waakzaamheid voor duivels bedrog blıft geboden Dat geldt volgens Bisschop vooral voor vrouwen, die hieraan tijdens gebed of meditatie gemakkelık ten prooı konden vallen.

'Daerom en sal onse Maghet aen geen revelatien, verbeeldingen, inwendighe vreemde raden en roeninghen ( ) ghehoor gheven, noch in eenige optooginghen ghenoechte nemen, ten zy sy die eerst aen haren gheestelı)cken Vader gheopenbaert heeft, ende van hem sı) ghevoelen, raedt ende wille ghehoort "312

In zijn uiteenzettıng over leefwijze en status van geestelıje maagden hekelt de apostolısch vicarıs Phılıppus Rovenıus allerlei gemoedsbewegingen van sommıge geestelı,ke maagden, die een bızondere, zelfs mystreke liefdesband met hun Bruidegom menen te hebben ${ }^{313}$ Naar ziln mening getuigt deze preoccupatie met wonderlı)ke zaken van een minachtung voor de gebrulkelıke relıgieuze oefenıngen en van een zekere trots of verhevenheid Een dergeliıke impliciete claim op uitverkorenhe1d in de ogen van God stond kennelı)k haaks op de nedenghe1d en deemoed die geestelıke maagden ten toon behoorden te spreiden.

In haar weergave van Rovenius' standpunt noemt Theissing deze gemoedsaandoeningen voorbeelden van 'ziekelı)ke mystrek'. 'Het euvel van z.g. [zogenaamde] extasen' schijnt bij tud en wijle voorgekomen te zijn. Opzettelık bedrog was niet urtgesloten, aldus Theissing, maar meestal bleek er sprake van 'opgewonden ver-

31I Leven ende deughden, 202-203

312 Bisschop, Lof der Suyverheydt, III, 287

313 Rovenuus, Retpublucae chrstzanae libn duo, 278-280 
beelding'. ${ }^{314}$ In een poging de vraag naar het waarheidsgehalte van allerlei visioenen en inspraken van kloppen te beantwoorden, gaat Theissing voorbij aan een veel belangrijker kwestie: in hoeverre had de aanspraak van deze vrouwen op bovennatuurlijke ervaringen zeggingskracht in de relatie met haar biechtvader en leidsman? Dat sommige auteurs dergelijke verschijnselen in hun kloppenboeken als volstrekt plausibel presenteren, wijst erop dat dergelijke aanspraken au serieux werden genomen. In theorie kon de gezagsverhouding tussen een geestelijke maagd en haar leidsman door zulke claims doorslaan in haar voordeel.

Bovenstaande analyse nuanceert de nadruk die in kloppenboeken gelegd wordt op de onderschikking en onderwerping van geestelijke maagden. Deze stichtelijke werken spiegelen hun een relatie met hun biechtvader voor die kenmerken van een bondgenootschap in zich draagt. Natuurlijk, een geestelijke maagd werd in feite iedere vorm van gezag over zichzelf ontzegd. Met het sluiten van een geestelijke verbintenis met God - hetzij door een belofte van zuiverheid, hetzij door een vast voornemen tot een maagdelijk leven - behoorde zij Hem voortaan geheel en al toe. Volledige gehoorzaamheid aan God en diens aardse plaatsvervanger heet een voorwarde om deze verbintenis te doen slagen. Geestelijke vader en geestelijke dochter worden in deze stichtelijke werken als het ware aaneengesmeed tot een hecht tweespan. Naar het oordeel van kloppenboek-auteurs zijn eerbaarheid en effectiviteit van dit duo gegarandeerd, wanneer het gezag berust bij de mannelijke helft, geheel conform de heersende denkbeelden over beide seksen. Al beschrijven deze auteurs de gezagsverhouding tussen maagd en priester als asymmetrisch, de indruk bestaat dat zij zich er toch ook van bewust zijn geweest dat er geen sprake was van eenzijdige afhankelijkheid. Als levende exempla van vroomheid konden geestelijke dochters hun vaders namelijk ook belangrijke diensten bewijzen binnen de katholieke geloofsgemeenschap.

\section{III.7 Identiteit in vroomheid}

Het hart van de kloppenboeken wordt gevormd door voorschriften die het gedrag van geestelijke maagden moesten reguleren. Met allerlei ge- en verboden probeerden kloppenboek-auteurs mentale muren op te trekken voor geestelijke maagden die kloostermuren als bescherming tegen de verleidingen van de wereld moesten missen. Een aan God gewijd leven in de geest van de evangelische raden vergde regelmaat en orde om de nagestreefde deugdzaamheid en volmaaktheid te kunnen waarborgen. Hielden kloppen zich aan de voorgeschreven regels, dan hoefde hun leefwijze in heiligheid niets onder te doen voor het kloosterleven, aldus de kloppenboeken. De leefregels van het strak georganiseerde kloosterleven boden, naast 
de geschriften over maagdelijkheid der kerkvaders en kerkleraren, aanknopingspunten voor de reglementering van de leefwijze van kloppen. Ook de Heilige Schrift fourneerde bruikbare gedragscodes, die werden ingebed in godsdienstig-morele rechtvaardigingen.

De voorschriften en regels die geestelijken in kloppenboeken aan geestelijke maagden voorhielden, zijn een uitdrukking van disciplinering. $\mathrm{Zij}$ structureren alle dimensies van vroomheid en sociale relaties van kloppen. Zonder de disciplinerende werking van deze richtlijnen te ontkennen, mag vastgesteld worden dat regels voor kleding, gedrag en vroomheid de kerkrechtelijk niet geformaliseerde kloppenstaat ook materialiseerden. ${ }^{315} \mathrm{Zij}$ gaven vorm en inhoud aan een nieuwe sociale identiteit voor vrouwen en waarborgden een zekere zelfstandigheid, die misschien groter was dan huwelijk of klooster konden garanderen; een identiteit die dankzij haar religieuze fundering overtuigend als eerbaar gold, hoewel zij afweek van de geaccepteerde opties van echtgenote en moeder, of kloosterlinge. ${ }^{316}$ Door hun vroom gedrag in de omgang met anderen en in de kerkgang demonstreerden kloppen hun deugdzaamheid en eerbaarheid. ${ }^{317}$ 'Vrouweneer' was in de vroegmoderne tijd onlosmakelijk verbonden met seksuele reputatie. ${ }^{318}$ Geestelijke maagden waren in feite 'ongebonden' vrouwen en dat maakte hun reputatie bijzonder kwetsbaar. Door de godgewijde status van hun maagdelijke leefwijze uit te drukken in voorkomen en gedrag, konden zij zichzelf boven alle verdenking stellen.

\section{Religieus regime $e^{3 t 9}$}

In kloppenboeken worden de evangelische raden geoperationaliseerd in een regime van vroomheid. Vrouwen die armoede en gehoorzaamheid naar de geest beleven, hun maagdelijkheid aan God opdragen en door een strak stramien van devoties en rituelen uitdragen, belichamen waarlijk het geestelijk leven in de wereld. 'De Maget en moet niet alleen Maghet zijn', aldus de jezuiet Bisschop, 'maer moet oock daer voren van eenen anderen ghekent worden ende ghelooft, op dat niemant, als hij eene Maget siet, twijfelt of sy Maghet zij. ${ }^{320}$ Kleding en uiterlijke gedragingen worden in de kloppenboeken opgevat als reflecties van

$315 \mathrm{Vgl} \mathrm{Ziegler,} \mathrm{Sculpture} \mathrm{of} \mathrm{compassion,} \mathrm{98-ror.}$

$316 \mathrm{Vgl}$. Crawford, Women and relggion, 10.

317 Vgl. Wunder, "Von der "frumkelt" zur "Frōmmıgkeıt".

318 Van de Pol, 'Prosututue en de Amsterdamse burgen), 179-190.

319 Onder regime wordt in dit verband het samenstel van voorschriften en regels verstaan dat vorm en uitdrukkung geeft aan de kloppenstaat. Het begnp wordt ook door de antropoloog Mart Bax gebrukt. In zijn onderzoek verwyst het echter naar "een meer of minder geformaliseerd en geunsutueerd samenstel van machts- en afhankelykheıdsverhoudıngen tussen mensen, dat gelegitumeerd wordt door een gedachtengang welke wordt gepropageerd door relıgeuze specıalısten'. Bax, 'Terug naar donkere tuden?', 122 (noot 6) en idem, 'Relıgeuze regımes'

320 Bisschop, Lof der Suyverheydt, II, 224; zie ook Een regel waer duer als een Spreghel, 't'Inhout'; kapittel IV (ongepagneerd). 
innerlijke deugdzaamheid. En deze uiterlijke kenmerken fungeren als dragers van de identiteit van kloppen, die bevestigd wordt door de herkenning van anderen. ${ }^{32 x}$

Dat zij afscheid had genomen van de wereld en voortaan een aan God gewijd religieus bestaan zou leiden, behoorde een vrouw aan haar omgeving kenbaar te maken door haar kleding. De zwarte, eenvoudige kleding, die zij in het vervolg zou dragen, was het gewaad van weduwen of 'oude vroukens'. Hoewel de kleding die kloppen gedurende de zeventiende eeuw droegen beslist niet uniform was, bleef de tekenwaarde van deze dracht niet verborgen voor de omgeving, getuige de vereenzelviging van kloppen met vrouwelijke religieuzen die in protestantse en ook katholieke bronnen te vinden is. In de sobere dracht lag de miskenning van het aardse besloten en werd de verstorven, geestelijke identiteit die een klop had aanvaard, uitgedrukt. Daarmee symboliseerde de kleding van een klop én de keuze voor het katholicisme én haar nieuwe geestelijke identiteit.

Haar status bevestigde zij door een vaste dagorde, dagelijkse kerkgang, liefdewerken en andere door de kloppenboeken geformaliseerde handelingen. Gelovig zijn en zich gelovig betonen door een strak ritueel regime van gebed, meditatie, mis en sermoen horen, biechten en ter communie gaan, kon respect afdwingen voor henzelf, alsook voor de gekozen levensstaat. ${ }^{322}$ Religieus handelen vormde, als het aan de kloppenboek-auteurs lag, de kern van de identiteit van geestelijke maagden. In de handelingen die deze geestelijken voorschreven lag deze identiteit besloten en met deze handelingen droegen vrouwen uit dat ze én katholiek waren, én zich aan God hadden gewijd. Hun vergeestelijkte maagdelijkheid werd in combinatie met dit rituele repertoire tot een nieuwe religieuze identiteit. De vormen waarin vrouwen hun vroomheid konden uitdrukken, werden niet door iedereen serieus genomen en werden zelfs geriduculiseerd, zo waarschuwen kloppenboek-auteurs. Maar door die hoon, die hun Bruidegom ook al ten deel was gevallen, deemoedig te verdragen, konden zij nog eens extra bewijzen Zijn bruiden te zijn.

De leef- en gedragsregels in de kloppenboeken kunnen beschouwd worden als een gedragsrepertoire, waaruit keuzes gemaakt werden. Op welke wijze kloppen uit de voorschriften kozen, hoe zij deze interpreteerden en in de praktijk brachten, kortom hoe het proces van betekenisgeving vanuit deze vrouwen bezien verliep, leren we niet uit deze boeken. De auteurs zelf anticiperen sterk op dit proces van betekenisgeving. $\mathrm{Zij}$ wijzen erop dat de invulling van de kloppenstaat in hoge mate afhankelijk is van de sociale en financiële achtergronden van vrouwen die deze informele religieuze positie ambiëren. Wie moest werken voor de kost, kreeg daarom dispensatie om aan de religieuze plichten te voldoen al naar gelang de

321 Vgl. Ziegler, Sculpture of compassion, 99-100. Volgens Schutte, 'Inquisition', I II, behoefden semireligieuze vrouwen die in een andere hoedanigheid dan echtgenote en moeder in de wereld leefden, niet alleen 'a social role but also a persona to present in public'.

$322 \mathrm{Vgl}$. Crawford, Women and religion, 73-97. 


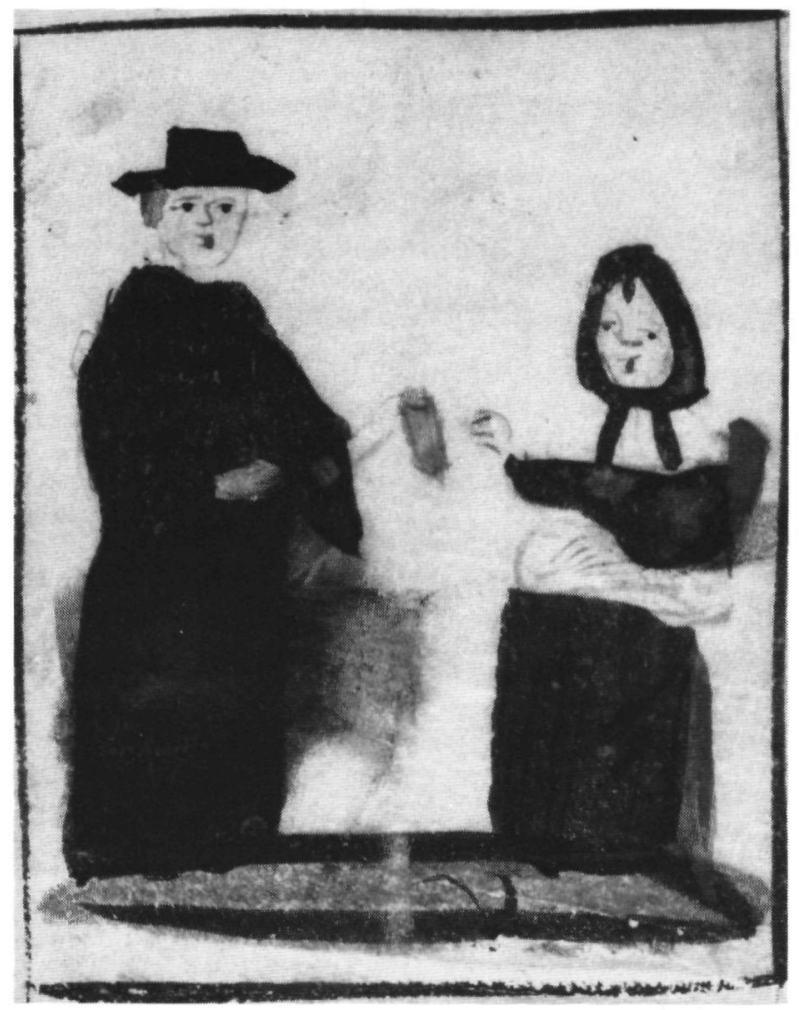

Afb. II Een geestelijke maagd met haar biechtvader, die haar iets overhandigt, mogelijk haar leefregel. De band tussen een klop en haar leidsman was fundamenteel voor haar religieus regime.

arbeid dat toeliet. Op zon- en feestdagen konden minder welgestelde maagdenhet religieuze programma, dat nog meer dan op doordeweekse dagen in het teken van gebed en kerkgang stond, wel volledig volgen.

Afhankelijk van hun voornaamste bronnen, kunnen kloppenboeken onderling verschillen. Sommige werken oriënteren zich sterk op kloosterregels. Dat blijkt dan onder andere uit het verplicht stellen van het bidden der getijden. ${ }^{323}$ Silentium was een andere gedragsregel die ontleend werd aan het kloosterleven. Vooral onderrichtingsboeken die geënt waren op of bedoeld waren voor vergaderingen van geestelijke maagden, schrijven absoluut stilzwijgen voor tijdens de arbeid 's ochtends en 's middags. ${ }^{324}$ In hun streven om orde en regelmaat te brengen in een kloppenleven vonden de stichtelijke auteurs elkaar, zo blijkt wanneer we verschillende dagordeningen naast elkaar leggen.

Als het aan de clerus lag, zag een dag in het leven van een geestelijke maagd er ongeveer als volgt uit. Tussen vier en vijf uur - 's winters tussen vijf en zes uur

323 Stevins, Regel, 4, schrijft bijvoorbeeld voor dat geestelijke dochters van de derde orde van St. Augustinus dagelijks de grote getijden van Onze Lieve Vrouw moeten lezen en de rozenkrans moeten bidden.

324 Reghel der Volmaecktheyt, 28, is hiervan een voorbeeld. 
- stond zij op. Tijdens het ochtendgebed dankte zij God dat hij haar gedurende de nacht had bewaard tegen onverhoedse aanvallen van de duivel, alsook tegen een onvoorbereid verscheiden uit het aardse. Verschillende regels bevelen aan het bidden voort te zetten tijdens het aankleden en opruimen van de eigen kamer. Van een ontbijt maken de meeste boeken geen melding; tijdens hun eerste openbare religieuze verplichting, het bijwonen van de mis, behoorden kloppen nuchter te zijn, zeker wanneer zij ter communie gingen. ${ }^{325}$ Als zij zich hieraan hielden, dan onderhielden zij een soberder maaltijdenpatroon dan gedurende de zeventiende eeuw gebruikelijk was. ${ }^{326}$ Voordat een klop zich ter kerke begaf om de mis bij te wonen, restte haar vaak nog wat tijd, die zij op aanwijzing van de kloppenboeken aan huishoudelijk werk, meditatie of het lezen van de getijden mocht besteden.

Dagelijks mishoren was een verplichting voor alle maagden die niet voor de kost hoefden te werken. In de kloppenboeken staat nauwkeurig beschreven hoe men zich tijdens en na de mis had te gedragen. Werd er geen communie uitgereikt, dan behoorden maagden tenminste geestelijk te communiceren. Wie de tijd aan zichzelf had, bleef na afloop van de mis nog enige tijd in de kerk om de vereniging met God op gepaste wijze te beleven. Vanaf een uur of negen waren enkele uren gereserveerd voor werk, hetzij uit existentiële noodzaak, hetzij uit liefdadigheid. Ter voorbereiding op de middagmaaltijd werd gebeden. Bij die gelegenheid werd doorgaans ook het eerste persoonlijke gewetensonderzoek van de dag gehouden. Aan de hand van de tien geboden of andere, in een kloppenboek aangereikte morele gedragscodes, moest een maagd onderzoeken of zij gezondigd had. $\mathrm{Zij}$ kon zich bij haar gewetensonderzoek concentreren op een zonde die zij in het bijzonder uit wenste te roeien. Bij het tweede gewetensonderzoek, 's avonds voor het slapen gaan, kon zij peilen in hoeverre zij haar eerder gemaakte voornemens gestand had gedaan.

$\mathrm{Na}$ de middagmaaltijd, waarvoor een uur was uitgetrokken, was enige tijd ingeruimd voor gesprekken met huisgenoten of leden van de eigen kloppenvergadering, het lezen van een geestelijk boek, of het zingen van stichtelijke liedjes. Rond een uur of éen werd het werk hervat. Dit werd nog enkele malen onderbroken voor het bidden van de rozenkrans of andere gebeden. Sommige kloppenboeken reserveren tijd voor het lezen van een geestelijk boek aan het einde van de middag. In de namiddag werden door degenen, die de getijden lazen, de vespers gelezen. Alle maagden begaven zich daarna naar het lof. De avondmaaltijd werd rond zes uur gebruikt. Evenals 's middags was hierna korte tijd ingeruimd voor wat ontspannende bezigheden. Tegen negen uur behoorde een maagd zich naar haar

325 Aldus wordt expliciet vermeld in Een regel waer duer als een Spieghel, 't'Inhout' (ongepagineerd). 326 Volgens Jobse, Eenvoudig maar voedzaam, 155-157, waren er - regionale en sociale verschillen in aanmerking genomen - gemiddeld 3 à 4 eetmomenten gedurende de dag, waaronder een ochtendmaaltijd of ontbijt. 
kamer te begeven. Na het tweede gewetensonderzoek en avondgebed was het dan rond then uur tud om te gaan slapen.

Moesten monialen de clausuur onderhouden, voor geestelı)ke maagden golden eveneens uitgaansrestricties, zij het minder drastische. Het paste een bruid van Christus net langs de straten rond te hangen, laat staan zich in achterbuurten af te geven met de heffe des volks. Voor kerkgang en liefdewerken mochten de maagden zich, in tegenstelling tot slotzusters, in de openbaarheid begeven. Volgens voorschnft dienden zi) zich dan zedig en ingetogen te gedragen, in overeenstemming met hun geestelıjke staat. Na de kerkdıenst of werk moesten zil zich zonder dralen weer in de beslotenheid van hun hus of kamer terugtrekken. Want:

't Is geen Maagd, wie niet behaagt

De stille eensaemhert' ${ }^{327}$

\section{Sacramentele vroomherd}

Kloppenboek-auteurs proberen ook de vroomheid van geestely)ke maagden in goede banen te leiden. Voorschnften dienaangaande vertonen vanaties die te herleiden zijn tot uiteenlopende denkbeelden van de auteurs over de pastoraal en moraal. Ruchtlınen ten aanzien van de communie blıken een brulkbaar ıkpunt voor deze verschillen. In de aan kloppen aanbevolen frequentie van de communie tekent zich het verschil af in opvatting over de sacramentele praktı)k, dat zich van-af het midden van de zeventiende eeuw tussen seculıere en reguliere geestelıjken deed gelden. ${ }^{328}$ Vanuit het streven een zekere verinnerlykung van het geloofsleven $b_{11}$ katholieken te bewerkstelligen, stonden sommige wereldheren een strenge controle op het ontvangen van de sacramenten voor. Neercassel instrueerde de clerus om penitenten in de biechtstoel nauwkeung te ondervragen over gedrag in leer en leven, hun nuet te snel absolutie te verlenen en af te raden vaak te communiceren. Vanuit de gedachte dat de mogelyjkheden van de door de erfzonde belaste mens om mee te werken aan de eigen zaligheid, beperkt waren, werd een grondıge voorbereiding op de communie onontbeerlı1k geacht. Dit sacrament diende alleen uitgereikt te worden aan degenen die reeds een grote mate van volmaaktheid hadden bereikt. ${ }^{329}$ Regulıeren, met name jezureten en franciscanen, stelden veel minder strenge eisen aan de uitreikng van de communie In hun visie zou het heilig brood gelovigen juist helpen een hogere graad van volmaaktheld te bereiken. ${ }^{330}$

In zowel de Latjnse als in de Nederlandse editne van zjon kloppenboek stelt Lindeborn dat maandelıkse communie passend is voor geestelıke maagden. ${ }^{331}$

327 Musius, Maagde-pligt, II

328 Spiertz, 'Godsdiensug leven', 35I-352

329 Voorvelt, De Amor Poenitens Spiert, 'Jansenisme', 159-160

330 Ceyssens, 'Het theologische denken', 418-438, Sp1ertz, 'Jansenisme', 145-146

331 Lindeborn, De Leeder Jacobs, 321 Nouwens, De veelvuldige $H$ Communue, 312 (noot 212), stelt mun inziens ten onrechte dat hetgeen Lindebom over het communiceren van geestelıke maagden zegt, 
Voor deze frequentue beroept hy zich op de voorschnften van het Concilie van Trente voor vrouwelıjke religieuzen. Joannes van Heumen, die net als Lindeborn tot de kring rond Neercassel gerekend kan worden, stond toch minder afwijzend tegen veelvuldig communiceren, mits de intentie hiertoe - hefde tot God aanwezıg was. Dremaal wekelı)ks ter commune gold bij hem als een maxumum..$^{332}$ Voor Mana Anna du Val de Dampierre, een maagd onder leiding van wereldheren, was maandelıkse communie eerder een vorm van versterving dan gebruik. $\mathrm{Na}$ verloop van tud begon zil, aldus haar vita, behalve op helligedagen ook op donderdag en zondag ter communie te gaan. ${ }^{333}$ Auteurs uit de knngen der regulieren, en dan vooral jezuieten, raden de maagden aan op zon- en hellgedagen ter communie te gaan. ${ }^{334}$ Bisschop verzucht dat hi) wel tot frequentere communie zou willen raden, maar bang is 'dat ghy te flau [zwak] zujt, om u daer toe met behoorlycke devotie te schicken'. ${ }^{335}$ Hieruit spreekt de zorg voor de juiste grondhouding en intentre waarmee een geestelıke maagd ter communie ging. In de ogen van de kloppenboek-auteurs is enkel de biechtvader in staat om te beoordelen of zlj over de juiste instelling beschikt om dit sacrament te ontvangen. Op diens zeggenschap willen de geestelıke auteurs geen inbreuk plegen en daarom geven zij slechts algemene nchtlujnen ten aanzien van de frequentıe Hoeveel maal per week of per maand een individuele maagd ter communie mocht, bepaalde uiteindelı)k haar biechtvader Of maagden nu eens per maand of enkele malen wekelıjks ter communie gingen, zij ontvingen dit sacrament vermoedelıjk vaker dan de meeste andere leken. ${ }^{336}$

Wereldheren én regulieren streefden een verınnerlıjkıng van de sacramentsbeleving na. Over de wijze waarop dit gedeelde ideaal verwezenlıjkt kon worden, liepen hun meningen nuet altud parallel. ${ }^{337}$ Verinnerlı)king en eerbıed voor de sacramenten waren naar de mening van een seculiere priester als Joannes Lindeborn beter gewaarborgd bij een lage communiefrequentıe. De jezuiet Valentınus Bisschop daarentegen lijkt zich op het standpunt gesteld te hebben dat een hoge communiefrequentue ook onherroepelyjk bi) zou dragen aan eerbied voor en liefde tot dit sacrament Niet de gewoonte maar de liefde tot God diende de impuls te zj)n om zich ter communie te begeven, zo stemden de kloppenboek-auteurs met elkaar overeen, vanaties in frequentie der commume ten spitt. $Z_{1 j}$ drongen met gedetailleerde instructies aan op een goede voorbereiding en mentale beleving van de

nauwelıjks verschilt van wat de jezuier Bısschop dienaangaande aanbeveelt

332 Van Heumen, Clooster van Ston, V, sermoen is

333 Leven Mana Anna du Val de Dampierre, 151, 153

334 Bisschop, Lof der Suyverheydt, III, 359 Instructie, 20, schruft de communue voor op zon- en feestdagen Hiervoor ook Nouwens, De veelvuldige $H$ Communie, 341

335 Bisschop, Lof der Suyverheydt, III, 360

$336 \mathrm{Vgl} \mathrm{Clemens,} \mathrm{De} \mathrm{godsdrenstrgherd,} \mathrm{I,} \mathrm{95-96}$

$337 \mathrm{Vgl}$ idem, 'Katholieke vroomherd', 204-205 
commune, die volgens sommige auteurs zelfs dagen in beslag nam. ${ }^{3{ }^{8}}$ De wereldheer Schoenius verbiedt de maagden bij het ontvangen der communie te lezen of zelfs maar te zuchten. ${ }^{339}$ Door nets mag een maagd haar aandacht laten afleiden tudens en na de communie, aldus de jezuiet Gerardi. De volledıge vereniging met God in de communie mag niet verstoord worden door het lezen van gebeden, van een boekje of door het bidden van de rozenkrans 340

Dit streven naar verinnerlıjkng kwam mogelık onder spanning te staan door de bıjzondere betekenıs die toegekend werd aan de communie voor geestelıke maagden. Volgens de jezuiet Bisschop kan een klop haar identiteit als bruid van Christus bevestigen door ontvangst van de communie. In dit sacrament kan zij haar Bruidegom vinden. $\mathrm{H}_{1}$ zal haar hart hierdoor met goedheid vullen en $\mathrm{Z}_{1 \text { jn }}$ gaven aan haar uitdelen, 'soo dat sy aldus gheheel heylich wordt ende goddelyck, bequaem om sulck een te wesen, die sın Bruydt wel mach genoemt worden'. ${ }^{341}$ Daarmee wordt het frequent communiceren een religieus ntueel dat de identiteit van een geestelıke maagd kan bevestigen In feite borduurt Bisschop voort op de laat-middeleeuwse euchanstische vroomheid van in het bijzonder religieuze vrouwen, voor wie de communie de volledıge geestelı)ke én lichamelıjke eenwording met hun Bruldegom representeerde. ${ }^{342}$ Deze voorstelling van functie en werkung van de hostie verklaart het verlangen van geestelıjke maagden om dagelıjks te communiceren, dat in verschillende kloppenboeken gedocumenteerd wordt.

De vitae laten zien dat sommige geesteliıke maagden de communie vaker ontvingen dan de auteurs van ondernchtıngsboeken wenselık achtten. Gezien de beschermende en identiteitsbevestigende werking die er aan dit sacrament wordt toegeschreven, is het waarschijnlıjk dat sommıge religieuze vrouwen zıch vooral aan Lidwina van Schiedam, Luisa de Carvajal y Mendoza of Joanna van Randenraedt spiegelden, die dagelıks ter communie gingen Volgens hun 'biografen' dankten deze maagden dit voorrecht aan hun buttengewone deugdzaamheid. Joanna van Randenraedt was 'soo verre verheven in deughden, ende soo innighlyck vereenight met Godt' dat haar het pnvilege van de dagelıjkse communie wel toekwam, aldus Huysmans ${ }^{343}$ Maar geestelıke maagden konden van deze levens ook leren dat de communiefrequentue altud bepaald werd door biechtvaders en andere geestelıken. Dagelı)kse communie was, met andere woorden, geen

338 Reghel der volmaecktheyt, 81 Nouwens, De veelvuldige $H$ Communie, 309, bespeurt in de beschnjving van voorbereiding en intentre tot dit sacrament, hefde tot God, de invloed van het als jansenistusch bestempelde werk van Antoine Arnauld, De la frequente communion Luefde tot God wordt echter ook door de jezulet Bisschop genoemd als voomaamste beweegreden

339 Weg, 232

340 Gherard, Spreghel van Phalotea, 34, 122-123

34I Bisschop, Lof der Suyverheydt, III, 358, zie ook Mantere, 18 Vgl Lindeborn, De Leeder facobs, 318-324, volgens wie de commune de beste bescherming is voor de zuiverheid der maagden

342 Vandenbroeck, Hooghed, 36, 82 Bynum, 'Women mystucs'

343 Kort Begryp, $75 \mathrm{Vgl}$ Van Miert, 'Over het veelvuldıg communiceren', 29-30 
algemeen gebruik, niet onder vrouwelijke religieuzen en niet onder geestelijke maagden. De jezuïet Bisschop begreep heel goed dat kloppen het 'gheluck der Priesteren' benijdden 'dat zij in hun Misse daghelijcx moghen dadelijck het $\mathbf{H}$. Sacrament ontfanghen'. ${ }^{344}$ Als 'remedie' voor geestelijke maagden die liefst iedere dag ter communie willen, wordt de geestelijke communie aanbevolen, waarbij men het sacrament der eucharistie niet werkelijk nuttigt, maar wel een groot verlangen heeft dit te doen. Volgens de kloppenboeken laat deze wijze van communiceren de gelovigen net zo volwaardig delen in de gaven Gods als de sacramentele

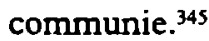

Niet alleen over de functie en frequentie van de communie werd verschillend gedacht, maar ook over de biecht. Terwijl Bisschop de biecht als het tweede doopsel der mensen beschouwt dat de vlekken der zonden verwijdert, houdt Lindeborn, als vertegenwoordiger van een strengere moraal, de maagden voor dat biecht hen niet vrijwaart van zonden, omdat die onuitroeibaar zijn..$^{36}$ Volgens zijn collega Van Heumen moet de biecht echter juist voorkomen dat mensen door hun zonden verzwolgen worden ${ }^{347}$ De kwestie van de graad en de aard van het berouw, die tegen het einde van de zeventiende eeuw in de jansenistische woelingen een belangrijke rol speelt, lijkt in de meeste kloppenboeken nog van ondergeschikt belang. Bisschop licht de maagden in over de twee bronnen waaruit het berouw over de zonden kan voortkomen, namelijk angst voor straf en lijden in het hiernamaals (attritio) en liefde tot God (contrtio). Is er sprake van contritio dan hoeft de biecht niet noodzakelijkerwijs te volgen. In geval van attrtio is de biecht noodzakelijk. ${ }^{348}$ Van Heumen keurt slechts één vorm van berouw goed, namelijk die wroeging die haar oorsprong vindt in de liefde tot God. Door angst voor de hel die haar als zondares eventueel te wachten staat, mag een maagd zich niet laten leiden. ${ }^{349}$ Bisschop daarentegen sluit de effectiviteit van het laatsgenoemde type berouw niet uit, maar geeft de maagd toch een duidelijk stappenplan hoe zij een meer volmaakt leedwezen, de contntio, kan bereiken. ${ }^{350}$

344 Bisschop, Lof der Suyverheydt, III, 299.

345 Bijvoorbeeld ibidem, 299, 304; Reghel der volmaecktheyt, 25-26. Lindeborn vermeldt niets over de geestelıke communie Voor de praktıjk van de geestelıje communie in de Nederlanden gedurende de late middeleeuwen, zie Caspers, De euchanstusche vroomherd

346 Bisschop, Lof der Suyverheydr, III, 80-82. Lindeborn, De Leeder Gacobs, 312-313.

347 Van Heumen, Clooster van Sion, VI, 21.

348 Bisschop, Lof der Suyverheydt, III, 9I-93.

349 Van Heumen, Clooster van Sion, I, sermoen 9; Lundeborn, De Leeder facabs, 307-318, spreekt in het hoofdstuk over de biecht nergens over wat in zijn ogen de juste bron van berouw is. Wel stelt hij nadrukkelı)k dat een geestelı)ke maagd de zonden, waaraan zı) zıch schuldıg heeft gemaakt, zelf moet bestrnjden. Daardoor laat zı 'blyken dat gy het Sacrament van penitentie niet te vergeefs gebruikt hebt, en dat gy met de behulp van de goddelıke genade, waer mede de Autheur van gratie u daer begunstigt heeft, van sins zijt mede te werken' (317)

350 Bisschop, Lof der Suyverheydt, III, 94-101. 


\section{Penitentiële vroomheid}

Natuurlijk was het te prijzen dat maagden dagelijks de mis bijwoonden, de getijden van Onze Lieve Vrouw lazen en op gezette tijden biechtten en communiceerden. Maar ware bruiden van Christus ijverden er ook voor zichzelf volledig te versterven en eigen lusten en behoeften volkomen te overwinnen. Echte maagden roeiden hun fouten en gebreken, 'daer gy een slaevinne van bent' en die God geenszins aangenaam waren, uit volgens Lindeborn. ${ }^{351}$ Doel van deze versterving was ootmoed, de voornaamste deugd waarover een ware geestelijke maagd moest beschikken. Want men moest 'diep in sy selven daelen, om hoogh in Godt te klimmen', zo houdt Adriaen Poirters zijn lezers voor. ${ }^{352}$ Ootmoed was een geestelijke kwaliteit, die door Gods genade verworven zou kunnen worden. ${ }^{353}$ Een maagd kon daaraan meewerken door zichzelf aan een streng, ascetisch regime te onderwerpen dat de wereld, eigenzinnigheid en eigen zinnelijkheid moest uitbannen. Besnijdenis der vijf zinnen, zo luidt kort samengevat de inhoud van het penitentieel programma dat de kloppenboeken aanreiken. Ogen, oren, mond, neus en handen - zien, horen, spreken, ruiken en tasten - gelden als de zintuigen en zinnen die onder controle gebracht moeten worden. De maagd die daartegen zondigt, pleegt zelfs overspel volgens de wereldheer Lumnius. ${ }^{354} \mathrm{Al}$ sinds Augustinus gelden de zintuigen als poorten van de ziel. Langs deze wegen kan de ziel besmet raken met duivelse verleidingen, want wie zich door haar eigen zinnen laat beheersen, die huisvest de duivel in zichzelf. ${ }^{3 s 5}$ Niet de duivel - verbeeld in de begrippen 'wereld', 'lichaam', 'menselijke natuur' en 'zinnelijkheid' - moet de mens regeren, maar God. En God geeft men ruimte daartoe door de geest te laten regeren over de lichamelijke lusten en behoeften. ${ }^{356}$

De geest behoort over het vlees te heersen, en niet andersom. De strijd voor de ootmoed en tegen de zonden dient daarom allereerst op het slagveld van eigen lichaam en geest geleverd te worden. Over de vormen van lichamelijke en geestelijke versterving zijn de kloppenboek-auteurs betrekkelijk eensgezind. Eten en drinken dienen uitsluitend voor het noodzakelijk onderhoud van het lichaam, dus gulzigheid is uit den boze. De vastendagen die de kerk voorschrijft, moeten in acht genomen worden. Uitgaan, kletsen, behagen scheppen in opschik, doelbewust gezelschap opzoeken, gelden als zondig.

Op het punt van fysieke boetedoeningen lopen de door de geestelijke auteurs

35I Lindeborn, De Leeder facobs, 48-49.

352 Poirters, Het daeghelycks meuwe-jaet spneghelken, 28-29

353 Bisschop, Lof der Suyverheydt, III, 77, beschn,ft deze geestelı,ke kwalite1t als 't welcke wonderlıjck troosuch is voor de Maghet, die door haer naturelyjcke kranckheyt ende teencheyt, net en wort verboden van seer in Ootmoedicheyt voort te gaen'

354 Lumnius, Van dleven, 27-28

355 Rosweydus, Leven der $H H$. Maeghden, 617-630. Van Heumen, Clooster van Sion, II, 332.

$356 \mathrm{Vgl}$ Manere, I5I e.v, 'Eenighe Regelen'. 
voorgeschreven gedragslijnen echter uiteen van aanmoedigend tot zeer prudent. ${ }^{357}$ Wederom blijkt dat men het ideaal van ootmoed voor de geestelijke maagd deelt, maar van mening verschilt over de weg waarlangs nederigheid het beste bereikt kan worden. Behoedzaam is zeker de seculiere priester Lindeborn, die oordeelt dat de matigheid absoluut aan te bevelen is in geval van fysieke boetedoening. 'Men moet het lichaem niet krenkken [sic], maer wel regeren', luidt zijn devies. ${ }^{358}$ Zijn opvatting stemt overeen met die van Neercassel, die Marie-Anne Voeller in I677 laat weten dat eenzaamheid, stilzwijgen, waken, lezen, bidden, vasten en het geven van aalmoezen de beste boetedoeningen zijn. ${ }^{359}$ Maagden moeten hun lichaam achten en niet maltraiteren door extreme verstervingen of penitenties, zo herhaalt de Franse wereldheer Girard de Vilthierry aan het begin van de achttiende eeuw..$^{360}$

Prudentie in penitentie wordt bij een auteur als de jezuiet Bisschop vooral gewaarborgd doordat hij de biechtvader naar voren schuift als degene die kan en moet beoordelen of boetedoeningen werkelijke vooruitgang van het geestelijk leven van een klop zullen bewerkstelligen. De functie en werking van penitentie is in Bisschops betoog meervoudig. ${ }^{36}$ Door boetedoening kan men het kwaad vereffenen waartoe het lichaam met zijn onuitroeibare zondige neigingen de maagd verleidt. Maar penitentie schenkt ook deugden, geeft kracht om de duivel te weerstaan en plaveit de weg naar het eeuwig leven. Ontleden we zijn betoog verder, dan blijkt dat penitentie een identiteitsbevestigende werking krijgt toegemeten. ${ }^{362}$ Wie zichzelf doet lijden, wordt bekleed met de 'livreye Christi'. Aangezien een geestelijke maagd aan Christus toebehoort als $\mathrm{Zijn}$ bruid, dient haar oogmerk te zijn om zoveel mogelijk aan Hem gelijk te worden. ${ }^{363}$ Door verschillende vormen van al dan niet zelf toegebracht lijden bereidwillig te doorstaan, zo blijkt uit het verloop van het betoog, kan een maagd deze gelijkenis bewerkstelligen. Ook Lindeborn, die wat betreft het penitentiële regime toch bij de meer prudente richting onder de kloppenboek-auteurs hoort, onderschrijft dat een maagd die niet bereid is tot fysieke penitentie, haar Bruidegom niet waarlijk bemint. ${ }^{364} \mathrm{En}$ Bisschops ordegenoot Heribertus Rosweydus put zich met zijn Leven der H.H. Maeghden uit om aan te tonen dat lijden om den gelove en uit liefde tot de Bruidegom van oudsher een integraal bestanddeel vormt van de identiteit van maagden. Mee-lijden met de Bruidegom bevestigt ook in de vitae van Agnes van Heilsbach, Joanna van Randenraedt, Sancia Carillo, Anna de Torres, Luisa de

357 Alleen in Steur, Lelie der maeghdelijcker suyverheydt, ontbreekt gedetailleerde informatie over penitenties.

358 Lindebom, De Leeder Jacobs, 265.

359 RAU, $A O B C$, inv.nr. 605, Neercassel aan Marie-Anne Voeller, 19 oktober 1677.

360 Girard de Vilthierry, Het leven der maegden, I35-156.

361 Bisschop, Lof der Suyverheydt, III, I03.

362 Zie ook Gabriël a S. Joanne Baptista O.Carm., De Bruydt Christi Christina, 26-27.

363 Bisschop, Lof der Suyverheydt, III, 9.

364 Lindeborn, De Leeder Jacobs, 264. 
Carvajal y Mendoza en Lidwina van Schiedam hun bruid-status. Wie de maagdelijke staat aanvaardt, moet daartoe bereid zijn, maar mag, bij wijze van tegenprestatie, ook rekenen op goddelijke genade.

De ootmoed die boetedoeningen als het dragen van een haren kleed of riem, het slapen op de vloer of op een plank mede moeten bewerkstelligen, krijgt in de betogen van Bisschop en Rosweydus, alsook in de verschillende vitae een andere lading dan bij de auteurs die zich op dit punt door voorzichtigheid laten leiden. Benadrukken laatstgenoemden de nederigheid en gehoorzaamheid die geestelijke maagden zich door penitenties eigen kunnen maken, eerstgenoemde auteurs accentueren impliciet de verhevenheid die er in ootmoed kan schuilen. Bisschop, bijvoorbeeld, citeert uit het Lucas-evangelie dat degene die zichzelf vemedert, verheven zal worden. Verootmoediging leidt naar nederigheid én verhevenheid. Bereidheid tot en doorstaan van lijden strookt met het streven naar nederigheid waardoor geestelijke maagden zich behoren te laten leiden. Tegelijkertijd beklemtoont hun lijden de eigen uitverkoren positie als bruiden van Christus. Wellicht was het angst voor de aanspraak op verhevenheid, die andere, meer prudente auteurs beschroomd maakte in hun aanbevelingen over boetedoeningen.

De verschillende vitae onder de kloppenboeken illustreren dat er inderdaad verhevenheid achter ootmoed kan schuilgaan. Bovendien laten zij zien dat fysiek lijden niet enkel de lijdzaamheid van een geestelijke maagd uitdrukt, maar ook haar daadkracht. De ontwikkeling die Sancia Carillo, Anna de Torres, Agnes van Heilsbach, Joanna van Randenraedt, Luisa de Carvajal y Mendoza en Maria Anna du Val de Dampierre hebben doorgemaakt, laat zich als volgt schetsen. Door een diep zondebesef, dat zich van hen meester heeft gemaakt nadat een ander meestal een geestelijke - hun de verderfelijkheid van hun handel en wandel heeft voorgehouden, kiezen deze vrouwen voor een religieus, boetvaardig leven. Hun praktijken van versterving en penitentie zijn vele malen strenger dan wat de onderrichtingsboeken op dit punt voorschrijven. Zij beogen hiermee eigen zondigheid af te wenden en zaligheid te bewerkstelligen. De kern van repetitieve, rituele handelingen bestaat uit gebed, strijd tegen de zonde en fysiek lijden, die onlosmakelijk met elkaar verbonden worden in de vitae. Bidden en lijden zijn de diensten die deze religieuze vrouwen, voor wie iedere vorm van actief apostolaat beladen is, hun naasten bewijzen. Hun gebeden behoeden familie en vrienden voor zonden en functioneren als een soort voorspraak bij God. Door vormen van zelf toegebracht lijden of andere fysieke aandoeningen te verdragen, smeken zij genade bij God af voor zondaars en zondaressen en verlichten zij het lot van de zielen in het vagevuur.

Door de strijd die geestelijke maagden met hun boetvaardig gedragsrepertoire tegen de zondige wereld leverden, gaven zij vorm en inhoud aan hun staat. Sporen van de fysieke uitputtingsslag die deze vrouwen met zichzelf aangingen, toonden anderen hoe vroom zij waren en hoezeer zij over de uitzonderlijke genade van God 
beschikten. Zonder Gods genade zou ummers geen mens dergelık strenge boetedoenıngen volhouden. En zeker geen vrouw, die 'van nature' minder gepredisponeerd was voor fysieke penitenties die door kloppenboek-auteurs als 'manhaftige werken' worden bestempeld. Boetvaardige vroomheid wordt aldus als een mannelık domeın bestempeld. Dat betekende met dat strenge boetedoeningen buiten het bereik van vrouwen lagen Want een vrouw die zichzelf tot bloedens toe kastıjdde en haar lichaam in toom hield met haren nemen of boete-armbanden, bewees dat zi) zichzelf niet uit een spreekwoordelıke vrouwelı)ke zwakheld spaarde. De geestelıke auteurs laten hun lezeressen en lezers op verschillende manieren zien hoe welgevallig God dergelıke boetedoenungen waren. $\mathrm{H}_{1}$ beloonde deze vrouwen met $Z_{1 j n}$ liefde en gratie, die hun aanzien binnen en buiten hun eigen geloofsgemeenschap vele malen vergrootte. Aan Sancia Canllo openbaarde $\mathrm{H}_{1]}$ geheimen van het geloof als erkenning voor haar boetedoeningen Haar vita vervolgt met de mededelıng dat zıj zich door $Z_{1 j n}$ blık van waardenng in het door haar gekozen bestaan bevestigd wist. ${ }^{365}$ En toen Wenen in 1683 door de Turken belegerd werd, verkoos God Joanna van Randenraedt in de stad Roermond om te verkondigen dat Wenen stand zou houden en dat het ware geloof hier niet in gevaar zou worden gebracht Deze ingeving Gods wordt in Van Randenraedts vita rechtstreeks in verband gebracht met haar geloofsıjver, uitgedrukt in gebed, smeekbeden, lıfkastıjdıngen en de bereidheid om lichamelıjke pıjnen op zich te nemen en te verdragen ${ }^{366}$

In zekere zin vertonen de verschillende vitae sporen van de laat-middeleeuwse vroomheid van religieuze vrouwen, de zowel een ascetisch als een affectief en mystiek karakter droeg Golden draconısche boetepraktı)ken en verstervingen toen als voor vrouwen toepasselı|ke relıgieuze uitdrukkungsmogelıjkheden en wegen om toenadenng tot God te zoeken, ${ }^{367}$ die waardenng was aan inflatie onderhevig sinds de Contrareformatıe Dat blıkt uit de levens van vrouwen die sinds de zestiende eeuw zalig of heilig werden verklaard. Vooral ziekte - met name het geduldig verdragen van een langdung ziekbed - blyjkt een belangri)ke maatstaf voor helligheid, in plaats van extreme versterving en zelfvernedenng. ${ }^{368}$ De clencale idealen die in de levens van geestelıke maagden worden vertolkt, blıken deze nieuwe standaard voor heiligheid op onderdelen nog niet volledig te onderschriven.

\section{Sprntuele voorhoede}

De auteurs van de kloppenboeken streefden emaar geestelıke maagden als het ware om te vormen tot een soort spintuele voorhoede binnen de katholıeke leken-

365 De Roa, Leven Sancra Canllo, I1 7-118

366 Kort begryp, 150

$367 \mathrm{Z}$ ie bijvoorbeeld Kueckhefer, Unquiet souls

368 Bell, Holy anorexia, I70-1 78, wiens onderzoek zıch beperkt tot Italiaanse religieuze vrouwen en helligen 
gemeenschap. Het ideaal van een waarlijk doorleefd geloof, dat met de contrareformatorische hervormingen nieuw leven was ingeblazen, probeerden geestelijken in de loop van de zeventiende eeuw aan katholiek gebleven gelovigen te bemiddelen. Van de godvruchtige leefwijze van geestelijke maagden konden katholieken, die hun kerk trouw waren gebleven maar in religieus-dogmatisch opzicht slecht onderlegd waren, veel leren. Een geestelijke maagd die dagelijks naar de mis gaat, sticht haar naasten door haar 'goet exempel' en zal 'vele verdoolde Christenen wederom tot de $h$. Kercke bringhen', meent de jezuïet Bisschop. ${ }^{369}$ Verschillen in opvattingen over communie, biecht of boetepraktijken waren in dit verband zeker niet van ondergeschikt belang. Via geestelijke maagden konden de uiteenlopende interpretaties hun weg vinden naar kinderen en ook volwassenen. Wat kloppen geleerd werd, gaven zij door aan anderen via hun eigen voorbeeld, catechisatie of persoonlijke gesprekken.

Als levende voorbeelden werden kloppen door de clerus tot bondgenoten gemaakt. Bondgenoten waarvan de geestelijkheid bij haar streven naar verbetering van allerlei misstanden binnen de kerk afhankelijk was, zeker binnen de grenzen van de Hollandse Zending waar de relatieve achterstandssituatie was verscherpt door het verbod op de katholieke eredienst. ${ }^{370}$ Maar uit de kloppenboeken blijkt dat de auteurs zich bewust waren van de risico's die zo'n bondgenootschap met zich meebracht. De medestanders waren vrouwen die naar de mening van de kloppenboek-auteurs altijd strakke supervisie behoefden. Bovendien leidden zij een religieus bestaan dat door kerk niet als een staat werd erkend. Banden met geestelijke maagden waren informeel van karakter en maakten de clerus in hoge mate kwetsbaar. Om die kwetsbaarheid wat te verminderen en de controle op het doen en laten van de vrouwelijke bondgenoten te vergroten, werden leefwijze en taken van geestelijke maagden aan voorschriften gebonden. Kloppenboek-auteurs hadden er, zo blı)kt uit de strekking van de geanalyseerde boeken, alle belang bij door regels en nchtlijnen de alliantie met kloppen, voor zover mogelijk, te formaliseren overeenkomstig de geaccepteerde gezagsverhoudingen tussen geestelijken en leken. Als herders en spiritueel leiders van hun geloofsgemeenschap waren geestelijken belast met de zorg voor de maagden, die de verheven positie van hun biechtvader of andere priesters onder geen beding uit het oog mochten verliezen. ${ }^{37 \mathrm{I}}$

369 Bisschop, Lof der Suyverheydl, III, 301.

370 Dergelinke pastorale problemen speelden miet alleen in Noord-Nederland maar bijvoorbeeld ook un Engeland en elders in West-Europa. Zie hervoor Rowlands, 'Recusant women' en Delumeau, Catholucssm, 194-199.

371 Leven Mana Anna du Val de Dampnerre, 145; Lindeborn, De Leeder facobs, 182-184. Of Lindeborn hoopt dat geestelı)ke maagden een helzame unvloed op pnesters konden uttoefenen, is niet geheel duidelık, maar hıj begunt een exposé over wat de grondhoudıng van een pnester tudens de mis behoort te zijn Vervolgens corrigeert hij zıchzelf 'dan wat maek $1 k$ ? waer loop $1 k$ heen? $1 k$ geef den Priester ondernchting, ik die de maagd moet leeren'. 
Het aan geestelijke maagden voorgeschreven religieuze gedragspatroon beoogde de dualiteit tussen geloof en leven, tussen het kerkelijke en het wereldlijke domein op te heffen. Kloppen moesten in de wereld een geestelijk leven leiden en konden bewijzen dat een religieus-geïnspireerde en moreel hoogstaande leefwijze voor leken bereikbaar was. Van hen werd verwacht dat zij de verschillende devoties en religieuze rituelen niet louter ondergingen, maar deze waarlijk beleefden en doorleefden. Dankzij gedetailleerde beschrijvingen in onderrichtingsboeken voor mentale en fysieke houding tijdens de mis, biecht, communie, gebed en meditatie, moest deze verinnerlijking van het geloof slagen. In de vitae krijgt de door geestelijken nagestreefde internalisatie een andere vertaling. Aan de hand van geestelijke maagden als exempla wordt aangetoond dat het in de praktijk mogelijk was een leven te leiden dat geheel in het teken van devotie en penitentie stond. Over een waarlijk doorleefde geloofsovertuiging konden geestelijke maagden en andere lezers leren uit de levens van Isabella van Frankrijk die tranen plengde tijdens haar gebed, van Lidwina van Schiedam die zich tijdens haar langdurige ziekbed volledig identificeerde met het lijden van haar Bruidegom, of van Joanna van Randenraedt en Agnes van Heilsbach, wier bewogen geloofsbeleving breed wordt uitgemeten.

\section{III.8 Conclusie}

Er bestond geen uniforme regel voor kloppen. Kloppenboeken voorzagen ad hoc in deze leemte. $\mathrm{Zij}$ eigenen zich echter slechts beperkte zeggenschap toe over het doen en laten van de maagden. Deze papieren leidsmannen 'op afstand' achten zichzelf niet competent om door gedetailleerde instructies leven en geloof van kloppen uit en te na te reguleren. De bevoegdheid daartoe heeft enkel de biechtvader annex geestelijk leidsman van een maagd, die de mogelijkheid en onmogelijkheid van verschillende richtlijnen beter kan inschatten. Deze machtiging van de biechtvader geeft natuurlijk een reeds bestaande situatie weer. Tegelijkertijd ligt hierin de erkenning besloten van het individuele karakter van de kloppenstaat en van de invloed die zowel biechtvader als klop hierop konden hebben. Aldus reflecteren kloppenboeken normen en idealen, die in de dagelijkse praktijk zeker nagestreefd, maar ook aangepast konden worden aan de persoonlijke omstandigheden van geestelijke maagden.

Het betrekkelijk kleine corpus van 34 kloppenboeken biedt een rijk geschakeerd beeld van denkbeelden die geestelijken huldigden over de kloppenstaat. Meest talrijk onder de kloppenboek-auteurs zijn de jezuïeten, die, zoals in het vorige hoofdstuk al werd opgemerkt, bijzondere zorg besteedden aan de vorming van geestelijke maagden in het algemeen. Geestelijke maagden mogen dan wel de beoogde lezeressen zijn geweest van kloppenboeken, gebrekkige gegevens wijzen 
slechts op enige, geringe, belangstelling voor de onderrichtingsboeken en vitae die speciaal voor hen te boek werden gesteld. Geestelijken die als leidsman van kloppen optraden, zullen zeker ook hun voordeel met deze stichtelijke handleidingen hebben gedaan. Vermoedelijk hebben zij kloppen in persoonlijke gesprekken of vanaf de kansel deelgenoot gemaakt van verschillende voorstellingen van de maagdelijke staat in de wereld, zijn oorsprong en merites. Onderzoek naar de preek-cultuur in Noord-Nederland, dat nog in de kinderschoenen staat, zou daarover alsnog uitsluitsel kunnen bieden. Direct of indirect raakten waarschijnlijk veel vrouwelijke gelovigen vertrouwd met het gedachtengoed over vrouwelijkheid en vroomheid dat in kloppenboeken zijn beslag heeft gekregen.

Op de voorstelling van de religieuze leefwijze in de wereld, zijn spirituele en (binnen)kerkelijke ontwikkelingen tussen 1570 en 1730 , waarin de onderzochte boeken verschenen, nauwelijks van invloed geweest. De scheidslijn tussen auteurs die 'staat' een aanvaardbare definitie achtten voor het leven van geestelijke maagden, en scribenten die zich hiertegen verzetten, valt beslist niet naadloos samen met de scheiding tussen seculiere en reguliere zielzorgers in Noord-Nederland. Eigenlijk delen alle kloppenboek-auteurs de opvatting dat geestelijke maagden geen religieuzen waren. Maar anders dan kerkelijke gezagsdragers als Rovenius en Neercassel, die het daarbij laten, onderstrepen reguliere auteurs, net als sommige van hun seculiere collega's, dat het bestaan van deze maagden in waardigheid en nagestreefde volmaaktheid niet onderdoet voor de kerkrechtelijk erkende religieuze staat. Doordat het kloosterleven als meest volmaakte leefwijze als richtsnoer geldt, bevatten de meeste kloppenboeken uitvoerige vergelijkingen tussen de kloppenstaat en de religieuze staat. De pleidooien voor de geestelijke staat buiten kloostermuren laten zich lezen als expliciet geformuleerde altematieven voor de kloosterstaat. De argumenten hiertoe variëren van ziekte en geldgebrek tot roeping. Het concept roeping, waarvan vooral jezuïeten zich bedienen, rechtvaardigt als geen ander argument de keuze van vrouwen voor het buiten-kloosterlijke geestelijke leven, omdat het niet gebonden is aan maatschappelijke of regionale politiek-religieuze verschillen. Uit hun voorkeur voor de omschrijving 'geestelijk' voor het leven en de personen van kloppen blijkt dat de kloppenboekauteurs eigenlijk een nieuwe categorie naast religieuzen en leken wilden scheppen.

In de katholieke geloofs- en zedenleer werd vrouwen een aan mannen ondergeschikte plaats toegewezen. Dat de sekseverhoudingen binnen deze confessie hiërarchisch gedacht werden, vormde echter niet per definitie een beletsel voor de religieuze ontplooiingsmogelijkheden van vrouwen, zo zijn de betogen van verschillende kloppenboeken samen te vatten. Vrouwen werden dan wel gezien als zwakker dan mannen, zij waren evengoed geschapen naar Gods beeld. Naar de ziel waren zij de gelijken van mannen. In deze zielsgelijkenis lag de oorsprong voor de overtuiging dat ook vrouwen over eigenschappen konden beschikken, die bin- 
nen de zeventiende-eeuwse confessionele context als mannelijk golden. Door daarop de aandacht te vestigen, verruimden de kloppenboek-auteurs de mogelijkheden en taken die vrouwen binnen het kerkelijke domein tot dan toe hadden. Natuurlijk wel op voorwaarde dat vrouwen hun spirituele potentieel optimaal de ruimte zouden geven, en dat kon naar de mening van deze geestelijke auteurs enkel wanneer zij de maagdelijke levensstaat verkozen.

Voor de ontplooiing van vrouwen binnen het kerkelijke domein werden in kloppenboeken in zekere zin voorwaarden geschapen. Vooral de vitae bevatten voorbeelden waaruit blijkt dat God met leden van het zwakke geslacht, in casu geestelijke maagden, een bijzondere band onderhield. Deze verbondenheid kwam tot uitdrukking in mystieke trances, visioenen of dromen. Voor tijdgenoten waren gebeurtenissen die in deze levensverhalen beschreven werden niet altijd onomstreden, maar zeker wel plausibel. Kloppenboeken van het vita-type getuigen ervan dat vrouwen als 'ervaringsdeskundigen' binnen de door kerk en clerus gehuldigde opvattingen over de vrouwelijke sekse enig aanzien en zelfs gezag konden genieten, dat herleid werd tot hun diepe geloofsovertuiging en liefde tot God. Vrouwen wier gezag binnen een geloofsgemeenschap gevestigd was door goddelijke openbaringen, werden door kloppenboek-auteurs als uitzonderlijk beschreven. Hun was een vorm van goddelijke genade ten deel gevallen waarop het overgrote deel van hun geestelijke zusters niet hoefde te rekenen. De meerderheid van deze groep vrouwen kon echter op andere wijze een eerbare en zelfs gezagvolle positie verwerven binnen de lokale gemeenschap.

Vrouwen waren dan wel van kerkelijke ambten uitgesloten, de kloppenboeken lieten hun zien hoe zij zich toch konden wijden aan geloofsverkondiging, polemiseren over het geloof en zelfs missioneren. Wie de wereld niet verliet om achter kloostermuren te bidden voor eigen en andermans zieleheil, droeg haar steen bij aan de instandhouding en verbreiding van het ware geloof door haar godsdienstige overtuiging uit te dragen in huiselijke en kerkelijke kring. Openlijk, herkenbaar vertoon van vroomheid was hiertoe een effectief middel, dat bovendien de eigen godgewijde maagdelijke identiteit onderlijnde. Een strikt religieus regime, dat zowel de sacramentele als de penitentiële vroomheid omvatte, moest geestelijke maagden transformeren tot een soort spirituele voorhoede binnen hun eigen geloofsgemeenschap, die andere gelovigen op bevattelijke wijze vertrouwd kon maken met een zekere verinnerlijking van de geloofsbeleving, die de seculiere en reguliere geestelijkheid nastreefde. Binnen de grenzen van maagdelijkheid en gehoorzaamheid aan God en Zijn aardse plaatsvervangers kwam er een nieuwe, in de religie gegrondveste identiteit voor vrouwen tot ontwikkeling. Juist omdat religie in de zeventiende eeuw het meest dominante referentiekader was, werd openlijk vertoon van vroomheid niet alleen geïnterpreteerd als uitdrukking van religiositeit, maar ook van eerbaarheid. Het geloof kon daarom in sociaal opzicht als motivatie én legitimatie dienen voor vrouwen die werkzaamheden in apostolaat en caritas am- 
bieerden, die voor hen op grond van hun sekse eigenlijk als problematisch golden. ${ }^{372}$ Vrouwen die de maagdelijke staat als leefwijze aanvaardden, waren in beginsel van de aardse zeggenschap van echtgenoten, vaders of broers verlost. De wil van hun hemelse Bruidegom was hun wet. In de praktijk van alledag betekende dit dat een maagd haar biechtvader, die door kloppenboek-auteurs wordt voorgesteld als de aardse plaatsvervanger van God, in alles moest gehoorzamen. Deze geestelijke was behalve biechtvader ook leidsman, op wie een klop volledig moest vertrouwen. Voor haar vormde hij het voornaamste referentiepunt in haar bestaan en bij haar streven naar religieuze volmaaktheid, waarop hij nauwlettend moest toezien. $\mathrm{Hij}$ zou haar Gods wil uitleggen, waartegen zij zich nooit mocht verzetten. Werd een geestelijke maagd door God, Zijn Zoon of de Maagd Maria rechtstreeks toegesproken in visioenen of inspraken, dan kon de aanspraak van haar biechtvader op het kennen van Gods wil onder spanning komen te staan. Het was zeker niet denkbeeldig althans zo blijkt uit verschillende kloppenboeken, in het bijzonder de vitae - dat geestelijke maagden zeiden Gods wil te kennen. Hun uitverkorenheid was te danken aan hun nederigheid en gehoorzaamheid, aldus de auteurs van deze boeken. Onvermeld blijft hoe deze vrouwen hun bevoorrechte positie, die gebaseerd was op goddelijke genade, verwoordden tegenover hun leidsman, wiens positie gefundeerd was op zijn ambt van priester. De bemiddeling van Gods kennis blijkt namelijk ook aan sekse-specifieke mogelijkheden en grenzen te zijn gekoppeld. De Roermondse maagden Agnes van Heilsbach en Joanna van Randenraedt stuitten op die grenzen zodra zij in opdracht van hun biechtvader goddelijke ingevingen aan het papier toevertrouwden. In het volgende hoofdstuk wordt beschreven hoe zij - rekening houdend met die begrenzingen - Gods wil tot uitdrukking brachten en daarmee invloed verwierven op de vorm die hun bestaan als geestelijke maagd aannam.

$372 \mathrm{Vgl}$. De Baar, 'Transgressing gender codes'. Voor vrouwen in de katholieke context zie Monteiro, "'Ick ben gekomen inde werelt"'. 


\section{IV \\ Geestelijke maagden aan het woord}

Gewetensrekeningen als bron voor onderzoek

Vormgeving en invulling van de kloppenstaat werden bepaald door geestelijken en geestelıjke maagden. Rekenung houdend met haar persoonlı,ke omstandıgheden stelde een biechtvader een leefregel op voor zıjn geestelıke dochter. Tydens gesprekken en de biecht zal een klop vragen en problemen aan haar leidsman hebben voorgelegd, waarop $h_{1 j}$ een passend antwoord zocht. $H_{1 j}$ hield haar de voorrechten maar vooral de plichten voor, die haar godgewijde staat met zich meebracht. Gedurende deze tweespraken controleerde deze pnester tevens de naleving van de - veelal ongeschreven - nchtlınen die hij zijn geestelıjke dochter had opgelegd. Aangezıen deze samenspraken niet schnftelık zıjn vastgelegd, onttrekken de gedachtenwisselingen tussen kloppen en hun leidsmannen zich grotendeels aan het blikveld van histonci. Van twee geestelıke maagden, Agnes van Hellsbach en Joanna van Randenraedt, zjn evenwel zogeheten gewetensrekenungen overgeleverd. Hoewel deze geschriften geen letterlyjke verslagen van hun gesprekken met de biechtvader vormen, weerspiegelen zij toch het dialogisch karakter van de verhouding tussen een klop en haar leidsman. ${ }^{x}$

In hun gewetensrekeningen vertrouwden beide vrouwen hun zieleroerselen in opdracht van biechtvaders aan het papier toe. Eigen handelingen en gevoelens staan expliciet centraal in deze geschnften. Op grond van deze karaktenstiek kunnen ze gerekend worden tot de egodocumenten, een neologisme dat de histoncus Jacques Presser muntte als verzamelnaam voor autobiografieen, memorres, dagboeken, persoonlıjke brieven en andere teksten waarın een schrıver of schrıfster zichzelf 'themauseert'. 2 Van geestelıjke dochters zıjn nauwelıks egodocumenten bewaard gebleven. In dat opzicht onderscheidt deze groep zıch niet van haar seksegenoten. Het aantal dagboeken, autobiografieen en memoires van de hand van vrouwen dat sinds de zestiende tot de negentuende eeuw is overgeleverd in Nederland, bedraagt naar schattung $10 \%$ van het totale aantal bewaarde egodocumenten ${ }^{3}$ Vooral persoonlıke bekeringsgeschiedenissen van vrouwen uit protestantse, pietıstische knng zijn bekend. Uit katholieke kring is de spintuele autobiografie

I Vgl De Boer, Sinews of discipline, 10, die erop wisst dat de relatue tussen biechtvader en penitent in het algemeen interactuef van karakter was, ondanks de asymmetnsche machtverhoudingen tussen beiden

2 Dekker, “"Dat mın lıeve kunderen weten zouden "', I, vgl Lindeman, Scherf en Dekker, Egodocumenten, 8

3 Dekker, "Dat mijn heve kunderen weten zouden "', 8 
van de Maastrichtse Elisabeth Strouven (I600-I66I) overgeleverd. ${ }^{4}$ Hienn wordt haar levensloop, of eigenlı)k haar relıgieuze ontwikkelıngsgang, verteld vanut een primair stıchtelıke doelstelling Strouven, die zichzelf nadrukkelı)k nuet als geesteli)ke maagd afficheerde, leefde volgens de derde orde-regel van St. Franciscus en stıchtte een nieuwe religieuze vrouwengemeenschap, die kort voor haar dood kerkelık erkend werd als klooster. Zlj schreef haar levensverhaal op verzoek van haar biechtvader Dat deden Van Heilsbach en Van Randenraedt eveneens Interessant genoeg zijn de bouwstenen van hun zelfpresentatues, hun gewetensrekeningen, ten dele bewaard Die maken verreweg de meerderheid van hun nagelaten manuscripten uit. Gewetensrekeningen vormen een type egodocument, waamaar voor het Nederlandse taalgebied nog geen onderzoek is gedaan. ${ }^{5}$ Aan de hand van deze bronnen kunnen de opvattungen die deze kloppen zelf koesterden over hun leefwı)ze, geanalyseerd worden. Hoewel deze geschnften nık aan informatue zijn, bergen zl), net als de kloppenboeken, de nodige voetangels en klemmen in zich. Anders dan de leef- en gedragsregels in de normatief geladen kloppenboeken, waaruıt enkel afgele1d kan worden hoe geestelı)ke maagden zouden moeten leven als het aan (mannelıke) geestelıken lag, bieden de nagelaten geschnften van Van He1sbach en Van Randenraedt vooral zıcht op ambivalenties en tegenstri)digheden van de kloppenstaat.

Hun gewetensrekenıngen vervulden een belangnjke functse in de verhouding tot hun biechtvader, een gegeven dat tot behoedzaamheid bi) interpretatie stemt. Hoe betrouwbaar deze egodocumenten van Van Helsbach en Van Randenraedt zi)n, is evenwel een weing vruchtbare vraag Dat autobıografische geschnften een loepzuivere blık op remands leven geven, is een illusie. Ten eerste is het onmogelıjk om alles in dergelyke notities vast te leggen. En ten tweede kan taal uit de grond van haar aard noott een volledige weergave bieden van temands ervanng ${ }^{6}$ Maar we knjgen wel een beter beeld van wat hun spintuele autobiografische geschnften kunnen vertellen wanneer we weten onder welke omstandigheden ze tot stand zijn gekomen Deze gewetensrekeningen confronteren ons met theoretısche kwesties rond zelfbeeld - ook wel aangeduid als zelfverstaan - en zelfpresentatie. Een nadere analyse van de omstandigheden waaronder Van He1sbach en Van Randenraedt schreven en van de functies van hun geschnften in de relatie met hun biechtvader en andere geestelıke maagden zet ons op het spoor van hun zelfbeeld en van wisselende machtsverhoudingen. $B_{1}$ ) de zoektocht naar hun eigen 'stem' in dit hoofdstuk staan deze vraagstukken centraal.

Alvorens de egodocumenten van beide vrouwen onder de loep te nemen, worden

4 Florence Koom bereidt cen uitgave hiervan voor Zie vooralsnog haar bıdragen 'Elisabeth Strouven' en 'Een chansmansche ant-heilige'

5 Lindeman, Scherf en Dekker, Egodocumenten, noemen gewetensrekenıngen bijvoorbeeld niet

6 Misch, 'Begnff und Ursprung der Autobiographe', in idem, Geschichte der Autobtographie, I, I, II Hobby, Virtue of necessity, 78 
hun levens in de eerste paragraaf in kort bestek geschetst. Een beschrijving van de overgeleverde bronnen in de tweede paragraaf maakt duidelijk wat zij hebben geschreven en voor wie. Hun geschriften lijken betrekkelijk uniek. Dat roept de vraag op of geestelijke maagden vaker werd opgedragen hun ervaringen en gevoelens aan het papier toe te vertrouwen. Rekenschap afleggen over de eigen religieuze ontwikkeling werd voorgeschreven in alle kloppenboeken en meer algemene stichtelijke werken. Alleen, zo wordt in de derde paragraaf uiteengezet, was dit geformaliseerd in het persoonlijk gewetensonderzoek en de biecht. Schriftelijke verslaglegging, zoals Van Heilsbach en Van Randenraedt gewoon waren te doen, was zeker geen unicum onder religieuze vrouwen, maar lijkt in kringen van geestelijke dochters toch geen usance te zijn geweest.

Zelfpresentaties in autobiografieën en dagboeken zijn per definitie niet ongecompliceerd en moeten als constructies of zelfrepresentaties beschouwd worden. ${ }^{7}$ Dat geldt zeker voor de gewetensrekenıngen van Van Heilsbach en Van Randenraedt, die in opdracht van hun biechtvader zijn geschreven. Juist omdat deze vrouwen op last schreven van een geestelijke aan wie zij tot gehoorzaamheid verplicht waren en van wie zij afhankelijk waren, doet de vraag naar de zeggingskracht van hun gepresenteerde zelfbeeld zich sterk gelden. Inhoud en structuur van hun teksten zijn beïnvloed door wat hun biechtvader wilde weten. Daarenboven zijn de vormen waarin deze vrouwen zichzelf en hun ervaringen op schrift konden voorstellen sterk bepaald door hun vrouw-zijn. Schrijven was een vorm om in de openbare sfeer te treden en die weg stond vrouwen in de zeventiende eeuw niet zo maar vrij. ${ }^{8}$ Hoe problematisch zelfthematisering en zelfpresentatie voor vrouwen waren, wordt in de vierde paragraaf verkend. Van Helsbach en Van Randenraedt besteedden in hun geschriften veel aandacht aan hun bovennatuurlijke ervaringen. Dat gebeurde niet enkel op instigatie van hun biechtvader, want aan hun droomgezichten en influisteringen konden zij zelf recht van spreken en handelen ontlenen. Naar gangbare maatstaven over de ontvankelijkheid van vrouwen voor bovennatuurlijke ervaringen, konden zij echter zowel een instrument van God als van de duivel zijn. Hoe Van Heilsbach en Van Randenraedt zich in hun schrijven tot deze tweeledige vatbaarheid verhielden, wordt in de vijfde paragraaf uiteengezet.

Voor religieuze vrouwen die op last van een mannelijke geestelijke hun zieleroerselen aan het papier toevertrouwden, bracht het schrijven allerlei dilemma's met zich mee. Een dergelijke opdracht stond per definitie onmondige vrouwen een zekere mate van mondigheid toe - in de letterlijke betekenis van spreken en zich uiten; echter, slechts onder bepaalde voorwaarden en via een gecontroleerd me-

7 Misch, 'Begnff und Ursprung der Autobiographue', in' Idem, Geschichte der Autobwographie, I, I, I I-13 Hahn, 'Identutat und Selbstthematisıenung'. Volgens Buikema, Meıer en Smelik, 'Postmodeme cultuur', 84, impliceert representate een bemiddelende actuvieit, waarbi) de voorstelling niet samenvalt met dat wat zij voorstelt.

8 Voor een beknopte weergave van deze problematuek, z1e Wiesner, Women and gender, 159-167. 
dium, ${ }^{9}$ dat tenminste gedeeltelijk tot stand gekomen was volgens aanwijzingen van de biechtvader en in eerste instantie voor zijn ogen bedoeld was. Welke moeilijkheden er verbonden waren met een dergelijke opdracht, wordt in de zesde paragraaf besproken. Hoewel de biechtvader zo zijn eigen redenen had om deze twee penitenten gewetensrekeningen te laten schrijven, hadden Van Heilsbach en Van Randenraedt op hun manier eveneens belang bij hun geschriften. In de zevende paragraaf wordt betoogd dat de controle die via gewetensrekeningen door een geestelijk leidsman werd uitgeoefend, ook in het voordeel van beide geestelijke maagden zelf werkte.

\section{IV.I Bezielde vrouwen}

Zowel Agnes van Heilsbach als Joanna van Randenraedt wilden oorspronkelijk in een klooster intreden. Agnes realiseerde haar voornemen, maar moest om gezondsheidsredenen het klooster weer verlaten. Joanna zag uiteindelijk - mede onder invloed van Agnes - af van haar plan. Voor hen beiden was de kloppenstaat in zekere zin een tweede keus. Dat neemt niet weg dat deze leefwijze beantwoordde aan de religieuze en maatschappelijke ontplooiingsmogelijkheden die beide vrouwen naarstig zochten.

\section{Agnes van Heilsbach (1597-1640)}

Voor biografische bijzonderheden over Agnes van Heilsbach zijn we vooral aangewezen op de gedrukte hagiografische levensbeschrijving van de jezuïet Daniël Huysmans, Leven ende deughden vande weerdighe Agnes van Heilsbagh (169I). Soms kan zijn voorstelling aangevuld of zelfs gecorrigeerd worden door gegevens uit twee fragmenten die bewaard zijn gebleven van haar autobiografie, afgeschreven door Joanna van Randenraedt. ${ }^{10}$ Voor haar laatste levensjaren bieden ook haar gewetensrekeningen soms informatie. In Huysmans' beschrijving beantwoordt Van Heilsbach natuurlijk aan de idealen van verstorvenheid en nederigheid, die voor geestelijke maagden golden. De veelvuldige citaten in zijn tekst wekken de indruk dat hij gedeelten rechtstreeks uit Van Heilsbachs gewetensrekeningen of autobiografie heeft overgenomen. Inhoudelijk wijkt zijn relaas soms echter af van haar eigen voorstelling, zoals we nog zullen zien.

9 Deze omschrijving wordt gebruikt door drs. Arianne Baggerman, 'Dagboeken als bron voor een onderzoek naar leeservaringen. De gedwongen lectuurconsumptie van Otto van Eck (1780-1798)' (lezing gehouden tijdens de studiedag Ego-documenten, georganiseerd door het zwaartepunt RENT (Rijksuniversiteit Leiden), 27 april 1994).

ro C.ss.R. Roermond, Speciaal Archief A pl. 7, GG ir. 
Afb. I2 Portret van Agnes van Heilsbach uit haar gedrukte levensbeschrijving. Hierop wordt haar 'gave van tranen' uitgebeeld. In Leven en deughden wordt verhaald hoe, zodra zij ging bidden, tranen onophoudelijk begonnen te vloeien. Niet alleen haar gezichtsvermogen, maar ook haar reputatie werd hierdoor bedreigd. Sommigen dachten namelijk dat dit een 'duyvels werck' was. God veranderde toen op haar verzoek de zichtbare tranen in onzichtbare.

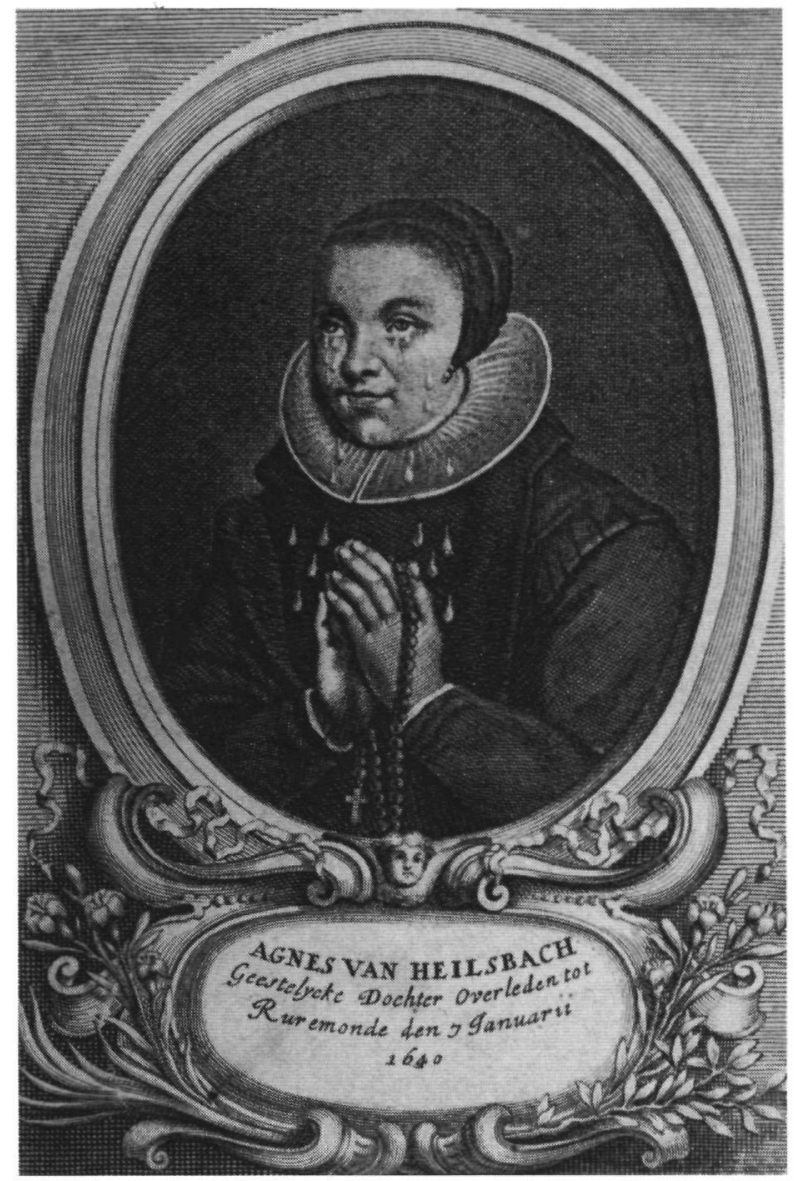

Agnes van Heilsbach werd in 1597 in Wassenberg geboren, een plaatsje niet ver van Roermond, in het hertogdom Gulik. Hier mocht het katholicisme in vrijheid beleden worden, maar in de confessionele pluriformiteit van haar geboortestreek ligt mogelijk een verklaring voor de vurigheid waarmee zij zich haast haar gehele leven inzette voor de verbreiding van het katholieke geloof, dat voor haar het enig ware representeerde. Medelingen over haar ouders zijn schaars; enkel haar vader komt regelmatig in de gedrukte levensbeschrijving voor. Was haar moeder misschien in het kraambed gestorven en groeide zij moederloos op? Zij had een broer, die priester was te Keulen, ${ }^{\text {II }}$ en vermoedelijk twee zusters. ${ }^{12}$

Agnes wordt door Huysmans voorgesteld als het prototype van een jonge

II Leven ende deughden, 70.

12 KB Brussel, Handschriften 18984 , I44-I45vo (5-6 februari [1638]). In de beschrijving van een droom over een vrouwenklooster schrijft Van Heilsbach dat ze ook haar 'geestelijcke suster' in dit klooster zag. Leven ende deughden, 76 , vermeldt een tweede zuster, die getrouwd was. 
zondares. Zij zou 'verkeerde' speelkameraadjes gehad hebben, die haar afhielden van haar religieuze plichten. Dankzij het woord Gods dat vanaf de kansel werd gepreekt, kwam zij echter tot inkeer:

'Hoorende den Predikant ende hem aensiende, scheen ick de helle enden den hemel geopent te sien, ende dat my door mijnen vryen wille den keus gheoffert wiert, om tot een van dese twee eeuwigh-durende woonplaetsen in te gaen. Eeuwelijck Godts aenschijn te besitten, oft eeuwelijck dat te derven, ende in die plaetse te branden, waer toe ick my een goet bereytsel ghemaeckt hadde, soo ick voort-gongh in mijne aengenomen weghen. Dit was afgrijselijck om [te] sien, ende onmoghelijck om met woorden te verklaeren. Inde eeuwighe blijdschap des Hemels sagh ick Godt, met een groote menichte van Heylighen, van de welcke ick vriendelijck genoot wiert, besonderlijck vande Koninghinne van alle [Maria]: inde helle sagh ick dat onsaligh geselschap, dat tot het eeuwigh vier veroordeelt was. ${ }^{13}$

Had zij tot dan toe Gods inspraken en aansporingen om haar 'zondig' leven te beteren genegeerd, gesteld voor de keuze tussen verdoemenis en zaligheid verkoos zij een vroom en godgewijd leven. $Z$ ij zal tussen de dertien en veertien jaar oud zijn geweest, toen zij voor een strenge, kuise levenswijze opteerde, waarin dagelijks kerkbezoek, dat in haar woonplaats opzien baarde, en liefdadige werken de boventoon voerden. ${ }^{14}$

Het gevoel zondig te zijn, zelfs zondiger dan wie dan ook ter wereld, bleef haar echter voortdurend bij, ook nadat ze haar leven gebeterd had. ${ }^{15}$ Huysmans gaat hier uitvoerig op in, omdat haar diepgewortelde zondebesef in zijn ogen een treffende illustratie vormt voor haar nederigheid tegenover God en naasten. Maar ook in haar overgeleverde gewetensrekeningen, die stof verschaften voor Huysmans' vita, zijn vele sporen aan te treffen van het besef van eigen zondigheid. Deze vorm van zelfpresentatie was inherent aan gewetensrekeningen. De biechtvader verwachtte hierin nu eenmaal te lezen hoe het gesteld was met de dispositie van zijn penitente, hoe haar inzicht in eigen tekortkomingen groeide. Het accent op de eigen zondigheid vervult in haar geschriften dan ook een andere functie dan in Huysmans' levensbeschrijving. Met de nadruk op haar verworpenheid bevestigt hij voornamelijk het ideaal waaraan geestelijke maagden moesten voldoen: nederigheid. Juist omdat hij zich baseert op haar eigen geschriften, wordt de indruk gewekt dat Van Heilsbach dit ideaal kritiekloos deelde. Hieronder wordt nog verduidelijkt dat zij dit weliswaar onderschreef, maar toch met behulp van haar gewetensrekeningen voor zichzelf een uitzonderingspositie creëerde, die eerder op gevoelens van verhevenheid dan van ootmoed stoelde.

Mogelijk modelleerde Agnes haar leven na haar 'bekering' al naar de bestaanswijze van geestelijke dochters, die zij in de kerk van de jezuieten te Roermond had gezien. ${ }^{16} \mathrm{Zij}$ verkeerde met enige regelmaat in deze stad, het bestuurlijk en religieus

13 Leven ende deughden, 25.

14 Ibidem, 28.

15 Ibidem, 40-43.

16 Ibidem, 27. 
centrum van Opper-Gelre. Hier ging zij te biecht bij een jezuïet, die haar meer gerust stelde dan de pastoor in haar woonplaats. ${ }^{17}$ De jezuïeten hadden in I6IO een college in Roermond geopend. Plannen voor vestiging in die stad dateerden al uit de ambtstermijn van de eerste bisschop van Roermond, Wilhelmus Lindanus (I569-1588), maar konden toen wegens geldgebrek niet gerealiseerd worden. Onder zijn opvolger Hendrikus Cuykius, die zijn ambt in 1596 aantrad, werden wel de noodzakelijke voorwaarden voor de vestiging van een jezuietencollege geschapen, vooral dankzij de bemiddeling van de landrentmeester-generaal van het Gelders Overkwartier, Ido Gramay. Deze legde ook de financiële basis van het nieuw op te richten college door fundatiegelden in te zamelen. Zowel het stadsbestuur als de Staten van Gelder zegden jaarlijkse subsidies toe. School en kleine jezuïeten-communiteit van zestien paters en broeders werden ondergebracht in het bisschoppelijk paleis. Cuykius' opvolger Jacobus a Castro, wiens episcopaat in I6II begon, was hiermee akkoord gegaan op voorwaarde dat de Sociëteit de kosten voor een nieuw te bouwen bisschopswoning voor haar rekening zou nemen. Lokale weldoeners en begunstigers namen de kosten hiervan op zich. ${ }^{18} \mathrm{De}$ jezuïeten probeerden bij te dragen aan een intensivering van het geloofsleven van de Roermondse bevolking. Zij stichtten onder andere sodaliteiten, die maandelijks religieuze oefeningen hielden en een belangrijke rol speelden bij processies en andere openbare godsdienstige plechtigheden. De kerk van het college, die dankzij vrijgevigheid van de aartshertogen, de kapitteldeken en enige gefortuneerde leken kon worden gebouwd en door allerlei giften rijk versierd kon worden, oefende aantrekkingskracht op de lokale geloofsgemeenschap uit, maar ook op gelovigen van buiten de stad, zoals Agnes van Heilsbach.

Doordat zij in de Roermondse jezuïetenkerk geestelijke maagden had gezien, was zij enigszins bekend met deze bestaanswijze. Voor een dergelijke leefwijze had zij aanvankelijk evenwel geen voorkeur. Met hulp van een neef, die deken was, overreedde ze haar vader om in een klooster te mogen intreden. De keuze viel op een cisterciënzerinnenklooster te Keulen. ${ }^{19}$ Van Heilsbach wijdde zich vol overgave aan haar noviciaat. ${ }^{20}$ Haar zwakke gezondheid, een 'lammigheyt haerder aermen', maakte het haar echter onmogelijk het noviciaat te voltooien en ze verliet het klooster. Na haar onvoorziene terugkeer in haar woonplaats Wassenberg begon ze aan een loopbaan in goede werken, die ze later in Roermond zou voortzetten. Haar intentie om een godvruchtig, kuis leven in de wereld te leiden maakte zij onder andere kenbaar door haar gewone kleding te verruilen voor eenvoudige zwarte kledij, zoals geestelijke dochters die droegen. ${ }^{21}$

17 Ibidem.

I8 Habets, Geschiedenis, II, 519-521; Poncelet, Hissoire, I, 422-424; Houben, 'Analecta', I08-I12.

19 Vermoedelijk was dit een adellijk stift, want Huysmans, Leven ende deughden, 49, merkt op dat Agnes in vergelijking met de andere novicen 'slechter van gheslacht was'.

20 Ibidem, 44-45. Zij zou in het klooster ook Latijn hebben geleerd, aldus Huysmans.

21 Ibidem, 68. 
De vraag welke levensstaat zij nu moest kiezen, baarde haar grote zorgen. Ze legde haar dilemma aan de pastoor van Wassenberg voor:

'Seggende, dat sy begeerigh was Godt oprechtelijck te dienen: dat sy dit niet konde doen in haers Vaders huys, daer sy geen ruste vondt: dat sy door de lammigheyt haerder aermen tot den Cloosterlijcken staet onbequaem was: dat haeren gheest gepranght wiert om Godts wille te kennen, aen-gaende den staet haers levens (...)'."2

Volgens Huysmans stelde de pastoor haar gerust met de woorden dat God met haar iets anders voor had dan het klooster. Van Heilsbach noteert evenwel dat zij zelf kort na de onverhoopte terugkeer uit Keulen reeds het besluit had genomen om geestelijke dochter te worden. ${ }^{23}$ Dat ze tot deze keuze werd geïnspireerd door het voorbeeld van de Roermondse geestelijke dochters lijdt geen twijfel, want ze bleef iedere zaterdag de tocht van Wassenberg naar Roermond maken om bij de jezuïeten te biechten. ${ }^{24}$

Haar verlangen naar een geestelijk bestaan gewijd aan gebed en apostolaat botste met de verwachtingen van haar familie. Agnes besefte dat zolang haar vader leefde, zij nooit alleen over haar leven kon beslissen. ${ }^{25} \mathrm{Na}$ enige tijd het huishouden voor haar vader waargenomen te hebben, werd ze door hem naar haar broer in Keulen gestuurd om zich van diens verzorging te kwijten. Hoewel het haar tegenstond haar vader te verlaten, zat er niets anders op dan naar Keulen te vertrekken. Toen ze daar ziek werd, vroeg ze toestemming om naar huis terug te mogen keren. Hoewel haar vader weigerde, kwam Agnes toch thuis, zich beroepend op Gods wil die zij hoger schatte dan die van haar vader. ${ }^{26}$ De daarop volgende twee jaar reisde Agnes regelmatig naar Roermond voor de geestelijke begeleiding van een niet nader geïdentificeerde jezuïet. Hij gaf haar aanwijzingen voor een godvruchtig leven die zij thuis in de praktijk kon brengen. ${ }^{27}$ In een fragment van Van Heilsbachs autobiografie staat te lezen hoe groot de invloed van deze pater op haar spirituele ontwikkeling was. $\mathrm{Hij}$ verbood haar bijvoorbeeld in te treden in de wereldlijke derde orde van St. Franciscus. ${ }^{28}$ Tegenover de minderbroeders die haar op andere gedachten probeerden te brengen, voerde zij - naast enkele niet gespecificeerde grieven tegen de regel van de Franciscaanse derde orde - aan dat ze vrij wilde zijn om te biechten bij wie ze wilde en niet enkel bij de minderbroeders. Deze geestelijken waren op de hoogte van haar betrekkingen met de Roermondse jezuïeten, want zij beschuldigden die ervan achter haar plotselinge weigering te zitten, hetgeen Agnes ontkende.

22 Ibidem, 62.

23 C.ss.R. Roermond, Speciaal Archief A pl. 7, GG II (ongepagineerd).

24 Leven ende deughden, 61.

25 C.ss.R. Roermond, Speciaal Archief A pl. 7, GG ir (ongepagineerd).

26 Leven ende deughden, $7 \mathbf{I}$.

27 Ibidem, 72-73.

28 C.ss. R. Roermond, Speciaal Archief A pl. 7, GG II (ongepagineerd). Dit voorval wordt beschreven in Monteiro, 'Den middelen staet', 152. 
Toen haar vader omstreeks 1623 overleed, dacht Agnes haar leven definitief geheel aan God te kunnen wijden als geestelijke dochter onder leiding van de jezuïeten te Roermond. Haar broer verwachtte echter dat zij weer naar Keulen kwam om voor hem te zorgen. Goddelijke voorzienigheid, zo lijkt het uit Huysmans' beschrijving en Van Heilsbachs eigen weergave, deed deze broer aan de pest bezwijken, kort nadat Agnes in Keulen was aangekomen. ${ }^{29}$ Nog was zij niet ontslagen van alle familieplichten, want toen poogde haar neef, de deken die bemiddeld had bij haar intrede in het Keulse cisterciënzerinnenklooster, haar in een ander klooster onder te brengen. Niet alleen een zekere weerstand tegen de jezuïeten, waarop Huysmans - zelf jezuïet - de nadruk legt, maar ook financiële motieven zouden volgens Van Heilsbach ten grondslag liggen aan het verzet van deze neef en andere verwanten tegen haar besluit om jezuïeten-klop te worden. ${ }^{30}$ Haar familie kon haar niet verbieden om naar Roermond te vertrekken, maar kon haar kennelijk wel datgene wat ze nodig had voor het eigen onderhoud onthouden, waardoor ze tot de bedelstaf zou vervallen. Dankzij enige juridische procedures, gesteund door jezuïeten in Roermond en Düsseldorf, waar de processen werden gevoerd, bleven toch nog enige inkomsten voor haar behouden. Liever had ze, zo schrijft ze, zich niet om haar aardse bezittingen bekommerd maar alles om Gods wil opgegeven, 'maer soe het scheen, dat en was Godts wil niet, die ick kenden deur mijnen bichtvader, wiens raedt ick daer in volghden (...) ' ${ }^{31}$ Naar haar zeggen was haar geestelijk leidsman de drijvende kracht achter de strijd om haar vermogen en misschien verklaart zijn betrokkenheid ook Huysmans' omissie op dit punt. De jezuïeten hadden in de zeventiende eeuw immers de naam enkel rijke vrouwen als geestelijke dochters aan te nemen om zo de materiële positie van de orde te verbeteren..$^{32}$

Rond 1624 arriveerde Van Heilsbach in Roermond. Hoewel ze nu inmiddels over enige financiële armslag beschikte, was deze misschien onvoldoende ruim om een eigen huishouden te starten. Motieven van betamelijkheid zouden ook een rol gespeeld kunnen hebben, want een betrekkelijk jonge ongehuwde vrouw - Agnes was toen 27 - behoorde naar maatstaven van haar tijdgenoten niet alleen te wonen. Aanvankelijk woonde ze bij een 'out vrouwken', zoals bij Huysmans te lezen staat. ${ }^{33}$ Enige jaren later betrok ze een kamer ten huize van juffrouw Botters, een geestelijke weduwe. ${ }^{34}$ Naar alle waarschijnlijkheid was dit Ida van Mierlo, de vrouw van Everard Botter - niet Botters. Botter was in augustus 1622

29 Leven ende deughden, 75-77. C.ss.R. Roermond, Speciaal Archief A pl. 7, GG II (ongepagineerd).

30 Leven ende deughden, 8o; C.ss.R. Roermond, Speciaal Archief A pl. 7, GG 1 I (ongepagineerd).

31 C.ss.R. Roermond, Speciaal Archief A pl. 7, GG 11 (ongepagineerd).

32 Zie II.4 van dit boek.

33 Leven ende deughden, 97.

34 Volgens het WNT werd de aanspreektitel 'juffrouw' in de zeventiende eeuw behalve voor ongehuwde jonge vrouwen ook gebezigd voor iedere gehuwde vrouw of weduwe beneden de rang van 'mevrouw'. Laatstgenoemde aanspreekvorm was gereserveerd voor adellijke vrouwen. 
benoemd tot raad en rekenmeester van de Gelderse Rekenkamer te Roermond. ${ }^{35}$ $\mathrm{Hij}$ overleed in 1625 , waama zijn echtgenote een pensioen van de Gelderse Rekenkamer ontving. ${ }^{36}$ Zowel Huysmans als Van Heilsbach en Van Randenraedt noemen deze vrouw de weduwe of juffrouw Botters. Deze naam zal hier verder gebruikt worden, om verwarring te voorkomen. Everard Botter gold als een voorvechter van het katholieke geloof en was, net als zijn echtgenote, een vrijgevig begunstiger van het Roermondse jezuietencollege. ${ }^{37}$ Nog in zijn sterfjaar had hij in verschillende termijnen 600 gulden gedoneerd aan het college. ${ }^{38}$ Behalve zijn vrouw liet hij ook een zoon achter, Matthias, die in 1626 zijn noviciaat bij de jezuieten in Mechelen begon. ${ }^{39}$

Mede dankzij de positie en reputatie van wijlen haar man kon Botters enige invloed aanwenden in kringen van jezuieten en lokale notabelen. Toen in 1638 inkwartiering van soldaten in haar huis dreigde, deed zij bijvoorbeeld met succes een beroep op haar biechtvader Simon van den Hove (I596-I64I), rector van het jezuietencollege, die dit wist te voorkomen..$^{40}$ Van de nauwe banden tussen Botters en de jezuïten ter plaatse kon Agnes als haar huisgenote mogelijk profiteren. In Leven ende deughden wordt de verhouding tussen Agnes en de weduwe Botters als harmonieus voorgesteld. Huysmans geeft een lofrede weer die Van Heilsbach op haar overleden huisgenote geschreven zou hebben. ${ }^{41}$ Hierin wordt Botters beschreven als een ware Martha, die de dienaren Gods gastvrij onthaalde, zoals Martha Jezus en zijn discipelen ontving. Impliciet geeft Van Heilsbach met deze karakterisering weer wat zij als fundamenteel verschil zag tussen de weduwe en haarzelf. Terwijl zij zich als een Maria op de religieuze dimensies van het bestaan concentreerde, bekommerde Botters zich vooral om wereldse en materiële zaken. Té zeer, zo blijkt uit Van Heilsbachs gewetensrekeningen, die een veel minder positief beeld van haar huisgenote geven, die volgens haar niet zó ingetogen was als het 'geestelijcke persoenen' betaamde. Tot een breuk tussen beiden kwam het echter niet, want tot Botters' overlijden, 28 juli 1639 , woonde Van Heilsbach in haar huis.

Een verklaring voor de gebrekkige verstandhouding tussen beide vrouwen zou

35 RAL, Archief Gelderse Rekenkamer Roermond, inv.nr. 148, Rekenıng landrentmeester der domeinen van Gelderland, 34-34vo (1622).

36 Ibıdem, unv.nr. 149, Rekening landrentmeester der domeunen van Gelderland, $37 v 0$ (I627). Vgl. KB Brussel, Handschnften 18984, 397-398 (8 december 1637). volgens Van Heulsbach moest Botters zich jaarlijks aan de 'finantie' in Brussel richten om het pensioen, dat haar toekwam, te knjgen.

37 PA SJ, Historsche handschnftemverzameling, doos I55, C 38 , , Lutrae annuae Collegii RuraemundensIs S.J., anno 1625. Van Hoeck, Schets, 225.

38 RAL, Archteven der fezureten te Maastrcht en Roermond. Archief College Roermond (ongeinventariseerd), Consuetudines Provinciae (...). Luber VII, Pars V, Benefactores

39 Leven ende deughden, 98-99. PA SJ, Histonsche handschnftenverzameling, doos 64, AG 3 b, Elogium Matthias Botter (1607-I637) (afschrift).

$40 \mathrm{~KB}$ Brussel, Handschnften I8984, 136-136vo (25 panuari [1638]); 153-153vo (18 februan [1638].

41 Leven ende deughden, I56-157. 
kunnen zj)n dat Botters het gezag, dat Van Heilsbach over andere maagden uttoefende, nuet eerbiedigde. Agnes fungeerde jarenlang als geestelı)ke moeder voor Joanna van Randenraedt, de van oorsprong Bossche dochter Cathanna van Gestel (1616-1696), de Roermondse gezusters Geertien (Geertruid) en Luesbeth (Elisabeth) van Tits, Anna van Kerckhoven en de stıftsdame en cısterciënzenn Cathanna di Ortigosa, pnonn van de Onze Lueve Vrouwe Munsterabdı. Van Heilsbach speelde bovendien een belangnjke rol in de devotie tot Onze Lieve Vrouw in 't Zand, die krachtig bevorderd werd door de jezuieten..$^{42}$ De kapel waar het beeld van Onze Lieve Vrouw in 't Zand zich bevond, lag een kwartier gaans van de stad. Op deze van oorsprong laat-middeleeuwse sacrale plaats hadden buttengewone genezingen van allerleı aandoenungen en kwalen plaats Van Heılsbach was hier zelf oolt op wonderbaarlıke wijze genezen van een levensbedreigende 'hert-pinne ende andere quaelen' nadat zl) op advies van haar biechtvader Onze Lieve Vrouw in 't Zand om verlichting hiervan had verzocht. ${ }^{43}$

Van Hellsbach maakte echter vooral naam als grondlegster van voorbereidend catechismusonderwijs in Roermond. Geinspireerd door het voorbeeld van Keulse geestelıke dochters nam ze samen met twee andere geestelıke dochters meer dan dertıg kınderen uit voornamelıjk arme gezınnen onder haar hoede om hun de beginselen van het katholieke geloof bij te brengen. Daarna troonde zij hen mee naar de jezuletenkerk, waar een pnester de catechisatıe voortzette ${ }^{44}$ Deze taken droeg ze in 1637 over aan Joanna van Randenraedt, die ook voorbestemd was om het geestelık leıderschap over andere geestelıjke maagden over te nemen De overdracht viel Agnes zwaar, zo blıkt uit haar eigenhandige levensbeschnjving. $Z_{\mathfrak{l}}$ miste de dynamiek van een geestelık leven waarvan verschillende vormen van dienstbaarheld aan haar naasten belangrilke bestanddelen waren ${ }^{45}$ Haar verslechterende gezondheidstoestand, die zich onder andere uitte in zware hoofdpijnen en hartklachten, dwong haar echter meer plaats te geven aan de contemplatueve aspecten van het geestelık leven in de wereld $\mathrm{Na}$ het overlyden van juffrouw Botters vond Agnes van Heilsbach een onderkomen in het ouderlyjk huis van Joanna van Randenraedt. Vermoedelık overleed zıj daar, op 7 januan I640.46 $\mathrm{De}$ laatste maanden van haar leven waren voor haar in fysiek en geestelı)k opzicht zwaar Aan schrjuen kwam zy) in het geheel niet meer toe, aldus haar 'dochter' Joanna. ${ }^{47}$

42 Kronenburg, Mana's heerlykhe1d, VI, 355-356

43 Leven ende deughden, 97-98

44 Ibidem, 89, C ss R Roermond, Specraal Archief A pl 7, GG II (ongepagineerd) Voor de catechisave-actuviteiten van Keulse geestelyke maagden, meestal devotessen genoemd, ze Theissing, Over klopjes, 14-15 en Conrad, Lwischen Kloster und Welt, 107-108

45 C ss R Roermond, Speciaal Archref A pl 7, GG II (ongepagineerd)

46 GAR, Handschnfien I A I (ongepagneerd)

47 Leven ende deughden, 16I-168 


\section{Foanna van Randenraedt (1610-1684)}

Ook voor de beschrijving van de levensloop van Joanna van Randenraedt is gebruik gemaakt van de hagiografische presentatie die Huysmans geeft in Kort Begryp des levens ende der deughden van de weerdighe foanna van Randenraedt (I690). Daarnaast is geput uit de gewetensrekeningen, brieven en Joanna's eigenhandig geschreven spirituele autobiografie, die in twee versies is overgeleverd.

$\mathrm{Zij}$ werd op 19 oktober I6IO te Brussel gedoopt als dochter van Cornelis van Randenraedt ( $\dagger_{\mathrm{I}} 643$ ) en Livina van der Meeren ( I 647$) .{ }^{48}$ Bij de doop kreeg zij de namen Joanna Baptista; later zou zij deze vernoeming naar Joannes de Doper als 'een mannelijcken Naem' bestempelen. ${ }^{49}$ Joanna had een oudere broer, Willem Hendrik (1608-I662). Haar vader was licentiaat in de rechten en werd in 1614 benoemd tot raadsheer aan het Hof van Gelder te Roermond. Dit Hof werd er in 1580 als regerings- en rechtscollege voor het Overkwartier gevestigd, ${ }^{50}$ dat als enige van de Gelderse kwartieren koning Filips II trouw was gebleven bij de totstandkoming van de Unie van Utrecht in 1579. Het gezin Van Randenraedt verhuisde naar Roermond. Een oom van vaderszijde, Willem van Randenraedt († 1636), was hier kanunnik en officiaal van het bisdom. Joanna woonde enige jaren bij hem toen haar ouders de stad tijdens de Staatse bezetting (1632-1637) verruilden voor veiliger oorden. Via haar vader en een oom van moederszijde, Carel of Charles van den Meeren, die eveneens raadsheer aan het Hof van Gelder was, verkeerde Joanna onder raadslieden van het Hof en de Rekenkamer en hun respectieve families. Functionarissen van het Hof hadden van meet af aan de vestiging van een jezuïetencollege in de stad gesteund en verschillende van hen traden op weldoeners. ${ }^{\text {si }}$ Sommige jonge vrouwen uit deze kring voelden zich aangetrokken tot een bestaan als geestelijke maagd. Bijvoorbeeld Joanna's vriendin en vertrouwelinge Lucia de Werimont, dochter van Elisabeth van Dael en Martinus de Werimont, raadsheer van het Hof van de Gelder. ${ }^{52}$ En de Bossche geestelijke dochter Catharina van Gestel, die regelmatig logeerde bij haar tante, Catharina Maes, weduwe van Gilles van Elshout, president van de Rekenkamer van Gelder. ${ }^{53}$

48 De genealogische gegevens van Joanna van Randenraedt en haar familie zijn, tenzij anders vermeld, ontleend aan Mosmans, 'Een Limburgsche magistratsfamilie'.

49 KB Brussel, Handschrifien 19073 (II), I4.

50 Van Beurden, 'Roermond en Gelre', 45 .

51 Houben, 'Analecta', 108-1 I2; PA SJ, Historische handschriftenverzameling, doos 154, C 38 e, Notities en kopieën Roermond College S.J. RAL, Archieven der jezuieten te Maastricht en Roermond. Archief College Roermond (ongeinventariseerd), Consuetudines Provinciae (...). Lib. VII, pars V, Benefactores. 52 GAR, Handschriften IV 8, kopie testamenten van Lucia de Werimont en haar zuster Françoise. Hun broer Martinus de Werimont (1613-1668) fungeerde van 1646 tot 1667 als momboir van het Hof van Gelder. Venner, 'De schepenen', I48, I54.

53 Wittert van Hoogland, 'Geslacht De Witte uten Limminghe', 260. Esther Maes, de moeder van Catharina van Gestel, en haar zuster Catharina waren dochters van Gervasia Grouwers van Lambroek 
Aanvankelijk prefereerde Joanna zelf het kloosterleven boven de kloppenstaat. In de overtuiging dat iedere man en minnaar het zou afleggen tegen de hemelse Bruidegom, heeft zij een huwelijk nooit serieus overwogen. De aardse liefde tussen de seksen met haar 'wondere pracktijcken ende sotricheeden' sprak haar niet aan..$^{54}$ Eénmaal was ze haast bezweken voor de charmes van een man. Toen deze echter zijn oog ook op een getrouwde vrouw liet vallen - een onvergeeflijke zonde in de ogen van Joanna - koos zij definitief voor een bestaan waarin enkel plaats was voor God. ${ }^{35}$ Haar hele jeugd had in het teken gestaan van 'devotiekens' en 'gebeedekens'. Doorslaggevend voor haar spirituele ontwikkeling waren echter de inspraken en visioenen die zij van de heilige Maagd Maria ontving. Van haar biechtvader leerde zij dat zij een keuze moest maken uit twee levensstaten, de wereldlijke en de geestelijke. Joanna koos voor de laatste en wilde intreden bij de clarissen, de orde die de strengste leefregel kende onder de vrouwenkloosters. Deze keuze werd deels bepaald door enkele vriendinnen van haar die claris geworden waren..$^{56}$ Deels echter werd deze voorkeur ingegeven door een sterke lijdensdevotie. $Z$ ij wilde de mentale en fysieke smarten die Christus voor de mensheid had doorstaan, in haar geestelijk leven evenaren en zo als het ware vergelden. Noch haar toenmalige biechtvader, noch haar ouders waren ingenomen met dit besluit. $\mathrm{Zij}$ drongen haar een korte bedenktijd op. ${ }^{57}$ Haar ouders waren er op tegen dat zij religieuze zou worden. Haar biechtvader niet; wél vond hij de leefregel van de clarissen te streng voor Joanna's zwakke gestel. Hij adviseerde haar bij de annunciaten in te treden, religieuzen die volgens een minder strenge regel leefden. Dat een dergelijke stap niet strookte met Gods wil, werd Joanna duidelijk toen haar biechtvader overleed. Zij interpreteerde zijn dood als een teken van God.

Mentaal bleek Joanna zelf nog niet voorbereid te zijn op de religieuze staat. Zij kon er niet toe komen een belofte van zuiverheid te doen. Bedoeld wordt een private belofte aan God, zoals kloppen die soms deden. In Joanna's ogen was deze belofte de grondslag van iedere 'geestelijcken staet'. ${ }^{58}$ Toen zij op zeventienjarige leeftijd deze belofte uiteindelijk toch deed, was het pleit van haar toekomstige levensstaat nog niet beslecht. Intussen was er bij haar twijfel gerezen over de meri-

en Thomas Maes, rentmeester van de koninklijke domeinen te Bommel, Tiel en in de Bommelerwaard en broer van Gijsbertus Masius, bisschop van 's-Hertogenbosch. Van Sasse van Ysselt, De voorname huizen, II, 356. P(i)eter van Gestel ( $f$ I635), Catharina's vader, was licentiaat in de rechten en schepen in Den Bosch. Hij vestigde zich na de Staatse inname van die stad in Breda, waar hij zowel schepen als burgemeester was. Ebeling en Juten, 'Noordbrabantsche schepenzegels', 157-158; Verreyt en Juten, 'Noord-Brabantsche schepenzegels', 258; Verreyt, 'Leden', 58-60 (noot 2).

54 KB Brussel, Handschriften 19073 (I), 37; zie ook 39-40, 46.

55 Ibidem, 44; vgl. Kort Begryp, 17 -18.

$56 \mathrm{~KB}$ Brussel, Handschriften 19073 (I), 82. Joanna vermeldt alleen de naam van Anna Woltera van Elshout, dochter van Catharina Maes en Gilles van Elshout, en een nicht van Joanna's vriendin Catharina van Gestel.

57 Ibidem, 45-46.

$5^{8}$ GAR, Handschriften II B i, 2I-22; Kort Begryp, 20. 
tes van de kloosterstaat. Zij vreesde dat zij in het klooster niet vrij zou zijn om te biechten bij wie zij wilde. Joanna was bang de zaligheid van haar ziel op het spel te zetten, wanneer ze haar geweten onvoldoende zou kunnen zuiveren in de biecht:

'Ende wat droeve saeck dat het toch sau sijn indien sulcx mi) quaem te gebeuren, als ick in sulcken besloette kloester sau sijn, ick saude meijnen in een wtneemende volmacktheijt Godt te dienen ende lief te hebben, ende sau in sulcke manieren (...) mın verdoemenus meugen haellen'.39

Een opmerkelijk argument, dat herinnert aan één van de bezwaren die Van Heilsbach aanvoerde tegen aansluiting bij de wereldlijke derde orde van St. Franciscus. Gezien de bedenking van de biechtvrijheid is het niet denkbeeldig dat zij in 1627 al een rol van betekenis speelde in Joanna's ontwikkeling tot geestelijke maagd, hoewel Joanna - en ook Huysmans - volhoudt dat zij Agnes pas rond 1630 leerde kennen. ${ }^{60}$ Eerder had zij haar wel via een kennis verzocht om voor haar te bidden, nu zij zo onzeker was over haar levensstaat. Uitlatingen in Joanna's eigen geschriften maken echter aannemelijk dat Agnes' rol in haar keuzeproces van doorslaggevende betekenis is geweest. ${ }^{61}$

Anders dan Huysmans het voorstelt, ${ }^{6 z}$ was Joanna beslist niet afkerig van de kloppenstaat. $Z_{1 j}$ overwoog een religieus bestaan in de wereld als altematief voor het klooster. Maar zij vreesde dat deze leefwijze onvoldoende streng en sober zou zijn. Het was haar niet duidelijk hoe zij als geestelijke maagd zou kunnen leven volgens de evangelische raden van gehoorzaamheid en armoede. Aan wie zou zij gehoorzaam moeten zijn? Hoe zou ze in armoede kunnen leven en zich losmaken van haar ouders? ${ }^{6_{3}}$ Dit dilemma loste zij frappant genoeg op door een geestelijk leidsvrouw te zoeken, aan wie zij gehoorzaam zou zijn. ${ }^{64}$ Haar besluit om klop te worden, wekte alom verbazing. Men had verwacht dat zij in een klooster zou treden, zoals verscheidene van haar 'cameraeden' ook hadden gedaan. Het gerucht ging dat Joanna omwille van haar ouders geen non werd. Over een zodanig gemotiveerde keuze tegen het kloosterleven werd zelfs tijdens een preek in de minderbroederskerk afkeuring uitgesproken. Joanna onderschreef dit misprijzen, want

59 KB Brussel, Handschnften, 19073 (I), 68, vgl. GAR, Handschriften II B 1, 27.

60 KB Brussel, Handschnfien 19073 (I), 74 GAR, Handschnfien II B l, 26. Kon Begryp, 28.

61 Zie hiervoor Monteiro, 'Den middelen staet', 154-155.

62 Kort Begtyp, 26

63 GAR, Handschnften II B , 27-28.

64 Ibidem, 29 Deze passage is aangepast in de tweede en laatste redactue van haar spintuele autobiografie, KB Brussel, Handschrifien, 19073 (I), 71, waar z1) schrift dat ze wenste dat ze een vrouw kon vinden 'daer ick my onder stelden, met goet vinden, van eenen wıjessen Geestelıcke man onder Haere gehoorsaemheı,t ende haer in alles volghden (...)'. Kennelıjk modelleerde Van Randenraedt haar eıgen levensverhaal overeenkoms dochter Was deze anpassing het gevolg van een aanwijzing van haar toenmalige bıechtvader' Mogelıjk illustreert deze toevoeging hoezeer zij de gedragsregels voor geestelıke maagden in de loop der tud vennnerlıjkt heeft. 
als God het wilde, dan moest iedereen bereid zijn ouders en vrienden te verlaten. ${ }^{65}$ God had haar echter niet tot het kloosterleven maar tot de kloppenstaat geroepen. Aan die roeping gaf zij gevolg, in de overtuiging dat zij Hem en haar naasten beter kon dienen in de wereld dan achter kloostermuren.

Niettemin was en bleef zij haar hele leven kind aan huis in verschillende Roermondse vrouwenkloosters. Zij frequenteerde vooral Godsweerd, het klooster van de reguliere derde orde van St. Franciscus, en de Munsterabdij, een cisterciënzerinnenklooster en adellijk damesstift, kennelijk ongehinderd door de clausuur, die zowel de dames van het Munster als de zusters van Godsweerd moesten eerbiedigen. ${ }^{66}$ De priorin van Munsterabdij, Catharina di Ortigosa, had enige tijd als haar geestelijk leidsvrouw gefungeerd. In die hoedanigheid trad zij op als tussenpersoon tussen Agnes en Joanna. Toen Agnes echter merkte dat de priorin Joanna probeerde in te lijven in de Munsterabd, zelf onder haar hoede. God had haar namelijk de opdracht gegeven ervoor te zorgen dat Joanna geestelijke maagd en geen non werd. ${ }^{67}$ De gespannen verhouding tussen Van Heilsbach en Di Ortigosa was niet van lange duur, want Joanna en Agnes waren regelmatig in de abdij te vinden.

Op 17 september 1630 werd Joanna's intrede in de kloppenstaat gevierd met een plechtigheid. Zij 'heeft (...) het swert kleedt aen-ghetrocken, ende is als-dan van Vader ende Moeder naer de Kercke der Societeyt Jesu vergheselschapt gheweest, al-waer sy met vernieuwinghe van haer Belofte sigh aen Godt op-geoffert heeft' ${ }^{68}$ Van Agnes kreeg zij te horen dat zij voortaan alleen nog bij de rector van het jezuietencollege mocht biechten, en niet meer-zoals ze vroeger kennelijk had gedaan - bij paters minderbroeders. ${ }^{69}$ Een belangri)k argument tegen intrede in een klooster, namelijk het gebrek aan gelegenheid om te biechten wanneer en bij wie zij wilde, kwam hiermee te vervallen, want als jezuïeten-klop genoot zij deze vrijheid evenmin. ${ }^{70}$

Van I630 tot 1633 ging zij, net als Agnes, te biecht bij rector Walter Clerikus (1574-1636). In die penode onderhielden beide vrouwen echter ook nauw contact met Jacob Wijns, die vermoedelık eind jaren twintig hun biechtvader was geweest. ${ }^{71} \mathrm{Na}$ zijn overplaatsing naar 's-Hertogenbosch, die rond $163 \mathrm{I}$ plaats vond,

65 GAR, Handschriften II B 1, 37-38.

$66 \mathrm{Z}_{1 \mathrm{e}}$ voor deze kloosters Pyls, 'Roermonds kloosterleven', 188-197 en 202-203.

67 Leven ende deughden, 104-106

68 Kort Begryp, 30; vgl GAR, Handschnften II B J, 37.

69 Over banden met de paters munderbroeders zijn haar eigen notttes onduidelıjk. Mogelı1k ging zuj tot haar intrede in de kloppenstaat zowel buj minderbroeders als bij jezuleten te biecht Een niet met naam genoemde oom van haar was minderbroeder. Voor haar keuze om als geestelijke maagd te leven, kon hij weing waardenng opbrengen. GAR, Handschrften II B ), 39

70 Ibidem, 36; KB Brussel, Handschriften 19073 (1), 75.

7 PA SJ, Histonsche handschnftenverzameling, doos I54, C 38 b, Catalogi ann (afschrften), anno 1625 $W_{1 j n s}$ fungeert dan als een van de raadgevers van de toenmalige rector Joannes Bapt Uwens (15881657). Mogelıjk behield hi) die functue bıj het aantreden van rector Amoldus Cathuis (1576-1629) rond 


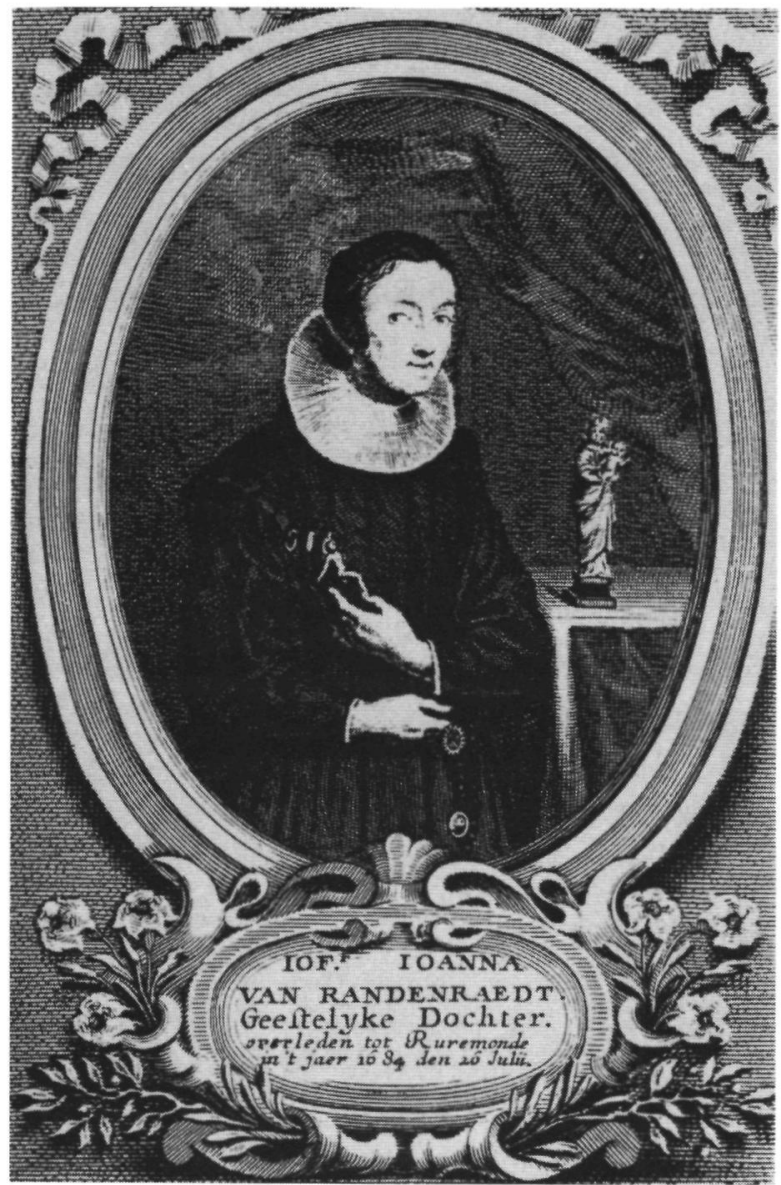

Afb. 13 Portret van foanna van Randenraedt, opgenomen als frontispice in haar gedrukte levensbeschrijving. Haar bijzondere devotie tot de Heilige Maagd wordt benadrukt door het Mariabeeld op de achtergrond, waarschijnlijk het beeld van Onze Lieve Vrouw in 't Zand, die foanna - evenals haar geestelijke moeder Agnes van Heilsbach - zeer toegedaan was.

bleven zij hem beschouwen als geestelijk leidsman. ${ }^{72}$ Of hij hun leidsman bleef tijdens het rectoraat van Clerikus' opvolger Balduinus Hiessche (1593-1647), is niet duidelijk. De volgende rector, Simon van den Hove, trad zijn ambt circa I636 aan. Hij verenigde in ieder geval het biechtvaderschap en geestelijk leiderschap weer in eigen persoon. Na zijn vertrek naar Kortrijk onderhield Joanna nog schriftelijk contact met hem tot zijn overlijden op 24 oktober I64I I. ${ }^{73}$ Zijn opvolger Andreas Hellin (1590-I643) was van I64I tot I643 Joanna's biechtvader. Rector Hellin kende confrater Valentinus Bisschop, auteur van Lof der Suyverheydt, persoonlijk en stak de loftrompet van diens diensten aan geestelijke maagden. ${ }^{74} \mathrm{De}$

1626. Deze figureert als 'Kaetsius' in Van Heilsbachs spirituele autobiografie. C.ss.R. Roermond, Speciaal Archief A pl. 7, GG II (ongepagineerd).

72 KB Brussel, Handschriften 19073 (II), 26.

73 PA SJ, Historische handschriftenverzameling, A E 23 b, Naamlijst S.J. in Nederland, begin-1850. 74 Ibidem, doos 64, AG 3 b, Elogium Valentinus Bisschop door Andreas Hellin, 12 juni 1636 
volgende rector, Franciscus l'Hermite (1598-1690), werd in 1643 benoemd. ${ }^{75} \mathrm{Hij}$ kweet zich maar korte tijd van Joanna's spirituele begeleiding. Deze taak liet hij vooral over aan twee andere paters, Cornelis de Moor (1593-1644) en Livinus de Clerck (I597-I652) ${ }^{76}$ Zelfs de beroemde dichter Adriaan Poirters (I606-I674) was in de zomer van 1646 een blauwe maandag haar leidsman. ${ }^{77}$ In 1647 en I648, de periode waaruit het merendeel van de laatste gewetensrekeningen van Joanna dateert, stond zij opnieuw onder leiding van Jacob Wijns, die toen het ambt van rector vervulde. ${ }^{7}$ Hun verstandhouding was ditmaal aanvankelijk gespannen als gevolg van een conflict dat in het verloop van dit hoofdstuk nog uitvoerig aan de orde zal komen. Als klop werd Joanna niet alleen door haar verschillende biechtvaders gevormd, maar ook door Van Heilsbach. Die waakte streng over haar spirituele ontwikkeling. Vanaf I637 nam Joanna de taken van Agnes als catechete en geestelijk leidsvrouw geleidelijk over. De eendracht tussen beiden, die Huysmans roemt, ${ }^{79}$ was zeker aan spanningen onderhevig, die samenhangen met de informele status van het geestelijk moederschap en met de persoonlijkheid van beide vrouwen. Aan deze aspecten wordt in het volgende hoofdstuk meer aandacht besteed.

Ten gevolge van veranderingen in haar persoonlijk leven gedurende de jaren veertig kwam haar streven naar een religieus bestaan in de wereld op gespannen voet te staan met allerlei familieplichten. Haar vader overleed in augustus I643. Het gezin kwam hierdoor in financiële problemen. Haar broer Willem Hendrik trok met vrouw en kinderen bij Joanna en haar moeder in, vermoedelijk om de kosten te drukken.$^{80}$ De betrekkelijk rustige levensomstandigheden waaraan Joanna gewend was, veranderden nu het huiselijk leven werd gedomineerd door jonge kinderen. ${ }^{81}$ Al beschikte Joanna over een eigen kamer waar zij zıch terug kon trekken om te bidden, te mediteren of te schrijven, zij kon zich minder dan ooit aan huiselıjke verplichtingen onttrekken. Zij bekommerde zich om de opvoeding van haar nichtje en neefjes, omdat hun moeder, Margaretha van Kessenich, fysiek

\section{(afschnft)}

75 Allard, 'Het jezueten-college', 12

76 PA SJ, Histonsche handschnftenverzameling, doos 154, C 38 b, Catalogi ann (afschnft)

77 Ibıdem Poirters' naam wordt anno 1646 net meer vermeld Allard, 'De Brabantsche Cats', 7, die stelt dat Poirters sinds I64I tenminste vjf jaar doorbracht aan het Roermondse college, waar hij onder andere studieprefect was Vermoedelıjk werd hy) in I646 overgeplaatst naar Antwerpen. Zie ook Rombauts, Leven en werken, 72.

78 Haar laatst overgeleverde gewetensrekening uit de jaren veertıg dateert van na het overlıden van Wijns GAR, Handschnften I A 2 (kopie Lucia de Werimont) Uit KB Brussel, Handschnften 19073 (II), 849, blıkkt dat Wijns' opvolger Antonius Meerhouts (I608-I678) toen Joanna's biechtvader was. 79 Kort Begryp, 34

8o KB Brussel, Handschrften 19070, $114-114$ vo en vgl. I17-1 20

81 Mosmans, 'Een Limburgsche magstraatsfamılie', 90-91, vermeldt zes kunderen van wie er èen, Everardus Ignatuus (geb 1642), vermoedelık zeer jong overleed Mana Cathanna van Randenraedt, die als oudste knd te boek staat, werd in $164 \mathrm{I}$ gedoopt Op grond van GAR, Handschnfien I A 5 (ongepagineerd, ongedateerd, me1 I640), is aannemelijk dat Joanna's schoonzuster daarvoór al, in meı I640, van een zoon bevallen was. 
noch mentaal sterk was. Willem Hendrik, die het schoutambt in Roermond vervulde, zocht zijn heil meer in plaatselijke herbergen dan thuis. In Joanna's ogen verzaakten beiden hun godsdienstige plichten schromelijk en voedden zij hun kinderen haast goddeloos op. ${ }^{{ }^{8}}$ Ruim een jaar na het overlijden van haar moeder in 1647 betrok Joanna een woning met Aldegonda van Horenbeek, vermoedelijk een Bossche jezuïeten-klop die zij begin jaren dertig via Wijns had leren kennen. ${ }^{83}$ Deze jezuïet, hun beider biechtvader, adviseerde hen in november 1648 over 'veel dingen onsse huishoudinge aengaende (...) ende (...) geestelijcke ordonnantien diemen sau instellen (...) ${ }^{8}{ }^{84}$ Toen Margaretha van Kessenich in $1651^{85}$ overleed, trok Joanna bij haar broer in. Tot 1658 rustte de zorg voor haar nichtje en neefjes volledig op haar schouders. Wanneer zij Roermond verliet voor één van haar veelvuldige en langdurige bezoeken aan famılie in de Zuidelijke Nederlanden, nam Catharina van den Broeck hun verzorging en opvoeding waar. ${ }^{86}$ Of het hier louter om een vriendınnendienst ging of dat deze van oorsprong Nijmeegse geestelijke dochter een betaalde betrekking had bij de Van Randenraedts, is ondurdelijk. ${ }^{87}$ Ook Lucia de Werimont hield tijdens Joanna's afwezigheid een oogje in het zeil. In 1658 ging Joanna op zichzelf wonen. ${ }^{88}$

Dat Joanna zich geheel en al opofferde voor het gezin van haar broer, zoals Huysmans de lezers van Kort Begryp wil doen geloven, ${ }^{89}$ is weliswaar niet volledig onjuist maar zeker vertekend, omdat Joanna regelmatig wist te ontsnappen aan deze zorgplicht. Wél had Huysmans het bıj het rechte eind toen hij schreef dat de financiele lasten die de zorg voor dit gezin met zich meebracht haast geheel en al door Joanna opgebracht werden. Geldgebrek was een voortdurende bron van zorg in de jaren vijftig, zo blijkt uit de brieven aan Cathanna van den Broeck.

82 KB Brussel, Handschnften 19070, II9vo-I 20 (oktober I643), GAR, Handschnften I A ro; I A II $83 \mathrm{~KB}$ Brussel, Handschnfien 19073 (I), 225

84 Ibidem, (II), 821. Vgl. RAL, Archieven der Jezureten te Maastncht en Roermond. Archief College Roermond (ongeinventanseerd), Consuetudines Provinclae ( ) Liber VII, Pars V, Benefactores, waann wordt vermeld dat beide vrouwen in 1650800 gulden aan het jezuietencollege hadden geschonken, op voorwaarde dat van dit bedrag een hus gebouwd zou worden dat zij mochten bewonen, zolang als zij leefden. Mogelık dateerde deze schenkung al uit 1648

85 Mosmans, 'Een Limburgsche magistraatsfamilie', 90 , vermoedt dat z1) in of voor 1656 stierf Joanna zelf sprak al in 1652 over 'mujn suster saelieger', met whe nemand anders dan Margaretha van Kessenuch bedoeld kan zijn Vgl. GAR, Archief Kerkfabnek St. Chrstoffel, registers van overluiden, waann het overlyden van de echtgenote van 'schout Randraidt' anno I65I vermeld wordt Uit een brief van Van Randenraedt aan Anna Theodora de la Crox Mongarde, karmelites te Aalst, d.d Io apnl 1658, afgedrukt in Kon Begryp, 84, blıkt dat Joanna al zeven jaar zorgde voor het gezin van haar broer 86 GAR, Handschnften I A 15, I A 20, I A 22, I A 24, I A 25, II B c.

87 GAR, Archref Hoofdgerecht Roermond, unv.nr 468, Stukken inzake de voldoenung van crediteuren uit nalatenschappen en falliete boedels. 1591-1794 Omslag Willem van Randenraedt, 1662-1663, nr 45, rekening van de kleermaker Pier of Peter Schanon, waarop vermeld staat dat een deel van de uitstaande schuld voldaan is door 'haer [hun] maecht Treineke van den Broeck'

88 Kort Begryp, 88

89 Ibidem, 81, 84-85, 90 en 100. 
Niet alleen ten opzichte van haar bloedverwanten, maar ook tegenover haar 'geestelijke familie', de jezuïeten, had zjj naar eigen gevoelen financiële verplichtingen..$^{\circ \circ}$ De erfenis die haar na het overlijden van haar moeder toeviel, kon zij evenwel niet ten goede laten komen aan de jezuieten, zoals ze eerder gewild had. Ze bestemde deze middelen voor de opvoeding van haar nichtje en neefjes. Haar eigen wensdroom om zich met Lucia de Werimont en Catharina van Gestel als 'arme bourinnekens' ergens te vestigen en een priester van de Socièteit te onderhouden die de gelovigen veel godsvrucht zou inboezemen, moest daarvoor wijken.9' $\mathrm{Bij}$ zijn overlijden in $\mathrm{I} 662$ liet Willem Hendrik een failliete boedel na. Joanna draaide op voor zijn schulden. ${ }^{92}$ Mede dankzij haar geldelijke steun konden drie van haar neven intreden in een klooster. ${ }^{93}$ Maria Catharina (I64I-na 1702) werd net als haar tante geestelijke maagd en woonde lange tijd bij haar in. ${ }^{94}$ Philip Jacob ( $f$ r697) opteerde voor een militaire carrière.

Toen in 1665 ongeveer driekwart van de stad Roermond ten prooi viel aan de grote stadsbrand, ${ }^{95}$ ging ook Van Randenraedts huis verloren. Joanna vertrok tijdelijk naar Mónchengladbach. Van 1669 tot circa 1673 woonde zij samen met Maria Catharina in het Roermondse klooster Godsweerd. In I673 voerde zij weer een eigen huishouden in een huis dat zij huurde van de paters jezuieten. ${ }^{96}$ Joanna mag dan onbaatzuchtig geweest zijn, onzakelijk was zij niet. In I675 presenteerde zij Maria Cathanna en Philip Jacob een overzicht van alle kosten die zij sinds de dood van hun vader voor beiden had gemaakt. ${ }^{97} \mathrm{Nicht}$ en neef hadden inmiddels met succes aanspraak gemaakt op een erfenis van moederszıjde. ${ }^{98} \mathrm{Hun}$ tante wilde

90 Zie II 4 van dit boek in het bijzonder 78,80 .

91 KB Brussel, Handschnfien 19070, 256 (september 1645).

92 GAR, Archief Hoofdgerecht Roermond, unv.nr 468, Stukken inzake de voldoening van credıteuren uit nalatenschappen en falliete boedels I59I-1794. Omslag Willem van Randenraedt, I662-I663 Uit het 'Register der Crediteuren pretenderende Opt Sterfthuys vanden H Scholas Randenraedt Zael ' blijkt dat zijn totale schuld bijna 5000 gulden bedroeg

93 Mosmans, 'Uit het leven', 38, 1dem, 'Een Lumburgsche magistraatsfamulie', 90-91. Cornelis Georgius (1643-1687) werd in 1665 geprofest in de benedictunenabdi) van Monchengladbach. W'lhelmus (1644-I68I) werd in datzelfde jaar eveneens in deze abdij geprofest Ignatuus Carolus (I6471709), het petekund van Joanna, trad ook al in diezelfde abdi) en werd in 1666 geprofest

94 RAL, Archief Hof van Gelder, Proces Joanna Baptusta van Randenraedt tegen Philip Jacob en Mana Catharna van Randenraedt (1675), 'Staet ende Reeckenunge' 'Anno 1663 alswanneer mune nuchte geestelicke dochter is geworden (..)'.

95 Venner, 'De stadsbranden', 129-130

96 RAL, Archtef Hof van Gelder, Proces Joanna Baptısta van Randeraedt tegen Philip Jacob en Mana Cathanna van Randeraedt (1675); Mosmans, 'U1t het leven', 38-40; Kont Begryp, II4.

97 RAL, Archtef Hof van Gelder, Proces Joanna Bapusta van Randeraedt tegen Philip Jacob en Mana Cathanna van Randeraedt (1675), 'Staet ende Reeckeninge'. Zie ook Mosmans, 'Uit het leven', 38-40. Joanna claunde Phulp Jacob in totaal 390 pattacons te hebben voorgeschoten en geleend De kosten die zi) voor Mana Cathanna maakte, beliepen in totaal 658 pattacons. In waarde was deze munt vergelıkbaar met de Noordnederlandse njksdaalder, ook al lag het zilvergehalte lager. De Vnes en Van der Woude, Nederland 1500-1850, 109 98 RAL, Archief Hof van Gelder, Proces Jr. Phulıp Jacobs en Joff Mana Cathanna van Randerath tegen 
nu haar gemaakte onkosten gerestitueerd zien, opdat zij haar oude dag nog enigszins verzorgd kon doorbrengen.

Godsvrucht en uitstraling van Joanna van Randenraedt waren exceptioneel. Huysmans documenteert de verering voor haar door in Kort Begryp verklaringen op te nemen van de bisschop van Roermond, de gouverneur van Opper-Gelre, Johan Frans Désiré van Nassau-Siegen, diens echtgenote, het Hof van Gelder, het kapittel van Roermond en de plaatselijke magistraat. ${ }^{99}$ Allen beklemtoonden Joanna's bijzondere gaven en de buitengewone band die zij met God, Christus, Maria en andere heiligen had. In de lokale katholieke gemeenschap, die gedurende de zeventiende eeuw vrijwel voortdurend direct of indirect geconfronteerd werd met dreiging van oorlog en plundering, vonden haar profetische uitspraken een vruchtbare voedingbodem. In het Overkwartier woedde de Opstand; tussen I632 en 1637 was Roermond bezet door Staatse troepen. Vrijheid van godsdienst werd weliswaar gegarandeerd door Frederik Hendrik, maar toch werden de burgers rechtstreeks geconfronteerd met mogelijke staatkundige en confessionele gevolgen van de Opstand. ${ }^{100}$ Het grondgebied van de naburige hertogdommen Gulik en Kleef was het toneel van de Dertigjarige Oorlog, hetgeen de stad evenmin onberoerd liet. ${ }^{\text {Ior }}$ In deze tijden van ontwrichting en angst fungeerden Joanna's profetieën als een baken, althans zo wordt het voorgesteld door Huysmans. In het rampjaar 1672 verzekerde zij haar stadgenoten dat zij niets te vrezen hadden van de troepen van Lodewijk XIV, maar zich verzekerd konden weten van de bescherming van de Moeder Gods. ${ }^{\text {Ioz }}$

In haar eigen tijd - en ook later in de historische overlevering - droeg zij bij aan het vertrouwen in de sacraliteit van de Kapel in 't Zand. ${ }^{103}$ Veel tijd en geld besteedde zij aan de zorg voor Onze Lieve Vrouw-beelden her en der in stad, waaronder dat op deze Mariale cultusplaats, waaraan ook haar eigen geestelijke moeder zeer verknocht was geweest. In 1683 smeekte Joanna de verlossing van

de Overste Mernich c s, anno 1675. Mosmans, 'U1t het leven', 38 Inzet van het proces was de erfenis van Everard van Hasselholt, kanunnik te Xanten en oudoom van moederszijde van Philip Jacob en Mana Cathanna Deze erfenis, bestaande uit goederen in het hertogdom Gelre en elders, was door Jan Willem van Stockheim zu Vollenhoven met onrechtmange uitsluitang van Margaretha van Kessenich en haar broer Johan Walraven van Kessenich, in bezit genomen Uit de 'Staet ende Reeckenunge' (RAL, Archref Hof van Gelder, Proces Joanna Bapusta van Randeraedt tegen Philip Jacob en Mana Cathanna van Randeraedt (1675)), blyjkt dat Joanna haar nicht en neef geld had geleend voor het voeren van dit proces.

99 Kort Begryp, 341-348.

I00 Habets, Geschredents, II, 78; Rogier, Geschiedenws, I, 626; II, 636; Janssens, 'De landvoogdı) van Isabelle', 379, 381; Houtman-Desmedt, 'De eindfase'.

10I Jappe Alberts, Geschiedents, II, 5-6.

102 Kon Begryp, II5 Voor het belang van dergelıje voorspellingen in relatie tot de katholieke gemeenschap en haar identiteitsbesef, zie Fnjhoff, 'Katholieke toekomstverwachtung'.

103 Kronenburg, Mara's heerlykherd, VI, 363-365, Wingens, Over de grens, 5I, 53. 
Afb. I4 Grafmonument van foanna van Randenraedt in de kathedraal van Roermond.

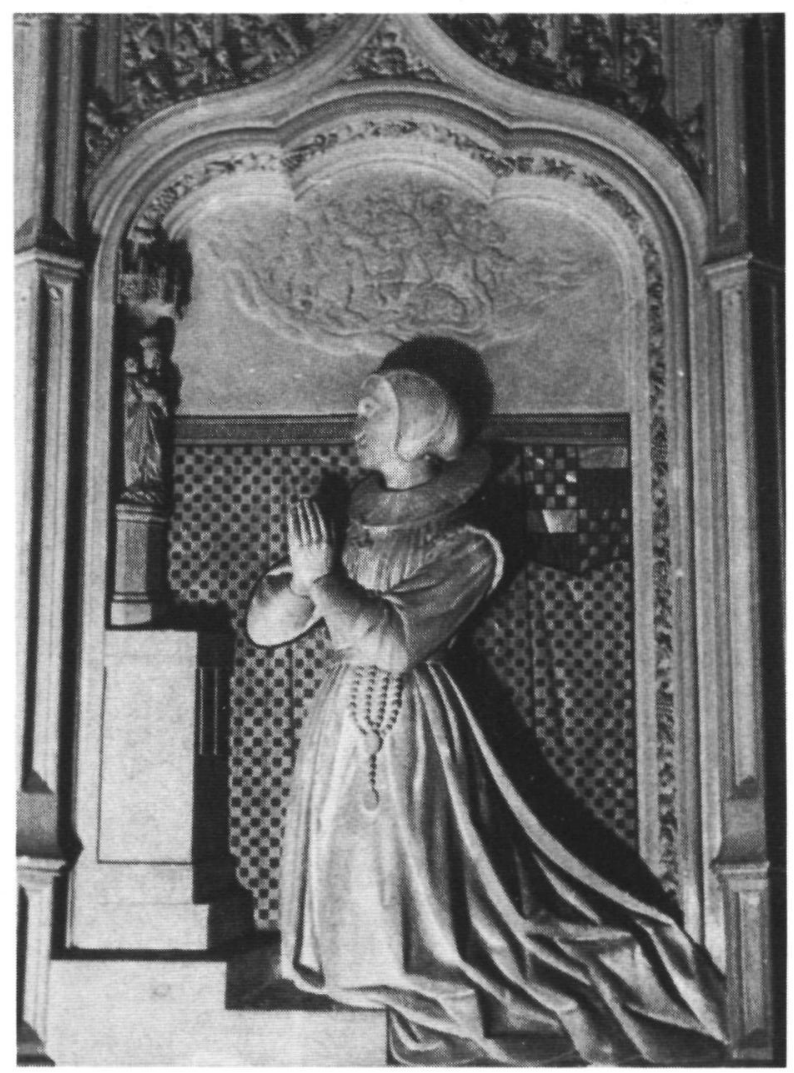

de stad Wenen, die werd belegerd door Turkse troepen, af bij Onze Lieve Vrouw in 't Zand. Op haar instigatie werden er biddagen afgekondigd. In een plechtige processie liet de toenmalige Roermondse bisschop Reginald Cools het beeld van Onze Lieve Vrouw in 't Zand de stad ronddragen. Het werd bij toerbeurt in alle lokale kerken opgesteld. Driemaal daags werd er voor de bevrijding van Wenen gebeden, waartoe Joanna in het openbaar het voorbeeld gaf. Hele dagen was zij te vinden in de kerk waar het beeld zich op dat moment bevond. Van God begreep zij dat het beleg gebroken was en de keizerlijke troepen een overwinning hadden behaald. Enkele dagen later bereikte een bericht van die strekking de stad en bevestigde de ingeving die Joanna reeds aan haar biechtvader had meegedeeld. ${ }^{104}$

Deze gebeurtenissen droegen in niet geringe mate bij tot haar aanzien. Zij werd vereerd als een heilige. Deze reputatie won aan kracht toen zij op haar sterfbed door handoplegging een dochter van de kanselier van het Gelderse Hof genas, die aan een geheimzinnige, slopende kwaal leed. Terwijl de jaarbrieven van het 
Roermondse jezuïetencollege doorgaans zwijgzaam zijn over optreden en werkzaamheden van geestelijke maagden, wordt deze daad breed uitgemeten in de jaarbrief van I684. ${ }^{\text {os }}$ En ook Huysmans gaat uitvoerig in op deze wonderbaarlijke genezing in de nacht voorafgaand aan Van Randenraedts dood. ${ }^{106}$ Met deze beschrijvingen werden misschien wel de fundamenten gelegd voor een proces tot zaligverklaring, waartoe het echter nooit gekomen is. Joanna voorspelde het tijdstip van haar overlijden tot op het uur nauwkeurig, ${ }^{107}$ hetgeen van oudsher werd gezien als een teken van heiligheid. $\mathrm{Zij}$ overleed in 1684 op 26 juli, de feestdag van de heilige Anna, en werd begraven voor het hoogaltaar in de kerk van de jezuieten te Roermond. Vóór de sloop van deze kerk in 1777 werden haar stoffelijke resten overgebracht en bijgezet in het familiegraf van de Roermondse raadsheer Rutger Jozef van Dunghen in het Mariakoor van de kathedrale kerk. Meer dan een eeuw later, op 7 maart 1884, werd dit graf ontdaan van andere stoffelijke resten dan die van Joanna van Randenraedt en voorzien van een monumentale epitaaf. ${ }^{\text {og }}$

\section{IV.2 Lotgevallen van de egodocumenten}

Dit grafmonument, waarop zij in gebed afgebeeld staat, bewijst dat Van Randenraedts reputatie aan het einde van de negentiende eeuw nog nauwelijks aan kracht had ingeboet. Haar vita werd in 1857 opnieuw met een naar de eisen des tijds aangepaste spelling en woordkeuze uitgegeven. ${ }^{109}$ Lemmata in biografische woordenboeken hielden de herinnering aan haar levend. ${ }^{10} \mathrm{Zij}$ en Van Heilsbach werden aan het begin van de twintigste eeuw vereeuwigd op verscheidene gebrandschilderde ramen in kerk en processiegang van de Kapel in 't Zand;"' een eerbetoon aan

105 PA SJ, Histonsche handschnftenverzameling, doos $155 \mathrm{C}_{38}$, Lutterae annuae collegu Ruraemundensw S J

106 Kort Begryp, 124-126.

107 Ibidem, 121-122. PA SJ, Histonsche handschnftenverzameling, doos 155, C 38 1, Litterae annuae Collegu Ruraemundensis S.J., anno 1684.

108 Bisschoppel1,k Archief Roermond, Archref van het Busdom Roermond, 1840-1940, inv.nr. 98. Procesverbaal van de opgraving van het hichaam van de eerw dienares Gods Joanne Baptista van Randenraedt, gestorven 26 julı 1684, wt het graf van de kathedrale kerk op 7 maart 1884 . Behalve Rutger Jozef van Dunghen ( $\dagger$ 1779), lag ook Joannes Baptist van Dunghen $(\dagger 1780)$ hier begraven

109 Stichtende leven.

110 Nreuw Nederlandsch Brografisch Woordenboek VII (Le1den 1927) 1036-137; Brographre Natzonale publieé par l'Academie Royale des Setence, des Lettres et des Beaux-Arts de Belgrque, XVIII (Brussel I905) 654-656.

III Eén van de ramen stelt Agnes van Heilsbach voor die met een groep kinderen knielt in de Kapel voor Mara. Op een tweede voorstelling knielt een kruisdragende Joanna van Randenraedt voor Christus. Beide vrouwen staan ook afgebeeld op een glas-in-loodraam in de westgevel van de kerk. De Kapel is eveneens in het bezıt van een twintigste-eeuws oheverfschuldenj van Joanna van Randenraedt dat zich in de sacnsue van de kerk bevindt De maker is niet bekend, maar het is spiegelbeeldig vervaardigd naar de zeventuende-eeuwse gravure die als frontispice is opgenomen in Kort Begryp (zie 
twee vrouwen die een belangrijke rol hebben gespeeld in de ontwikkelingsgeschiedenis van deze cultusplaats. Zorg voor hun nagelaten handschriften illustreert de voortdurende verering eveneens. Paradoxaal genoeg hebben aard en inhoud van deze handschriften hun overlevingskansen vergroot. De handschriften raakten in de loop der eeuwen over verschillende eigenaars en eigenaressen verspreid. Door circulatie en veelvuldige lezing waren ze vermoedelijk meer aan slijtage onderhevig dan egodocumenten voor strikt persoonlijk gebruik. Toch moeten lezeressen en lezers er zuinig op geweest zijn, uit eerbied voor de schrijfsters, wier faam reeds in de zeventiende eeuw buiten de stadsgrenzen van Roermond reikte, niet in de laatste plaats dankzij hun notities waarin zij geturgen van visıenen, inspraken en andere buitengewone gebeurtenissen. ${ }^{122}$ Geinspireerd door de gedrukte vita van Joanna zouden vele vrouwen te Antwerpen een religieus bestaan buiten het klooster verkozen hebben. ${ }^{13}$ In de Zuidelijke Nederlanden riepen religieuze vrouwen hen aan in de "litanien van heijlighe gheestelijcke dochters', hoewel geen van beiden zalig, laat staan heilig verklaard was. ${ }^{144}$ Voor sommlgen die de eigenhandıge geschriften van beide vrouwen in handen kregen, waren deze een bron van kennis over God en het geloof. Voor anderen hadden ze misschien de status van een relikwie. Toen Catharina van Gestel in 1696 door haar zuster levenloos werd aangetroffen, hield zij een Mariabeeldje en enkele handschriften van haar voormalige geestelijke moeder Agnes van Heilsbach tegen de borst gedrukt. ${ }^{175}$

Zelfs bij benadering is niet vast te stellen hoeveel beide Roermondse geestelijke maagden tijdens hun leven hebben geschreven. In elk geval delen niet al hun pennevruchten het lot dat veel autobıgrafische geschriften treft: verwaarlozing, zoekraken of zelfs doelbewuste vernietiging. Niet alleen nabestaanden, maar ook auteurs zelf probeerden geheimhouding van hun schnjfsels te waarborgen door deze opzettelijk te vernietigen. ${ }^{116}$ Ook Van Randenraedt zou een deel van haar handschriften die niet voor haar biechtvaders bedoeld waren, verbrand hebben. ${ }^{117}$

afb. 13). Volgens Kerkelyk kunstbeztt, inv nr 56, bezat de Kapel een vergelıkbaar olıeverfschıldenj van Agnes van Heilsbach, eveneens vervaardigd naar de zeventiende-eeuwse gravure uit haar gedrukte levensbeschriving (zıe afb 12) Desgevraagd deelde de archivans, pater Ch Donker C ss R, mi) mee dat dit doek wegens onherstelbare beschadiging vermoedelık vernietıgd is

112 KB Brussel, Handschnfien 19070, 315 (december 1645)

113 Thiss, Van geuzenstad tot katholiek bolwerk, 71.

114 Vandenbroeck, Hooghed, 226 (cat nr 7) en 299-30I Deze litaneen zujn opgenomen in Verscheyde Gheestlycke Oeffeninghen ( ) (ongedateerd; vermoedelyk end zeventuende, begin achtuende eeuw, samengesteld ten behoeve van een Gents vrouwenklooster)

115 GAR, Handschrifien III C 5, M. van Gestel aan Luc1a de Wenmont (I696).

116 Mendelson, 'Stuart women's dianes', 185. De geschnften van Joanna van Chantal, die samen met Franciscus van Sales de Visitatie van Annecy opnchtte, werden op eigen verzoek na haar dood verbrand Conrad, Zweschen Kloster und Welt, 180.

117 Aldus Huysmans, Kort Begryp, 269-270 Mogelık was dit het lot van de Nederlandse vertalıng

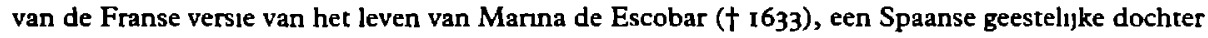
onder leiding van de jezuīeten en de latere suchteres van de hervormde birgitinessen Hieraan werkte 
Niettemin zijn er meer dan drieduizend pagina's van haar hand overgeleverd, tegenover ongeveer driehonderd van Van Heilsbach. ${ }^{118}$

\section{Bourustenen voor een vita}

Vijf jaar na de dood van Van Randenraedt vatte de jezuiet Daniël Huysmans (I643-1704) het plan op haar leven te boekstaven. Een belangrijk deel van haar geschriften was toen nog in het bezit van haar vertrouwelinge Lucia de Werimont, die haar nalatenschap beheerde. Huysmans bezwoer haar de manuscripten onder geen beding aan wie dan ook af te staan indien 'ghij de Eere van Joff. van Randenraedt ende de glorie godt[s] bemint' ${ }^{119}$ Uit zijn brieven aan De Werimont blijkt dat hij delen van Van Randenraedts geschriften in Antwerpen, Leuven en Aalst had gevonden. Vermoedelijk circuleerden haar geschriften tijdens haar leven reeds onder andere religieuze vrouwen en geestelijken, hetzij in origineel, hetzij in afschrift. Dit was geenszins ongebruikelijk, ${ }^{120}$ ook niet in kringen van geestelijke maagden. Misschien werden er zelfs speciaal kopieen vervaardigd om anderen in de gelegenherd te stellen kennis te nemen van Joanna's spirituele lotgevallen. Lucia de Werimont schreef in elk geval enkele gewetensrekeningen van Joanna af, ${ }^{121}$ kopıën die door Joanna werden gewaarmerkt. 'Dit is een copie van reekeninge gegeven inden maent Juli. J.B.R.', staat er te lezen op de voorzijde van een afschrift uit 1649. ${ }^{122}$ Van Randenraedt kopieerde zelf de notities van Agnes van Heilsbach, waarover hieronder meer. ${ }^{123}$ Terzijde zij opgemerkt dat zij ook geschriften van andere geestelijke maagden afschreef. Haar eigenhandige kopie van een gewetensrekening van de Antwerpse klop Godefrida Buijs, die zij in I645 had leren

Van Randenraedt sinds 1637 KB Brussel, Handschnfien 19073 (I), 230-23I Vgl Verschueren, 'De boeken', 193 en $D B S$ VI, 1291 de eerste gedrukte versie van deze vita verscheen pas in 1665 , van de hand Luss de la Puente S J Mogelıjk beschıkte Joanna over een Franstalıg manuscript

I18 Zoals heronder nog verduidelı)kt zal worden, zı)n behalve de autografen van Van Heilsbach ook afschnften daarvan bewaard, gemaakt door Van Randenraedt. Deze ongeveer achthonderd pagna's komen ten dele overeen met de overgeleverde autografen

II9 GAR, Handschnften III C I5.

120 Dekker, "'Dat mınn lieve kunderen weten zouden. "', 10, wi)st op het circuleren van egodocumenten in protestantse, pietususche knng. Dit was eveneens gangbaar in katholieke kring, met name onder vrouwelıke religieuzen. Matter, 'The personal and the paradıgm', 89, merkt bijvoorbeeld op dat het manuscnpt van de spintuele autobıografie van de Italıaanse capucines Mana Domiulla Galluzzı in diverse afschnften in omloop was

I2I B1jvoorbeeld GAR, Handschnfien I A 8, 9, 10, I1. De onginelen hiervan bevinden zich ten dele in KB Brussel, Handschnften 19504

122 GAR, Handschnften I A 2, volgens E J., Inventans, gedateerd 26 julı 1640 B1) de passage waarmee de kopıe van deze gewetensrekening opent, staat echter duidelıjk 26 julı 1649.

123 Mogelı)k maakte Lucia de Wenmont hıervan weer afschnften, getuige de dne fragmenten in GAR, Handschnften II B m (ongedateerd, niet geinventanseerd) Twee fragmenten zijn op enkele afwijkungen in de spelling na identiek met KB Brussel, Handichnften 18984, 311 (5 oktober [1638]) en 319-320 (13 oktober [1638]) 
kennen, is bewaard gebleven. ${ }^{\mathrm{r} 24}$ Kennelijk putte Van Randenraedt zelf ook inspiratie uit de geschriften van andere geestelijke dochters, zoals anderen dat uit de hare deden.

Werd de versnipperde schriftelijke nalatenschap van deze geestelijke maagd vermoedelijk door Huysmans weer enigszins bijeengebracht, in de tijd erna raakte het materiaal opnieuw verspreid en ging wellicht zelfs gedeeltelijk verloren. ${ }^{125}$ Wat bewaard is gebleven, is te verdelen in vier categorieën: gewetensrekeningen; correspondentie - voornamelijk brieven van Van Randenraedt aan anderen; overwegingen en religieuze oefeningen en tenslotte twee eigenhandige levensbeschrijvingen. De eerste versie van deze spirituele autobiografie is geschreven rond I640 en bestrijkt haar leven tot eind $1636{ }^{126}$ In 1667 begon zij op last van haar toenmalige biechtvader aan een nieuwe versie, een project dat vermoedelijk jaren in beslag nam. ${ }^{127}$ Deze tweede versie bestaat uit twee delen, haar eigenlijke levensloop en de verwikkelingen rond haar communie-praktijk. Die thematische scheiding is de auteur echter al schrijvende vaak uit het oog verloren. Voor de compositie van deze versie nam zij haar eigen, meer gedetailleerde gewetensrekenıngen van eerdere datum door en construeerde daaruit een levensverhaal, waarin veelzeggende bijzonderheden, twijfels, angsten of wrok grotendeels gestileerd zijn tot een voortdurende geestelijke strijd en opgaande ontwikkeling in deugdzaamheid. ${ }^{128}$ Vermoedelijk heeft Huysmans bij het schrijven van Kort Begryp vooral uit deze levensbeschrijvingen geput. Ook al biedt de gedrukte vita voornamelijk een van stichtelijke bedoelingen doordrenkte voorstelling van Van Randenraedt, de bouwstenen hier-

124 GAR, Handschnfien I A 6.

125 Bılage IV biedt een overzıcht van haar dusver achterhaalde en geraadpleegde manuscnpten (autografen en kopieen). Het merendeel berust in het Gemeentearchief Roermond en in de Koninklı)ke Bibliotheek Albert I te Brussel. De in Brussel bewaarde handschnften zijn in de negentiende eeuw gebonden in marokjnen banden, getoord met het monogram van koning Leopold I. Dit is dermate onoordeelkundig gebeurd, dat volgorde en oorspronkelıje staat slechts moeizaam te reconstrueren zujn Een inventansatie van Van Randenraedts handschnften die in Roermond worden bewaard, werd in 1937 gemaakt E J. C ss R [E Janssen C.ss R ], Inventans De stukken die toenterti)d in de St Chnstoffel-kerk te Roermond berustten, zıjn aan het begin van de jaren zeventıg overgebracht naar het plaatselıjke gemeentearchief De manuscnpten die zich in 1937 in het archief van de Kapel van Onze Lieve Vrouw in ' $t$ Zand bevonden, behoren tegenwoordig tot archief van het Redemptonstenklooster Roermond, Speciaal Archief Kapel O.L Vrouw in 't Zand. De geschriften die Janssen in 1937 in het particuliere 'Archief Geradts' mocht inzien, konden helaas tot dusver niet opgespoord en bestudeerd worden Voorts berusten er nog enkele handschnften in het Rıjksarchief Lumburg, Archief Busschoppen Roermond, inv nr I3S Zıe voor een beschnjving, Lindeman, Scherf en Dekker, Egodocumenten, nr. 95.

126 GAR, Handschnften $\Pi$ B , Haar relaas eindıgt met de vermeldıng van het overlıjden van haar oom Willem van Randenraedt op 8 december 1636

127 KB Brussel, Handschnfien 19073 (I), 10. Als verantwoordelıke biechtvaders noemt zı) Theodorus Bosman S J (I60I-I666) en diens opvolger, Ignatius van Munster S J (I624-I683)

128 Soms neemt Van Randenraedt bewust gedeelten uit haar gewetensrekeningen integraal over, zie bıvoorbeeld ıbidem, (II), 887 . 


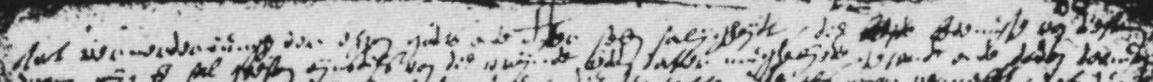

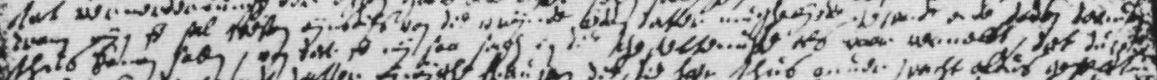

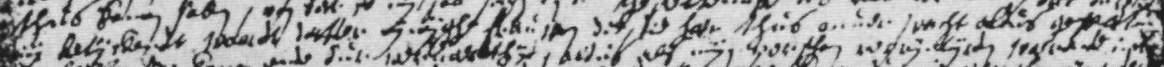

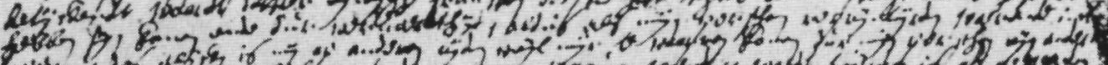

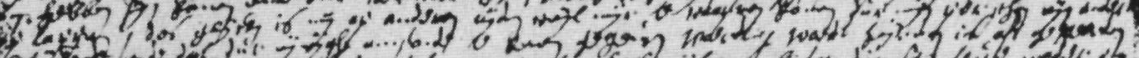

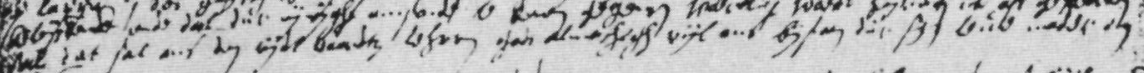
140

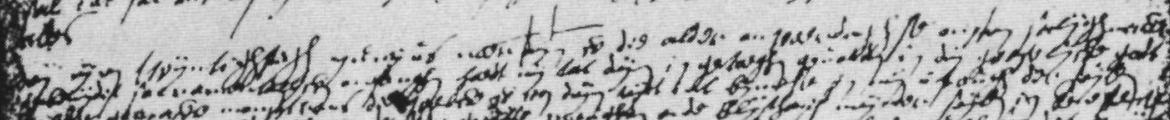

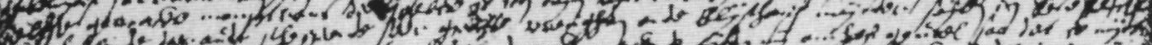

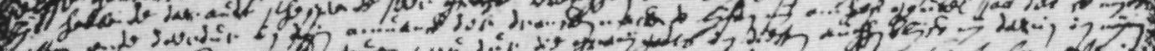
24

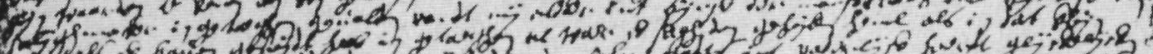

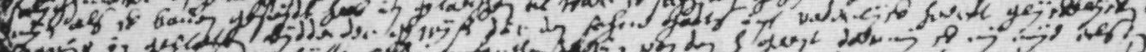

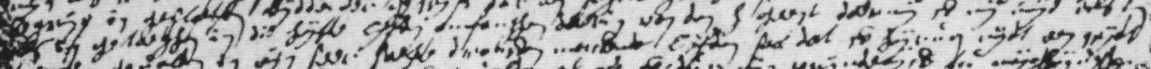

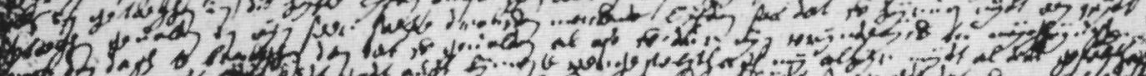

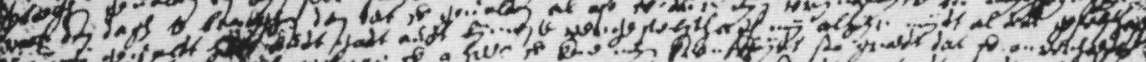

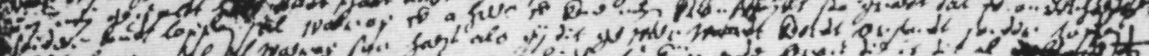

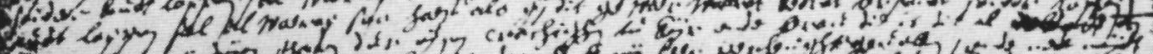

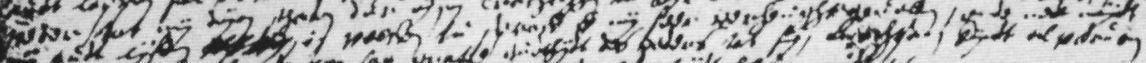

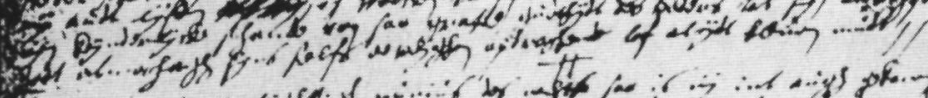

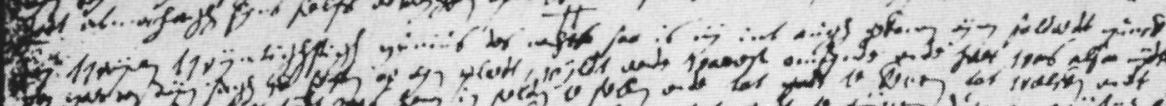

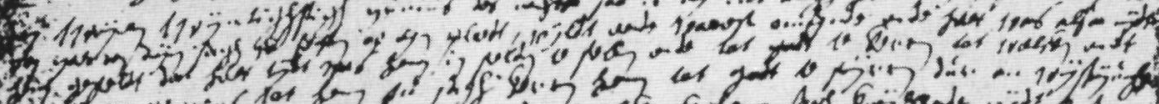

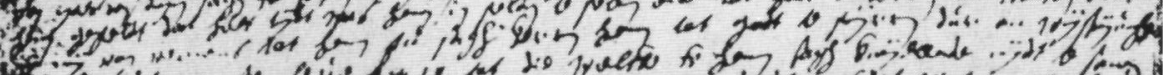

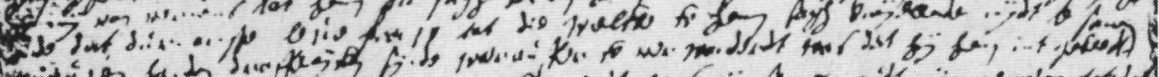
Y.

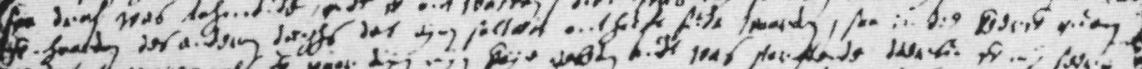

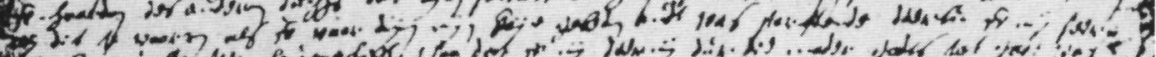

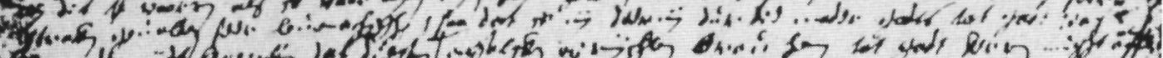

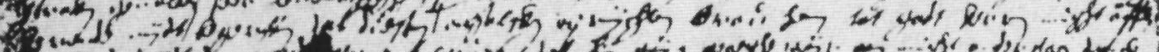

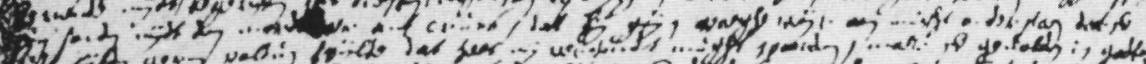

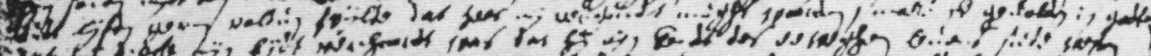

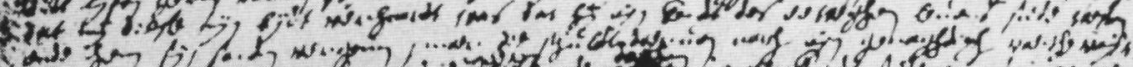

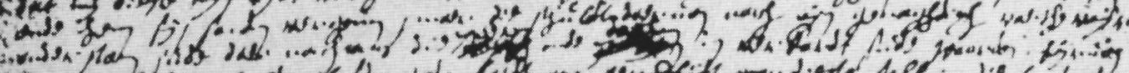

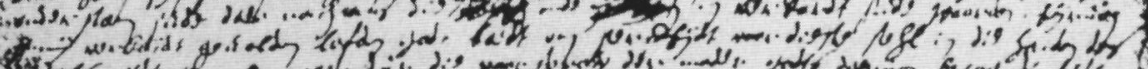

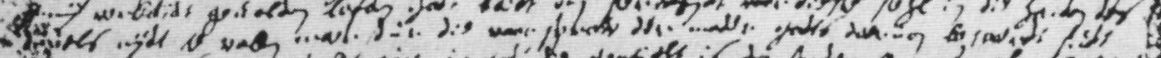

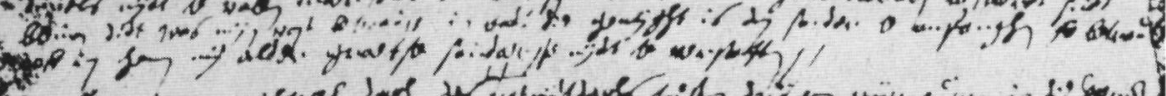

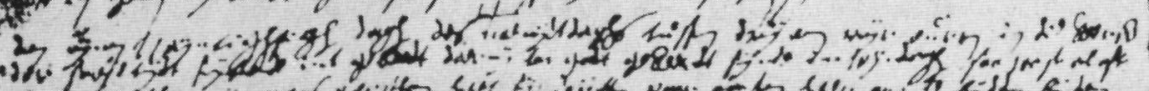

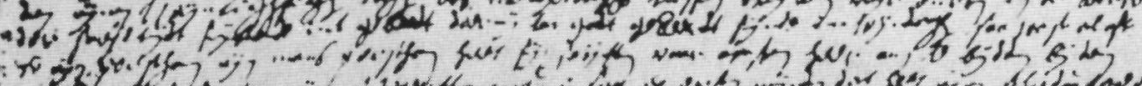

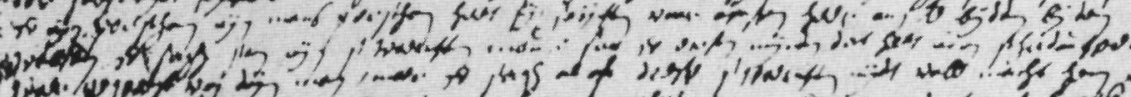

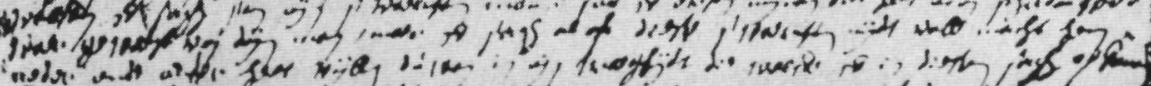

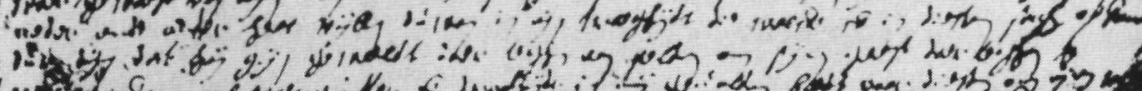

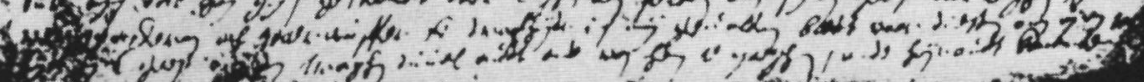


Afb. I5 Fragmenten van gewetensrekeningen van Agnes van Heilsbach (links) en foanna van Randenraedt (rechts).

maegrolicke Mooder, en didier. craghtiegen falfem des berdiensten hrinzi Laes alle die randkex bloem chrner tace alke diegareken blom men'truchten foe hreve bedaud thor dende groeiende en aengeraem sor Len,en blivien en alle gracien does Leur hebben becoemeng baer focht ich ock met alle foridaess en geloebiege

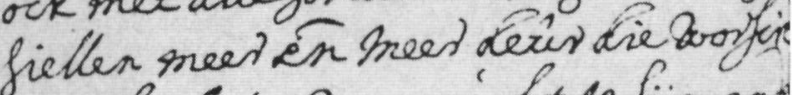
ien hulf in beveenicht te fir ent felaudz te voordin en Lat ick is bedaudz te iborden in dat ick in groeici en in Hem gequant moch ten Giuzen tot aingenzence mei foemen incer Eestoicheit 26 ick Qras feet begeerigh tien Bnerges te bif tren de eerste be fyr int ontfangep tax minnex Bribegon Sacramequtelliok, om min feluen es alie tie pillex aen flem als beüh ien alfa te geven ex mï bief to mignen trei ant binnenste bry.

voor werden door haar zelf in haar spirituele autobiografieën aangeleverd. ${ }^{129} \mathrm{Of}$, zoals Huysmans het verwoordt: 'Den gront-steen op den welcken de beschrijvinge van dit Leven principaelijck ghebouwt is, [zijn] de Schriften (...), die Ioanna met haer eyghen handt gheschreven heeft'. ${ }^{10}$ De godvruchtige idealen, weergegeven

129 Vgl. Matter, 'The personal and the paradigm', die hiervoor het begrip 'autohagiografie' gebruikt, in plaats van autobiografie.

130 Kort Begryp, 2. 
door de auteur van Kort Begryp, werden in belangrijke mate gedeeld door de hoofdpersoon van deze vita.

In I69I, een jaar na het verschijnen van Van Randenraedts leven, bracht Huysmans ook de vita van Agnes van Heilsbach uit. Naar eigen zeggen was de positieve ontvangst van het boek over Van Randenraedt aanleiding om de levensbeschrijving van haar geestelijke moeder te boekstaven. Het oordeel 'oft het leven van Agnes de schetse ende voor-beeldt gheweest is, die Ioanna in't voltrecken van haer gheestelijck leven ghevolght heeft', liet Huysmans aan de lezer over. ${ }^{131}$ Met deze zinsnede gaf de auteur echter tevens aan dat Van Heilsbachs levensbeschrijving niet enkel ter stichting, maar zeker ook ter verificatie van die van Van Randenraedt diende. Wederom maakte Huysmans gebruik van autobiografische notities. Hij zou haar leven 'schier met d'eygen woorden die Agnes in haere schriften ghebruyckt' beschrijven. ${ }^{132}$ Wat hij echter in handen had, waren geen autografen, maar transcripties daarvan, vervaardigd door Van Randenraedt. Volgens Huysmans was Agnes pas enkele jaren vóór haar dood begonnen dagelijkse voorvallen in haar leven te beschrijven. Hiertoe had zij de opdracht gekregen van rector Simon van den Hove, haar toenmalige biechtvader. Die had moeite haar handschrift en taal te ontcijferen. ${ }^{133}$ Van Heilsbach bezigde namelijk een mengelmoes van Duits en Nederlands, hetgeen zij in een kriebelig handschrift noteerde. Haar eigenhandige gewetensrekeningen, waarvan tot dusver slechts gedeelten terug gevonden zijn, bevestigen dit. ${ }^{134}$ Niet pas na Agnes' dood, zoals Huysmans stelt, maar reeds tijdens haar leven moest Joanna deze aantekeningen transcriberen en tot leesbaar Nederlands omwerken. ${ }^{135}$ Noodgedwongen besteedde zij zóveel tijd aan dit karwei dat eigen nachtrust en religieuze plichten eronder leden. ${ }^{136}$

131 Leven ende deughden, 6

132 Ibidem, 13.

133 Ibidem, 7, zie ook 92 en 96-97.

134 KB Brussel, Handschrfien 20422, Iohanna van den Raedt Receul Ascétique (1637-I638). Zie voor een gecorngeerde beschnjving van dit manuscnpt en van andere tot dusver getraceerde geschnften van Van Heilsbach (autografen en kopıeen) bılage V Anders dan de bestaande beschnjving van dit manuscnpt doet vermoeden, betreft het gewetensrekeningen van Van Helsbach, die de penode van 1637 tot 1639 bestruken. Een deel van dit manuscnpt bevat noutues van Van Randenraedt (f. 163-187, die in de hand van Van Randenraedt 512-558 zנ)n gepagineerd); notuties die vermoedeli)k in haar eigenhandig opgestelde levensbeschrijing horen, KB Brussel, Handschnften I9073 (I), waar pagina's ontbreken tussen 467 en 601 .

I35 KB Brussel, Handschnften 19073 (I), 236-237. Volgens Huysmans het Van den Hove de gewetensrekeningen van Van Heilsbach na haar dood opneuw utschrjven door Van Randenraedt omdat hy overtuıgd was van haar 'verheven geest'. Deze verklaning heb $1 k$ overgenomen in "'Ick ben gekomen inde werelt"', 68.

136 KB Brussel, Handschnften 19073 (I), 236-237. Illustratuef voor de hoeveelhe1d tıjd die het transcriberen vergde, lijkt ook het gennge aantal overgeleverde notıties van Van Randenraedt zelf die dateren van vóór januan I640 RAL, Archtef Bisschoppen Roermond, inv nr. 135, [gewetensrekenung, 1634], GAR, Handschrnften I A I, gedateerd januan 1638, maar blijkens de marginalia pas in 1640 geschreven; GAR, Handschnften I A 5, waann enge notitues utt 1639 
Kon Joanna, die vermoedelijk hooguit enig huisonderricht had genoten, meer lezen van een moeilijk leesbaar handschrift dan een geschoolde jezuiet? ${ }^{\text {?37 }}$ Hoe kweet zij zich van deze taak? Mogelijk leerde Van Heilsbach haar haar handschrift lezen. Wellicht vroeg zij haar geestelijke moeder veelvuldig om toelichting en dicteerde die op haar beurt weer een deel van haar geschriften. Of ging Joanna eenvoudigweg aan de slag en corrigeerde Agnes vervolgens het afschrift? De gedeelten van de transcriptie die overgeleverd zijn, sluiten laatstgenoemde mogelijkheid uit, want hierin zijn nauwelijks wijzigingen of correcties aangebracht. Maar wellicht waren op- en aanmerkingen al in eerdere versies gemaakt, die vernietigd werden zodra de definitieve versie er was. Over dit alles zijn we niet geïnformeerd. Vergelijking tussen autograaf en afschrift wijst uit dat Van Randenraedt zich nauwkeurig aan de oorspronkelijke tekst heeft gehouden. Sterke overeenkomsten in de opbouw, verhaallijn en beeldspraak van haar eigen gewetensrekeningen met die van haar geestelijke moeder Van Heilsbach verraden de invloed van haar transcriptietaak op haar eigen wording als schrijfster van gewetensrekeningen. ${ }^{1{ }^{8}}$ Dat lijkt ook onontkoombaar, want terwijl zij zelf nog maar net begonnen was met het vastleggen van haar eigen gemoedsaandoeningen, ${ }^{139}$ moest ze zich met de transcriptie van gelijksoortige geschriften bezighouden. ${ }^{14}{ }^{\circ}$ Over het effect van het transcriberen en lezen van Van Heilsbachs geschriften worden we indirect ingelicht door de kritiek die Van Randenraedts biechtvaders op haar uitoefenden. Eind april I640 - drie maanden na de dood van haar geestelijke moeder - beschuldigde Simon van den Hove haar ervan Agnes te imiteren. ${ }^{141}$ Een vergelı,kbare beschuldiging werd door Livinus de Clerck in augustus 1645 geuit. ${ }^{142}$ In haar gewerensrekeningen wees Van Randenraedt dergelijke kritiek kalm van de hand.

Misschien zijn gedeelten van Van Heilsbachs eigenhandig geschreven gewetensrekeningen wel bewaard gebleven omdat zij, evenals de transcriptie, zijn aangezien als geschriften van Joanna van Randenraedt. ${ }^{143}$ Van gewetensrekeningen die zij op last van leidsmannen vóór 1637 geschreven zou hebben, ${ }^{\mathrm{T} 44}$ is tot dusver niets

137 Over Joanna's opleiding is slechts bekend dat zij op veertienjange leeftud enige tjd bij familie in Walloniē doorbracht om daar Frans en de omgangsvormen voor meisjes van haar stand te leren. KB Brussel, Handschrften 19073 (I), 33. Over het niveau van husonderncht in het algemeen is weinig bekend. Voor meisjes behelsde dit waarschujnlık lezen, schnjven, Frans, godsdienst, nuttige en fraaie handwerken. De Booy, Kweekhoven der wyshend, I40-142 Voor het hulsonderwils in de Zuidelıke Nederlanden, zie Put, De cleyne schoolen, I15-I16.

$13^{8}$ Van Randenraedt herlas de geschnften van Van Heilsbach zelf ook. Zie bijvoorbeeld GAR, Handschriften II B n (ongedateerd, ongepagineerd).

139 De oudste overgeleverde gewetensrekening dateert uit 1634 RAL, Archref Busschoppen Roermond, inv nr 135 [gewetensrekening I634].

140 De oudste gewetensrekening van Van Heilsbach, die overgeleverd is, dateert uit 1637.

I4I Zie GAR, Handschnften I A 5 (ongepagineerd, apnl I640)

$142 \mathrm{~KB}$ Brussel, Handschnften 19070, 247.

143 Zie noot 134 van dit hoofdstuk.

144 C.ss.R. Roermond, Speciaal Archief A pl. 7, GG II (ongepagineerd). 
teruggevonden. Wel zijn afschriften van twee fragmenten gevonden van Van Heilsbachs spirituele autobiografie, waarvan het origineel vermoedelijk verloren is gegaan. ${ }^{145}$ Joanna werkte hieraan samen met Lucia de Werimont. ${ }^{146}$ Deze transcriptie vond gretig aftrek onder geestelijke dochters te Antwerpen en droeg bij aan Van Randenraedts eigen reputatie als vrome maagd in die groep, zoals zij zelf beschaamd constateerde. ${ }^{147}$ Vermoedelijk kon Huysmans over dit afschrift beschikken toen hij Leven ende deughden schreef; wederom een boek gebaseerd op ingrediënten die door de hoofdpersoon zelf werden geleverd.

\section{Kronieken van 'inwendige gesteldheid'}

Al wat hun gemoedsgesteldheid betrof, moesten beide vrouwen op uitdrukkelijk verzoek van hun biechtvader in hun gewetensrekeningen noteren. ${ }^{14^{8}}$ Kennelijk deed hij zijn voordeel met deze notities bij hun spirituele begeleiding. Althans, dat was de functie van haar gewetensrekeningen waarop Joanna zelf alludeerde in 1643 , toen ze schreef dat ze vlijtig haar geestelijke wel en wee had genoteerd, opdat

'u eerw. mijn inwendicheijt eens claer weeder sien sau, om mij wat meer voort te drijven ende in mij quaet te straffen om mij lief naerder te coemen'. ${ }^{149}$

Door middel van haar gewetensrekeningen zou haar biechtvader haar kunnen helpen om zoveel mogelijk gelijk te worden aan Christus, haar hemelse Bruidegom. Gebed, meditatie, kerkgang en communie domineren haar gewetensrekeningen. Daarin verweven nemen auditieve ingevingen (inspraken, samenspraken, influisteringen) en visuele ingevingen (dromen, visioenen) een belangrijke plaats in. Van Van Randenraedt zijn eigenlijk twee typen gewetensrekeningen overgeleverd. In sommige doet zij verslag van haar gebeden, alsook van de thema's en wijze van haar religieuze meditatie. In andere beschrijft zij vooral haar dromen. In Van Heilsbachs gewetensrekeningen zijn de beschrijvingen van haar religieuze praktijk inhoudelijk ondergeschikt aan haar verslagen van dromen en ingevingen, die verwijzen naar incidenten die al hadden plaatsgevonden dan wel zich na de droom voltrokken. Gevraagd of ongevraagd maakten beide vrouwen hun biechtvader ook deelgenoot van meer alledaagse beslommeringen. Vooral Joanna beperkte zich niet tot het optekenen van de buitengewone voorvallen, vermoedelijk omdat die voor haar juist betekenis kregen in de context van meer triviale gebeurtenissen of strubbelingen met familie, biechtvaders of geestverwanten.

145 Ibidem. Vgl. Leven ende deughden, 96, waar staat dat Van Heilsbach op last van haar biechtvader aan een dergelijke levensbeschrijving sinds haar vroegste jeugd was begonnen.

146 KB Brussel, Handschriften 19070, 369vo (augustus 1646).

147 GAR, Handschriften I A 11, gewetensrekening maart 1648 (kopie Lucia de Werimont).

148 Als zodanig is de functie van deze bronnen enigszins te vergelijken met die van het dagboek in protestantse, piëtistische kring. Dat diende vooral als hulpmiddel bij spiritueel zelfonderzoek. Van Lieburg, Levens van vromen, I58. Vgl. Mendelson, 'Stuart women's diaries', I85-I86.

149 KB Brussel, Handschrifien I9070, I38vo (december I643). 
Beide vrouwen waren gewoon maandelijks verslag te doen, ook al hielden zij zich niet altijd hieraan. Dankzij deze bronnen beschikken we over informatie voor een vrijwel aangesloten periode van een decennium, van ca. I637 tot I648. De voor deze studie gebruikte afschriften van de gewetensrekeningen van Agnes van Heilsbach beslaan - met lacunes - de jaren 1637, I638 en I639. Haar laatst overgeleverde notitie dateert van 24 augustus 1639 . Voor het gebruik van de afschriften, en niet van de autograaf, is behalve omwille van de leesbaarheid om de volgende reden gekozen. In deze studie staat niet alleen de inhoud van deze spirituele egodocumenten centraal, maar ook hun functie in verhouding tot de biechtvader of andere geestelijke maagden. Van Heilsbachs eigenhandige geschriften speelden in dat opzicht tijdens haar leven nauwelijks een rol, want haar biechtvader zei deze niet te kunnen lezen. ${ }^{5 \circ}$ Wie Van Heilsbachs geschriften te lezen kreeg, kreeg naar alle waarschijnlijkheid de getranscribeerde versie in handen. ${ }^{15 t}$

De bewaard gebleven gewetensrekeningen van Van Randenraedt bestrijken vooral de jaren 1640, I643, I645. Uit I634, I638, I639, I64I, I647, I648, I649 en 1668 zijn verslagen van één of meer maanden overgeleverd. Haar laatst overgeleverde gewetensrekening dateert van augustus $1683,{ }^{152}$ een bewijs dat Joanna tot op hoge leeftijd schreef. Toch lijkt er na ongeveer 1648 een stilte te vallen in haar gewetensrekeningen, die moeilijk verklaarbaar is. Opmerkelijk is dat de laatste versie van haar autobiografie weinig gegevens bevat over de periode na 1648 . Het tweede gedeelte hiervan, dat hoofdzakelijk de perikelen rond haar communiepraktijk beschrijft, behandelt nog enkele episodes uit 1649 en wordt besloten met zeer summiere opmerkingen over de jaren 1650 - onder verwijzing naar haar gewetensrekeningen - en $1652 .{ }^{153} \mathrm{~W}$ ellicht kon zij bij het schrijven van deze versie van haar autobiografie niet meer over al haar gewetensrekeningen beschikken, omdat een deel ervan verloren was gegaan bij de grote stadsbrand in 1665 . Ongeveer 800 van de 1200 huizen in de stad gingen verloren, naast vele kloosters, waaronder het college der jezuïeten. ${ }^{154}$ Ook Joanna's huis viel, zoals gezegd, ten prooi aan de vlammen. Huysmans schrift het in elk geval aan deze brand toe dat Van Randenraedt in de periode tussen 1665 en I 669 weinig 'rekeninghe der conscientie by geschrift' gegeven heeft. ${ }^{155} \mathrm{Zi}$ ) verbleef geruime tijd buiten de stad en moest het ook zonder een jezujet als biechtvader stellen, aangezien de meeste paters uit Roermond bij gebrek aan behuizing naar elders vertrokken waren. Een

150 Wél is de autograaf (KB Brussel, Handschrften 20422) op verschillende plaatsen gecensureerd. Of dit door Van den Hove, door Van Randenraedt op zujn aanwijzing na lezing van haar transcripue, of door een latere lezer(es) is gebeurd, kan niet worden vastgesteld.

151 Uizonderingen in dit opzicht waren vermoedelyjk de jezuieten Franciscus l'Hermite en Jacob

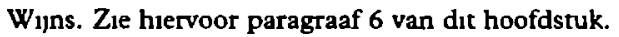

152 C.ss R. Roermond, Spectaal Archief A pl. 7, HH 8.

153 KB Brussel, Handschnften 19073 (II), 849-904

154 Venner, 'De stadsbranden', 129.

155 Kort Begryp, 106. 
andere mogelijke verklaring voor het ontbreken van vrijwel alle gewetensrekeningen na 1648 is dat haar toenmalige biechtvaders minder nadrukkelijk vroegen om gewetensrekeningen dan hun voorgangers. Wellicht wilden zij Joanna gezien de veranderde huiselijke omstandigheden en haar zorg voor het jonge gezin van haar broer niet ook nog met gewetensrekeningen belasten. Maar misschien stelden zij er geen prijs meer op om haar zieleroerselen te lezen of waren zij er inmiddels van overtuigd dat zij werkelijk een bijzondere band met God had.

Frappant is dat de overgeleverde correspondentie van Joanna van Randenraedt vooral van nà 1648 dateert. Veel van de tot dusver gevonden brieven zijn gericht aan haar geestelijke 'zusters' Catharina van den Broeck en Lucia de Werimont. Die namen in Roermond de honneurs waar en onderhielden contact met haar biechtvader en andere geestelijke dochters. Tot vlak voor haar dood correspondeerde Joanna ook met de Bossche klop Catharina van Gestel, zo blijkt uit de afschriften van twee brieven uit mei $1684 .{ }^{156}$ Aangezien Joanna's brieven niet voor de ogen van haar biechtvader bedoeld waren, worden deze minder gekenmerkt door allerlei conventies die golden voor gewetensrekeningen. Van Randenraedt presenteert zich in haar brieven aan haar vertrouwelingen zelfbewuster dan in haar gewetensrekeningen. Brieven aan Catharina van den Broeck tekende zij bijvoorbeeld met 'uw g. [eestelijke] moeder'. ${ }^{157}$

De gewetensrekeningen fungeerden niet als dagboek. Soms lagen er grote tijdspannes tussen de periode die Van Randenraedt beschreef en het moment waarop ze erover schreef. ${ }^{158}$ Niet altijd had dat te maken met tijdgebrek of vergeetachtigheid. Nu en dan was er ook sprake van een regelrechte weerstand tegen het schrijven, die verderop in dit hoofdstuk nog ter sprake zal komen. Twijfel over de betrouwbaarheid van de beschrijving en dateringen van sommige gebeurtenissen lijkt gerechtvaardigd, aangezien Van Randenraedt incidenteel met terugwerkende kracht, steunend op haar geheugen, schreef. Dat verschillende voorvallen vanuit de eigen herinnering op papier werden gezet, vergroot het geconstrueerde karakter van haar gewetensrekeningen. Dergelijke flash-backs zijn ook aanwijsbaar in Van Heilsbachs notities. ${ }^{159}$ Die liet nu en dan de thematische samenhang tussen gebeurtenissen prevaleren boven de chronologische volgorde - een indicatie dat zij niet zelden uit haar herinnering putte voor haar gewetensrekeningen. ${ }^{160}$

De handschriften van beide vrouwen bieden letterlijk een eenzijdig beeld, want

156 C.ss.R, Speciaal Archref A pl. 7, HH 6. Wie deze afschnften maakte, is nuet bekend. Ook de onginelen konden niet getraceerd worden.

157 GAR, Handschnfien II B g

158 B1j wijze van voorbeeld. KB Brussel, Handschnften 19070, 26: het verslag gaat over de maand met in het jaar I643. Ze tekent aan dat ze door omstandigheden pas eind juni deze gewetensrekening kon opmaken.

159 Bıvoorbeeld KB Brussel, Handschriften 18984, 251v0-256 (januan [1638]).

160 Ibidem, 37vo-39vo, I9 of 20 jun 1637, gevolgd door 39vo-4I, 26 junl, gevolgd door 4Ivo-43, 30 juni 1637 . 
sporen van hun beoogde eerste lezer, de biechtvader, in hun aantekeningen zijn schaars. Toch kan uit de notities van Van Heilsbach opgemaakt te worden dat haar biechtvader geschriften van geestelijke dochters van aantekeningen voorzag of via deze met hen communiceerde. Soms stopte hij losse briefjes in hun schriftjes met gewetensrekeningen. ${ }^{161}$ Onmiskenbaar zijn de gewetensrekeningen gecensureerd; in sommige passages zijn namen of handelingen opzettelijk onleesbaar gemaakt. Of dit zonder meer aan biechtvaders toegeschreven moet worden, is echter de vraag. In maart 1645 noteert Joanna met spijt dat zij de naam van een andere geestelijke dochter, Anna van Kerckhoven, niet heeft doorgestreept in haar gewetensrekening. ${ }^{162} \mathrm{Zij}$ was boos op Van Kerckhoven, omdat die zich negatief had uitgelaten over Agnes van Heilsbach. Ooit was Van Kerkchoven één van Van Heilsbachs geestelijke dochters geweest, maar zij had haar 'moeder' begin jaren dertig verlaten. Sindsdien was de verhouding tussen haar en andere jezuïetenkloppen, onder wie Van Randenraedt, gespannen. Deze voorgeschiedenis verklaart Joanna's boosheid in maart 1645 , die zij in haar gewetensrekening ventileerde. Toen haar biechtvader met een andere geestelijke maagd over dit incident sprak, dreigde er een werkelijk conflict te ontstaan tussen Van Randenraedt en Van Kerckhoven. Kennelijk was het biechtgeheim niet van toepassing op de gewetensrekeningen. Om enige mate van discretie te verzekeren, zichzelf en anderen te vrijwaren van problemen of achterklap, heeft Van Randenraedt misschien zelf namen in haar geschriften onleesbaar gemaakt. Natuurlijk schreven en streepten ook anderen in haar notities. Want wie is er bijvoorbeeld verantwoordelijk voor de aanvulling van haar gewetensrekening utt maart 1640 ? Hierin verhaalt zij over een verwant van haar schoonzuster Margaretha van Kessenich, die 'geus' was. In een andere hand staat aangetekend: 'hij is eeniege iaeren hier naer bekeert'. ${ }^{163}$ Nog in de twintigste eeuw kwamen geestelijken in de verleiding Van Randenraedts geschriften te kuisen naar toenmalige maatstaven. ${ }^{164}$ In de wetenschap dat de

I6I Zie bijvoorbeeld GAR, Handschnfien I A 5 (ongepagneerd; 7 maart I640)

$162 \mathrm{~KB}$ Brussel, Handschnften 19070, 159 (maart 1645)

I63 GAR, Handschnften I A 5 (ongepagineerd, 3 maart [1640]).

164 RAI, Archref Busschoppen Roermond, inv nr. 135 [bnef van H. van Krugten C.ss.R., zonder datum; adressaat onbekend] ' Wat nu verder de uitdrukkking aangaat in hare meditatie over het lijden van J.C., ofschoon deze ten goede uitgelegd kan worden door de betekenis van "consideratam mente et in abstracto confusionem et dolorem ejus", ware het misschien beter die woorden uit te schrappen, daar zij niet voor publicitert bestemd waren, maar als gewetensrekenıng aan een zielbestierder beschouwd kunnen worden.' Welke gewetensrekenıng of passage precies bedoeld is, blukt niet wt de tekst. Vermoedelı)k gaat het om een zinsnede in notities van Van Randenraedt uit 1634 (Archref Busschoppen Roemond, inv.nr. 135). Hienn beschnjft zlj hoe zij tudens haar meditatie op de geseling van Chnstus ıeder lichaamsdeel overweegt, ook 'de beschaemelıckste partie sııns $H$. lichgaems'. Ovengens is deze passage niet onleesbaar gemaakt Vgl KB Brussel Handschrfien I9070, 127 vo en ıbidem, 19073 (II), 302. Hier wordt eenzelfde meditane beschreven, waann Van Randenraedt wat langer sulstaat bij de pijnen die Jezus Chnstus doorstond aan de 'litmaeten die niet en genoumpt worden, daer (. . ) in alle die siellen die deur onsuivere wellusten des vlees haer beestelıjcke natuer sın in volgende (. )'. 
geschnften beider vrouwen tujdens en na hun leven vele malen van lezer(es) hebben gewisseld, is het een onmogelı)ke opgave na te gaan wie welke ingreep in de tekst heeft gepleegd.

\section{IV.3 Zelfportretten volgens bestaande patronen?}

Dat Joanna van Randenraedt en Agnes van Heslsbach hun geweten ontleedden, is geenszins bijzonder. In kloppenboeken worden geestelıke maagden aangespoord om tenminste eenmaal per dag een gewetensonderzoek te doen. Blykens haar overgeleverde dagorde onderzocht Joanna haar geweten tweemaal daags. ${ }^{165} \mathrm{~B}_{1 \text { - }}$ zonder is dat zly, net als haar geestelıjke moeder, zo uitgebreıd schnftelı)k verslag daarvan deed aan de biechtvader. Bekend is dat nonnen in Spaanse kloosters 'cuentas de consciencia' in opdracht van hun biechtvader schreven. ${ }^{166}$ Van een dergelık gebruik onder geestelıjke maagden is tot dusver niets gebleken. Van Randenraedt en Van Heilsbach waren echter niet de enigen die hun spintuele wel en wee op papier aan hun biechtvader voorlegden. Uit hun aantekeningen blijkt dat ook andere vrouwen dit deden. Joanna droeg haar vnendin Lucia de Wenmont in I645 zelfs op om 'schnftelıcke reekeninge' te doen aan haar biechtvader, vooropgesteld dat die hiermee akkoord ging. ${ }^{167}$ Lucia toonde volgens Joanna weinig bezielıng in haar geloof en was zelfs ongehoorzaam. Aan de hand van de verslagen van haar geestesgestelheid zou haar biechtvader haar kunnen helpen bij de toenadenng die zij tot God zocht. Joanna zelf werd in februan 1640 gevraagd door de klop Liesbeth van Tits of zij notitues wilde maken in haar 'schriften'. ${ }^{168}$ Hieruit valt op te maken dat niet alleen geestelıke vaders, maar ook geestelıke moeders de gewetensrekeningen van hun 'dochters' lazen. ${ }^{169}$

Biecht en systematisch gewetensonderzoek zijn van oudsher vormen van zelfreflectue die bıjdragen tot de vorming van een eigen ' $1 \mathrm{k}$ ', tot identiteitsontwikkelıng. Het methodisch zelfonderzoek gencht op God en de eigen geestelıke gesteldheld, dat reeds door de Moderne Devoten werd aangehangen, beoogde geestelı)ke, morele en affectieve vorming door zelfreflectie. ${ }^{170}$ Zelfbeschouwing met behulp van de generale biecht werd in de zeventiende eeuw onder anderen door Franciscus van Sales gepropageerd en gedetalleerd beschreven. Dergelıke 'auto-analyses'

165 GAR, Handschnfien II B k

I66 Herpoel, "'Nosce te ipsum"' Misch, Geschichte der Autobıgraphie, IV,2, 746, spreekt over 'Selbstbekenntnissen' die in Franse vrouwenkloosters doorgaans in opdracht van een geestelijke werden geschreven

167 KB Brussel, Handschnfien 19070, 252 (augustus 1645)

168 GAR, Handschnfien I A s (ongepagineerd, 24 februan I640)

I69 Vgl KB Brussel, Handschnften 18984, 49vo (7 december 1638)

170 Weıler, 'Over de geestelıjke praktık' Idem, 'De betekenıs van de Moderne Devotıe', 41-46 
waren soms de grondslag voor spirituele autobiografische geschriften. ${ }^{171}$ Bevindingen van het dagelijkse persoonlijke gewetensonderzoek werden daarentegen vermoedelijk zelden schriftelijk vastgelegd. In de gedrukte ascetische literatuur uit de zeventiende eeuw ontbreekt doorgaans de expliciete aanbeveling aan gelovigen om hun gewetensonderzoek op schrift aan hun biechtvader voor te leggen. ${ }^{12}$ Een uitzondering is het kloppenboek Spieghel van Philotea van de jezuiet Gerardi. Die spreekt over gewetensrekeningen, zonder echter instructies voor inhoud en opmaak hiervan te geven. ${ }^{173}$ Waaraan Joanna van Randenraedt en Agnes van Hellsbach of hun geestelijk leidsman het raster voor gewetensrekeningen ontleenden, is een kwestie die van belang is voor een goed begrip van hun zelfpresentatie. ${ }^{174} \mathrm{Om}$ dit na te gaan worden in het onderstaande eerst doelstelling en methode van het persoonlijk gewetensonderzoek op beperkte schaal verkend. Vervolgens worden die werken die aantoonbaar een rol hebben gespeeld in het religieuze ontwikelingsproces van beide maagden, onder de loep genomen. Gezien de uitermate schaarse informatie over de lectuur van beide vrouwen en over de bijdragen die hun biechtvader en anderen, onder wie mogelijk vrouwelijke religieuzen, aan hun spirituele vorming hebben geleverd, wordt deze beknopte analyse met het nodige voorbehoud gepresenteerd.

\section{Gewetensonderzoek in theorie}

Het gewetensonderzoek werd gezien als een middel bij uitstek om als gelovige met God te spreken. Dit gold vooral in kringen geonënteerd op de ignatiaanse spiritualitelt. Ignatius van Loyola, de stichter van de jezuïetenorde, begon zijn Exercitia sprrituales (1540) met het gewetensonderzoek, dat naar zijn mening tweemaal daags behoorde plaats te vinden. ${ }^{175}$ 's Ochtends moest een gelovige zich voornemen om een specifieke zonde gedurende die dag te bestrijden. 's Middags en 's avonds werd onderzocht welke fouten men intussen begaan had. Tegenover God moest

171 Misch, Geschichte der Autobrographie, IV,2, 743-744.

$172 \mathrm{Vgl}$ een voorbeeld uit de vierde eeuw van een aansponng om schnftelıjk verslag te doen van het gewetensonderzoek Athanasius raadt in zijn inta van de heilige Antonius eenieder aan de uitkomst van het persoonlyjke gewetensonderzoek op schnft te zetten, alsof men het aan anderen zou willen laten zien. Guy, 'Examen de conscience', 1805 . Volgens Huizinga, Herfstty, 263, had de veertiendeeeuwse heilige Peter van Luxemburg, wiens neiging tot biechten dwangmatig was, de gewoonte een lust te maken van door hem begane zonden Het gebruk om dagelyks eigen zonden op te tekenen is, zo stelt Huzinga, een zeer oude en geheiligde traditie, reeds beschreven door Climacus (600), Scala Paradusı (Parijs Radenus 1633) 65.

173 Gerard, Spteghel van Phalotea, 30

$174 \mathrm{Vgl} \mathrm{Graham} \mathrm{e} \mathrm{a.} \mathrm{Her} \mathrm{own} \mathrm{lffe,} \mathrm{4,} \mathrm{die} \mathrm{ten} \mathrm{aanzien} \mathrm{van} \mathrm{persoonlijke} \mathrm{bekenngsgeschiedenissen} \mathrm{op-}$ merken dat conventies van de 'conversion narrative' de auteur een kader bieden waarbinnen handelingen of gevoelens benoemd en geclassificeerd kunnen worden Ditzelfde geldt zeker ook voor gewetensrekeningen.

175 Geestelyke oefeningen, nr 21, nrs. 24-26. Zie ook Noye, 'Examen de conscience', I823 
men hierover berouw betuigen en om vergeving en kracht vragen, om niet wederom in die fouten te vervallen. Volgens de ignatiaanse methode, die ook buiten eigen kring veel navolging vond, werd dit gewetensonderzoek in vijf stappen verricht. Nadat men God gedankt had voor alle ontvangen weldaden, vroeg men Hem gratie om de eigen zonden te kennen en uit te roeien. Die zonden werden daarna geïnventariseerd door ieder uur van de dag in gedachten te doorlopen en na te gaan welke fouten gemaakt waren in gedragingen, woorden of gedachten. De volgende stap was om God voor alle begane zonden om vergeving te vragen. Tenslotte nam men zich voor de eigen fouten te verbeteren met behulp van Gods genade. Tijdens het laatste gewetensonderzoek voor het slapen gaan moest de gelovige nagaan of er al verbetering was opgetreden in de maat of emst van de zonden waaraan hij of zij zich eerder op de dag schuldig had verklaard. Het stramien van onderzoek, zelfbeschuldiging, God vragen om genade en Hem om hulp verzoeken, moest besloten worden met een samenspraak met God.

Een dergelijke zuivering van de eigen ziel of het geweten was een voorwaarde voor de toenadering die de gelovige tot God zocht. Deze vorm van introspectie bevorderde de ootmoed, het besef van de nietigheid van de mens ten opzichte van de almachtige God. Zelfkennis leidde tot kennis over God, maar inzicht in de eigen zondigheid zou er hopelijk ook toe bijdragen dat de gelovige voortaan minder zonden zou begaan. Daarom was het gewetensonderzoek een onontbeerlijke stap voorafgaande aan de biecht. In kloppenboeken wordt het dagelijkse gewetensonderzoek, dat geestelijke maagden in alle beslotenheid moesten doen, vooral besproken in verband met de biecht. Voor de geoefende maagd die eens per week ging biechten, was een gewetensonderzoek van een kwartier tweemaal daags voldoende, aldus de jezuïet Valentinus Bisschop in zijn kloppenboek Lof der Suyverheydt. ${ }^{176} \mathrm{Hij}$ geeft een opsomming van mogelijke zonden, die als leidraad bij het gewetensonderzoek ter voorbereiding op de biecht kon dienen. Deze lijst biedt enig inzicht in wat een geestelijke vader van zijn geestelijke dochter wilde weten en waarop zij zich zelf dagelijks persoonlijk diende te onderzoeken. Dergelijke zondencatalogi maken ook deel uit van zogenaamde biechtboeken, aan de hand waarvan gelovigen hun 'geestelijke boekhouding' konden bijhouden. ${ }^{177}$

De eerste serie vragen in Bisschops zondenlijst zijn gericht op de religieuze plichten: hoe heeft de maagd zich gedragen tijdens de dienst in de kerk, tijdens de voorgaande biecht, bij het ontvangen van de communie, bij het mishoren, bij het lezen der getijden, het bidden van het rozenhoedje, tijdens het ochtend- en avondgebed? Is er een zekere slapte of juist hoogmoed geslopen in het aanhoren van de preek, in het lezen van een geestelijk boek, in de verering van de heiligen, in het denken aan God? De tweede groep vragen is geconcentreerd rond dagelijkse beslommeringen. Heeft zij tijd verkwist, teveel gepraat, haar ogen teveel de kost 
gegeven, is zij ijdel, trots of lichtvaardig geweest, heeft ze gelogen of bedrogen, heeft zij zich aan iets of iemand geërgerd, was haar kleding niet té werelds, heeft ze té gulzig of teveel gegeten en gedronken, heeft ze haar religieuze oefeningen wel in de juiste dispositie verricht? Haar gedrag jegens haar naaste staat centraal in de laatste reeks vragen: heeft zij deze niet getergd, verbitterd, ontsticht, heeft zij anderen wellicht een verkeerd voorbeeld gegeven, of heeft zij andermans deugdzaamheid benijd of zelfs belasterd en vooral, heeft zij alle onvolmaaktheden van haar naasten zonder mokken verdragen?

\section{Gewetensonderzoek in praktijk}

Van de grondslagen van het zelfonderzoek zoals aanbevolen door Ignatius, of van de meer praktische aanbevelingen van Bisschop, zijn in Van Heilsbachs en Van Randenraedts gewetensrekeningen slechts vage sporen aanwijsbaar. Natuurlijk fixeren beide vrouwen zich in hun beschrijvingen op eigen zondigheid, een tendens die mogelijk door toedoen van hun biechtvaders werd versterkt. Simon van den Hove, die zowel Agnes als Joanna jarenlang begeleidde, prentte Agnes bijvoorbeeld in: 'ghy zijt areger dan den duvel sellever', hetgeen zij zelf, zo schrijft zij, ook ondervond. ${ }^{17} \mathrm{Zij}$ was bijzonder vatbaar voor de 'pastoraal van de angst', waarmee deze biechtvader op haar geweten werkte. ${ }^{179}$ Nooit eerder, noteert Van Heilsbach, is zij 'op sulcken voet geleidt, deur den wech van vrees'. En omdat 'die vrees mij van selfs genoch te vooren is coemende', heeft zij moeite genoeg om die te overwinnen. ${ }^{\text {Bo }}$

Beide vrouwen rapporteren over de vervulling van hun religieuze plichten, alsook over hun gedrag in het algemeen. Van Heilsbach besteedt eigenlijk geen aandacht aan de praktijk van het gewetensonderzoek als zodanig. Toch vormde dit een vast bestanddeel van haar geestelijk leven, als we de aantekeningen van Van Randenraedt mogen geloven. Joanna beschrijft hoe zij in januari 1638 met enkele andere geestelijke dochters te gast was bij Van Heilsbach en haar huisgenote Botters. De vrouwen werkten aan een sluier voor een Onze Lieve Vrouw-beeld. Zij onderbraken hun werk voor de middagmaaltijd. Daaraan voorafgaand deden zij tezamen geknield hun 'examen' ${ }^{18 I}$ In Joanna's eigen notities zijn opmerkingen over het gewetensonderzoek schaars. Wel beveelt zij het 'particulier examen' warm aan in een ongedateerde losse notitie, die gericht lijkt te zijn aan een andere geestelijke dochter. Kennelijk overwoog de geadresseerde om een nieuwe biechtvader te zoeken. Van Randenraedt adviseert dit niet te doen, maar de vermaningen van

$178 \mathrm{~KB}$ Brussel, Handschnften I8984, il (28 apnl 1637).

179 Delumeau, La peur en Occrdent, introduceert de omschrijung 'pastoraal van de angst' voor de wize waarop geestelijken en kerkelıje overheden in de contrareformatonsche kerk bewust een schuldbesef probeerden aan te kweken bij gelovigen, bij wijze van morele vorming.

I80 KB Brussel, Handschnften 18984, 4Ivo (30 junı 1637).

181 GAR, Handschrfien I A I (ongepagineerd; januan I638 [opgetekend in 1640]). 
haar huidige leidsman te gehoorzamen en zichzelf daarop te onderzoeken:

'Ende tekent het elcke keer aen, als U.L. failliert, ende let wel op alle klein puncttiens als van Godt deur sıjn eerw tot u gesprocken, wordt u geen oeuffeninge gegeven, neemt dat alsdan veur een oeuffenunge, ende tracht uwe gewoonlijcke dingen soe veel te volmackter te doun' ${ }^{182}$

Wat beide vrouwen wisten van doel en functie van het gewetensonderzoek, hadden zij mogelijk opgestoken via instructies tijdens retraites. Volgens Huysmans besteedde Agnes rond 1623-1624 'eenighe daeghen inde gheestelijcke Exercitien van den H. Ignatius' ter voorbereiding op haar geestelijk dochterschap te Roermond. ${ }^{{ }^{183}}$ Joanna wijdde zich acht dagen per jaar aan Ignatius' oefeningen, ${ }^{1{ }^{84}}$ bij wijze van herbezinning op haar geestelijk leven. Mogelijk putten zij ook informate voor de praktijk van het gewetensonderzoek uit stichtelijke werken. Bisschops kloppenboek ontbreekt op de lijst van boeken die vermoedelijk aan Joanna van Randenraedt hebben toebehoord.$^{185}$ Hierop staan echter andere geestelijke handleidingen en devotieboeken waarin het gewetensonderzoek uiteengezet wordt, zoals bijvoorbeeld het onmiskenbaar ignatiaans geïnspireerde devotieboek Den Wech des eeuzvich levens (I623) van Antonius Suquet S.J. ${ }^{186}$ Aan diens uiteenzetting over het gewetensonderzoek ligt de fundamentele oppositie tussen Gods almacht en oneindige barmhartigheid en de slechtheid en nietigheid van de mens ten grondslag, die ook duidelijk herkenbaar is in Joanna's en Agnes' geschriften. Al wordt gelovigen nergens expliciet opgedragen schriftelijk rekenschap af te leggen van hun zelfonderzoek, er is niettemin een belangrijke rol weggelegd voor de biechtvader in de strijd tegen de ondeugd en het voortdurend streven naar een groes in deugdzaamheid die integraal deel uitmaken van het gewetensonderzoek. ${ }^{187}$ In het onderzoek zijn de vijf stadia herkenbaar die Ignatius in zijn Exerctia aanbeveelt. ${ }^{188}$ Als leidraad voor het zelfonderzoek dienen de tien geboden en de regels die gelden voor de levensstaat die een gelovige heeft gekozen. Geestelijke dochters waren op grond van hun staat verplicht hun geestelijke en lichamelijke zuiverheid te waarborgen.

In haar jeugd had Joanna Het gulden wreroock-vat van Philippus Rovenius gelezen. ${ }^{189}$ Voor de samenstelling van dit boek was Rovenius schatplichtig aan verscheidene jezuïeten, onder wie toonaangevende godgeleerden als Leonardus Lessius, Alphonsus Rodriguez, Luis de la Puente, Franciscus Arias en Jacobus Alvarez

I82 GAR, Handschnften II B n, geestelıke ondernchtıng aan een onbekende adressaat (ongedateerd, ongepagineerd).

183 Leven ende deughden, 81.

184 Kort Begryp, 271.

$185 Z_{1}$ 139-142 van dit boek.

186 Verschueren, 'De boeken', 202 (nr 35), vermoedt dat dit boek bedoeld wordt op de list, waarop enkel de naam van de auteur, 'Pater Sucket', staat.

187 Sucquet, Den wech des eeuwrch levens, 66I, 667, 675-676

188 Ibidem, 658-66r.

189 Kort Begryp, I4; KB Brussel, Handschnften I9073 (I), 32, waar ze schryft dat z1) dit boek gekregen had van een oom van moeders $\angle 1$ de, die augustun was 
de Paz. ${ }^{190}$ Gods geboden vormden ook het raamwerk van het gewetensonderzoek zoals dat door Rovenius uiteen wordt gezet. Bij de korte opsomming van zondige gedragingen wordt, net als in Bisschops zondenlijst, de nadruk gelegd op het beheersen van de vijf menselijke zintuigen: ogen, oren, mond, reuk- en tastzin. Evenals Bisschop onderscheidt Rovenius twee vormen van gewetensonderzoek. Tijdens het zelfonderzoek voorafgaande aan de biecht moet een penintent(e) begane zonden inventariseren. In de biecht volgen dan schuldbekentenis, berouw en verzoek om vergiffenis aan God. In het dagelijkse gewetensonderzoek staan de voortdurende strijd tegen de zonden en het streven naar deugdzaamheid centraal. Dit zelfonderzoek is opgedeeld in drie stadia, die sterk herinneren aan de door Ignatius van Loyola beproefde methode. Belangrijker in dit verband is echter dat Rovenius pen en papier aanbeveelt als hulpmiddelen. Men kon 'het getal van die fauten aenteeckenen op een pampier ofte tafel-boecxken, makende op een linie soo menige streeck, als wy fauten den voormiddagh hier in hebben begaen'. ${ }^{191} \mathrm{Hij}$ spoorde gelovigen aan boek te houden van hun spirituele ontwikkeling. Breedvoerige uiteenzettingen, zoals Agnes van Heilsbach en Joanna van Randenraedt die gaven, lijkt Rovenius echter niet bedoeld te hebben.

Volgens haar dagindeling las Van Randenraedt regelmatig een punt (waarmee vermoedelijk een hoofdstuk wordt bedoeld) uit Thomas a Kempis' Navolging van Christus. ${ }^{192}$ In het zevende hoofdstuk van het vierde boek wordt het gewetensonderzoek besproken. ${ }^{293}$ Ook Thomas behandelt het gewetensonderzoek als voorbereiding op de biecht en de heilige communie, met als doel algeheel berouw over begane zonden. In een korte reeks van mogelijke zonden vormen wereldse verlangens en gedragingen het middelpunt, naast nalatigheid in de vervulling van religieuze plichten. Voor een wel heel bijzondere vorm van zelfonderzoek dat het gebruikelijke gewetensonderzoek ontsteeg, ging Joanna in december 1645 te rade bij het Kasteel der ziel van Teresa van Avila. ${ }^{194} \mathrm{Zij}$ vreesde dat $\mathrm{zij}$ door de duivel misleid was. Hierop onderzocht zij zich volgens Teresa's beproefde methode, zo schrijft zij in haar gewetensrekening. Van Randenraedt was in die situatie geïnteresseerd in aanknopingspunten om vast te kunnen stellen of God haar genaden bewees of dat de duivel haar poogde te begoochelen. Anders dan om geloofsplichten of alledaagse gedragingen gaat het in de beschrijving van Teresa's zelfonderzoek vooral om de beproevingen die een gelovige die bijzondere gunsten van God ontvangen heeft, te wachten staan: wantrouwen, kwaadsprekerij en vooral de beschuldiging van bedrog. ${ }^{195}$ Juist hieraan was Joanna in het najaar van 1645 ten

190 Visser, Rovenuus, 29-34, 95-I42.

IgI Rovenius, Gulden wreroock-vat, II 2. Zie ook Ir3-I14.

192 GAR, Handschnften II B k.

193 Thomas a Kemp1s, De navolging van Chrstus, 336-339.

194 Joanna was in bezit van dit boek. Verschueren, 'De boeken', 198 (nr. 17)

195 Gezien de doelstelling van dit gewetensonderzoek, heeft Van Randenraedt zich misschen wel verdiept in het eerste hoofdstuk van het zesde verbluf. In een recente Nederlandse vertaling van Castzllo 
prooi gevallen in een conflict, dat hieronder nog aan de orde komt.

Uit de gewetensrekeningen laat zich aflezen dat de ervaringen van Van Heilsbach en Van Randenraedt de standaardrichtlijnen van deze devotieboeken overstegen. Het raster voor zelfonderzoek dat deze boeken boden, schoot tekort. Over visioenen of inspraken wordt hierin niet of nauwelijks gerept, laat staan hoe hiervan op schrift verslag gedaan behoorde te worden. Voor de beschrijving van auditieve en visuele ingevingen waren beide vrouwen vermoedelijk vooral afhankelijk van hun biechtvader. Met de opdracht om te schrijven gaf deze geestelijke 'zijn' dochters, die het in beginsel betaamde om te zwijgen, een stem.

\section{IV.4 Tong en pen hoeden}

In kloppenboeken werden geestelijke maagden vermaand hun tong te 'bewaren'. Wie haar tong hoedde, gaf blijk van grote innerlijke wijsheid en volmaaktheid. Zo min mogelijk spreken, luidt het devies en de eindeloze herhaling hiervan illustreert zowel de priesterlijke preoccupatie met dit thema, als wellicht een zekere mate van onverschilligheid van de doelgroep ten aanzien van dit voorschrift. In De lelie der maeghdelijcker suyverheyt (1622) gaf de dominicaan Arnoldus Steur in eigen woorden weer wat de kerkvader Ambrosius reeds eeuwen eerder had gezegd: 'Ick hadde liever, dat den Maeghden woorden ghebreken, dan dat sy heur overschieten'. Daarop liet hij het bekende nieuw-testamentische zwijggebod volgen: 'Want ist dat die Vrouwen bevolen wordt, in die Kercke oft vergaederinghe te swijgen oock van Goddelijcken dingen' ${ }^{196}$ De tong was weliswaar 'een teer ledeken' maar het was 'sterck ende gheweldich int lasteren'. Een exegese van Genesis 3, dat de zondeval verhaalt, adstrueerde dit; Eva was immers degene, aldus Steur, die Gods gebod om geen vruchten van de boom te eten, met haar tong 'valschelijck' had veranderd. ${ }^{x 97}$ De tong niet hoeden wordt door Steur praktisch gelijk gesteld met het verlies van de fysieke maagdelijkheid, ${ }^{198}$ dat gold als het fundament van het bestaan van geestelijke dochters.

Geestelijke maagden moesten liever luisteren dan spreken. De rol van leidsman of predikant paste hun niet; evenmin mochten zij, zo is in het vorige hoofdstuk

intenor, Innerlyke burcht, 142, wordt de inhoud hervan verkort weergegeven: 'Hoe de beproevingen toenemen wanneer de Heer grote gunsten begint te schenken. Over de beproevingen, en hoe zil die dit verblıf hebben bereikt, ze doormaken Het is een goed hoofdstuk voor wie deze inwendige beproeungen ondergaan'.

196 Steur, De lelse der maeghdehycker suyverheyt, 195.

197 Ibidem, 215

198 Ibidem, 188; Steur somt hierbij een reeks gezaghebbende bronnen op het Oude en het Nieuwe Testament, Ambrosius, Basılius, Bernardus, Hieronymus, Johannes Chrysostomus, Cypnanus, en Augustunus, maar ook klassieke wereldlıke auteurs als Seneca en Cicero. Wiesner, Women and gender, 160 , stelt dat het spreken van vrouwen in het openbaar over het algemeen gezien werd als oneerbaar gedrag. 
toegelicht, anderen lichtvaardig adviezen geven. Dat zij wel werden aangespoord om hun didactische kwaliteiten aan te wenden om kinderen in de beginselen van het geloof te onderrichten of anderen - volgens specifieke spelregels - te bekeren, betekende geen schending van dit zwiiggebod. Doordat zij deze taken in opdracht van hun biechtvader uitvoerden, werd de tegenstrijdigheid tussen zwijggebod en taken in de dagelijkse praktijk namelijk opgeheven.

\section{Weerspannige schrijfsters}

Niet alleen geestelijke maagden, maar ook andere vrouwen werd de macht over het woord ontzegd. ${ }^{199}$ Vrouwen golden, net als kinderen, als onmondigen. Alleen al de handeling van het schrijven bracht voor Van Heilsbach en Van Randenraedt daarom het gevaar met zich mee in botsing te komen met de voor hen geldende gedragscode, die stilte voorschreef in woord en geschrift. ${ }^{200}$ Toch was het niet zo dat geestelijke maagden niet mochten schrijven. In het streven naar zelfheiliging, dat het leven van een klop behoorde te beheersen, kon schrijven zeker een functie vervullen. De augustijn Fulgentius Stevins beveelt geestelijke dochters bijvoorbeeld aan notities te maken van passages in stichtelijke werken die hun bijzonder aanspraken. Het terugvinden van de betreffende tekstgedeelten zou daardoor vergemakkelijkt worden. ${ }^{201}$ Overschrijven mocht dus, maar schrijven? Wat voor de tong van vroegmoderne vrouwen gold, gold zeker ook voor hun pen. Een dergelijke zienswijze klinkt door in Huysmans' representatie van Van Heilsbach en Van Randenraedt als auteurs. In alle toonaarden benadrukt hij de 'wederspannigheyt van haer oodtmoedigh ghemoet' waarmee Agnes haar dromen en visioenen aan haar biechtvader kenbaar maakte. ${ }^{202}$ Ook Joanna wordt afgeschilderd als een geestelijke dochter die 'de Bestierders van haere Conscientie ghehoorsaem [is] gheweest (..); niet-tegen-staende den tegen-strijdt die sy hierin hadde: begheerigh zijnde, de besondere jonsten [gunsten], die Godt mede-deelde aen haere siele, aen gheen menschen kenbaer te maecken' ${ }^{203}$ Hoe ambivalent zij tegenover haar eigen geschriften stond, blijkt volgens Huysmans uit het verbranden van 'verscheyde Boecken van haer hant geschreven'. Toen Joanna dankzij een ingeving van God wist dat ze zou gaan sterven, wierp ze deze handschriften in het vuur. ${ }^{204}$

Huysmans plaatst Joanna nadrukkelijk in een traditie van religieuze vrouwen die op last van mannen schreven. Liever dan van God zagen zeventiende-eeuwse

199 Zwijgzaamheid paste niet alleen religieuze vrouwen, maar zeker ook lekevrouwen. Zie bijvoorbeeld Sucquet, Den wech des eeuwich levens, 58-60. Ook in gedrukte preekboeken zijn dergelijke aanwijzingen te vinden: Rotsaert, Tussen Eva en Maria, o.a. 78-79 en 87-91.

$200 \mathrm{Vgl}$. Hobby, Virtue of necessity, I-25.

201 Stevins, Regel, 15.

202 Leven ende deughden, 9.

203 Kort Begryp, 3.

204 Ibidem, 269-270. 
geestelijken dat religieuze vrouwen hun opdracht kregen van Diens plaatsvervanger op aarde, hun biechtvader. 'Want ghelijck (...) meermaels de voorsichtighe Bestierders van uytmuntende sielen, naementlyck Maeghden, en Vrouw-persoonen, aen de selve sorgvuldelijck op-ghelydt hebben, seer beduydelijck aen-te teeckenen, ende schriftelijck over te gheven, dat dienstigh konde wesen tot klaerder kennisse en vaste bestieringhe van haeren gheest $(. . .)^{\prime}{ }^{205}$. Als biechtvader die zijn pentente opdroeg om te schrijven, wist hij zich in het gezelschap van de leidsmannen van eminente religieuze vrouwen als Teresa van Avila, ${ }^{206}$ Angela de Foligno, ${ }^{207}$ Birgitta van Zweden, ${ }^{208}$ Maria Magdalena de Pazzi, ${ }^{209}$ en Baptiste Varani ${ }^{20}$. Met deze passage in Kort Begryp bekrachtigt Huysmans in fette dat alleen mannen zich vrijelijk in woord en geschrift mochten uiten. Slechts in hoge uitzondenng konden die dit recht onder hun elgen verantwoordelijkheid aan vrouwen delegeren. De uitdrukkelijke vermelding van de weerstand van 'uitzonderlijke' vrouwen als Joanna van Randenraedt of Agnes van Heilsbach lijkt te impliceren dat zij ermee instemden dat vrouwen slechts beperkte schriftelijke uitdrukkıngsmogelijkheden hadden.

205 Ibidem, 3

206 Alvarez, 'Thérese de Jésus (sainte)'. Teresa van Avla (1515-1582) was de grondlegster van de teresıaanse hervorming van de Orde der Broeders van Onze-Lueve-Vrouw van de Berg Karmel, die in 1593 leidde tot het ontstaan van een nieuwe tak van de orde, die der ongeschoeide karmelieten en karmelitessen Van haar vele geschnften is hier haar autobıografie van belang, Libro de la vida, ook wel $V u d a$ of Autobıgrafia genoemd, want het ongineel bevat geen tutel Dit werk is een bewerkung van de verschullende verslagen van haar gemoedsgesteldheid en generale biechten die zij schnftelijk aan haar biechtvader overlegde sinds $1555 / 1556$

207 Doncoeur, 'Angele de Foligno' Angela de Folıgno (1249-1309) bekeerde zich rond haar veertigste tot een boetvaardıg leven en werd zuster van de derde orde van St. Franciscus in $1290 / 1291 Z_{1}$ liet verscheidene geschnften na, waaronder een 'memonaal' dat z) haar biechrvader had gedicteerd Haar werk bleef tot in de achtriende eeuw unvloedrijk onder religieuze vrouwen en geestelıken.

208 Vernet, 'Bngitte de Suède'. Birgitta van Zweden (1303-1373) trouwde op veertienjange leeftıd en kreeg acht kunderen $\mathrm{Na}$ een bedevaart naar Santiago de Compostella trad haar echtgenoot in blj de cistercienzers, waar hij spoedıg overleed In 1345 legde Birgitta het fundament voor de nieuwe orde van de Allerheligste Zalıgmaker en stelde hiervoor zelf de regel op Daamaast tekende zuj behalve gebeden en preken die voor het dagelı)ks gebruk in de orde bedoeld waren, ook haar goddelıke openbanngen op In opdracht van God liet zil die vertalen in het Latijn door haar biechtvaders Peurus Olav van Alvastra en Petrus Olavi van Skanningen Alfons de Vadaterra verdeelde de openbaringen in hoofdstukken en over acht boeken, de Revelationes

209 Ancill, 'Mane-Madeleıne de Pazzı (sant)' Mana Magdalena de Pazzı (1566-1607) trad in 1582 in een karmelitessenklooster. Omdat zj) zich nauwelı)ks iets hennnerde van wat ze gezien of gezegd had tudens haar extases, besloten haar mede-zusters in overleg met de biechtvader notitues te maken van wat zi) ujdens een extase zel Deze nottues, die tezamen vif boeken vormen, werden door haar zelf naderhand gecontroleerd en gecorngeerd

210 Heenclox, 'Baptuste Varanı' Baptiste Varanu (1458-1 524) was clans en stichtte in 1484 met andere clanssen van Urbino, waar ze was ingetreden in 1481 , het klooster van de clanssen van Camerino, waar 2 j) lange tud als abdis in functie was $Z_{1 j}$ liet diverse geschnften na. tractaten, religieuze oefeningen, spirtuele egodocumenten en bneven In La condotta della vnta spintuale deed ze haar biechrvader verslag van haar geestelık leven sinds haar achtste of tuende levensjaar tot haar dneēndertıgste 
Door hen af te schilderen als onwillige schrijfsters, laat Huysmans beide vrouwen spreken en zwijgen tegelijk. Hij ontneemt hun de macht om te spreken, doordat hij uitdrukkelijk verwijst naar een instantie buiten henzelf - de biechtvader - die hun schrijven autoriseerde. In overeenstemming met de scholastieke traditie waren geestelijken als Daniël Huysmans de mening toegedaan dat God Eva en haar vrouwelijke nakomelingen terecht de zeggenschap had ontnomen over het woord als een medium waarmee ze eigen verlangen tot uitdrukking konden brengen, verlangen dat tot dan toe alleen maar ongeluk en chaos had gebracht. Had niet Eva Adam met woorden verleid een vrucht te eten van de boom der kennis, tegen Gods expliciete verbod in? Haar woord was als het woord van de slang in het Paradijs, waar zij op haar beurt door verleid was: bedrieglijk, listig, kwaadsprekend. ${ }^{211}$ Daarop zinspeelde ook de dominicaan Steur in zijn uitleg van de zondeval, zoals we hierboven zagen.

\section{Schrijven in opdracht}

Gesteund door mannelijke autoriteit konden religieuze vrouwen schrijven. ${ }^{212}$ Sommige vrouwen, onder wie van Van Heilsbach, Van Randenraedt en beroemde voorgangsters als Teresa van Avila, schreven in opdracht van een geestelijke. ${ }^{213}$ Anderen beriepen zich op goddelijke inspiratie, waardoor als het ware een schrijvende of sprekende stem in het leven werd geroepen, waarvan de oorsprong buiten de vrouwen zelf lag. ${ }^{214}$ Ingevingen of zelfs bevelen van God legitimeerden dat vrouwen de pen op papier zetten. Zo konden zij Gods wil - of hun eigen stem, gepresenteerd als Gods wil - kenbaar maken. Een tijdgenote van Van Heilsbach en Van Randenraedt, Antoinette Bourignon (1616-1680), beriep zich uitdrukkelijk op Gods opdracht aan haar om Zijn boodschap aan anderen bekend te maken. Bourignon was afkomstig uit de Zuidelijke Nederlanden en groeide op in een katholıek milieu. Als instrument van God maakte deze vrouw, die zich graag afficheerde als ongeletterde maagd, aanspraak op spirituele kennis die direct door God was ingegeven. Op grond van goddelijke openbaringen eiste zij een profetisch gezag voor zichzelf op, dat in haar ogen de autoriteit van theologisch geschoolde geestelijken overtrof. ${ }^{215}$ Opdrachten van God legitimeerden ook dat religieuze vrouwen zich uitdrukten in genres die eigenlijk binnen het theologisch bereik vielen. De Italiaanse capucines Maria Domitilla Galluzzi (1595-1671) schreef bijvoorbeeld

21 Smith, $A$ poetics of women's autobiography, 27-28.

212 Religieuze vrouwen schreven evenwel ook poezie of bneven die niet voor hun geestelijke leidsmannen bedoeld waren. Arenal en Schlau, Untold sisters. Hobby, Virtue of necessity, laat zien dat vrouwen zıch wel degelı,k van andere rechtvaardıgingen bedienden dan opdrachten van mannen om te kunnen schrijven in uiteenlopende genres

213 Vgl Herpoel, "Nosce te ipsum"'

214 Petroff, Medieval women's visionary literature, 27, constateert dit al voor de middeleeuwen.

215 De Baar, “'Ik moet spreken"' en idem, 'Transgressing gender codes'. 


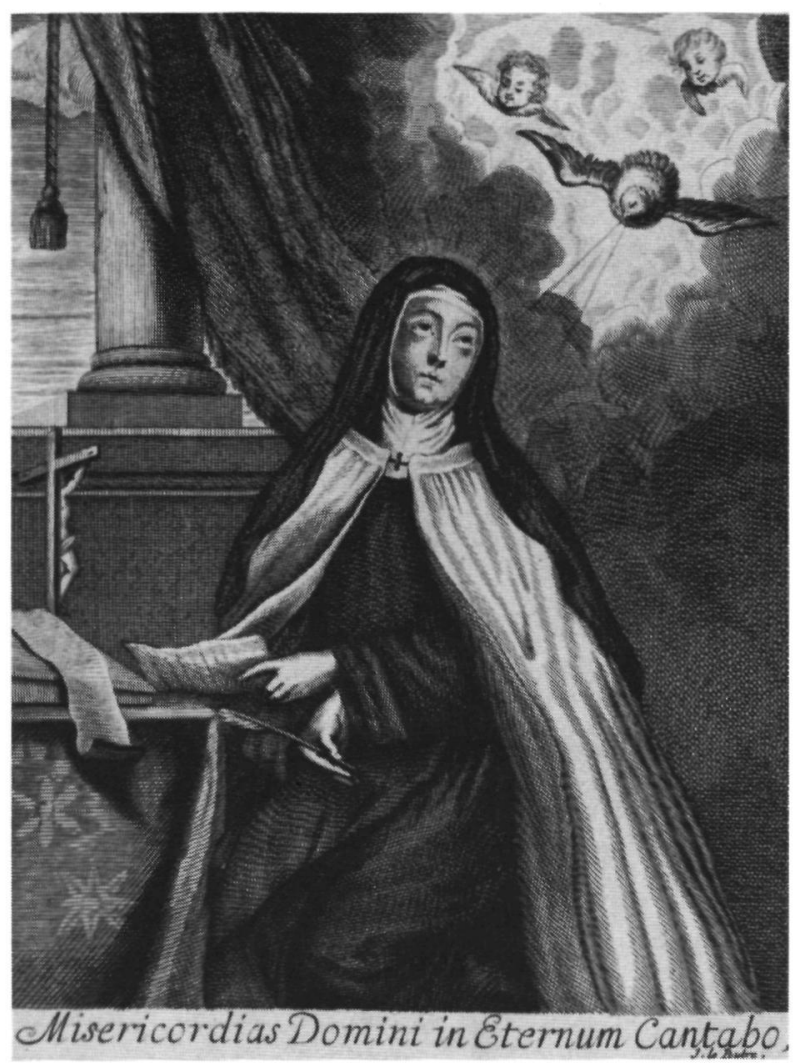

Afb. I6 Teresa van Avila aan haar schrijftafel.

een commentaar op de clarissenregel, waarvan de heilige Clara van Assisi als auteur wordt aangemerkt. Met klem verzekert Maria Domitilla haar lezerspubliek dat niet haar eigen overwegingen, maar Gods intenties ten aanzien van Clara's regel in haar commentaar worden weergegeven. ${ }^{216}$ Het domein van de theologie, dat voor vrouwen verboden terrein was, werd langs de 'omweg' van de direct door God ingegeven kennis beperkt toegankelijk gemaakt.

Dat vrouwen wel de pen voortbewogen maar dat de eigenlijke oorsprong van het geschrevene niet in henzelf gezocht moest worden, werd in de zeventiende eeuw ook iconografisch verbeeld. Voorstellingen van Teresa van Avila illustreren dit. Doorgaans wordt zij zittend achter een schrijftafel afgebeeld, de pen in de aanslag (afb. I6). ${ }^{217}$ Vóór haar zijn soms reeds voltooide werken van haar hand te zien, soms losse vellen papier of perkament, deels beschreven. Haar ogen zijn

216 Matter, 'The commentary'.

217 Vgl. Vandenbroeck, Hooglied, 253 (cat.nr. 185). Een 25-delige prentenreeks uit 1613 van Adriaan Collaert en Cornelis Galle, die gewijd was aan het leven van Teresa, vormde een belangrijke bron voor de Teresa-iconografie. 
niet hierop gericht, maar omhoog naar de hemel. Ze zit ook niet bepaald in een schrijfhouding, maar wijkt met haar bovenlichaam juist van haar schrijftafel terug. Alsof ze zich openstelt voor een woord van God, dat dan ook komt, want rechts boven haar hoofd zien we een witte duif, die de Heilige Geest symboliseert, die haar inspireert tot schrijven.

Deze voorbeelden illustreren hoe de cultureel bepaalde complexe relatie tussen de vrouwelijke sekse en het geschreven of gesproken woord werd geneutraliseerd door een externe autoriteit. Eén van de weinige vrouwen die zonder opdracht van een legitimerende instantie schreef, was de Mexicaanse non Juana Inès de la Cruz (I65I-1695). Anderen hadden haar weliswaar aangezet tot het schrijven van haar autobiografie, maar de inhoud ervan kwam voor haar rekening. $\mathrm{Zij}$ zelf had kennis vergaard door studie en scherpe waarnemingen. $\mathrm{Zij}$ presenteerde zich niet als een instrument van God of als Zijn spreekbuis. In tegenstelling tot andere religieuze vrouwen verontschuldigde zij zich nauwelijks voor haar studieuze activiteiten en kennishonger. Gezien haar streven God nog beter te leren kennen, leken dit haar passende bezigheden, óók voor vrouwen. ${ }^{218}$ Kerkelijke gezagsdragers deelden haar opvatting niet, zo bleek na de publikatie van een theologisch tractaat van haar hand. Naar hun opvatting moest Sor Juana haar kennis vóór zich houden in plaats van anderen te leren. Zó had de apostel Paulus het geboden en zó betaamde het vrouwen. ${ }^{219}$

Anders dan Sor Juana verwezen vrouwen als Teresa van Avila en Antoinette Bourignon naar God als degene die verantwoordelijk was voor de inhoud van hun geschriften. Teresa beriep zich daarenboven voor het schrijven zelf op de opdracht van haar biechtvader. Een dergelijke verdubbeling van externe autoriteit is ook bij Antoinette Bourignon waarneembaar; God gaf haar Zijn wil te kennen en droeg haar op deze in woord en geschrift aan anderen mee te delen. Inhoud én bemiddeling van die inhoud stonden onder $\mathrm{Zijn}$ auspiciën. Ook Agnes van Heilsbach en Joanna van Randenraedt maakten inhoud en handeling van het schrijven van God afhankelijk. Herhaaldelijk geven zij hun biechtvader via de gewetensrekeningen te kennen dat zij aangewezen zijn op Gods genade om hem, hun leidsman, de ingevingen en influisteringen die zij van God kregen, mee te kunnen delen. Weerspiegelde deze aanspraak op direct van God afkomstige inzichten een besef van goddelijke uitverkiezing? ${ }^{220}$ Of is deze claim te verklaren uit de naar sekse begrensde uitdrukkingsmogelijkheden, die voor religieuze vrouwen nu eenmaal beperkter waren dan voor hun mannelijke tegenhangers? Mijns inziens past hun beroep op goddelijke inspiratie inderdaad naadloos binnen heersende opvattingen over het

218 Dit argument werd reeds in $164 \mathrm{I}$ ingezet door de Nederlandse protestantse geleerde Anna Maria van Schurman (1607-1678) om het recht van vrouwen op studie en wetenschapsbeoefening te verdedigen. Van Eck, 'Het eerste Nederlandse feministische traktaat?'.

219 Uuana de la Cruz], $A$ woman of genius.

220 Gössmann, 'Das Gotres- und Menschenbild', I34. 
vrouwelijk geslacht en vroomheid. Zonder het gevoel van roeping en uitverkorenheid van deze religieuze vrouwen volledig te negeren of te diskwalıficeren moet toch worden gesteld dat hun weinig andere mogeli)kheden restten dan een beroep op God om hun kennis of ervanngen kenbaar te maken en daaraan de nodıge zeggenschap te verlenen. Schrijven of spreken op andermans gezag - of het nu van God of van $Z_{1 j n}$ plaatsvervanger op aarde was - wekte de suggestue dat de inbreng van vrouwen zelf bij de totstandkoming van een tekst nuhl was ${ }^{221}$ Niet alleen geestelı)ken hingen dit pnncipe aan, ook relıgieus geinspireerde vrouwen zelf. Sommige zeventiende-eeuwse profetessen in Engeland bedienden zich van deze strategie. ${ }^{222}$ Door naar goddelijke ingevingen als bron te verwizzen, dwongen zij de lezers als het ware op het gezag van de tekst af te gaan, in plaats van hun aandacht te vestigen op de sekse van de auteur ervan. Dit patroon likkt ook enige geldigheid te hebben voor de zelfpresentatie en ook de representatie van vroegmoderne rel1gieuze vrouwen in de katholieke traditie, van prominente heiligen als Teresa van Avila tot veel minder bekende geestelıje maagden als Agnes van Heilsbach en Joanna van Randenraedt.

\section{IV.5 Kwetsbaar voor de duivel, ontvankelijk voor God}

Het schnjven van gewetensrekeningen, die Van Heilsbach en Van Randenraedt aan hun biechtvader ter lezing voorlegden, werd beınvloed door godsdienstige en sociale referentiekaders. Die gaven niet alleen structuur en betekenis aan hun ervanngen, maar boden tevens een taal- en tekensysteem waann zil hun ondervindingen konden verwoorden. Zowel zelfbesef en zelfbeeld, als de parameters van zelfpresentatie werden medebepaald door cultureel bepaalde opvattingen over mannelı)kheıd en vrouwelı)kheid De histonca Natahe Zemon Davis ıllustreert dit treffend in haar analyse van een geheel andere categone van schnftelijke zelfportretten, namelıjk zestiende-eeuwse remissiebneven uit Franknjk. ${ }^{23}$ Terwıl mannen zich ter verdediging van halsmisdrijven benepen op ontoerekenıngsvatbaarheid ten gevolge van woede of drank, zochten vrouwen hun heil bij een beroep op overmacht waarbij hun eigen leven, hun reputatie of die van hun famile op het spel stond.

De implicaties van bestaande denkbeelden over vrouwelı)kheid en vroomheid voor religieuze vrouwen als Van Heilsbach en Van Randenraedt waren tweeledig. Als nakomelıngen van Eva waren deze bruiden van Christus, net zo min als hun

221 Een suggesue die ook doorwerkt in de receptie van teksten geschreven door religieuze vrouwen In een analyse van zeventiende-eeuwse spintuele biografieen van Franse nonnen stelt de histoncus Jacques Le Brun, 'Die geistliche Biographie', 158, dat deze religieuzen niet als eigenlijke auteurs van het door hen geschrevene aangemerkt moeten worden, omdat 21) in opdracht van geestelyken schreven 222 Wiseman, 'Unsilent instruments', 183

223 Davs, Futron in the archtves, 77-104 
seksegenoten, gevrijwaard van toespelingen als 'het is altemael dat vrouwelic is, tot val geneyght' [alles wat vrouwelijk is, valt gemakkelijk]. ${ }^{224}$ Zeiden zij de wereld en haar verleidingen vaarwel en wijdden zij zich met lichaam en ziel aan God, dan getuigden zij van een moed die in zeventiende-eeuwse termen enkel als 'mannelijk' omschreven kon worden. De staat van geestelijke maagd en de afhankelijkheidsrelatie tot een geestelijk leidsman boden gelegenheid de minderwaardige positie, die vrouwen eigen was, althans gedeeltelijk te ontstijgen. Vigerende opvattingen over vrouwelijkheid stelden echter de geloofwaardigheid van uitzonderlijke religieuze ervaringen, zoals Agnes en Joanna die documenteerden, op de proef. 'Broosch ende schaemel' als vrouwen waren, werden zij door sommige geestelijken gezien als een gemakkelijke prooi voor de duivel. Hun 'condition féminine' bevestigde anderen evenwel in de overtuiging dat juist zij tot uitzonderlijke vroomheid in staat waren. ${ }^{225}$ Deze twee uitersten in waardering van vrouwelijkheid en religiositeit speelden een rol in de belevingswereld van Van Heilsbach en Van Randenraedt en beïnvloedden hun zelfpresentaties op schrift. Joanna zou hierover volgens Huysmans het volgende hebben geschreven:

'De menschen die van my verstaen, dat [lees: wat] ick door natuerlijcke krachten niet weten en kan, sullen besluyten dat dit aen my veropenbaert is van Godt, oft vanden duyvel. ${ }^{\text {226 }}$

Aan anderen was het oordeel over de bron van haar ervaringen, die haar kennis als mens - en misschien vooral als vrouw - ver te boven gingen.

\section{Gemakkelijke prooi}

De opdracht om te schrijven over eigen religieuze beleving en bijzondere ervaringen stuitte bij Agnes van Heilsbach en Joanna van Randenraedt op weerstand. Door deze aversie tegen het schrijven te verwoorden, erkenden zij enerzijds de grenzen die aan schriftelijke uitdrukkingsmogelijkheden van vrouwen gesteld waren. Anderzijds was er voor hen zeer waarschijnlijk ook daadwerkelijk sprake van een dilemma, omdat zij niet konden volstaan met het louter beschrijven van hun geloofsleven en -beleving. In de volgende paragraaf zullen de dilemma's waarmee beide vrouwen zich in hun schrijven geconfronteerd zagen, nog uitvoerig aan de orde komen. Hier wordt kort aandacht besteed aan een aspect van de sociaalreligieuze context, waarin dergelijke dilemma's mogelijk deels hun oorsprong vonden.

Agnes en Joanna beseften terdege hoe buitengewoon hun ingevingen en dromen waren. Zij waren zich er ook van bewust dat hun positie en reputatie kwetsbaar waren. De grens tussen heiligheid en schijnheiligheid was niet altijd duidelijk gemarkeerd en hing vaak af van de beschouwer. Roermond was aan het begin van de zeventiende eeuw het toneel geweest van vervolging van vooral vrouwen, die

224 Lumnius, Van dLeven, 227.

225 Vgl. Dinzelbacher, 'Rollenverweigerung', 3, 9-10; Rotsaert, Tussen Eva en Mana, 194-195.

226 Kort Begryp, 170. 
van hekserij werden beschuldigd. In 1613 waren er in deze stad 64 vrouwen op grond van zo'n beschuldiging ter dood gebracht. ${ }^{227}$ Daarna vonden dergelijke terechtstellingen nog op aanzienlijke schaal plaats in dorpen rondom Roermond. In 1622 werden te Haelen zeven doodvonnissen geveld, in het graafschap Horn zestien. Aan het einde van I 636 en het begin van 1637 was er een kleinere procesgolf te Beegden, waarbij zes vrouwen tot de dood veroordeeld werden. ${ }^{228}$ En in augustus en september 1638 werden er in Roermond wederom vijf personen op de brandstapel ter dood gebracht. Vier vrouwen en een man werden schuldig bevonden aan toverij; een man werd ervan beschuldigd een weerwolf te zijn. ${ }^{229}$

De terechtstellingen veroorzaakten nogal wat opschudding in de stad. Getuige haar gewetensrekeningen maakten de processen en executies ook diepe indruk op Van Heilsbach. ${ }^{230}$ Willem Hendrik van Randenraedt, Joanna's broer, was als schout van Roermond belast met de opsporing en gevangenneming van de vermeende heksen en weerwolf. Via hem of zijn zuster kreeg Van Heilsbach mogelijk direct informatie over het verloop van het onderzoek en de personen die waren vastgezet. Joanna zelf was eveneens op de hoogte van haar broers rol in de opsporing en berechting van deze gewaande heksen. In een notitie van 30 augustus 1638 beschrijf zij hoe een ontsnapte 'toveres' op zijn gezag weer gevangen genomen werd. ${ }^{231}$ Door hun frequente bezoeken aan de Kapel in 't Zand is het niet denkbeeldig dat beide vrouwen terechtstellingen van vermeende heksen hebben gadegeslagen. De gerechtsplaats bevond zich achter deze kapel. ${ }^{232}$ Van Heilsbach droomde over heksen. Nog voordat er vrouwen op beschuldiging van toverij gevangen werden genomen in augustus 1638 , had zij eind juli al een droom. Hierin

227 Dresen-Coenders, 'De grote "heksenbrand"'. Idern, Het verbond van heks en duivel, 247-265. 228 Gıswı)t-Hofstra, 'Hoofdlynen', 273. Vgl. Evers, 'Maaslandse heksenprocessen', 87, roo-105 229 De Waardt en De Blecourt, 'Aantekeningen', 41, vermelden deze laatste kleine procesgolf onder verwizing naar C P. [P1ot], 'Condemnation et execution des sorciers', in' Messagers des sciences hestonques de Belgrque (1841) 505-507. P1ot baseert zich op een petitie uit 1640 van de Roermondse schout, Wllem Hendnk van Randenraedt, gencht aan thesauner van de Rekenkamer van de domeinen des konings, die de executies van vier 'sorciers' en een 'loup garou' vermeldt Piot noemt vervolgens de slachtoffers' Martıne van Bruggen werd op 18 augustus 1638 verbrand; Geertgen Murens op i1 september 1638; een vrouw genaamd Cremers Wyfken, de echtgenote van Johan van Melick, op i6 september 1638; Nelisken, de moeder van Wenckeler, op I8 september 1638, en tenslotte Hendrik Meyers op 4 oktober Of en wanneer Hendnck Peeters, die ervan werd beschuldigd een weerwolf te zijn, terechtgesteld werd, is niet bekend Mogelıjk gebeurde dit reeds eind julı 1638 Van Heilsbach vermeldt dan namelıjk de terechtstelling van een jongen. KB Brussel, Handschnften I8984, 56vo (eund juh [1638])

230 KB Brussel, Handschrften I8984, 56vo (eind julı [1638]).

23I KB Brussel, Handschnften 20422, 54I-542 (30 augustus [1638]) [nummenng Van Randenraedt; in andere hand gefolıeerd (178vo)-179]; de betreffende passage heeft vermoedelı)k oorspronkelı)k deel uitgemaakt van de tweede versie van haar spuntuele autobiografie, KB Brussel, Handschnfien 19073 (I)

232 G H A Venner, 'Inleiding', in. Idem, Inventans van het archief van het Hoofdgerecht Roermond 14591796 (Maastncht 1987) 21 
loopt zij via de Neerstraat in de richting van de markt. Ze komt voorbij een huis, waar een vrouw woont van wie wordt gezegd dat zij kan toveren. In de droom lopen leden van de magistraat langs het betreffende huis zonder iets tegen de vrouw te ondernemen. Van Heilsbach toont zich verbaasd en spreekt hen aan. $\mathrm{Zij}$ antwoorden haar dat $\mathrm{zij}$ de vrouw niet als eersten willen aanklagen. ${ }^{233}$ In een andere droom ziet zij een niet nader geïdentificeerde vrouw - vermoedelijk een van de vermeende heksen - die door een beul gepijnigd wordt, maar geen kik geeft. ${ }^{234}$ Tot in oktober bleven de heksen haar bezighouden. In een gewetensrekening van die maand schetst zij een droom waarin haar door een man en een vrouw wordt verteld dat er opnieuw toveressen gevangen genomen zijn. Als zij vraagt wie dit zijn, antwoorden de anderen dat zij dat niet weten, want er zijn nog zoveel heksen in de stad dat zij wel met tien of twintig tegeliik opgepakt kunnen worden. Agnes schrijft daarop dat de magistraat in dezen veel te laks optreedt. De gedachte dat deze vrouwen, die zij bestempelt als zondaressen, gewoon ter communie gaan, breekt haar hart. ${ }^{235}$

Reeds lang voor de Roermondse procesgolf in 1638 , die Van Heilsbach en Van Randenraedt van nabij meemaakten, was de stad in de ban van toverij, hekserij en ideeën over de werkzaamheid van de duivel. Vrijwel uitsluitend vrouwen werden beschuldigd en terechtgesteld. Het is niet denkbeeldig dat in dit gegeven tenminste ten dele een verklaring gezocht moeten worden voor de weerstand die beide vrouwen te berde brachten tegen het schriftelijk vastleggen van hun ervaringen. Zowel de ervaringen als de bewijsvoering dat deze inderdaad van God en niet van de duivel afkomstig waren, brachten immers de nodige gevaren met zich mee. Dat de biddende of mediterende mens ten prooi kon vallen aan duivels bedrog was een overbekend gegeven. En vrouwen werden, zoals gezegd, in dat opzicht als een bijzonder kwetsbare groep beschouwd. ${ }^{236}$

\section{Vertrouwd met God}

In de religieuze belevingswereld die leidsmannen en geestelijke maagden tot op grote hoogte met elkaar deelden, was het eveneens alleszins plausibel dat God zich aan leden van het zwakke geslacht openbaarde, al was het maar om (sterke) mannen te beschamen, zoals het bijbelse gezegde wilde (I Kor. 1,27) ${ }^{237}$ Plaatsbepalin-

233 KB Brussel, Handschnften 18984, 56 [juli 1638].

234 Ibrdem, 289 (10 september 1638 ).

235 Ib1dem, 322-323 (16-17 oktober [1638])

236 Zic bijvoorbeeld Bisschop, Lof der Suyverheydr, III, 287.

237 Vrouwen alludeerden daar zelf op. Cathanna van Siena had volgens haar biechtvader en hagiograaf Raymond van Capua van God zelf vernomen dat $z_{1 j}$ in $Z_{1 j n}$ opdracht als vrouw zou preken en leren, juist om immorele mannen te beschamen Bynum, 'Women's stones', 39. Met woorden van vergelıkbare strekkıng legitımeerde Antoinette Boungnon dat God haar uitverkoos als bemiddelaarster van $Z_{1 j n}$ woord. De Baar, "'Ik moet spreken"', I04. 
gen van vrouwen in het maatschappelijke en religieuze domein vertrokken traditioneel vanuit een dichotomie tussen mannen en vrouwen, tussen mannelijk en vrouwelijk. Werden mannen vereenzelvigd met geest en ratio, vrouwen en vrouwelijkheid stonden voor lichaam en lust. Al bleef deze dichotomie de onderliggende structuur van het denken over gezagsverhoudingen tussen de seksen, over de menselijke natuur of over vroomheid bepalen, de betekenis ervan was wel onderhevig aan verandering. In haar onderzoek naar aspecten van laat-middeleeuwse spiritualiteit laat de mediaeviste Caroline Walker Bynum zien dat de notie dat vrouwen zich als het stoffelijke verhielden tot het geestelijke, dat door mannen gerepresenteerd werd, op verschillende wijzen werd ingezet. Theologen en hagiografen gebruikten deze tegenstelling bijvoorbeeld om het falen van mannen in religiosis te veroordelen. Mannen, clerici in het bijzonder, werden met het voorbeeld van uiterst deugdzame vrouwen die geen middel onbeproefd lieten om de vereniging met God tot stand te brengen, gewezen op hun zelfgenoegzaamheid en gebrek aan religieuze ijver. Dat vrouwen minder rationeel waren dan mannen, werd in het denken van laat-middeleeuwse geestelijken soms ook in positieve zin uitgelegd. In plaats van niet rationeel beschouwden zij vrouwen dan als boven-rationeel. In die redenering viel het domein van de rede nog steeds buiten het bereik van vrouwen. Maar vrouwen konden dankzij visioenen en andere bovennatuurlijke ervaringen op een supra-rationele wijze contact hebben met het goddelijke. ${ }^{23^{8}}$ In de ogen van hun mannelijke tijdgenoten waren zij limineel; zij vielen buiten iedere categorie van de middeleeuwse standenmaatschappii. ${ }^{239}$

Ook in de vroegmoderne tijd konden vrouwen het andere, het buiten- of bovenwereldlijke representeren. Omgang met vrouwen bood geestelijken een ontsnapping aan de wereld en, in bepaalde gevallen, ook contact met God. De geloofwaardigheid van visioenen, dromen of inspraken waarover vrouwen mondeling of schriftelijk rapporteerden, bleef wel gehandhaafd, maar werd met grotere scepsis bejegend. Geestelijken eisten het monopolie op de duiding van dergelijke bijzondere gebeurtenissen voor zich op. Hechtten zij geloof aan de mondelinge of schriftelijke verslagen van buitengewone ervaringen, dan konden gezag en handelingsvrijheid van religieuze vrouwen hierdoor vergroot worden. Niet voor niets vervulden visioenen een sleutelfunctie in de levens van vrouwen in de vroegmoderne tijd die een actief religieus leven ambieerden. Zag de Engelse Mary Ward de weg die zij van God moest volgen uitgestippeld door verschillende visioenen, haar biechtvader probeerde haar bepaalde stappen te ontraden met een beroep op kennis van Gods wil, waarover hij als diens plaatsvervanger meende te beschikken. God wilde volgens Ward dat zij een gemeenschap voor vrouwen zou stichten waarin gebed én apostolaat centraal zouden staan. De Sociëteit van Jezus zou voor dit nieuwe

238 Bynum, Holy feast, 262-263.

239 Bynum wijst er in 'Women's stories' op dat laat-middeleeuwse vrouwen zichzelf en hun visionaire en extatische ervaringen geenszins als limineel beschouwden. 
type vrouwengemeenschap als voorbeeld moeten dienen. Ward besefte dat God haar daarmee een opdracht had gegeven die indruiste tegen de bestaande gedragscodes voor vrouwen. ${ }^{20}$ Alix le Clerc (1576-1622) wilde oorspronkelijk in een slotklooster intreden. $\mathrm{Na}$ een 'ingeving' besloot zij met drie andere vrouwen een eigen gemeenschap te stichten. Met Pierre Fourier (I565-I640), regulier kanunnik en haar geestelijk leidsman, riep zij de Congrégation de Notre Dame in het leven, die in Frankrijk gedurende de zeventiende eeuw een belangrijke onderwijsorde werd. God had haar, naar eigen zeggen, het karakter van haar gemeenschap getoond in twee visioenen. De nieuwe communiteit zou het midden houden tussen een orde als die der clarissen, en een gemeenschap als de franciscaanse hospitaalzusters. De structuur van de Sociëteit van Jezus zou als blauwdruk moeten dienen, hetgeen in de door Fourier opgestelde constituties gerealiseerd werd. ${ }^{241}$

Gezien de stringentere controle op het geloofsleven van vrome penitentes, aan wie God bijzondere genaden bewees, wekt het geen verbazing dat de biechtvaders van Van Heilsbach en Van Randenraedt vooral belangstelling hadden voor influisteringen en droomgezichten. 'Volgens u eerw. believen sal ick hier stellen eeniege droemen ende sommige buitten ordinarisse beweegingen', schrijft Van Randenraedt in $1648 .{ }^{242}$ Voor zover zij en Agnes zich manifesteerden als instrumenten of spreekbuizen van God waren zij interessant voor deze geestelijken. Over hun precieze motieven zwijgen de gewetensrekeningen natuurlijk. Professionele interesse, toezicht op en steun aan hun penitenten, was misschien slechts één reden om hen te laten schrijven. Misschien hoopten zij via deze vrouwen op een andere wijze toegang tot God te kriigen dan zij zelf hadden, hun ambtelijke status en bevoegdheid ten spijt. Wellicht wilden zij via deze tussenpersonen van God vernemen hoe het met hun eigen zieleheil gesteld was en of zij hun ambt naar behoren uitoefenden. ${ }^{243}$ Contacten met deze religieuze vrouwen, in en buiten de biecht, hielpen hen mogelijk om hun persoonlijke en ambtsgebonden identiteit te definiëren. ${ }^{244}$

\section{Grondslagen voor profetisch gezag}

Religieuze vrouwen konden geen aanspraak maken op de ambtsgebonden, geïnstitutionaliseerde zeggenschap van pnesters. De autoriteitsrelaties tussen geestelijken

$24^{\circ}$ Conrad, Zewschen Kloster und Welt, 79 (noot 3), 85-87; Rapley, The dévotes, 29.

241 Conrad, Zwnschen Kloster und Welt, 73-83, Rapley, The dévotes, 60-72. In 1628 verwierf de Congregation de Notre Dame pauselı)ke goedkeunng, op voorwaarde dat de clausuur werd ingevoerd. 242 GAR, Handschrifien I A Io (ongepagineerd). Zie ook KB Brussel, Handschrfien 19070, 264 (september 1645).

$243 \mathrm{Vgl}$. Bynum, Holy feast, 229 Middeleeuwse clenci zochten in heilige vrouwen zowel cen standaard van vroomheid als 'uitzicht' op het goddelıke. Bynum stelt dat het beslist niet $z 0$ is dat clenci enkel gemanipuleerd werden door de visioenen en andere ervanngen van religieuze vrouwen, maar hier wel degelıkk zelf ook belang bi) hadden. Zie hervoor ook Coakley, 'Fnars, sanctity, and gender' en idem, 'Gender and the authonty of frars'

244 Vgl. Bilunkoff, 'Confessors'. 
en religieus geïnspireerde vrouwen waren asymmetrisch. ${ }^{245}$ In de spirituele en theologische context van de Gregoriaanse hervorming van het einde van de elfde eeuw werden zielzorg en prediking als de voornaamste vormen van de navolging van Christus gezien. Vrouwen werden in toenemende mate van die taken, die steeds meer als clericale taken bij uitstek beschouwd werden, uitgesloten. Op grond van hun ambt konden priesters beschikken over erkende vormen van religieus gezag. Vrouwen daarentegen beriepen zich op de rechtstreekse inspiratie van God en ontwikkelden zo een 'profetisch' of 'charismatisch' alternatief voor dit ambtsgebonden gezag. ${ }^{246}$ Dit alternatief werd in de vroegmoderne tijd sterk afhankelijk van de steun van geestelijken. Visoenen of inspraken alléén waren voor vrouwen als bron van autoriteit onvoldoende. Erkenning van hun uitverkoren positie door een priester, hun biechtvader en leidsman, zou voortaan een conditio sine qua non zijn voor hun profetisch gezag en religieuze activiteiten. ${ }^{247}$ Via de verslaglegging van hun bijzondere ervaringen in hun gewetensrekeningen konden Agnes van Heilsbach en Joanna van Randenraedt zich verzekeren van de voor hen onmisbare steun van hun biechtvaders.

Niet alleen inhoud, maar ook vorm waren daarbij belangrijk. Bewust of onbewust, op eigen initiatief of op verzoek van hun biechtvader, specificeerden beide vrouwen de mentale en fysieke toestand waarin zij verkeerden wanneer zij droomden of 'zagen'. ${ }^{248}$ Agnes van Heilsbach duidt de toestand waarin zij voorvallen waarneemt aan als 'droom gewijs'. Deze formulering verwijst misschien naar een in de middeleeuwen gangbare bewoording voor dromen of visioenen, in somnis visionem videre, in de slaap een visioen zien. ${ }^{249}$ Die droomgewijze gesteldheid hield het midden tussen slapen en waken. In deze gesteldheid nam Agnes personen of gebeurtenissen waar als in een droom. Meestal trad deze toestand in na haar nachtelijke gebed of meditatie. Misschien was dit gebruik geïnspireerd op het koorgebed van slotzusters. $\mathrm{Zij}$ onderbraken hun nachtrust om de metten, het eerste gedeelte van het breviergebed, te bidden. Agnes bad in de vroege uren vaak ter intentie van anderen of mediteerde op het lijden van haar Bruidegom. Wanneer zij tijdens of na haar devotie in de beschreven droomtoestand raakt, voelt zij zich 'omcingelt' en volledig in God versmolten. In mystieke taal van de volledige overgave aan God onderstreept zij dat zij in deze situatie 'soe geheel bij mij selleven niet en was'. ${ }^{250}$ En dan, 'sonder van mij selleve meester te worden', 'ziet' zij. ${ }^{25 x}$

245 Bynum, 'The fernale body and religious practice', 195.

246 Idem, fesus as Mother, 9-21.

$247 \mathrm{Vgl}$. Ranft, 'A key'.

248 Vgl. Ahigren, 'Visions'.

249 Dinzelbacher, 'Körperliche und seelische Vorbedingungen', 58.

250 KB Brussel, Handschriften 18984, 107 (25 november [1637]).

251 Tbidem, $119 v 0$ ( 6 januari z.j.). Vgl. in dit verband de definitie die de psycholoog Vergote, 'Psychologische interpretatie', 226, geeft van visioenen: 'percepties van beelden en woorden die normaal niet met de zintuigen waameembaar zijn, en die tóch waargenomen worden als beeiden en woorden die door de zintuigen gepercipieerd worden.' 
Soms overvielen de droomgezichten haar. Op 9 mei $163^{8}$ gebeurde dat toen zij over straat liep. Plotsklaps 'is mij inwendich [in] den geest te voore coemen te sien' de processie, die de komende dagen gehouden zal worden ter viering van de Kruisdagen. Ze ziet die processie 'int gesicht des geestelijcken ooghs der siellen', zoals ze zelf schrijft. ${ }^{252}$ Op grond van de invloedrijke classificatie die de kerkvader Augustinus opstelde van visioenen, ${ }^{253}$ zou dit visioen misschien gerangschikt kunnen worden onder de geestelijke of verbeeldingsvisioenen. Volgens Augustinus worden deze waargenomen met dat deel van de ziel waarmee verbeeld wordt wat de mens in lichamelijk opzicht gewaar wordt. Dergelijke visioenen acht hij minder betrouwbaar dan intellectuele visioenen, die volgens hem doorgaans beeldloos zijn. Dwaling is naar zijn mening eigenlijk uitgesloten in geval van een intellectueel visioen. Een voorbeeld van zo'n intellectueel visioen lijkt Agnes op 19 mei 1638 te documenteren. ${ }^{254}$ Uit deze beschrijving blijkt ook dat zij zich in mentaal opzicht voorbereidde op ingevingen van God. 's Nachts ontwaakt zij en begeeft zich tot gebed

'om mijn memori te ververssen ende mijn verstant te verlichten, ende mijn wil meer ende meer in die liefde Godts t'ontsteeken in het geene dat sijn hoege Maiesteit deur die veurspraeck der Moeder Godrs, na[ar] sijnen alder behaeghlixcten wil, mij beliefden veur te stellen, ende deur die veurcoemende ende sterck mee werckende graci in ende deur mij, als het alder onweerdichste instrument te werck te stellen (...)'.

Het duurt echter even voordat 'mij iet veur gesteldt waerdt'. Agnes benadrukt vervolgens dat God de bron van de ingevingen is, 'want ick mij van zelleven als geheel duister ende onweetende gevoulde als een kint dat geen a voor een $b$ kost onderkennen, ia dat geheel machteloes was sonder hem iveringhs [ergens] aen vast te connen hauden'. Tenslotte komt dan de ingeving:

'soe wast dat ick een grooter licht in mij verstant op rijsen sach, dat mij voorstelden claer in een licht, met dat selleve licht deese naer volgende kennisse te vatten (...)'.

Behalve 'leevende gesichten' kreeg Agnes ook inspraken. Zelf spreekt ze over 'voeis'. ${ }^{255}$ Stemmen die haar - en haar biechtvader vermoedelijk ook - vaak geruststellen. In oktober 1637 bijvoorbeeld, een maand nadat de vijfjarige bezetting van Roermond afgelopen is maar de angst bij de burgers voor hernieuwde bezetting nog niet geweken is, hoort Agnes zo'n 'voeis' die haar verzekert dat een nieuwe belegering uit zal blijven. ${ }^{256}$ Stemmen die zweren dat niets ter wereld haar

252 KB Brussel, Handschriften 18984, 213vo-214vo (9 mei [1638]).

253 Adnès, 'Visions', 965-966, 991-992. In de drieledige, hiërarchische indeling van visioenen, die Augustinus hoofdzakelijk uitwerkte in boek XII van De Genesi ad litteram, worden intellectuele, geestelijke of verbeeldingsvisioenen en lichamelijke visioenen onderscheiden. Deze classificatie was invloedrijk onder jezuieten-theologen die zich in de vroegmoderne tijd bezig hielden met oorsprong en duiding van visioenen.

254 KB Brussel, Handschriften I8984, 218-220.

255 Ibidem, 79 (27 juli [1637]); IIs (24 juni z.j.); I20 (6 jan. z.j.).

256 Ibidem, 90 ( 14 oktober [1637]). 
van haar Bruidegom kan scheiden, stemmen die haar manen zich naar de kerk te spoeden om ter communie te gaan en zich zo met haar lief te verenigen. ${ }^{257}$ Soms twijfelt ze of ze niet de duivel hoort, zoals in maart 1638 , wanneer ze in haar slaap een mannenstem bij haar oor hoort, die almaar luider wordt. ${ }^{258}$ Ook andere zintuigelijke waamemingen spelen een rol bij de dromen en visioenen. Zo nu en dan 'ziet' zij tijdens haar gebed een licht, dat haar in het binnenste van haar hart raakt, ${ }^{259}$ of voelt zij haar hart opgaan in een helder licht. ${ }^{260} \mathrm{Na}$ een sacramentsprocessie in oktober 1638 'ziet' Agnes stralen uit het in de minderbroederskerk opgestelde Heilig Sacrament, stralen gericht op de harten van de aanwezigen. Niet alle stralen zijn, zo schrijft zij, gelijk; brede en vurige stralen bereiken mensen, maar iele stralen zijn vaak net iets te kort. God geeft haar te kennen dat de werking van die stralen samenhangt met de mate waarin de harten van mensen openstaan voor Zijn invloed. ${ }^{261}$ Zelf deelt zij in de goddelijke genade. Een visioen dat vermoedelijk in 1639 plaats had, verbeeldt dit. Agnes ziet zichzelf in een brandend vuur. Voor haar mond verschijnt een sneeuwwitte borst als van een vrouw en zij 'voelt' een inspraak van God. Hij nodigt haar uit zich te laven aan 'het aldersoetste sogh wt mijnder goddelijcker Borsten u toevloeiende dien aldersoetsten smaeck mijnder Goetheijt een deel, die die saeligen wt mij sijn geniettende gedurich [voortdurend]' ${ }^{262}$ Dit voorproefje - in de letterlijke zin van het woord - van wat haar in de hemel te wachten staat, bevestigt haar uitverkoren status.

In de gewetensrekeningen van Joanna van Randenraedt tekent zich een intensivering van haar bijzondere gewaarwordingen af. In I639 en I640 documenteert zij vooral dromen, die haar overkomen als zij slaapt. Slechts incidenteel gebruikt zij de aanduiding 'droom gewijs', die Agnes van Heilsbach vaak bezigt in haar gewetensrekeningen. Vermoedelijk was zij met dit begrip vertrouwd geraakt tijdens het kopiëren van Agnes' gewetensrekeningen. Joanna gebruikt zelfs het begrip 'visioun' een keer, ${ }^{263}$ hoewel de beschrijving ervan zich in niets onderscheidt van haar gebruikelijke droomverslagen. Ook Joanna beschrijft wat zij 'ziet' als 'inwendiege kennisse'. Sommige beschrijvingen van haar droomgezichten tenderen echter in de richting van lichamelijke visioenen, die volgens de classificatie van Augustinus het minst betrouwbaar waren: 'ick scheen heel levende te sien ende te gevoullen'. ${ }^{264} \mathrm{Net}$ als Agnes onderbrak Joanna haar nachtrust voor gebed of meditatie. Ze memoreert veelvuldig de slaapdronken toestand waarin ze haar gebed of medi-

257 Ibidem, I7rvo-172vo (28 maart [1638]); 174vo-175 (2 april [1638]).

258 Ibidern, 163-164 (12 maart [1638]).

259 Ibidem, 123vo-124 (6 januari 2.j.).

260 Ibidem, I47-148vo (I2 februari z.j.).

26I Ibidem, 310-3rovo (4 oktober [1638]).

262 Ibidem, 379vo-380 (13 februari [1639?]).

263 GAR, Handschriften I A 5 (ongepagineerd; maart I640).

264 Ibidem (ongepagineerd; maart-april 1640). 
tatie volbrengt, zoals ze ook regelmatig schrijft dat zij gedurende de dag, vooral wanneer ze in de kerk zit, overmand wordt door slaap. Haar fysieke vermoeidheid zal haar percepties 's nachts en overdag ongetwijfeld beinvloed hebben. Fysieke verstervingen, zoals vasten, en allerlei penitenties, die zij net als Agnes praktiseerde, zullen eveneens in hun mentale toestand, zintuigelijke en bovenzintuigelijke waarnemingen doorgewerkt hebben. Door doelbewuste 'vernieting' - zichzelf als het ware te niet doen in een proces van onthechting via ascetische oefeningen probeerden beide vrouwen open te staan voor God en ruimte te bieden aan de genadewerking van Hem in hen. ${ }^{265}$ Dit proces van onthechting, dat in hun gewetensrekeningen gedocumenteerd wordt, makte de visioenen, dromen en inspraken als uitdrukkingen van Gods genade vermoedelijk ook aannemelijk in de ogen van hun geestelijk leidsmannen.

Gaandeweg namen God, Christus en Maria steeds meer bezit van Joanna, ook overdag. Behalve de ontwikkeling van haar religieuze beleving is hiervoor nog een andere (deel)verklaring mogelijk. In 1640 las Simon van den Hove haar gewetensrekeningen. Hierboven is er al op gewezen dat hij haar ervan betichtte Agnes te willen imiteren. Deze aantijging zou Joanna getemperd kunnen hebben in haar rapportage. Zó terughoudend hoefde zij bij nieuwe biechtvaders misschien niet te zijn. De beschuldiging van Livinus de Clerck, die haar net als Van den Hove van doelbewuste imitatie van Agnes betichtte, bracht geen verandering in haar verslagen. In haar gewetensrekeningen van 1643 en later worden dagdromen, visioenen, inspraken, maar ook fysieke gewaarwordingen als omhelzingen tijdens of na de communie, uitvoerig beschreven. Haast hysterische lach- of huilbuien, thuis en in de kerk, gaven uitdrukking aan de intense vreugde of verdriet die liefdesbetuigingen van haar Bruidegom of $\mathrm{Zijn}$ lijden in haar teweeg brachten. Tijdens een maaltijd verloor Joanna zich in het bijzijn van haar disgenoten dermate in een overweging van het lijden van haar Bruidegom, dat ze in het geheel niet meer aanspreekbaar was. ${ }^{266}$ Deze voorvallen bevestigden voor haar dat zij geen controle over zichzelf had. Haar beschrijving beoogde ook haar biechtvader hiervan te overtuigen.

\section{IV.6 Weerstanden en dilemma's}

Het beeld dat Daniël Huysmans schetst van Agnes van Heilsbach en Joanna van Randenraedt als auteurs tegen wil en dank, is grotendeels gestileerd naar vigerende opvattingen over schrijvende vrouwen. Zijn dilemma hoe enige schrijfactiviteit van vrouwen aan lezeressen en lezers aannemelijk gemaakt kon worden, was daarmee vermoedelijk opgelost. Dilemma's waarvoor vrouwelijke auteurs als Van Heils-

265 KB Brussel, Handschriften 19073 (II), 127; vgl. Blankers, 'De betekenis van het genot', 39.

266 KB Brussel, Handschriften 19070, 13vo-I4 (januari 1643). 
bach en Van Randenraedt zich al schrijvende geplaatst zagen, lieten zich evenwel niet zo gemakkelijk oplossen. Want met het overdragen van hun gewetensrekeningen aan hun biechtvader, leverden beide geestelijke maagden zich uit aan zijn oordeel. Hieraan konden zij zich niet zomaar onttrekken. Op grond van hun staat als geestelijke maagd waren zij hun leidsman gehoorzaamheid verschuldigd. Formeel was hun gezagsverhouding ongelijkwaardig; een geestelijke dochter was in haar religieuze en ook meer profane doen en laten afhankelijk van de goedkeuring van haar geestelijke vader. Agnes en Joanna waren zich bij het schrijven van hun gewetensrekeningen bewust van deze afhankelijkheid. ${ }^{267}$ De opdracht om hun geloofsbeleving en (religieuze) ervaringen te beschrijven, was en bleef een oefening in gehoorzaamheid voor hen. Dat het biechtgeheim kennelijk niet automatisch van toepassing was op de schriftelijk vastgelegde uitkomsten van hun gewetensonderzoek, zal hun animo om aan deze opdracht te voldoen zeker niet vergroot hebben. Het schrijven bracht dilemma's met zich mee die niet opgelost werden door de opdracht van haar biechtvader, maar daardoor juist veroorzaakt. Bevraagd over zichzelf, eigen ervaringen en gedragingen, construeerden zij op papier een identiteit die tegemoetkwam aan het verwachtingspatroon van hun biechtvader. ${ }^{268} \mathrm{Bij}$ hun schriftelijke zelfpresentaties verloren zij echter hun eigen aspiraties niet uit het oog.

\section{'Vrauwe fantasien'}

Aan het schrijven op bevel waren verschillende spanningen inherent, die verscherpt werden door de sekse en de officieuze religieuze status van de auteurs. Deze spanningen worden verkend aan de hand van een conflict dat zich voordeed in december I645 en voortduurde tot de zomer van I646. In dit geschil stond de vroomheid van geestelijke dochters als Van Heilsbach en Van Randenraedt ter discussie. We volgen de verwikkelingen aan de hand van Van Randenraedts gewetensrekeningen.

In december 1645 velde de toen in Brussel werkzame jezuïet Jacob Wijns een vernietigend oordeel over de inhoud van een deel van de geschriften van Agnes van Heilsbach, Joanna's geestelijke moeder. ${ }^{269} \mathrm{~W}_{1 j n s}$ was een neef van de gezag-

$267 \mathrm{Vgl} \mathrm{Foucault,} \mathrm{De} \mathrm{wzl} \mathrm{tot} \mathrm{weten,} \mathrm{98-99,} \mathrm{die} \mathrm{in} \mathrm{het} \mathrm{algemeen} \mathrm{de} \mathrm{biechtvader} \mathrm{in} \mathrm{de} \mathrm{vroegmoderne}$ context omschnfft als een controlerende instantue waar een sterk disciplinerende werking van ustging. De Italıanse filoloog De Maio, Donne e Rinascımento, I67, wijst op de macht die een biechtvader heeft over een penitente die in zi)n opdracht schnjft.

268 Egodocumenten, maar ook zelfpresentatues in gerechtelı,k bronnenmatenaal, zıjn te beschouwen als voorstellingen van zowel het unieke en persoonlyke, als het algemene Auteurs, verdachten of getungen geven in hun relaas een sociale identiteit pros waann nauwkeung bepaalde bekende, geaccepteerde vormen van presentatie van zichzelf en anderen tot uitdrukkung komen, aldus Fnjhoff, 'Normeren of waarderen', is Vgl. Tomizza, Heavenly Supper en Brown, Onkuise handelingen Een kntische apprecıatie van Browns analyse van de Toscaanse non Benedetta Carlını, de daarbıy gehanteerde ıdentıteitscategoneen en de eenzı)dıg seksuele duidıng van door Carlını en andere nonnen beschreven gebeurtenissen geeft Matter, 'Discourses of desire'

269 KB Brussel, Handschnften 19070, 323-336 (december 1645) 
hebbende theoloog Lessius, die onder andere over de geestelijke staat buiten het klooster had geschreven. ${ }^{270}$ Aan het einde van de jaren twintig was Wijns biechtvader van Agnes en Joanna geweest. Na zijn vertrek uit Roermond rond r63I bleven zij hem beschouwen als hun geestelijk leidsman. Voor Agnes' weergave van haar buitengewone ervaringen in de gewetensrekeningen had hij meer dan een decennium later geen goed woord over. Vermoedelijk had hij haar notities in handen gekregen via de toenmalige rector van het Roermondse college, Franciscus l'Hermite. In haar spirituele autobiografie noemt Joanna hem als degene aan wie zij een gedeelte van Van Heilsbachs geschriften afstaat. Over deze daad betuigt zij met terugwerkende kracht spijt, want l'Hermite blijkt geloof te hechten aan 'quaeij informatie' over Agnes. ${ }^{271}$ Deze informatie was waarschijnlijk aanleiding voor l'Hermite om een onderzoek in te stellen naar de op schrift gestelde ervaringen van $\mathrm{Van}$ Heilsbach. Hij zal de gewetensrekeningen aan Wijns hebben voorgelegd om hierover zijn oordeel te vernemen. Wijns deed de dromen, visioenen en goddelijke inspraken die Van Heilsbach vastlegde, af als 'vrauwe fantasien'. Zijn bevindingen werden via Catharina van Gestel, één van Wijns' geestelijke dochters, en via Joanna gestuurd aan haar toenmalige biechtvader, Livinus de Clerck. Joanna hield dit 'memoriael' echter achter, naar zij schrijft uit angst voor onenigheid tussen Wijns en haar biechtvader. Vrees voor haar eigen positie, die immers eveneens berustte op goddelijke genade die door dromen, visioenen en inspraken kenbaar werd gemaakt, speelde echter mogelijk tevens een rol. Want ook over haar had Wijns kennelijk geoordeeld. Helaas maakt Joanna hiervan verder geen gewag in haar gewetensrekening; zij beperkt zich tot de mededeling dat het haar niet kan schelen wat Wijns over haar schrijft. Haar biechtvader mag dat best lezen, al is zij bang dat hij vervolgens haar 'pampieren' zal opeisen. Zelf vermoedt zij dat het l'Hermite en Wijns enkel om Agnes' gewetensrekeningen te doen is. Het vernietigende oordeel zou niet meer geweest zijn dan "eenen deckmantel (..) om de selve [de geschriften van Agnes]' te behouden. ${ }^{272}$ Een opzet waarin zij maar gedeeltelijk slaagden; die delen die zij aan l'Hermite had afgestaan, kreeg ze weliswaar nooit meer terug, 'maer ick hadder copie van, met mijn hant gescreven'. ${ }^{273}$

Wijns' oordeel rakkte Van Randenraedt diep, want zij beschouwde Agnes als haar voorbeeld. Bovendien had zij - nota bene op verzoek van Agnes' laatste biechtvader Simon van den Hove - een belangrijk deel van haar gewetensrekeningen afgeschreven. Het conflict over Agnes' geschriften tastte haar leefwiize, religieuze ervaringswereld, haar reputatie als geestelijke maagd en niet in de laatste plaats de inhoud van haar eigen gewetensrekeningen ernstig aan. Zij schrijft dat ze haast alle geestelijke zaken als fabels en bedrog is gaan zien. En ze neemt zich

270 PA SJ, Histonsche handschrftenverzameling, A E 23 c, Naamlijst tot 1850.

$271 \mathrm{~KB}$ Brussel, Handschnften 19073 (II), 330-331.

$272 \mathrm{~KB}$ Brussel, Handschnfien 19070, 331 (december 1645).

273 KB Brussel, Handschnfien 19073 (II), 33I. 
voor nooit meer iets te schrijven. Toch vergde, zo blijkt uit haar gewetensrekeningen, niet alleen de nagedachtenis van Agnes, maar ook haar eigen positie, dat zij stelling nam tegen de diskwalificaties van Wijns en l'Hermite. Kennelijk besefte zij dat zij hierbij omzichtig moest opereren om haar tegenspelers Wijns en l'Hermite niet te schofferen. In haar gewetensrekening van die maand doet het dilemma van het schrijven in opdracht zich in volle omvang gelden, de dimensie van het persoonlijk belang dat Joanna hierbij had incluis.

\section{Onverenigbare eisen}

De Amerikaanse hispaniste Alison Weber, die de retorische structuren in de autobiografie van Teresa van Avila onderzocht, heeft het dilemma van het schrijven in opdracht geanalyseerd. $\mathrm{Zij}$ spreekt in dit verband van een 'double bind'. ${ }^{274}$ Een begrip waarvoor een doeltreffende vertaling ontbreekt en dat daarom het best geillustreerd kan worden aan de hand van het voorbeeld van Teresa. $\mathrm{Zij}$ moest van haar leidsman haar wijze van gebed beschrijven, alsook de goddelijke genaden die haar daardoor ten deel vielen. Het was volstrekt ondenkbaar deze opdracht van haar biechtvader te weigeren. Tegelijkertijd wist Teresa ook - en dat is de kem van het dilemma - dat wanneer zij voldeed aan die opdracht, zij naar alle waarschijnlijkheid het verwachtingspatroon van haar biechtvader op een ander niveau zou bruuskeren. Als ongeletterde vrouw kon zij zich natuurlijk tegenover haar theologisch geschoolde lezerspubliek nimmer aanmatigen over de noodzakelijke kennis te beschikken om eigen spirituele ervaringen volledig te begrijpen. En dat terwijl haar positie op het spel stond, omdat de verdenking op haar rustte dat zij het slachtoffer was van diabolische misleidingen. Zelfs al kon zij haar biechtvader overtuigen dat de genaden die zij kreeg geen duivelse machinaties waren, hoe kon zij dat doen zonder zich op het voor haar verboden mannelijk domein van de theologische bewijsvoering te begeven? Weber laat zien dat voor Teresa het bewijzen van waardigheid én nederigheid de logische contradictie van de 'double bind' vormde, zeker omdat in de toenmalige context nederigheid een stille en zwijgende deugd was.

Joanna van Randenraedt maakte eenzelfde tweestrijd door tijdens het incident in december 1645 : hoe kon zij de religieuze ervaringen van haar geestelijke moeder en haarzelf verdedigen zonder inbreuk te plegen op de voorschriften van nederigheid en ootmoed, de fundamenten waarop haar identiteit als geestelijke maagd rustte? Hoe kon zij theologisch geschoolde paters jezuïeten overtuigen van de waarheid en waardigheid van de godservaringen van geestelijke maagden zonder het clericale voorrecht op de duiding hiervan aan te tasten? Joanna trachtte zich al schrijvend uit dit lastige parket te redden. Tegen Wijns aantijging dat Agnes' geschriften niets anders zijn dan vrouwenfantasieën brengt zij de autoriteit van 
twee andere geestelıken in stellıng. Volgens haar heeft Van den Hove, die Van Helsbach oorspronkelık opdroeg om te schnjven, de geloofwaardigheid van Agnes' en haar eigen ervanngen noot betwıfeld. Dat geldt ook voor Van den Hove's opvolger, Andreas Hellin. Twee mannen die door Joanna worden beschreven als 'wel soe seer ervaren ende geleert'. Hun overtuiging en steun adstrueert ze vervolgens met haar eigen standpunt dat $\mathrm{z} 1$ schraagt met de autonteit van God: 'Ende mi) docht dat men dingen die van Godt quaemen soe niet en mocht verachten (...)'. Deze voor een vrouw ongepaste aanval op het oordeelsvermogen van de beide geestelıken $W_{1 j n s}$ en l'Hermite zwakt ze vervolgens weer af door ruimte te laten voor enige twyfel over het waarheidsgehalte van de beschreven ervanngen: 'Ick geloef wel datter wel eenrege fantasien daer onder sıjn geweest (...)'. ${ }^{275}$

Joanna realiseerde zich dat haar positie als geestelı)ke maagd en moeder onder grote druk stond. Vertwıfeld probeerde zil, zoals reeds hierboven werd toegelıcht, aan de hand van richtlınen van Teresa van Avila vast te stellen of zlj door de duivel misleid was. Teresa had al geschreven dat wie genade van God ontving, van medemensen kon verwachten voor schijnheilig urtgemaakt te worden. Dat was ook precies het lot van Van Randenraedt en andere Roermondse geestelıje dochters Het conflict pakte niet gunstig uit. In julı 1646 werd hun biechtvader De Clerck overgeplaatst naar Antwerpen. Zelf brengt Van Randenraedt zı)n overplaatsing in verband met de problemen rond de geschnften van Van Heılsbach. Inmiddels had l'Hermite namelı)k het gerucht bereikt dat onder anderen Joanna gezegd zou hebben dat De Clerck omwille van zıjn geestelıke dochters veel te verduren kreeg van de rector. Joanna bestreed dit praatje in haar gewetensrekening. Durdelık is echter dat zij gedurende het incident met succes de steun van Luvinus de Clerck had weten te verwerven. Het 'goedt werck' dat zil samen waren begonnen, werd bedreigd doordat 'de waeracht1ege godtvruchtigheijt, die van soe veel weerdıege wijesse geleerde mannen voor goet ende opreght bevonden' door gebrekkug onderzoek gedıskwalificeerd werd. ${ }^{276}$

Aan de onenigheid lagen vermoedelık meningsverschillen ten grondslag over wat als ware godsvrucht gold: de uitbundige, extatische vroomheid van Van Heilsbach en Van Randenraedt tegenover een meer ingetogen godsvrucht waann uitzonderlıke ervanngen strakker gecontroleerd werden. ${ }^{277}$ Dat De Clerck de zıjde

275 Ruim een half jaar na dato echter geeft ze nogmaals haar eigen visie op dit voorval Dan oordeelt z1) - wederom scherp - dat bij de aanval van l'Hermite en Wins op Van Heilsbachs geschriften 'al wat passien' hebben meegespeeld Deze utspraak was daarom zo scherp, omdat ze beide geestelıken van beweegredenen beschuldıgt die in de toenmalıge verhoudingen als vrouwelıjk golden $\mathrm{Z}_{1 \mathrm{e}} \mathrm{KB}$ Brussel, Handschrfien 19070, 347 (Jul 1646)

276 Ibıdem, 344vo-345vo (julı I646)

277 Andere mogelı,ke motieven die aan de scherpe veroordelıng door $W_{1, n s}$ en l'Hermite ten grondslag gelegen zouden kunnen hebben, verdienen nader onderzoek In de eerste plaats zouden sommige jezuieten in Roermond beducht geweest kunnen zujn voor de opspraak de het gedrag van maagden als Van Randenraedt veroorzaakte Die zou hun eigen positie in diskrediet kunnen brengen en maakte hen kwetsbaar voor cnticı van binnen en buiten de Societelt Niet denkbeeldig is verder dat bij het 
van zijn geestelijke dochter koos, zal hem niet in dank afgenomen zijn door zijn confraters Wijns en l'Hermite. Die oordeelden wellicht dat hij te zeer onder haar invloed was geraakt. De opspraak die zij en andere jezuïeten-kloppen uit haar nabijheid veroorzaakten - en die zeker mede te wijten was aan roddel en achterklap onder hun geestelijke broeders, de jezuijeten - moest ingedamd worden. Want tot in Nijmegen deden verhalen de ronde over 'die heiliegen van Ruremundt' en waren Joanna's 'revelacien' onderwerp van gesprek. ${ }^{278}$ Het leek wel, zo merkt zij zelf op, alsof men dacht dat de geestelijke maagden 'hier alle dingen ten thoen van alle menschen had[den] willen bringen'. De in Nijmegen werkzame jezuiet Carolus Isenbaert (1595-I666) had de praktijken van de Roermondse geestelijke dochters bespot met 'een gelijkenis, ghelijck oft iemant ginck dissiplien neemen int midden van de mert omdat een iegelijck het selve sien sau (...) ${ }^{\prime}{ }^{279}$

De uitzonderlijke vroomheid van Agnes en Joanna, die niet alleen door hun daden, maar nu ook door allerlei geruchten gebaseerd op hun geschriften wijd en zijd bekend raakte, dreigde de geïnstitutionaliseerde machtspositie van hun geestelijk leidsmannen aan te tasten. Uit hoofde van hun priesterschap werden die beschouwd als de plaatsvervanger van God op aarde. De daarop gefundeerde gezagsverhoudingen tussen geestelijken en religieus geïnspireerde vrouwen werden verstoord, zodra God zelf in contact trad met een religieuze vrouw via auditieve en visuele ingevingen. Dat $\mathrm{Hij}$ zich langs die wegen aan hen kenbaar maakte, was de claim die de gewetensrekeningen van zowel Agnes als Joanna bemiddelden aan hun wederzijdse biechtvaders. De verslaglegging van hun visioenen, inspraken en droomgezichten was instrumenteel voor deze vrouwen die zich niet konden beroepen op enig ambtelijk, clericaal gezag. Maar het incident van december I645 maakt eveneens duidelijk dat het van cruciaal belang was dat hun biechtvaders hen geloofden. Was dat niet het geval, dan vormden de gewetensrekeningen en de daarin vastgelegde buitengewone gebeurtenissen maar een zeer wankele basis voor een informele gezagspositie binnen de lokale katholieke gemeenschap.

De rector van het Roermondse jezuietencollege, l'Hermite, oordeelde kennelijk dat er een strengere biechtvader dan Livinus de Clerck nodig was om religieus bevlogen vrouwen als Van Randenraedt en haar geestelijke zusters met strakke hand te begeleiden. Deze priester moest er vermoedelijk ook op toezien dat de genade die God zijn bijzondere gunstelinge Joanna bewees, niet buiten de biechtstoel de ronde deed. Zo'n strenge biechtvader was echter niet gemakkelijk te vinden in de nasleep van het incident. Joanna benaderde onder andere Adriaan Poirters met het verzoek om als biechtvader te fungeren voor haar en haar 'zusters'. Hij was zeer verlegen met haar vraag en vertrouwde haar toe, zo lezen we

oordeel van Wijns meer persoonlijke grieven tegen Van Heilsbach, die ooit zijn geestelijke dochter was geweest, een rol speelden.

278 KB Brussel, Handschrifien 19070, 346vo (juli I646).

279 Ibidem, 347. 
in haar gewetensrekening, dat hij tegen zijn confraters had gezegd:

'Ick en weedt niet watse in mij versien hebben, ick en bin geenen devoetten paetter, sij coemen bij mij tegen mijnen danck; ick en kanse niet quidt worden. ${ }^{380}$

Met grote terughoudendheid ging hij uiteindelijk op haar verzoek in, maar hij zal zeker opgelucht geweest zijn, toen hij wegens overplaatsing naar elders van deze lastige taak ontheven werd. Geestelijke leiding geven aan vrouwen wier religieuze ervaringen achterdocht wekten, kon kennelijk afbreuk doen aan de reputatie van een priester in eigen gelederen. Gegeven de omstandigheden was 'devote pater' eerder een stigma dan een aanbeveling. Het incident van december 1645 markeert in zekere zin een hoogtepunt in het wantrouwen waarmee zowel Van Heilsbach en Van Randenraedt soms bejegend werden. Deze achterdocht verklaart deels ook hun weerstand tegen het schrijven, die Huysmans zo nadrukkelijk memoreert. Van die weerstand zijn ook sporen in hun geschriften te vinden.

\section{Retorische oplossingen}

Van Heilsbach beschrijft expliciet de oorsprong van de problemen die zij met het schrijven had. Hierin zijn globaal een vijftal verschillende redeneringen te onderkennen. Soms deed zich een regelrechte tegenzin bij haar gelden om goddelijke gunsten aan een andere sterveling kenbaar te moeten maken. Alle gratie die zij van God ontving, moest 'voor der menschen oogen verborgen blijven, alleen veur Godt mijn eenich lief bekent sijn, den gever der sellever, ende den besitter van die selleve in dien die het hem gelieft te geven' ${ }^{28 \mathrm{r}}$ Angst is een tweede verklaring voor een tijdelijk gebrek aan schrijflust; angst dat zij iets zou schrijven dat niet overeenkwam met wat haar door God was ingegeven. ${ }^{2{ }^{2}}$ Wanneer zij ten prooi viel aan wat zij zelf benoemde als allerlei duivelse verleidingen en fantasieën waarover zij geen controle had, dan voelde ze eveneens een aversie om haar biechtvader door middel van haar gewetensrekeningen hierin te betrekken. Deze vorm van verzet tegen het schrijven schaarde zij onder de noemer 'duivelse tentatie'. ${ }^{283}$ Niet zelden echter ontbrak het haar letterlijk aan uitdrukkingsmogelijkheden om haar ervaring met God te beschrijven. 'Van al dat in eenen oogenblick tijts van [door] Godt in een siel gestort wort (...), ia duister ende stom moeten wij blijven, nochtans niet sonder inwendich voetsel daervan te genieten'. ${ }^{284}$ Tenslotte verzette zij zich soms tegen het schrijven hierover, omdat zij naar eigen zeggen als vrouw hiertoe niet competent was. Van een 'double bind' die het schrijven over eigen religieuze ervaringen voor vrouwen met zich meebracht, lijkt zij zich terdege

280 Ibidem, 347-355 (juli-augustus 1646)(citaat: 354vo).

28I KB Brussel, Handschriften I8984, 319vo (13 oktober ([1638?]).

282 Ibidem, 4Ivo-42vo (30 juni 1637). Frijhoff, Wegen van Evert Willemsz., 413, wijst erop dat meer zieners leden onder de angst dat hun beschrijving van goddelijke ingevingen tekort schoot.

283 KB Brussel, Handschriften 18984, 37vo-39vo (19 of 20 juni 1637).

$\mathbf{2 8 4}$ Ibidem, 88vo (29 september [1637]). 
bewust te zijn geweest. Niet aan haar, maar aan geleerden moest het schrijven daarover worden overgelaten. ${ }^{285}$ Dat neemt niet weg dat ze zelden naliet het voor haar dubbel onzegbare toch onder woorden te brengen.

Woorden ontbraken ook Joanna van Randenraedt soms om de goddelijke ingevingen of haar groot verdriet over eigen en andermans zondigheid adequaat te beschrijven. ${ }^{286} \mathrm{Al}$ zag zij haar gewetensrekeningen als een middel waardoor haar biechtvader haar streven naar religieuze perfectie adequaat kon begeleiden, toch was ze ook bang haar zieleheil in gevaar te brengen door het schrijven. Want op grond van haar geschriften hielden anderen haar voor goed en godvruchtig. Met andere woorden, haar eigen eer leek er meer mee gediend te zijn dan die van God, aan wie juist alles opgedragen zou moeten zijn. ${ }^{287}$ Sporen van verzet tegen het schrijven zijn in haar notities minder frequent en ook minder duidelijk dan in die van Agnes van Heilsbach. Pas na I643 lijkt er enige weerstand aanwijsbaar, ook al rechtvaardigde Van Randenraedt lacunes in haar verslagen door zich op haar vergeetachtigheid te beroepen. Misverstanden over het al dan niet moeten schrijven tussen Joanna en haar geestelijke vader in de jaren 1645 en 1646 zijn echter niet enkel te wijten aan communicatiestoomissen. Sinds het conflict met Wijns en l'Hermite in december 1645 lijkt Joanna meer dan ooit op haar hoede bij alles wat zij schrijft. Aanvankelijk neemt ze zich, zoals gezegd, zelfs voor nooit meer iets te schrijven, uit angst dat haar eigen gewetensrekeningen, net als die van Agnes, het voorwerp van ongeloof en spot zullen worden. Hoewel ze haar voornemen niet heeft gerealiseerd, is er in de gewetensrekeningen van na die datum een duidelijke reserve waarneembaar, die soms gecamoufleerd wordt door vergeetachtigheid of misverstanden.

In hun geschriften zochten beide vrouwen oplossingen om hun biechtvader tevreden te stellen zónder hun eigen positie in gevaar te brengen. Sommige van die retorische oplossingen doen denken aan de ontsnappingsmogelijkheden die Teresa van Avila al schrijvende voor zichzelf realiseerde: de retoriek van het toegeven en de retoriek van de nederigheid. ${ }^{288}$ In het beeld dat Teresa van zichzelf schetst, komt ze deels tegemoet aan de verwachting van haar biechtvader dat ze haar zonden en zondigheid aan hem zou belijden. Dat deed ze evenwel op een zodanige manier dat haar eigen zonden afgezet tegen andermans zonden altijd geringer lijken. Ook al bekent ze en geeft ze dus toe, Webers analyse laat zien dat het retorische effect hiervan juist defensief is. Teresa wordt genoemd als bron van inspiratie in de geschriften van zowel Van Heilsbach als Van Randenraedt. Joanna was in het bezit van Weg naar de volmaaktheid en Kasteel der ziel dat zij, zoals reeds uiteengezet, ook bij haar gewetensonderzoek gebruikte. ${ }^{289}$ In haar spirituele auto-

285 Ibidem, 3ovo (4 juni 1637).

286 Zie bijvoorbeeld KB Brussel, Handschriften 19070, I55-I55vo (maart I645).

287 Ibidem, 247 (augustus 1645).

288 Weber, Teresa of Avila, 50-64.

289 Verschueren, 'De boeken', 198 (nrs. 16 en 17 ). 
biografie memoreert zij bovendien dat zij een passage in 'het leven van de Heijliege moeder Theresa' naleest, die haar in een droom was aangewezen. ${ }^{290}$ In hoeverre er sprake was van bewuste navolging van Teresa's retorische strategieën valt echter moeilijk te zeggen.

Van Heilsbach lijkt de strategie van concessie, bewust of onbewust, in haar gewetensrekeningen dicht te benaderen. $\mathrm{Zij}$ toont zich niet alleen bezorgd om haar eigen zondigheid, maar vooral om die van anderen. Zonder zichzelf geheel vrij te pleiten heft ze in haar notities niet zelden de beschuldigende vinger op tegen personen die in haar ogen Gods geboden overtraden. Voortdurend is zij beducht voor de duivel en beschrijft hoe zij diens werkzaamheid niet alleen in zichzelf waarneemt, maar vooral in anderen. ${ }^{291}$ Met name de weduwe Botters, de vrouw met wie zij lange tijd samenleefde, moest het in dat opzicht ontgelden. Haar schetst Van Heilsbach als een geestelijke weduwe met een driftig, haast duivels temperament en wereldse verlangens. ${ }^{292}$ In zekere zin creëert ze hiermee een tegenbeeld waarbij zij zelf gunstig afsteekt. Door dit tegenbeeld in te zetten, kan zij haar eigen zondigheid belijden zonder het positieve beeld van zichzelf werkelijk aan te tasten.

De retoriek van concessie bood ook een kans om de beperkende voorschriften die voor vrouwen golden, te ontduiken of in eigen voordeel te gebruiken. Al te uitvoerige uiteenzettingen in haar gewetensrekeningen wijt Van Heilsbach bijvoorbeeld aan 'vrauwen manieren'. ${ }^{293}$ Daarmee verklaart zij de dominante opvatting over vrouwen als kletstantes op zichzelf van toepassing. Zo eist ze ruimte om te spreken op. Dat doet ze eveneens wanneer ze haar wijdlopigheid verklaart door eigen macht over haar schrijven te ontkennen: 'Want ick en heb die pen niet connen dwingen, ick en weet niet wat ick segh ofte geseidt heb', God is naar haar zeggen de auteur. ${ }^{294}$ Agnes onderschreef de heersende opvattingen over de inferioriteit en zwakheid van haar sekse. Haar beschrijvingen van andere vrouwen en metaforiek echoën misogyne opvattingen die in preken en ook kloppenboeken door geestelijken werden geventileerd. In haar gewetensrekeningen belichamen juffrouw Botters en andere geestelijke maagden dergelijke typisch 'vrouwelijke' eigenschappen. Daarmee worden zij tegenbeelden van haarzelf. $Z_{i j}$ illustreert immers dat vrouwen met 'mannelijke' moed begiftigd kunnen zijn en dat zij - zoals de kloppenboek-auteur Valentinus Bisschop S.J. het verwoordt - waar het gaat om hun zaligheid, hun 'vrouwenghedachten' kunnen verruilen voor de 'kloeckmoedigheydt

$290 \mathrm{~KB}$ Brussel, Handschriften 19073 (II), 326-327 (anno 1644). Onduidelijk is echter, zoals reeds werd opgemerkt in het vorige hoofdstuk (noot 103) of Van Randenraedt het over de autobiografie, dan wel over de vita van Teresa heeft.

291 KB Brussel, Handschriften I8984, 308-308vo (30 september [1638?]).

292 Ibidem, 343vo-344 (9 november 1638 ).

293 Ibidem, Iovo (28 april 1637 ).

294 Ibidem, 31vo (4 iuni 1637); zie ook 33vo (4 juni 1637). 
van den man'. 295 In een beschrijving van een droom uit 1638 geeft zij weer hoe zij zelf te paard met 'een grootte mannelijcke resoluci' een kar vol geestelijke dochters over een gevaarlijke weg leidt, 'gelijck eenen man te perd sittende in die perrickelen is doende, die thoemmen alle beide in sijn handen neemende, ende daer deur in bedwanck haudende'. 296 In de ogen van Van Heilsbach vormt de menselijke natuur, en die van vrouwen in het bijzonder, een obstakel voor de ware toenadering tot God. Een obstakel dat enkel weggenomen kan worden, doordat God zelf een ziel de gratie schenkt om met 'een mannelijcke volstandicheijt in alle deughden voort te gaen'. ${ }^{297}$ In haar gewetensrekeningen presenteert zij zichzelf als het levende bewijs van deze goddelijke genade. ${ }^{298}$

Van Randenraedt dacht in vergelijkbare termen over vrouwen en mannen. Anders dan haar geestelijke moeder lijkt zij juist in de spreekwoordelijke vrouwelijke zwakheid kracht gezocht te hebben om zich te handhaven ten opzichte van haar leidsmannen en de geestelijke dochters onder haar leiding. Als Christus' bruid weet zij zich verzekerd van Zijn bijstand. De retoriek van concessie is in de gewetensrekeningen van Joanna ook waarneembaar in de kwalificaties die zij zelf verbindt aan haar eigen buitengewone religieuze ervaringen. Haar beschrijvingen calculeren de diskwalificatie hiervan door haar tegenstanders in. Zij anticipeert op hun afkeuring door zich al schrijvende af te vragen of de inspraken en vertoningen geen fantasieën zijn. De door haar naar voren gebrachte argumenten van haar critici ontkracht ze vervolgens door te debiteren dat alleen God haar kan dwingen datgene, wat om verschillende redenen onzegbaar of onbeschrijlijk is, te uiten in woord en geschrift. Zo laat zij twijfelaars en tegenstanders als bıjvoorbeeld Jacob Wijns en Franciscus l'Hermite in hun waarde, terwill ze hun tezelfdertijd de wind uit de zeilen neemt. ${ }^{299}$

Een tweede strategie die Teresa van Avila toepaste om aan de 'double bind' van het schrijven in opdracht te ontsnappen, was een consequent vertoon van nederigheid. Geen gelegenheid liet zij ongebruikt om haar deemoed en verworpenheid te benadrukken. Dat Teresa haar nederigheid beklemtoont, moet volgens Weber niet gezien worden als een topos of als de gebruikelijke captatio benevolentiae die ook deel uitmaakt van geschriften van mannen. Daarvoor komen de toespelingen op eigen ellende en verachtelijkheid naar haar mening veel te frequent voor in Teresa's tekst. Deze retoriek van nederigheid vormt volgens Weber de sleutel tot de inschatting die Teresa maakte van haar eigen positie tegenover haar publiek;

295 Bisschop, Lof der Suyverheydt, II, 49-50.

$296 \mathrm{~KB}$ Brussel, Handschnften 18984, 357-358vo (28 november [1638]).

297 Ibidem, 38I ( 16 februan I639).

298 Dit geselksueerde taalgebruik is niet uitzonderly)k en evenmin specifiek voor de katholeke context. Mack, Visinary women, ro, wijst er bijvoorbeeld op dat zeventlende-eeuwse Engelse profetessen hun vrouw-zıjn in hun schnjven negeerden, terwıl zı), evengoed als mannelıjke tujdgenoten, een 'gendered discourse' bezigden

299 Zie bijvoorbeeld KB Brussel, Handschnfien 20422, 165. 
voor haar als onopgeleide vrouw, die voorwerp was van oncontroleerbare goddelijke genaden, was het winnen van de gunst van haar lezers, in het bijzonder haar geestelijk leidsman, een absolute noodzaak.

Ook van geestelijke maagden werd deemoed verwacht. Dat Van Randenraedt en Van Heilsbach hier in hun gewetensrekeningen blijk van geven, is daarom niet verwonderlijk. Hun manuscripten weerspiegelen gangbare opvattingen over de zondige menselijke inborst. $\mathrm{Zij}$ betuigen eigen nietigheid, intrinsieke slechtheid ten gevolge van de zondeval, en machteloosheid. Het beeld van God fungeert als pendant, God die oneindig barmhartig en goed is, die hun telkenmale vergiffenis schenkt voor begane zonden en hun Zijn liefde toont. ${ }^{300}$ Toch lijkt het hier om meer te gaan dan louter een conformeren aan in katholieke context heersende denkbeelden over de verhouding van de mens ten opzichte van God. Van Randenraedt en ook Van Heilsbach lijken zich door hun voortdurende vertoon van nederigheid ook terdege rekenschap te hebben gegeven van hun achtergestelde positie als vrouwen. Naar de maatstaven van hun tijd kwam hun een aan mannen ondergeschikte plaats toe en daarvan waren zij zich bewust. In haar correspondentie met andere geestelijke maagden is Van Randenraedt bijvoorbeeld aanzienlijk minder deemoedig. Zelfbewust claimt zij de leidersrol die ze vervult ten opzichte van haar 'zusters'. Maar tegenover haar biechtvader kwam het erop aan een evenwicht te vinden tussen de gehoorzame houding die van haar werd verwacht, en de zelfverzekerdheid die zij ontleende aan haar positie als intermediair tussen God, Christus en Maria enerzijds en de lokale geloofsgemeenschap anderzijds.

Beide geestelijke maagden maakten schrijvenderwijs van de nood van de aan hen voorgeschreven nederigheid als het ware een deugd. ${ }^{301}$ Met een beroep op die nederige status steunden zij hun aanspraak dat God hen uitverkoren had voor $\mathrm{Zijn}$ genade. Wat $\mathrm{Hij}$ hun ingaf, ging verstandelijke kennis te boven, maar heette 'leevende gesichten' en 'gevoullens'. Deze betekenden in feite geen aanslag op het rationele, door geestelijken beheerde domein van de theologie. Dat beide vrouwen over hun godservaringen schreven, werd gerechtvaardigd door de opdracht van hun biechtvader, aan wie zij tot gehoorzaamheid verplicht waren. Gelijktijdıg zorgde hun zelfpresentatie als nederige en gehoorzame vrouwen ervoor dat hun

300 Mogelıjk fungeert deze sterke nadruk op de eigen nıetıgheıd en machteloosheid niet enkel om de pendant, Gods almacht, te benadrukken, maar ook om te onderstrepen dat de mens God wel kan zoeken, maar dat deze zoektocht gedoemd is te mislukken zolang deze nog ingegeven is door een zekere mate van eigenbelang De mens is daardoor niet leeg en God kan niet aan hem of haar verschujnen, noch hem of haar vervullen met Zichzelf De eıgen nietigheid en machteloosheid kunnen daarom ook in positieve zin opgevat worden, namelık als de mate waann men openstaat voor Gods gratue Deze opvatung van menselıke nietigheid wordt onder meer door Teresa van Avila uirgewerkt. Zie hiervoor Blankers, 'De betekenis van genot', 38-39.

301 Hobby, Virtue of necessity, maakt van dit beeld de sleutel om het schrijven van vrouwen en hun retorische strategieen te begnjpen. Naar haar mening bood de un het zeventiende-eeuwse Engeland heersende sekse-ıdeologie vrouwen juist aangrijpingspunten om hun schnjfactuviteiten te legiumeren. 
biechtvader bereid was om naar hen, onwetende vrouwen, te luisteren. In hun notities bevestigden zij keer op keer het gezag van zijn oordeel over hun ervaringen. Maar net als Teresa schikten zij zich niet klakkeloos naar de heersende gezagsverhoudingen. Via hun gewetensrekeningen trachtten zij de bestaande autoriteitsrelatie tot hun leidsman ook te modificeren in hun eigen voordeel. Vooral Van Heilsbach probeerde dit door keer op keer te bezweren de hoogste waarde te hechten aan het oordeel van haar biechtvader, maar vervolgens steeds een eigen interpretatie te geven van haar ervaringen. Voor Teresa en vermoedelijk voor ontelbare andere religieuze vrouwen, onder wie ook geestelijke dochters als Van Heilsbach en Van Randenraedt, gold dat biechtvaders niet enkel controle-instanties waren. Biechtvaders konden ook bondgenoten zijn. Daarom vervullen de gewetensrekeningen als medium niet alleen voor de biechtvader een wezenlijke functie, maar ook voor zijn 'dochters'.

\section{IV.7 Vrouwenstemmen met goddelijke macht versterkt}

Hun kennis over zichzelf, over anderen, hun verlangens, ambities of angsten verwoordden beide vrouwen in het religieuze taal- en tekensysteem dat zij kenden uit de biecht, de omgang met hun geestelijk leidsman en misschien wel uit kloppenboeken. Deze religieuze taal, doordrenkt van negatieve zelfopvattingen en wens tot zelfopoffering was de enige taal waarin deze geestelijke dochters konden uitdrukken wie zij waren of wat zij wilden. ${ }^{302}$ Religieuze beleving en vroomheid zouden, zo is wel geopperd, domineren in de geschriften van vrouwen in de vroegmoderne tijd, omdat zij hierover konden schrijven zonder in botsing te komen met heersende normen die hun stilte in woord en geschrift voorschreven. ${ }^{303}$ Zeker, maar toch laat zich het overwicht van religieuze thematiek in de geschriften van beide geestelijke maagden niet enkel verklaren als een keuze voor onderwerpen die hen vrijwaarde van de kritiek dat zij letterlijk buiten hun boekje gingen. Religieuze taal en symboliek vormden nu eenmaal het heersende referen-

302 Deze opvatting staat haaks op de visie van Misch, Geschrchte der Autobrographre, IV,2, 745-746, die het autoblografisch karakter van religieus getante egodocumenten uit de zeventende eeuw just kleun acht, omdat de auteurs zichzelf schetsen als indıviduen die zıch wegcıferen ten gunste van God en naasten. Dat beeld strookt nuet met het individualistusche, op zichzelf genchte karakter waarvan autobıografische geschnften vanaf de achttuende eeuw zouden getuigen en dat sindsdien, ook voor Misch, als maatstaf geldt voor autobiografisch schrijven.

303 Crawford, 'Women's publıshed writings 1600-1700', 216, 221. Vgl. Dekker, “'Dat mun heve kunderen weten zouden .."', 16. Heller Mendelson, 'Stuart women's dianes', 185, concludeert dat $75 \%$ van de door haar geraadpleegde egodocumenten van Engelse vrouwen uit de tweede helft van de zeventiende eeuw een devotionele strekkung had. W/esner, Women and gender, 165-I66, stelt daarentegen dat autobıografische geschnften uit de zeventiende eeuw van zowel vrouwen als mannen een spintueel karakter droegen. Religieuze ontwikkeling en beleving waren volgens haar geen exclusieve thema's van vrouwelı)ke auteurs. 
tiekader waarin ook niet-religieuze ambities of behoeften werden verwoord en tegelijkertijd gelegitimeerd. ${ }^{304}$

\section{Onderhandelen}

Uit hun geschriften weerklinken verschillende stemmen: van God, Christus, Maria of andere heiligen, van de biechtvader, van henzelf. Die stemmen worden soms scherp gemarkeerd doordat beide vrouwen inspraken van God of andere heiligen letterlijk weergeven. Deze veelstemmigheid attendeert op een spannungsveld tussen direct door God ingegeven woorden of beelden, opdrachten van de biechtvader, en eigen verlangens, beslommeringen en angsten. Van Randenraedt en Van Hellsbach moesten enige cohesie aanbrengen in deze polyfonie om iets ervan te kunnen verwoorden naar anderen. Hoe dat gebeurde kan natuurlijk niet met zekerheid gezegd worden, maar we mogen aannemen dat zij bij hun keuzes hun persoonlijke religieuze en niet-religieuze verlangens niet volledig ondergeschikt maakten aan wat wel de hegemonie van het mannelijk vertoog wordt genoemd. ${ }^{305}$

Voor de duiding van teksten van vrouwen, die binnen een domınant patriarchale context tot stand zijn gekomen, is het concept van 'meerstemmigheld' fundamenteel. ${ }^{306}$ Met behulp van dit concept kan namelijk de dynamiek zıchtbaar gemaakt worden die er bestaat tussen de wijzen waarop vrouwen zich in vgerende patnarchale (religieuze) cultuurpatronen invoegden en tegelijkertijd middelen en wegen zochten om zich daaraan te onttrekken. Waarom religieuze vrouwen in hun doen en laten impliciet of expliciet de katholieke geloofsleer, inclusief de voor hen beperkende of zelfs onderdrukkende implicaties, onderschreven, wordt inzichtelijk als bezien wordt hoe zij binnen het heersende vertoog en de symbolische orde mee-

$304 \mathrm{Vgl}$ Gilchnst, Gender and matenal culture, die religieuze ıdeologie als referenuekader vergelıjkt met 'habitus', in de betekenıs die de socioloog Pierre Bourdieu daaraan geeft een welhaast vanzelfsprekende kennis over hoe men zich - als vrouw of man - in de eigen geloofsgemeenschap te gedragen had Showalter, 'Florence Nightungale's feminist complaint', 397, attendeert erop dat relıgieuze taal niet noodzakelykerwijs alleen in relıgieuze termen geinterpreteerd hoeft te worden Derks en Van Heıjst, 'Katholieke vrouwenculnuur', 338-339, werken Showalters suggestie nader uit E1,t, Relggeuze vrouwen, 64-77, past deze urtwerking toe in een analyse van de moteven van vrouwen die, met presters, aan de wieg stonden van twee negentiende-eeuwse zustercongregaties in Nederland 305 Le Brun, 'Die geıstlıche Biographie', stelt dat religieuze vrouwen die in opdracht van geestelıjken schreven, zıch enkel bunnen de hegemonie van het mannelık vertoog konden bewegen Fnjhoffs analyse van de zelfpresentatue van de eveneens onmondıge protestantse wees)ongen Evert Willemsz (I607-1647) laat echter zien hoe deze, net als Van Randenraedt en Van Heilsbach, tradiuonele vormen van religieuze expresue als profetieen en visioenen unzette om een eigen voorstelling van zijn levensweg utt te drukken. Zie zנjn 'Enfants saints' en meest recent Wegen van Evert Willemsz., vooral 389-429.

306 Gössmann, 'Das Gottes- und Menschenbıld', 133-34. Van Heljst en Derks, 'Godsvrucht en gender', 26-32, werken het concept van 'meerstemmigheid' uit voor histonsch onderzoek naar de relane tussen religie en sekse. Dit begnip is afgeleid van het concept 'double voiced' van de antropologen Shirley Ardener en Edward Ardener en de toepassing daarvan door de literatuurwetenschapster Elaine Showalter 
én tegenspraken. De retorische strategieën van concessie en nederigheid, het dwingend beroep op auditieve en visuele ingevingen van God, Christus of Maria, zijn variaties op een dominant vertoog die de eigenheid van Van Heilsbachs en Van Randenraedts stemmen weerspiegelen. In het religieuze denk- en handelingskader dat hun ter beschikking stond, konden zij een eigen geluid laten horen, waaraan evenwel - dat blijft onbetwist en daar waren zij zich waarschijnlijk ook van bewust - vooral gewicht werd gehecht als dit versterkt werd door andere stemmen. In hun verslagen echoden stemmen van God, Christus, Maria of heiligen mee. Dat bleek in de meer alledaagse betrekkingen met biechtvaders vaak opportuun. Hierdoor konden beide geestelijke maagden binnen de door mannen beheerste kerkelijke en maatschappelijke kaders waarin zij functioneerden, een eigen positie veroveren.

De dynamiek tussen aanpassing aan, ontduiking van en verzet tegen heersende cultuurpatronen krijgt vorm in de onderhandelingen die zij via hun gewetensrekeningen voerden met hun leidsman. ${ }^{307}$ De notie 'onderhandelen' geeft de asymmetrische (machts)positie die zij ten opzichte van hun biechtvader innamen weer zónder hen per definitie te zien als machteloze en onmondige tegenpolen van deze geestelijke. Het attendeert ons juist op andere, vaak meer informele wijzen waarop zij hun eigen visie op de wereld om hen heen, zichzelf en hun eigen belangen probeerden te doen gelden. Aan deze onderhandelingen namen Joanna en Agnes dan wel vanuit een relatieve achtergestelde situatie deel, zij waren in elk geval niet bij voorbaat kansloos. De opstelling van Van Randenraedt in december 1645 naar aanleiding van Agnes' handschriften illustreert hoe een maagd positie kon kiezen en steun probeerde te verwerven van haar biechtvader. Vertrouwend op het meer positieve oordeel van God en Zijn dienaren Van den Hove en Hellin, verwoordde zij haar mening over het waarheidsgehalte van Van Heilsbachs gewetensrekeningen. Daarmee trad zij in onderhandeling met Wijns en l'Hermite, die haar mening niet deelden.

Inzet van onderhandeling waren vooral de inspraken, dromen en visioenen, omdat daarop het informele gezag van Van Heilsbach en Van Randenraedt stoelde. Vanuit zijn ambt kon hun biechtvader de authenticiteit van deze buitengewone ervaringen staven en zo hun profetisch gezag bekrachtigen. Via hun gewetensrekeningen moesten beide maagden telkens weer bewijzen dat God en niet de duivel

307 Het navolgende is geinspireerd door het antropologische concept van 'negouatoon of reality' dat Lawrence Rosen introduceert bıj zıjn onderzoek naar de man-vrouw-relaties in hedendaags Marokko. In deze in hoge mate naar sekse gesegregeerde cultuur ontwikkelen mannen en vrouwen andere visies op en betrekkingen tot wat zı ervaren als de werkelıjkheid om zich heen $W_{a a r}$ deze uiteenlopende voorstellingen van de werkeli,kheid met elkaar botsen of te zeer divergeren om noodzakelıke overeenstemming te bereiken, treden beide 'partıjen' in onderhandelıng. Hierbij staat niet de eigen opvattıng van de realiteit ter discussie, maar het gewicht en de reıkwijdte van ieders visie in een gegeven situaue. Rosen, 'The negotiation of reality' en idem, Bargaining for reality. Vgl. Weber, 'Between ecstasy and exorcism', die spreekt over 'relıgious negotiation'. 
deze buitengewone voorvallen veroorzaakte, dat God hun het gezag verleende om direct te spreken of te handelen naar $\mathrm{Zijn}$ gebod, ook al druiste dat in tegen wat Zijn aardse plaatsvervanger hun opgedragen had. ${ }^{308}$ Voorzichtig opereren was daarbij geboden, opdat zij geen inbreuk pleegden op het voor hen ontoegankelijke voorrecht van theologische kennis. Zonder het privilege van hun leidsman op de duiding van hun ervaringen te miskennen, namen zij bij het schrijven van hun gewetensrekeningen de gelegenheid te baat om zelf de betekenis van dromen en dergelijke alvast toe te lichten. Treffend is hoe ook hier weer de strategie van concessie wordt toegepast. Op hun eigen interpretatie laten zij namelijk onmiddellijk volgen dat hun biechtvader natuurlijk beter weet wat de verhaalde gebeurtenis te betekenen heeft.

Ingevingen en gedachten die hen afleidden van de smalle, gevaarlijke maar rechte weg tot God, definiëren zij zelf al als duivelse tentaties. ${ }^{309}$ Daarmee schiepen zij een plausibel contrast tussen deze invallen en andere, die naar hun zeggen wel degelijk door God, Christus of Maria waren teweeggebracht. Dromen waaraan naar hun idee geen spirituele betekenis gekoppeld kon worden of waarvan de betekenis hun ontging, werden afgedaan als 'drolliche droemen' of 'eenen droom int wildt'. Van Heilsbach had de gewoonte om de eigen uitleg van een droom of ingeving te koppelen aan de communie. Pas nadat ze ter communie was geweest, was haar de betekenis ervan duidelijk geworden. Zo schraagde ze haar interpretatie op subtiele wijze met goddelijke autoriteit die zij op het moment dat zij de betekenis onderkende in zich droeg in de vorm van de hostie.

Behalve over oorsprong en betekenis van hun bovennatuurlijke ervaringen moesten beide maagden ook onderhandelen over het eigen regime van vroomheid. Dit samenstel van devotionele en boetvaardige praktijken werd in beginsel vastgesteld en gecontroleerd door hun biechtvader. Dat gold eveneens voor de taken die zij als geestelijke moeders tot de hunne mochten rekenen. Ook voor andere werkzaamheden - van catechisatie tot fraaie handwerken - waren zij aangewezen op de instemming van hun leidsman. Niet zij, maar hun biechtvader had formeel zeggenschap over devoties, penitenties en apostolaat die de kern van hun identiteit vormden.

\section{Bondgenoten}

Door hun gewetensrekeningen smeedden Agnes en Joanna een bondgenootschap met hun biechtvader. Via deze medestander kregen zij toegang tot de machtsverdeling in het kerkelijke domein, dat formeel het monopolie was van de kring van

$308 \mathrm{Vgl}$. in dit verband de spanning die ingevingen en opdrachten van God teweeg brachten in de gehoorzaamheidsrelatie die de Oisterwijkse begijn Maria van Hout ( $\dagger$ I547) had tot haar biechtvader. Willeumier-Schalii, 'Maria van Houts gehoorzame ongehoorzaamheid', I4I-144.

309 KB Brussel, Handschriften 18984, 28vo-39vo (19 of 20 juni [1637]). 
gewijde mannen waartoe hij zelf behoorde. Goedkeuring en instemming van de biechtvader verleende hun als religieuze vrouwen zonder kerkrechtelijk erkende status een zekere mate van bewegings- en ontplooiingsruimte. Juist dankzij de gehoorzaamheid die zij als geestelijke maagden aan hun biechtvader verschuldigd waren, hadden zij betrekkelijk veel vrijheid om zich binnen hun geloofsgemeenschap op allerlei manieren te manifesteren. Paradoxaal genoeg kregen zij recht van spreken en handelen door zich te schikken naar bestaande gezagsverhoudingen. ${ }^{30}$ Gezien het informele karakter van hun leefwijze hadden deze geestelijke maagden zelf behoefte aan controle en correctie door hun biechtvader. Aan hem konden zij zich spiegelen. Hij fungeerde als een belangrijk referentiepunt voor hun zelfpresentatie, op papier en in de dagelijkse omgang met anderen. In hun streven naar zelfheiliging, hun raison d'être, vervulden zijn reprimandes en adviezen een belangrijke functie. Zijn kennis over geaccepteerde maatstaven van vroomheid en religieuze volmaaktheid gaf ongetwijfeld richting aan hun eigen voorstellingen van een devotioneel en penitentieel regime. ${ }^{311}$

Van Randenraedt maakte haar leidsman deelgenoot van haar ambitie om 'kaude hertten ende flauwe siellen' tot hernieuwde vurige geloofsovertuiging te manen. Haar verlangen om zich omwille van het geloof en uit liefde tot God te versterven of kastijden, hield zij evenmin voor hem verborgen. Een bondgenoot zal ook Van Heilsbach vanaf haar vestiging in Roermond zeker niet onwelkom geweest zijn. Als vreemdelinge en vrouw zonder verwanten of vrienden in die stad, had zij eigenlijk alleen een band met haar geestelijke familie, de jezuïeten. Via hen, zo mogen we aannemen, breidde zij haar contacten uit tot vrouwen als de weduwe Botters en Joanna van Randenraedt. Haar geestelijke vaders konden de terughoudendheid en twijfel, die haar gedrag en ervaringen bij anderen teweeg brachten, wegnemen. Van die scepsis was zij zich terdege bewust. ${ }^{3 r z}$

Niet alleen Van Heilsbach of Van Randenraedt waren gebaat bij een dergelijk bondgenootschap, maar ook hun biechtvaders. Het aanzien dat zij genoten, kon bijdragen aan het prestige van hun biechtvaders en hun streven om het geloofsleven van de lokale bevolking op een hoger peil te brengen. Deze geestelijken hoopten misschien, zoals gezegd, via deze uitzonderlijke vrouwen zelf op een andere manier toegang tot God te krijgen. In elk geval deden de priesters, die als leidsman van beide vrouwen fungeren, regelmatig een beroep op hun voorspraak en gebed. De wijze waarop zij figureerden in dromen en droomgezichten van deze vrouwen, bevestigde dat zij als geestelijke en biechtvader een waardig instrument van God waren. Het gezag dat zij uit hoofde van hun ambt genoten, werd erdoor bevestigd. Vooral de gewetensrekeningen van Van Heilsbach bevatten daarnaast meer subver-

310 Vgl. Ranft, 'A key', die in de nauwe biechtrelatie tussen priesters en religieuze vrouwen in de vroegmodeme tijd de verklaring ziet voor de verruimde actieradius van laatstgenoemden.

3 II Vgl. Schutte, 'Per speculum in enigmate'.

312 Bijvoorbeeld KB Brussel, Handschriften I 8984, 367-368 (15 december [1638?]). 
sieve voorstellingen, waarin haar geestelijk leiderschap dat van haar leidsman lijkt te overtreffen. Daarover meer in het volgende hoofdstuk. Dat haar biechtvader Van den Hove zich van de potentieel ontwrichtende effecten van haar profetisch gezag bewust was, bewijst het expliciete gebod om met niemand behalve hemzelf over haar dromen en andere buitengewone verschijningen van God te spreken..$^{313}$ Dit gedragsvoorschrift lijkt ten dele ingegeven te zijn door angst, angst dat haar reputatie zijn positie als priester die claimde dat zijn gezag rechtstreeks van God was afgeleid, zou aantasten. Ten dele was het spreekverbod dat Van den Hove Agnes oplegde misschien ook het gevolg van zijn taakopvatting als geestelijk leidsman. Hij was medeverantwoordelijk voor de nederigheid en deemoed van de godgewijde maagden onder zijn leiding. Kwamen geestelijke maagden door hun bijzondere godservaringen in groot aanzien te staan bij anderen, dan kon dit uiteraard inbreuk plegen op hun nederige status.

\section{IV.8 Conclusie}

De gewetensrekeningen van Van Heilsbach en Van Randenraedt vertegenwoordigen een uniek type bron onder de egodocumenten. Vorm noch inhoud mag als representatief beschouwd worden voor geschriften van geestelijke maagden in Noord-Nederland. Beide schrijfsters, zo blijkt uit dit hoofdstuk, waren evenmin typerende vertegenwoordigsters van de Noordnederlandse geestelijke maagden. Maatstaf voor hun uitzonderlijkheid is onder meer het gegeven dat grote delen van hun gewetensrekeningen, spirituele autobiografieën en brieven bewaard zijn gebleven. Beide vrouwen laten zich uit hun handschriften kennen als bezielde vrouwen. Gedreven door onmiskenbaar apostolaire ambities en overtuigd van hun uitverkoren status verwierven zij een vooraanstaande plaats onder de jezuietenkloppen in hun woonplaats Roermond. Deze uitzonderingspositie stoelde in hoge mate op hun dromen, visioenen en inspraken, waarvan zij verslag deden in hun gewetensrekeningen.

Als modus van zelfpresentatie behoorden gewetensrekeningen geconcentreerd te zijn rond eigen zondigheid en spiritueel wel en wee. Het stramien van deze gewetensrekeningen werd niet volledig bepaald door richtlijnen voor het persoonlijk gewetensonderzoek, dat geestelijke maagden dagelijks in één of twee stappen behoorden te verrichten. De verslaglegging van Van Heilsbach en Van Randenraedt overtreft de aanbevelingen in enkele devotie- en dagheiligingsboeken, die in hun spirituele vorming mogelijk een rol hebben gespeeld. Korte aantekeningen die als hulpmiddel gebruikt konden worden bij de persoonlijke spirituele boekhouding, worden daarin wel aanbevolen, bijvoorbeeld door Rovenius. Van uitvoerige

313 Ibidem, 99vo-IOI (6 november [1637]); 103vo [1637]; I 20vo-I 21 (6 januari z.j)); 141-I44 ( 5 februari [1638?]). 
verslagen over eigen geloofsbeleving, buitengewone visuele of auditieve ingevingen is echter geen sprake. Dergelijke voorvallen vormen nu juist wel de hoofdmoot in de gewetensrekeningen van Van Heilsbach en Van Randenraedt. Vooral de belangstelling van hun biechtvader zal vorm gegeven hebben aan hun geschriften. Als biechtvader was deze geestelijke verplicht zich in het zieleleven van zijn penitentes te verdiepen en vast te stellen of hun buitengewone ervaringen hun oorsprong in God dan wel de duivel vonden. Naast deze meer professionele interesse hadden de geestelijken die als hun biechtvaders optraden, misschien ook een meer persoonlijk belang bij deze penitentes. Via hen kregen zij wellicht langs andere weg inzicht in Gods wil, de toestand van hun eigen zieleheil of hun functioneren als priester.

Door hun 'biograaf' worden Van Heilsbach en Van Randenraedt weerspannige schrijfsters genoemd. Maar alleen al de hoeveelheid overgeleverde manuscripten - slechts een deel van wat zij tijdens hun leven aan het papier hebben toevertrouwd - logenstraft deze voorstelling. In zekere zin modelleerde Huysmans beiden naar heersende normen die uitdrukkingsmogelijkheden voor vrouwen op schrift beperkten door deze afhankelijk te maken van supervisie en legitimatie door mannen. Door middel van deze vitae plaatste Huysmans de Roermondse maagden in een traditie van eminente religieuze vrouwen, onder wie Teresa van Avila, die in opdracht van hun geestelijke vader ervaringen en aspecten van hun geloofsbeleving aan het papier toevertrouwden. Eenzelfde opdracht stelde Agnes van Heilsbach en Joanna van Randenraedt in staat te schrijven. Beiden gaven gehoor aan deze opdracht, maar makkten zowel de handeling als de inhoud van het schrijven afhankelijk van Gods genade. Daaruit blijkt dat hun wijze van zelfpresentatie in belangrijke mate werd beïnvloed door heersende ideeën over vrouwen en vrouwelijkheid. Geen van beiden onderschreef deze noties echter klakkeloos. Door middel van hun gewetensrekeningen ondermijnden zij deze voorstellingen regelmatig door zichzelf hetzij als mannelijke maagd, hetzij als vrouwelijke bruid uit te zonderen van algemeen geldig geachte kwalificaties voor vrouwen.

Globaal kenden opvattingen van geestelijken over vrouwelijkheid en vroomheid twee polen. Sommigen beschouwden vrouwen als lichtgelovig, uiterlijk vroom maar innerlijk mogelijk schijnheilig en als zodanig een instrument van de duivel. Anderen waren juist de mening toegedaan dat vrouwen dankzij eigenschappen waarmee hun sekse begiftigd was, in staat waren tot buitengewone vroomheid. Beide polen speelden een rol in de verslagen die Van Heilsbach en Van Randenraedt voor hun biechtvaders schreven. Via vorm en inhoud probeerden zij hun leidsmannen ervan te overtuigen dat God, en niet de duivel, de bron was van hun dromen, droomgezichten en inspraken. Nauwkeurige beschrijvingen van de fysieke en mentale toestand tijdens dergelijke ervaringen verhoogden kennelijk hun geloofwaardigheid. De vraag of en hoeveel geloof we moeten hechten aan hun voorstellingen van zichzelf en hun religieuze ervaringen, heeft in dit hoofdstuk niet ter 
discussie gestaan. Nemen we de aard van de bronnen, de gewetensrekeningen, in overweging en bedenken we dat we hier te maken hebben met ervaringskaders die geestelijke maagden in elk geval tot op grote hoogte deelden met hun leidsmannen, dan lijkt de vraag naar het waarheidsgehalte zelfs irrelevant. Voor zover dat uit hun eigen notities te peilen is, moeten hun beschrijvingen van hun geloofsleven, hun uitzonderlijke ervaringen incluis, zeker geldigheid en zeggingskracht hebben gehad in kringen van geestelijken en geestelijke maagden. Onbetwist waren ze niet, zoals het incident rond de gewetensrekeningen van Agnes van Heilsbach in december 1645 illustreert.

Joanna's gewetensrekeningen van december 1645 en juli 1646 bieden als het ware een uitvergroting van de machtsverhoudingen tussen geestelijken en hun geestelijke dochters. De diskwalificatie van Van Heilsbachs persoonlijke beschrijvingen van haar dromen en andere bijzondere voorvallen door de jezuiet Wijns noopte Van Randenraedt tot verdediging, niet alleen om de nagedachtenis van haar geestelijke moeder te beschermen, maar ook om zichzelf van aantijgingen te vrijwaren. Joanna maakte gebruik van de schrijfopdracht van haar biechtvader om in haar gewetensrekeningen haar eigen visie uiteen te zetten. Bij deze verdediging deden zich tegenstrijdige eisen gelden. Om Van Heilsbach en zichzelf adequaat te verdedigen was het noodzakelijk het negatieve oordeel van Wijns te betwisten. Haar status als geestelijke maagd vereiste echter dat zij nederig en deemoedig alles verdroeg, óók hetgeen zij beschouwde als smaad en laster. Als vrouw paste haar zwijgzaamheid. Over het waarheidsgehalte van Agnes' of haar ervaringen kon zij niet spreken zonder het voorrecht van haar theologisch geschoolde biechtvaders op de duiding hiervan te schenden. Binnen dit complex van onverenigbare eisen, dat is aangeduid als 'double bind', moest Joanna schipperen tussen verwachtingen van haar biechtvader en eigenbelang.

Helemaal ongelijk had Huysmans niet, toen hij benadrukte dat Van Heilsbach en Van Randenraedt een weerstand tegen het schrijven hadden. Vertellen wat hun biechtvader wilde weten zónder hun eigen positie te compromitteren, vergde een mentale flexibiliteit waarover Van Heilsbach en Van Randenraedt doorgaans bleken te beschikken. Bewust of onbewust schiepen zij met behulp van retorische strategieën - door toegeving of door voortdurende nadruk op eigen nederigheid - ruimte voor een eigen voorstelling van zaken. Juist in de concessie aan de bestaande opvattingen over de vrouwelijke sekse lag voor beide vrouwen de opening voor een dwingende aanspraak op zeggenschap. Bestaande gezagsverhoudingen tussen henzelf en hun leidsmannen probeerden zij met behulp van hun gewetensrekeningen in eigen voordeel aan te passen. Eigenbelang speelde dus wel degelijk een rol bij het schrijven van gewetensrekeningen. Natuurlijk vormden deze geschriften voor de biechtvader een controle-medium. Maar ook van dit toezicht profiteerden beide vrouwen. Dankzij hun geschriften kon hij hun streven naar een volmaakt godsdienstig bestaan in de wereld in goede banen leiden. Kerkrechtelijk 
gezien was hun leefwijze niet erkend. Steun van hun biechtvader, in de vorm van regelgeving en controle, hield impliciet bevestiging en erkenning in. Deze erkenning verruimde de handelingsvrijheid van beide vrouwen. Bovenal konden Van Heilsbach en Van Randenraedt met behulp van deze geschriften onderhandelen. Niet alleen over de dromen en andere uitzonderlijke voorvallen waarop hun informele gezag gevestigd was, maar ook over hun religieuze regime, devoties, penitenties en werken van barmhartigheid. Ook hun status als geestelijke maagd, hun gezag als geestelijke moeder en hun gehoorzaamheid als geestelijke dochter waren inzet van onderhandeling. Welke opvattingen zij hier zelf over huldigden, wordt in het volgende hoofdstuk nader onderzocht. 


\section{$\mathrm{V}$ \\ Godsvrucht en gezag buiten kloostermuren}

Agnes van Heilsbach en Joanna van Randenraedt konden hun stem laten horen. Hiertoe werden zij in de gelegenheid gesteld door de opdracht van hun leidsman om hun bijzondere religieuze ervaringen te beschrijven. Schrijven in zijn opdracht veroorzaakte weliswaar allerlei dilemma's, maar toch konden beide geestelijke maagden hun gewetensrekeningen ook inzetten voor eigen aspiraties en ambities. Hierin onderhandelden zij als het ware over de vormgeving van hun leefwijze. Hun denkbeelden over eigen staat en status, verhouding ten opzichte van hun leidsman, andere geestelijke maagden, werkzaamheden en religieus regime, vormen de kern van dit hoofdstuk.

Beide geestelijke maagden presenteren zich in hun geschriften betrekkelijk zelfbewust als religieuze vrouwen. $\mathrm{Zij}$ beschouwden zichzelf als geestelijke zusters van de jezuïeten. Naast zelfverzekerdheid zijn er zeker ook ambivalenties en onzekerheden waarneembaar in de opvattingen die beiden over hun staat huldigden. Waaruit deze voortkomen en hoe deze van invloed waren op hun zelfbeeld en religieus leven, wordt in de eerste paragraaf verkend. De levens van Van Heilsbach en Van Randenraedt illustreren dat kloppen geenszins verstoken waren van invloed in het lokale kerkelijke domein. Hun gezag was niet verankerd in een kerkelijk erkend ambt, maar droeg een informeel karakter. Een belangrijk deel van die informele zeggenschap werd gedelegeerd door hun biechtvaders en strekte zich uit over andere geestelijke dochters. Voor hen fungeerden beide vrouwen als 'geestelijke moeders'. Hun zeggenschap over andere Roermondse jezuïeten-kloppen was altijd betrekkelijk. Instemming en toestemming van de biechtvader waren onontbeerlijk. Het informele karakter van het geestelijk moederschap noodzaakte Van Heilsbach en Van Randenraedt te onderhandelen over taken en bevoegdheden en te bewijzen dat zij het vertrouwen van hun leidsman niet beschaamden. Gezagsverhoudingen tussen 'vaders' en 'moeders' en taken van laatstgenoemden worden in de tweede paragraaf besproken. Hoe beide moeders met hun 'dochters' omgingen, wordt in de derde paragraaf aan de orde gesteld.

De kloppenstaat werd gekenmerkt door de combinatie van bidden en werken. Een combinatie die in de dagelijkse praktijk de nodige spanningen met zich meebracht, aangezien geestelijke maagden naast liefdewerken ook andere, familiale of sociale, verplichtingen hadden. Behalve deze waren er nog andere spanningen inherent aan het religieuze leven buiten het klooster, zo wordt in de vierde paragraaf uiteengezet. Bij gebrek aan een algemeen geldende regel waren Van Heilsbach 
en Van Randenraedt voor die werkzaamheden waarop hun identiteit en religieuze uitstraling voornamelijk stoelden, aangewezen op de autorisatie van hun leidsman. Een veranderende houding van deze geestelijke ten opzichte van hun activiteiten bleef niet zonder gevolgen voor hun takenpakket. Aan hun werkzaamheid waren bovendien sekse-specifieke grenzen gesteld waarover vooral Van Randenraedt zich uitsprak in haar gewetensrekeningen. Dergelijke en andere beperkingen probeerde zij, net als haar geestelijke moeder, op verschillende manieren het hoofd te bieden. Hierbij speelden verschillende vormen van al dan niet zelf toegebracht fysiek lijden en de heilige communie een rol van betekenis. Hoe deze vrouwen hieruit kracht en zelfbevestiging putten, wordt in de vijfde paragraaf beschreven.

\section{V.I 'Onsen minsten staedt'}

In het schrijven over hun eigen status probeerden Van Heilsbach en Van Randenraedt zich expliciet of impliciet te verhouden tot andere religieuze vrouwen in hun woonplaats. Er waren verschillende vrouwenkloosters in de stad: de Munsterabdij, een adellijk stift en cisterciënzerinnenklooster; de clarissen, die sinds 1614 in de stad gevestigd waren; Mariagaard, waar kanunnikessen volgens de regel van St. Augustinus leefden; Mariawee, waar dominicaanse tertiarissen woonden die in I647 werden toegelaten tot de tweede orde en bijgevolg dominikanessen werden; Godsweerd, waar reguliere tertiarissen van St. Franciscus leefden en tenslotte de ursulinen, die in 1644 een convent binnen de stad betrokken. ${ }^{1}$ Maar er waren ook vrouwen die hun religieuze bestaan geheel of gedeeltelijk buiten kloostermuren vorm gaven, zoals begijnen. ${ }^{2}$ Daamaast waren er zwartzusters die zich bezig hielden met ziekenverpleging, in het bijzonder de zorg voor pestlijders. Hoewel zij wel drie geloften aflegden, werden zij niet als kloosterlingen beschouwd, omdat zij uit hoofde van hun werkzaamheden de clausuur niet konden onderhouden. ${ }^{3}$ En er waren ook geestelijke maagden, zo merkte Agnes van Heilsbach bij haar bezoeken vanuit Wassenberg aan de jezuietenkerk in Roermond. Tegen het einde van de zeventiende eeuw waren er niet alleen jezuïeten-kloppen in de stad, maar ook geestelijke dochters van de derde orde van St. Franciscus, ${ }^{4}$ en kloppen van

I Pyls, 'Roemonds kloosterleven'. Anno 1663 leefden er iets meer dan I50 religieuzen in deze kloosters. Zie Hamans, Geschiedenis, 167.

2 Habets, Geschiedenis, III, 720-721; Pyls, 'Roermonds kloosterleven', 197-198.

3 Cornelissen, "Relationes", 53 (anno 1619), 72 (anno 1627).

4 GAR, Archief Hoofdgerecht Roermond, inv.nr. 320 (f. 186vo-187; 3 juli 169I) en inv.nr. 321 (f. 87-94; 14 juli 1696): Margriet Beeck; ibidem, inv.nr. 320 (f. 170-173; Io april I69I) en inv.nr. 32 I (f. 5vo-6; I9 februari 1694): Ida Dirks (Dirrix). Beide vrouwen hadden overigens (financiële) banden met de jezuieten ter plaatse. RAL, Archief Jezuieten-college Roermond, port. 3043, nr. 25 [overzichten van de aflossing van leningen die het Roermondse college bij Margriet Beeck had uitstaan, I686-I687; I687I693; kopie testament Margriet Beeck, 30 juni I691]. Ibidem, port. 3043, nr. 5 [verschillende obligaties op naam van Ida Dirclo, 1686, I688, afgelost 15 februari 1690]. 
Afb. I7 Stadskaart van Roermond van Herman fanssens (omstreeks I67I).

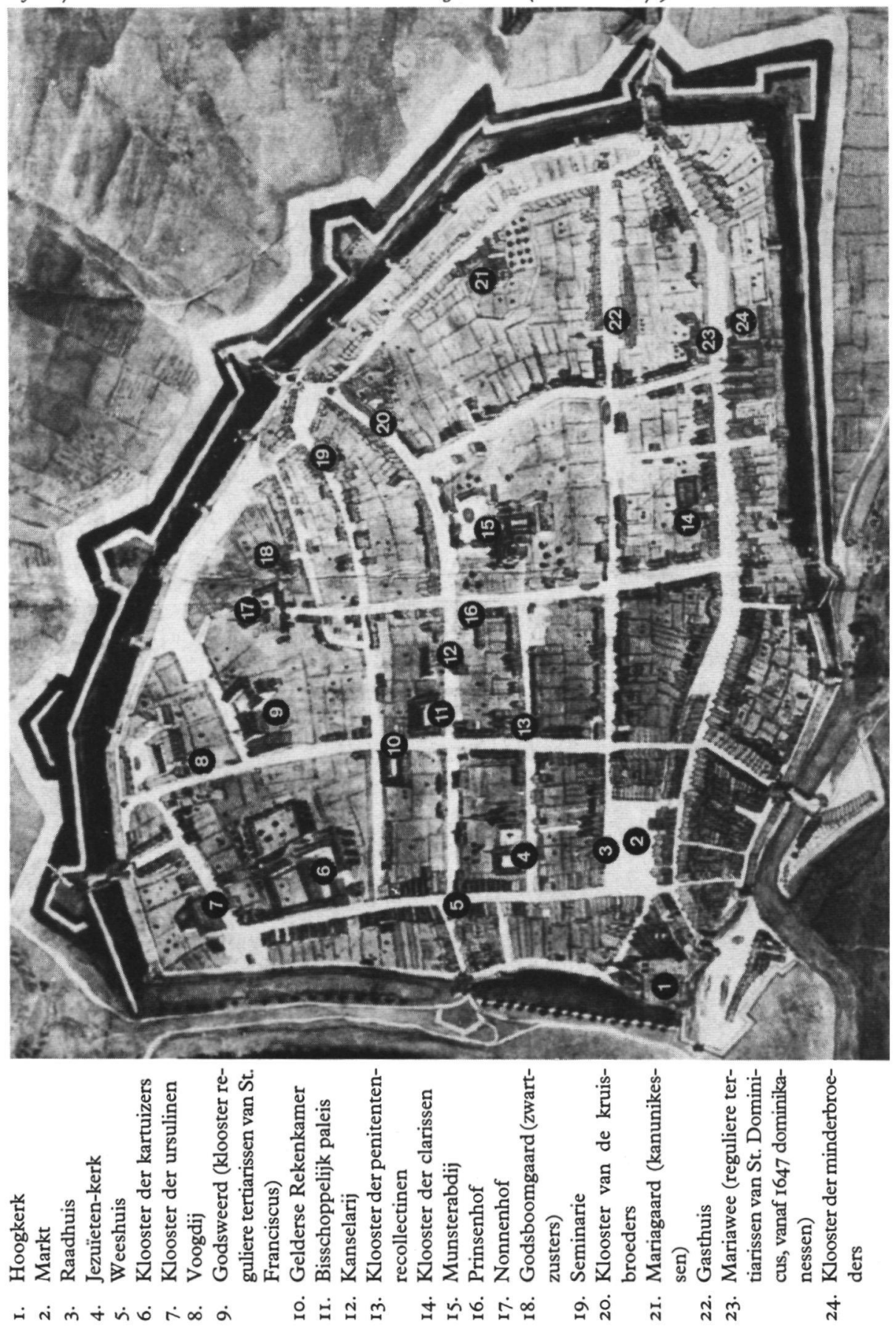


wie niet duidelijk is of zij onder geestelijke leiding van seculiere dan wel reguliere priesters stonden. ${ }^{5}$ In hun zelfverstaan en vormgeving van hun leefwijze waren deze lokale geestelijke maagden misschien geïnspireerd door Van Heilsbach en Van Randenraedt.

\section{Geestelijk zelfverstaan}

Wie de evangelische raden van armoede, gehoorzaamheid en kuisheid onderhoudt, verdient het predikaat ' $g$ eestelijk', zo betoogt de wereldheer Joannes van Heumen in zijn kloppenboek Clooster van Sion. ${ }^{6}$ Ook de jezuïet Valentinus Bisschop rangschikt kloppen onder de 'gheestelijcke personen' in Lof der Suyverheydt.' De toeschrijving 'geestelijk' aan vrouwen die een religieus bestaan buiten het klooster leidden, kwam ook elders voor in de vroegmoderne tijd. Keulse devotessen, die aangesloten waren bij het Ursula-gezelschap, riepen, zoals in het eerste hoofdstuk is toegelicht, associaties op met de seculiere clerus. Op grond van de combinatie van de ongehuwde staat, specifieke religieuze rituelen en werkzaamheden in onderwijs en catechese, werden deze vrouwen door tijdgenoten tot de geestelijke stand gerekend, hoewel dat in kerkrechtelijk opzicht geen hout sneed. In de Nederlandse versie van zijn kloppenboek De Leeder facobs gebruikte de seculiere priester Joannes Lindeborn de omschrijving 'wereld-geestelijke maagden'. Vertolkte hij met dit neologisme een zelfverstaan waarvan geestelijke maagden al langer blijk gaven?

Agnes van Heilsbach maakt in haar gewetensrekeningen expliciet verschil tussen religieuze, geestelijke en wereldlijke personen. De omschrijving 'religieus' reserveert zij voor kloosterlingen, mannen en vrouwen. Tot de wereldlijke personen rekent zij alle leken. Hiervan zondert zij zichzelf en andere geestelijke dochters echter uit, hoewel zij kerkrechtelijk gezien zeker in die categorie thuishoren. Naar haar idee behoren zij en haar geestverwanten tot de 'geestelijcke persoenen'. ${ }^{8}$ De eisen die er voor geestelijke en religieuze personen gelden, wijken volgens haar niet van elkaar af. Van Heilsbach noemt beide categorieën dan ook vaak in één adem.9

5 GAR, Archief Hoofdgerecht Roermond, inv.nr. 320 (f. 73-73vo; 9 augustus I689): Jenneken van Stockem; inv.nr. 320 (f. I88-188vo; 20 juli 1691): Geertruijt Catharina Smabers; inv.nr. 320 (f 266; 21 meart 1692): Maria Buggenum; inv.nr. 320 (f. 337; 2 oktober 1693): Geertruijd Maria Cloots; inv.nr. 321 (f. 27v0-28; I I oktober I694): Ida Thomassen; inv.nr. 32I (f. 33vo-35vo; 2 april I695): Margariet Waels; inv.nr. 321 (f. 94vo-95vo; 17 juli 1696): Catharina Melchiors; inv.nr. 321 (f. 104; 7 september 1696): Hendrickje van Ool [vermoedelijk een jezujeten-klop]; inv.nr. 32 I (f. IO6vo-Io8vo; 3-4 oktober 1696): Maria Catharina van Haelen; inv.nr. 321 (f. I56vo-r 57vo; ig juli 1697): Catharina Teresia Claessens. Met dank aan de heer O.J. Nienhuis van het gemeentearchief Roermond.

6 Zie hiervoor III.3.

7 Bisschop, Lof der Suyverheydt, III, 13.

8 Zie bijvoorbeeld KB Brussel, Handschriften 18984, 157vo (27 februari 1638); 237 vo (12 december [1637]).

9 Ibidem, 144-145Vo (5-6 februari [1638]). 
Opmerkelijk is dat zij priesters, onder wie de jezuieten, ook als geestelijke personen benoemt. In dat opzicht tekent zich een parallel af tussen haar opvatting en het beeld en zelfbeeld van de leden van het Keulse Ursula-gezelschap. Het onderscheid dat Van Heilsbach maakt tussen geestelijk en religieus zou gelegen kunnen zijn in het actief, apostolair karakter van de leefwijze van priesters en geestelijke maagden als zij zelf enerzijds, en de meer contemplatieve aard van het leven van mannelijke en vrouwelijke religieuzen anderzijds.

Joanna van Randenraedt maakt een tweedeling tussen geestelijke en wereldlijke personen. ${ }^{\circ}$ Ook zij noemt zichzelf en andere kloppen geestelijke personen. Enkele jaren nadat zij definitief voor een leven als geestelijke maagd had gekozen, werd zij gevraagd naar de status van haar leefwijze. Dit gebeurde tijdens het inzamelen van aalmoezen voor zieke militairen die gedurende de Staatse bezetting in de stad gelegerd waren." In haar spirituele autobiografie schetst Van Randenraedt de deplorabele toestand waarin deze manschappen verkeerden; honger en ziekten bedreigden hen. ${ }^{12}$ Een hooggeplaatste officier, de 'grootten meester vande artiellerie', kon Joanna's actie niet goed rijmen met de religieuze uitstraling, die vermoedelijk van haar sobere dracht in combinatie met haar jeugdige leeftid uitging. 'Hij vraeghde mij oft ick een Religieusse was; ick seijde neen, maer inde weerelt een geestelijck leven leefden, meede tot dienst van mijnen Eevenaesten om die in haere aermoede ende noet bij te staen; hij vraegden oft ick gelofte van Eeuwiege suijverheijt hadde gedaen, ick seijde iae, van over Eeniege iaeren [een paar jaar geleden], want ick docht, spreeck ick niet claer wt, men mochte peissen [menen] dat ick eenen man quaem soecken'. ${ }^{\text {I3 }}$

Van Randenraedt definieert haar leefwijze als een geestelijk leven in de wereld. Ze benoemt zichzelf uitdrukkelijk niet als religieuze. Evenmin beschouwt zij zich als een gewone lekevrouw en zij wil vermijden dat men denkt dat haar leefwijze niet meer dan een intermezzo is, dat duurt zolang zij nog geen geschikte huwelijkspartner heeft gevonden, een vooroordeel dat onder tijdgenoten van de kloppen beslist niet ongebruikelijk was. ${ }^{44}$ De geldigheid van de gelofte van zuiverheid, die

Io $Z_{1 j}$ maakt eenzelfde onderscheid nog eens uitdrukkelijk in de tweede versie van haar spintuele autobiografie KB Brussel, Handschrifien I9073 (II), 128.

II Het betreft Franse troepen, die krachtens een allanueverdrag met Lodewik XIII het Staatse leger steunden Jappe Alberts, Geschredenis, II, 4-5

12 KB Brussel, Handschnfien 19073 (I), 189-196 Misschuen was het aan het voorbeeld van Joanna - gestumuleerd en gesteund door Agnes - te danken dat een dergelıjke inzamelingsacue door geestelıke maagden en gehuwde dames van stand na afloop van de Staatse bezetrng nogmaals plaatsvond, ditmaal min of meer onder toezicht van de paters jezuieten en ten behoeve van de soldaten des konings die in de stad gelegerd waren PA SJ, Histonsche handschnftenverzameling, doos $155, \mathrm{C}_{38} \mathrm{j}$, Lutterae annuae collegu Ruraemundensis S J., anno 1637.

13 KB Brussel, Handschrften 19073 (I), 192-193.

14 Zo noemt de veelschrijver Simon de Vnes, die niets op had met het katholıcisme, kJoppen vrouwen die 'haer kansje verkeken hebben, ofte niet knjgen konnen dien sy geerne hadden'. Geciteerd door Baggerman, Een drukkend gewicht, 71 . 
zij naar eigen zeggen gedaan heeft, is beperkt. In formeel kerkrechtelijke zin moet zij als een persoonlijke belofte beschouwd worden, die stoelt op Van Randenraedts eigen intentie en de gewetensdwang die daaruit voortkomt. In beginsel is zij vrij deze gelofte aan God te breken. Maar het private karakter van de gelofte vergt dat wanneer zij dat doet, zij dat tegenover God en voor haar eigen geweten moet verantwoorden.

Het geestelijk zelfverstaan van Van Heilsbach en Van Randenraedt berustte vooral op hun identiteit als bruid van Christus. De sekse-specifieke invulling van het bruidschap impliceerde dat vrouwen een positie in Gods directe nabijheid konden bekleden. Van Heilsbach en Van Randenraedt waren ervan overtuigd dat zij als bruiden deelden in de genade van hun Bruidegom. Dit kon dankzij de voorspraak van Maria, de Moeder Gods, die zij als hun patrones beschouwden. ${ }^{\text {Is }}$ Christus gaf hun de kracht om inderdaad dapper en onverzettelijk te volharden in hun geestelijk leven. "Want die schatten die den Brudegom heeft coemen ock die bruidt toe als haer aeijgen, ende dat deur die gunst des Brudegoms (...)', aldus Van Heilsbach. ${ }^{16}$ In de dromen en visioenen toonde haar Bruidegom dat zij deelde in het kostbaarste geschenk dat Hij de mensheid had gedaan, de verlossing. Haar wil moest de Zijne zijn, opdat Zijn macht de hare werd. ${ }^{17}$ Ook Van Randenraedt beschouwde $\mathrm{Zijn}$ macht als de hare, waarover zij enkel kon beschikken wanneer ze handelde in overeenstemming met Zijn wil.$^{18}$ Eigenzinnigheid en eigenwilligheid zagen beide maagden als ongeoorloofde opstandigheid. In theorie keurden zij dergelijke rebellie af. In de praktijk waren zij zelf regelmatig ongehoorzaam aan hun biechtvader, naar wie zij als Gods aardse plaatsvervanger moesten luisteren. Zelf zagen zij dat anders, omdat zij gehoorzaamheid aan de Vader of de Zoon altijd lieten prevaleren boven die aan hun leidsman. Uit de aanspraak op de status van bruid spreekt een gevoel van gelijkwaardigheid. Hoewel geen van beide vrouwen loochende dat zij aan hun biechtvader ondergeschikt waren, waren zij er op grond van hun geestelijk zelfverstaan toch van overtuigd een uitzonderingspositie onder de gelovigen te bekleden. Deze claim bekrachtigden zij door zichzelf niet alleen als geestelijke dochters, maar ook als geestelijke zusters van de jezuieten te presenteren.

\section{'Fezuitinnen'}

Aan de stichting van verschillende religieuze vrouwengemeenschappen in de vroegmoderne tijd lag het verlangen ten grondslag een vrouwelijk gezelschap als tegenhanger van de Sociëteit van Jezus op te richten. Onder andere Mary Ward en Alix

I5 KB Brussel, Handschriften I8984, 383vo [1 maart 1639].

16 Ibidem, I98vo (29 april [1638]).

17 Ibidem, 27I (30 juli [ 1638 ?]).

$18 \mathrm{~KB}$ Brussel, Handschriften I9070, 281-282 (september I645). 
le Clerc, die al ter sprake zijn gekomen, zagen zichzelf als vrouwelijke pendanten van de jezuieten. Stonden de jezuïeten onder de bescherming van Jezus, religieuze vrouwen als Ward en Le Clerc beschouwden Maria expliciet als hun patrones. ${ }^{19}$ In de levens van Agnes van Heilsbach en Joanna van Randenraedt speelde Maria eveneens een belangrijke rol als beschermvrouwe en inspiratiebron. En zij voelden zich in spiritueel opzicht nauw verwant met de jezujeten, die het geloofsleven in Roermond nieuwe impulsen gaven vanuit een duidelijk contrareformatorische inspiratie. De paters ijverden op allerlei manieren voor een intensivering van de godsvrucht onder de Roermondse bevolking. Agnes van Heilsbach en Joanna van Randenraedt vonden het vanzelfsprekend dat zij als geestelijke maagden onder leiding van de jezuieten hun streven naar verdieping van de vroomheid onder gelovigen steunden.

Van Heilsbach beschouwde zich, zo zouden we kunnen zeggen, als 'jezuïtin': een vertegenwoordigster van de vrouwelijke tak der Sociëteit van Jezus die zij aan zij met haar geestelijke broeders vocht voor de verbreiding van het katholieke geloof. Waren de paters jezuïeten zonen van hun heilige vader Ignatius, ${ }^{20} \mathrm{zij}$ zag zich als een dochter van deze ordestichter. In 1638 , één dag voor de feestdag van Ignatius, 31 juli, kreeg zij een visioen in de jezuietenkerk, nadat ze ter communie was geweest. ${ }^{21}$ Het tijdstip voor dit visioen was misschien niet toevallig. Haar verbeeldingskracht kan gestimuleerd zijn door een vlammende preek over de heilige ordestichter, wiens feestdag doorgaans met veel luister werd gevierd. ${ }^{22}$ In het visioen dat Van Heilsbach beschrijft, ziet zij in een soort bliksemflits hoe zij de rechterhand van de heilige Ignatius pakt. Die spreekt tot haar: 'Staedt op mijn dochter, volght mij'. Zij gehoorzaamt en volgt hem - in het beeld dat haar voor ogen komt - tot in het hart van God de Vader.

De overtuiging van gelijkwaardigheid tussen de zonen van Ignatius en hun geestelijke dochters, die uit deze passage spreekt, maakte Van Heilsbach via haar gewetensrekeningen vaker kenbaar aan haar geestelijk leidsman. $Z \mathrm{ij}$ verheelde niet dat Ignatius' zonen en dochters verschillende bevoegdheden en taken hadden. Dit inzicht tastte echter haar overtuiging niet aan dat ook de dochters bijdroegen aan de bekering van de wereld. $\mathrm{Zij}$ zag de paters en hun geestelijke dochters als elkaars complement. Een visioen dat zij in 1637 in een gewetensrekening opnam, maar dat naar eigen zeggen twaalf jaar eerder had plaatsgevonden, verbeeldt deze complementariteit. ${ }^{23} \mathrm{Ze}$ zag hoe de vijand, oftewel de duivel, een net had getrokken over de hele wereld om er de zielen van de mensen in te vangen. Ignatius en zijn zonen verscheurden dat net. Ook zij zelf 'scheen meede te helpen die siellen der menschen in sijn [Ignatius'] net te vangen'. Dit visioen verklaarde, zo schrijft zij,

19 Conrad, Zwischen Kloster und Welt, 70 (noot 22).

20 In de jaarbrieven van het Roermondse college wordt over Ignatius als vader gerept.

21 KB Brussel, Handschriften 18984, 270-271vo (30 juli 1638).

22 Vgl. Poncelet, Histoire, I, 463-470; II, 364.

$23 \mathrm{~KB}$ Brussel, Handschriften I8984, 78-78vo (vermoedelijk 30 juli [1637]). 
haar diepgevoelde behoefte om haar naasten, kinderen én volwassenen, aan te sporen, ja zelfs te dwingen, zich aan God te onderwerpen. Geestelijke dochters van de jezuieten deden volgens haar in werkzaamheid en slagvaardigheid niet onder voor hun 'vaders'. In typisch contrareformatorische beeldspraak schetst zij het verloop van een processie waarover zij gedroomd heeft. De jezuïeten marcheren als 'geestelijcke soldaetten' onder leiding van 'Capitein Christus', present in het Heilig Sacrament dat wordt gedragen in een rijk versierde monstrans. In de processie-stoet bevonden zich tevens 'bruitten van den Alderhoeghsten', de geestelijke maagden. $\mathrm{Zij}$ hielpen mee in de geestelijke strijd, 'oorlogh voerende'. En net als de geestelijke soldaten volgden zij in de voetsporen van Christus, die hun was voorgegaan. ${ }^{24}$

Van Heilsbach was bij tijd en wijle een opstandige dochter van Ignatius en zijn volgelingen. Loftuitingen aan het adres van de ordestichter ter gelegenheid van de viering van zijn geboortedag veroorzaakten in 1637 sterke weerstand bij haar. ${ }^{25}$ Haar lichamelijke condicie liet zeer te wensen over; in haar gewetensrekening schrijft zij dat ze overal pijn heeft en bang is dat ze koorts heeft. Ze vreest dat ze de feestdag van Ignatius niet naar behoren zal kunnen vieren. Wanneer haar biechtvader begint aan een lange opsomming over de deugden van 'onsen $H$. Vader', voelt zij inwendig verzet. Dat groeit wanneer Joanna van Randenraedt iets over de gehoorzaamheid voorleest uit het werk van Ignatius. Agnes tekent aan dat zij haat voelde jegens Ignatius en allen die hem waren nagevolgd. Die haat gaat zover dat zij, naar zij schrijft, zijn leer en zijn volgelingen zou willen 'verniellen' als ze daartoe bij machte was, opdat er op aarde en in de hemel geen 'gedachtenisse' meer van hem bestond. Dit van haat doortrokken verlangen naar de damnatio memoriae van Ignatius van Loyola wijt zij zelf aan duivelse ingevingen. Zij probeert deze het hoofd te bieden door zich er niet tegen te verzetten, maar ze te zien als een bron voor zelfvernedering. Euforische bespiegelingen over de wapenfeiten van Ignatius en de zijnen en een duidelijk jezuïtisch zelfbeeld hadden een tegenhanger in een intense haat tegen deze geestelijken. Wijst een dergelijke uitbarsting er misschien op dat Van Heilsbach in haar doen en laten weerstand van haar 'broeders' ondervond? De precieze aanleiding is uit haar gewetensrekeningen niet te reconstrueren. Voortdurend gehoorzaam en nederig zijn was misschien wel een té grote opgave voor een vrouw die zichzelf als dochter van Ignatius en zuster van zijn volgelingen beschouwde.

Ook Joanna van Randenraedt noemde zichzelf een 'levende litmaet vande Societeit'. Net als Van Heilsbach beschouwde zij de jezuïeten als haar 'geestelijcken

24 Ibidem, II4 ( 12 juli z.j.). Militaristische metaforen zijn kenmerkend voor bespiegelingen over het geestelijk leven ten tijde van de Contrareformatie. In de jaarbrieven van het Roermondse college worden jezuïeten ook wel omschreven als 'soldaten'. Het beeld van het geestelijk leven als een strijd, die een geestelijke maagd als een dappere soldaat moet leveren onder leiding van haar kapitein, in de persoon van haar leidsman, wordt bijvoorbeeld ook gebruikt door Bisschop, Lof der Suyverheydt, III, 13.

25 KB Brussel, Handschriften 18984, 76-77 (vermoedelijk 30 juli [1637]). 
broeders' ${ }^{26}$ en Ignatius als haar heilige vader. In een gewetensrekening van 30 juli 1647, aan de vooravond van de geboortedag van deze heilige, noteert zij dat zij zich 'sot' en 'kienderlijck' voelde ten opzichte van hem. Ignatius en zijn zonen vormden de bron waaruit God gelovigen als Joanna liet delen in Zijn genade. '(...) Ick voulde mij gevought in godt mijnen $\mathrm{h}$. Vader als een kient aen sijns moeders borst wt welcke borst de heel societeit ende ick deur hem [Ignatius] wt godt deur sijne soenen [zonen: de jezuïeten] mede, ende kinderen ons geestelijck voudtssel hadden ontfangen, och wonderlijcke borst, godt in hem [Ignatius] ende hem in Godt'. Met Gods hulp wilde Van Randenraedt proberen de hele Sociëteit en alle zielen 'in godt, in dat lieffelijcke soch in die wtnemende borst te verdrincken', opdat zij hemieuwd en vol vuur de lieve Heer zouden dienen. ${ }^{27}$ Haar jezuïtisch zelfverstaan maakt ook begrijpelijk waarom zij zich in december 1645 zo gekwetst voelde, toen Jacob Wijns een negatief oordeel uitsprak over de inhoud van de geschriften van Van Heilsbach. Joanna beschouwde dit incident, dat in het vorige hoofdstuk reeds uitvoerig ter sprake is gebracht, als een aanval op de nagedachtenis van haar geestelijke moeder en op haar eigen positie als geestelijk leidsvrouw van de jezuïeten-kloppen in Roermond. Wijns' diskwalificatie van Van Heilsbachs' ervaringen kwam hard aan bij Van Randenraedt, omdat deze van een zoon van 'vader' Ignatius afkomstig was met wie zij zich 'ingelijfd' voelde als een lid van een lichaam. ${ }^{28}$

Mogelijk bekrachtigden de biechtvaders van beide maagden in hun geestelijke leiding dat zij geestelijke dochters van de stichter van Sociëteit van Jezus waren. Een bijzonder blijk van bevestiging van haar status als jezuieten-klop ontving Van Randenraedt in augustus I64I. Op verzoek van Simon van den Hove verleende de generaal van de orde haar toestemming voor de dagelijkse communie. Sinds de heilige Maagd Maria haar op elfjarige leeftijd in een inspraak had gevraagd of zij voortaan dagelijks ter communie wilde gaan, had Joanna geprobeerd hieraan gevolg te geven. ${ }^{29}$ In de jezuïeten vond zij biechtvaders die ijverden voor de frequente communie. ${ }^{\circ \circ}$ In 1637 introduceerden zij de generale communie in Roermond. Iedere eerste zondag van de maand werden alle gelovigen, ongeacht tot welke parochie zij behoorden, bij de misviering uitgenodigd om de communie te ontvangen. ${ }^{31}$ Dit gebruik had elders reeds ingang gevonden. ${ }^{32}$

Al waren de jezuïeten voorstanders van de veelvuldige communie, een frequentie

26 KB Brussel, Handschriften 19070, 35I (juli 1646).

27 GAR, Handschriften I A 9 (ongepagineerd).

28 KB Brussel, Handschriften 19070, 325vo (december 1645).

29 KB Brussel, Handschriften 19073 (I), 27, 29.

30 Poncelet, Histoire, I, 425; II, 352. Van Hoeck, Schets, 225-226.

3I PA SJ, Historische handschriftencollectie, doos I55, C 38 j, Litterae annuae collegii Ruraemundensis S.J., anno 1637.

32 Poncelet, Histoire, $\Pi, 351$. Het gebruik van de generale communie was in 1609 te Rome ingesteld. Het werd in de Vlaamse provincie van de Sociëteit, waartoe Roermond behoorde, rond I63o ingevoerd. 
van meer dan eens per week stuitte bij hen doorgaans op verzet. ${ }^{33}$ Van Randenraedt ondervond dat eveneens, zoals in het verloop van dit hoofdstuk nog aan de orde zal komen. Om toch dagelijks ter communie te kunnen, moest Joanna toestemming van haar biechtvader hebben. Aangezien dagelijkse communie voor Van Randenraedt uitermate belangrijk was, besloot Van den Hove om toestemming te verzoeken van de generale overste, Mutius Vitelleschi. ${ }^{34}$ Vitelleschi gaf Van den Hove verlof om naar zijn goeddunken aan 'nobili illi Ruraemondanae virgini' (deze eerbiedwaardige maagd uit Roermond) toe te staan dagelijks ter communie te gaan, wanneer duidelijk was dat zij anderen [in godsvrucht] overtrof; dit echter op voorwaarde dat dit [haar dagelijkse communiegang] niet leidde tot navolging door anderen. ${ }^{35}$ Van den Hove stuurde de goedkeuring met uitleg door aan Joanna en schreef eronder: 'U. L. is die Dochter, vande welcke in desen zijnder brief tot mij is schrijvende onsen seer Eerweerdighen Pater Generael Mutius Vitellescus'. Voor een klop die zichzelf als een 'dochter' van Ignatius en een 'zuster' van de jezuieten beschouwde, betekende deze brief van de generaal van de orde wellicht een vorm van erkenning.

\section{Ambivalenties}

Uit het jezuïtische zelfverstaan en het bruidschap spreekt zelfvertrouwen. Toch getuigden beide geestelijke maagden in hun geschriften ook van onzekerheid ten aanzien van hun staat. De oorsprong van deze twijfels moet gezocht worden in de onduidelijke status van de kloppenstaat. Voordat Van Randenraedt besloot geestelijke maagd te worden, uitte zij haar zorg al over de merites en de vormgeving van deze leefwijze. Het geestelijk leven buiten kloostermuren was in mentg opzicht kwetsbaarder dan het kloosterleven. Blootgesteld aan de verlokkingen van de wereld liep zij als geestelijke dochter meer risico om te zondigen dan een kloosterzuster. Vooral de vraag of deze alternatieve geestelijke route na de dood in zaligheid zou uitmonden, hield haar bezig. De nagestreefde zaligheid zou gewaarborgd worden door het onderhouden van armoede, gehoorzaamheid en kuisheid, maar hoe zij als geestelijke maagd deze evangelische raden moest implementeren, was haar niet geheel duidelijk. ${ }^{36}$

33 Vgl. ibıdem, 347-350: sommige godvruchtige personen, onder whe voomamelijk vrouwen, whlden vaker ter communie. Hun biechivaders zagen zich genoodzaakt aan deze behoefte enigszins tegemoet te komen om geen weldoensters en toegewhje gelovigen te verhezen.

34 Van den Hove was inmiddels overgeplaatst naar Kortujk, maar hueld schrftelık contact met Joanna en fungeerde als haar geestelıjk leidsman.

35 De aan Van den Hove genchte bnef, waann de goedkeunng wordt uitgesproken, is bigebonden in KB Brussel, Handschriften I9073 (II), tussen 70 en 71 . De betreffende passage luidt letterlujk.

'Permitto R[everentae] V [estrae] ut arbitratu suo nobly illı Ruraemondanae Vurgun quando Illam habet prae alıs perspectam, quotidianam Communionem concedat, ea tamen cautione, ne fiat alıs ad aemulationem.' Met dank aan drs. Saska Stegeman voor haar hulp bij de vertalıng van deze zinsnede. 36 GAR, Handschriften II B 1, 26-29. 


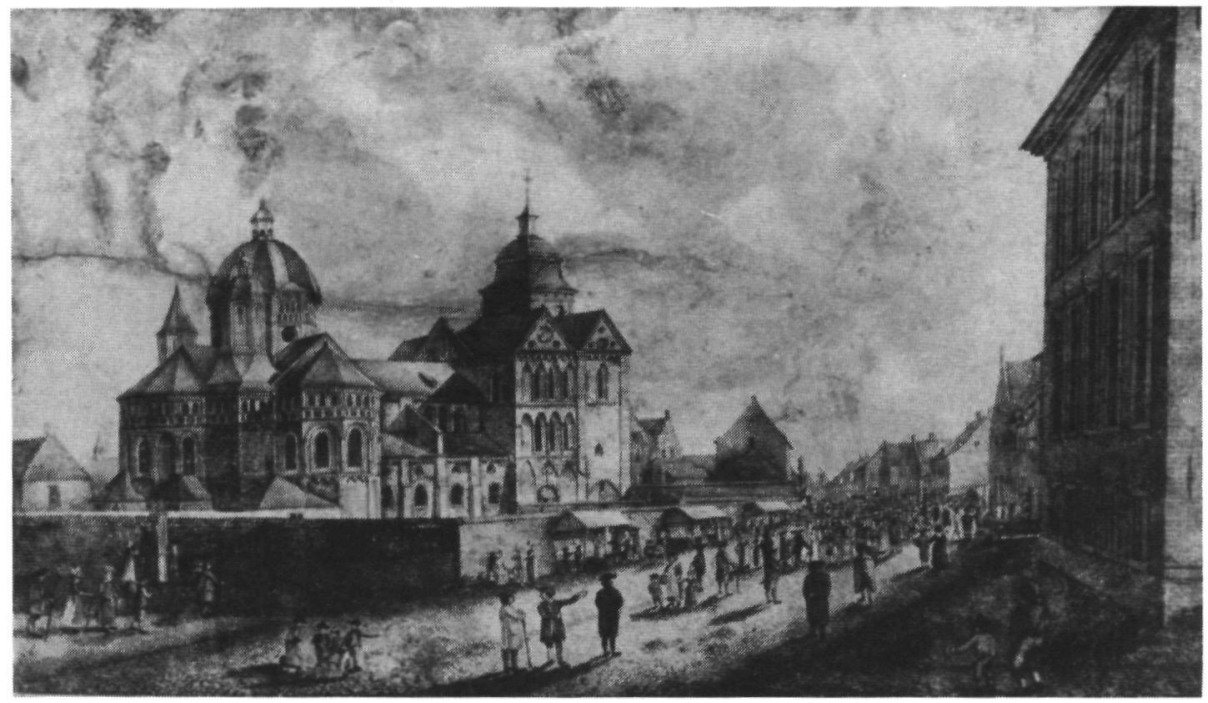

Afb. I8 Gezicht vanuit het noordoosten op de Munsterkerk te Roermond.

In haar spirituele autobiografie uit Joanna van Randenraedt de behoefte aan houvast, aan een regel en aan de verzekering dat het naleven ervan haar streven naar zelfheiliging zou bevorderen. $\mathrm{Zij}$ makkte zich zorgen over de 'meerder vrijichheijt' (...) als de Religieussen inde gehoorsaemheijt' die zij meende te hebben, omdat ze geen gelofte had gedaan. Vermoedelijk om haar zorg enigszins weg te nemen gaf haar toenmalige biechtvader haar toestemming om een belofte van gehoorzaamheid te doen aan de priorin van de Munsterabdij, Catharina di Ortigosa, die enige tijd als haar geestelijk leidsvrouw fungeerde voordat Joanna volledig onder Agnes' hoede kwam. Joanna deed die belofte op de dag van Onze Lieve Vrouwe Presentatie, 'met sulck een vast propoest [voornemen] gelijck oft het gelofte waer geweest'. Ze bedong echter expliciet dat deze belofte niet de kracht van gelofte had, opdat 'indien ick deur cranckheijt [(morele) zwakheid] quaem te vallen, dattet toch niet tot sonde en mocht gereekent worden' ${ }^{37} \mathrm{Haar}$ angst om te zondigen was kennelijk vele malen groter dan het verlangen om gehoorzaam te zijn. Al leek de kloosterstaat in sommige opzichten meer heilszekerheid te bieden, Van Randenraedt was ervan overtuigd dat de zaligheid van de ziel ook hier niet automatisch gegarandeerd was.

Hoewel zij vooral dacht in een tweedeling tussen wereldlijke en geestelijke personen, onderkende Van Randenraedt de statusverschillen tussen kloppen en vrouwelijke religieuzen. Door anderen werd zij wat dat betreft ook wel met de neus op de feiten gedrukt, zoals tijdens een tafelconversatie met de prior van de kartui-

37 KB Brussel, Handschriften 19073 (I), 80-8I. Vgl. GAR, Handschriften II B i, 44. In deze vroegste versie van haar levensverhaal is de volgende passage doorgehaald: 'nochtans en was toch geen gelofte'. 
zers te Roermond in 1645 . Beiden waren zij te gast was bij Martinus, de broer van Lucia de Werimont. ${ }^{38}$ Niet zonder aarzeling, omdat de prior 'de geestelijcken dochters altijt soe gequeldt' had, had Joanna, na ruggespraak met haar biechtvader, de uitnodiging aangenomen. $\mathrm{Zij}$ had zich voorgenomen 'maer al amen te seggen al laghense wijes' tegen de vernederende opmerkingen die ze van de prior verwachtte. En inderdaad bracht de prior de 'minsten staedt' van de geestelijke maagden ter sprake. Maar Van Randenraedt liet zich niet uit haar tent lokken en antwoordde dat zij haar staat zou laten voor wat die was; haar enig streven was God beminnen. Van het hiërarchische verschil tussen de prior en haarzelf was zij zich echter pijnlijk bewust, zo blijkt uit haar gewetensrekening. Als religieus was hij 'in sulcken volmaeckten staet', terwijl zij in de minst geachte staat leefde en daarom door anderen tot een niemand gereduceerd werd. Dit besef wekte haar jaloezie, ook al bleef zij overtuigd dat zij Gods wil eerbiedigde door geestelijke maagd te worden. Om deze gehoorzaamheid aan God draaide het, ongeacht in welke staat men leefde.

Deze en andere passages in de geschriften van Joanna van Randenraedt wijzen op een spanningsverhouding tussen de erkende staat van religieuzen en de nieterkende staat van geestelijke maagden. Voor haar persoonlijk werd deze spanning verminderd door roeping. ${ }^{39}$ Dat God haar tot deze staat zonder formele status geroepen had, verlichtte de druk van de bestaande hiërarchie enigszins. Bovenal legitimeerde deze roeping haar keuze die, zoals reeds opgemerkt, verbazing en verzet opriep bij anderen. Met een beroep op God verdedigde ze de waardigheid van haar staat, die naar haar opvatting niet minderwaardig was ten opzichte van de religieuze staat. Integendeel, in haar gewetensrekeningen zijn aanwijzingen te vinden dat naar haar oordeel de leefwijze van geestelijke dochters hoger gewaardeerd moest worden dan die van vrouwelijke religieuzen. Geestelijke maagden trotseerden immers de gevaren van de wereld. Daarvoor was meer kracht en steun van God nodig dan religieuzen achter hun kloostermuren behoefden. Typerend voor haar eigen positie bracht ze dergelijke positieve opvattingen over de eigen staat zelden rechtstreeks naar voren, maar doorgaans in de beschrijving van haar dromen..$^{\circ}$ Toch bleef de behoefte aan bevestiging. Vanaf de intrede in de kloppenstaat vroeg zij God keer op keer haar duidelijk te maken dat zij werkelijk in de staat leefde die $\mathrm{Hij}$ voor haar uitverkoren had.

Agnes van Heilsbach deed weinig concessies ten aanzien van haar ideeën over de hiërarchie van de verschillende levensstaten. $Z_{i j}$ liet zich zeer kritisch uit over vrouwelijke religieuzen. Haar beschrijvingen van dromen over vrouwenkloosters

$38 \mathrm{~KB}$ Brussel, Handschnften 19070, 225vo-228, z.d. [vermoedelijk juli 1645].

39 Dit beroep op roeping speelt een belangrijke rol in kloppenboeken die door jezuieten zijn geschreven. Zie hiervoor III.3.

40 Zie bijvoorbeeld GAR, Handschriften II B i, 114-115. De betreffende passage en een mogelijke interpretatie zijn uitvoerig beschreven in Monteiro, 'Den middelen staet', 155-156. 
en hun bewoonsters staan bol van metaforen die overduidelijk verwijzen naar instabiliteit en gevaar: wankele gebouwen met brokkelige funderingen, met daken en vloeren vol gaten. In de interpretaties die zij gewoonlijk op de beschrijving van haar droomgezichten laat volgen, vertaalt zij deze beelden naar gebrekkige religieuze ijver, slapheid van geest, of te grote belangstelling voor aardse beslommeringen. ${ }^{4 \mathrm{I}}$ Deze gebreken contrasteren scherp met het zelfbeeld dat zij in haar geschriften schetst: ijverig, daadkrachtig en onverschrokken in haar dienstbaarheid aan God. Haar streven was een godgewijd leven leiden in volmaakte zuiverheid, naar ziel en lichaam. Een dergelijk bestaan kon niet onderdoen voor het kloosterleven. Hoe zij haar eigen weg naar spirituele volmaktheid aflegde, wordt beschreven in een droom in $1639 .{ }^{42}$ Drie koorden, waarlangs iemand zich naar de staat van perfectie omhoog kan trekken, verbeelden de zaken die absoluut onmisbaar zijn om die staat te bereiken: de almogende hand van God, de wijsheid van $\mathrm{Zijn}$ zoon, en tenslotte de liefde van zowel de Vader, de Zoon als de Heilige Geest. Van Heilsbach omschrijft haar weg als een zeer gevaarlijke; wie valt, breekt de nek. In de droom volgt zij deze riskante route niettemin praktisch alleen. Bovendien helpt zij maagden die aan haar zorg zijn toevertrouwd, Joanna van Randenraedt en Catharina van Gestel, eveneens omhoog. In de beschrijving van deze droom doet Van Heilsbach zich voor als een volhardende, moedige vrouw die geen gevaar schuwt en over voldoende geestkracht beschikt om een religieus bestaan buiten het klooster te leiden. Een zelfpresentatie die scherp afsteekt bij haar descriptie van menige vrouwelijke religieuze en geestelijke maagd.

Bij tijd en wijle bekropen echter óók haar twijfels over de door haar gekozen geestelijke leefwijze buiten het klooster. In een gewetensrekening uit I 637 maakte zij haar biechtvader deelgenoot van een droom waarin haar ziel, voorgesteld als een kasteel, ${ }^{43}$ belegerd wordt door gewapende mannen te paard, incarnaties van duivels. ${ }^{44}$ Deze droom benauwt haar zeer en zij piekert of zij wel voor de juiste weg naar God heeft gekozen. Zou een gemakkelijkere weg niet veel doelgerichter zijn dan de smalle en moeilijk begaanbare die zij zelf ingeslagen was? De beeldspraak van de brede en de smalle weg werd vaak door zeventiende-eeuwse geestelijken in preken verwerkt om gelovigen te waarschuwen voor de verleidingen van de duivel, die met de brede weg werden geassocieerd. Wie de brede en gemakkelijk begaanbare weg insloeg, belandde uiteindelijk in de hel, terwijl degene die het smalle en steile pad verkoos, bij de hemelpoort uitkwam. ${ }^{45}$ Ook in de contrare-

41 Bijvoorbeeld KB Brussel, Handschnften 18984, 29-30 (4 junı [1637]); 144-145vo (5-6 februari [1638]).

42 Ibidem, 376-377 (12 januari [1639]).

43 Een beeld dat bekend werd door Teresa van Avla's Kasteel van de zzel.

44 KB Brussel, Handschrfien 18984, 37vo-39vo (I9 of 20 junı [I637]).

45 Vanden Bosch, 'Satan op de kansel', 318 . Voor de oorsprong en doorwerking van dit twee-wegenmotief in de volkscultuur, zie Rooijakkers, 'De brede en de smalle weg'. 
formatorische religieuze iconografie was dit een geliefd thema. ${ }^{46}$ Van Heilsbach verwerpt de vraag of zij het verkeerde traject gekozen heeft vrijwel onmiddellijk. Natuurlijk heeft zij goed gekozen; twijfels hierover zijn slechts duivelse fantasieën.

In kerkrechtelijke zin had de prior van de kartuizers gelijk, toen hij de kloppenstaat als de minste staat betitelde. Door zijn omschrijving over te nemen in het verslag van de tafelconversatie in haar gewetensrekening, onderschrijft Van Randenraedt dit beeld. Wellicht had deze concessie een ander retorisch effect dan louter instemming; want door toe te geven dat geestelijke maagden de minste staat vertegenwoordigden, haalde zij de angel uit de onduidelijkheid over hun precieze positie. De vergaande jezuïtische identificatie en zelfbewuste opstelling als bruid van Christus getuigen ervan dat zij, evenals haar geestelijke moeder Agnes, de omschrijving 'minste staat' zeker met een korreltje zout nam. Toch lijkt er in de houding van de Roermondse geloofsgemeenschap en de geestelijke leidsmannen een kentering te zijn opgetreden ten aanzien van Van Randenraedt en andere jezuieten-kloppen. Vermoedelijk hangt deze verandering samen met het incident rond de handschriften van Agnes van Heilsbach in december 1645. Geruchten over Joanna's 'revelacien' deden de ronde tot in Nijmegen toe. $\mathrm{Na}$ het vertrek van haar biechtvader Livinus de Clerck kon Joanna, zoals in het vorige hoofdstuk uiteen is gezet, slechts met grote moeite Adriaan Poirters overhalen om de geestelijke leiding over haar en de andere maagden op zich te nemen. Poirters was bevreesd voor kritiek van zijn confraters als hij deze penitentes onder zijn hoede nam. Wanneer Van Randenraedt een onbekende vrouw in 1647 wil overhalen geestelijke maagd te worden, dan doet zij dat per brief, hoewel de anonieme adressaat eveneens in Roermond woont. ${ }^{47}$ In haar brief verklaart zij waarom zij geen persoonlijk contact zoekt. Ze vreest dat de vrouw bang zou zijn 'datmen dan sau seggen dat U.E. geestelijcke dochter sau worden, deurdien de queesseltiens met U.E. verkeerden' ${ }^{48}$ Geestelijke dochters zijn hier ineens kwezeltjes geworden, die iemands reputatie kunnen aantasten. In de keuze voor het verkleinwoord kwezeltjes lijken kritiek en ongeloof besloten te liggen, die Van Randenraedt sinds december 1645 in toenemende mate moest incasseren en pareren.

Het conflict rond de handschriften van Van Heilsbach vormde vooral een aanleiding om de buitengewone ervaringen, dromen en inspraken waarop de informele autoriteit van geestelijke maagden stoelde, grondig ter discussie te stellen. De bakens werden verzet en het zelfstandig optreden van sommige jezuieten-kloppen in de catechisatie en geloofsverbreiding onder andere gelovigen werd aan banden gelegd. Was het vóór december 1645 wellicht nog retoriek om over 'onsen minsten

46 Knipping, De iconografie van de Contra-Reformatze, I, 91-92, I02.

47 Dit is af te leiden uit de aansporing van Joanna aan haar adres om de rector van het Roermondse college als biechtvader te kuezen.

48 C.ss.R. Roermond, Specraal Archtef A pl. 7, GG 10. 
staedt' te spreken, daarna lijkt het bittere ernst. De speelruimte voor actief apostolaat en uitzonderlijke devotionele praktijken als de dagelijkse communie werd kleiner, de noodzaak om hierover te onderhandelen met geestelijk leidsmannen des te groter.

\section{V.2 Geestelijke vaders en moeders}

Leidsmannen delegeerden een deel van hun taken aan Van Heilsbach en Van Randenraedt. Vooral werkzaamheden die verband hielden met de dagelijkse begeleiding van andere geestelijke maagden, werden aan hen overgelaten. Hoewel het niet met zekerheid te zeggen valt, lijkt het alsof de jezuieten-kloppen in Roermond allen dezelfde biechtvader hadden. ${ }^{49}$ De groep rond Van Heilsbach en Van Randenraedt telde, in wisselende samenstelling, tussen de tien en vijftien maagden. Deze vrouwen vormden geen vergadering, maar woonden bij familie of leefden zelfstandig. $\mathrm{Zij}$ verenigden zich uit hoofde van hun streven een religieus bestaan te combineren met liefdewerken en op grond van het gegeven dat zij een jezuiet als biechtvader gekozen hadden. Aan het hoofd van dit groepje plaatste de biechtvader een geestelijke moeder, die toezicht hield op 'zijn' dochters. Agnes en Joanna vervulden deze informele functie jarenlang.

\section{Geestelijk moederschap}

Geestelijk moederschap is een diffuus begrip. Enerzijds kan het verwijzen naar een informele functie binnen of buiten een kloppenvergadering. Anderzijds doelt het op de vruchten van een religieus leven, in de vorm van deugden of liefdewerken. Geestelijke maagden hadden het huwelijk en biologisch moederschap dan wel afgezworen, dit bleven niettemin de fundamentele ordeningsprincipes in hun bestaan. Zij waren een kuise verbintenis aangegaan met hun hemelse Bruidegom, een geestelijk huwelijk dat hen net zo min als hun gehuwde zusters vrijwaarde van de gehoorzaamheidsplicht aan mannen. Bruiden van Christus en dochters van God hadden zich loyaal en volgzaam te gedragen tegenover Gods plaatsvervanger op aarde, hun biechtvader. Als een vrouw aan haar echtgenoot, als een dochter aan haar vader dienden ook zij te gehoorzamen. Net als voor hun seksegenoten die het huwelijk met een aardse bruidegom hadden verkozen, lag het moederschap voor hen in het verschiet. $\mathrm{Zij}$ behoorden geen kinderen van vlees en bloed te baren, maar wel 'geestelijke kinderen'. Geen sterfelijke maar onsterfelijke kinderen, waarmee zowel persoonlijke deugden als werken van barmhartigheid bedoeld werden. ${ }^{\text {so }}$

49 De Lutterae annuae van het Roermondse college geven geen uitsluitsel over de vraag of de geestelıke leiding aan kloppen een specifieke taak was, die telkens door eén pater in het bijzonder werd vemcht. 50 In verschillende kloppenboeken worden deze van oorsprong vroeg-chnstelıke denkbeelden, die 
Als officieuze functie kende het geestelijk moederschap onder kloppen twee varianten. Beide verschaften geestelijke maagden een zekere handelingsurijheid. Binnen de Haarlemse kloppenvergadering De Hoek vervulden 'moeders' een organisatorische functie met vastomlijnde taken en verantwoordelijkheden. ${ }^{5 x} \mathrm{Hier}$ is sprake van een geïnstitutionaliseerd geestelijk moederschap. Het dagelijks bestuur van de hele kloppengemeenschap was in handen van de moeder-generaal; kleinere deelgemeenschappen, particuliere vergaderingen genaamd, werden bestierd door de zogeheten particuliere moeders. Deze vorm van geestelijk moederschap lijkt geënt op de organisatie van vrouwenkloosters, waar een abdis of een priorin als 'mater' aan het hoofd stond van de gemeenschap en de hoogste vrouwelijke autoriteit was. Het hoogste gezag binnen Haarlemse Hoek werd vertegenwoordigd door een man, namelijk de priester-overste. Bij afwezigheid werd hij vervangen door de moedergeneraal. Naast bestuurlijke en organisatorische taken, zoals de verdeling van de werkzaamheden in en buiten de gemeenschap, hielden de moeders zich bezig met de geestelijke begeleiding van de maagden. $\mathrm{Zij}$ moesten erop toezien dat dagorde en leefregels van de communiteit werden nageleefd. Daarnaast fungeerden zij als vraagbaak en raadgeefster voor jonge maagden.

Laatstgenoemde taken vormden de kern van de tweede, minder scherp afgebakende, variant van geestelijk moederschap zoals Van Heilsbach en Van Randenraedt dat vervulden. $Z \mathrm{ij}$ hadden, zoals gezegd, niet de leiding over een vergadering, maar over een groep kloppen van wisselende samenstelling. Voor zover uit de gewetensrekeningen is na te gaan, was dit leiderschap getrapt van aard; hun biechtvader gaf hun specifieke taken en opdrachten en plaatste andere geestelijke dochters onder hun leiding. Net als in de Haarlemse Hoek beperkten hun begeleidende taken zich tot vrouwen. Rechtstreeks gezag over mannen, laat staan geestelijken, was niet aan de orde. Op dit punt wijkt hun geestelijk moederschap af van wat bekend is over andere religieuze vrouwen in de late middeleeuwen en vroegmodeme tijd. De begijn Maria van Oignies ( + I213) werd door bisschop Jacobus van Vitry (I160/I I 70-1240) als zijn mater spiritualis beschouwd op grond van haar strenge ascetische vroomheid, die haar reeds bij leven een reputatie van heilige bezorgde. ${ }^{52}$ Ongevraagd onderwierp deze geestelijke zich aan het gezag van deze vrouw, door wie hij zich geïnspireerd wist. De Maastrichtse geestelijke dochter Elisabeth Strouven kreeg gedurende haar leven maar liefst drie maal te maken met een priester die haar als zijn geestelijk leidsvrouw verkoos. Zelf vond zij het, althans zo is te lezen in haar spirituele autobiografie, ongepast dat een man zich onder leiding van een vrouw stelde. $\mathrm{Zij}$ was beducht voor de mening van anderen hierover. Haar biechtvader gebood haar echter telkens de betreffende priesters onder haar hoede te nemen en zich niet te storen aan wat mensen daar van dach-

theologen en kerkvaders vertolkten, met instemming aangehaald. Zie p. 175-I77 van dit boek.

5I Theissing, Over klopjes, 43-47.

52 Bolton, Vitae matrum, 267-268. 
ten. Toch voelde Strouven zich ongemakkelijk in deze positie, die niet alleen een omkering teweeg bracht in de bestaande gezagsverhouding tussen man en vrouw, maar ook in de hiërarchie tussen priester en leek. Een omkering die Strouven bij haar tweede 'geestelijke zoon' op een zeer inventieve wijze weer neutraliseerde door de ontstane moeder-zoon-verhouding gelijk te stellen aan die tussen Christus en Maria. Daardoor werd de superieure positie van de zoon bevestigd en haar eigen macht als moeder gerelativeerd..$^{33}$

De profetes Antoinette Bourignon gebruikte moederschapsmetaforen om haar geestelijk leiderschap vorm te geven. Ook in haar geval is er, net als bij Strouven, sprake van een symbolische omkering van de man-vrouw-verhouding in een moeder-kind-relatie door middel van het geestelijk moederschap. Worden echter de functie en het functioneren van dit moederschap nader geanalyseerd, dan lijken er belangrijke verschillen in taakopvatting en taakvervulling tussen Bourignon en contemporaine geestelijke dochters te ontwaren. ${ }^{54} \mathrm{~W}$ as het geestelijk moederschap voor Bourignon een hulpmiddel dat zij zich toeëigende uit eigen beweging om haar geestelijk leiderschap gestalte te geven, voor geestelijke maagden was het veeleer een status of identiteit die hun door anderen werd toebemeten op grond van een vrome, ascetische leefwijze. De moeder-identiteit van Strouven, maar ook die van Van Heilsbach en Van Randenraedt stoelde op het aanzien dat zij genoten in de geloofsgemeenschap, onder geestelijken en leken. De welhaast heilige reputatie van beide Roermondse maagden was gevestigd op influisteringen, 'openbaeringhen', 'verbeeldinghen' en dromen, die erop wezen dat zij bijzonder in Gods gunst stonden. Mede op grond hiervan werden zij door hun biechtvaders geschikt bevonden voor het geestelijk moederschap, dat hun een zeker recht van spreken en handelen gaf.

\section{Gezagsverhoudingen}

De gewetensrekeningen van beide Roermondse maagden bieden inzicht in de wijze waarop geestelijke 'vaders' en 'moeders' hun leidinggevende taken verdeelden uit oogpunt van doelmatigheid. De biechtvader droeg de dagelijkse begeleiding en het toezicht op de spirituele voortgang van zijn geestelijke dochters over aan een geestelijke maagd, maar behield de eindverantwoordelijkheid over hun religieus regime. Invulling en reikwijdte van het geestelijk moederschap waren uiteindelijk afhankelijk van de biechtvader. De op het oog functionele werkverhouding tussen 'vaders' en 'moeders' ging met spanningen gepaard, omdat haar karakter in hoge mate informeel was. Over bevoegdheden en grenzen moest telkens weer onderhandeld worden. Sporen van deze onderhandelingen zijn te vinden in de gewetensrekeningen van Van Heilsbach en Van Randenraedt.

53 Koorn, 'Elisabeth Strouven', 144-147.

54 De Baar, '“Ik moet spreken"', 100. 
Agnes vervulde het geestelijk moederschap vermoedelijk al sinds de tweede helft van de jaren twintig. Kort nadat zij in Roermond aankwam, moet zij voor deze taak zijn aangezocht door haar biechtvader. De naam van deze biechtvader is niet bekend, maar het is niet denkbeeldig dat dit Jacob Wijns was, die zich in 1645 zo negatief zou uitlaten over haar handschriften. Details over haar zeggenschap over haar geestelijke zusters ontbreken, maar die zal betrekkelijk ruim geweest zijn want bij het aantreden van haar nieuwe biechtvader, Walter Clerikus, beklaagde zij zich volgens Joanna van Randenraedt over een inperking van haar taken. ${ }^{55}$ Onder leiding van Simon van den Hove, vanaf ongeveer 1636, genoot zij weer meer vrijheid, al bracht zijn aantreden voor Agnes ook ingrijpende wijzigingen in geestelijke vorming met zich mee. ${ }^{56} \mathrm{Zijn}$ geestelijke begeleiding stond, zoals reeds is opgemerkt, in het teken van de pastoraal van de angst. Agnes beschrijft zichzelf als van nature scrupuleus genoeg en onthoudt hem haar kritiek niet over zijn spirituele begeleiding. Niettemin erkende zij zijn gezag over haar, omdat immers 'Godt almachtich deur u eerw. is spreekende tot mij'. ${ }^{57}$

Toch probeerde Van Heilsbach de gezagsverhoudingen misschien iets meer in haar eigen voordeel uit te balanceren. In verschillende passages van haar gewetensrekeningen spreekt zij openlijk haar bezorgdheid uit over de gesteldheid van Van den Hoves ziel. Soms neemt ze naar eigen zeggen een 'zielsverduistering' bij hem waar, alsof haar biechtvader niet zeker wist of hij nog wel in Gods gratie verkeerde. Daarop verzekert zij hem dat zij hem hierover duidelijkheid kan verschaffen. Daartoe beroept zij zich dan niet op rechtstreeks contact met God, maar met Maria, de Moeder Gods. Die had een bijzondere band met de jezuïeten, die zich immers tot levenstaak hadden gesteld haar zoon te eren en te dienen. Haar vraagt Van Heilsbach of haar biechtvader in ongenade is gevallen bij haar Zoon of bij haarzelf. Door een inspraak wordt Van Heilsbach te kennen gegeven dat dit beslist niet het geval is. ${ }^{58}$ Zo pareerde Agnes de zeggenschap van haar biechtvader met rechtstreeks ingegeven kennis van een hoger gezag, in dit geval Maria. De principieel asymmetrische autoriteitsrelatie tussen haar leidsman en haarzelf kreeg daardoor mogelijk een gelijkwaardiger vorm.

Van Heilsbach uitte ook waardering voor de werkzaamheden van haar biechtvader. In verschillende dromen belichaamt Van den Hove onmiskenbaar een arbeider in de wijngaard des Heren, die zorg draagt voor bomen en planten. De vruchten daarvan deelt hij aan anderen uit; Van Heilsbach, Van Randenraedt, Van Gestel en Botters profiteren hiervan. ${ }^{59}$ Geheel werkloos blijven deze vrouwen hierbij niet,

55 KB Brussel, Handschriften 19073 (II), 26.

56 Wanneer Van den Hove rector van het Roermondse college werd, is niet nauwkeurig vast te stellen. Allard, 'Het jezuieten-college', I44, noemt het jaartal I635 met vraagteken. Uit Leven ende deughden, 114-115, blijkt dat Van den Hove in 1636 biechtvader van Van Heilsbach was.

$57 \mathrm{~KB}$ Brussel, Handschriften 18984, 41vo (30 juni 1637).

58 Ibidem, 314vo-315vo (9 oktober [1638]).

59 Zie bijvoorbeeld ibidem, I6rvo-I62vo (10 maart [1638]). 
want in de dromen wordt, net als in het leven van alledag, hun 'kleine meehulp' verzocht door geestelijken. ${ }^{60}$ Het aandeel van Van Heilsbach lijkt doorgaans groter dan de omschrijving 'kleine meehulp' doet veronderstellen. In haar dromen deelt zij, net als deze priesters, verschillende soorten voedsel uit dat volgens haar uitleg een geestelijke betekenis heeft en waarvoor haar biechtvader grote waardering heeft. ${ }^{61}$ Sommige soorten stellen de vruchten voor van geestelijke onderrichtingen, maar andere interpreteert zij zelf als verbeeldingen van de hostie. Mét priesters, maar soms ook alleen, bereidt Van Heilsbach deze spijzen en onthaalt anderen hierop. ${ }^{62}$

Hoewel haar functie van geestelijke moeder een informeel karakter had, lijkt zij impliciet aanspraak gemaakt te hebben op de status, de taken en de voorrechten die priesters op grond van hun wijding hadden. $\mathrm{Zij}$ onderschatte haar eigen aandeel in de spirituele leiding aan andere zielen in geen geval. In haar taakuitoefening als geestelijk leidsvrouw beschouwde Van Heilsbach zich vrijwel als de gelijke van een priester. Haar persoonlijke leiderschapskwaliteiten komen in haar gewetensrekeningen vaak beter uit de verf dan die van haar biechtvader. Die verschijnt dikwijls in de hoedanigheid van een ruiter, die 'soe mannelijcken te peerd voor rijdt' om een kar te begeleiden op een gevaarlijke smalle weg, die de weg der volmaaktheid voorstelt. ${ }^{6}$ Gaandeweg de beschrijving van de droom verdwijnt de ruiter-figuur naar de achtergrond. Van Heilsbach zelf, die zich op de kar bevindt, komt dan prominent in beeld als degene die het voortouw neemt bij het afweren van vijanden die haar en de andere passagiers dreigen te belagen. Lijken er in eerste instantie twee kapiteins op het spreekwoordelijke schip te functioneren, naarmate de tekst van de gewetensrekening vordert, blijft er nog slechts één over, Agnes zelf. Haar biechtvader kunnen de implicaties van dergelijke dromen nauwelijks ontgaan zijn.

Gehoorzaamheid en nederigheid waren zeker niet Agnes' sterkste kwaliteiten. Dat geeft zij zelf toe in haar gewetensrekeningen, maar ze definieert haar oprispingen van ongehoorzaamheid als 'tentaties' van duivelse oorsprong. Regelmatig kwam zij in de verleiding om Gods geboden en de opdrachten en voorschriften van haar geestelijk leidsman te laten voor wat zij waren en elders te gaan wonen, waar ze niet aan controle onderhevig was; ergens waar niemand haar kende en waar zij onder 'den schijn van devoci (...) in vrijicheyt [kon] leven sonder bedwanck, naer mijnen wil'. ${ }^{64}$ Dergelijke opwellingen mondden niet alleen uit in

60 Ibidem, 160-160vo (28 februari I638).

61 Tbidem, 246vo-247 (21 december [1637]).

62 Een droom waarin zij samen met een priester de voorbereidingen treft en zelf wat van het gevogelte uitdeelt aan een geestelijke, staat beschreven in ibidem, 330-33I (25 oktober [1638]). Vgl. ibidem, 322323vo (17 oktober [1638]), waar zij een droom weergeeft waarin zij alleen een maaltijd voorbereidt, die volgens haar de generale communie representeert.

63 Bijvoorbeeld ibidem, $121-123$ (6 januari z.j.).

64 Ibidem, I53vo-I 55 vo (I9 feburari [1638]). Omdat haar de gedachte is gekomen haar vroomheid 
vluchtgedrag. Zij kenden ook een meer heerszuchtige vorm. Dan streefde Agnes naar een omkering van de bestaande gezagsverhoudingen tussen haar en haar leidsman, naar een mentaal overwicht op hem. Van den Hove verzette zich hiertegen en liet haar weten dat zij niet moest denken dat zij over hem kon heersen. Hij hield haar voor dat hij wijzer was dan zij. Dit beaamde Van Heilsbach weliswaar, maar ze beriep zich op een andere vorm dan intellectuele wijsheid, namelijk kennis die haar door God zelf was ingegeven. ${ }^{65}$ En daarover beschikte zij.

Om haar eigen gezagspositie onder de Roermondse jezuïeten-kloppen te handhaven, zette Van Heilsbach haar gewetensrekeningen in. Hierin klikte zij niet zelden over anderen, geestelijke maagden incluis. Haar informele en onzekere positie als geestelijke moeder verklaart dit klikken. Door gebreken en misstappen van haar geestelijke zusters aan hun gezamenlijke leidsman door te vertellen, maakte Van Heilsbach duidelijk dat zij een uitzondering onder de maagden was. Daarenboven kon zij door te klikken laten zien dat zij haar rol als geestelijke moeder naar behoren vervulde. Toen zij naar eigen zeggen reden had om te vrezen voor de aantasting van haar goede naam door een andere vrouw, die tijdelijk bij Van den Hove ging biechten, nam zij via haar aantekeningen maatregelen om haar reputatie veilig te stellen. ${ }^{66}$ Van Heilsbach brandmerkt de anonieme vrouw als een instrument van de duivel. Om wie het ging, zal de biechtvader zeker geweten hebben. In haar gewetensrekeningen wijst zij erop dat deze vrouw zou proberen haar bij hem zwart te maken. Dit was haar uit een droom gebleken. Aan een daaropvolgende droom koppelt zij de mededelıng dat ze hoognodig eens een boekje moet open doen over de betreffende vrouw. Van deze opmerking schrikt zij, naar eigen schrijven, omdat zij hierin de invloed van de duivel meent te herkennen. Ze betuigt dat ze liever zou sterven dan kwaad spreken van een ander. Zo bewerkstelligde zij via haar gewetensrekeningen vermoedelijk een hoge graad van geloofwaardigheid als geestelijk leidsvrouw bij Van den Hove, zónder dat ze verviel in allerlei beschuldigingen die haar reputatie van vrome maagd, die de naastenliefde hoog in haar vaandel droeg, schade berokkenden.

Voor Joanna van Randenraedt was het geestelijk moederschap de ultieme vervulling van haar apostolaire ambities. Hiervan getuigde zij reeds op jonge leeftijd. $\mathrm{Zij}$ ging geen gelegenheid uit de weg om met wie dan ook een onderhoud aan te knopen over religieuze kwesties. Niet alleen in persoonlijke gesprekken, maar ook via brieven oefende Van Randenraedt haar taak als geestelijke moeder uit. Zij erkende dat het gezag van de vele geestelijke vaders die zij had gekend tijdens haar leven, was afgeleid van God. Over de geestelijke leiding van vrouwen drukte zij

als dekmantel te gebruıken, vergelıkt zuj zıchzelf met Judas en jammert vervolgens over haar kwade inborst.

65 Ibidem, 228-229vo (29 me1 [r638]).

66 Ibidem, I4-18 ( 5,8 en 9 me1 1637). De naam van de betrokken vrouw is onleesbaar gemaakt 
ooit haar twijfel uit op papier, namelijk toen de priorin van de Munsterabdij zich van haar begeleiding kweet. ' $\mathrm{Mij}$ docht dattet een gewaeght werck was, eens vrauwen raedt te volgen in sulck een saeck daer alle mijnen voortganck ende saelicheijt aen hinck'. Maar in de overtuiging dat het gezag van deze religieuze eveneens afgeleid was van God en dat Hij zelfs door 'een mierken (...) wondere wercken kost wercken', legde zij zich neer bij de autoriteit van de priorin. ${ }^{67}$ Later, toen zij zelf geestelijke moeder was, was zij er eveneens van overtuigd dat haar autoriteit over andere kloppen een goddelijke oorsprong had. In 1643 gelastte zij Catharina van den Broeck dat deze haar 'door die macht die mij van Godtsweegen over haer gegeven was (...) gehoorsaem sau sijn' ${ }^{68}$ Deze gezagsopvatting sterkte Van Randenraedt om in conflicten met haar biechtvader duidelijk positie te kiezen. Hoe spanningsrijk de informele machtsverdeling tussen geestelijke vader en geestelijke moeder kon zijn, illustreert een voorval in oktober $16433^{69}$

Haar biechtvader, Comelis de Moor, gebiedt Lucia de Werimont, trouwe vriendin van Joanna, om minder vaak ter communie te gaan. Als geestelijke moeder van Lucia vindt Joanna 'dat $\mathrm{u}$ eerw. tegenwoordich in dat punct veel te rigoureux' is. Voor haar is het onverdraaglijk dat zij niet door hem geconsulteerd is over de vraag of een dergelijke beproeving Lucia wel ten goede komt. En dat terwijl 'u eerw haer (...) mij ock gegeven hadt tot een geestelijck kint'. Hoewel ze zichzelf betitelt als 'onweerdich ende de onbequaemste' om de taak van geestelijke moeder uit te oefenen, wil ze in die hoedanigheid wel serieus genomen worden. Nu krijgt ze echter, aldus haar gewetensrekening, de indruk dat zij belachelijk gemaakt wordt en dat haar geestelijk moederschap 'maer eenen bloetten tittel' was, zeker omdat ze niets in te brengen heeft over haar geestelijk kind 'bij den Geestelijcken vader'. Haast obligaat besteedt ze de volgende regels aan verschillende betuigingen van nederigheid en diskwalificaties van haar eigen opinie die ze daarvoor ongezouten ten beste heeft gegeven. Wanneer ze besluit zich volledig te schikken naar Gods wil, geeft die haar door een 'soette toespeellinge' te kennen dat Hij wél bereid is naar haar te luisteren. Joanna vertelt Hem vrijmoedig over 'die cleine macht die ick had, om mij[n] geestelijck kint' te beschermen. Minder macht dan een kloek die haar kuikens verdedigt heeft zij, zo vertrouwt zij Hem toe. Daarop vraagt zij om in Zijn macht te mogen delen, als Zijn bruid. Dan zou zij de zeggenschap van haar biechtvader over Lucia kunnen breken ten gunste van haar eigen invloed. Wanneer De Moor enige tijd daama De Werimont inderdaad toestemming geeft om weer te communiceren, interpreteert Van Randenraedt dit als een uitwerking van Gods gezag en is tot tranen toe bewogen. Met gepaste nederigheid vraagt ze De Moor vervolgens om haar te leren wat zij in deze kwestie misdaan heeft en haar hier zonder pardon voor te straffen.

67 GAR, Handschrifien II B i, 33; KB Brussel, Handschrifien I9073 (I), 72-73.

$68 \mathrm{~KB}$ Brussel, Handschriften I9070, 43 vo (mei 1643).

69 Ibidem, 102vo-108vo (oktober 1643). 


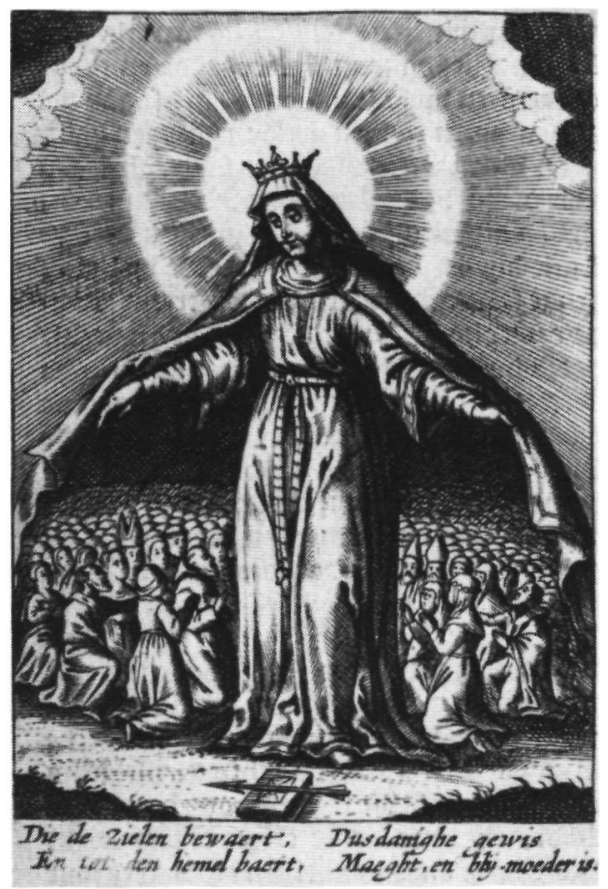

Afb. I9 Het ideaal van geestelijk moederschap, zoals dat belichaamd werd door de heilige Maagd Maria.

Dit incident is natuurlijk niet illustratief voor de opstelling van andere geestelijke vaders. Maar het geeft wel weer hoe serieus Van Randenraedt haar taak als geestelijke moeder nam. Tegelijkertijd laat de hierboven geschetste gebeurtenis zien dat sommige biechtvaders weinig respect hadden voor de eigen verantwoordelijkheden van een geestelijke moeder. Meestal echter verliep de niet-geïnstitutionaliseerde samenwerking tussen 'vader' en 'moeder' minder moeizaam. Toen Lucia de Werimont in augustus 1645 ten prooi viel aan de 'tentatie' van ongehoorzaamheid jegens haar beide geestelijke superieuren, wisten 'moeder' en 'vader' haar met vereende krachten weer in het gareel te krijgen. ${ }^{70}$ Van Randenraedt had ditmaal met een andere leidsman te maken, Livinus de Clerck, met wie zij een zeer sterke band had. In deze kwestie onderschrijft zij in haar gewetensrekening dat de biechtvader uiteindelijk de verantwoordelijkheid draagt voor de geestelijke leiding over 'haar' dochters. Zijn zeggenschap over haar en De Werimont verbeeldt zij aan de hand van de metafoor van het schip en de stuurman: hij is de schipper en stuurman van hen, zijn geestelijke kinderen, en zij, Joanna, verzoekt zijn bijstand, 'want een schip sonder stierman in sulcke ockasien ende perickelen sau lichtelijck te grond gaen'. 


\section{Vertrouwelingen}

Wederzijds vertrouwen was een voorwaarde voor het goed functioneren van het geestelijk moederschap. Persoonlijke sympathieën of antipathieën zullen hun uitwerking op de vertrouwensrelatie tussen geestelijke vader en geestelijke moeder zeker niet gemist hebben. Geheel vrij waren Van Heilsbach en Van Randenraedt niet in hun keuze voor een biechtvader. Joanna kreeg na haar intrede in de kloppenstaat van Agnes te horen dat zij voortaan alleen nog bij de rector van het college mocht biechten. Beide vrouwen biechtten, zoals gezegd, jarenlang bij de respectieve rectores. Voldeed één van hen niet aan hun voorstelling van een goede leidsman, dan bleven zij wel bij hem biechten maar zochten tevens hun toevlucht tot correspondentie met een geestelijke, in wie zij meer vertrouwen hadden en die hen ook serieus nam. ${ }^{71}$ Van Heilsbach bleef in contact met Jacob Wijns in 's-Hertogenbosch, omdat haar biechtvader Clerikus haar activiteiten als geestelijke moeder te zeer beknotte. Van Randenraedt onderhield schriftelijk contact met Simon van den Hove na diens vertrek uir Roermond in I64I. En ook toen Livinus de Clerck in de zomer van 1646 , in de nasleep van het incident in december 1645 , naar Antwerpen werd overgeplaatst, bleef Joanna hem schrijven.

Met Wijns, vanaf 1647 rector van het college en eveneens haar biechtvader, was de verhouding aanvankelijk moeizaam. Hun onderlinge botsing over de geschriften van Van Heilsbach lag Van Randenraedt nog vers in het geheugen. $\mathrm{Zij}$ had geen vertrouwen in hem en was bang haar gewetensrekeningen aan hem te geven. Haar eigen geestelijke ontwikkeling, haar toenadering tot God, werd hierdoor belemmerd, zo vreesde zij. ${ }^{72} \mathrm{Had}$ De Clerck haar geleerd hem onbevangen te vertellen wat haar bezighield, in het bijzijn van Wijns voelde zij zich geremd. Dit gevoel van onbehagen, dat Van Randenraedt in haar gewetensrekeningen tot uitdrukking brengt, was wellicht wederzijds. Op verwijtende toon vermeldt zij dat $\mathrm{W}_{\mathrm{ijn}}$ zelden tijd heeft om haar en andere vrouwen de biecht af te nemen. $\mathrm{Zij}$ en haar geestverwanten zien zich daarom genoodzaakt bij andere priesters te biechten. Helemaal verstoord was hun verhouding echter niet. Wanneer Joanna in 1647 een onbekende vrouw per brief aanspoort een geestelijk leidsman te kiezen die haar zou helpen met de keuze van een levensstaat, dan beveelt zij Wijns aan. ${ }^{73}$ In het daarop volgende jaar treedt er een verbetering op in de onderlinge verstandhouding en begeleidt Wijns Van Randenraedt en een andere klop, Aldegonda van Horenbeek, bij het opzetten van hun gezamenlijke 'geestelijk' huishouden. ${ }^{74}$

Gods aardse plaatsvervanger had niet voor niets een deel van zijn gezag aan hen

71 Vgl. Bilinkoff, 'Confessors', 89-90, die ten aanzien van de biechtrelatue tussen sommige Spaanse beatas en hun leidsmannen stelt dat het doorgaans enige tijd duurde voordat deze vrouwen hun zielsverwant hadden gevonden.

$72 \mathrm{~KB}$ Brussel, Handschniten 19504, 20-23 (ongedateerd; [1647]).

73 C.ss.R. Roermond, Spectaal Archref A pl. 7, GG Io.

74 KB Brussel, Handschrfien I9073 (II), 820-822. 
gedelegeerd, daarvan waren Van Heilsbach en Van Randenraedt overtuigd. God bevestigde immers hun autoriteit in dromen, influisteringen en visioenen. Op grond van deze aanspraak positioneerden beide geestelijke moeders zich naast hun geestelijk leidsman; een positie die inbreuk pleegde op de plaats die hun als geestelijke dochters was toebedeeld, namelijk onder hun leidsman. Spanningen tussen het geïnstitutionaliseerde gezag, dat de positie van de biechtvader schraagde, en de informele autoriteit, die geestelijke moeders als Van Heilsbach en Van Randenraedt claimden, kwamen niet altijd tot uitbarsting, maar domineerden de verhouding tussen 'vaders' en 'dochters' wel. De wijze waarop beide vrouwen invulling gaven aan hun identiteit als geestelijke moeder botste soms met wat er van hen als geestelijke dochters werd verwacht. Biechtvaders reageerden verschillend op hun aanspraken. De Moor schuwde een conflict niet, evenmin als Wijns en l'Hermite. Van den Hove appelleerde vooral aan de buitensporige en vaak ongegronde angst van beide geestelijke maagden om te zondigen om zich van hun trouw te verzekeren. Volledig machteloos waren zij hier niet tegen, zoals hierboven uiteengezet is. Vaak betaalden ze hun biechtvader met gelijke munt terug door hem deelgenoot te maken van goddelijke ingevingen die even kwetsend of beangstigend waren als zijn beschuldigingen aan hun adres.

\section{Taken}

De begeleiding van andere maagden nam vaak de vorm aan van samenspraken over 'goddelijcke dingen'. Eigenmachtige ingrepen in het religieus regime van de 'dochters' waren uit den boze. Wanneer de geestelijke moeders op eigen van God afgeleid gezag hun 'kinderen' meetroonden ter communie tegen het uitdrukkelijke verbod van de biechtvader, dan overschreden zij eigenlijk de grens van hun functievervulling. Van Heilsbach doet dit enkele malen. In april $1637 \mathrm{krijgt}$ zij van haar biechtvader de opdracht om een vrouw, genaamd 'Merricken in den Raef te vermanen om vaker ter communie te komen..$^{75}$ Met succes weet Agnes deze vrouw hiertoe te bewegen. Daarop doet zij 'wat (...) Godt mij ingaef' en neemt Merricken mee naar de kerk van klooster Mariawee van de zusters van de derde regel van St. Dominicus. Daar laat zij haar ter communie gaan, hoewel - zo schrijft zij zelf nadrukkelijk - de vrouw hiertoe geen verlof had, vermoedelijk van de biechtvader. Toch achtte zij zich als 'onweerdich instrument', waardoor God verkoos te spreken, kennelijk bevoegd om Merricken toe te staan ter communie te gaan. Hoewel ze besefte met deze toestemming inbreuk te plegen op het gezag van haar biechtvader, dacht ze dat hij haar dit niet kwalijk zou nemen. Via haar gewetensrekeningen stelde zij hem met terugwerkende kracht van haar handelwijze op de hoogte. Aangezien in haar daarop volgende verslagen geen melding gemaakt wordt van scherpe reprimandes, is het aannemelijk dat Van den Hove haar 
optreden in deze kwestie billijkte en misschien zelfs sanctioneerde. Mogelijk was hiermee tevens een precedent geschapen.

Via haar gewetensrekeningen bracht Van Heilsbach haar biechtvader op de hoogte van de spirituele vorderingen van de maagden die onder haar toezicht waren geplaatst. In geval een maagd in gebreke bleef, beperkte zij zich niet tot informatie, maar stelde zij meteen een remedie voor. Om verbetering in de leefwijze van de weduwe Botters aan te brengen, was naar haar oordeel dwang noodzakelijk; alleen pressie van anderen zou deze vrouw ervoor kunnen behoeden dat zij tijdens haar aardse bestaan verdoemenis over zich afriep. ${ }^{76}$ De religieuze vorming van geestelijke dochters als Joanna van Randenraedt beschouwde zij als een gedeelde plicht van haar en haar leidsman. Van Heilsbach zou blij geweest zijn, zo staat er in Leven ende deughden te lezen, dat zij de verantwoordelijkheid voor de geestelijke leiding aan Joanna kon delen met Van den Hove. 'Niet om dat sy onghewilligh was tot dit goet werck: Maer om dat sy oordeelde sorghelijck te wesen, voor een soo verheven ziele, ghelijck Ioanna was, van een Dochter onderwesen ende gheleydt te worden." 7 Van Heilsbach zou in dit verband zelf geschreven hebben: 'Want als eenen blinden den anderen leyt, (...) vallen beyde lichtelijck in den gracht ${ }^{9},{ }^{88}$ een zinsnede die voor zover bekend niet is overgeleverd. Het is niet denkbeeldig dat Huysmans deze geestelijke moeder een opinie over haar eigen leiderschap toedichtte, die door Van Heilsbach zelf niet onderschreven werd. We zagen immers al dat zij zich in haar gewetensrekeningen eerder zelfbewust dan schuchter toonde ten aanzien van haar rol als geestelijk leidsvrouw.

Van Randenraedt koesterde lang vóór zij zelf geestelijke moeder werd al de ambitie om anderen te onderrichten. Tijdens een kortstondig verblijf in het Land van Cuijk nam zij de gelegenheid te baat om de kennis van het geestelijk leven, die zij van haar geestelijke vader en moeder had opgedaan, met anderen te delen. Hier verbleef zij in 1634 , omdat in Roermond de pest was uitgebroken. ${ }^{79}$ Haar eerste leerling was een tante, 'die soe veel als geestelijcke dochter was'. De vrouw, wier naam niet vermeld wordt, was nooit getrouwd omdat zij ziekelijk was; 'soe bleef sij soe int suart gaen, hebbende ock niemant die haer wat onderrechten oft eeniege geestelijcke oeffeningen gaef ${ }^{80}$ Het stoorde Joanna dat haar tante haar huiselijke besognes nauwelijks wilde onderbreken voor geestelijke oefeningen. Haar volgende leerlinge was gewilliger. Deze 'huismans dochter' ontmoette zij in Boxmeer, waar zij aansluitend nog enige tijd doorbracht. Haar wist Joanna tot de kloppenstaat te bewegen. De jonge vrouw deed een belofte van kuisheid en

76 Voor dit laatste zıe bijvoorbeeld ibidem, 60-63vo (5 julı I637); 64-65vo (13 juli I637).

77 Leven ende deughden, i15.

78 Ibidem.

79 Van het uitbreken van deze besmettelıke ziekte wordt melding gemaakt in de jaarbnef van het jezuetencollege anno 1634. PA SJ, Histonsche handschnftenverzameling, doos I55, C 38 , Lutterae annuae collegn Ruraemundensts S.J.

80 GAR, Handschrifien II B 1, 125-126. 
koos de plaatselijke pastoor als leidsman. Deze geestelijke was dermate onder de indruk van Joanna's spirituele begeleiding, dat hij haar vroeg om 'de oeffeningen der geestelijcke dochters'. $\mathrm{Zij}$ antwoordde dat zij die niet zo maar kon geven. Eenmaal terug in Roermond kreeg zij - van haar 'moeder' of van haar 'vader'? - toestemming om enige praktijken en devoties op papier te zetten en naar de Boxmeerse herder te sturen. Zelf tekent zij aan dat sindsdien het aantal geestelijke maagden in die plaats gegroeid is. ${ }^{81}$

Vanaf 1637 nam Joanna in toenemende mate de taken van haar geestelijke moeder Agnes waar. Zij kreeg nu ook gerichte opdrachten van haar biechtvader. In februari 1639 vroeg hij haar bijvoorbeeld om met een andere geestelijke dochter, juffrouw De Rau, te spreken over enkele geestelijke oefeningen. De Rau wilde op de feestdag van Maria Lichtmis (2 februari) haar gelofte van zuiverheid hernieuwen. Uit naam van de biechtvader moest Joanna haar nog enige verstervingen opdragen. ${ }^{82}$ Soms onderhield ze schriftelijk contact met andere geestelijke dochters op uitdrukkelijk verzoek van haar biechtvader. In juli 1645 vroeg hij haar om een briefje aan Agnes Pauwels (Paulessen) te schrijven. Vermoedelijk was deze klop oorspronkelijk uit Nijmegen afkomstig. ${ }^{83}$ Pauwels behoorde kennelijk niet tot de kleine kring van Joanna's vertrouwelingen, want ze schreef haar een kort briefje. De rest van haar tijd besteedde ze daarna aan een uitvoerige brief aan Catharina van Gestel, aan wie zij zeer gehecht was. De indruk bestaat dat verschillende biechtvaders een beroep deden op Joanna om banden met geestelijke maagden in en buiten Roermond te cultiveren. Sommigen van hen droegen door schenkingen en leningen bij aan de instandhouding van het Roermondse college. Bij verschillende geestelijke maagden, onder wie genoemde Pauwels, had het college leningen uitstaan. ${ }^{{ }_{4}}$ Joanna zelf maakt in haar gewetensrekeningen, zoals gezegd, ook de toespeling dat haar geestelijke 'vrindinnen' meer geld kunnen contribueren aan de Sociëteit dan zij zelf. Nader onderzoek naar het financiële reilen en zeilen van het Roermondse jezuïetencollege zou het aandeel van dergelijke vrouwelijke

B1 Ibıdem, 122-129. Vermoedelık was deze zielzorger Antonius Peelen, die van I628 tot 1654 het pastoorsambt in Boxmeer vervulde Zie voor deze Bots, Matthey en Meyer, Noordbrabantse studenten, s64 (nr. 4015). De aanwezigheid van geestelıke maagden in Boxmeer en nabuje omgeving is voor de achtuende eeuw aanwijsbaar Voor de zevenuende eeuw ontbreken gegevens $\mathrm{Z}_{1} \mathrm{NCI}$, Archref van de carmeletenpastoor, de sacrista en de kerkmeesters van de parochte van St Petrus te Boxmeer, $\mathrm{nnv} \mathrm{nr} 4 \mathrm{I}$, kasboeken van de ontvangsten der kerk van Boxmeer in verband met uitvaarten en begrafenissen

82 GAR, Handschnften I A 5 (ongepagineerd, februan 1639).

83 KB Brussel, Handschnften 19070, 215 (julı 1645) Haar testament is evenwel te Roermond gedeponeerd en aldaar ten overstaan van de schepenen na haar overlıjden geopend (GAR, Archref Hoofdgerecht Roermond, inv.nr 353, 178-180vo). In haar testament vermaakt Pauwels onder andere een huss te Nijmegen, aan de Brouwerstraat, waar zi) oolt met haar ouders woonde. Pauwels was een van de weldoeners van het Roermondse college RAL, Archteven der fezureten te Maastncht en Roermond. Archtef College Roermond (ongeinventarnseerd), Consuetudines Provincrae (.. ). Liber VII, Pars V, Benefactores 84 RAL, Archief fezuneten-college Roermond, port. 3043, nr 9. 
financiers en de rol van Van Randenraedt als intermediair kunnen verhelderen. ${ }^{85}$

In haar gewetensrekeningen laat Joanna weinig los over de inhoud van de veelvuldige gesprekken die ze met andere maagden voerde over devoties en penitenties. Soms vroegen die haar welk onderwerp zij voor hun meditatie zouden kiezen of vertelden zij haar over hun devoties. ${ }^{86}$ Anders dan in de gewetensrekeningen van haar eigen geestelijke moeder, vinden we in haar notities aanwijzingen dat het geestelijk leiderschap haar in conflict bracht met wat zij zelf en haar omgeving gepast achtten voor geestelijke maagden. De samenspraken lijken haar veel wroeging te hebben bezorgd. Het aanzien dat ze genoot op grond van haar status als geestelijke moeder, ervoer zij als pijnlijk. Niet haar, maar God kwam alle eer toe. Natuurlijk werd een dergelijke deemoedige attitude van haar verwacht en misschien betreft het hier vooral een gemeenplaats. Maar de vervulling van haar taken stond haar eigen spirituele ontwikkeling in de weg en verhinderde regelmatig dat zij zich kon terugtrekken, thuis in haar eigen kamer of in de kerk. Naar eigen zeggen wilde zij dat juist zo graag. Daarenboven was ze vaak bang dat ze té vrij had gesproken met haar geestverwanten. $\mathrm{Zij}$ schrijft dat zij zich, wanneer zij met andere religieuze vrouwen sprak, onmogelijk kon inhouden. $\mathrm{Zij}$ deelden immers dezelfde Bruidegom. Om deze andere bruiden, maar ook gewone gelovigen, te kunnen laten profiteren van haar kennis en ervaring, moest zij wel openhartig over haar eigen leefwijze spreken. Ze besefte echter terdege dat veel of vrijmoedig spreken niet gepast was voor geestelijke maagden. Zwijgzaamheid, onderdanigheid en gehoorzaamheid waren deugden die hen, net als andere vrouwen, moesten sieren. Als geestelijk leidsvrouw kon - en wilde misschien - Van Randenraedt zich niet altijd naar dergelijke voorschriften richten. Gewetensnood was de prijs die zij ervoor betaalde. Compensatie vond zij in de gedachte dat zij met het vervullen van deze taak een offer bracht 'tot voorderinge mijns naesten', in opdracht van God. Hij zou haar, zo schrijft zij, niet zo snel van haar taak ontslaan en uit liefde tot Hem zou zij de geestelijke pijn die voortvloeide uit de taakvervulling graag verdragen. ${ }^{87}$ Haar van God afgeleide autoriteit legitimeerde haar zeggenschap over geestverwanten en verzoende Van Randenraedt met opdrachten die gezien haar status en sekse minder passend voor haar geacht werden.

\section{V.3 Moeders en maagden}

Hoewel Van Heilsbach een veeleisende 'moeder' geweest moet zijn, was Joanna diep onder de indruk van haar. $\mathrm{Zij}$ entte haar leven en religieuze praktijk op wat

85 Daartoe zouden de overzichten van inkomsten en uitgaven, van uitstaande schulden en andere financiële stukken die bewaard worden in het RAL, Archef Yezuieten-college Roermond, aan nader onderzoek onderworpen moeten worden.

$86 \mathrm{~KB}$ Brussel, Handschriften 19070, 47 (mei 1643).

87 GAR, Handschnften I A 5 (ongepagineerd; 5 mel 1640). 
Agnes haar had geleerd. Joanna was aan haar verknocht en zeker in de eerste jaren nadat zij de kloppenstaat aanvaard had, viel het haar zwaar van Agnes gescheiden te zijn. Haar streven naar religieuze volmaaktheid zou hierdoor geschaad kunnen worden, zo vreesde zij. $^{88}$

Ook lang nadat Agnes was overleden, nam Joanna haar toevlucht tot haar en riep haar bijstand aan in gebeden.

\section{Vorming}

Agnes beïnvloedde Joanna's religieuze vorming diepgaand en maakte haar vertrouwd met het religieus regime van geestelijke maagden, waarvan gebeden, devoties, penitenties en liefdewerken de kern uitmaakten ${ }^{89}$ Agnes leerde haar bidden en mediteren. $\mathrm{Zij}$ instrueerde haar om via boetedoeningen Gods genade af te smeken, niet alleen voor zichzelf maar ook voor anderen, bijvoorbeeld in september I637, nadat de Staatse troepen Roermond hadden verlaten. Het gevaar voor hernieuwde bezetting of plundering was nog niet geweken. Hiervoor waren de burgers van de stad zeer beducht en het bericht dat deze soldaten onder andere Tienen in Brabant, waarnaar zij deels uitgeweken waren, geplunderd hadden, wakkerde deze angst alleen maar aan. Agnes droeg Joanna toen op om haar gebeden kracht bij te zetten door penitenties: 'eenen sack aen, keetenen, koorden, assen opt hoeft, dissiplien, [en] diesgelijcx veel (...)'. ${ }^{90}$ Agnes vermaande haar om beter op haar manieren en wijze van lopen te letten en om haar ogen te 'bewaren'; gangbare aansporingen aan het adres van geestelijke maagden, zoals ze ook in kloppenboeken voorkomen. Agnes toonde haar hoe zij zonder zelf over een cent te beschikken toch aalmoezen kon uitdelen of geld moest inzamelen voor de versiering van een heiligenbeeld. Zelfs over de dood heen viel Joanna op Agnes terug. Op Agnes' raad beriep zij zich bijvoorbeeld in 1647. Haar biechtvader oefende pressie op haar uit om de erfenis, waarover Joanna na het overlijden van haar moeder kon beschikken, aan de Sociëteit ten goede te laten komen.91 Joanna was bereid om maximaal een som van 800 à rooo gulden aan de Sociëteit na te laten..$^{92}$ In haar gewetensrekening beargumenteert zij dit besluit door te verwijzen naar Van Heilsbach, die ooit tegen haar had gezegd dat zo'n schenking voldoende was. Wanneer haar biechtvader haar ooit zou opdragen om alles wat zij bezat na te laten aan de paters, dan moest zij aan die opdracht geen gevolg geven volgens Agnes.

Bij tijd en wijle lijkt Joanna ook de spirituele adviezen van haar geestelijke moeder bruikbaarder te hebben gevonden dan wat zij van haar geestelijk leidsman

88 GAR, Handschnfien II B j, 122.

89 Ibidem, 4I-48, 88; Kort Begryp, 33-34.

$90 \mathrm{~KB}$ Brussel, Handschnften 19073 (I), I88.

91 KB Brussel, Handschnften 19504, 25vo-26vo (ongedateerd; [I647]).

$92 \mathrm{Vgl}$. hoofdstuk IV (noot 84). 
aangereıkt kreeg. In een gewetensrekening uit I634 tekent z1) aan "dat ick soe lange soe ongestaedich ende sonder vasticheijt geweest heb met de meditacı, omdat ick die niet en wist te verdeillen naer behoeren, ende eer $1 \mathrm{k}$ d'een geproeft had, liep ick weer naer een ander, ende soe loepende bleef ick al werckende sonder te genieten ofte voetsel t'ontvangen (...)'.93 Als thema voor haar meditatie kiest zij het lijden van de Verlosser, maar ze neemt zich ditmaal voor in kleine stapjes te mediteren en de meditatie op dit thema helemaal af te ronden alvorens met een nieuw thema te beginnen. Dat Agnes deze wijze van mediteren goedkeurde, gaf haar, zo schrift Joanna, een gerust gevoel.

Haar geestelıke moeder, die haar in haar gewetensrekenungen vnjwel altıjd haast streng aanduidt als 'Randenraedt', was echter bi) lange na niet onder de indruk van de vorderingen. Joanna's goede voornemens in I634 ten spijt kon haar manier van mediteren in I637 nog geen genade vinden in Agnes' ogen Te hoogdravend en weinig gefundeerd vond z1) Joanna's meditaties. Maar liefst twee onderwerpen tegelık koos Joanna hiervoor, bıvoorbeeld de oneindigheid Gods en Mana Magdalena als verpersoonlıjking van iemand die de Verlosser vung had gezocht. Deze ambitieuze themakeuze ontlokt Agnes de veelzeggende kwalıficatie. 'Het is Joanna die wilt vliegen eer dat sij vleugelen heeft'.94 Aangezien Joanna in spintueel opzicht nog 'een beginnende kunt' was, moest zij volgens Agnes niet op eigen houtje een geestelı)ke weg inslaan zonder raad van anderen. De wijze van meditatie die zı) in strijd met de aanwijzingen van haar geestelıke moeder praktıseerde, zou vruchteloos blijven. Zelf hechtte Van Heilsbach aan wat zl) noemde kleıne, eenvoudige oefenıngen. In gebed probeerde ze zıch als de minste en meest nedenge te plaatsen in de tegenwoordigheid van God.

'Och laet ons kleın blijven sonder hoegh te vliegen, alst Godt gelieft Hi) sal ons haest hoegh brengen het welcke sck nochtans noeit begeert en heb, dan mu met gewelt om leegh gehauden, want die misteenen, soe van Oneeındelijckheijt Godts als van die wijsheıt, ende goetheijt Godts ende diergelıjcke die en sal ick mi) niet veel mi selleven voorstellen dan als sij mij met gewelt te vooren coemen, dat ick gehoersaem moet weesen aen Godt ${ }^{95}$

$Z_{1}$ liet het, in tegenstelling tot Joanna, aan God over of verheven onderwerpen als de mysterieen van $Z_{1 j n}$ oneindigheid, goedheid en wijshe1d voorwerp van haar gebed of meditatie zouden zijn.

Of Joanna Agnes' instructies niet wilde of niet kon navolgen, is onduidelijk Dat zij geen gevolg gaf aan haar richtlınen, beschouwde Agnes als een aantasting van haar reputatie en functioneren als geestelijke moeder Een dergelijke ongehoorzaamheid schaadde de vruchten van haar eigen geestelıjke leıdıng. Vermoedelıjk om zichzelf van mogelijke blaam te zuveren, lichtte zij hun beider biechtvader soms uitvoeng in over Joanna's spirituele gebreken. Haar eigen onmacht om

93 RAL, Archief Btsschoppen Roermond, inv nr 135 [gewetensrekening, 1634](ongepagineerd)

94 KB Brussel, Handschnften 18984, 2 vo (I I apnl 1637), 71e ook Leven ende deughden, 277

95 KB Brussel, Handschriften 18984, 2vo-3 (1 I apnl 1637) 
Joanna adequaat te leren mediteren, weet zij aan onwil van laatstgenoemde. Een dergelijk verwijt is begrijpelijk, gezien Van Heilsbachs positie als tussenpersoon tussen leidsman en dochter. In haar functioneren als geestelijke moeder was zij afhankelijk van de biechtvader; hem moest zij tonen dat zij tegen haar taak opgewassen was. Zelf lijkt zij haar verantwoordelijkheid voor Joanna's religieuze vorming in juli 1637 niet langer te willen dragen. Hoewel deze aantekeningen in de eerste plaats voor Van den Hove bedoeld zijn, wendt zij zich rechtstreeks tot Joanna. Aan de hand van één van haar favoriete metaforen, het gebouw dat de ziel verbeeldt, legt Agnes aan Joanna uit dat zij nog altijd niet de vereiste basis gelegd heeft voor het geestelijk leven. Naarmate een gebouw hoger wordt, dient ook het fundament dieper te worden gelegd. En juist een goed fundament ontbreekt in het geestesleven van Van Randenraedt. Zes jaar lang had Van Heilsbach haar, zo schrijft zij verwijtend, laten zien waaruit een stevige fundering bestaat, namelijk een grote nederigheid jegens God en de mensen. In plaats van deze zware en moeilijke weg die haar geestelijke moeder haar wijst, verkiest Joanna wegen die aangenamer en gemakkelijker oogden. ${ }^{96}$

Deze scherpe kritiek nam niet weg dat Joanna toch tot Van Heilsbachs favorieten behoorde. Dat gold ook voor de Bossche Catharina van Gestel die, wanneer zij bij haar tante in Roermond verbleef, in de leer ging bij Van Heilsbach. Laatstgenoemde vreesde wél dat dat Van Gestel net zo min als Van Randenraedt haar lessen in ootmoed tot in de uiterste consequentie zou willen en kunnen volgen. ${ }^{97}$ Toch staken beiden gunstig af bij de andere dochters, die Agnes bekritiseerde om hun schijnheiligheid; voor de buitenwacht leidden zij een geestelijk leven, maar van enige vooruitgang in religieuze volmaaktheid was geen sprake door hun slapheid. Het ontbrak hun aan nederigheid, gehoorzaamheid en aan de moed om alle wereldse ijdelheid en eergevoel af te zweren en zich volledig aan God te wijden. Deze geestelijke dochters waren nog steeds 'kinders', terwijl zij 'naer iaeren int geestelijck leven behoorden mannelijcke wercken voort te brengen ${ }^{\prime} .^{8}$ Vooral de gebrekkige vorderingen van haar huisgenote, de weduwe Botters, baarden haar zorgen. Haar wereldse manieren en ruzieachtige houding getuigden volgens Van Heilsbach van haar minachting voor 'dien staedt daer Godt almachtich haer in geroepen heeft om Hem in stilte ende met geruster herten te dienen'. ${ }^{99}$ Dromen waarin Van Heilsbachs geestelijk leiderschap over andere geestelijke maagden, juffrouw Botters incluis, wordt verbeeld, getuigen van haar kritische zorg voor deze vrouw. In deze dromen domineren huiselijke handelingen als het poetsen van

96 Ibidem, 7ovo-7Ivo (2 julı [1637]).

97 Ibidem.

98 Ibıdem, 206vo-208 (4 me1 1638). Van Heılsbach noemt hier slechts één van deze in haar ogen slappe geestelı)ke maagden met name, juffrouw Dienbergh Deze kon goed overweg met Van Randenraedt, hetgeen hun geestelıjke moeder allerminst aanstond. Mogelık wordt haar scherpe uitval huerdoor verklaard

99 Ibıdem, 94vo-95vo (28 oktober [1637]). 
kapellen of kerken, die door Agnes worden uitgelegd als metaforen voor de zorg voor de eigen ziel. Botters blijkt de minst ijverige, maar ook de meest eigenwijze onder de maagden. Altijd is zij buiten of in een voorportaal bezig, lokaties die volgens Van Heilsbach haar achterstand in religieuze ontwikkeling symboliseren. Agnes is ervan overtuigd dat Botters' toestand haar kwetsbaar maakt voor duivelse machinaties. En in haar gewetensrekeningen schildert zij de weduwe weleens ondubbelzinnig af als slachtoffer en instrument van de duivel. ${ }^{100}$ In haar kritiek schiet zij zelfs zó ver door dat zij aanvaringen en conflicten tussen Botters en haarzelf benoemt als confrontaties met de duivel. ${ }^{\text {10I }}$

Of haar biechtvader dergelijke aantijgingen heel ernstig heeft opgevat, is de vraag. Feit is dat niet iedereen zó onder de indruk was van Van Heilsbachs geestelijk leiderschap als Joanna. De priorin van het Munster, Catharina di Ortigosa, die aan het einde van de jaren twintig korte tijd namens Agnes als haar geestelijk leidsvrouw optrad, waarschuwde haar toen reeds dat het veeleisende leiderschap van Agnes niet zonder gevaren was. Eén vrouw was hiervan al het slachtoffer geworden volgens de priorin. Conflicten die zich gedurende de jaren dertig voordeden, wijzen inderdaad op een strenge en misschien wel onorthodoxe leiderschapsstijl van Van Heilsbach. Anna van Kerckhoven, die Agnes als haar opvolgster beoogde, weigerde haar langer als leidsvrouw te erkennen. ${ }^{102}$ Ook de gezusters Liesbeth en Geertien van Tits verlieten haar. ${ }^{103}$ Liesbeth had Agnes ooit bijgestaan bij het voorbereidend catchismus-onderwijs. Over de toedracht van het conflict met deze zusters laat Van Randenraedt helaas niets los. De breuk had zij wel voorzien in een droom vol symbolische verwijzingen naar Van Heilsbachs leiderschap. ${ }^{104}$ Terwijl Agnes haar krachtig een hoge heuvel optrok, die de weg van de volmaaktheid verbeeldde, moesten de gezusters Van Tits, die zich krampachtig aan Joanna vastklampten, tenslotte loslaten. Het volgen van deze weg was té zwaar voor hen en zij bleven onder aan de heuvel staan, terwijl Agnes met Joanna in haar kielzog onverdroten voortklom. Toen Joanna in haar droom nog eenmaal omkeek naar beide vrouwen, zag ze hen staren naar een schip dat schipbreuk had geleden. Een beeld waarmee tot uitdrukking werd gebracht dat beide vrouwen reddeloos verloren waren zonder hun geestelijke moeder.

Een staaltje van de ongebruikelijke methoden die Van Heilsbach toepaste in de vorming van haar dochters is te vinden in Joanna's notities. ${ }^{105}$ Vanaf eind 1636 tot het najaar van 1637 vond zij enige tijd onderdak bij haar geestelijke moeder

100 Ibidem, 343-344 (9 november [1638]).

IoI Ibıdem, 73vo-75vo (6 julı [1637]).

102 GAR, Handschnften II B 1, 75-78, 82-83. Vgl. Leven ende deughden, 104-I05.

103 De gezusters van Tits behoorden tot de weldoensters van het college. RAL, Archieven der fezuīeten te Maastricht en Roermond. Archref College Roermond (ongeinventanseerd), Consuetudines Provnciae

(...) Luber VII, Pars V, Benefactores.

104 GAR, Handschritien II B 1, 129-130.

$105 \mathrm{~KB}$ Brussel, Handschnften I9073 (I), 347-349 (vermoedelık 1637) 
en de weduwe Botters. In deze periode stelde Agnes haar godsvertrouwen eens op de proef. $Z$ ij gaf de weduwe Botters de opdracht Joanna 's nachts een enorme schrik aan te jagen om vast te stellen hoe die zich gedroeg als zij 'de duivel had gezien'. Hun wederzijdse biechtvader Van den Hove moest hartelijk lachen toen hij van deze beproeving vernam. Vanuit Joanna's gezichtspunt zag deze test er vermoedelijk anders uit. Ze hult zich hierover in stilzwijgen. In feite was zij aangepakt met het middel dat Van Heilsbach zelf zo verfoeide in de geestelijke leiding van haar biechtvader: intimidatie.

\section{Religieuze vrouwencultuur}

Ten tijde van Agnes' leiderschap onder de maagden lijkt er een duidelijke hiërarchie te hebben bestaan die afstand schiep tussen moeder en dochters. Polarisatie onder de Roermondse jezuïeten-kloppen bleef niet uit. En misschien moet in de conflicten die zich vanaf het midden van de jaren dertig tussen haar en andere maagden openbaarden, de aanleiding gezocht worden voor een verandering in leiding. Toen de door Agnes zelf beoogde opvolgster Anna van Kerckhoven het liet afweten, werd Joanna klaargestoomd voor het geestelijk moederschap. Hoewel zij alles wat zij hierover wist van Agnes had geleerd, was zij waarschijnlijk veel minder autoritair. Conflicten met 'dochters', die haar net zo min als Agnes bespaard bleven, werden niet op het scherp van de snede uitgevochten. ${ }^{106}$ In haar gewetensrekeningen en spirituele autobiografie laat Joanna zich kennen als een meelevende 'moeder', die een hechte band met haar dochters onderhield. De wijze waarop zij Lucia de Werimont in bescherming nam tegen De Moors besluit om haar communie-frequentie te reduceren, laat zien dat het welzijn van haar 'dochters' haar zeer ter harte ging. Helaas weten we niet hoe haar leiderschap er uitzag vanuit het perspectief van de vrouwen die onder haar leiding stonden. Van de onderlinge band komt wel iets tot uitdrukking in Joanna's gewetensrekeningen. Uit haar notities en brieven spreekt een diepe liefde voor Lucia de Werimont, Catharina van Gestel en Catharina van den Broeck. Een liefde die vooral wortelde in het gegeven dat zij dezelfde Bruidegom deelden. In een aantekening uit juni I643 beschrijft Joanna hoe ze ter communie geweest was en zich als doorvloeid voelde met diepe genegenheid. 'Sot, sot' van liefde wenste ze dat ze iemand in haar armen kon nemen om uitdrukking te geven aan haar gevoelens. Ze verzucht op papier: had Lucia de Werimont maar dichterbij gezeten, dan had ze haar hand stevig vast kunnen pakken. Christus mag dan het object van haar affectie geweest zijn, uitdrukking hieraan kon of wilde Van Randenraedt soms geven door fysiek contact met één van haar geestelijke dochters.

Haar gevoelens voor andere vrouwen lijken innige vriendschap soms te overstijgen. Dan dringt zich de vraag op of haar gehele hart en ziel inderdaad haar

106 Zie bijvoorbeeld ibidem (II), 792-797. 
Bruidegom toebehoorden. Op een middag in juni 1643 ziet zij de kamenier van haar moeder, Cathrien van der Haegen, thuis boven aan de trap in een licht snelder als den blixem (...) ende in dat selve licht daer ick mij als in een fontein in versoncke vont ontspringende, ende daer ick met mij alle sielen in vont levende'. ${ }^{107}$ Dat licht zag zij naar eigen schrijven in Cathriens oogopslag en ze kreeg op dat moment door een diepgevoelde liefde een opwelling om de kamenier in haar armen te nemen en aan het hart te drukken. Net als andere emoties die in haar gewetensrekening beschreven worden - angst, boosheid, gelukzaligheid drukt zij ook dit gevoelen, dat misschien omschreven kan worden als verliefdheid, uit in een religieus vocabulaire. ${ }^{\text {108 }}$ Betekenissen van deze taal met een sterk mystieke inslag waren wellicht meerduidig. ${ }^{109}$ Joanna's biechtvader, De Moor, gebood haar minder familiair met deze vrouw om te gaan. Dit gebod werd vermoedelijk ingegeven door overwegingen die samenhingen met Van Randenraedts positie als geestelijke maagd. Haar leefwijze vergde volledige onthechting; aardse affecties als intense genegenheid voor naasten diende zij zoveel mogelijk te onderdrukken. Door haar emotionele ontboezemingen in haar gewetensrekening had Joanna deze gedragscode geschonden en misschien ook wel de grenzen van eerbaarheid overschreden. Wellicht achtte De Moor het ook gezien het standsverschil tussen beide vrouwen niet gepast dat Van Randenraedt zich al te veel aan de kamenier gelegen liet liggen. Want hoe nederig een geestelijke maagd ook behoorde te zijn, haar maatschappelijke stand mocht zij nooit verloochenen en dienovereenkomstig moest zij zich gedragen.

Vrouwen als De Werimont en Van Gestel kwamen wel uit hetzelfde milieu als Van Randenraedt. De vriendschap met de Bossche geestelijke maagd Catharina van Gestel dateert van het begin van de jaren dertig. Door toedoen van Jacob Wijns, die van Roermond naar 's-Hertogenbosch was overgeplaatst, kwamen zij met elkaar in contact. Van Gestel logeerde regelmatu in Roermond bij haar tante,

107 KB Brussel, Handschnften 19070, 55-55vo (26 juni 1643). Voor de identuficatie van deze vrouw, die in genoemde gewetensrekenıng slechts 'Cathnen' wordt genoend, zie KB Brussel, Handschnfien 19073 (II), 214-215, waar hetzelfde incident wordt verhaald, ditmaal met naam en toenaam.

108 In haar studie $Z$ iel en zinnen over vormen en betekenissen van verhoudingen tussen vrouwen in de achthende eeuw wijst histonca Mynam Everard erop dat vóór de negentiende eeuw eigenlıjk niet gesproken kan worden over 'vrouwelyke homoseksualıteit'. Dat begnp behoeft histonsenng. Everard lat zien dat hefde en lust tussen vrouwen in de tweede helft van de achttuende eeuw onder andere vorm kregen in zielsvrnendschappen, die stoelden op het verlangen de deugdzaamheid wederzijds te versterken Nader onderzoek moet uttwizen of het verschujnsel zielsvnendschap, dat door Everard in een achttuende-eeuwse, overwegend protestantse context is onderzocht, ook van toepassing is op relanes russen katholieke vrouwen in de zeventiende eeuw. Het lı,kt de banden die Joanna van Randenraedt met Lucra de Wenmont, Cathanna van den Broeck en Catharna van Gestel onderhueld, vnj nauwkeung te omschnjven.

$109 \mathrm{Vgl}$. Van Gemert, 'Hidıng behind words?', die laat zien dat de conventies van de hefdespoezie zeventiende-eeuwse dichteressen in staat stelden hun passie voor andere vrouwen ut te drukken. Derks, 'Vrouwen, confessionalisenng en biografie', i26, wilst erop dat de schnffster Cathanna Alberdingk Thum (1848-1908) haar liefde voor vrouwen verwoordde in een religieus geladen vocabulare. 
Catharina van Elshout. Gedurende die periodes werd zij volledig opgenomen in de kloppengroep rond Van Heilsbach en Van Randenraedt. De vriendschap tussen Joanna en Catharina kwam in 1648 onder spanning te staan, toen laatstgenoemde de jezuïeten als leidsmannen verruilde voor de minderbroeders. $\mathrm{Zij}$ trad toe tot hun wereldlijke derde orde. Joanna toont zich in haar gewetensrekening boos en grootmoedig tegelijk. Al stak er naar haar idee geen kwaad in dat Catharina nu op eigen gezag gekozen had voor biechtvaders van een andere orde, haar gedrag getuigde niettemin van 'een wonder waepperachticheijt [onstandvastigheid] (...) aengesien sij alle haere fondamenten alhier onder de eerw. paters der Societeit had geleidt, soe veel goedts daer af ontfangen (...) ende wij haer soe veel hadden betraudt' ${ }^{\text {Iro }}$ Ze verheelde haar teleurstelling niet, maar voorkwam een volledige breuk, doordat ze alsnog begrip opbracht voor Van Gestels stap.

Haar opstelling in deze kwestie tekent de verhoudingen. Banden tussen geestelijke dochters waren hecht. ${ }^{\text {III }}$ Bindend element was de keuze voor de geestelijke staat buiten het klooster, waarin het eigen streven naar zelfvolmaking en deugdzaamheid gestalte kreeg volgens een spirituele oriëntatie die gevormd was onder leiding van jezuieten. Daarnaast deelden zij een ondergeschikte positie ten opzichte van geestelijken en bekleedden zij binnen hun eigen familie eveneens een inferieure positie. Overeenkomst in maatschappelijke achtergrond versterkte mogelijk het ontstaan van een soort groepsbewustzijn. Dit werd gekenmerkt door maagdelijkheid en vroomheid. Sekse, staat, stand en religie kunnen beschouwd worden als de dominante organisatieprincipes onder de Roermondse jezuieten-kloppen. Het religieuze vrouwendomein van deze geestelijke maagden kende eigen regels en wetten, eigen normen en waarden die de betrokken vrouwen tot op zekere hoogte met elkaar deelden. De religieuze vrouwencultuur, die de groep rond Van Heilsbach en Van Randenraedt zelf gestalte gaf, stond niet geheel op zichzelf. Zij werd doorsneden door mannenculturen, in het bijzonder die van de jezuïeten. Als hun biechtvaders en leidsmannen begeleidden en controleerden die hun spirituele ontwikkeling en oefenden daardoor invloed uit op de devoties, penitenties, communie-frequentie, geestelijke en wereldlijke taken en andere aspecten van geloofsbeleving die de leefwereld van de geestelijke maagden onderscheidde van die van andere katholieken.

Hoezeer allerlei hoogdravende uitingen van godsvrucht eigen waren aan de jezuïeten-kloppen rond Van Randenraedt blijkt uit reacties van buitenstaanders. Eén van die reacties heeft zij zelf opgetekend. Eind juli 1647 vertrok Joanna naar Spa voor een kuur. Ontspanning en een beetje vermaak zouden haar goed doen,

I10 GAR, Handschriften I A II (ongepagineerd; 15 maart I648).

IIr Deze alinea is geïnspireerd door het concept 'katholieke vrouwencultuur', zoals uitgewerk door Derks en Van Heijst, 'Katholieke vrouwencultuur', 332-335. Hoewel zij dit concept toepassen op de twintigste eeuw zijn, is het ook bruikbaar voor de vroegmoderne tijd, al namen de organisatiewijze en -graad toen andere vormen aan. Het begrip 'vrouwencultuur' werd al eerder op geestelijke maagden van toepassing verklaard, namelijk door Bosch, 'Vrouwencultuur'. 
zo had haar toenmalige biechtvader Jacob $W_{1 j n s}$ haar voorgehouden. Van Randenraedt wilde Roermond met verlaten, vooral omdat dne weken tevoren haar moeder was overleden. De penode waann dertıg missen gedaan zouden worden voor haar zieleheil, was nog niet voorbij. Bovendien zag zil op tegen de reıs en de wereldse

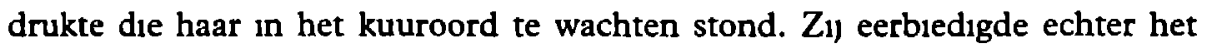
dwingende advies van haar biechtvader, omdat die, naar zll schnift, de wil van God vertolkte. In het gezelschap van Aldegonda van Horenbeek vertrok zij naar Spa. De kuur die zij daar onderging, bestond uit het dnnken van water uit verschillende bronnen, dat een geneeskrachuge werkung had op allerle1 kwalen. Grote hoeveelheden water moesten dagelı)ks geconsumeerd worden, tot een maximum van maar liefst twaalf glazen van zo'n drie deciliter ${ }^{112}$ Geen wonder dat Joanna 'sulk een geweldrege teegenthe1t had int drincken van soe veel waetter' en na een aantal dagen zelfs bukppın kreeg Devoties, kerkgang en gebeden werden evenwel niet verwaarloosd. 'Wonderlyjk minnespel' dat zich tussen haar Bruldegom en haar tudens gebed in de kerk afspeelde, deed haar uitbarsten in tranen ${ }^{13}$ Dergelıke hulbuien werden afgewisseld met haast hystensche lachbuien. Twee onbekende geestelıke maagden, met wie zi) en Aldegonda een kamer deelden in het logement waar zly hun intrek hadden genomen, stonden - anders dan de jezureten-kloppen waar Van Randenraedt doorgaans mee omging - sceptusch tegenover haar emotionele uitbarstingen. Een van hen, juffrouw Klops, hield

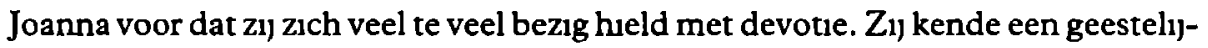
ke dochter die daar gek van was geworden. Deze toespeling op dreigende godsdienstwaanzin maakte geen indruk op Joanna, die er juist behagen in schiep uit liefde tot haar Bruldegom voor gek aangezien te worden Als $Z_{11 n}$ bruid moest zi) dergelı)ke insinuaties kunnen verdragen en dat deed zil graag

Roermondse kloppen onderschreven evenmin klakkeloos alle ongeschreven regels van hun informele relıgieuze gemeenschap. Van Randenraedts zucht naar lijden, die verderop in dit hoofdstuk nog uitvoeng aan de orde gesteld wordt, ging sommigen echt te ver. In jun1 $1643 \mathrm{kreeg}$ ze naar eigen zeggen toestemming om twee andere geestelıke dochters letterly)k over zich heen te laten lopen en zich door hen te laten bespuwen. ${ }^{114}$ Toen Van Randenraedt zich evenwel uitstrekte op een bed - klaar om deze beproeving te ondergaan - lieten de vrouwen in kwestie, De Wenmont en Van den Broeck, het afweten. Joanna's lijdensdevotie, maar vooral de wijze waarop zlj deze probeerde te bevredıgen, konden zıj kennelıjk net verenigen met eigen opvattingen over hun geestelı,k dochterschap.

$112 Z_{1 e}$ hiervoor Disstelberghe, 'Het lot van de waterdnnker', 332-334

113 GAR, Handschnfien I A 9 (ongepagineerd)

I1 KB Brussel, Handschnften 19070, 64-64vo (jun 1643) 


\section{V.4 God dienen buiten het klooster}

Alle onduidelıkheid over staat en status ten spijt voerden beide Roermondse maagden ook goede redenen aan voor een rehigieus bestaan buiten het klooster. Naar eigen zeggen konden $z_{11}$ God en naasten beter dienen in de wereld dan in het klooster. Deze dienstbaarheld kreeg vorm in verschillende liefdadige taken, varierend van het borduren van een antependium, het uitdelen van aalmoezen, het verstrekken van spintueel advies tot het geven van elementair geloofsonderncht. Vooral de twee laatstgenoemde taken bevredigden het verlangen naar een actief apostolaat bı Van Heilsbach en Van Randenraedt. Als geestelıke zusters van de jezuieten beschouwden 21 het als hun opdracht om naar vermogen bij te dragen aan de bekenng van zielen. Naar vermogen is hier dneledig op te vatten: voor zover zlj hiertoe fysiek en mentaal in staat waren; voor zover dit in hun financiele en matenele macht lag; en tenslotte voor zover hun dit als vrouwen werd toegestaan. In deze dne spanningsvelden probeerden zil hun actieve religieuze bestaan gestalte te geven.

\section{Bidden en werken}

Gebed, meditatie en mishoren waren religieuze plichten die de dagen van geestelıke maagden vulden In kloppenboeken wordt daarnaast handwerk als taak genoemd. Of het betaalde arbeld of liefdewerk betreft, blıft vaak in het midden. Voor andere werkzaamheden, die in de praktıjk integraal deel uitmaakten van de kloppenstaat en de 1dentıteit van geestelı)ke maagden tot op grote hoogte bepaalden, is in veel leefregels en dagordeningen nauwelıjks tijd ingeruimd. Elementair geloofsonderncht wordt welıswaar warm aanbevolen door auteurs van kloppenboeken, maar in de aan kloppen voorgeschreven tıjdsbesteding is dit doorgaans net ingepast. Evenmin hielden deze voorschriften rekening met meer wereldlı)ke taken waarmee geestellyke maagden belast waren met het oog op de zorg voor hen zelf of hun naasten.

Van Joanna van Randenraedt is een eigenhandig geschreven dagorde overgeleverd ${ }^{\text {Is }}$ Deze opent als volgt ' $O m$ int kort te kennen te geven wat mujn geestelijcke oeuffeningen sıjn nul in deesen tijt van iaeren ( .. '. Een formulenng die wijst op een geintendeerd publiek, dat zinn voordeel kan doen met haar dagorde. Aangezien een datering ontbreekt, is onduidelyjk wat Joanna bedoelt met 'deesen tijt van Iaeren'. Zijn dit de oefeningen, die zi) op verzoek van de pastoor van Boxmeer in het midden van de jaren dertıg voor geestelı)ke maagden aldaar op papier zette?

I5 Het navolgende is gebaseerd op GAR, Handschnften II B k, dagordening (ongepagineerd) Vgl GAR, Handschnften IV 3, 'Godrvruchughe tijtwerdeılinge' (ongedateerd), anders dan de inventans vermeldt, betreft het her geen autograaf Of Van Randenraedt deze dagorde gebruikt heeft, is onduldelı)k 
Hoe het ook zij, deze dagorde biedt een beeld van de verhouding van geestelijke en meer wereldlijke taken in Joanna's leven.

's Zomers stond Joanna rond vier uur 's ochtends op. In de winter mocht ze een uur langer blijven liggen. Haar dag begon met het ochtendgebed dat ruim een uur duurde. Kon ze 's nachts niet slapen, dan bracht ze de tijd bij voorkeur biddend door. Uit haar gewetensrekeningen blijkt dat zij, net als Van Heilsbach, gewoon was tussen twaalf en twee uur 's nachts op te staan voor het gebed. Een gewoonte die, zoals al is opgemerkt, vermoedelijk geïnspireerd was door het koorgebed van kloosterzusters. Na het ochtendgebed begaf zij zich tussen zes en zeven uur naar de kerk voor de eerste mis. Tijdens de mis bereidde ze zich voor op de heilige communie, onder andere door het bidden van de rozenkrans of een rozenhoedje, een praktijk die door de regulieren werd bevorderd. In haar religieuze beleving nam de communie een centrale plaats in. De verschillende betekenissen van dit sacrament in haar belevingswereld worden in de volgende paragraaf nader bezien. Doorgaans woonde Joanna dagelijks drie missen bij, al naar gelang ze tijd had. Deze toevoeging impliceert dat ze haar dagritme op dit punt desgewenst of desnoods kon aanpassen. Gedurende de dag hield ze nog enige 'recolectien', korte oefeningen of meditaties ter religieuze bezinning. Sommige werkzaamheden gingen ook gepaard met devoties. Bij het 'hantwerck' dat ze 's ochtends uitvoerde, deed zij 'een klein cransken van St. Ignatius', vermoedelijk een gebed ter ere van de heilige Ignatius. Haar 'werck' 's middags gebeurde onder 'eeniege recolectie en stilswijgen met een klein cransken van St. Xaverius'. Gedurende de hele dag herhaalde ze voor zichzelf ook vaak 'eeniege puncties van de passie op de 24 uren', die ze, al naar gelang haar gemoedstoestand, ook weleens zong. Ook de maaltijden werden aangegrepen voor godvruchtige overwegingen, die zij niet nader omschrijft. $\mathrm{Na}$ het middagmaal was er korte tijd ingeruimd voor 'recriatie'. Deze vrije tijd besteedde ze aan lofzangen of aan het lezen van een geestelijk boek. Het gewetensonderzoek, waarover in het vorige hoofdstuk uitvoerig verslag is gedaan, vond plaats voor het middagmaal. 's Avonds deed ze 'recolectie vanden heellen dach', waarmee het tweede gedeelte van het gewetensonderzoek, volgens het stramien van Ignatius, bedoeld wordt. De dag werd besloten met het avondgebed, waaronder vijf onzevaders en weesgegroeten 'ter Eeren van de $\mathbf{H}$. vijf wonden ons salichmakers'. Hierna begaf zij zich te ruste, 'met goeij intentie'.

Schrijft Van Randenraedt over handwerken, dan bedoelt zij de fraaie borduursels en versieringen waaraan zij werkte voor verschillende kerken, bijvoorbeeld altaarkleden of decoraties voor Mariabeelden. Voor dit liefdewerk was tijd gereserveerd in haar persoonlijke dagorde; voor geestelijke onderrichtingen, vrome samenspraken met anderen of geloofsonderricht aan kinderen daarentegen niet. En met de tijd die meer profane taken in en buitenshuis vergden, werd al helemaal geen rekening gehouden. Een zekere spanning tussen religieuze oefeningen, werken van barmhartigheid en meer profane, huiselijke taken was met zo'n strak schema 
van bidden, mishoren, communiceren en handwerken nauwelijks te vermijden. Deze spanning doet zich gelden in Joanna's geschriften. Ook uit Agnes' notities blijkt dat meer alledaagse verplichtingen haar religieuze ritme regelmatig doorkruisten. In de eigen kamers, die ieder van hen thuis had, waren zij vaak onvoldoende afgeschermd van belangstelling en bemoeizucht van hun huisgenoten. De combinatie van bidden en werken in een omgeving die de dagorde van geestelijke maagden niet respecteerde, kon acute gewetensnood veroorzaken. De angst dat hun zaligheid in gevaar kwam wanneer zij hun religieuze plichten noodgedwongen moesten onderbreken of zelfs niet konden vervullen, moet in emotioneel opzicht zeer belastend geweest zijn voor beide kloppen. Twee voorbeelden uit hun gewetensrekeningen illustreren deze diepgewortelde vrees.

In april I638 werden Van Heilsbach en Botters tijdens de avondmaaltijd gestoord door iemand die wijn kwam bottelen. Niet alleen het avondeten kwam hierdoor in het gedrang, maar ook het gebruikelijke avondgebed, dat voor het slapengaan rond een uur of tien werd gedaan. Van Heilsbach nam zich voor dit verzuim goed te maken door 's nachts langer te bidden. Omdat zij overmand werd door slaap, kwam hiervan echter niets terecht. In haar gewetensrekening beschrijft zij haar groeiende ongerustheid hierover. Vertwijfeld vraagt zij zich af of zij gezien deze nalatigheid wel ter communie mag. Twijfel en angst worden weggenomen door een inspraak van haar Bruidegom, die haar verzekert dat haar schuld door $\mathrm{Hem}$ met Zijn leven en bloed is betaald. ${ }^{116}$ Van Randenraedt werd regelmatig van het bidden afgehouden, niet alleen door allerlei aardse besognes, maar ook door liefdewerken. Zo was op 22 maart 1645 haar gewone gebed erbij ingeschoten. ${ }^{117}$ Toen ze 's avonds rond zeven uur thuis kwam, wilde ze haar gebed alsnog doen. Dat ging niet, omdat er bezoek voor haar moeder arriveerde. Aangezien de gast een man was, kon zij haar moeder niet met hem alleen laten. Na zijn vertrek had haar moeder hulp nodig bij het schrijven van enkele brieven over 'tijttelijcke noetsaeckelijckheeden'. Wederom geen gelegenheid voor gebed. In haar gewetensrekening klaagt zij: alles wil zij volmaakt doen, maar telkens wordt zij daaraan door anderen gehinderd. Haar onvrede hierover blijkt dan een nieuwe bron van wroeging, want gezien haar staat behoort zij dergelijke tegenslagen en het daaruit voortvloeiende verdriet te accepteren als beproevingen door $\mathrm{God}$. $\mathrm{Zij}$ zelf leert anderen nota bene om tevreden te zijn, in blijdschap en verdriet. Wanneer zij haar eigen onwaardigheid belijdt, bespeurt zij dat God haar haar onvolmaaktheid vergeeft.

De volledige aandacht voor God, die beide geestelijke maagden zozeer nastreefden, werd gemakkelijk verstoord. Daardoor kwamen zij in de naar eigen zeggen weinig benijdenswaardige toestand van 'uitgekeerdheid'. Hoezeer zij God en naasten ook in de wereld wilden dienen, zij waren voortdurend bevreesd dat het vlees de geest zou overheersen en hun geestelijke vooruitgang zou belemmeren.

116 KB Brussel, Handschriften I8984, 197vo-199 (29 april I638).

117 KB Brussel, Handschriften 19070, 152-153vo (22 maart 1645). 
Ontsnappen aan deze spanning, die nu eenmaal intrinsiek deel uitmaakte van het geestelijk leven in de wereld zoals dat vorm kreeg in de kloppenstaat, was natuurlijk een illusie. Ook de verlangens van beide vrouwen zelf waren tegenstrijdig. Soms wilden zij, aldus hun gewetensrekeningen, wel voor alle mensen wegvluchten om zich ongestoord aan God te kunnen wijden. Soms echter kreeg hun wens om anderen te leren en bij te staan de overhand.

\section{Loopbaan in goede werken}

Na haar onvoorziene terugkeer uit het Keulse klooster in haar woonplaats Wassenberg legde Agnes van Heilsbach zich toe op een loopbaan in goede werken. Huysmans kwalificeerde haar vasthoudend en innovatief optreden als het 'jacht maken op zielen' ${ }^{1{ }^{18}}$ Kinderen noch volwassenen waren veilig voor haar bekeringsijver. De kinderen in de leeftijd van tien tot twaalf jaar, die zij bij haar thuis onderwees in de beginselen van het geloof, leerde zij wat zonde was en hoe zij hiervoor door een goede biecht vergeving konden kriigen. $\mathrm{Zij}$ bracht hen hoogstpersoonlijk naar de pastoor van Wassenberg, opdat zij bij hem zouden biechten. Met volwassenen volgde Van Heilsbach een andere strategie. Hen maakte zij deelgenoot van enkele ernstige zonden die zij zelf had begaan. Sommigen vertrouwden haar daarop zonden toe die zij niet aan de pastoor hadden durven biechten. " Vaak wist zij hen daarna wel te bewegen om bij de pastoor te biecht te gaan. ${ }^{120}$ Ook bekeringsdrang, die haaks stond op wat de apostel Paulus - en na hem vele geestelijken - voor vrouwen gepast achtte, was haar niet vreemd. Met succes deed zij een 'ketter' zijn geloofsdwaling inzien: 'Ick beloefden hem [de ketter] ick sau hem helpen, onderwijsen ende ondervraegen dat hij mij opreght de waerheijt seggen sau (...)'. Hij moest van haar zijn zonden optekenen. Daarna troonde zij hem mee naar de pastoor. Deze lijkt Van Heilsbach bij haar apostolaat geen strobreed in de weg gelegd te hebben. Paulus' gebod werd, zoals al eerder opgemerkt, niet klakkeloos of ongedifferentieerd onderschreven door alle geestelijken.

In Roermond ging Van Heilsbach onverdroten voort op de door haar ingeslagen weg, vermoedelıjk met de zegen van haar nieuwe geestelijke vaders. Godsdienstonderricht en lekenapostolaat werden krachtig bevorderd door de jezuïeten. ${ }^{121} \mathrm{~V}_{1 a}$ Maria-congregaties of sodaliteiten probeerden zij het apostolaat onder leken te

118 Leven ende deughden, 57, 88-90. De opmerkelı)ke metafoor van het jagen wordt ook door Lumnus, Van dleven, 229, gebruikt. Hij schrift dat de duvel de piylen van zijn wreedheid net zo lang afschiet 'tot dat hy, ghelıck een raegher, den ghenen die hy dooden sal, bunnen zijn netten ghevanghen heeft' Een posinevere uitleg van jacht, die Huysmans beoogt, is te vinden in het gedicht 'Tras de un amoroso lance' ('Na een hefdevolle jacht') van de Spaanse mystucus Johannes van het Kruss (1542-1591) over de jacht van een ziel op 'goddelıke prool'. Fuente, 64-67. Met dank aan drs. Jacquelıne Kerkhoff

119 Leven ende deughden, 57-58.

120 C.ss.R. Roermond, Speciaal Archref A pl 7, GG II (ongepagineerd).

121 Poncelet, Histoire, II, 298-345; Put, 'Een nieuw pastoral model'. 


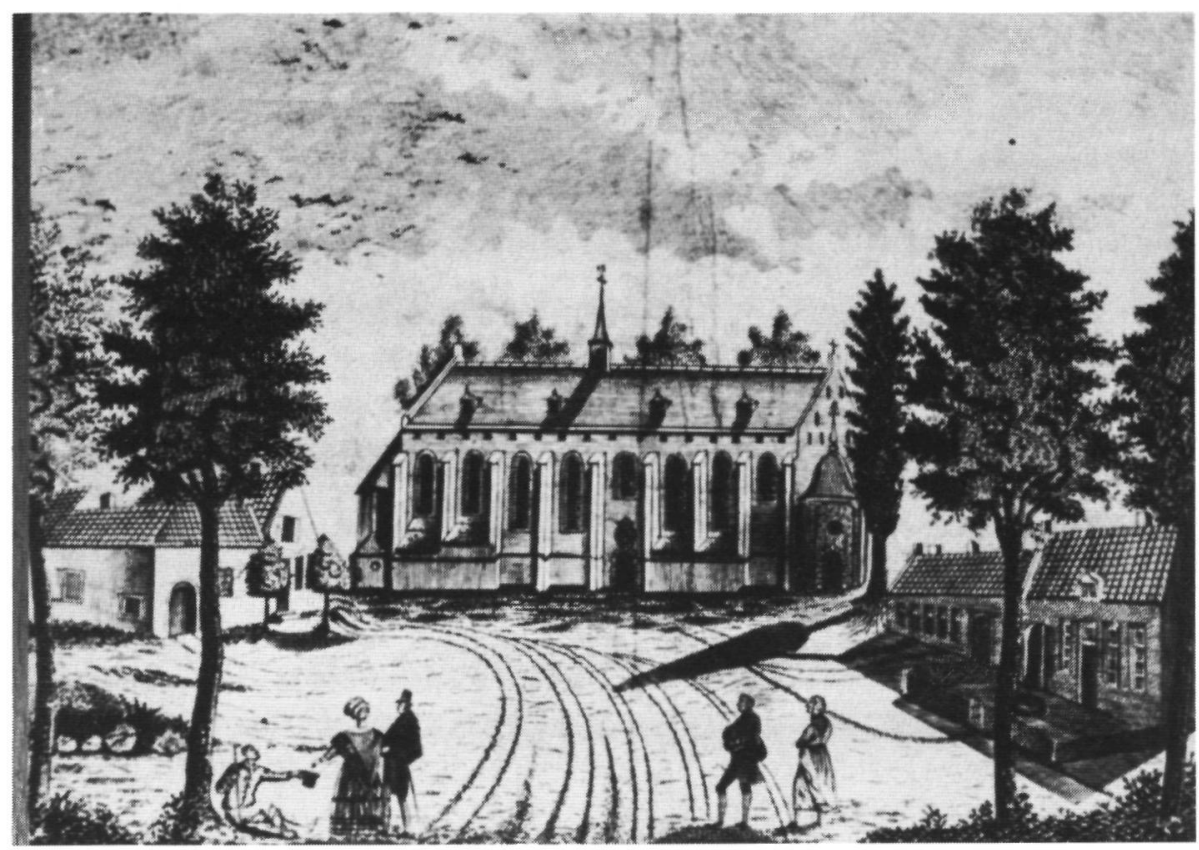

Afb. 20 De Kapel in 't Zand speelde een belangrijke rol in de religieuze beleving van foanna van Randenraedt en Agnes van Heilsbach. Na de catechismus ging Agnes vaak naar deze kapel om voor de kinderen die aan haar zorg waren toevertrouwd, te bidden, opdat Maria 'door haer Moederlijcke liefde sorghe soude draeghen, dat dese kinders haeren Sone altijt souden behaeghen ende hem in alle Eeuwigheydt loven ende ghebenedijden' (Leven ende deughden, 90).

bevorderen. Ook in Roermond werden kort na de opening van het college in I6IO sodaliteiten gesticht. Sinds het generalaat van Aquaviva was het lidmaatschap voor vrouwen van deze vrome verenigingen formeel uit den boze. Wellicht ligt in dit verbod een verklaring voor de soms nauwe samenwerking tussen jezuïeten en geestelijke dochters. Deze vrouwen konden misschien vooral onder kinderen en vrouwen voorwaarden scheppen voor de pastorale arbeid van de paters. Van Heilsbach droeg daaraan op verschillende manieren bij. Ook hier begeleidde zij vrouwen en mannen die haar hun zonden hadden opgebiecht, tot aan de biechtstoel; zij 'hielsse in het oogh', tot zij hun biecht gesproken hadden. ${ }^{122}$ In Roermond legde zij zich wederom toe op het voorbereidend catechismus-onderwijs aan kinderen, ditmaal geassisteerd door andere kloppen. ${ }^{123}$ Nadat zij haar onderwijstaken in I637 overgedragen had, verzuchtte zij dat zij anderen nu enkel nog een dienst kon bewijzen met haar gebed. ${ }^{124}$ Die voorstelling lijkt op grond van haar gewetensrekeningen niet helemaal correct. Want hoewel Van Randenraedt ook

122 C.ss.R. Roermond, Speciaal Archief A pl. 7, GG II (ongepagineerd).

123 Ibidem.

$124 \mathrm{~KB}$ Brussel, Handschriften 18984, 78vo (30 juli [1637]). 
haar plaats als geestelijk leidsvrouw van de andere jezuĩeten-kloppen geleidelijk ging innemen, bleef Van Heilsbach in haar laatste levensjaren nog als vraagbaak fungeren, voor geestelijke dochters, geestelijken en leken. Menigeen kon rekenen op advies of een stevige reprimande. Ondanks lichamelijke gebreken, die haar functioneren bemoeilijkten, bleef zij zichzelf beschouwen en gedragen als een 'onweerdich instrument' van God.

Joanna's loopbaan in goede werken begon onder het toeziend oog van Agnes. Die had haar geleerd hoe zij aalmoezen aan de armen kon uitdelen hoewel zij zelf volkomen onbemiddeld was. Ze zamelde geld in en deelde dat dan vervolgens uit. ${ }^{\text {I25 }} \mathrm{Op}$ instigatie van Van Heilsbach werd deze praktijk ook toegepast om de kosten, die gemoeid waren met de versiering van kerken en kapellen, te bestrijden. Collecteren mocht dan wel een taak zijn waar geestelijke dochters zich aan wijdden, dit mocht slechts met toestemming van de biechtvader. ${ }^{126}$ In haar spirituele autobiografie verhaalt Joanna hoeveel moeite haar deze praktijk kostte, toen zij nog maar pas geestelijke dochter was. Het is niet denkbeeldig dat zij deze strijd in haar levensverhaal bewust veel nadruk heeft gegeven om te verduidelijken dat het religieuze leven buiten het klooster een zware opgave was. Om haar weerstand, waarvan zij de oorsprong zelf benoemt als 'hoeveerdiege natuer' die maar 'qualijck' wilde afsterven, te breken, moest Joanna in opdracht van Agnes juist vaak aalmoezen gaan vragen bij de notabelen van de stad. De giften die zij kreeg, werden uitgedeeld aan de huisarmen die hun armoede voor de buitenwereld verborgen hielden. Sinds 1593 werden de huisarmen in Roermond bedeeld vanuit de parochiekerk. Iedere zondag, na de hoogmis, vond de bedeling, die bestond uit brooduitkeringen, plaats voor het oog van de verzamelde geloofsgemeenschap. ${ }^{127}$ Stille huisarmen verkozen armoede boven deze openbare bedeling, die ongetwijfeld als beschamend werd ervaren. $\mathrm{Zij}$ waren afhankelijk van particuliere initiatieven, onder andere van geestelijke maagden zoals Van Randenraedt en Van Heilsbach. ${ }^{128}$

Bijzondere weerstand memoreert Joanna tegen Agnes' opdracht om vrijwel wekelijks bij de toenmalige Roermondse bisschop, Jacobus a Castro (I6II-I639), aalmoezen te gaan vragen. Deze stak haar dan wat geld toe, vroeg of het genoeg was, en spoorde haar aan het te distribueren. Maar vaak vroeg hij haar ook wie haar gestuurd had, en dat mocht zij van Agnes niet zeggen. Ze antwoordde dan maar, Onze Lieve Heer, hetgeen in wezen, zo tekent zij aan, ook waar was, want voor haar eigen gevoel zamelde zij in naam van haar Bruidegom in. Vooral wanneer de prelaat zich verbaasd toonde haar al weer te zien, of omstandig begon uit te leggen dat ook hij zo zijn kosten had en niet ongelimiteerd aalmoezen kon

I25 GAR, Handschrifien I A 5 (ongepagineerd; mei 1640).

126 Zie hiervoor ook KB Brussel, Handschriften 18984, I20vo-I2I (6 januari z.j.).

127 Linssen, 'Instellingen van weldadigheid', 246-25I.

128 KB Brussel, Handschrifien 19073 (I), 196-199. 
doneren, voelde Joanna het schaamrood naar de kaken stijgen. ${ }^{129}$ Behalve dat zij het als vernederend, en dus als oefening in nederigheid, ervoer om bij mensen van stand, waartoe zij zelf ook behoorde, om aalmoezen te vragen, was zij beducht voor opspraak. Mensen dachten soms, zo schrijft zij, dat zij zelf van de ingezamelde giften profiteerde. En wie haar langs de deuren zag gaan en huizen van bijvoorbeeld officieren binnen zag treden, zou misschien wel kunnen denken 'dat ick lichtveerdich, ia een hour [hoer] bin'..$^{130}$ Toch stonden haar veelvuldige inzamelingsacties ook gunstig bekend bij haar stadgenoten. Sommigen riepen haar toe: 'Godt help u, Godt help u' ${ }^{\text {.3r }}$ Anderen spraken haar aan op straat: 'Jouffrau comt hier, wij hebbe[n] wat voor den aermen'. ${ }^{132}$

Toen Joanna alle werkzaamheden van haar geestelijke moeder had overgenomen, voltrok zich een verandering in haar takenpakket. Over deze wijziging geven haar gewetensrekeningen slechts indirect informatie. Worden activiteiten als ziekenbezoek, het uitdelen van aalmoezen of werkzaamheden in verband met de catechisatie nog regelmatig vermeld in haar aantekeningen van rond I640, dergelijke vermeldingen worden schaars vanaf 1643 . Liefdewerk lijkt in toenemende mate synoniem te zijn geworden met gebeden voor gelovigen of de kerk in het algemeen, met deelname aan processies en met fraaie handwerken. Voor haar gebed was meer dan voldoende belangstelling, al kon Joanna zich niet voorstellen, naar zij schrijft, wat haar 'kranke gebeden' bij God zouden uitrichten. Deze bescheidenheid zal zeker ingegeven zijn door haar gevoel van nietigheid ten opzichte van een almachtige God, al moet dit blijk van bescheidenheid ook als een topos gezien worden. Zij was er immers van overtuigd dat zij als Christus' bruid deelde in Zijn macht en kracht. Als geestelijke maagd paste het haar echter niet hier prat op te gaan.

Al besefte ze wel dat het de wil van de Heer was dat zij zich toelegde op allerlei borduurwerk voor kerken en kapellen, toch beklaagde zij zich hierover in haar gewetensrekening van juli I645. Dit liefdewerk begon namelijk langzaam maar zeker ten koste te gaan van de tijd die haar restte voor haar devoties. ${ }^{133}$ Bovendien moest ze uit hoofde van die taak haar moeder veel alleen thuis laten, die zich hieraan ook steeds meer begon te storen. Tezelfdertijd beleed ze op papier haar verdriet dat ze de paters van de Sociëteit alleen door dergelijk liefdewerk van dienst kon zijn. ${ }^{134}$ Het speet haar dat haar bijdragen ook minder werden gewaardeerd dan financiële donaties. Zoals toen de rector van het college, l'Hermite, ternauwernood een blik wierp op een borduurwerk waaraan zij samen met

129 Ibidem, 197, 207-209.

130 Ibidem, 205.

131 Ibidem, 200.

132 Ibidem, 199.

133 KB Brussel, Handschriften 19070, 212-213 (juli 1645).

134 Ibidem, 216-217 (juli 1645). 
Lucia de Werimont negen maanden had gewerkt. ${ }^{135}$

Dat handwerken voor kerken en kapellen in toenemende mate hun liefdewerk bij uitstek werd, betekende niet dat zij hiermee per definitie teruggedrongen werden uit de openbare sfeer van het kerkelijk domein. Het decoreren van beelden en het borduurwerk gebeurde in elk geval gedeeltelijk in de openbare, gewijde ruimten zelf, waarneembaar voor andere gelovigen. Ook het resultaat van hun artistieke ijver was publiekelijk zichtbaar. Zo konden geestelijke dochters in Roermond hun vroomheid na 1645 openlijk manifesteren. Een dergelijke manifestatie werd door hun geestelijke vaders mogelijk meer met de voor hun sekse geldende gedragsvoorschriften in overeenstemming geacht dan het bedelen om aalmoezen, het verzamelen van kinderen in straatjes en steegjes voor de catechisatie, of het begeleiden van gelovigen naar de biechtstoel. Vormde kritiek uit de Roermondse gemeenschap op het optreden en de werkzaamheden van de jezuïeten-kloppen misschien de achtergrond van de verandering in hun takenpakket? Helaas gaan de jaarbrieven van het jezuïetencollege nauwelijks in op de werkzaamheden van geestelijke maagden. $\mathrm{Bij}$ gebrek aan die informatie is het moeilijk vast te stellen of en zo ja, waarom zich veranderingen in hun taken op instigatie van hun leidsmannen voltrokken. Enkele ontwikkelingen speelden mogelijk een rol. Midden jaren veertig ebde de ergste oorlogsdreiging langzaam weg; voorkomende werkzaamheden konden door geestelijken, aan wie de stad steeds minder gebrek kreeg, ${ }^{136}$ uitgevoerd worden. De jezuïeten hadden in Roermond inmiddels een uitgebreid en invloedrijk sociaal netwerk opgebouwd, dat hun met gulle donaties steunde. Uit de jaarbrieven van I640 en later spreekt een soort nieuw élan, waarmee de paters zich in ruimere getale bijvoorbeeld op de catechisatie richtten. ${ }^{137}$ Naar het zich laat aanzien kon de inzet van geestelijke maagden onder deze omstandigheden beperkt worden tot ondersteuning in de vorm van gebed, intensieve devotionele praktijk en decoratieve werkzaamheden die het aanzien van hun geestelijke broeders en de aantrekkingskracht van verschillende kerken konden vergroten.

\section{Grenzen aan werkzaamheid}

Van Randenraedt rationaliseerde haar gevoelens van onvrede over het borduurwerk door zich voor te houden dat zij al haar werk voor God en haar hemelse Bruidegom deed. Nog afgezien van de schamele waardering die zij ervoor kreeg van geestelijken als l'Hermite, vervulde deze arbeid haar apostolaire ambities vermoedelijk nauwelijks. Juist in andere vormen van liefdewerk - ziekenbezoek,

135 Ibidem, 222vo-223vo (juli 1645).

$136 \mathrm{Vgl}$. Comelissen, "Relationes status"', 76.

137 PA SJ, Historische handschriftenverzameling, doos $155, \mathrm{C}_{3} 8$ i, Litterae annuae collegii Ruraemundensis S.J., anno 1641 . 
aalmoezen inzamelen, kinderen voorbereiden op de catechisatie - had zij haar dadendrang kunnen bevredigen. Vaak voelde zij zich 'ongedurich driftich'. Wanneer zij dit gevoel in allerlei goede daden wilde omzetten, realiseerde zij zich dat zij nog niet de helft van alles wat zij wilde, zou kunnen volbrengen. ${ }^{138} \mathrm{Het}$ 'vliechachtich' gevoel dat werken van barmhartigheid haar konden bezorgen, sloeg dan om in ineffectiviteit. Regelmatig botsten haar ambities met haar fysieke mogelijkheden. Klachten over allerlei kwalen en moeheid, die gezien de lange dagen en de nachtelijke gebeden niet verwonderlijk zijn, wijzen op de lichamelijke grenzen die aan haar werkzaamheid waren gesteld.

Als geestelijke maagd werd zij bovendien - anders dan kloosterlingen - geconfronteerd met beperkingen in haar religieus leven die haar ouders probeerden op te leggen. Cornelis van Randenraedt en Livina van der Meeren waren er bijvoorbeeld op tegen dat Joanna langs de huizen ging bedelen om aalmoezen. Via haar biechtvader gaf Cornelis haar een reprimande, omdat zij tijdens een kortstondig verblijf in Geldern giften had ingezameld en daarmee de capuciinen ter plaatse had benadeeld. ${ }^{139}$ Een dergelijke openbare oefening in nederigheid mocht Joanna voortaan slechts uitvoeren, wanneer haar vader hiervoor toestemming gaf. Ook haar moeder schaamde zich ervoor dat haar dochter bij anderen om geld vroeg. $\mathrm{Na}$ verloop van tijd kreeg Joanna echter wel de benodigde permissie. Haar vader was immers, zoals zij zelf schrijft, een godvruchtig man. De aanvankelijke weerstand van hem en zijn echtgenote werd vermoedelijk veroorzaakt doordat hun dochter zich publiekelijk manifesteerde als een religieuze vrouw en geen taken schuwde die volstrekt ongepast waren voor iemand met haar maatschappelijke achtergrond. ${ }^{1{ }^{\circ}}$ Hun verzet illustreert dat geestelijke maagden bij hun taakuitoefening terdege rekening moesten houden met bezwaren die sommige activiteiten bij hun verwanten opriepen.

Gevoelens van onmacht bekropen Joanna vooral wanneer zij onder ogen zag dat zij als vrouw maar beperkte mogelijkheden had om haar diepe verlangen te verwezenlijken om anderen tot een doorleefd geloof te inspireren of zelfs te bekeren. Opmerkelijk zijn de toespelingen die zij hierop maakte; allusies die geheel ontbreken in de gewetensrekeningen van haar geestelijke moeder. In 1640 schrijft zij dat ze zich de beperkte uitwerking van haar bijdrage aan het heil van anderen realiseert. Haar aandeel bestaat immers vooral uit bidden. In dat verband verzucht zij op papier: 'Maer helaes, wat kan ick doun, waer ick [maar] eenen man (...)'. ${ }^{14 \mathrm{r}}$ De vroegste aanwijzing dat zij zich bewust was van sekse-specifieke grenzen dateert uit ${ }^{6} 634$. Ze is zojuist ter communie geweest. $\mathrm{Na}$ de mis gaat zij op weg naar een

I38 GAR, Handschnfien I A 5 (ongepagineerd; februan 1640).

139 KB Brussel, Handschnfien 19073 (I), 257-262.

$140 \mathrm{Z}$ j) bezwaren doen denken aan de negatneve reacties die neuwe religeuze vrouwengemeenschappen aan het einde van de zesuende en het begin van de zeventiende eeuw moesten incasseren. Zie hiervoor I 2 van dit boek.

141 GAR, Handschnften I A 5 (ongepagmeerd; september 1640). 
kerk of kapel ergens in de stad. Daar hoort zij 'iet virichs van eene g. [eestelijke] man'. Misschien sprak deze geestelijke haar persoonlijk toe. Zijn opmerking doet haar in elk geval in jaloezie ontsteken en ze beklaagt zich inwendig 'dat ick geen man en was, ick sau wonder dingen aengerecht hebben' ${ }^{142}$

Joanna's aspiraties gingen duidelijk verder dan het collecteren van giften of het opsieren van Mariabeelden. Een droom die zij 1647 had en haar interpretatie, die verweven is in het verslag daarvan, zijn veelzeggend. ${ }^{143}$ Deze droom is aangetekend in een gewetensrekening die zij schreef tijdens haar verblijf in Spa. In de droom was Catharina van Gestel priester geworden. Zij droeg heimelijk de mis op. Die geheimzinnigheid had waarschijnlijk vooral te maken met het gegeven dat de openbare uitoefening van de katholieke eredienst in de Meierij, waar Van Gestel woonde, onder Staats bestuur verboden was. Van Randenraedt vroeg Van Gestel - nog steeds in de droom - hoe zij priester geworden was, omdat zij dit beslist ook wilde worden. Zij overpeinsde hoe wezenlijk anders Van Gestel vorm gaf aan haar navolging van Christus. Zelf gaf zij zich met Christus over aan God, als zoenoffer voor de zonden van de mensheid. Van Gestel verkondigde daarentegen het geloof. Uit de meer feitelijke beschrijving van Van Gestels taken die dan volgt, blijkt echter dat deze geestelijke dochter beslist niet de sacramenten bediende. Eigenlijk lijken haar taken zich nauwelijks onderscheiden te hebben van Van Randenraedts werkzaamheden in Roermond: kinderen en volwassenen onderwijzen in de beginselen van het geloof en gelovigen aansporen hun geloofsplichten te onderhouden. Dat zij Catharina van Gestel om haar taken benijdde, wijst op de inperking van haar handelingsvrijheid en takenpakket, die hierboven reeds aan de orde is gesteld. Vooral interessant in dit verband is echter dat Van Randenraedt zelf een onderscheid maakt tussen de navolging van Christus' leven en van Zijn lijden. En hoewel de navolging van $\mathrm{Zijn}$ lijden voor vrouwen een geaccepteerde vervulling van religieuze inspiratie was, blijkt zij - de strekking van deze droom beziend - toch ook een meer actieve vorm van navolging te hebben nagestreefd.

Een jaar voor haar dood, in I683, herhaalde zij tegenover haar biechtvader eerdere verzuchtingen over de grenzen die haar op grond van haar sekse waren gesteld in het kerkelijk domein. Ditmaal maakt zij uitdrukkelijk de koppeling tussen man-zijn en het priesterambt: 'Och waer ick eenen man, ende dat ick priester kost geworden (...)'. ${ }^{144}$ Maar priester worden en de mis opdragen zoals Van Gestel deed in de droom, was uit den boze voor vrouwen, dat wist Van Randenraedt maar al te goed. Van dat inzicht had zij blijk gegeven in haar verslag van een droom of verschijning in mei $1640 .{ }^{145} \mathrm{Ze}$ beschrijft dat ze bang was die dag niet ter communie te kunnen gaan, een voor haar beangstigend vooruitzicht.

142 RAL, Archief Bisschoppen van Roermond, inv.nr. 135 [gewetensrekening, 1634](ongepagineerd).

143 GAR, Handschriften I A 9 (ongepagineerd).

144 C.ss.R. Roermond, Speciaal Archief A pl. 7 HH 8 (ongepagineerd).

145 GAR, Handschrifien I A 5 (ongepagineerd; mei 1640). 
In haar gebed deed zij een beroep op haar geestelijke moeder, die in januari dat jaar was overleden. In haar droom staat Agnes klaar om haar te helpen. Maar Van Randenraedt weet dat de enige die haar echt kan helpen een priester is, die 'mij mijnen Brudegom [de communie] sacramenteellijck geeft want dat de vrauwen niet gegundt en is'. Hulp die Agnes haar wilde bieden, kon dus niet bestaan uit het uitreiken van de communie, want dat was vrouwen niet toegestaan.

Zich welbewust van de sekse-specifieke beperkingen die er aan haar werkzaamheid waren gesteld, zocht en vond Joanna troost en kracht in de heilige communie. Door dit sacrament kon zij zich met haar Bruidegom verenigen, ja soms zelfs vereenzelvigen, en daardoor tevens haar status als $\mathrm{Zijn}$ bruid bevestigen. Eenzelfde bevestiging vond zij ook in fysieke boetepraktijken en lichamelijke kwalen, die fysiek lijden veroorzaakten. Een lijden waarmee zij enerzijds uitdrukking probeerde te geven aan haar liefde voor Christus; anderzijds kon zij dankzij dit lijden de grenzen waarop haar apostolaire ambities botsten, in zekere zin ontstijgen.

\section{V.5 Lijden en liefhebben}

Wie de handschriften van Van Heilsbach en Van Randenraedt leest, wordt getroffen door hun verslagen van strenge verstervingen en penitenties en van hun voortdurende verlangen naar de communie. Hun egodocumenten beschrijven overschrijdingen van grenzen in geestelijke en fysieke zin en kunnen een zekere vervreemding teweegbrengen bij een hedendaagse lezer(es). ${ }^{146}$ Waarom sliepen zij liever op de planken vloer dan in hun eigen bed? Waarom kastijdden zij zichzelf tot bloedens toe, droegen zij soms een haren kleed en namen zij de daarin genestelde vlooien op de koop toe? Vanwaar die eindeloze - en vaak vruchteloze pogingen - om kadavers te kussen of dierlijke en menselijke faecaliën en andere uitscheidingen in de mond te nemen? En hoe is het te begrijpen dat zware hoofdpijnen en martelende rugpijnen letterlijk als een godsgeschenk in vreugdevolle lijdzaamheid werden aanvaard? Het gevaar om dergelijke verlangens en ervaringen naar anachronistische normen te meten, is groot. De uitkomst daarvan is voorspelbaar: deze geestelijke maagden waren dweperige vrouwen, wier zucht naar versterving en penitentie enkel als een vorm van masochisme uitgelegd kan worden ${ }^{147}$ en wier verhaalde dromen, visioenen, openbaringen en inspraken met de nodige scepsis moeten worden gelezen. Door echter hun autobiografische verhalen te

$146 \mathrm{Vgl}$. Mack, Visionary Women, 9, die schrijft: 'The observer who seeks to understand the seventeenth-century religious visionary finds a group of women and men whose sensibilities ultimately elude the tools of the modern scholar.'

147 Meest recent is zo'n oordeel op basis van Huysmans' vitae geveld door De Vroede, 'Kwezels' en 'zusters', 66, 68. Veelzeggend is dat De Vroede stelt dat deze geestelijke dochters 'het ongewone, wat dus valt buiten het normale' met elkaar - en met geestverwanten als Elisabeth Strouven en Anna de Torres - gemeen hadden. 
contextualiseren wordt aannemelijk dat beiden zowel aan strenge boetedoeningen alsook aan de heilige communie verschillende betekenissen hechtten die een lange traditie kenden onder religieuze vrouwen en deels ook aangemoedigd werden door hun leidsmannen. ${ }^{148}$

\section{Lijdende bruiden}

In hun eigen tijd werd de lijdensdevotie van Van Heilsbach en Van Randenraedt al als exceptioneel beschouwd. Deze kwalificatie had echter beslist niet alleen een negatieve connotatie. Onverholen bewondering klinkt bijvoorbeeld door in Huysmans' levensbeschrijvingen. Van Heilsbachs 'begeerte tot het lijden [was] soo over-groot, dat het lijden haer leven scheen te wesen, ende het derven van het lijden haere doodt', aldus deze jezuïet. ${ }^{149} \mathrm{Hij}$ prijst ook Van Randenraedts lijdzaamheid die in een aparte paragraaf, 'Lijf-kastijdinghe', wordt beschreven. ${ }^{150}$ Terwijl verscheidene geestelijke auteurs juist waarschuwen voor overmatige verstervingen, presenteert Huysmans de penitentiepraktijken van beide vrouwen haast als nastrevenswaardig ideaal. Daarmee wijkt hij, net als de auteurs van andere vitae onder de kloppenboeken, af van het standpunt dat de schrijvers van de onderrichtingsboeken huldigen. Die moedigen over het algemeen juist matigheid aan in penitenties en verstervingen. ${ }^{15 x}$ Lezeressen en lezers van deze kloppenboeken worden gewaarschuwd dat degenen die het minste in staat zijn om strenge boetepraktijken te volbrengen, er vaak het meest toe genegen zijn. Daarom doen geestelijke maagden er verstandig aan zich vooral in alledaagse dingen te versterven: iets niet doen wat men graag doet, of iets eten wat men niet lust. Voor andere verstervingen en penitenties, zoals het slapen op de grond of het dragen van een haren kleed, moet de biechtvader om toestemming gevraagd worden.

Van Heilsbach ging zich bij tijd en wijle eigenmachtig te buiten aan fysieke zelfkwellingen. ${ }^{152}$ In overgeleverde fragmenten van haar eigen levensbeschrijving wordt dit uitvoerig beschreven. ${ }^{153}$ In haar gewetensrekeningen daarentegen zijn vermeldingen van strenge boetedoeningen schaars. De indruk bestaat dat zij in haar latere levensjaren, waaruit de rekeningen dateren, nauwelijks meer boetedoeningen praktiseerde. Verschillende kwalen voorzagen misschien al in haar verlangen naar fysiek lijden. Zij benoemt die niet expliciet, maar in de gedrukte levensbeschrijving is sprake van zware hoofdpijnen en hartklachten. ${ }^{154}$ Ook haar intense geloofsbeleving en verschillende godservaringen veroorzaakten pijn. In april I637

$148 \mathrm{Vgl}$. voor de noodzaak van contextualisering Frijhoff, 'Normeren of waarderen', I8-19.

149 Leven ende deughden, 237; vgl. KB Brussel, Handschriften 18984, 193vo-195 (25 april 1638).

150 Kort Begryp, 227-242.

151 Zie hiervoor III.7 van dit boek en Theissing, Over klopjes, Ir3-II4.

152 Vgl. Leven ende deughden, 237-258.

153 C.ss.R. Roermond, Speciaal Archief A pl. 7, GG 11.

I54 Leven ende deughden, 96-98; zie ook KB Brussel, Handschrifien 19073 (I), 236. 
beschrijft zij hoe al haar zielekrachten door God zijn ontstoken in een hete brand, zodat het leek alsof 'het binnenste mijnder beenderen' in vuur en vlam stond. Deze pijn houdt de hele nacht aan. Pas de volgende ochtend, nadat zij ter communie is geweest, ebt die enigszins weg, al blijft zij haar voelen in haar ziel. ${ }^{155}$ Hoewel zij geen strenge boetedoeningen meer deed, was haar verlangen daarnaar niet geweken, naar blijkt uit haar dromen. ${ }^{56}$

In hun streven naar lijden, waaraan een zekere masochistische neiging niet altijd vreemd was, kunnen verschillende functies en dimensies onderkend worden. Deze dimensies hangen samen met de identiteit als geestelijke maagd en met de ambitie daadwerkelijk steun aan kerk, clerus en naasten te verlenen. Het lijden van Christus vormde zowel voor Van Heilsbach als Van Randenraedt een belangrijke drijfveer voor handelen. Eigen lijden was een antwoord op Zijn lijden, een antwoord waarmee zij hun diepgevoelde liefde voor de Verlosser tot uitdrukking brachten. Van Randenraedt schrijft dat zij God op de meest volmaakte manier lief wil hebben; ze wil net als haar Bruidegom lichamelijke en geestelijke vormen van lijden en vernedering doorstaan en verdragen uit liefde tot Christus. Ze hoopt dat zij 'met Hem [Christus] mach worden een offerhande van versouninge, sijnde gans verteert ende geconsomeert voor de saelicheijt vant heel menschelijck geslacht (...)'. ${ }^{157}$ Uit liefde tot haar hemelse Bruidegom, die de verlossing van het mensengeslacht zo duur betaald had, voelde Van Heilsbach een diepe behoefte om zelf ook te lijden. ${ }^{158}$ Dagelijks mediteerde zij over de navolging van de lijdende Christus. Beide vrouwen namen daarbij vroeg-christelijke martelaren ten voorbeeld. Volgens Agnes was het geen wonder dat deze tijdens het doorstaan van de hun aangedane kwellingen blijdschap voelden, want

'het is de liefde, de liefde, de liefde, die stercker is als dood, vier [vuur], ende vlammen, als alle metaelen ende instrumenten. Ach hoe dickwils hebbe ick Godt ghebeden, dat hy my een luttelken van dese gratie soude verleenen, van veel ende langh te moghen lyden'. 59

Door zichzelf geestelijk of lichamelijk te pijnigen, maar ook door pijn ten gevolge van ziekte te verdragen, leden zij niet alleen letterlijk mee met hun Bruidegom, maar bevestigden aldus ook hun identiteit als bruid van Christus. Immers - zo citeert Huysmans de kennelijk retorische vraag van Van Helsbach - 'sal een Bruydt haeren Bruydegom sien overgoten van pijnen, ende swemmende in sijn

$155 \mathrm{~KB}$ Brussel, Handschnften 18984, 9vo-10 (28 apnl 1637).

156 Bijvoorbeeld ibidem, 361vo-362 (4 december [1638]).

157 GAR, Handschnften II B 1, I48; zie ook 149.

$158 \mathrm{~KB}$ Brussel, Handschnften I8984, 260-260vo (I5 julı [1637?]).

159 Leven ende deughden, 255 Dit citaat is niet terug te vinden in haar overgeleverde gewetensrekeningen Het geeft echter treffend Van Heılsbachs visıe op hchamelyk luden weer, zoals die in passages uit haar eigen nonties tot uutıng komt Zle bijvoorbeeld KB Brussel, Handschrifien I8984, 257vo (8 jul1 [1637?]). zl) verklaart zich bere1d om ut liefde tot de Verlosser 'duisent miliounen hellen te lijden, aldus lıden en ist geen lıden, maer eenen heemel'. 
H. Bloedt, ende oock niet wat mede ghevoelen?'r60 Beide geestelijke maagden stonden in de traditie van middeleeuwse religieuze vrouwen en mysticae, voor wie het ascetisch lijden de vereniging met de lijdende Christus representeerde. ${ }^{161}$

$\mathrm{Nu}$ en dan was Joanna bang tekort te schieten tegenover haar Geliefde en schenen haar de penitenties en verstervingen, die zij als geestelijke dochter kon doen, niet zwaar genoeg. Haar verzoeken om strenge vasten of lijfkastijdingen werden niet altijd gehonoreerd door haar biechtvaders, niet in de laatste plaats - als we de gedrukte levensbeschrijving mogen geloven - omdat Van Randenraedt zich hieraan met gevaar voor eigen lijf en leden nogal eens te buiten ging. ${ }^{162}$ Werden haar echter beperkingen opgelegd, dan maakte onzekerheid zich van haar meester. In 1639 twijfelde zij daarom of zij er wel goed aan had gedaan om geestelijke maagd te worden. Misschien was het beter alsnog in een streng klooster in te treden, want zij leefde 'soe sachtelijck'. ${ }^{163}$ Diskwalificeerde zij eigen boetedoeningen op grond van een vergelijking met de penitenties die vriendinnen van haar deden, die claris waren geworden? Haar gewetensrekeningen geven daarover geen uitsluitsel. Wel blijkt uit deze passage dat fysieke boetepraktijken in haar ogen een graadmeter vormden voor het religieuze karakter van haar status en haar staat van volmaaktheid.

Lijden stond niet alleen in het teken van zelfheiliging, maar was ook een intensieve vorm van naastenliefde, en wel op twee manieren. Verschillende passages in de gedrukte levensbeschrijvingen wijzen erop dat beide geestelijke maagden zichzelf kastijdden in de overtuiging dat zij daardoor Gods toorn, opgewekt door de zondigheid van haar naasten, enigszins konden verzachten. ${ }^{164}$ Huysmans vertolkt hun intentie treffend. Beide vrouwen stond het beeld van de Verlosser, gekweld door pijnen die Hem door zondaars werden aangedaan, op het netvlies gegrift. Van Heilsbach verklaarde zich bereid de straffen die Hij hun hiervoor wilde geven, geheel en al op zich te nemen, opdat alleen zij zou lijden en anderen gespaard zouden blijven. ${ }^{65}$ Zelf toegebracht lijden als vorm van naastenliefde was niet uitsluitend op het aardse bestaan gericht. Hierdoor trachtten beide vrouwen ook het lijden van de zielen in het vagevuur te bekorten. ${ }^{166}$ In het vagevuur, zo werd gelovigen steeds voorgehouden, ondergingen zielen, alvorens tot de hemel

160 Leven ende deughden, 237; vgl. voor Van Randenraedt GAR, Handschriften, II B j, 94-96.

16I Bynum, 'The mysticism', 69. Ochsenbein, 'Leidensmystik', 360, beschrijft het streven van de Zwitserse dominicanes Elsbeth von Oyen (ca. 1280 - ca. 1350) naar de volkomen compassio met Christus als voorwaarde voor een uitslutend in het lijden ervaren vereniging met God.

162 Kort Begryp, 21 2-242.

163 GAR, Handschriften I A 5 (ongepagineerd; ongedateerd, anno 1639).

164 Bijvoorbeeld Kort Begryp, 198-200; Leven ende deughden, 253, 268-271. Vgl. F.V.O.C.S., Leven Anna de Torres, 55-60.

165 KB Brussel, Handschriften I8984, I 73vo-I74vo ([30?] maart [1638]). Voor Van Randenraedt zie bijvoorbeeld GAR, Handschnften II B i, I16-II7; 132 .

I66 Kort Begryp, 59, 20I; voor Van Heilsbach, zie KB Brussel, Handschriften 18984, 259-260 (10/12 juli [1637]) 
te worden toegelaten, de noodzakelykke louternng voor kleine, dagelı1kse zonden. ${ }^{167}$ Eenmaal in dit purgatonum, konden de zielen slechts geholpen worden door hun nabestaanden, die door middel van gebed, missen, aalmoezen en aflaten de verblıfsduur in het vagevuur konden verkorten De bıjdrage van Van Randenraedt en Van Heilsbach aan de verlossing van de zielen uit het vagevuur bestond, naast gebed, vooral uit verstervingen en penitenties. ${ }^{168}$

Het verlangen om de Bruldegom in $Z_{1 j n}$ liden na te volgen, was één van de bindende elementen van de groep Roermondse jezuieten-kloppen, waarover Van Heilsbach en Van Randenraedt achtereenvolgens de leiding hadden $Z_{11}$ maakten elkaar deelgenoot van boetedoenıngen of fysieke kwalen. Daarenboven vervulden zl) incidenteel een rol in elkaars penitenties. In sommige gevallen versterkten dergelıke praktujken wellıcht de onderlınge band. Allerleı conflicten, die hierboven al ter sprake zijn gekomen, roepen echter ook twıfel op over het effect ervan op de groepsband. De gewetensrekeningen van Van Randenraedt geven enkele collectreve penitenties pnjs ${ }^{169}$ Ook de notities van Van Heilsbach bevatten incidenteel aanwi)zingen ${ }^{170}$ Uit de spintuele autobıografie van haar geestelıke dochter Joanna blıjt eveneens dat onder Agnes' supervisie gezamenlıjke boetepraktıjken voorkwamen. Op Goede Vrudag, vermoedelık anno I637, onderging Joanna bijvoorbeeld een 'dissiplien (.. ) van boven tot beneen' van de hand van juffrouw Botters. Naar eigen schnjven had Joanna hiernaar al lang verlangd. Agnes verleende toestemming en Joanna wachtte spiernaakt - ze had zelfs de rozenkrans die zij om haar hals droeg afgedaan - deze boetedoenıng af. $Z_{1 j}$ onderging de slagen die Botters uitdeelde met 'tacken van hulst met die steekende bladeren'. Nooit eerder, zo schrift zı, had zıj zo'n 'leevende gevoullen ( ..) vande nacktheijt ende pın' gehad, die haar Bruıdegom tydens $Z_{1 j n}$ geselıng had doorstaan. ${ }^{171}$ Door het ondergaan van deze kastıjding kon zı) Christus navolgen, zıch waarlıjk met Hem identıficeren en $Z$ ı)n pın delen Deze oefening bewerkstelligde een intensieve, fysiek voelbare vorm van een-zijn met haar Bruidegom.

Biechtvaders speelden een ambivalente rol bi) extreme verstervingen. Livinus de Clerck en zijn opvolgers lijken Van Randenraedts hang naar lijden en zelfvernedering te hebben willen temperen. Mannen als Van den Hove en De Moor

167 Vanden Bosch, Hemel, hel en vagevuur, II3-II7, 132-I4I

168 Vgl De Roa S J, Leven Sancza Canilo, I82 en F V O C S, Leven Anna de Torres, 94-99 Ook borduurwerk voor een stıchtelijk doel kon bıjdragen aan de verlossing van een ziel wt het vagevuur Zie hervoor KB Brussel, Handschriften 19070, 86-92 (eind augustus - begin september 1643) Van Randenraedt verhaalt hoe $z ı$ bidt voor de verlossing van de ziel van haar vader, die 28 augustus 1643 is overleden Via een unspraak begrijpt zij dat zijn ziel uit het vagevuur verlost wordt, zodra het kroontje van het kindje Jezus van het grote Onze Lieve Vrouw-beeld in de Kapel in 't Zand af zal zujn $169 \mathrm{~KB}$ Brussel, Handschnfien I9070, $72 \mathrm{vo-73}$ (me1/junı 1643), GAR, Handschnften I A 9 (ongepag1neerd)

170 Byvoorbeeld KB Brussel, Handschnfien I8984, 272-272vo (7 augustus [1638']), 367vo-368 [I5 december $168^{\prime}$ ']

$171 \mathrm{~KB}$ Brussel, Handschnften 19073 (I), 306-312 
moedigden haar verlangen naar extreme penitenties en verstervingen, die soms door Joanna zelf ook als 'onnatuerelijck' werden aangemerkt, bewust of onbewust juist aan. Joanna beschrijft in een gewetensrekening uit 1643 dat De Moor haar opdraagt een fistel bij De Werimont uit te zuigen. ${ }^{172}$ Deze onsmakelijke opdracht is bedoeld als een oefening in zelfversterving. Haar aanvankelijke - en begrijpelijke - weerzin overwint zij door zich voor te houden dat deze fistel de wonden van Christus voorstelt. Geheel nieuw was een dergelijke versterving niet voor Van Randenraedt. Simon van den Hove had haar namelijk ooit gevraagd of zij 'volgens het exempel vanden Heijliegen fransiskus Xaverius' bereid zou zijn om uit liefde tot haar Bruidegom 'het veuil waetter daer den Etter ende de seeren [zweren] vande melaetse menschen meede afgewassen sauwen sijn' te drinken. $\mathrm{Zij}$ beschrijft dat zijn vraag haar op het idee brengt om een zweer bij een andere geestelijke maagd uit te zuigen. Van den Hove verleent zijn toestemming, maar de maagd in kwestie, Anna van Staveren, weigert haar medewerking. 'Haer liede vraeghden mij wat ick mij voor liet staen, dat ick gelijck naer wilde volgen den Heijliegen Xaverius in sulcx mij laettende duncken dat haer liede sau peissen [menen] dat ick soo heijlich waer (...)'. ${ }^{173}$ Van Staverens weigering bevestigt dat niet alle jezuïeten-kloppen de vergaande zucht naar lijden en versterving van iemand als Van Randenraedt deelden en zich soms, niet geheel ten onrechte, afvroegen of zij niet streefde naar zelfverheffing in plaats van zelfvernedering. Van Randenraedt realiseert zich het bijzondere karakter van haar verzoek. Maar dat Anna van Staveren haar vraag vreemd vindt, begrijpt zij niet: 'mij docht dat dat [het verzoek] soo wonder niet en was, aengesien Godt soo wel machtich is door sijn alderminste dienerssen ende alder onmachtichste creatuerkens onnatuerelijcke dingen te doen, als deur sijn Alder grootste dienaers ende bequaemste instrumentten (...)'. ${ }^{174}$

Van Randenraedts gewetensrekeningen geven aanleiding tot de veronderstelling dat haar leidsmannen na 1644 haar in toenemende mate ontmoedigden als het ging om fysieke zelfkwellingen. Misschien waren zij bevreesd dat Joanna gefixeerd raakte op boetedoeningen en het belang ervan voor de vooruitgang van haar geestelijk leven schromelijk overschatte. Wellicht echter waren zij de mening toegedaan dat de pijn die hoofdpijnen en niet nader gespecificeerde kwalen haar bezorgden, niet vergroot hoefde te worden. Mogelijk was Joanna dat met hun eens. Dat zware fysieke penitenties als kastijding niet langer vanzelfsprekend deel uitmaakten haar vroomheidsregime, blijkt uit een gewetensrekening van maart I648. ${ }^{175}$ Tijdens een verblijf te Antwerpen bij bevriende geestelijke maagden komt

172 KB Brussel, Handschrften 19070, 70vo-72vo (mei/juni 1643).

173 Het gebruik van 'haer liede' en de persoonsvorm 'vraeghden' suggereren een meervoud en roepen de vraag op of deze conversatie gevoerd werd door Van Randenraedt en Van Staveren, of dat laatstgenoemde gesecondeerd werd door een derde persoon. Het gebruik van 'sau' spreekt echter tegen die mogelıkheid.

174 KB Brussel, Handschriften 19073 (II), 109-112.

175 GAR, Handschnfien A I II (ongepagineerd). 
een niet met naam genoemde geestelijke dochter in opdracht van haar biechtvader bij Van Randenraedt haar schuld over iets belijden. De vrouw vertelt haar dat zij een kastijding als penitentie toebedeeld heeft gekregen. Naar aanleiding daarvan voelt Joanna, naar zij schrijft, zich 'wederom als vliegende ende vlaemmende in die selve affecsien om nackt ende bloet te loepen ende mij tot de geesselingen te presenteren gelijck in voorgaende tijen'. Dergelijk zware boetedoeningen waren voor haar anno 1648 verleden tijd en zij betuigt haar spijt dat 'een luttelke lijens of penitenci' voor haar niet meer is weggelegd.

\section{'Bose natuer'}

Lijden droeg niet uitsluitend een plaatsvervangend karakter, maar werd door Van Randenraedt en Van Heilsbach zeker ook gezien als boetedoening voor eigen zondigheid. Hun geschriften geven een zeer negatief zelfbeeld prijs. Van Randenraedt beschrijft zichzelf bijvoorbeeld veelvuldig als de meest onwaardige van alle schepsels en benoemt zich zelfs als 'ick die aerger was ende veuilder als alle veuillicheijt (...), afgrijsselijcker ende stinckender als alle etterachtiege sueeringen (...), fenijniger in quaei geneegentheeden als eenige fenijnige serpenten' ${ }^{176} \mathrm{Hoewel}$ dergelijke zelfkwalificaties ten dele verklaard kunnen worden door het genre waarin ze gepresenteerd zijn - in gewetensrekeningen krijgen persoonlijke tekortkomingen natuurlijk veel nadruk - en ten dele gelezen kunnen worden als uitdrukkingen van een retoriek van nederigheid, weerspiegelen ze ook een dialectiek tussen mens en God: menselijke verdorvenheid, nietigheid en onmacht als pendant van Gods oneindige goedheid en macht. In nederigheid en onzelfzuchtigheid, noodzakelijke voorwaarden voor een oprechte en pure liefde tot God, schoten zij naar eigen gevoelen tekort. De wens om Christus na te volgen in $\mathrm{Zijn}$ lijden drukte hun verlangen uit om fysiek en mentaal meer gelijk te worden aan dit toonbeeld van ootmoed en onthechting en zichzelf daardoor te bevrijden van hun zondigheid, die zij als intrinsiek beschouwden.

Deze negatieve zelfopvattingen van beide vrouwen zijn deels te herleiden tot hun staat; als geestelijke dochter moesten zij immers nederig zijn en geenszins meer aan de wereld met al haar geneugten en verleidingen hechten. Daarnaast mogen denkbeelden over vrouwen, vervat in maatschappelijke en kerkelijke vertogen, niet verwaarloosd worden als invloedrijke factor op hun zelfverstaan. In hun eigen geschriften en de latere neerslag ervan in de gedrukte levensbeschrijvingen klinken bepaalde opvattingen door over de functie van lichamelijk lijden in hun vroomheid, die gekleurd worden door vooronderstellingen ten aanzien van de vrouwelijke sekse. In sommige bronpassages grijpen lijden en vrouw-zijn als het ware ineen en geven een sekse-specifieke lading aan hun zelfbeeld en opvattingen over de kloppenstaat.

176 GAR, Handschriften I A 3 (ongepagineerd). 
Van Randenraedt verkeerde, zoals gezegd, regelmatig in onzekerheid over haar bestaan als geestelijke maagd. De grotere vrijheid die zij in tegenstelling tot kloosterzusters genoot boezemde haar angst in voor de duivel die zij in zichzelf lokaliseerde als haar 'bose natuer'. ${ }^{177}$ Huysmans concludeert in Kort Begryp terecht dat de oprechte liefde tot God voor haar gepaard ging met 'eenen Heyligen haet van het lichaem, ende t'samen de begeerte om de quaede genegentheden des selfs te stutten [weren] $(. . .)^{\prime} .{ }^{1{ }^{8}}$ Van Heilsbach beschouwde de menselijke natuur, waarmee zij behalve het lichaam ook de mentale constitutie bedoelde, als het grootste obstakel voor de toenadering tot God. In verscheidene passages van haar gewetensrekeningen verhaalt zij hoe zij ervoor ijvert haar boze of halstarrige natuur meester te worden. Haar geest moest voortdurend heersen over haar lichaam. Hieruit spreekt het klassieke christelijke dualisme van geest en vlees, waarin vlees niet langer - zoals bij Paulus - de opstandige menselijke natuur verbeeldt, maar synoniem is voor het lichaam dat tegen de geest rebelleert, voor fysieke lusten en behoeften die als een inwendige vijand bevochten en overwonnen moeten worden. Vlees/lichaam is de bron van zonde; het dient gekruisigd te worden om Gods genade te verwerven. ${ }^{179}$

Dit motief dat door de eeuwen heen door verscheidene christelijke auteurs is gebruikt, is herkenbaar in de levensbeschrijvingen van Van Randenraedt en Van Heilsbach en lijkt in hun geval versterkt te zijn door hun vrouw-zijn. Sinds vroegchristelijke tijden werden, zo is in het vorige hoofdstuk uitvoerig aan de orde gesteld, vrouwen en vrouwelijkheid nauw met lichamelijkheid geassocieerd. Mannen personifieerden rationaliteit, kracht, moed en loyaliteit, terwijl vrouwen vooral werden vereenzelvigd met passie, zwakheid, wispelturigheid en lichamelijkheid. De handschriften van Van Heilsbach en Van Randenraedt vertonen sporen van dergelijk dichotomisch denken. Van Heilsbach associeert het optreden van vrouwen in haar dromen steevast met zwakheid en werelds gedrag dat haaks staat op het door haar zelf nagestreefde geestelijk leven. Mannen staan daarentegen voor onverschrokkenheid en standvastigheid. De toeschrijving van dergelijke hoedanigheden is echter niet onlosmakelijk verbonden met biologisch geslacht of fysieke eigenschappen. Anders gezegd, zeventiende-eeuwse vrouwen konden over eigenschappen beschikken die naar maatstaven van hun tijd als 'mannelijk' werden gekwalificeerd. Op dergelijke karakteristieken maakt Van Heilsbach onverbloemd aanspraak in haar gewetensrekeningen, zoals reeds uiteen is gezet. Zelf lijkt zij zich niet zo door bestaande sekse-specifieke omschrijvingen van verschillende morele of fysieke kwaliteiten belemmerd gevoeld te hebben. Volgens Huysmans was zij zich er echter terdege van bewust dat 'jonghe dochters genootsaeckt [waren om] haer lichaem in dwanck te houden, ende krachtighe middelen te gebruycken, om

177 GAR, Handschriften II B j, 43.

I78 Kon Begnyp, to; vgl. voor Van Heilsbach Leven ende deughden, 174-175.

179 Bonsirven, 'Chair'. 
den duyvel, de wereldt, vleesch ende bloedt t'overwinnen' ${ }^{180}$ 'Een nauw toesicht op vrouwen' was noodzakelı]k, 'want den vyant [was] seer listıgh'. ${ }^{181}$ Van Randenraedt lijkt zich de les dat de duivel vooral vrouwen te slım af was, die door Huysmans aan haar geestelıke moeder wordt toegeschreven, meer te hebben aangetrokken.

Door lijden - al dan niet zelf toegebracht - gewillig te doorstaan, beleden beide maagden berouw over eıgen zondigheid en gaven zl] bly,k van hun nedengheid. Wie zichzelf vernedert en zich nedeng betoont aan God, die zal door God verheven en beloond worden met genade, zo leert het evangelie (Luc. I8,14). De wens om Christus' vernedenng en pijn te delen hield nauw verband met dit heilsverlangen. Maar wellicht was deze vorm van navolging tevens ingegeven door of gepaard aan een streven om zich te onderscheiden van andere gelovigen, waann zil - als we de levensbeschnjvingen volgen - ook slaagden Immers, het karakter van de verschillende verstervingen en penitenties, alsook de wijze waarop beide geestelıjke maagden huenn konden volharden, worden nadrukkelıjk benoemd als exceptioneel Huysmans citeert Joanna van Randenraedt: ' $\mathrm{Nu}$ ben ick meer ghelı)ck aen milnen Bruydegom ' want de teekenen van sı)n lijden draegh ick in mijn vleesch' ${ }^{182} \mathrm{Ze}$ wilde een zoenoffer zı)n voor de zalıgheid van haar medemensen. Als een martelares voor haar geloof wilde zij ertoe bijdragen dat het verlossingswerk volgens de wil van haar Beminde voltoold zou worden. ${ }^{{ }^{1 / 3}}$ Haar bydrage hieraan zou vooral uit lijden bestaan Of zij er volledig mee verzoend was dat dit haar aandeel was, is de vraag.

Deze kwestue raakt aan een andere dimensie, die te onderkennen is in de lijdensdevotue van beıde geestelı)ke maagden. De zucht naar lıden vormde mogelık ook een uitlaatklep voor ambities die gefrustreerd werden door maatschappelıjke en kerkrechtelı)ke grenzen die op grond van hun sekse gesteld waren aan hun werkzaamheden in dienst van God en hun naasten De onduidelyke status van hun leefwıze, de voortdurende afhankelıkheid van hun biechtvader en de beperkingen waaraan hun actief apostolaat gebonden was, konden Van Randenraedt en Van Heilsbach wellıcht gedeeltelık overstı)gen door zıch sterk te nchten op de navolging van hun Bruıdegom in Zın lijden. In eıgen lijden konden zij die gevoelens van onzekerheid en machteloosheid misschien zelfs omkeren in een gevoel van macht. Dit complexe proces van mee-lijden met een onschuldıge protagonst, van boetedoening voor wat hem is aangedaan, maar ook van idenuficatie met hem en aldus groot te zun in het martelaarschap, is door de theologe Gnetje Dresen benoemd als 'onschuldfantasie'. ${ }^{184}$ Vooral vrouwen die in de verwezenlykkng van hun idealen gefrustreerd werden door de sekse-specifieke grenzen van hun tijd,

180 Leven ende deughden, 36

181 Ibidem, 187

182 Kort Begryp, 237

183 GAR, Handschnften II B 1, 6I

184 Dresen, Onschuldfantaszeen, 29-49 
Afb. 21 Een bruid met haar hemelse Bruidegom verbeeld aan de hand van de parabel van de vijf wijze en de vijf domme maagden (Mat. 25,I-I3). De wijze maagden hadden in tegenstelling tot de domme maagden hun lampen voorzien van olie en waren voorbereid op de komst van hun Bruidegom. Geestelijke maagden werd voorgehouden dat zij door een kuis en vroom leven te allen tijde geprepareerd moesten zijn op de vereniging met hun Bruidegom.

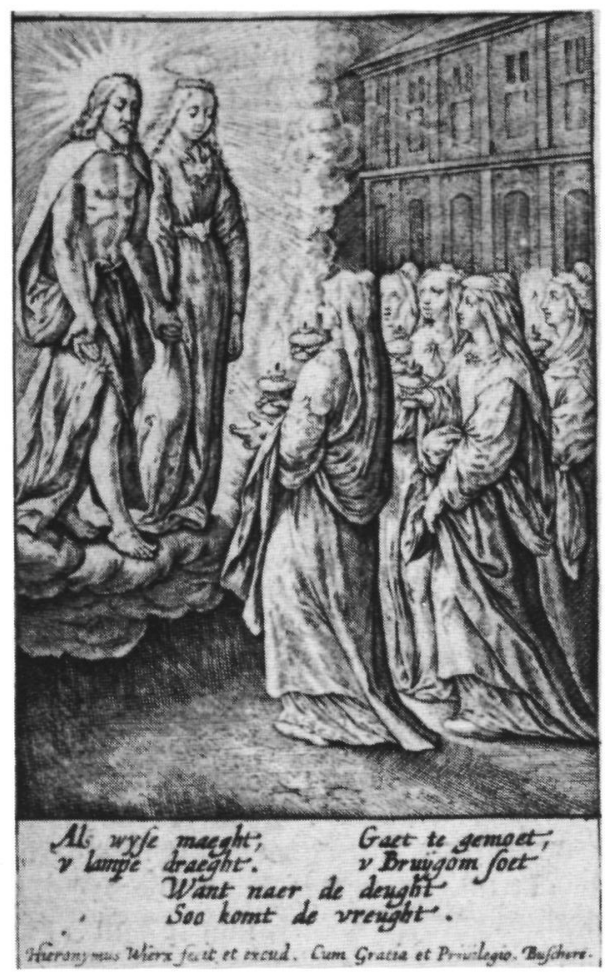

zochten volgens Dresen een zekere mate van bevrijding en genoegdoening in offerzin. Voor Van Heilsbach en Van Randenraedt was dit verlangen naar zelfopoffering uit frustratie onlosmakelijk verbonden met de begeerte om te lijden uit liefde tot God en hun naasten. ${ }^{185}$

\section{Kostbaarste schat}

Het bruidschap van Christus vond behalve in het lijden ook uitdrukking en bevestiging in de frequente communie. De kloppenboek-auteur en jezuïet Bisschop stelt nadrukkelijk dat een geestelijke maagd in de hostie haar Bruidegom kan vinden. Door dit sacrament zal Hij Zijn gaven met haar delen, haar 'heylich (...) ende goddelijck' maken, opdat zij met recht Zijn bruid mag heten. Het communiceren werd door Van Heilsbach en Van Randenraedt begrepen als een volledige geestelijke en lichamelijke eenwording. Met het nuttigen van de hostie aten zij het vlees van Christus en werden zij zo 'naturelijck' één met Hem. ${ }^{186}$ Ook in dit opzicht stonden beiden in de traditie van middeleeuwse religieuze vrouwen in en buiten

I85 Analoog aan de functie die de strenge ascese in het leven van verschillende middeleeuwse mysticae vervulde. Bynum, 'The mysticism', 66-74.

186 Bijvoorbeeld KB Brussel, Handschriften I8984, I38vo-I39vo (29 januari [1638?]). 
kloosters, wier identiteit en geloofsbeleving wortelden in een sterke eucharistische vroomheid. ${ }^{187}$ Van Randenraedt werd reeds op jonge leeftijd door een neef, de jezuiet Dominicus Schenckel (1584-1648), aangemoedigd om dit sacrament vaak te ontvangen. Met vaak bedoelde hij op zon- en feestdagen. De heilige Maagd Maria had Joanna echter ooit gevraagd of zij dagelijks ter communie wilde gaan. In haar eigenhandig geschreven levensverhaal tekent zij aan dat dit een zeer ongebruikelijk verzoek was; zij kende niemand die dagelijks de hostie ontving, zelfs geen religieuzen. Haar 'wirdt (...) voor ooge gesteldt' door Maria hoe zij dit speciale verzoek kon inwilligen. $\mathrm{Zij}$ zou in verschillende kerken en kloosterkapellen ter communie gaan.

Pas onder de geestelijke leiding van Van Heilsbach begon Joanna buiten de vaste communiedagen - zon- en heiligedagen - ter communie te gaan. Op andere dagen 'nam de Eerw. Agnes mij (...) al eens mee, om mijnen Brudegom Sacramenteellijck te genietten, om sijne $\mathrm{Ma}^{\mathrm{t}}$ [Majesteit] soo naer te comen ende soo lief te hebben, als meugelijck was (...) ${ }^{188}$ Een voorrecht waarvoor soms geld betaald moest worden aan de priester die haar 'heimelijck' de communie uitreikte. ${ }^{189}$ In het tweede deel van haar spirituele autobiografie, dat grotendeels gewijd is aan haar communie-praktijk, memoreert zij hoeveel tijd en moeite de dagelijkse communie haar kostte. Regelmatig moest zij ergens in een kerk of kapelletje wachten; soms zat zij er al om zeven uur 's ochtends en moest zij geduld oefenen tot tien uur voordat de communie werd uitgereikt. Was er iemand anders aanwezig die haar kon zien, dan mocht zij van haar biechtvader vaak niet gaan om opspraak te voorkomen. Zelf vergelijkt zij deze plicht tot geheimhouding met de situatie waarin de katholieken in Holland hun geloof moesten beleven. ${ }^{\text {I90 }}$

De invloed van haar geestelijke moeder op haar communie-frequentie is onmiskenbaar. Zelf ontving Van Heilsbach de hostie vermoedelijk veelvuldig, al laten haar gewetensrekeningen hierover weinig directe aanwijzingen los. In Wassenberg ging Van Heilsbach alle zon- en feestdagen ter communie. In Roermond kreeg ze daarenboven toestemming om op donderdagen te communiceren, een gebruik dat volgens Huysmans allengs ingang vond onder andere geestelijke dochters ter plaatse. ${ }^{191}$ Haar eigen gewetensrekeningen doen evenwel vermoeden dat haar communie-frequentie hoger lag, misschien wel buiten medeweten van haar biechtvader. In het verslag van een droom in mei 1637 schrijft Van Heilsbach dat iemand haar haar kostbaarste schat probeert te ontfutselen. De volgende dag wordt haar duidelijk wat daarmee bedoeld wordt: de heilige communie. Aangezien

187 Bynum, Holy feast; Langer, 'Geistliche Sinnlichkeit', wijst nadrukkelijk op de zinnelijke aspecten van de eucharistische vroomheid die voor vrouwen in hun devotie een belangrijke rol speelden.

188 KB Brussel, Handschriften 19073 (II), 18-24. Voor haar praktijk van de veelvuldige communie zie ook Van Miert, 'Over het veelvuldig communiceren', 29.

189 KB Brussel, Handschriften 19070, 307-312 (november 1645).

$190 \mathrm{~KB}$ Brussel, Handschriften 19073 (II), 38.

191 Leven ende deughden, 84. 
haar eigen biechtvader afwezig is, moet zij zolang een andere jezuïet om toestemming vragen voor de communie. Die weigert toestemming en geeft te kennen dat hij haar biechtvader zal meedelen dat naar zijn mening eens per week ter communie gaan vaak genoeg is. Agnes legt zich hier niet bij neer en gaat als altijd ter communie. Zij tekent aan dat zij pas minder vaak zal communiceren, wanneer haar biechtvader, via wie God tot haar spreekt, haar dit zal opdragen. ${ }^{192}$ Ook Van Randenraedt legde een uitdrukkelijk verbod om te communiceren soms naast zich neer en ging stilletjes toch. ${ }^{193}$ Vrees dat haar dit sacrament onthouden zou worden, weerhield haar er bovendien incidenteel van toestemming te vragen om ter communie te gaan. ${ }^{194}$

In het verlangen - en de bevrediging daarvan - naar de communie kwam ook hun bijzondere band met Maria tot uitdrukking. Dit blijkt vooral uit de gewetensrekeningen van Van Heilsbach. Als het heilig brood werd uitgereikt, dan gebeurde dit steevast door een priester. Soms zag Agnes echter in haar dromen dat de celebrant de hostie overhandigd kreeg door Onze Lieve Vrouw. Dit beeld doet denken aan de parallel die Bernardus van Clairvaux in een van zijn preken trekt tussen het kind in Maria's baarmoeder en de hostie op het altaar. Naar zijn mening geeft Maria de gelovigen het lichaam dat hun verlossing betekent. ${ }^{195}$ In de religieuze voorstellingswereld van Van Heilsbach speelt de idee van Maria als moeder én celebrant eveneens een rol. $\mathrm{Zij}$ was ervan overtuigd dat Maria de verlossing in haar sacramentele vorm aan de gelovigen gaf. Agnes beschrijft dit naar analogie van een geboorte: de Zoon Gods wordt dagelijks via de communie in de zielen der gelovigen geboren. Wanneer zij zich in april 1638 vertwijfeld tot Maria richt met de vraag of ze die dag de communie nog wel zou ontvangen, belooft die haar dat $z i j$ haar Zoon aan Van Heilsbach zal geven door de handen van een priester. ${ }^{196}$ Een paar weken later ziet Agnes in een droom hoe dit gebeurt. Terwijl zij in de jezuïetenkerk op de uitreiking van de communie wacht, neemt ze plotsklaps waar hoe Maria haar Zoon aan haar geeft via de handen van de priester die de mis opdraagt. ${ }^{197}$

De ontvangst van de hostie wordt door beide vrouwen in mystieke taal uitgedrukt. De vereniging met de Bruidegom via de communie wordt veelvuldig beschreven als een omhelzing, waardoor de Verlosser als het ware bezit van hen neemt. De liefde die beide vrouwen gewaarworden tijdens en na de ontvangst van dit sacrament is intens. In hun gewetensrekeningen gebruiken zij verschillende beelden om die uit te drukken: dronkenschap die hun van zelfcontrole berooft; een vuur dat om zich heen grijpt en alles verzengt; een zee die hen verzwelgt. Uit

192 KB Brussel, Handschnften 18984, 26vo-27 (24 mei 1637).

193 Bıvoorbeeld KB Brussel, Handschnfien 19070, 7-8 (januari 1643).

194 Bijvoorbeeld GAR, Handschnfien I A 5 (ongepagineerd; me1/junı I640).

195 Bynum, Holy feast, 268.

196 KB Brussel, Handschnfien I8984, 184-185vo (18 apnl [1638]).

197 Ibidem, 202vo-204vo (2 me1 [1638]). 
hun geschriften spreekt een verlangen naar zelfverlies, naar overgave aan God. Inspraken en visioenen overtuigden beide vrouwen ervan dat ook de Verlosser ernaar hunkerde om via de communie in hen een rust- of verblijfplaats te vinden. ${ }^{\text {rg8 }}$ Hun sterke liefde voor God en Christus zagen zij beantwoord in de communie, waarin Christus zichzelf door de handen van een priester als voedsel aan gelovigen geeft. ${ }^{199}$ Door dit blijk van liefde werden beiden overweldigd. Regelmatig maakten zij in hun gewetensrekeningen gewag van emotionele uitbarstingen die onmiddellijk na de communie plaatsvonden en Gods macht over hen uitdrukten. Gevoelens van diepe ontroering of opperste gelukzaligheid werden geventileerd door huil- of lachbuien. Van deze emoties maakten zij hun biechtvaders mondeling of schriftelijk deelgenoot, die dergelijke uitvoerige beschrijvingen van de vereniging met de hemelse Bruidegom soms wat teveel werden. ${ }^{200}$

Behalve liefde schonk dit sacrament ook kracht, zo waren Van Heilsbach en Van Randenraedt overtuigd. Het genas de wonden die zonden in hun ziel geslagen hadden en het wapende hen tegen de duivel. ${ }^{201}$ Hun eigen natuur, die hen zo kwetsbaar maakte voor zondigheid, konden zij dankzij de communie beter weerstaan. Deze vereniging met de Bruidegom bewerkstelligde in de ogen van Van Randenraedt een verandering, waardoor zij 'alle mijne quaeden aerdt der natuere' verloor. ${ }^{202} \mathrm{De}$ communie fungeerde ook als drijfveer om anderen aan te zetten tot grotere liefde voor God. ${ }^{203}$ Van Heilsbach ontleende aan dit sacrament bovendien recht van spreken. In het vorige hoofdstuk is er al op gewezen dat zij haar eigen interpretatie van dromen of ingevingen koppelde aan de communie. Pas nadat zij de hostie ontvangen had, werd de betekenis van bepaalde buitengewone voorvallen haar duidelijk. Zo bekrachtigde zij als het ware eigen interpretaties met goddelijk gezag.

Het gewicht dat beide vrouwen aan de communie hechtten, verklaart waarom zij soms de zeggenschap van hun biechtvaders over hun communie-frequentie omzeilden of zelfs negeerden. De gedachte dat zij de 'geniettinge' van de communie zou moeten missen, gaf Van Randenraedt het gevoel dat haar hart scheurde, 'want mij docht dat ick nu veel meer als in veurgaende tijden was verlangende naer mijn lief. ${ }^{204}$ Mocht zij op last van haar biechtvader niet communiceren, dan ervoer zij dit als 'de alderpijnelijckste beproevinge' die zij ooit doorstond. ${ }^{205}$ Geestelijk leidsmannen stonden over het algemeen aarzelend tegenover een communie-

198 Tbidem, 138vo-r39vo (29 januari [1638?]). KB Brussel, Handschriften 19073 (II), 2-3.

$199 \mathrm{~KB}$ Brussel, Handschriften 18984, 323vo-326vo (18 oktober [1638]).

200 KB Brussel, Handschriften 19070, 59 vo (juli 1643).

20I KB Brussel, Handschrifien I8984, I84-185vo (I8 april [1638]; GAR, Handschriften I A 5 (ongepagineerd; juni 1640).

202 KB Brussel, Handschrifien I9073 (II), 27 en vgl. 24.

203 Bijvoorbeeld KB Brussel, Handschniften 19070, svo (januari 1643).

204 GAR, Handschriften I A s (ongepagineerd; mei 1640).

205 GAR, Handschriften I A 2 (ongepagineerd). Deze gewetensrekening werd in I649 geschreven voor Antonius Meerhouts, de toenmalige rector van het college en Joanna's biechtvader. 
frequentie van meer dan eens per week. Uit Van Randenraedts geschriften blijkt dat ook degenen die haar bij tijd en wijle het voorrecht van frequentere communie toestonden - Wijns en Van den Hove - toestemming afwisselden met afwijzing. Hieruit spreekt een zekere voorzichtigheid ten aanzien van de intentie en de grondhouding waarmee geestelijke maagden dit sacrament zouden ontvangen. Eenzelfde zorgvuldigheid met betrekking tot dit sacrament komt naar voren in de verschillende kloppenboeken, zoals hierboven uiteen is gezet. Strikte regulering van de communie-frequentie was echter misschien ook een uitdrukking van een zekere angst. Dat Van Randenraedt soms dagelijks ter communie ging, ontging andere gelovigen, geestelijke maagden incluis, natuurlijk niet, hoezeer zij dit ook - soms mede op last van haar biechtvader $-{ }^{206}$ geheim probeerde te houden. ${ }^{207}$ De toestemming die, zoals boven vermeld, de generaal van de jezuïetenorde Joanna in I64I verleende voor de dagelijkse communie, veranderde daar niets aan, want daarin werd immers uitdrukkelijk gestipuleerd dat Van Randenraedt anderen niet tot navolging mocht inspireren. Opspraak kon echter niet uitblijven. ${ }^{208}$ Geestelijken zagen zich geconfronteerd met andere kloppen die erop aandrongen dat ook zij vaker ter communie mochten. ${ }^{209}$ Dergelijke ongewenste ontwikkelingen probeerden haar biechtvaders vermoedelijk een halt toe te roepen door Van Randenraedts communie-gang te beperken. Dan bleek eens te meer hoe betrekkelijk Vitelleschi's toestemming was. ${ }^{210}$

In de jaren dertig had Van den Hove Agnes eens opgedragen erop toe te zien dat Joanna dit sacrament enkel op de gewone communie-dagen zou ontvangen. Van Heilsbach volbracht deze missie niet, want zij spoorde Joanna op een donderdag aan ter communie te gaan. Misschien deed zij dit uit medelijden, want Joanna verzucht - jaren na de beproeving - op papier: 'Och Agnes, waert dat ghij wist wat tormentten ghij mij aen doet [door de communie-frequentie te beperken], ghij en saudt het waerachtelijck niet doun (...)'. ${ }^{211}$ Zelf twijfelde Van Heilsbach regelmatig of zij waardig genoeg was om de communie zo vaak te ontvangen. Inspraken of visioenen bevestigden echter haar waardigheid in de ogen van God. ${ }^{212}$ Ook Joanna herinnert zich in haar autobiografie dat zij zich wel eens afvroeg of zij wel zo veelvuldig mocht communiceren. Agnes was dan degene die haar bemoedigde, 'mij voorleghgende die Goetheijt Godts, waer in ick terstondt betrauwden' ${ }^{213}$

206 Op last van Van den Hove gebeurde dit bijvoorbeeld GAR, Handschrften I A s (ongepagineerd; Jun1 1640).

207 Ibidem, (ongepagineerd, maart 1640).

208 Ibidem, (ongepagineerd; me1 1640).

209 Ibıdem, (ongepagineerd, augustus I640) Vgl. KB Brussel, Handschnften I9073 (II), 34.

$210 \mathrm{Vgl}$ in dit verband KB Brussel, Handschnften 19073 (II), 847-848, 850, 855, 858, 899-901, 903904.

2II Ibidem, 29-37 (citaat: 37)

212 Zie bıvoorbeeld KB Brussel, Handschnften I8984, 190-I9 Ivo (23 apnl 1638), 1bidem, 197vo-I99 (29 april 1638 )

$213 \mathrm{~KB}$ Brussel, Handschnfien 19073 (II), 25. 
Werd de sacramentele communie om wat voor reden dan ook onthouden, dan konden gelovigen via de geestelijke communie toch deelachtig worden aan de genaden van dit sacrament. Een klop die geestelijk communiceerde kon volgens de kloppenboek-auteur en jezuïet Bisschop niet meer klagen, noch priesters hun voorrecht om dagelijks de communie te genieten tijdens het opdragen van de mis, benijden. ${ }^{214}$ Sommige geestelijken waren ervan doordrongen dat vrouwen, geestelijke maagden in dit geval, priesters hun voorrecht van dagelijkse communie benijdden. Een zekere afgunst spreekt inderdaad uit de spirituele autobiografie van Joanna van Randenraedt. Uit haar herinnering tekent zij op dat zij zich tijdens een verblijf buiten Roermond in 1636 zorgen had gemaakt of zij de communie wel zó vaak als zij gewend was, zou kunnen ontvangen. Bij die gelegenheid klaagde zij tegen haar Bruidegom 'waerom $\mathrm{Hij}$ mij toch geenen man en had gemaeckt, opdat ick priester had kunnen worden, och wat begeerte had ick hier toe (...)'. ${ }^{215}$ Zonder twijfel beschouwde Joanna de geestelijke communie als een onvolwaardige vervanging van de sacramentele. Toen haar biechtvader haar in januari 1643 verbood ter communie te gaan, nam ze zich voor geestelijk te communiceren. Haar gewetensrekening beschrijft dat $\mathrm{zij}$, toen zij zich tijdens de mis hierop voorbereidde, haar Bruidegom meende te horen: 'Wildt ghij Mij dan niet hebben tot uwen meedegesel'. Een retorische vraag die Joanna in dit geval aangreep om het verbod van de aardse plaatsvervanger van haar Bruidegom te omzeilen ten gunste van de aansporing van haar Beminde zelf. ${ }^{216}$

\section{V.6 Conclusie}

De denkbeelden die Agnes van Heilsbach en Joanna van Randenraedt over hun eigen levensstaat huldigden waren ambivalent. Uit hun gewetensrekeningen spreekt een zelfbewustheid. $Z$ ij rekenden zichzelf niet tor de leken, die zij op grond van het kerkrecht waren, maar tot de geestelijke personen. Als bruiden van Christus wisten zij zich gesterkt door Zijn macht. Hoewel zij geestelijke dochters van de jezuïeten waren, beschouwden zij zich in de eerste plaats als dochters van ordestichter Ignatius, hetgeen betekende dat zij zichzelf als 'zusters' van hun leidsmannen zagen. In dit jezuïtisch zelfverstaan ligt een aanspraak op gelijkwaardigheid besloten met de geestelijken onder wier leiding zij stonden, een gelijkwaardigheid die vooral stoelde op complementariteit: zonen en dochters van Ignatius hadden verschillende taken en bevoegdheden maar droegen gezamenlijk bij tot de bekering van de wereld. Tegelijkertijd getuigen de gewetensrekeningen van beide maagden ook van onzekerheid. Die hing vooral samen met de kwestie of

214 Bisschop, Lof der Suyverheydt, III, 299.

215 KB Brussel, Handschriften 19073 (I), 223-224.

$216 \mathrm{~KB}$ Brussel, Handschriften 19070, 7-8 (januari 1643). 
de door hen gekozen religieuze leefwijze buiten het klooster wel zou leiden tot de nagestreefde zaligheid. Twijfels over de strengheid van hun leven en over de implementatie van de evangelische raden bekropen hen soms. Van Randenraedt was zich er terdege van bewust dat de kloppenstaat minderwaardig was ten opzichte van de kloosterstaat. God had haar echter geroepen tot dit leven buiten kloostermuren. Die roeping rechtvaardigde zowel de waardigheid van deze staat als haar keuze daarvoor. Van Heilsbach liet zich duidelijk minder gelegen liggen aan formele kerkelijke hiërarchische ordeningen. Zij was ervan overtuigd dat haar leefwijze, anders dan die van vele vrouwelijke religieuzen die zij bekritiseerde, daadwerkelijk gegrondvest was in nederigheid en niet aflatende religieuze ijver.

In het geestelijk moederschap werden pastorale ambities, die beide vrouwen koesterden, enigszins bevredigd. De invulling van deze informele functie was afhankelijk van eigen initiatief en van medewerking van hun biechtvader. Hierover moest voortdurend onderhandeld worden. Als geestelijke moeders waren zij in feite gedelegeerden van de biechtvader. Hun zeggenschap strekte zich uit over andere jezuïeten-kloppen. Begeleiding van deze vrouwen behelsde doorgaans gesprekken over godsdienstige zaken. De eindverantwoordelijkheid voor het religieus regime van deze vrouwen bleef bij de biechtvader berusten. Vertrouwen tussen 'vader' en 'moeder' onderling was een voorwaarde voor de vervulling van het geestelijk moederschap. Bęide 'moeders' probeerden aan te tonen dat zij dit vertrouwen waard waren door het doopceel van de 'dochters' te lichten tegenover de biechtvader. Vooral Van Heilsbach informeerde haar leidsman uitvoerig over de wederwaardigheden van andere maagden en beoogde zo onder meer haar eigen positie veilig te stellen. $\mathrm{Zij}$ had een hoge dunk van haar persoonlijke leiderschapskwaliteiten. En ook haar aandeel in de geestelijke begeleiding van anderen onderschatte zij geenszins, hoewel zij die zelf omschreef als 'kleine meehulp'. Op grond van de verslagen en eigen interpretatie van haar dromen kan vastgesteld worden dat zij haar werkzaamheden eenzelfde gewicht toekende als de taken die priesters uit hoofde van hun ambt vervulden. Ondervond Van Heilsbach beletselen bij de uitoefening van haar geestelijk moederschap, dan wist zij deze vaak handig te omzeilen en haar ongeoorloofde handelwijze adequaat te verantwoorden in haar gewetensrekeningen. Hierbij beriep zij zich op Gods gezaghebbende rol bij haar beslissingen. Haar zelfverzekerd en soms eigenmachtig optreden werd weer uitgebalanceerd door voortdurende nadruk op haar eigen nederigheid en nietigheid, die haar een zekere handelingsvrijheid verschafte. Ook Van Randenraedt beschouwde haar gezag als geestelijke moeder als van God afgeleid. Tijdens haar leiderschap veranderde de attitude van haar leidsmannen ten opzichte van haar taken en zeggenschap echter. Veel meer dan Van Heilsbach stuitte zij op de grenzen van haar taakuitoefening.

Beiden waren volstrekt verschillende moeders. Van Heilsbach stelde hoge eisen aan haar geestelijke dochters, beoordeelde hen scherp en bespaarde hun haar soms 
ongezouten kritiek niet. Bij tijd en wijle paste zij ook strenge en onorthodoxe middelen toe in de vorming van haar dochters. Conflicten bleven niet uit en enkele jezuieten-kloppen verlieten haar. Joanna bleef haar 'moeder' echter trouw, hoewel zij zich vaak in een ongemakkelijke positie bevonden moet hebben, aangezien zij Van Heilsbachs commentaar op haar leefwijze alsook haar geloofsleven niet alleen te horen kreeg, maar ook nog eens las in de gewetensrekeningen die zij moest afschrijven. Toch was zij uitermate verknocht aan Agnes en sloeg haar geestelijke adviezen soms hoger aan dat die van haar biechtvader. Zelf had zij als geestelijke moeder een minder autoritaire leiderschapsstijl. Onder haar leiding ontwikkelden de Roermondse jezuïeten-kloppen zich tot een betrekkelijk hechte groep. Behalve een streven naar een maagdelijk, religieus bestaan in de wereld hadden zij eenzelfde sociale achtergrond gemeen. Zij deelden bovendien de spanningen die de combinatie van bidden en werken voor hen als kloppen met zich meebracht. In tegenstelling tot vrouwelijke religieuzen, die bij intrede in het klooster de wereld, verwanten en vrienden geheel en al achter zich lieten, konden deze geestelijke maagden zich vaak niet aan familiale en sociale verplichtingen onttrekken.

De geschriften van Van Heilsbach en Van Randenraedt laten zien dat hun hunkering naar een actief apostolaat slechts tot op zekere hoogte bevredigd kon worden. Voorvallen in Van Heilsbachs dromen en hun metaforiek wijzen erop dat haar verlangen naar een aandeel in de verbreiding van het katholieke geloof onvoldoende bevredigd werd door de taken die haar leidsman haar als geestelijke maagd toestond. Dat zij in deze dromen voedsel uitdeelt, dat door haar zelf soms als een metafoor voor de hostie wordt uitgelegd, wijst erop dat zij priesterlijke waardigheid en voorrechten nastreefde. Van Randenraedt verzuchtte in de loop van haar leven enige malen dat zij liever als man geboren was; dan had zij priester kunnen worden en God en naasten beter kunnen dienen dan zij nu als vrouw kon. De beperkingen die er aan de werkzaamheid van de Roermondse maagden werden gesteld, werden vanaf I 643 verscherpt. Anders dan ten tijde van Van Heilsbachs leiderschap was liefdewerk niet langer synoniem met elementair geloofsonderricht, gelovigen aansporen tot de biecht of aalmoezen inzamelen voor heimelijke huisarmen. Door een intensieve devotionele praktijk en fraaie handwerken konden jezuïeten-kloppen voortaan de bekering van de wereld bevorderen; een veel kleinere bijdrage dan voorheen, die ook op steeds minder waardering van hun geestelijke 'broeders' kon rekenen. Actieve steun van deze geestelijke maggden bij catechisatie en apostolaat was vermoedelijk minder noodzakelijk, nu de pastorale activiteiten en het sociale netwerk van hun leidsmannen tot volle bloei waren gekomen.

De sekse-specifieke beperkingen die er aan de werkzaamheid van Van Heilsbach en Van Randenraedt gesteld waren, probeerden beiden tenminste gedeeltelijk te ontstijgen door een sterke lijdensdevotie. In hun streven naar fysieke boetedoening en versterving, dat door sommige biechtvaders werd gestimuleerd, zijn verschillende dimensies te onderkennen. Behalve plaatsvervangend lijden voor het zieleheil 
van anderen of voor de zielen in het vagevuur, waren hun boetepraktijken vooral een antwoord op Christus' lijden. Een antwoord waarmee zij hun eigen identiteit als Zijn bruid beklemtoonden en voor zichzelf het religieuze karakter van hun leefwijze bevestigden. Tegelijkertijd konden zij in het lijden hun natuur overwinnen, die hen als vrouwen bijzonder kwetsbaar maakte voor zondigheid. Bevestiging van hun uitverkoren positie als bruiden van Christus werd niet alleen door het mee-lijden met de Bruidegom bevestigd, maar ook door de frequente communie. De ontvangst van de communie werd door Van Heilsbach en Van Randenraedt gezien als een volledige geestelijke en lichamelijke eenwording met Christus. Eucharistische vroomheid werd sterk bevorderd door de jezuïeten, die ijverden voor de wekelijkse communie. Voor Van Heilsbach en Van Randenraedt was deze frequentie absoluut onbevredigend. Dagelijkse communie was evenwel een uitzonderlijk voorrecht dat aan priesters die de mis opdroegen was voorbehouden. Als geestelijke maagden waren zij voor dit privilege in beginsel afhankelijk van de biechtvader, hoewel zij diens zeggenschap ook wel omzeilden of zelfs negeerden. De communie schonk hun immers liefde en kracht, wapende hen tegen de duivel en heelde de wonden die zonden hadden gemaakt. Dit sacrament gaf ook kracht om te handelen en - zoals Van Heilsbachs gewetensrekeningen illustreren - te spreken.

Met hun keuze voor een levensstaat die geen formele erkenning kreeg, noch door algemeen geldende regels was bestendigd, waren zij degenen die aan hun omgeving duidelijk dienden te maken dat zij door God geroepen waren tot een door Hem ingestelde staat. Sober gekleed belichaamden zij voor iedereen zichtbaar de verstorvenheid die bij hun levensstaat hoorde. Andere accenten werden gezet door gedrag en uiterlijk vertoon van vroomheid: frequent kerkbezoek, aanwezigheid bij processies en bedevaarten en werkzaamheden ten behoeve van de kerk - of het nu om handwerken of aalmoezen uitdelen ging. Dit alles moest anderen overtuigen van de waardigheid van hun staat. Geruchten over frequente communie of direct contact met God, Christus of Maria, kregen extra zeggingskracht, doordat beide vrouwen door huilbuien of trances in het openbaar Gods macht over hen voor allen zichtbaar tot uitdrukking brachten. Tekenen van lijden hadden dezelfde uitwerking en waren als zodanig wezenlijk voor de erkenning van hun staat en hun aanspraak op de positie die zij als religieuze vrouwen die in Gods macht deelden, ambieerden. Om deze status te verkrijgen en te behouden bedienden zij zich, bewust en onbewust, in hun persoonlijke en schriftelijke presentatie van vormen van religieuze expressie die weliswaar uitzonderlijk, maar niettemin acceptabel en zelfs plausibel waren. Deze vormen lagen besloten in het religieuze referentiekader dat zij deelden met hun geestelijk leidsmannen. 


\section{VI \\ Slotbeschouwing}

'Als die ghedierten diemen seght eens-deels watersche, eens-deels aerdsche ghedierten te zijn, die noch op d'aerde, noch inde Zee blijven, maer leven in eenen middelen staet van leven '.

Het beeld van amfibieën, dat in het kloppenboek Spieghel der Maeghden wordt gebruikt, geeft de positie tussen klooster en wereld, die geestelijke maagden innamen, treffend weer. Vanuit deze 'middelen staet' laveerden kloppen tussen hemel en aarde, tussen toewijding aan God en alledaagse beslommeringen, tussen het kerkelijke en het wereldlijke domein. Hoe er gedurende de zeventiende eeuw gedacht werd over de kloppenstaat door geestelijken en geestelijke maagden, vormde de kernvraag van deze studie. Het zwaartepunt van het onderzoek lag bij die kloppen, die niet in een vergadering woonden, maar individueel, bij familie of in kleine groepjes leefden en onder leiding stonden van een seculiere of reguliere priester. In hoofdzaak zijn twee typen bronnen geanalyseerd: devotieboeken die speciaal voor geestelijke maagden werden geschreven en de geschriften van twee geestelijke maagden.

In de kloppenboeken kregen opvattingen van seculiere en reguliere geestelijken over de leefwijze van geestelijke maagden hun beslag. Met deze denkbeelden raakten vele kloppen vermoedelijk niet zozeer via deze boeken vertrouwd, maar vooral via preken en persoonlijke gesprekken met hun leidsman. Hoewel de kloppenboekauteurs allen beoogden de kerkrechtelijk niet gefundeerde kloppenstaat te rechtvaardigen, dachten zij niet eender over de status ervan. Sommigen oordeelden dat deze leefwijze geenszins onderdeed voor de door de kerk erkende religieuze staat van kloosterlingen. Anderen benadrukten verschillen, maar ijverden voor nieuwe hiërarchische indelingen waarin ook voor de kloppen een plaatsje was ingeruimd, weliswaar aan de onderkant van de hiërarchie, maar toch relativeerden zij daardoor de lekenstatus die deze religieuze vrouwen formeel hadden. Of vrouwen hun leven nu aan God wijdden in of buiten een klooster werd tot een onbeduidend, technisch verschil gedegradeerd. De kloppenstaat kreeg veelal het predikaat 'geesteliik'. In kerkrechtelijk opzicht konden kloppen onmogelijk als geestelijke personen bestempeld worden; die benaming was voorbehouden aan leden van de seculiere en reguliere clerus. Vrouwen golden, ook al waren zij religieuzen of leidden zij een religieus bestaan, per definitie als leken. Niettemin werden kloppen door verschillende auteurs onder de geestelijke personen geschaard. Als ongehuwde, kuis levende vrouwen, die zich in de wereld en niet 
achter kloostermuren toelegden op barmhartige werken, onderscheidden zij zich immers van religieuzen en kregen daarom een aparte positie toebedeeld, waarin zij dichter bij de clerus kwamen te staan dan welke andere leek ook. Met hun ingenieuze redeneringen - hoe omzichtig geformuleerd ook - tornden de kloppenboek-auteurs bovendien aan het primaat van de kloosterstaat als enige, erkende religieuze bestaanswijze voor vrouwen. Hun betogen illustreren eens te meer dat er binnen de katholieke kerk in de zeventiende eeuw verschillend gedacht werd over de status van een godgewijd bestaan in de wereld, dat niet bestendigd was door plechtige geloften en niet gebonden was aan clausuur.

Een belangrijk oogmerk van de kloppenboek-auteurs was om de kloppenstaat te reguleren. Duidelijke leef- en gedragsregels zouden het religieuze karakter van deze leefwijze waarborgen. Deze regels structureerden het gehele bestaan van een klop - van de dagelijkse kerkgang, de frequentie van de communie, het gebed, de liefdewerken, tot en met de orngang met anderen. Het beoogde effect van deze regulering was tweeledig. Enerzijds stond de auteurs een disciplinering van geestelijke maagden voor ogen, opdat zij in gedrag en vroomheid aanwinsten voor de geloofsgemeenschap zouden worden. Anderzijds kreeg de kerkrechtelijk niet erkende en niet gefundeerde kloppenstaat dankzij deze regels vorm en inhoud, waardoor hij ook voor anderen herkenbaar werd. De evangelische raden, die ook de grondslag van deze leefwijze vormden, werden geoperationaliseerd in een regime van vroomheid. Door het samenstel van sobere kleding, ingetogen gedrag, intense devotionele praktijk en werken van barmhartigheid konden vrouwen hun innerlijke deugdzaamheid en godgewijde status aan anderen kenbaar maken. Als zodanig drukte dit regime niet enkel een door geestelijken voorgeschreven orde uit, maar bood het tevens een zinvol handelingskader waaraan geestelijke maagden hun identiteit konden ontlenen. Vroomheid, opgevat als een complex van sociale, devotionele en rituele handelingen, gaf hun een mogelijkheid om hun geloof uit te dragen op een wijze die vrouwen binnen de katholieke kerk was toegestaan. Al zijn de regels die vervat zijn in de kloppenboeken niet op alle punten uniform, in de stelling dat uiterlijk en gedrag iemands vrome deugdzaamheid weerspiegelen, stroken zij met elkaar. Door het voorgeschreven regime van vroomheid na te leven bevestigden ongehuwde vrouwen en weduwen het religieuze, eerbare karakter van hun identiteit, die niet verankerd was in het kerkrecht.

Volgens de auteurs kwam vrouwen een aan mannen ondergeschikte plaats toe in het kerkelijke en maatschappelijke domein, omdat God dat zo gewild had. Voor geestelijke maagden werd wat dat betreft geen uitzondering gemaakt, al waren zij in beginsel enkel Hem gehoorzaamheid verschuldigd. Deze plicht moest in de dagelijkse praktijk vorm krijgen in de gehoorzaamheid jegens de geestelijke die de taken van biechtvader en leidsman in zijn persoon verenigde. Zo werden 'ongebonden' vrouwen, die kloppen natuurlijk in feite waren, toch nog ingepast in de gezagsverhoudingen tussen de seksen die vanuit het perspectief van de kloppen- 
boek-auteurs vanzelfsprekend waren. De asymmetrische. machtsrelaties tussen mannen en vrouwen werden gelegitimeerd vanuit de eigenschappen waarmee de leden van beide geslachten 'van nature' begiftigd zouden zijn. Voor vrouwen werd de kuise kloppenstaat zeer heilzaam geacht. Door de maagdelijke staat te verkiezen zouden zij zich namelijk dissociëren van negatieve eigenschappen als hoogmoed, lichtgelovigheid, zinnelijkheid, lichamelijkheid, morele en intellectuele inferioriteit die steevast met hun sekse werden vereenzelvigd. Naar de ziel waren vrouwen aan mannen gelijk en waren zij, net als mannen, naar het evenbeeld Gods geschapen. Deze zekere mate van gelijkheid met mannen kwam echter vooral tot uitdrukking wanneer zij, met 'mannelijke' moed, voor het maagdelijke religieuze bestaan in de wereld opteerden. Daarmee werden kloppen grensgangers tussen de geslachten. In gedrag konden zij laveren tussen wat in hun tijd als mannelijk en als vrouwelijk gold. Al is een begrip als sekse, in de betekenis van culturele constructies van mannelijkheid en vrouwelijkheid, een anachronistisch, want analytisch begrip, bronnen als kloppenboeken tonen hoe invloedrijk denkbeelden over mannelijkheid en vrouwelijkheid waren voor identiteitsopvattingen in de zeventiende-eeuwse belevingswereld van geestelijken en geestelijke maagden. Het geseksueerd vertoog van de kloppenboeken weerspiegelt niet alleen de vroegmoderne maatschappelijke orde, maar heeft daaraan zeker ook een bijdrage geleverd.

In zekere zin ondergroef deze contributie echter de nagestreefde hiërarchische ordening tussen de seksen, want beperkingen voor vrouwen in religieus en maatschappelijk opzicht werden voor kloppen soms versoepeld. Hun geestelijke staat rechtvaardigde, ja vergde zelfs, volgens de kloppenboek-auteurs dat deze vrouwen zich toelegden op het apostolaat. Deze geestelijken waren zich, net als hun collega's elders, er scherp van bewust dat kloppen nieuwe, contrareformatorische vroomheidsidealen soms effectiever uitdroegen via onderwijs, zieken- en armenzorg, dan een priester dat kon in mis of preek. Kerkelijke gezagsdragers in NoordNederland deelden dit inzicht. Als informele intermediairs werden geestelijke maagden soms beter toegerust geacht om kinderen en vrouwen - groepen die het voortleven van het katholicisme in een multi-confessioneel gebied konden waarborgen - in godsdienstig opzicht te vormen. In kloppenboeken worden zij aangespoord tot verschillende charitatieve activiteiten, die hen in nauw contact brachten met leken en geestelijken. In de door de seculiere en reguliere clerus nagestreefde geloofsverinnerlijking en eerbied voor de sacramenten konden geestelijke maagden hun geloofsgenoten het goede voorbeeld geven. Strikte naleving van hun regime van vroomheid werd eveneens voorgesteld als een vorm van apostolaat, waardoor maagden als een spirituele voorhoede de wereld rijp maakten voor bekering.

Natuurlijk drukte het vertoog in de kloppenboeken gedeeltelijk een bestaande praktijk uit, want vrouwen manifesteerden zich reeds in het onderwijs, de ziekenen armenzorg vóórdat het eerste kloppenboek het licht zag. Maar door hun apologetisch karakter schiepen deze werken tevens de voorwaarden voor een uitbreiding 
van het religieus-maatschappelijke takenpakket van godgewijde vrouwen. Zij bevestigden daarenboven dat kloppen onder de leken een uitzonderingspositie innamen, die op een dubbel fundament rustte: de maagdelijke staat en de religieuze invulling daarvan onder strakke begeleiding van een geestelijk leidsman. Deze tweeledige fundering rechtvaardigde volgens verschillende geestelijken dat kloppen (semi-)pastorale taken voor hun rekening namen. Natuurlijk speelde het officiële verbod op de eredienst in de Republiek en het aanvankelijke priestertekort in de eerste helft van de zeventiende eeuw vrouwen met een hang naar een actief religieus bestaan in de kaart. Geestelijke maagden wijdden zich aan geloofsonderwijs, armen- en ziekenzorg en andere zielzorgelijke bezigheden. Het actieve, apostolaire karakter van deze taken en het gegeven dat die in de wereld vervuld werden, versterkte hun imago van geestelijke personen.

In de praktijk werd de bijzondere positie van geestelijke maagden gemarkeerd door de 'staatsie'. Met dit ritueel van de geestelijke bruiloft voltrok zich een statusverandering van lekevrouw tot geestelijke maagd en bruid van Christus. Ondanks deze verandering bleef zij deel uitmaken van de haar vertrouwde netwerken van familie en vrienden. Haar op familie-identiteit gebaseerde sociale positie bleef gehandhaafd, maar kreeg er wel een nieuwe, geestelijke dimensie bij. Passende referentiekaders voor de nagestreefde religieuze volmaaktheid zochten vele maagden in het lidmaatschap van één of meer broederschappen, of in de aansluiting bij een wereldlijke derde orde. Hun verankering in de eigen gemeenschap makkte hen een aantrekkelijke bondgenoot voor geestelijken, die als bedienaars van een statie zeker in het begin van de zeventiende eeuw relatieve buitenstaanders waren. Maagden investeerden financiële middelen en werkkracht in de statie van hun voorkeur. Hun patronage kon daarenboven - afhankelijk van de eigen sociale positie - ook tot uitdrukking komen in het leggen en onderhouden van contacten die voor hun leidsman van belang konden zijn.

De invulling van de kloppenstaat was variabel. Deze differentiatie werd gesanctioneerd door de kloppenboeken. De sociaal-economische positie van een geestelijke maagd, haar gezondheid en haar familieomstandigheden bepaalden de intensiteit van het religieus regime dat zij kon onderhouden. Hierover werd op individueel niveau onderhandeld door een geestelijke maagd en haar biechtvader. Anders dan de kloppenboeken het voorstelden, werd de relatie tussen leidsman en maagd door wederzijdse afhankelijkheid gekenmerkt. Vooral in de Hollandse Zending waren seculiere en reguliere priesters veelal aangewezen op de materiële en immateriële bijdragen van kloppen voor de financiering, organisatie en ten dele ook voor de uitvoering van de zielzorg. Hun inbreng bepaalde in niet geringe mate het aanzien en de uitstraling van de kerk op lokaal niveau. Zo droegen zij bij aan de confessionele profilering, waamaar de geestelijkheid in de Hollandse Zending streefde, ondanks het min of meer clandestiene karakter dat de katholieke kerk 
door omstandigheden had gekregen. Geestelijke maagden op hun beurt waren afhankelijk van hun leidsman. Zijn supervisie verzekerde de religieuze aard van hun levensstaat, sanctioneerde dat zij werkzaamheden verrichtten die als omstreden golden voor vrouwen en vergrootte daarmee hun actieradius. Onderhandelingen over de vormgeving van de kloppenstaat, de status die daaraan kon worden toegekend in het kerkelijke domein en de daaraan gekoppelde taakopvatting, werden vooral mondeling gevoerd tussen de betrokkenen. De gewetensrekeningen van Agnes van Heilsbach en Joanna van Randenraedt bevatten een eenzijdige neerslag van dergelijke onderhandelingen. Eenzijdig, want directe reacties van hun biechtvaders voor wie zij in de eerste plaats schreven, ontbreken.

Noch Van Heilsbach, noch Van Randenraedt mag als representatief voor de geestelijke maagden in Noord-Nederland beschouwd worden. Zelfs in hun eigen lokale gemeenschap, Roermond, werden zij gezien als exceptionele vrouwen. Ook hun nagelaten geschriften zijn in omvang en aard buitengewoon. Vooral hun gewetensrekeningen zijn in deze studie aan een analyse onderworpen. Deze werden in opdracht van hun biechtvader geschreven, die hun eerste lezer was. Zijn belangstelling en vragen vormden het raster voor hun geschriften. Hij was uit hoofde van zijn biechtvaderschap - en misschien ook uit een persoonlijk belang - vooral geïnteresseerd in dromen, inspraken en visioenen, waarin God, Christus, Maria of andere heiligen zich aan deze maagden openbaarden. Toch schroomden Van Heilsbach en Van Randenraedt niet eigen preoccupaties, verlangens, angsten en voorstellingen van hun status en werkzaamheden via hun gewetensrekeningen aan hun leidsman voor te leggen. Schrijven in opdracht stond beiden een begrensde vorm van mondigheid toe, maar confronteerde hen ook met allerlei dilemma's. $\mathrm{Zij}$ moesten zich op papier verhouden tot een binair denken over vrouwelijkheid en vroomheid, dat even aannemelijk maakte dat hun bovennatuurlijke ervaringen het werk van de duivel waren als van God. Bij hun schrijven moesten zij zich tevens conformeren aan de voorgeschreven gezagsverhouding tussen hen en hun eerste lezer. Dat vergde vaak een geschipper tussen eigen aspiraties en verwachtingen van hun biechtvader.

Van Heilsbach en Van Randenraedt beschouwden de verschillende jezuïeten, die door de jaren heen als hun biechtvader fungeerden, als Gods plaatsvervanger op aarde. Zo werden de gezagsverhoudingen ook voorgesteld in de meeste kloppenboeken. Het gezag van de biechtvader over hen was van God afgeleid en gefundeerd in zijn wijding als priester. Maar omdat God, Christus en Maria, of heiligen zoals Ignatius van Loyola, zich via visioenen, dromen en inspraken ook aan beide vrouwen zelf manifesteerden, presenteerden beiden zich in hun gewetensrekeningen ook als spreekbuizen van de hemel. Zó eisten zij recht van spreken en handelen op tegenover hun biechtvader. $\mathrm{Zij}$ beschouwden zich niet als religieuze maar als geestelijke personen. Waren hun biechtvaders de zonen van ordestichter Ignatius van Loyola, zij zagen zichzelf als diens dochters. Strikt genomen waren 
zij geestelijke dochters van de paters, maar zelf maakten zij aanspraak op de meer gelijkwaardige en complementaire positie van geestelijke zusters. Ook al waren beiden zich terdege bewust van de ambivalenties van de kerkrechtelijke nieterkende leefwijze van geestelijke dochters, uit hun geschriften spreekt een zelfverzekerdheid die vooral voortkwam uit hun zelfverstaan als bruiden van Christus.

Hun vooraanstaande positie onder de jezuïeten-kloppen in Roermond werd door de paters bevestigd door beide vrouwen achtereenvolgens aan te stellen als geestelijke moeder. Daarmee waren zij verantwoordelijk voor de dagelijkse leiding over andere geestelijke maagden. Hun biechtvader behield in dezen de uiteindelijke verantwoordelijkheid. Het officieuze karakter van het geestelijk moederschap bevestigde de afhankelijkheid van hun biechtvader. $\mathrm{Zij}$ moesten per definitie voortdurend met hem in onderhandeling treden om de grenzen van hun zeggenschap te verkennen. De informele functie van geestelijke moeder was volgens Van Randenraedt, net als het geestelijk vaderschap van de biechtvader, gegrondvest in een van God afgeleid gezag. Het geestelijk moederschap bevredigde de apostolaire ambities van beide vrouwen slechts gedeeltelijk. De wijze waarop Van Heilsbach sommige dromen interpreteerde, duidt erop dat zij mogelijk haar zinnen gezet had op de waardigheid en de taken die verbonden waren aan het priesterambt. Van Randenraedt spreekt eenzelfde verlangen tegenover haar biechtvader uit en verzucht soms op papier dat zij priester had kunnen worden als zij maar als man geboren was.

De jezuïeten die deze vrouwen in hun geestelijk leven begeleidden, zagen hun ambtsgebonden autoriteit soms gesteund, maar soms ook bedreigd door deze vrouwen. Van Heilsbach en Van Randenraedt genoten in hun woonplaats een haast heilige reputatie, die zij met een publiek vertoon van vroomheid schraagden. Hun dagritme werd bepaald door het bijwonen van missen en preken, door gebed in kerken en kapellen en door uiteenlopende goede werken. $\mathrm{Zij}$ participeerden in lokale processies en trokken dan de aandacht door hun vrome uitstraling. Hun toewijding tot Onze Lieve Vrouw, die tot uitdrukking kwam in de zorg voor verschillende Mariakapellen, was wijd en zijd vermaard. Visioenen van Joanna van Randenraedt bevestigden de bijzondere band van God - via Maria - met de lokale bevolking en droegen mede bij aan de versterking van de katholieke identiteit van de inwoners van Roermond, dat direct en indirect geteisterd werd door oorlogsgeweld. De grote uitstraling van beide maagden kwam de positie van hun leidsmannen in de stad ten goede. Die waren zich er echter ook terdege van bewust dat het charisma van deze vrouwen die positie ook in gevaar kon brengen, doordat het bestaande verhoudingen kon aantasten. Daarom probeerden de biechtvaders geloofsbeleving en uitzonderlijke ervaringen van beide maagden nauwgezet te controleren.

Zoals het ook in de kloppenboeken wordt voorgesteld, was de identiteit van Van Heilsbach en Van Randenraedt meervoudig; zij waren geestelijke dochters, geestelijke moeders, bruiden van Christus. Hun sekse vormde de kern van deze identi- 
teiten. Als geestelijke dochters waren zij ondergeschikt aan hun biechtvader. Maar als geestelijke moeders gaven zij leiding aan andere maagden en voelden zij zich gerechtigd andere leken op hun geloofsleven aan te spreken. En als bruiden van Christus wisten zij zich gesterkt door Zijn macht, die ze ook wel uitspeelden tegen Zijn aardse plaatsvervanger. $\mathrm{Zij}$ onderschreven én ondergroeven de heersende machtsverhoudingen tussen de seksen en hun eigen ondergeschiktheid aan hun biechtvader. Want net als sommige kloppenboek-auteurs waren zij ervan overtuigd dat vrouwen in den gelove moedig en standvastig als mannen konden zijn en dat ook zij, net als hun biechtvaders, op grond van hun verdiensten en goddelijke genade het morele gezag bezaten om anderen de weg tot God te wijzen. Hun bevoorrechte relatie met de hemelse Bruidegom beleefden zij in verschillende vormen van (zichzelf toegebracht) lijden en de frequente communie. Niet alleen een geestelijke verwantschap maar ook een fysieke eenwording ondervonden zij hierin, waardoor hun identiteit als $\mathrm{Zijn}$ bruid bevestigd werd. In dit opzicht is een continuiteit in vroomheid tussen laat-middeleeuwse religieuze vrouwen en mysticae en deze Roermondse kloppen waarneembaar. Aangezien geestelijke maagden in de wereld bleven, bleven zij ook zusters en dochters. De eisen van het nagestreefde religieuze bestaan stonden niet zelden op gespannen voet met dagelijkse zorgen en meer profane eisen waarmee ouders en andere familieleden geestelijke dochters bezwaarden. Ook Van Heilsbach en Van Randenraedt moesten deze tegenstrijdigheden die inherent waren aan hun levensstaat, het hoofd bieden, hetgeen niet altijd een gemakkelijke opgave was.

Het beeld dat uit de geschriften van beide vrouwen oprijst, is oneindig veel complexer dan voorstellingen die tot dusver in de geschiedschrijving zijn geboden van de leefwijze en de identiteit van geestelijke maagden. Zij verduidelijken hoezeer de positie van religieuze vrouwen zonder kerkrechtelijke status binnen een lokale geloofsgemeenschap afhankelijk was van de steun van geestelijken die zich als hun leidsmannen opwierpen. Dat betekende niet dat zij machteloos waren, maar wel dat zij binnen de gehoorzaamheidsrelatie met hun biechtvader zeer omzichtig te werk moesten gaan, opdat zij enige zeggenschap over eigen leven konden behouden. Die bleek het beste gewaarborgd door overgave; niet aan aardse maar aan hemelse autoriteit, aan het ultieme gezag van God over hun bestaan. Om een zekere mate van zelfbeschikking te garanderen in de alledaagse omgang met de biechtvader, bleken nederigheid en zich inschikkelijk betonen de meest werkzame gedragslijnen. Beide geestelijke maagden beseften terdege dat zij op grond van hun geslacht gezien werden als zwak en minderwaardig. In een retoriek van concessie schilderden zij zichzelf soms ook als zodanig af. Toch beschouwden zij zichzelf ook als uitzonderingen die de regel bevestigden. God had hun immers begiftigd met een moed die naar zeventiende-eeuws begrip enkel als mannelijk kon worden omschreven. Bovendien hadden zij een religieus leven in de wereld 
verkozen, een Imitatio Christi die naar hun zeggen een daadkracht en standvastigheid vergde, die de kracht van vrouwen in het algemeen te boven ging.

Van Heilsbach en Van Randenraedt kozen voor een bestaan als geestelijke maagd omdat zij God en hun naasten wilden dienen, hetgeen zij naar eigen opvatting het beste konden doen buiten het klooster. Zij zullen onder kloppen zeker geen uitzondering geweest zijn. Natuurlijk waren er onder de meer dan vijfduizend vrouwen die gedurende de zeventiende eeuw in Noord-Nederland voor de kloppenstaat kozen, ook die eigenlijk verlangden naar het kloosterleven of die zich als klop lieten inlijven door priesters. De Reformatie- en de recruterings-these doen nog steeds opgeld, al is genoegzaam gebleken dat sommige vrouwen uit zichzelf juist streefden naar een actief religieus bestaan waarin zij konden bijdragen aan de instandhouding en hervorming van hun kerk. In dit opzicht kenden de kloppen hun gelijken elders in Europa: de volgelingen van Mary Ward, de visitandinnen, de Filles de la Charité, allen vrouwen die gegrepen waren door contrareformatorische hervormingsidealen.

De kloppenstaat bood voor- en nadelen. De informele status kon spirituele onzekerheid tot gevolg hebben. Een prangende kwestie, die Joanna van Randenraedt bijvoorbeeld aansnijdt in haar gewetensrekeningen, was in hoeverre het streven naar zaligheid, dat beslist ook ten grondslag lag aan de keuze voor een geestelijk leven, verzekerd zou zijn. Daarenboven ging er een zekere mate van maatschappelijke onzekerheid gepaard met de keuze voor de kloppenstaat. Want niet iedereen achtte de kloppen zo hoog als menige katholieke geestelijke. Omdat kloppen religieuzen noch gewone leken waren, riep hun leefwijze ook weerstand op, en niet alleen onder protestanten. Ongebonden vrouwen die enkel Gods gezag aanvaardden, werden gezien als een bedreiging voor de bestaande gezagsverhoudingen tussen de seksen, alsook tussen clerus en leken.

Daartegenover stonden voordelen die voor verscheidene vrouwen de doorslag gegeven zullen hebben. De wens om een actief religieus leven te leiden waarvan werken van barmhartigheid een integraal bestanddeel vormden, kon door de kloppenstaat bevredigd worden. Hoewel zij door de intrede in de kloppenstaat als het ware een religieuze transformatie ondergingen, die voor hun omgeving natuurlijk nauwelijks verborgen kon blijven, vervreemdden zij daar toch minder van dan wanneer zij in een klooster intraden en abrupt alle banden met familie en vrienden moesten verbreken. De eerbaarheid, die voor ongehuwde vrouwen een kwetsbaar punt was, was in hun geval gewaarborgd door het religieuze karakter van hun staat. Door een strak vroomheidsregime, dat zich ten dele voltrok in de openbare ruimte van de (schuil)kerk, konden geestelijke maagden respect afdwingen voor henzelf, alsook voor de door hen gekozen levensstaat. Net als andere vrouwen behoorden ook kloppen onder het gezag van mannen te staan. Maar gehoorzaamheid aan mannelijk gezag was anders geordend en geformaliseerd dan in een echtverbintenis. $\mathrm{Zij}$ dienden God en Diens aardse plaatsvervanger te gehoorzamen en waren 
zo verzekerd van mannelijke supervisie, die in de ogen van tijdgenoten onmisbaar was. Met de betrekkelijk vrije beschikking over eigen tijd, energie en financiële middelen, konden zij de basis leggen voor hun geestelijke staat in de wereld. Op de invulling daarvan konden $\mathrm{zij}$ in overleg met hun leidsman invloed uitoefenen, omdat er geen vaste regel bestond.

Geestelijke maagden illustreren en personifiëren als geen andere groep binnen de zeventiende-eeuwse katholieke geloofsgemeenschap de paradox van onderschikking en ontplooiing. Het leergezag van de katholieke kerk bedeelde hun een aan mannen ondergeschikte plaats toe en beschouwde hen als onmondigen; ogenschijnlijk schikten deze vrouwen zich hierin wanneer zij het geloof aangrepen als fundament voor eigen levensinvulling, identiteit en werkzaamheid. Toch vonden zij in hun geloofsovertuiging ook motivatie én legitimatie om datgene te doen wat hun in de sociaal-culturele context van de eigen tijd op grond van hun sekse vaak niet was toegestaan. Verstoken als zij waren van vele uitdrukkings- en ontplooiingsmogelijkheden vonden zij in hun geloof bovendien een taal waarin zij zichzelf en hun plaats in de wereld konden benoemen en begrijpen. Deze taal bood hun als we de kloppenboeken volgen - meer dan enkel het jargon van lijdzaamheid en gehoorzaamheid, dat deels al door vigerende denkbeelden over vrouwen werd gedicteerd. In deze stichtelijke werken konden kloppen ook aansporingen vinden tot handelen en voorbeelden van wat hun daadkracht bij God en hun naasten zou kunnen bewerken. De gewetensrekeningen van Agnes van Heilsbach en Joanna van Randenraedt laten zien dat er inderdaad vrouwen waren die dergelijke aanmoedigingen ter harte namen. 


\section{Bijlage I}

\section{Visitatierapporten 1691-1695}

Bron: Rijksarchief in Utrecht, Archief Oud-Bisschoppelijke Clerezie, inv.nr. 679.

\section{Toelichting}

De gegevens in het onderhavige overzicht zijn gepresenteerd in de volgorde waarin ze door mij zijn aangetroffen. Iedere statie is voorzien van een nummer (eerste kolom) voor nadere identificatie bij verschillende berekeningen.

Van de in de visitatieverslagen gepresenteerde gegevens zijn overgenomen:

- plaats waar de statie zich bevindt (tweede kolom);

- naam van de bedienaar van de statie (derde kolom);

- of het een seculiere priester ('dominus', afgekort d.), dan wel een reguliere priester (afkorting van de orde waartoe hij behoort) betreft (vierde kolom);

- de leeftijd van de priesters ten tijde van de visitatie (vijfde kolom);

- het aantal communicanten per statie (zesde kolom);

- het aantal kloppen per statie (zevende kolom).

Daarenboven is aangegeven of staties op het platteland of in een stad gelokaliseerd zijn (achtste en laatste kolom; $s$ = stad; $p=$ platteland). Staties in steden met een omvang kleiner dan 2500 inwoners zijn door mij als plattelandsstaties aangemerkt. ${ }^{\text {? }}$

\begin{tabular}{|c|c|c|c|c|c|c|c|}
\hline Nr. & Statie & Bedienaar & Sec./reg. & Lft. & Comm. & Kloppen & Lokatie \\
\hline 1 & Utrecht & Velthuysen & d. & 59 & ca.30o & 28 & s \\
\hline 2 & Utrecht & Lindeborn & d. & 62 & ca.450 & 60 & $\mathbf{s}$ \\
\hline 3 & Utrecht & Horstyne & O.P. & - & ca.400 & 30 & $\mathbf{s}$ \\
\hline 4 & Utrecht & J. Cats & d. & 54 & 550 & ca.115 & $\mathbf{s}$ \\
\hline 5 & Utrecht & Amerongen & d. & 55 & 500 & 23 & s \\
\hline 6 & Utrecht & Van Strazeele & S.J. & 65 & 500 & 28 & $\mathbf{s}$ \\
\hline 7 & Utrec ht & Coumscher & S.J. & 65 & 700 & 75 & s \\
\hline 8 & Utrecht & J. Matthias & O.S.A. & 36 & 250 & 13 & s \\
\hline 9 & Utrecht & Ploeg & d. & 40 & 400 & 40 & s \\
\hline 10 & Utrecht & Schade & d. & 45 & 500 & 17 & s \\
\hline II & Utrecht & Stock & d. & 35 & 300 & 24 & $\mathbf{s}$ \\
\hline
\end{tabular}

I Gegevens voor de omvang van steden zijn ontleend aan Van der Woude, 'Demografische ontwikkeling', in het bijzonder 137 . 
Nr. Statie

Bedienaar

Sec./reg. Lft. Comm. Kloppen Lokatie

\begin{tabular}{|c|c|c|c|c|c|c|c|}
\hline 12 & Utrecht & Van Grave & d. & 43 & 1400 & ca.6o & $\mathbf{s}$ \\
\hline 13 & Utrecht & De Minnen & O.P. & 56 & 500 & ca. 52 & s \\
\hline 14 & Amsterdam & Hieronymus Gratianus & O.Carm. & 43 & 600 & - & s \\
\hline 15 & Amsterdam & P. Lettebos & d. & 42 & 70 & 7 & $\mathbf{s}$ \\
\hline 16 & Vianen & A. van der Schinnen & d. & 38 & 450 & 33 & $\mathbf{p}$ \\
\hline 17 & Culemborg & P. Sibbius & d. & 49 & 250 & - & $\mathbf{s}$ \\
\hline 18 & Culemborg & J. van Hoof & d. & 56 & 130 & - & $\mathbf{s}$ \\
\hline 19 & Culemborg & Fr. Breekevelt & S.J. & 42 & 450 & 49 & $\mathbf{s}$ \\
\hline 20 & Culemborg & M. Tirza & d. & 34 & 800 & 28 & $\mathbf{s}$ \\
\hline 21 & Vianen & Dalius & S.J. & $3^{8}$ & 450 & 26 & $\mathbf{p}$ \\
\hline 22 & Culemborg & Meinarts & d. & 33 & 200 & - & $\mathbf{s}$ \\
\hline 23 & Amsterdam & G. Fox Gisberti & d. & 38 & 340 & 5 & $\mathbf{s}$ \\
\hline 24 & Amsterdam & J. de Graef & d. & 3I & $\mathrm{ca} .800$ & is & $\mathbf{s}$ \\
\hline 25 & Amsterdam & De Coninck & S.J. & - & ca.60o & - & $\mathbf{s}$ \\
\hline 26 & Amsterdam & Glabbais & O.F.M. & 73 & ca.I 600 & 60 & $\mathbf{s}$ \\
\hline 27 & Amsterdam & G. de Praeter & d. & 39 & 400 & 12 & $\mathbf{s}$ \\
\hline 28 & Utrecht & Stakenburg & d. & 59 & 700 & 85 & $\mathbf{s}$ \\
\hline 29 & Delft & J. Roos & d. & 73 & 400 & 35 & $\mathbf{s}$ \\
\hline 30 & Delft & Van Mol & S.J. & - & 1400 & - & $\mathbf{s}$ \\
\hline $3 \mathrm{I}$ & Delf & N. van Erckel & d. & 73 & 500 & 54 & $\mathbf{s}$ \\
\hline 32 & Haarlem & A. Beez & d. & 33 & 400 & 16 & $\mathbf{s}$ \\
\hline 33 & $\begin{array}{l}\text { Enkhuizen' } \\
\text { Grootebroek }\end{array}$ & H. Calus & S.J. & 54 & 500 & Io & $\mathbf{s}$ \\
\hline 34 & Enkhuizen & H. Keesman & d. & 52 & 250 & 15 & $\mathbf{s}$ \\
\hline 35 & Grootebroek & Van de Velde & d. & 37 & 500 & Ca. 23 & p \\
\hline 36 & Westeinde & Futs [lezing onzeker] & d. & 34 & 150 & 13 & $\mathrm{p}$ \\
\hline 37 & Medemblik & Brouwers & d. & 38 & 300 & 15 & $\mathbf{p}$ \\
\hline 38 & Bovenkarspel & Rosa & d. & 52 & 260 & 18 & $\mathbf{p}$ \\
\hline 39 & Lutjebroek & H. Volkardus Roos & d. & $4 I$ & 330 & 18 & p \\
\hline 40 & Assendelft & C. Poelenburgh & d. & 38 & 1100 & 30 & $\mathbf{p}$ \\
\hline $4 \mathrm{I}$ & Hoogkarspel & Th. Spoors & d. & 46 & 400 & 12 & $\mathbf{p}$ \\
\hline 42 & Enkhuizen & J. Knotter & d. & 30 & 210 & - & $\mathbf{s}$ \\
\hline 43 & Noordwijk & Th. Groenehout & d. & 56 & ca.50o & ca.2I & $\mathbf{p}$ \\
\hline 44 & Den Haag & Joh. Hooft & d. & 64 & 900 & I6 & $\mathbf{s}$ \\
\hline 45 & Den Haag & W. Daelenoort & d. & - & - & - & $\mathbf{s}$ \\
\hline 46 & Brielle & Fr. Basius & d. & 35 & 120 & $\mathbf{I}$ & $\mathbf{s}$ \\
\hline 47 & $\begin{array}{l}\text { Rotterdam/ } \\
\text { Berkel }\end{array}$ & N. Benschop & d. & 53 & ca.30o & ca.32 & $\mathbf{s}$ \\
\hline 48 & $\begin{array}{l}\text { Rotterdam/ } \\
\text { Delfshaven }\end{array}$ & M. van Gulik & d. & 45 & Ca.IIo & - & $\mathbf{s}$ \\
\hline
\end{tabular}




\begin{tabular}{|c|c|c|c|c|c|c|c|}
\hline Nr. & Statie & Bedienaar & Sec./reg. & Lft. & Comm. & Koppen & Lokatie \\
\hline 49 & Rotterdam & Kuijk & d. & - & $\overline{c 8.900}$ & 57 & $\mathbf{s}$ \\
\hline 50 & Harderwijk & A. Costers & d. & 49 & 100 & $\mathbf{I}$ & 8 \\
\hline $5 \mathbf{I}$ & Putten & - & - & - & ca.5o & - & $\mathbf{p}$ \\
\hline 52 & Leeuwarden & E. Wissekerk & S.J. & 52 & ca. 300 & 28 & s \\
\hline 53 & Leeuwarden & J. Ardenois & S.J. & ca.5o & Ca.400 & - & $\mathbf{s}$ \\
\hline 54 & Leeuwarden & J. Kistemaeker & O.F.M. & 46 & ca.48o & ca.2I & s \\
\hline 55 & Leeuwarden & G. Van Lent & O.F.M. & 60 & ca. 300 & ca.12 & $\mathbf{s}$ \\
\hline 56 & Leeuwarden & J. Indervelde & O.P. & 44 & ca.16o & ca. I 4 & s \\
\hline 57 & Leeuwarden & W. Foppens & d. & 59 & ca.800 & 42 & s \\
\hline 58 & Dokkum & J. van Roode & S.J. & 38 & ca. 350 & ca.6o & s \\
\hline 59 & Workum & G. Parys & d. & 59 & ca.300 & 15 & $\mathbf{s}$ \\
\hline 60 & Oosterend & A. Tiara & d. & 58 & ca.50o & $\mathbf{I}$ & $\mathbf{p}$ \\
\hline 61 & Bolsward & M. Chinay & O.F.M. & 58 & ca.440 & 16 & $\mathbf{s}$ \\
\hline 62 & Bolsward & A.A. Claissers (Clayson) & S.J. & 54 & ca.150 & - & s \\
\hline 63 & Hemelum & W. Ema & d. & 34 & ca. 400 & - & $\mathbf{p}$ \\
\hline 64 & Wytgaard & P. Velthoen & S.J. & 35 & - & - & $\mathbf{p}$ \\
\hline 65 & Imsum & H. Pese & d. & 30 & ca. 700 & - & $\mathbf{p}$ \\
\hline 66 & Franeker & Steenbicker & O.F.M. & 44 & ca.700 & 6 & s \\
\hline 67 & Heerenveen & Bloemmaeker & O.F.M. & $\mathrm{ca} .33$ & ca.I5o & 2 & $p$ \\
\hline 68 & Oldehilpa & Priem & O.F.M. & 32 & ca.200 & 5 & $\mathbf{p}$ \\
\hline 69 & Pepengo & Meurs & O.F.M. & 53 & ca.300 & - & $\mathbf{p}$ \\
\hline 70 & Harlingen & Overbeek & S.J. & 33 & ca.300 & - & $\mathbf{p}$ \\
\hline 71 & Makkum & G. Ubbius & d. & 33 & ca. 700 & 12 & $\mathbf{p}$ \\
\hline 72 & Sneek & B. Gaijtsma & d. & 63 & ca. 400 & 12 & $\mathbf{P}$ \\
\hline 73 & $\begin{array}{l}\text { Idskenhuizen/ } \\
\text { Doniawerstal }\end{array}$ & A. Kokkaert & d. & 31 & ca. 240 & $\mathbf{I}$ & p \\
\hline 74 & Joure & J. Saers & S.J. & 60 & ca.230 & - & $\mathbf{p}$ \\
\hline 75 & Woudsend & U. Swaga & d. & 47 & ca.22o & 2 & p \\
\hline 76 & Follega & Zuurhuys & d. & 28 & ca.r7o & - & $\mathrm{p}$ \\
\hline 77 & Sensmeer & J. Geersma & d. & 53 & $c a .450$ & - & $\mathbf{p}$ \\
\hline 78 & In de Kuinder & M. Canter & O.F.M. & $4 I$ & Ca.220 & $\mathbf{I}$ & p \\
\hline 79 & Steenwijkerwold & Stalpaert van der Wielen & d. & 42 & ca.300 & $\mathbf{I}$ & $\mathbf{p}$ \\
\hline 80 & Haarlem & Alanus Stam & O.P. & 59 & ca. 400 & 39 & s \\
\hline 81 & Slootdijk & Rijser & d. & 62 & ca.38o & 12 & $\mathbf{p}$ \\
\hline 82 & Maasland & A. van Haeften & d. & $3 I$ & 225 & 4 & $\mathbf{p}$ \\
\hline 83 & Abcoude & Vennix & d. & $4^{8}$ & ca.350 & ca. 8 & $\mathbf{p}$ \\
\hline 84 & $\begin{array}{l}\text { Amstelland } \\
\text { (in de Nes) }\end{array}$ & Van Aelst & d. & 37 & ca.550 & 28 & $\mathbf{p}$ \\
\hline 85 & $\begin{array}{l}\text { Amstelland/ } \\
\text { Diemen }\end{array}$ & Cuijs & d. & 29 & ca.215 & 4 & $\mathbf{p}$ \\
\hline
\end{tabular}




\begin{tabular}{rlllrrrr} 
Nr. & Statie & Bedienaar & Sec./reg. & Lft. & Comm. & Kloppen Lokatie \\
\hline 86 & $\begin{array}{l}\text { Delfland/ } \\
\text { Vlaardingen }\end{array}$ & C. De Bont & d. & 44 & ca.150 & 2 & s \\
87 & $\begin{array}{l}\text { Delfland/ } \\
\text { Schipluiden }\end{array}$ & N. Aerts & S.J. & - & ca.300 & I & p \\
88 & Amstelland & Van Linge & d. & 60 & 120 & 2 & p \\
89 & Amstelland & de Wolf & O.S.A. & 55 & 800 & 27 & p \\
90 & IJsselstein & Adr. Ter Lauw & d. & 56 & ca.550 & ca.40 & s \\
91 & Gorcum & B. van Wevelinckhoven & d. & 55 & ca.80 & 9 & s \\
92 & Gorcum & Claessens & S.J. & ca.55 & ca.160 & 20 & s \\
93 & Gorcum & Eelkens & O.F.M. & - & ca.240 & 9 & s \\
94 & Schagen & Nicolaus van der Meer & d. & 39 & ca.800 & 30 & p
\end{tabular}




\section{Bijlage II}

\section{Lijst van kloppenboeken (1570-1730)}

\section{Verantwoording}

Uitgangspunt van deze lijst vormde het overzicht van speciaal voor kloppen geschreven onderrichtingsboeken door Eugenie Theissing, Over klopjes en kwezels (Nijmegen/Utrecht 1935) 222. Aanvullingen zijn gedaan aan de hand van de Bibliotheca catholica Neerlandica impressa ('s-Gravenhage 1954) en M. de Vroede, 'Kwezels' en 'zusters'. De geestelijke dochters in de Zuidelijke Nederlanden, r7de en r8de eeuw (Brussel r994). Daarnaast zijn de grootste collecties kerk- en devotieboeken in Nederland, de Collectie Thomaasse (Bibliotheek van de Rijksuniversiteit Utrecht) en de Jezujetencollectie (Bibliotheek van de Rijksuniversiteit Limburg) systematisch doorgenomen.

Alleen geraadpleegde edities worden vermeld. Waar nodig wordt tussen teksthaken het oorspronkelijke jaar van uitgave vermeld. De werken zijn alfabetisch op auteur, of eerste zelfstandig naamwoord wanneer een auteur ontbreekt, gerangschikt.

\section{Gebruikte afkortingen}

AntwRG Ruusbroec-genootschap te Antwerpen

KBB Koninklijke Bibliotheek Albert I te Brussel

OKPU Oud-katholieke parochie van Utrecht

RULimburg Bibliotheek van de Rijksuniversiteit Limburg te Maastricht

RUU Bibliotheek van de Rijksuniversiteit Utrecht

UBN Bibliotheek van de Katholieke Universiteit Nijmegen

UvA Bibliotheek van de Universiteit van Amsterdam

I. Bisschop S.J. Valentinus, Den Lof der Suyverheydt (...) Van Nieuws oversien ende verbetert (2 dln.; Antwerpen: Hieronymus Verdussen 1626 [1625]) $15,5 \mathrm{~cm}, \mathrm{xx}+297+$ vi p., UBN.

Goedkeuring: E. Spitholdius, Antwerpen, 05-09-1624.

Idem, Den Lof der Suyverheydt. Het Derde Boeck, Inhoudende de Gheestelijcke Oeffeningen ende Regel der Maechden (Antwerpen: Joan. Cnobbaert 1627) I6 cm, i $+551+x i$ p., Klooster Soeterbeeck, Deursen.

Goedkeuring ontbreekt (alleen goedkeuring van de provinciaal van de Vlaamse provincie van de orde, Florentinus de Montmorency S.J., Kortrijk, 24-04-1627). 
2. [Bosch O.M.C., Albertus van den], Het geestelyck verborgen manna tot een spys ghegheven Aen alle Godtvruchtige soo werelijcke als Geestelijcke Peersoonen, die geen Religieusen en zijn, haer leerende, in wat staet, oft van wat conditie dat sy zijn, te konnen leven een waerachtigh volmaeckt geestelijck ende Religieus leven. En dat oock in geloften Van Gehoorsaemheyt, Van Amoede des Geest, En van Suyverheyt (Antwerpen: Alexander Everaerts z.j.) [tweede druk, verzorgd door G. Ridder 'Ouwt Deken' en vermoedelijk verschenen in 1726] $13 \mathrm{~cm}$, ii + 8I + iii p., AntwRG.

Goedkeuring: H. Damen, Leuven, 28-10-1709 en 12-10-1707.

3. Bouchout O.P., Alanus, Spiegel voor alle gheestelicke dochters, leerende het beginnen, onderhouden en vol brengen van haeren Gheestelijcken Staet (Brugge: Gregorius Clouwet 1688

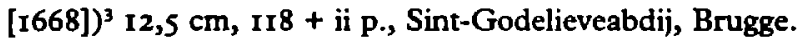

Goedkeuring: I.H. Anchemant, z.p., 22-12-1668.

4. F.V.O.C.S. [F. van der Weyden], Het leven van de Godtvruchrighe ende Deughtsaeme Anna de Torres, geestelycke dochter, salighlijck in den Heere overleden binnen Antwerpen op den 13 januarii 1698. Uyt ware Ondervindinghe, ende ghetrouve Overleveringhe by een vergaedert, ende voor-gestelt aen alle Godt-minnende Zielen (Antwerpen: Hieronymus Verdussen 1710) $16,5 \mathrm{~cm}$, xvi + $199+\mathrm{ix}$ p., UBN.

Goedkeuring: A. Eyben, Antwerpen, 23-04-1710.

5. Gabriël a S. Joanne Baptista O.Carm., De bruydt Christi Christina, ghekleedt naer de mode van Parys en Paradys, betoonende aen alle Maeghden, hoe sy heden-daeghs naer Siel ende Lichaem konnen verciert gaen (Antwerpen: Augustinus Graet 1690) $16 \mathrm{~cm}$, xvi +278 + iii p., RUU (Collectie Thomaasse).

Goedkeuring: A. Hoefslach, Antwerpen, 16-12-1689.

6. Gabriël a S. Joanne Baptista O.Carm., Het gheestelyck houwelyck tusschen Christum en de siele onder den naem van Amadea. Aen de getrouwde oft naer het Vleesch oft naer den Gheest hunne verbintenisse, En aen de ongetrouwde de Oeffeninghe van verscheyden deugden voorhoudende (Antwerpen: Augustinus Graet r691) $16 \mathrm{~cm}$, xxviii + 369 + xxi p., RUU (Collectie Thomaasse).

Goedkeuring: A. Hoefslach, Antwerpen, 29-09-169r.

7. De geestelyke besnydenisse der vyf sinnen, voor een nieuw-iaergifte opgedragen aen de geestelyke maegden; Als eenen noodigen middel om van de bloedige Besnydenisse van het kindeken fezus deelagtig te worden (Antwerpen: Jacobus Bernardus Jouret z.j.) $15 \mathrm{~cm}, 59$ p., RUU (Collectie Thomaasse).

Goedkeuring: A. van Ertborn, Antwerpen, z.d. [1727?]

8. Gerardi S.J., A. [Egidius Gheeraerdts], Den Spiegel van Philotea, ende der Godturuchtighen zielen (Antwerpen: weduwe van Jan Cnobbaert 1646$) 12 \mathrm{~cm}$, xii $+187+$ iii p., RULimburg (Jezuïerencollectie).

Goedkeuring: A.V.L., z.p., z.d.

2 Hildebrand, 'Een vergeten ascerisch schrijver', 256.

3 De Vroede, 'Krvezels' en 'zusters', hoofdstuk I, rekent dit werk tot de kJoppenboeken. Ofschoon het door mij niet is bestudeerd, wordt het hier volledigheidshalve vermeld. Zie voor nadere inhoudelijke gegevens de genoemde studie van De Vroede. 
9. Girard de Vilthierry, J., Het leven der maegden, of De plichten en verbintenissen der Christelycke maegden (Gent: C. Meyer 2.j.) [oorspronkelijk in 1693 in het Frans verschenen; vertaald door Adriaan van Loo] $15 \mathrm{~cm}$, xii $+382+$ ii p., RUU (Collectie Thomaasse). Goedkeuring: J. van den Hove, Gent, 08-03-1717.

10. Godtvruchtige Maniere van leven in het kort voorgestelt in verscheyde regels ende geestelyke oeffeninghen Seer dienstigh tot vervoorderinge in de Christelijke deught, ende volmaekthyt voor alle Zielen, die buyten het Clooster in den Maegdelijken Staet soecken Godt wel te dienen, en besonderlijk voor de Geestelijke Dochters, onder de bestieringe van de Eerw. Paters van d'Ordre der Alderh. Maget Maria des Berghs Carmeli (Antwerpen: Robijns 1717) 13,5 cm, 96 p., AntwRG.

Goedkeuring: J.L. de Carvajal, Antwerpen, 23-12-1717.

II. Hazart S.J., Cornelius, Lof van den maegdelijcken staet naemelyck in de werelt. Daer beneffens de deughden ende gheestelycke oeffeninghen ende maniere van leven voor de ghene die desen Staet hebben aenveert. Alles ghetrocken uyt de H.H. Out-vaders (Antwerpen: Michiel Cnobbaert 1678) is cm, $164+$ iv p., UBN.

Goedkeuring: A. Hoefslach, Antwerpen, 06-04-1678.

12. Heumen, Joannes van, Het Clooster van Sion, leerende een volmaeckt Geestelijck leven, verdeylt in Ses Deelen (Antwerpen: voor Hendrick de Bruyn [Rotterdam] 1662-I666) drie banden.

Dl. I-II: $16 \mathrm{~cm}$, xlviii +416 p. (I) en xiv +352 p. (IN), UBN.

Goedkeuring: Petreaus, ${ }^{4}$ z.p. 22 juni 1662.

D1. III-IV, $16 \mathrm{~cm}$, xxoui +368 p. (III) en xiii +39 I p. (IV), UBN.

Goedkeuring: A. van Outheusden senior, z.p., 08-07-1663.

Dl. V-VI: $16 \mathrm{~cm}, x \mathrm{xl} 296$ p. (V) en xvi +288 p. (VT), UBN

Goedkeuring: A. van Outheusden senior, z.p., 04-01-1666.

13. [Huysmans S.J., Daniël], Kort Begryp des levens ende der deughden van de weerdighe foanna van Randenraedt geestelycke dochter onder de Bestieringhe der Societeyt Iesu (Antwerpen: Augustinus Graet 1690) $20 \mathrm{~cm}$, viii + 35I + iii p., UBN.

Goedkeuring: N. Du Bois, Leuven, 03-07-1689; A. Hoefslach, Antwerpen, 16-r 2-I689.

14. [Huysmans S.J., Daniël], Leven ende Deughden vande weerdighe Agnes van Heilsbagh gheestelycke dochter onder de bestieringhe der Societeyt Iesu (Antwerpen: Michiel Cnobbaert 1691) $20 \mathrm{~cm}, \mathrm{ii}+336+$ vii, UBN.

Goedkeuring: N. Du Bois, Leuven 24-I 2- 1690; A. Hoefslach, Antwerpen, 26-12-I690.

15. Instructie voor een geestelycke dochter Om Godt wel te dienen in den Maeghdelijcken Staet (Gent: James Eton 1706 [1703]) 15,5 cm, 32 p., RULimburg (Jezuïetencollectie). Goedkeuring: C.J. Legier, Gent, 15-02-1703.

16. [Jacobi S.J, Ludovicus], Den Spieghel der Maeghden, Die inde werelt de godvruchtigheyt met de suyverheyt paren, uyt-ghebeeldt in twee H.H. Maeghden, te weten de $H$. Isabella van Vranckrijck [door N.Caussin S.J.] ende de H. Lydwina [door J. Brugman O.F.M.], In welcke de weerdigheydt, vruchtbaerheydt ende eyghendommen vanden gheestelijcken staet inde wereldt bewesen worden, overgheset in onse Neder-duytsche tale door E.P.L.F. Priester der

4 Petraeus (Petreius) was een pseudoniem van Joannes Schade ( $\downarrow$ I665), aartspriester van Delft en sinds 1653 provicaris van het Hollandse deel van het aartsbisdom Utrecht. 
Societeyt fesu (Antwerpen: weduwe van Jan Cnobbaert 1657) $15 \mathrm{~cm}$, xix + I19 + i p.; xii $+206+$ xiii p., UBN.

Goedkeuring: G. Bolognino, [Antwerpen], z.d.

17. [Kemp, Willibrord], Zedelessen voor de Maegden, die, haer zelve aen Godt opgedragen hebbende, trachten volgens de plichten van de maegdelijke staet te leven: Vergadert uit Gods Woord, en uit de Schriften der heilige Vaderen; En tot een t'zamenspraek tusschen Christus en een Maegd, opgestelt door W.K. (Utrecht: Theodorus van den Eynden 1710 ) $15 \mathrm{~cm}$, xvi +252 p., UBN.

Goedkeuring: H. Damen, Leuven, 15-08-1709; A. Eyben, Antwerpen, 03-10-1709.

18. [Leroy, Guillaume]', Een christelyke maegd Sich tot de werken van liefde bestedende, Afgebeeld in het leven van juffrouw Maria Anna du Val de Dampierre. Uyt het Frans vertaald. (Antwerpen: voor Hendrik Van Rhijn [Delft] 1697 ) $16 \mathrm{~cm}$, xiv + $543+\mathrm{ix}$ p., RUU (Collectie Thomaasse).

Goedkeuring: J.D. Cuyper, Brussel, 30-08-1684. ${ }^{6}$

19. Lindeborn, Joannes, De Leeder facobs. De Maegden, die Godt met opzet van eeuwige Reinigheit in de Wereld dienen, toegepast (Antwerpen: Michiel Cnobbaert voor Joachim van Metelen [Amsterdam] 1670) [oorspronkelijk in I666 in het Latijn verschenen; vertaald door Adrianus Terlou] $17 \mathrm{~cm}$, xxvi + $351+\mathrm{i}$ p., UBN.

Goedkeuring: J. van Heumen, z.p., o1-03-1670.

20. Lumnius, Joannes Fredericus, Van dleven der christeliicker maechden, vier dialogi, dat is tsamenspreeckinghen van twee persoonen: Ghemaeckt by Ioannem Fredericum Lumnium Pastoor des Beghijnhofs T'Antwerpen. Noch een Boecxken vanden H. Doctoor Ambrosius Bisschop tot Melanen, ghescreven aen een Maghet die tot val ghecomen was, door den selven nu eerst in duytsch overghesedt (Antwerpen: Plantijn 1571) $16 \mathrm{~cm}, 333$ p., RUU (Collectie Thomaasse).

Goedkeuring: S. Baer Delphius, Antwerpen, z.d.

21. Munnos, Ludovicus, Het stichtbaer leven van de doorluchtighe en weerdighe maget Dona Aloysia de Caravaial y Mendoca: Spieghel der sielen welcke in Suyverheyt in de wereld leven. In het spaensch, door den Licentiaet Ludovicus Munnos beschreven, Ende in Duyts door R.P. Franciscus de Smidt der Societeyt Iesu ghestelt (Antwerpen: Comelis Woons 1649) [oorspronkelijk in 1632 in het Spaans verschenen; vertaald door Franciscus de Smidt S.J.] $15 \mathrm{~cm}$, viii $+334+$ ii p., UvA.

Goedkeuring: G. Bolognino, [Antwerpen], 09-12-I648.

22. Musius, Cornelius, Maagde-pligt, Ofte De ware maagd (Antwerpen: voor Hendrik van Rhijn te Delft I690) [vertaald - vermoedelijk uit het Latijn - door R.H.] ${ }^{7}$ 4, $5 \mathrm{~cm}$, 36 p., KBB.

Goedkeuring ontbreekt.

5 Barbier, Dictionnaire, II, p. 877, vermeldt als auteur van de oorspronkelijke Franstalige editie van dit werk (1684) Guillaume Leroy, 'abbé de Haute-Fontaine'. Wie het in het Nederlands vertaald heeft, is niet bekend.

6 Het betreft een vertaling van de goedkeuring uit de Franse editie uit 1684 .

7 Volgens Hensen, 'Musius', 1050, is Maagde-pligt de vertaling van Institutio foeminae christianae (...) Eiusdem odae et psalmi aliquot (Poitiers 1536 ). 
23. Onderwysingen of mantere van leven voor de geestelycke dochters van het Oratone (Gent: Mauntuus van der Ween z.j.) 15,5 cm, v1 +172 p. [incompleet], OKPU (Pastoorsbibliatheek).

Goedkeunng ontbreekt [C J. Legier, Gent, 17-07-1709]..$^{8}$

24 Poirters, Adnaan S.J., Het daeghelycks nueuwe-jaer spieghelken van Phtlagie, verctert met pnnten, duchten, seden-leernghen (Antwerpen: Jacobus Woons 1680) [1673] 14,5 cm, xii $+81+$ il p., UBN.

Goedkeuring. A. Hoefslagh, [Antwerpen], 24-I I-I679.

25. Een regel waar duer als een Spreghel, die Christelycke maechden met Gods gratie soude moghen comen tot waerachtighe inwendighe schoonheyt, om also haer Bruydegom Thesu Christo te behagen, ende van hem die Croon des levens te ontfangen (z.pl., $\mathrm{z}$ ] ) [ca. I583] I3 cm, 132 p. [pagunering ontbreekt; afgesneden] RULumburg (Jezuletencollectue). Goedkeunng: G H.C., z p , z.d.

26. Regel der volmaecktheyt voor alle christene maeghden. Behelsende een verdeylinghe van den dagh, ende eenighe duenstighe waerheden raeckende de voornaemste maeghdelycke plichten (Antwerpen: weduwe van Petrus Jacobs 1709 [1696]) I5 cm, $11+166+11$ p, UBN. Goedkeuring A. Eyben, Antwerpen, z d.

27 Roa S J., Martunus de, Op-rechte Af-beeldinghe van den maeghdelycken staet: betrocken op het leven van de Edele en godturuchtige Sancia Carillo eerst beschreven in de Spaensche tale, Ende nu in het Neder-landtsch overgheset (Antwerpen: weduwe van Jan Cnobbaert I639 [1630]) [oorspronkelijk in I615 in het Spaans verschenen; vertaler onbekend] I3 $\mathrm{cm}, \mathbf{x x u v}+265+$ xi p., UBN

Goedkeuning G. Estnx, Antwerpen, I 2-II-I638.

28. Rosweydus S.J., Henbertus, Het leven vande heylighe Maghet ende Moeder Godts Mana, prncesse der Maeghden. Met een cort tractaet vanden Maeghdelycken Staet (Leuven Francols Fabri voor Pieter Jacobszoon Paets [Amsterdam] 1629 [1620]) I5,5 cm, 1 $+112+1$ p., UBN.

Goedkeuning E. Spitholdius, Antwerpen, 15-05-1629

29. Rosweydus S J, Henbertus, Het Leven der H.H. Maeghden die van Chrstus tyden tot dese Eeuwe in den Salighen staet der Suyverheyt in de werelt gheleeft hebben, met een cort tractaet vanden Maeghdelyken Staet (Antwerpen: Hieronymus Verdussen 1696 [1626]) $17 \mathrm{~cm}, \mathrm{xv}+630+11 \mathrm{p} ., \mathrm{UBN}$.

Goedkeuning: A Hoefslach, [Antwerpen], z d

30. Schoenus, Wilhelm, De Weg der Suyverheyt van d'Hollantse Maegden (Antwerpen: voor Philıppus van Eyck [Amsterdam] 1676) $16 \mathrm{~cm}, 321+11$ p., UBN.

Goedkeunng: A. van den Eede, Antwerpen, 14-03-1676.

8 Vanderhaeghen, Biblıographie gantowe, $\mathrm{nr} 1872$ Onderwysingen werd gedurende de achttuende eeuw verschullende malen herdrukt als Onderwyzingen voor de geestelyke dochters behelzende de Voordeelen, de Phuchten en Oeffeningen van haren Staet, met Eene voor-afgaende verdeelinge van hare oeffeningen door den dag en door het faer Een jaar van verschijning ontbreekt in deze herdrukken $Z_{1 j}$ werden gedrukt door Domunicus van der Ween te Gent (werkzaam tussen 1734 en 1748), door P F de Goesin te Gent (werkzaam tussen 1717 en 1740) en door Johannes Ignauus de Rave te Ieper (werkaam tussen 1745 en 1749), telkens met de goedkeuning van C J Legier, Gent, 17-07-1709. 
31. Een Sendbrieff Inhoudende seer profijtelijcke ende troostelijcke Vermaninghe alle Christelijcke Maechden, die Godt dienen, versterckende om in reynicheydt te volherden, ende die te bewaren totten eynde, ter liefde Godts die haer die Croon des eeuwighen Levens gheven sal (z.pl., z.j.) [1583] $13 \mathrm{~cm}, 63$ p. [paginering ontbreekt; afgesneden], RULimburg (Jezuietencollectie).

Goedkeuring ontbreekt.

32. Smidt S.J., Franciscus de, Van den salighen staet der genen die in de werelt Reynicheyt beloven (Antwerpen: Cornelis Woons 1650) $13 \mathrm{~cm}$, xxiv + I64 + ii p., RULimburg (Jezuïetencollectie).

Goedkeuring: G. Bolognino, [Antwerpen], o6-12-1649.

33. Steur O.P., Amoldus, De lelie der maeghdelijcker suyverheyt, seer nut ende profijtelijck voor alle godtwruchtighe maeghden die de suyverheydt zijn beminnende (Antwerpen: Guilliam van Tongeren 1622) $16 \mathrm{~cm}$, xiv $+378+v$ p., RULimburg (Jezuïetencollectie).

Goedkeuring: L. Beyerlinck, Antwerpen, 03-r 2-r62r.

34. [Stevins O.E.S.A, Fulgentius], Regel voor de geestelyke Dogters, voornamelyk in de Hollandsche Sending, van de Derde Orden der Eremyten van den Heyligen Vader Augustinus, met verscheyde Gebeden, Litanien ende eenige levens der voornaamste Heyligen van 't selve Orden (Amsterdam: Willem van Bloemen 1705) 12,5 cm, vi + 92 p., Klooster Soeterbeeck, Deursen.

Goedkeuring ontbreekt (alleen goedkeuring van de provinciaal van de Nederlandse provincie van de orde, fr. Emmanuel Ballexo, Gent, 10-09-1705). 


\section{Biogrammen van de auteurs van kloppenboeken"}

Bisschop S.J., Valentinus (1586-1636)

In 1610 ingetreden bij de jezuieten. Werd in 1621 werd naar de Hollandse Zending gestuurd. Assisteerde enıge tijd de dienstdoende jezwet in Groningen. Hier ontstonden moeilijkheden met wereldheren die de wettigheid van zijn werkzaamheden betwistten. ${ }^{3}$ De geloofsgemeenschap raakte in beroering; men maakte zich zorgen over de geldigheid van de door Bisschop toegediende sacramenten. Geestelijke maagden schijnen daarom als eersten deze jezuïeten-statie gemeden te hebben. Bediende vervolgens een statie te Rotterdam. Richtte hier een Maria-congregatie voor mannen op, die spoedig werd gevolgd door eenzelfde sodalitest voor vrouwen. Gaf in de periode $1625-1626$, waarin ook zijn kloppenboek het licht zag, leiding aan geestelijke maagden. ${ }^{4}$ In 1629 overgeplaatst naar Nijmegen. Een jaar later teruggeroepen uit de Hollandse Zending. Was nog enkele jaren werkzaam in Antwerpen, Brugge en Kortrijk, alwaar hij aan de pest bezweek.

Bouchout O.P., Alanus (1620-1676)

Geboren te Brugge; trad aldaar in de dominkanerorde. Deed professie in 1638. Vervulde in 1669 het ambt van prior te Brugge en was er nog tweemaal subprior. Fungeerde tevens als prefekt van de broederschap van de Allerheiligste Rozenkrans. Nam tevens enige tijd de leiding waar over de vrouwelıjke leden van de derde orde. Mogelyk werd hij hierdoor geïnspireerd tot het schnjven van zijn kloppenboek.

1 Cornelis Musius (1500-1572) en Jan Brugman O F M (na 1400-1473) worden hier butten beschouwing gelaten. Musius' Institutio foeminae chrstianae (...) Ejusdem odae et psalmı aliquot (Poitiers 1536) is volgens Hensen, 'Musius', Ioso, in 1690 vertaald als Maagde-pligt. De betreffende vertaling en redactue van $\mathrm{R} H$ kan, anders dan Musius' oorspronkelyjke werk, als kloppenboek beschouwd worden. Wie er achter de initialen $R$ H. schuıl gaat, kon niet achterhaald worden. De vtta van Lidwina van Schiedam, die Brugmans in 1456 in het Latjn schreef, maakt deel uit van het kloppenboek Spieghel der Maeghden van de jezuiet Jacobı, die heronder wordt besproken. Van de auteur van Het leven van (...) Anna de Torres, die door De Vroede, 'Kwezels' en 'zusters', 35 (noot 135), geidenuficeerd wordt als F. van de Weyden O.C.S., zijn geen nadere brografische gegevens gevonden Dat geldt tevens voor Gullaume Leroy, die door Barbier, Ductionnaire, II, 877, als auteur wordt aangemerkt van Een chrstelyke maegd Such tot de werken van hefde bestedende, Afgebeeld in het leven van juffrouw Mana Anna Du Val de Dampierre.

2 Menologium, I, 227-230a.

3 Vgl. Van Lommel, "Van de Velde, "Narratio Histonca", 19-20.

4 A H L. Hensen, 'Het Roomsch-Katholieke Rotterdam', in. Rotterdam in den loop der eeuvven, II, 76, geciteerd in Theissing, Over klopjes, 60.

5 Axters, 'Budragen', 51-53. 
Daarnaast had hij nog enkele andere stıchtelijke boeken op zıjn naam staan.

Bosch O.C.M , Albertus van den (1664-1740)

Trad in de kapucıjnerorde in en deed zujn noviciaat te Leuven, waar hu in I682 ingekleed werd of professie deed. Woonde rond 1702 in Gelder, waar de Vlaamse kapucı)nen een klooster hadden. Van daaruit had huj de geestelıke leıding over een gemeenschap van geestelıjke maagden, due in Horst leefden volgens de derde orde-regel van St. Franciscus. Deze vrouwen leidden een teruggetrokken leven en voorzagen in hun onderhoud door handwerken. Schreef voor deze communiteit constututies. Enige van zijn werken, waaronder Het geestelyck verborgen manna, zijn door deze geestelujke dochters geinspireerd. Was rond 17 II enige ujd als predikant werkaam in Tienen. In 1714 vicans van het klooster te St.-Truiden. Korte tud werkaam als lector in de filosofie en de theologie. Was vanuit Gent gerume tıjd als zielzorger werkzaam in Westdorpe (Zeeuws-Vlaanderen). Publiceerde verschillende ascetusche werken, niet alleen voor kloosterlıngen, maar ook voor leken.

Caussin S.J, Nicolas (1583-165I) ${ }^{7}$

Geboren in Troyes. Begon in I607 aan het noviciaat by de jezuieten. Doceerde retonca onder andere aan het College de Clermont te Parijs. Vanaf I620 werkzaam in het professenhuis te Panjs. Ontwikkelde zich als predikant ten overstaan van een meest adellıjk publıek Was sterk geïnspireerd door Francıscus van Sales Hem stond de opbouw van een door en door chnstelıjke samenlevng voor ogen, waarbij de adel het voortouw zou moeten nemen. Vertolkte dit ideaal in het dnedelige La Cour Sainte, waarvan het eerste deel in 1624 verscheen en dat sindsdien vele herdrukken beleefde. La vie de Ste Isabelle soeur du Roy Saint Lovis, (...) , dat hier deel van uitmaakt, verscheen afzonderlık in I644. Vertalıng ervan werd opgenomen in Jacobı's Den Spreghel der Maeghden Met onder meer deze vita beoogde de auteur blj te dragen tot de hervorming van de zeden aan het Franse hof, waar hij in 1637 zelf korte tud vertoefde als biechtvader van Lodewı)k XIII. Door toedoen van kardınaal Richelieu verbannen van het hof naar Quimper. Na de dood van Lodewıjk XIII op verzoek van Anna van Oostenrı) in 1643 teruggekeerd naar Parıs. Zın oeuvre omvat naast wetenschappelı)ke tractaten verschillende devotie- en dagheiligingsboeken

Gabnel a S. Joanne Baptista O Carm. (1640-1692)

Deed in I660 professie bij de carmelieten te Mechelen en werd in 1665 tot priester gewi)d Doceerde enige tud humaniora in de karmels te Boxmeer en Gelder Publiceerde op latere leeftıd een viftal werken, die vooral de jeugd tot deugdzaamheid moesten inspireren Deze werken, waaronder twee kloppenboeken, zijn gebaseerd op moralıserende exempla, ontleend aan klassieke en chnstelıke auteurs.

Gerardı S.J , Egidius [Gheeraerdts] (1596-1655)

In I6I3 novice bij de jezuieten. Het kloppenboek Spreghel van Philotea is het enige van hem bekende werk.

6 Hildebrand, 'Een vergeten ascetusche schrijver'.

7 DBS, II (1891) 902-927, Châtellier, L'Europe des devots, I21, 130, 158, I6I-162, Campbell, 'Nicolas Caussin's Spintualty of Communication'

8 Aubert, 'Gabnel de Saint-Jean-Bapuste', Rosier, Brografisch en brbliografisch overzzcht, I35-1 36

9 DBS, III (1892) 1365-1367 
Girard de Vilthierry, Jean (1641-1709)

De kerkelijke loopbaan van deze Franse wereldheer is nauwelijks bekend. Een deel van zijn omvangrijk oeuvre bestaat uit werken waarin hij een algemene zedenleer voor christenen uirwerkt, al naar gelang hun staat. La vie des vierges (1693) werd in 1717 door de wereldheer Adriaan van Loo (1658/59-1727) ${ }^{11}$ vertaald als Het leven der maegden. De oorspronkelijke Franse versie van zijn kloppenboek kende in de zeventiende en achttiende eeuw zeven drukken. Staat wel als jansenist te boek; in zijn kloppenboek zijn hier betrekkelijk weinig aanwijzingen voor, hoewel hij overtuigd blijkt van de zondige aanleg van de mens en diens onvermogen om deze aanleg te overstijgen. Hazart S.J., Comelius (1617-1690) ${ }^{12}$

Vooraanstaand polemist onder de jezuieten, die ongeveer tachtig publikaties op zijn naam heeft staan. Fel bestrijder van de protestanten. Leidde van 1654 tot zijn dood iedere zondag een bijeenkomst over de geloofsverdediging in de Antwerpse jezuietenkerk. ${ }^{13}$ In de strijd tussen jansenisten en anti-jansenisten schaarde hij zich in het laatste kamp. Bestreed in woord en geschrift de tegenstanders van de milde moraal en het probabilisme dat hij zelf voorstond.

Heumen, Joannes van (16II-1673) ${ }^{14}$

Studeerde theologie te Keulen. In 1642 benoemd tot pastoor te Schoonhoven. Van 1642 tot zijn dood pastoor van de oudste Rotterdamse statie St. Laurentius en Maria Magdalena in de Oppert. Bekend is dat er ten minste twaalf geestelijke maagden binnen deze statie hand- en spandiensten verrichtten bij het catechismus-onderwijs. Zijn assistent gaf leiding aan deze vrouwen. ${ }^{\text {is }}$ Wordt gerekend tot intimi van apostolisch vicaris Joannes van Neercassel (1663-1686). Deze benoemde hem in 1664 tot assessor (en later tot praeses) van het vicariaat van Utrecht en in 1665 tot aartspriester van Delft en Schieland. Schreef behalve Clooster van Sion nog enkele pastoraal-theologische werken, waarvan er drie in het Latijn voor de clerus bedoeld waren.

Huysmans S.J., Daniël (1643-1704)

Begon noviciaat bij de jezuïeten in I66r. Is auteur van twee kloppenboeken. Spoorde voor de vita van Joanna van Randenraedt zelf een deel van haar nagelaten handschriften op. Correspondeerde in 1689 met de geestelijke dochter Lucia de Werimont, vertrouwelinge van Van Randenraedt, die ook haar nalatenschap beheerde. Uit zijn brieven blijkt dat hij zich intensief bezig hield met Van Randenraedts levensbeschrijving, die volgens hem reeds vóór verschijning de andacht trok. ${ }^{17}$ Memoreert in zijn correspondentie met $\mathrm{De}$ Werimont dat een groep Antwerpse geestelijke maagden bereid

Io Noye, 'Girard de Vilthierry (Jean)'.

II Kapelaan van de St. Jacobskerk te Gent, die tekende voor de vertaling van verscheidene devorieen kerkboeken uit het Frans en het Latijn, waaronder ook enige werken met een jansenistisch karakter. Viaene, 'Het stichtelijk vertaalwerk'.

12 Aubert, 'Hazart, Comeille'.

13 Spiert, 'Jansenisme', 166.

14 Idem, 'Heumen, Joannes van'.

I5 A. Hensen, 'Hubrecht en Bernard Hoogewerff, $B B H 47$ (193I) 33I e.v., geciteerd door Theissing, Over klopjes, 59.

$16 D B S$, IV (1893) 542.

17 GAR, Handschrifien C III 9 en C III I5, brieven van Daniël Huysmans aan Lucia de Werimont, ongedateerd [vermoedelijk I689]. DBS, IV (1893) 542. 
was de kosten te dragen voor het portret van Van Randenraedt, dat als frontispice in het boek werd opgenomen.

Jacobi S.J., Ludovicus (I594-I66I) ${ }^{\text {ts }}$

In 1613 novice bij de jezuieten. Novicenmeester te Lier. Legde zich tijdens zijn leven toe op de prediking. Stelde een compilatie van godvruchtige oefeningen samen, onder andere uit het werk van zijn medebroeder Alphonsus Rodriguez. Publiceerde daarnaast een werkje over de vrome voorbereiding op de dood. Voor zijn kloppenboek Spieghel det Maeghden vertaalde hij de Latijnse vita van Lidwina van Schiedam, die door de minderbroeder Jan Brugman was geschreven. ${ }^{19} \mathrm{Het}$ tweede leven waarmee hij geestelijke maagden een spiegel wilde voorhouden was dat van de middeleeuwse Franse prinses Isabella, geschreven door de jezuïet Nicolas Caussin. ${ }^{20}$

Kemp, Willibrord († 1747) ${ }^{21}$

Priester van de Rooms-Katholieke Kerk van de Oud-Bisschoppelijke Clerezie. Was van 1712 tot 1747 pastoor van St. Gertrudis. ${ }^{22}$ Nabij deze kerk, in de Mariahoek, woonden de geestelijke maagden van deze statie. Of deze vrouwen samen een vergadering vormden, is niet bekend. Wordt wel beschouwd als degene die organisatie aanbracht in deze katholieke gemeente, door onder andere enkele vrouwen, onder wie geestelijke maagden, als 'moeders' aan te stellen, die verantwoordelijk waren voor de armenzorg in de statie. Kocht in 1733 en 1736 grond aan onder de kruisgang van het pand van St. Marie, waarvan een deel bestemd werd als begraafplaats van de maagden die bij de statie hoorden.

Lindeborn, Joannes (1630-1696) ${ }^{23}$

Studeerde godgeleerdheid te Keulen en werd aldaar tot priester gewijd. In I656 benoemd tot kapelaan in de Utrechtse statie St. Nicolaas; in 1671 pastoor aldaar. Sinds 1674 lid van het vicariaat van Utrecht, dat in 1633 in het leven was geroepen om de apostolisch vicaris als adviescollege terzijde te staan. Bekleedde tevens het ambt van provicaris van het vacante bisdom Deventer. De Latijnse editie van zijn kloppenboek deed veel stof opwaaien onder geestelijken; werd in het Nederlands vertaald door de wereldheer Adrianus Terlou. ${ }^{24}$ Publiceerde daarnaast een driedelig werk over het lijden

18 DBS, III (1892) 708-709.

19 De Troeyer, Bio-bibliographia Franciscana Neerlandica ante sceculum XVI, I, 74-75. De oorspronkelijke versie van zijn Vita Alme Virginis Liidwine, die uit 1456 dateert, is verloren gegaan. Hiervan zijn twee afschriften bekend. Het eerste afschrift uit 1457, vervaardigd door Brugmans medebroeder Amold van Oostende, ging eveneens verloren, nadat het in druk was verschenen (de inkunabel Schiedam 1498). Een tweede afschrift dateert uit 1459, van de hand van Nicolaus Symons van Beverwijk; dit wordt bewaard in de Bibliotheek van de Rijksuniversiteit Utrecht (uitgegeven door A. de Meijer O.S.A., Gohannis Brugmanni O.F.M., Vita Alme Virginis Liidwine, Groningen 1963). Jacobi vertalde deze vita als eerste in het Nederlands, zoals hij zelf (p. 5) opmerkt.

20 Zie zijn biogram.

2I Van de Ven, 'De driehoek van St. Marie te Utrecht'; Lagerwey, 'De Oud-Katholieke begraafplaats', $51,53,62$.

22 Van der Loos, 'Jansenistica: 174I', 10r. Op grond van zijn keuze voor de zijde van de oud-bisschoppelijke clerezie werd Kemp in 1712 geëxcommuniceerd door de rooms-katholieke kerk.

23 [Van Heussen], Batavia Sacra, II, 124-125; Brugmans, 'Lindeborn (Jan)'; Haitsma Mulier en Van der Lem, Repertorium, 252 (nr. 305).

24 Studeerde vermoedelijk aan het college Alticollense te Keulen. Was in 1664 socius van Johannes 
van Christus. Deed voorts enkele onderrichtingen het licht zien, die handelen over de sacramenten van huwelijk, biecht, heilig oliesel, priesterschap en doopsel. Geniet bekendheid wegens zijn geschiedkundige beschrijving van het bisdom Deventer en van het religieus en kerkelijk leven vóór de oprichting van dit diocees.

Lumnius, Johannes Fredericus (1533-1602) ${ }^{25}$

Wordt beschouwd als de hervormer van het Antwerpse begijnhof. Verkreeg het pastoraat van dit begijnhof door toedoen van zijn leermeester Nicolaas van Essche (15071578), pastoor van het begijnhof te Diest. IJverde voor een diep doorleefde Christusdevotie onder de begijnen. Auteur van enkele ascetische werken, enkele tractaatjes. De in handschrift nagelaten 'Historia Beghinarum' is verloren gegaan.

Munnos (Muñoz), Ludovicus

Van deze Spaanse auteur, die het leven van de geestelijke maagd Luisa de Carvajal y Mendoza te boek stelde, is niet meer bekend dan dat hij op het titelblad van dit boek 'licentiaat' wordt genoemd. Onbekend in welk vakgebied, maar niet uitgesloten is dat hij theologie had gestudeerd. Of hij priester was, is niet bekend. Mogelijk de enige leek onder de kloppenboek-auteurs.

Roa S.J., Martinus de (156I-1637) ${ }^{26}$

Werd in Cordova geboren; begon zijn noviciaat bij de jezuïeten in 1578. Gedurende zestien jaar doceerde hij humaniora en retorica. Hij leidde de jezuïetencolleges te Xerés, Ecija, Sevilla, Malaga en tenslotte Cordova. Hij heeft 24 werken op zijn naam staan, waaronder enkele (heiligen)levens. Sancia Carillo, wier stichtelijk leven De Roa te boek stelde, was een biechtelinge van Juan de Avila, die in 1530 voor haar zijn Audi Filia schreef, dat tegen zijn zin in 1538 gepubliceerd werd. ${ }^{27}$

Rosweydus S.J., Heribertus (1569-1629) (38 $^{28}$

Verwierf grote bekendheid als hagiograaf en kerkelijke geschiedschrijver. Begon in 1588 het noviciaat bij de jezuïeten. Werd in 1599 tot priester gewijd. Doceerde logica aan het jezüetencollege van Dowaai en was belast met het toezicht op het onderwijs aan het Antwerpse college. Was drie jaar leerstoelhouder in de controversetheologie aan de colleges te Sint-Omaars en Antwerpen. Vooral bekend als grondlegger en wegbereider van het grootscheepse hagiografische 'project' van de Acra Sanctorum dat met succes werd voortgezet door Joannes Bollandus (1596-1665), wiens naam daar onlosmakelijk mee verbonden is gebleven. Polemiseerde tevens tegen de Reformatie, waarvan ook zijn kerkhistorische publikaties getuigen. Publiceerde (compilaties) van (heiligen)levens met een duidelijk stichtend oogmerk, waaronder twee kloppenboeken.

Puckamer. Ten tijde van het vervaardigen van de vertaling van $L$ indeborns $S c a l a$ Jacob was hij vermoedelijk nog werkzaam in Utrecht. Vervulde daarna nog korte tijd het pastoraat in Deventer. Werd rond 1674 overgeplaatst naar IJsselstein, waar hij tot zijn dood in 1696 werkaam was. Met dank aan drs. Gian Ackermans.

25 Philippen, 'Begijnhoven en spiritualiteit', 183-184.

26 DBS, VI (1895) 1887-1895.

27 Juan de Avila kwam hierdoor in aanraking met de Spaanse Inquisitie. Groult, Les mystiques des Pays Bas et la littérature Espagnole, 81. Vgl. Bilinkoff, The Avila of Saint Teresa, 80-87. Juan de Avila geldt als één van de grote lokale hervormers van de Spaanse katholieke kerk in het zestiende eeuw, die sterk door het humanistische gedachtengoed van Erasmus was beïnvloed. Hij was een voorstander van geloofsonderricht en actief apostolaat van leken.

28 Grausern, 'Rosweyde, Héribert'. 
ook zijn kerkhistorische publikaties getuigen. Publiceerde (compilaties) van (heiligen)levens met een duidelijk stichtend oogmerk, waaronder twee kloppenboeken.

Schoenius, Willem $(t \text { 1684 })^{29}$

Studeerde godgeleerdheid. Bediende verschillende staties: Oost- en West-Blokker, Zaandam, Edam en de statie Het Hert te Amsterdam. In 1667 te Zaandam verwikkeld in meningsverschillen met zijn parochianen, in het bijzonder de kerkmeesters. Aanleiding tot deze onenigheid was de kwestie aan wie de aalmoezen ten goede kwamen die kraamvrouwen bij hun kerkgang schonken. Aanvaardde dazzelfde jaar het pastoorsambt te Edam. Kon echter het conflict met de West-Zaandamse kerkmeesters niet vergeten en bekritiseerde hen in zijn kloppenboek, De weg der suyverheyt van d'Hollantse Maegden.

Smidt S.J., Franciscus de (1576-r659) $)^{30}$

Trad in 160I bij de Sociëteit van Jezus in. Doceerde grammatica. Vrijwel zijn gehele leven stond in het teken van prediking. Heeft vele vertalingen van theologische en ascetische werken uit het Latijn op zijn naam staan. Naast enkele levensbeschrijvingen verschenen van zijn hand nog enkele dagheiligingsboeken, alsook handleidingen voor godvruchtige retraites en meditaties.

Steur O.P., Arnoldus ( $\dagger$ 1669) ${ }^{31}$

Trad rond 1600 in de dominicanenorde in. Werd in 1616 naar de Hollandse Zending gestuurd. Bleef er de rest van zijn leven werkzaam. Zijn missioneringswerk begon in Groningen, waar hij door de protestantse overheid gevangen werd genomen. Vertrok na zijn vrijlating naar Friesland. Begaf zich naar Den Haag, waar hij zich gedurende 45 jaar aan het apostolaat wijdde. Van hem zjin geen andere werken bekend dan zijn kloppenboek.

Stevins O.E.S.A, Fulgentius (1654-1710 $)^{32}$

Trad in 1674 te Gent in de augustijnenorde. Werd in 1680 tot priester gewijd. Vertrok in 1692 als missionaris naar de Hollandse Zending. Eerst in Nijmegen werkzaam als socius van Matthias Agolla. Bediende vanaf 1695 de statie De Posthoom, gelegen aan de Prinsengracht te Amsterdam. Kwam wegens zijn anti-jansenistische overtuiging later in conflict met de toenmalige apostolisch vicaris Petrus Codde.

29 [Van Heussen], Batavia Sacra, II, 390, 409, 439; Van der Heyden, 'Schoen (Wilhelmus)'.

$30 D B S$, VII (1896) 1310-1319.

31 Axters, 'Bydragen', 295-296.

32 Teeuwen, ' $P$. Fulgentius Stevins'; idem, 'Stevins, Fulgentıus'. 


\section{Bijlage IV}

\section{Overzicht van de handschriften van Joanna van Randenraedt ${ }^{1}$}

\section{Verantwoording}

Onderstaande handschnften zıjn gedeeltelık beschreven in de volgende unventanssen:

E J. [E Janssen] C.ss.R., Inventans der handschnften van de eerbiedwaardige foanna van Randenraedt, geb. te Brussel 18 october 1610, overl. te Roermond 26 Juli 1684 (Roermond 1937).

B. van de Eerenbeemt C.ss.R., Grel Hutschemaekers, F. Wouterlood C ss R, Inventans Speciaal Archief Onze Lieve Vrouw in ' $t$ Zand, gewızigde en verbeterde versie door Giel Hutschemaekers (typoscnpt; Roermond 1978).

J. Van den Gheyn S.J., Catalogue des manuscrts de la Brbliothèque Royale de Belgrque dl. III (Brussel 1903) 49I-492.

Het volgende overacht volgt de nummenng van de bovengenoernde inventanssen Omissies, onjusste datenngen of foutieve identficate van auteurs zijn verbeterd. Tenzy) anders vermeld, betreft het autografen.

Gemeentearchref Roermond

Handschnftencollectse, Handschriften J B van Randenraedt.

Gewetensrekening, r640. I A I [beschnfft gebeurtenis uit januan 1638]. (6 p.).

Gewetensrekening, 26 julı I649. I A 2 [afschnft door Lucia de Wenmont]. ${ }^{2}(26$ p.)

Gewetensrekening, 6 december I640. I A 3. (9 p)

Gewetensrekening, 28 januan I64I I A 4. (7 p)

Gewetensrekeningen, februan I639- december 1640. I A 5 . (422 p.)

Afschnft door Joanna van Randenraedt van gewetensrekening Juffrouw Buys, Antwerpen, 16 me1 I645 [oorspronkelı)k I626]. I A 6. (16 p.)

Fragment van brief van Joanna van Randenraedt aan een tante (adressaat onbekend), 21 oktober 1647 I A 7.3

I Met uitzondenng van haar geschnften die anno 1937 nog in het particuliere 'Archief Geradts' berustten Deze konden tot dusver niet opgespoord en bestudeerd worden $Z_{1}$ voor een beschriving huervan E J , Inventans, 7-8

2 Pagina's 25 en 26 zijn autografen van Joanna van Randenraedt In E J Inventans is deze gewetensrekenıng abusievelı,k 26 julı I640 gedateerd

3 Afschnft door M J Rats (1933-1934), C ss R Roermond, Speciaal Archief, A pl 7, GG 2 Ibidem, A pl $7, \mathrm{HH}_{3}$, kopie in typoscnpt 
Gewetensrekening, 18 december 1647. I A 8 [afschrift door Lucia de Werimont]. 4 (I8 p.) Gewetensrekenıng, [juli/augustus] 1647. I A 9 [afschrift door Lucia de Werimont]. ${ }^{3}$ (36 p.)

Gewetensrekening, februari 1648. I A ro [afschrift door Lucia de Werimont]. (37 p.)

Gewetensrekening, 15 maart I648. I A II [afschrift door Lucia de Werimont]. ${ }^{6}$ (84 p.)

Brief aan Lucia de Wermont (en in geval van haar absentie aan Catharina van den Broeck) te Roemond, 8 juni 1648 . I A $12 .^{7}$

Brief aan Catharina van den Broeck of Lucia de Werimont te Roermond, 8 juni r649. I A 13."

Brief aan Catharina van den Broeck, 'ten huisse van Juff. Randenraedt de geestelijcke dochter' te Roermond, 22 juni I649. I A I4.9

Brief aan Catharina van den Broeck, 'ten huisse van Juff. Randenraedt de geestelijcke dochter' te Roermond, 25 juni 1649. I A I $5^{10}$

Brief aan Catharina van den Broeck te Nijmegen, Roermond 28 juli 1649. I A $159 .{ }^{\text {" }}$

Bnef aan een geestelijke', adressaat onbekend, Roermond 28 augustus I649. I A I6. ${ }^{13}$

Brief aan Lucia de Werimont, ten huize van de heer Loufs te Grave, Roermond I4 december I649. I A $17 . .^{14}$

Brief aan Cathanna van den Broeck, ten huize van mevrouw Machgee [Michgea/ Michgee?] te Brussel, 4 mei 1650. I A 18 . $^{15}$

Brief aan Catharina van den Broeck te Brussel, Roermond 29 oktober I650. I A I9. ${ }^{16}$

Brief aan Cathanna van den Broeck te Brussel, Roermond 16 november I650. I A 20. ${ }^{17}$ Bnef aan Catharina van den Broeck te Roermond, 26 augustus I652. I A $21 .^{18}$

4 Origineel in KB Brussel, Handschnften, 19504, 27-36.

5 Ongineel in KB Brussel, Handschnfien 19504, 1-18vo.

6 Fragment van ongineel in KB Brussel, Handschnfien 19504, 37-44vo.

7 Afschrift door M.J. Rats (1933-1934), C.ss.R. Roemnond, Speciaal Archief A pl. 7, GG 2. Ibidem, A pl. 7, $\mathrm{HH} 4$, afschnft door $\mathrm{M}$ Frenken (1938).

8 Afschnft door M J. Rats (1933-1934), C.ss R. Roermond, Speczaal Archief A pl. 7, GG 2. Ibidem, A pl. $7, \mathrm{HH}_{4}$, afschnft door M. Frenken (1938).

9 Afschnft door M.J. Rats (1933-1934), C ss.R. Roermond, Spectaal Archref A pl. 7, GG 2. Ibıdem, A pl. $7, \mathrm{HH}_{3}$, kopie in typoscnpt.

10 Afschnft door M.J. Rats (1933-1934), C.ss.R. Roermond, Spectaal Archtef A pl. 7, GG 2. Ibıdem, A pl. $7, \mathrm{HH}_{3}$, kopie in typoscnpt.

II Afschnft door M.J. Rats (1933-1934), C ss.R. Roermond, Speciaal Archief A pl. 7, GG 2. Ibidem, A pl. $7, \mathrm{HH}_{4}$, afschnft door M. Frenken (1938).

12 Mogel11k Luvnus de Clerck S.J. (1597-1652).

13 Afschnft door M.J. Rats (1933-1934), C ss.R. Roermond, Speciaal Archief A pl. 7, GG 2. Ibidem, A pl 7, HH 4, afschnft door M. Frenken (1938); Ibidem, A pl. 7, HH 3, kopie in typoscript

14 Afschnft door M.J. Rats (1933-1934), C.ss.R Roermond, Spectaal Archref A pl. 7, GG 2. Ibidem, A pl. $7, \mathrm{HH}_{4}$, afschrift door $\mathrm{M}$. Frenken (1938); ibıdem, A pl. 7, $\mathrm{HH}_{3}$, kopie in typoscnpt

15 Afschnft door M.J. Rats (1933-1934), C ss.R. Roermond, Speciaal Archief A pl. 7, GG 2. Ibidem, A pl. $7, \mathrm{HH}_{3}$, kopie in typoscript.

I6 Afschnft door M J. Rats (1933-1934), C ss.R. Roermond, Spectaal Archtef A pl. 7, GG 2. Ibıdem, A pl. $7, \mathrm{HH}_{3}$, kopie in typoscript.

17 Afschnft door M J Rats (1933-1934), C.ss.R. Roermond, Speczaal Archief A pl. 7, GG 2.

18 Afschnft door M J. Rats (1933-1934), C.ss R Roermond, Speczaal Archref A pl 7, GG 2. Ibidem, A pl. $7, \mathrm{HH}$ 3, kopie in typoscript. 
Brief aan Catharina van den Broeck, 'ten huisse van mijn heer den scholtus Randenraedt', 5 september 1652. I A 22."9

Brief. Adressaat onbekend, 2 I juni 1656. I A 23.

Brief aan Catharina van den Broeck te Roermond, 7 augustus 1656 . I A 24. ${ }^{20}$

Brief aan Catharina van den Broeck 'bij mijn heer Randenraedt' te Roermond, 14 september 1656. I A 24.

Brief aan Catharina van den Broeck 'bij mijn heer Randenraedt' te Roermond, I9 september I656. I A 25. ${ }^{21}$

Brief. Adressaat onbekend, 24 september r656. I A 26.

Brief. Adressaat onbekend, 13 november 1659 . I A $27 .{ }^{22}$

Gewetensrekening, ongedateerd [18 augustus I668]. Twee niet geheel identieke versies. I A 29. (resp. I I en 13 p.)

Brief aan Lucia de Werimont, vermoedelijk I666. I A 30. ${ }^{\text {33 }}$

Brief aan Catharina van den Broeck te Roermond, 28 mei z.j. II B a. ${ }^{24}$

Brief aan Catharina van den Broeck te Roermond, 30 november z.j. II B b. ${ }^{25}$

Brief aan Catharina van den Broeck, 'ten huisse van mijn heer den scholtus Randenraedt', z.d., z.j. [1652]. ${ }^{26}$ II B c. ${ }^{27}$

Rekest aan de Staten van Gelre van Joanna van Randenraedt en Lucia de Werimont ten behoeve van Anna Margaretha Schabrieres, voor wier intrede in de Karmel in Aalst geldelijke ondersteuning wordt verzocht. II $B \mathrm{c}^{2}$ [KJad]. ${ }^{28}$

Brief aan Catharina van den Broeck ten huize van mevrouw Michgee [Machgee/Michgea?] te Brussel, 27 december z.j. II B d.

Brief aan Catharina van den Broeck te Roermond, Brussel, z.d., z.j. II B e. Brief aan Catharina van den Broeck te Roermond. z.d., z.j. II B f. ${ }^{29}$

Brief aan Catharina van den Broeck ten huize van mevrouw Michgea [Machgee/Michgee?]

19 Afschrift door M.J. Rats (1933-1934), C.ss.R. Roermond, Speciaal Archief A pl. 7, GG 2. Ibidem, A pl. 7, $\mathrm{HH} 4$, afschrift door M. Frenken (1938); ibidem, A pl. 7, $\mathrm{HH} 3$, kopie in typoscript.

20 Afschrift door M.J. Rats (1933-1934), C.ss.R Roermond, Speciaal Archief A pl. 7, GG 2. Ibidem, A pl. 7, HH 4, afschrift door M. Frenken (1938); ibidem, A pl. 7, $\mathrm{HH}_{3}$, kopie in typoscript.

21 Afschrift door M.J. Rats (1933-1934), C.ss.R. Roermond, Speciaal Archief A pl. 7, GG 2. Tbidem, A pl. $7, \mathrm{HH}_{4}$, afschrift door M. Frenken (1938).

22 Afschrift door M.J. Rats (1933-1934), C.ss.R. Roermond, Speciaal Archief A pl. 7, GG 2. Ibidem, A pl. $7, \mathrm{HH}_{3}$, kopie in typoscript.

23 Afschrift door M.J. Rats (1933-1934), C.ss.R. Roermond, Speciaal Archief A pl. 7, GG 2.

24 Afschrift door M.J. Rats (1933-1934), C.ss.R. Roermond, Speciaal Archief A pl. 7, GG 2. Ibidem, A pl. $7, \mathrm{HH}_{4}$, afschrift door M. Frenken (1938).

25 Afschrift door M.J. Rats (1933-1934), C.ss.R. Roermond, Speciaal Archief A pl. 7, GG 2. Ibidem, A pl. $7, \mathrm{HH}_{4}$, afschrift door M. Frenken (1938).

26 In de brief wordt het overlijden van pater Melchior Hulshoudt S.J. vermeld. Volgens de necroloog van zijn orde stierf hij op 24 juli 1652.

27 Afschrift door M.J. Rats (1933-1934), C.ss.R. Roermond, Speciaal Archief A pl. 7, GG 2. Ibidem, A pl. $7, \mathrm{HH}_{4}$, afschrift door M. Frenken (1938).

28 Niet in E.J., Inventaris.

29 Afschrift door M.J. Rats (1933-1934), C.ss.R. Roermond, Speciaal Archief A pl. 7, GG 2. Ibidem, A pl. $7, \mathrm{HH}_{3}$, kopie in typoseript. 
te Brussel, z.d., z.j. II B g. ${ }^{30}$

Brief aan Catharina van den Broeck, 'ten huisse van mijn heer den scholtus Randenraedt', Westerloo, z.d., z.j. II B h. ${ }^{31}$

Brief aan de eerbiedwaardige mater Anna de St. Xaverius, ursuline, z.d., z.j. II B i.. ${ }^{32}$

Eigenhandige levensbeschrijving van Joanna van Randenraedt, tot en met 1636 . Rond 1640 geschreven. II B j. (I50 p.)

Dagorde. Ongedateerd. II B k. ${ }^{33}$

Brief. Adressaat onbekend. Ondertekend J B R [Joanna Baptista van Randenraedt]. II B 1 [afschrift Lucia de Werimont]. ${ }^{34}$

Gewetensrekening, ongedateerd [na I643], en geestelijke onderrichting aan een onbekende adressaat, ongedateerd, ongepagineerd. II $\mathrm{B}$ n. ${ }^{35}$

Geestelijke liedjes, ongedateerd. IV I. (3 p.)

Vragenlijst bij visitatie van religieuzen. Waarschijnlijk afschrift door Joanna van Randenraedt, ongedateerd. IV 2.

'Noepende de daegelijcxe communie wt gegeven te Roemen, den 12 Februarij int iaer 1679', afschrift door Joanna van Randenraedt, ongedateerd. IV 5.

'Eloge de la Somption de la Ste Vierge', ongedateerd. IV 6.

\section{Redemptoristenklooster, Roermond}

Speciaal Archief Onze Lieve Vrouw in 't Zand

Brief aan Mère Anna Victoer, Ursuline, Roermond, 2 I maart i684. A pl. 7, HH 7.

Brief. Adressaat onbekend. I4 december I647. A pl. 7, GG Io.

Beschrijving van de meditatie ter voorbereiding op Kerstmis. Ongedateerd. A pl. 7, GG $14 .^{36}$ (15 p.)

Twee brieven aan Catharina van Gestel, 26 en 27 mei 1684. A pl. 7, HH 6 [geen autograaf]. ${ }^{37}$

Gewetensrekening, I-IO augustus 1683 , gericht aan haar biechtvader. A pl. 7, HH 8. ${ }^{38}$ (I6 p.)

Rijksarchief Limburg, Maastricht

Archief van de Bisschoppen van Roermond

Gewetensrekening, 1634. Inv.nr. 135. (21 p.)

30 Afschrift door M.J. Rats (1933-1934), C.ss.R. Roermond, Speciaal Archief A pl. 7, GG 2. Ibidem, A pl. 7, $\mathrm{HH}_{3}$, kopie in typoscript.

31 C.ss.R. Roermond, Speciaal Archief A pl. 7, HH, kopie in typoscript.

32 Afschrift door M.J. Rats (1933-1934), C.ss.R. Roermond, Speciaal Archief GG 2. Ibidem, A pl.

7, $\mathrm{HH}_{3}$, kopie in typoscript.

33 Niet in E.J., Inventaris. Vgl. GAR, Handschriften IV 3: 'Godtvruchtighe tijtverdeijlinge', die door Janssen mijns inziens ten onrechte als autograaf van Van Randenraedt is geidentificeerd.

34 Niet in E.J., Inventaris. Afschrift door M.J. Rats (1933-1934), C.ss. R. Roermond, Speciaal Archief A pl. 7, GG 2. Ibidem, A pl. 7, $\mathrm{HH}_{4}$, afschrift door M. Frenken (1938).

35 Niet in E.J., Inventaris.

36 C.ss.R. Roermond, Speciaal Archief, A pl. 7, GG 13, afschrift (2oe eeuw).

37 De originelen van deze beide brieven zijn niet bekend.

38 C.ss. R. Roermond, Speciaal Archief, A pl. 7, HH 9, afschrift (20e eeuw). 
Overzicht van devoties, ongedateerd. Inv.nr. I35 (13 p.)

Aansporing aan andere gelovigen ter gelegenheid van de geboorte van Jezus Christus ('tot troest ende hulp van alle godtvruchtiege siellen, devoedt tot Jesus, int cribbeken'), ongedateerd. Inv.nr. 135. (5 p.)

Koninklijke Bibliotheek Albert I, Brussel

Afdeling Handschriften

Eigenhandige beschrijving van haar leven en geloofsbeleving. Ongedateerd, geschreven vanaf 1667. Inv.nr. 19073. (I band; 2 dln.; 1434 p.)

Gedeelte van eigenhandige levensbeschrijving, ongedateerd. Inv.nr. 20422, Gewetensrekeningen Agnes van Heilsbach 1637-1639, folio 164-187. (46 p.)

Gewetensrekeningen, januari I643-oktober I643; maart I645-december I645; juni 1646 - augustus I646; eind I646 of begin 1647. Inv.nr. 19070. (746 p.)

Gewetensrekeningen, I647. Inv.nr. $19504 .^{39}$ (100 p.) 


\section{Bijlage V}

\section{Overzicht van de handschriften van Agnes van Heilsbach}

\section{Verantwoording}

Onderstaande handschriften zijn gedeeltelijk beschreven in de volgende inventarissen:

E.J. [E. Janssen] C.ss.R., Inventaris der handschriften van de eerbiedwaardige foanna van Randenraedt, geb. te Brussel 18 october I6Io, overl. te Roermond 26 juli 1684 (Roermond 1937).

B. van de Eerenbeemt C.ss.R., Giel Hutschemaekers en F. Wouterlood C.ss.R., Inventaris Speciaal Archief Onze Lieve Vrouw in 't Zand, gewijzigde en verbeterde versie door Giel Hutschemaekers (typoscript; Roermond 1978).

J. Van den Gheyn S.J., Catalogue des manuscrits de la Bibliothèque Royale de Belgique, dl. III (Brussel 1903) 491.

Het volgende overzicht volgt de nummering van de bovengenoemde inventarissen. Omissies, onjuiste dateringen of foutieve identificatie van auteurs zijn verbeterd. Tenzij anders vermeld, betreft het autografen.

\section{Gemeentearchief Roermond}

Handschriftencollectie, Handschriften J.B. van Randenraedt

Drie fragmenten van gewetensrekeningen van Agnes van Heilsbach. Ongedateerd ( 5 oktober [1638], 13 oktober [1638]). II B m [afschrift Lucia de Werimont, naar afschrift van Joanna van Randenraedt, KB Brussel, Handschriften 18984, 31 I; 319-320]. ' (8 p.)

\section{Redemptoristenklooster, Roermond}

Speciaal Archief Onze Lieve Vrouw in 't Zand

Twee fragmenten van de levensbeschrijving door Agnes van Heilsbach. Ongedateerd. A pl. 7, GG I I [afschrift Joanna van Randenraedt]. (42 p.)

Koninklijke Bibliotheek Albert I, Brussel

Afdeling Handschriften

Gewetensrekeningen, I637-I639. Inv.nr. 20422, folio I-I63. (326 p.)

Gewetensrekeningen, 1637-I639. Inv.nr. 18984 [gedeeltelijk een afschrift van inv.nr. 20422, door Joanna van Randenraedt]. (798 p.)

I Niet in E.J., Inventaris. De corsprong van het derde fragment is nog nict achterhaald. 


\section{Bronnen en literatuur}

\section{Archieven}

Algemeen Rijksarchief te Brussel (ARAB)

- Archief der Jezuieten (Vlaamse Provincie)

Rijksarchief in Gelderland (RAG)

- Archief van het Bestuur van de Synode van Gelderland

- Archief Nederlands Hervormde Classis Tiel

- Archief van het bestuur van de Classis Nijmegen

- Archief Hof van Gelre en Zutphen

Rijksarchief in Limburg (RAL)

- Archief Bisschoppen van Roermond

- Archief Gelderse Rekenkamer Roermond

- Archief Hof van Gelder

- Archief Jezuïeten-college Roermond

- Archieven der Jezuïeten te Maastricht en Roermond. Archief College Roermond (ongeïnventariseerd, twee dozen; in januari 1994 overgedragen door het Rijksarchief te Brussel aan het RAL)

Rijksarchief in Noord-Brabant (RANB)

- Archief van de Raad van Brabant

Rijksarchief in Utrecht (RAU)

- Archief Oud-Bisschoppelijke Clerezie $(A O B C)$

Gemeentearchief Amsterdam (GAA)

- Archief van de statie en de hulpkerk 't Boompje of H. Franciscus van Assisie te Amsterdam in de Kalverstraat

- Notarieel Archief

Gemeentearchief Groningen (GAG)

- Archief Sint-Martinusparochie

Gemeentearchief Nijmegen (GAN)

- Archieven van de Nederlands Hervormde Gemeente te Nijmegen (ANHGN)

- Oud Archief Nijmegen (OAN)

- Oud-Rechterlijk Archief Nijmegen (ORAN) 
Gemeentearchief Roermond (GAR)

- Handschriftencollectie, Handschriften J.B. van Randenraedt (Handschriften)

- Archief Hoofdgerecht Roermond

- Archief Kerkfabriek St. Christoffel

Gemeentearchief Utrecht (GAU)

- Archief Oud Rooms-Katholieke Aalmoezenierskamer (ORKA)

- Archief St. Willibrordusparochie (voormalige dominicanen-statie Dorstige Hartsteeg aan de Nieuwstraat te Utrecht)

Gemeentearchief Waalwijk

- Doop-, trouw- en begraafregisters

Katholiek Documentatie Centrum te Nijmegen (KDC)

- Archief De Sleutelbos

Bisschoppelijk Archief Roermond

- Archief van het bisdom Roermond I840-1940

Provinciaal Archief van de Orde der Augustijnen te Eindhoven (PA OSA)

- Verspreide archivalia van Noordnederlandse staties

- Fonds De Star 2,1: Annales Ordinis FF. Eremitarum S.P. Augustini Amstelodami, deel II (De Star)

Provinciaal Archief van de Orde der Jezuïeten te Nijmegen (PA SJ)

- Historische handschriftenverzameling

Provinciaal Archief van de Orde der Dominicanen te Nijmegen (PA OP)

- Verspreide archivalia van Noordnederlandse staties

- Namen van de broeders en susters van het Aartsbroederschap van den heyligen Roose-krans van de alderheyligste Maget ende Moeder Godts Maria, tot Amsterdam van het jaar 1638 Erc.

Provinciaal Archief van de Orde der Minderbroeders te Utrecht (PA OFM)

- Verspreide archivalia van Noordnederlandse staties

- Parochie dossier Ammerzoden

- Historisch Archief Leiden

- Archieven van de Latijnse school te Megen

Nederlands Carmelitaans Instituut te Boxmeer (NCI)

- Archief van de Carmelieten-pastoor, de sacrista en de kerkmeesters van de parochie van Sint Petrus te Boxmeer

Redemptoristenklooster Roermond (C.ss.R. Roermond)

- Speciagl Archief Onze Lieve Vrouw in 't Zand (Speciaal Archief)

Koninklijke Bibliotheek Albert I te Brussel (KBB)

- Handschriftencollectie (Handschriften) 


\section{Gedrukte bronnen en literatuur}

Gebruikte afkortingen

\begin{tabular}{|c|c|}
\hline$A A U$ & Archief voor de geschiedenis van het Aartsbisdom Utrecht \\
\hline$A G K K N$ & Archief voor de Geschiedenis van de Katholieke Kerk in Nederland \\
\hline$A G N$ & Algemene Geschiedenis der Nederlanden (15 dln.; Haarlem 1979) \\
\hline$B B H$ & Bijdragen voor de geschiedenis van het Bisdom Haarlem \\
\hline$B B$ & Bossche Bijdragen. Bouwstoffen voor de geschiedenis van het bisdom 's-Hertogenbosch \\
\hline$B C N I$ & Bibliotheca catholica Neerlandica impressa ('s-Gravenhage I954) \\
\hline$B M G N$ & Bijdragen en Mededelingen betreffende de Geschiedenis der Nederlanden \\
\hline$D B S$ & $\begin{array}{l}\text { Augustin de Backer en Aloys de Backer, Bibliothèque de la Compagnie de Fésus. } \\
\text { Nouvelle édition par Carlos Sommervogel (I I dln.; Parijs I890-1932) }\end{array}$ \\
\hline$D D C$ & Dictionnaire de Droit Canonique \\
\hline$D H G E$ & Dictionnaire d'Histoire et de Géographie Ecclésiastique \\
\hline DThC & Dictionnaire de Théologie Catholique \\
\hline$D S$ & Dictionnaire de Spiritualité ascétique et mystique \\
\hline$L W$ & Liturgisch Woordenboek (2 dln.; Roermond/Maaseik 1958-1962) \\
\hline$N N B W$ & Nieuzw Nederlandsch Biografisch Woordenboek (10 dln.; Leiden 1911-1937) \\
\hline$O G E$ & Ons Geestelijk Erf \\
\hline PSHAL & Publications de la Société historique et archéologique dans le Limbourg \\
\hline$R G P$ & Rijks Geschiedkundige Publicatiën ('s-Gravenhage 1905-) \\
\hline$T h W$ & Theologisch Woordenboek (3 dln.; Roermond/Maaseik 1952-1958) \\
\hline Trajecta & Trajecta. Tijdschrift voor de geschiedenis van het katholiek leven in de Nederlanden \\
\hline TSG & Tijdschrift voor Sociale Geschiedenis \\
\hline$T v G$ & Tijdschrift voor Geschiedenis \\
\hline$T v V$ & Tïdschrift voor Vrouwenstudies \\
\hline WNT & Woordenboek der Nederlandsche Taal \\
\hline
\end{tabular}

Gedrukte werken voór 1800

(met uitzondering van de kloppenboeken; zie daarvoor bijlage II)

Binnart, M., Biglotton amplificatum sive dictionarium Teuto-Latinum novum [1659] (Amsterdam: Henricus \& weduwe Theodorus Boon $\mathbf{1 6 8 8}^{2}$ ).

Cats, J., Alle de wercken, So ouden als nieuwe, van den Heer Iacob Cats, Ridder, oudt Raedtpensionaris van Hollandt, Erc. (Amsterdam: Ian Iacobsz Schipper I655).

Geertruid van Helfta, [vert. door C.D.W. (C. de Witte)], Het leven vande H. Maghet Geertruyt Abdisse tot Eisleben, als eenen invloedt der godsdienstigheyt, ende godtvruchtigheyt (Antwerpen: Hieronymus Verdussen [1607]).

Groot Gelders placaet-boeck Inhoudende de Placaeten ende Ordonnantien, soo by wylen Keyser Kaerle en Coninck Philips als Hertogen van Gelre ende Graven van Zutphen, als by de Edele Mogende Heeren Staeten des Furstendoms Gelre ende Graeffschaps Zutphen, sedert den Jaere 1543 tot den Jaere 1700, uitgegeven door W. van Loon (2 dln.; Nijmegen: Suerus van Goor 1701).

Groot placaet-boeck inhoudende de placaten ende ordonnantien vande Hoogh-Mog. Heeren van 
de Staten-Generael der Verenighde Nederlanden, ende vande Ed. Groot Mog. Heeren Staten van Hollandt ende West-Vrieslandt, missgaders vande Ed. Mog. Heeren Staten van Zeelandt, uitgegeven door C. Cau (10 dln.; 's-Gravenhage/Amsterdam 1658-1797).

[H.F. van Heussen], Batavia Sacra, sive Res Gestae Apostolicorum, qui fidem Bataviae primi intulerunt, in duas partes divisa (Brussel: Foppens 1714).

[Heussen, H.F. van], [vert. door H. van Rijn], Batavia Sacra, of Kerkelyke Historie en oudheden van Batavia, Behelzende de Levens van onze eerste Geloofsverkondigers; mitsgaders van de Utregusche Bisschoppen, En van de voomaamste Personen die hier te lande in geleerdheid of heiligheit uytgemunt hebben (Antwerpen: voor Christianus Vermey 1715-1716).

L'Idée d'une vierge chrestienne consacrée aux oeuvres de charité, dans la vie de Mademoiselle Marie Anne du Val de Dampierre (Luik/Brussel: Lambert Marchant 1684).

Kiliaen, C., Etymologicum Teutonicae linguae sive dictionarium Teutonico-Latinum, praecipuas Teutonica linguae dictiones et phrases Latine redditas, $\mathcal{G}$ cum alijs nonnullis linguis obiter collatas, complectens: (...) (Utrecht: Herman Borculo 1623).

Onpartydige Schets, wegens de inkomsten by manier van gifien, enz. van de roomsche priesters, in de Nederlanden: benevens een plan om dezelve een aanzienlyk bestaan, de kerken een deftig onderhoud en de roomsche arme ledematen meerder nooddruft te verschaffen, door een oprecht vaderlander, onder de zinspreuk: pro patria (Amsterdam etc. 1790).

Puente, L. de la, [vert. door L. Jacobi S.J.], Het leven van P. Balthazar Alvarez Religieus der Societeyt Iesu (Antwerpen: Guilliam Lesteens 1639).

Rovenius, Ph., Reipublicae christianae libri duo, Tractantes de variis Hominum statibus, Gradibus, Officizs $\mathcal{E}$ functionibus in Ecclesia Christi $\mathcal{E}$ quae in singulis amplectanda, quae fugienda sint (Antwerpen: Amold van Brakel I648).

Rovenius, Ph., Het gulden wieroock-vat, eenen ieghelycken nut ende oorbaer om sym gebeden Godt op te dragen. Van niews vermeerdert ende verbetert bij den Autheur (Antwerpen: Jan Cnobbaert 1636).

Sucquet S.J., Antonius, Den wech des eeuwich levens beschreven int Latijn door (...), over-geset door P. Gerardus Zoes (...). Door den Aucteur van niews oversien en vermeerdert. Met beelden verlicht door Boëtius $A$. Bolswert (Antwerpen: Hendrick Aertssens 1623).

Wiltens, N., Kerkelyk Plakaat-Boek, Behelzende de plakaaten, ordonnantien ende resolutien, over de kerkelyke zaken (s dln.; 's-Gravenhage: Paulus en Isaac Scheltus 1722-1807).

\section{Overige literatuur en uitgegeven bronnen}

Acta der particuliere Synoden van Zuid-Holland, 162I-I700, uitgegeven door W.P.C. Knuttel ('s-Gravenhage 1908) I (RGP kleine reeks 3).

Adnès, P., 'Marriage et vie chrétienne', in: $D S X$ (I980) 384-408.

Adnès, P., 'Visions', in: DS XVI (1994) 949-1002.

Adrichem O.F.M., D. van, 'Een lijst van oude handboekjes', Maandblad voor directeuren der Derde orde van den H. Franciscus van Assisië 6 (I917) I4I-I44.

Aerts, M., 'Op zoek naar konstrukties van vrouwelijkheid. Naar aanleiding van drie katholieke vrouwenorganisaties in het interbellum', in: J. Blok, e.a. (ed.), Tweede jaarboek voor vrouwengeschiedenis (Nijmegen 198r) 132-145.

Aerts, M., 'Over de historische noodzaak om op de tenen te lopen. Vrouwenstudies als nationaal ballet', TvV 13,I (1992) 30-42. 
Ahlgren, G.T.W., 'Visions and rhetorical strategy in the letters of Hildegard of Bingen', in: K. Cherewatuk en U. Wiethaus (ed.), Dear sister. Medieval women and the epistolary genre (Philadelphia 1993) 46-63.

Allard S.J., H.J, 'Het jezuïeten-college te Roermond 1611-I773', in: Limburgs faarboek I (1894) I33-I 47.

Allard S.J., H.J., 'De Brabantsche Cats', in: Pater Poirters 1605-1674. Gehuldigd te Oisterwijk 1926 (Nijmegen 1926) 5-14.

Alvarez, T., 'Thérèse de Jésus (sainte)', in: $D S$ XV (I99r) 6II-658.

Ancilli, E., 'Marie-Madeleine de Pazzi (saint)', in: DS X (1980) 576-588.

Andreae Tiarae Annotationes. Aanteekeningen betreffende de Roomsch-Katholieke Kerk in Friesland, sedert de Hervorming tot het jaar 1696, uitgegeven door G.H. van Borssum Waalkes (Leeuwarden z.j.).

An., 'Katholieke armenverzorging te Rotterdam', De Oud-Katholiek 23 (1907).

An., 'Volquerus Herkinge', $A A U$ 9 (188I) 268-283.

André S.J., E. 'Oprichting, goedkeuring en algemene organisatie', in: Put en Wynants (ed.), De jezuieten in de Nederlanden, 7-19.

Appleby, J., L. Hunt en M. Jacob, Telling the truth about history (Norton 1994).

Arenal, E. en S. Schlau (ed.), Untold sisters. Hispanic nuns in their own works (Albuquerque 1989).

Aubert, R, 'Gabriel de Saint-Jean-Baptiste', in: $D H G E$ I9 (198I) 564.

Aubert, R., 'Hazart, Corneille', in: DHGE 23 (1990) 679-680.

Auxentius, 'Derde Orde', in: ThW I, 990-993.

Axters O.P., S., 'Bijdragen tot een bibliographie van de Nederlandsche dominikaansche vroomheid', $O G E_{7}$ (1933) 24I-304; 8 (1934) 39-104.

Axters O.P., S. Geschiedenis van de vroomheid in de Nederlanden (4 dln.; Antwerpen r9501960).

B., de [M.G. de Boer], 'Een bijdrage tot het leven der katholieken', TvG 51 (1936) 212-2 13.

Baar, M. de, 'Van kerk naar sekte: Sara Nevius, Grietje van Dijk en Anna Maria van Schurman', De Zeventiende Eeuw 7,2 (1991) 159-170.

Baar, M. de, "'Ik moet spreken." Het spiritueel leiderschap van Antoinette Bourignon', in: Derks en Van Heijst (ed.), Terra incognita, 87-108.

Baar, M. de, 'Transgressing gender codes. Anna Maria van Schurman and Antoinette Bourignon as contrasting examples', in: Kloek, Teeuwen en Huisman (ed.), Women of the Golden Age, 143-I 52.

Baetens, R., 'De bibliotheek van een geestelijke dochter uit de XVIle eeuw te Antwerpen', OGE 44 (1970) 213-226.

Baggerman, A., Een drukkend gevvicht. Leven en werk van de zeventiende-eeuwse veelschrijver Simon de Vries (Amsterdam/Atlanta 1993).

Barbier, A.-A., Dictionnaire des ouvrages anonymes (4 dln.; Hildesheim 1963; troisième édition, revue et augmentée par Mm. Olivier Barbier, René et Paul Billard).

Bartelink, G.J.M., De bloeiende woestijn. De wereld van het vroege monachisme (Baarn 1993).

Barten S.J., J., 'Catechismusonderricht en eerste communie bij de jezuïeten te Leiden gedurende de zeventiende en achttiende eeuw', $A G K K N$ I (1959) 240-256.

Bavel, J. van en M. Schrama (ed.), Jansénius et le Jansénisme dans les Pays-Bas (Leuven I982). 
Bax, M., 'Religieuze regimes en staatsvorming. Notities voor een figuratie-benadering', Sociologisch Tijdschrift 12,1 (1985) 22-48.

Bax, M.,'Terug naar donkere tijden? Over het falen van een voorgeschreven kerkelijke orde in hedendaags ruraal Brabant', in: Rooijakkers en Van der Zee (ed.), Religieuze volkscultuur, 119-135.

Becher, U.A.J., 'Religiöse Erfahrung und weibliches Lesen - zu einigen Beispielen des 18. Jahrhunderts', in: Bödeker, Chaix en Veit (ed.), Le livre religieux, 316-334.

Beel, J.A. en H.J. Hooykaas, Naamlijst der pastoors van de oud-katholieke kerk in Nederland, bewerkt door H.J.W. Verhey (Amersfoort 1979)(Publicatieserie Stichting Oud-Katholiek Seminarie 7).

Begheyn S.J., P.J., 'De verspreiding van de Evangelische Peerle', OGE 5 I (I977) 39r-42r.

Begheyn S.J., P.J., 'Die Evangelische Peerle. Nieuwe gegevens over auteur en invloed', OGE 63 (1989) I70-189.

Bell, R., Holy anorexia (Chicago/Londen 1985).

Berquin, K., 'Grimmincks "Regels voor eene geestelyke dogter"', OGE 5 I (1978) I 29-151.

Beurden, A.F. van, 'Roermond en Gelre van 1543 tot aan den Franschen tijd', in: Gedenkboek Roermond 37-6r.

Bilinkoff, J., The Avila of Saint Teresa. Religious reform in a sixteenth-century city (Ithaca/ Londen 1992).

Bilinkoff, J., 'Confessors, penitents, and the construction of identities in early modern Avila', in: B.B. Diefendorf en C. Hesse (ed.), Culture and identity in early modern Europe (1500-1800). Essays in honor of Natalie Zemon Davis (Ann Arbor 1993) 83-100.

Blankers, H., 'De betekenis van genot in de mystiek van Teresa van Avila', in: M. ter Steeg e.a., De verlokking van de liefde. Eenzaamheid en erotiek bij mystieke vrouwen (Aalsmeer 1994) 28-42.

Blécourt, A.S. de, Kort begrip van het oud-vaderlands burgerlijk recht (Groningen $1969^{7}$ ).

Bock, G., 'Women's history and gender history: aspects of an international debate', Gender and History I,I (1989) 7-30.

Bock, G., 'Women, gender and dichotomies in history', in: M. de Baar e.a. (ed.), In de ban van het verhaal. faarboek voor vrouwengeschiedenis II (Nijmegen 1990) 79-97.

Bödeker, H.E., G. Chaix en P. Veit (ed.), Le livre religieux et ses pratiques/Der Umgang mit dem religiösen Buch (Göttingen I991).

Boekholt, P.Th.F.M., Het lager onderwijs in Gelderland 1795-1858 (Zutphen 1978).

Boekhorst, P. te, P. Burke en W. Frijhoff (ed.), Cultuur en maatschappij 1500-1850: Een historisch-antropologisch perspectief (Meppel/Amsterdam/Heerlen 1992).

Boer, W. Th. de, Sinews of discipline. The uses of confession in counter-reformation Milan (Rotterdam 1995; proefschrift Erasmus Universiteit Rotterdam).

Bolton, B., 'Vitae matrum: a further aspect of the "Frauenfrage"', in: D. Baker (ed.), Medieval women (Oxford 1978) 253-273.

Bonsirven, J., 'Chair', in: DS III (I953) 439-449.

Booy, E.P. de, Weldaet der scholen. Het plattelandsonderwijs in de provincie Utrecht van 1580 tot het begin der rode eeuw (Zutphen 1977).

Booy, E.P. de, 'Volksonderwijs in de Noordelijke Nederlanden', in: $A G N$ 7, 264-267.

Booy, E.P. de, Kweekhoven der wijsheid. Basis- en vervolgonderwijs in de steden van de provincie Utrecht van 1580 tot het begin der rge eeuw (Zutphen 1980). 
Bosch, M., 'Vrouwencultuur', in: H. d'Ancona e.a. (ed.), Vrouwenlexicon: tweehonderd jaar jaar emancipatie van $A$ tot $Z$ (Utrecht 1989) 408-410.

Bossy, J., Christianity in the West 1400-1700 (Oxford/New York 1985).

Bots, H., I. Matthey en M. Meyer, Noordbrabantse studenten 1550-1750 (Tilburg 1979).

Bouman, C.A., 'Biecht', in: $L W I$, 263-267.

Braun, D. en E. Gössmann (ed.), Eva - Verführerin oder Gottes Meisterwerk (Stuttgart 1987).

Bremond, C., J. le Goff en J.C. Schmitt, L'exemplum (Turnhout 1982).

Brom, Gisb., 'Neerkassels bestuur van 1662 tot 1676 ', $A A U$ I8 (1890) I73-294.

Brouns, M., M. Verloo en M. Grünell (ed.), Vrouwenstudies in de jaren negentig. Een kennismaking vanuit verschillende disciplines (Bussum 1995).

Brouns, M., 'Kernconcepten en debatten', in: idem, Verloo en Grünell (ed.), Vrouwenstudies in de jaren negentig, 29-5I.

Brown, J.C., Onkuise handelingen. Het leven van een lesbische non in Italië tijdens de Renaissance (Amsterdam 1987).

Brown, P., Body and society. Men, women and sexual renunciation in early christianity (New York 1988).

Brugmans, H., 'Lindebom (Jan)', in: NNBWVIII, 1056-1057.

Bruinvis, C.W., 'De statie van St. Franciscus te Alkmaar', BBH 22 (1897) I88-199.

Bugge, J., Virginitas: an essay in the history of a medieval idea (Den Haag 1975).

Buikema, R., M. Meijer en A. Smelik, 'Postmoderne cultuur en representatie', in: Brouns, Verloo en Grünell (ed.), Vrouwenstudies in de jaren negentig, 79-106.

Bynum, C. Walker, fesus as mother. Studies in the spirituality of the high middle ages (Berkeley/Los Angeles 1982).

Bynum, C. Walker, 'The complexity of symbols', in: idem, S. Harrell en P. Richman (ed.) Gender and religion: on the complexity of symbols (Boston 1986) I-20.

Bynum, C. Walker, Holy feast and holy fast. The religious significance of food to medieval women (Berkeley/Los Angeles/Londen) 1987.

Bynum, C. Walker, Fragmentation and redemption. Essays on gender and the human body in medieval religion (New York 1992 ).

Bynum, C. Walker, 'The mysticism and ascetism of medieval women: some comments on the typologies of Max Weber and Emst Troeltsch', in: idem, Fragmentation and redemption, 53-78.

Bynum, C. Walker, 'Women's stories, women's symbols: a critique of Victor Tumer's theory of liminality', in: idem, Fragmentation and redemption, 27-51.

Bynum, C. Walker, 'The female body and religious practice', in: idem, Fragmentation and redemption, $\mathrm{I} 8 \mathrm{I}-238$.

Campbell S.J., S.F., 'Nicolas Caussin's Spintuality of Communication: a meeting of divine and human speech', Renaissance Quarterly 46,I (1993) 44-70.

Caron, M., "'Van de geest ende meeningh daar een maaght haar hantwerck in behoort te doen." Naar aanleiding van enige bisschoppelijke paramenten uit de voormalige statie van St. Bernardus in den Hoeck te Haarlem', in: Schilderen met gouddraad en zijde (Utrecht 1987) 20-3I.

Caspers, C.M.A., De eucharistische vroomheid en het feest van Sacramentsdag in de Nederlanden tijdens de late middeleeuwen (Leuven 1992).

Castelli, E., 'Virginity and its meaning for women's sexuality in early christianity', fournal 
of Feminist Studies in Religion 2,1 (1986) 61-88.

Ceyssens O.F.M., L., 'De Congregatie der geestelijke dochters van den derden regel sancti Francisci te Tumhout', Taxandria (nieuwe reeks) I (1932) 10-38.

Ceyssens O.F.M., L., 'Het theologisch denken en het jansenisme I640-1730', in: $A G N 8$ (1979) 418-438.

Ceyssens O.F.M., L., "La pratique de la confession générale: "la confession coupée” suivant le P. Christophe Leurbrewer', in: Van Bavel en Schrama (ed.), fansénius et le fansénisme, 93-II3.

Chartier, R., Cultural history between practices and theory (Cambridge r988).

Chartier, R, 'Le monde comme représentation', Annales ESC 6 (1989) I505-1520.

Chartier, R., 'Texts, printing, readings', in: Hunt (ed.), The new cultural history, 154-175.

Châtellier, L., L'Europe des dévots (Parijs 1987).

'Chronologische lijst van doctoraal-examens in de geschiedenis aan de Katholieke Universiteit Nijmegen, 1923 - I juli 1983', Ex Tempore. Periodiek voor de studierichting Geschiedenis van de KU Nijmegen 3,I (1984) 57-77.

Christian Jr., W.A., Person and God in a Spanish valley (New York/Londen 1972).

Clemens, Th., De godsdienstigheid in de Nederlanden in de spiegel van de katholieke kerkboeken 1680-1840 (2 dln.; Tilburg 1988).

Clemens, Th., 'Kerkboeken en kerkgeschiedenis. De noodzaak en de perspectieven van een vergelijkend onderzoek in de Nederlanden', Trajecta I (1992) 252-26I.

Clemens, Th., 'Katholieke vroomheid en het schisma van 1723', Holland 25 (1993) r97-220.

Clemens, Th., 'De terugdringing van de rooms-katholieken uit de verlicht-protestantse natie', $B M G N$ i 10 (1995) 27-39.

Cloet, M., 'Het gelovige volk in de I7de eeuw', in: $A G N$ 8, 393-4I7.

Cloet, M., P. Nissen en H. Storme, 'Inleiding: status quaestionis van het preekonderzoek in Vlaanderen en Nederland', Trajecta 2 (1993) 193-203.

Coakley, J., 'Gender and the authority of friars: the significance of holy women for thirteenth-century franciscans and dominicans', Church History 60 (1991) 445-460.

Coakley, J., 'Friars, sanctity, and gender. Mendicant encounters with saints, I250-1325', in: C. Lees (ed.), Medieval masculinities. Regarding men in the middle ages (Minneapolis/Londen 1994) 9I-IIO.

Concilium Tridentinum: diarionum, actorum, epistularum, tractatuum. Nova collectio, ed. Societas Goerresiana IX (Actorum pars sexta, complectens acta post sessionem sextam (XXII) usque ad finem concilii (17. sept. 1562-4. dec 1563) (Freiburg im Breisgau 1965).

Conrad, A., "Katechismusjungfrauen" und "Scholastikerinnen". Katholische Mädchenbildung in der frühen Neuzeit', in: Wunder en Vanja (ed.), Wandel der Geschlechterbeziehungen, 154-179.

Conrad, A., Zwischen Kloster und Welt. Ursulinen und fesuitinnen in der katholischen Reformbewegung des 16./17. Jahrhunderts (Mainz 1991).

Comelissen, J.D.M., "Relationes Status" van het bisdom Roermond", PSHAL 64 (I928) 37-120.

Corpus Iuris Canonici. Editio Lipsiensis secunda post Aemilii Ludouici Richteri curas ad librorum manu scriptorum et editionis Romanae fidem recognovit et adnotatione critica instruxit Aemilius Friedberg (2 dln.; Leipzig 1879-1881).

Crawford, P., 'Women's published writings I600-1700', in: Prior (ed.), Women in English 
society, 2 II-282.

Crawford, P., Women and religion in England $1500-1720$ (Londen/New York 1993).

Creusen S.J., J., 'Clôture', in: DDC III (1942) 892-908.

Creusen S.J., J., 'Les instituts religieux à voeux simples', Revue des Communautés religieuses I6-17 (1940-45) 34-43, 52-63.

Creusen S.J., J., 'Congrégation religieuse', in: $D D C$ IV (1949) 18I-194.

Daniëls S.J., Jos., Les rapports entre Saint François de Sales et les Pays-Bas (Nijmegen I932).

Davis, N. Zemon, 'City women and religious change', in: idem, Society and culture in early modern France. Eight essays (Stanford 1975) 65-95.

Davis, N. Zemon, Fiction in the archives. Pardon tales and their tellers in sixteenth-century France (Princeton 1987).

Dekker, R., 'Vrouwen in middeleeuws en vroeg-modem Nederland', in: Farge en Davis (ed.), Geschiedenis van de vrouw, 415-443.

Dekker, R., “Dat mijn lieven kinderen weten zouden ..." Egodocumenten in Nederland van de zestiende tot de negentiende eeuw', Opossum 3 (1993) 5-22.

Delumeau, J., Catholicism between Luther and Voltaire (Londen 1977).

Delumeau, J., La peur en Occident (XIVe-XVIIIe siècles) Une cité assiégée (Parijs 1978).

Derks, M., e.a., 'Res novae. Evoluties in de beeldvorming over katholieke vrouwen', $E x$ Tempore. Historisch Tijdschrift KU Nijmegen II,2 (1992) I2I-I33.

Derks, M., C. Halkes en A. van Heijst (ed.), 'Roomse dochters'. Katholieke vrouwen en hun beweging (Baarn I992).

Derks, M., "Ik was altijd mezelf - ik denk, omdat ik de dochter van mijn vader was." Maria van Nispen tot Sevenaer-Ruys de Beerenbrouck (r903) en de katholieke vrouwenbeweging', in: Derks, Halkes en Van Heijst (ed.), 'Roomse dochters', 13-48.

Derks, M. en A. van Heijst, "'De kleur van vakantie en vorming." Maria (Dé) Groothuizen en De Graal', in: Derks, Halkes en Van Heijst (ed.), 'Roomse dochters', 249-279.

Derks, M. en A. van Heijst, 'Katholieke vrouwencultuur. Een theoretische verkenning', in: Derks, Halkes en Van Heijst (ed.), 'Roomse dochters', 325-346.

Derks, M., 'Vrouwen, confessionalisering en biografie. Catharina Alberdingk Thijm of de eigenaardigheid van een karakter', in: Van Heijst en Derks (ed.), Terra incognita, Io9-128.

Deursen, A.Th. van, Bavianen en slijkgeuzen. Kerk en kerkvolk ten tijde van Maurits en Oldebarnevelt (Assen 1974).

Deursen, A.Th. van, Mensen van klein vermogen. Het kopergeld van de Gouden Eeurw (Amster$\left.\operatorname{dam} 1992^{2}\right)$.

Dijstelberghe, P., 'Het lot van de waterdrinker. De Spa-gedichten van Joannes Six van Chandelier', Literatuur 6 (1993) 331-336.

Dinzelbacher, P., 'Körperliche und seelische Vorbedingungen religiöser Träume und Visionen', in: T. Gregory (ed.), I sogni nel medioevo (Rome 1985) 57-86.

Dinzelbacher, P. en D.R. Bauer (ed.), Religiöse Frauenbezvegung und mystische Frömmigkeit im Mittelalter (Keulen/Wenen 1988).

Dinzelbacher, P., 'Rollenverweigerung, religiöser Aufbruch und mystisches Erleben mittelalterlicher Frauen', in: idem en Bauer (ed.), Religiöse Frauenbewegung, I-58.

Dolhagaray, B., 'Clôture', in: DThC III (1908) 255-256.

Doncoeur, P., 'Angèle de Foligno', in: DS I (1937) 570-571.

Doornbos, W.G., Rooms-katholieke bewonerslijsten van de stad Groningen I665-1688 (Gronin- 
gen 1994).

Doornmalen, S.E.M. van, 'Accomodatie of confrontatie: klopjes in de classis 's-Hertogenbosch 1677-1800. Een verkenning' (ongepubliceerd werkstuk in het kader van het doctoraal werkcollege Nieuwe Geschiedenis en Geschiedenis van het Nederlands Katholicisme, 'Confrontatie of accomodatie', KU Nijmegen 1990).

Doommalen, S.E.M. van, 'Een opmerkelijk franciscaans broederschappenboek I653-r88I', Franciscana 46 (199I) 8I-89.

Doommalen, S.E.M. van, 'Kwezels en kwezelaars in de classis 's-Hertogenbosch 16771739', Brabants Heem. Driemaandelijks tijdschrift voor Brabantse Heem - en Oudheidkunde 43,I (1991) 32-40.

Dorren, G. en G. Verhoeven, 'De twee gezichten van Nicolaas Braau (circa 1636-1707). Een katholieke drukker en boekverkoper in Haarlem', Holland 26 (1994) 235-273.

Dresen, G., Onschuldfantasieën. Offerzin en heilsverlangen in feminisme en mystiek (Nijmegen 1990).

Dresen, G., 'Heilig bloed, ontheiligend bloed. Over het ritueel van de kerkgang en het offer in de katholieke traditie', TvV I4,I (1993) 25-4I.

Dresen-Coenders, H.M.C., Het verbond van heks en duivel. Een rvaandenkbeeld aan het begin van de moderne tijd als symptoom van een veranderende situatie van de vrouw en als middel tot hervorming der zeden (Baarn 1983).

Dresen-Coenders, L., 'De grote "heksenbrand" van Roermond (1613)', in: Gijswijt-Hofstra en Frijhoff (ed.), Nederland betoverd, I6I-I 72.

Dudok van Heel, S.A.C., 'Amsterdamse schuil- of huiskerken', Holland 25 (1993), I-10.

Duhr, J., 'Confréries', in: DS II (1953) 1469-1479.

Duinkerken, A. van, Dichters der Contra-Reformatie. Een bloemlezing met bibliografische aantekeningen (Utrecht 1932).

Durand, H., 'Confrérie', in: DDC IV (Parijs 1949) 128-176.

Duverger, E., 'De Antwerpse geestelijke dochter Suzanna Forchondt (1637-1711)', in: C.

De Backer (ed.), Cultuurhistorische caleidoscoop aangeboden aan prof. dr. Willy L. Braekman (Gent 1992) 167-195.

Ebeling, J.M. en W.J.F. Juten, 'Noordbrabantsche schepenzegels', Taxandria 23 (1916) I52-158.

Eck, C. van, 'Het eerste Nederlandse feministische traktaat? Anna Maria van Schurmans verhandeling over de geschiktheid van vrouwen voor de wetenschapsbeoefening', in: $M$. de Baar e.a. (ed.), Anna Maria van Schurman (1607-1678). Een uitzonderlijk geleerde vrouw (Zutphen I992) 48-60.

Eck, X. van, Kunst, twist en devotie. Goudse katholieke schuilkerken 1572-I795 (Delft 1994).

'Editorial', L'Homme. Zeitschrift für feministische Geschichtswissenschaft I, I (1990) (themanummer over religie) 3-5.

Eeghen, I.H. van, 'De eigendom van katholieke kerken in Amsterdam ten tijde van de Republiek', $B B H 64$ (1957) 21 7-279.

Eijt, J., Religieuze vrouwen: bruid, moeder, zuster. Geschiedenis van twee Nederlandse zustercongregaties, 1820-1940 (Hilversum 1995).

Elm, K., 'Die Stellung der Frau im Ordenswesen, Semireligiosentum und Häresie zur Zeit der Heiligen Elisabeth', in: Sankt Elisabeth. Fürstin, Dienerin, Heilige (Sigmaringen 198r) 7-28. 
Encyclopaedisch kerkelijk woordenboek. Verklaring van woorden en termen uit het katholieke leven, met een inleiding van J.B. Kors O.P. (Bilthoven $1938^{6}$ ).

Evenetr, H.O., 'The new orders', in: The New Cambridge Modern History, II, The Reformation 1520-1559 (Cambridge 1968).

Everard, M., Ziel en zinnen. Over liefde en lust tussen vrouwen in de tweede helft van de achttiende eeuw (Groningen 1994).

Evers, I.M.H., 'Maaslandse heksenprocessen. Honderd jaar Limburgse regionale geschiedschrijving', in: W. de Blécourt en M. Gijswijt-Hofstra (ed.), Kwade mensen. Toverij in Nederland (themanummer Volkskundig Bulletin 12 (1986)) 77-106.

Farge, A. en N. Zemon Davis (ed.), Geschiedenis van de vrouw. Van de Renaissance tot de moderne tijd (Amsterdam 1992).

Filedt Kok, J.P., E. Hinterding en J. van der Waals, 'Jan Harmensz. Muller as Printmaker - II', Print Quarterly XI, 4 (1994) 35I-378.

Fockema Andreae, S.J., Bijdragen tot de Nederlandsche rechtsgeschiedenis I (Haarlem I888).

Foucault, M., De wil tot weten. Geschiedenis van de seksualiteit I (Nijmegen $1985^{2}$ ).

Frenay, J.D., 'Aanteekeningen betreffende de Leydsche pastoors sedert "de Hervorming" tot aan de "de herstelling" van I557-I857', $\mathrm{BBH}_{4}$ (1876) I6I-244.

Frenken, A.M., 'De Roomsche kerkschuur te Helmond', $B B 6$ (1923/1924) 20-36.

Frenken, A.M., 'Nog eenige bijzonderheden betreffende de parochiekerk van Helmond', $B B 8$ (1926/1927) 150-174.

Frijhoff, W., 'Pleidooi tegen de androcentrische geschiedschrijving', TvG 94 (I981) 640641.

Frijhoff, W., "Van "histoire de l'église" naar "histoire religieuse". De invloed van de "Annales"-groep op de ontwikkeling van de kerkgeschiedenis in Frankrijk en de perspectieven daarvan voor Nederland', Nederlands Archief voor Kerkgeschiedenis 6I,2 (I981) I 13-I53.

Frijhoff, W., 'Katholieke toekomstverwachting ten tijde van de Republiek: structuur, en grondlijinen tot een interpretatie', BMGN 98 (r983) 430-459.

Frijhoff, W., 'Vraagtekens bij het vroegmoderne kersteningsoffesief, in: Rooijakkers en Van der Zee (ed.), Religieuze volkscultuur, 71-98.

Frijhoff, W., 'Normeren of waarderen. Over cultuur, geschiedenis en geschiedfilosofie', in: R. Sanders e.a. (ed.), De verleiding van de overvloed. Reflecties op de eigenheid van de cultuurgeschiedenis (Amsterdam/Atlanta 1991) 15-35.

Frijhoff, W.,'Identiteit en identiteitsbesef. De historicus en de spanning tussen verbeelding, benoeming en herkenning', BMGN 107 (1992) 614-634.

Frijhoff, W., 'Inleiding: historische antropologie', in: Te Boekhorst, Burke en Frijhoff (ed.), Cultuur en maatschappij, $1 \mathrm{I}-38$.

Frijhoff, W., 'De Noordnederlandse oratorianen en de katholieke identiteit. Rond een stelling', in: Monteiro, Rooijakkers en Rosendaal (ed.), De dymamiek, 210-217.

Frijhoff, W., 'Enfants saints, enfants prodiges: l'expérience religieuse au passage de l'enfance à l'âge adulte', Pedagogica Historica. Intemational journal of the history of education 29,I (1993) 53-76.

Frijhoff, W., Wegen van Evert Willemsz. Een Hollands weeskind op zoek naar zichzelf, 16071647 (Nijmegen 1995).

Fruin, R., 'De wederopluiking van het katholicisme in Noord-Nederland, omstreeks den aanvang der XVIle-eeuw' [1894], in: idem, Verspreide geschrifien III ('s-Gravenhage I90I) 
249-344.

Fuente. Fuan de la Cruz 159I-1991 (Amsterdam 1991).

Garrer, A.H., 'Dina Noortdijck. Een klopje uit de 17de eeuw', Onze Eeuw 8,3 (1908) 425446.

Gedenkboek ter gelegenheid van het zeven-honderdjarig bestaan van Roermond als stad (Roermond 1932).

Geerdink, J., Eenige bijdragen tot de geschiedenis van het Archidiaconaat en aartspriesterschap Twenthe en Calendarium St. Plechelmi te Oldenzaal (z.p. 1895).

Geertz, C., 'Religion as a cultural system' [1966], in: idem, The interpretation of cultures. Selected essays (New York 1973) 87-125.

Gemert, L. van, 'Hiding behind words? Lesbianism in 17th-century Dutch poetry', Thamyris. Mythmaking from past to present 2,1 (1995) $11-44$.

'Geschiedenis van een afvallige priester over de organisatie der roomsch-katholieke kerk in Nederland omstreeks I630', $A A U$ I4 (1886) 24I-244.

Gijswijt-Hofstra, M. en W. Frijhoff (ed.), Nederland betoverd. Toverij en hekserij van de veertiende tot in de twintigste eeuw (Amsterdam 1987).

Gijswijt-Hofstra, M., 'Hoofdlijnen en interpretaties van Nederlandse toverij en hekserij', in: idem en Frijhoff (ed.), Nederland betoverd, 256-279.

Gilchrist, R., Gender and material culture. The archaeology of religious women (Londen/New York 1994).

Gils, P.J.M. van, 'Het onderwijs', in: Gedenkboek Roermond, 228-243.

Gössmann, E., 'Das Gottes - und Menschenbild in der Frauentradition als Korrektiv und Replik zur männlichen Schultheologie', Fahrbuch für Volkskunde (nieuwe reeks) 14 (1991) 127-I42.

Gonnet, C.J., 'De "Vergaderinghe van de Maeghden in den Hoeck" te Haarlem', $B B H$ 42 (1923) 34-57.

Gorissen, F., Stede-atlas van Nijmegen (Amhem 1956).

Graaf, J.J., 'Uit de levens der "Maechden van den Hoeck” te Haarlem', $B B H$ I7 (189I), 18 (1893), 19 (1894).

Graaf, J.J., 'De "vergaderinghe der Maechden van den Hoeck" te Haarlem', $B B H 29$ (I905), 30 (1906), 31 (1908), 32 (I909), 34 (1912), 35 (1913).

Graham, E. e.a. (ed.), Her own life. Autobiographical writings by seventeenth-century Englishwomen (Londen/New York 1989).

Grausem, J.-P., 'Rosweyde, Héribert', in: DThC VI (1939) 9-1I.

Grever, M., 'Het verborgen continent. Een historiografische verkenning van vrouwengeschiedenis in Nederland', TSG 12 (1986) $221-269$.

Grever, M., 'De kracht van de inwendige strijd. Het biografisch oeuvre van Johanna W.A. Naber (1859-I94I)', BMGN IO5 (1990) 578-604.

Grever, M., Strijd tegen de stilte. Johanna Naber (1859-194I) en de vrouwenstem in geschiedenis (Hilversum 1994).

Grisar S.J., J., 'Das erste Verbot der Ordensgründung Maria Wards (I628)', Stimmen der Zeit I 13 (1927) 34-51.

Grisar S.J., J., 'Der Endkampf um Maria Wards erste Ordensgründung (I628-I63I)', Stimmen der Zeit I13 (1927) 131-I50.

Grisar S.J., J., 'Das Urteil des Lessius, Suarez und anderer über den neuen Ordenstyp der 
Mary Ward', Gregorianum 38 (1957) 658-712.

Grisar S.J., J., "Jesuitinnen". Ein Beitrag zur Geschichte des weiblichen Ordenswesens von 1550-1650', in: E. Iserloh en K. Repgen (ed.), Reformata Reformanda. Festgabe für Huber Yedin zum I7. Funi I965 (2 dln.; Münster I965) II, 70-II3.

Groult, P., Les mystiques des Pays Bas et la littérature espagnole du seizième sïcle (Leuven 1927).

Grundmann, H., 'Zur Geschichte der Beginen im 13. Jahrhundert', Archiv für Kulturgeschichte 21 (193I) 296-320.

Grundmann, H., Religiöse Bervegungen im Mittelalter. Untersuchungen über die geschichtlichen Zusammenhänge zwischen der Ketzerei, den Bettelorden und der religiösen Frauenbewegung im I2. und 13. Jahrhunden und über die geschichtlichen Grundlagen der deutschen Mystik [1935] (Hildesheim 196 $\mathrm{r}^{2}$ ).

Gueudre, M.-C., 'La femme et la vie spirituelle', XVIIe Siècle 62/63 (I964) 47-77.

Guy, J.C., 'Examen de conscience (chez les Pères de l'Église)', in: DS IV (I96I) r80I-I807.

Haan, F. de, ' $\mathrm{Na}$ vijftien jaren. Vrouwengeschiedenis in Nederland, 1976-1991', in: $\mathrm{S}$. Dumont e.a. (ed.), In haar verleden ingewijd. De ontwikkeling van vrouwengeschiedenis in Nederland (Zutphen 1991) 13-44.

Habets, J., Geschiedenis van het tegenwoordig bisdom Roermond (4 dln.; dl. IV voortgezet door W. Goossens; Roermond 1875-[1927]).

Hahn, A., 'Identität und Selbstthematisierung', in: idem en V. Kapp (ed.), Selbstthematisierung und Selbstzeugnis: Bekenntnis und Gestāndnis (Frankfurt a/M 1987) 9-24.

Haitsma Mulier, E.O.G. en G.A.C van der Lem, Repertorium van geschiedschrijvers in Nederland 1500-1800 (De Haag 1990).

Hamans, P.W.F.M., Geschiedenis van het seminarie van het eerste bisdom Roermond (1570-1813) (Brugge I986).

Heel O.F.M., D. van, 'Rotterdamse klopjes', Neerlandia Seraphica. Van het leven en werken onzer provincie 13 (1939) 327-329.

Heel O.F.M., D. van, 'De statie der minderbroeders te Hoorn', Bijdragen voor de geschiedenis van de minderbroeders in de Nederlanden I (1947) 15-96.

Heel O.F.M., D. van, De minderbroeders te Gouda (2 dln.; Gouda 1947).

Heel O.F.M., D. van en B. Knipping O.F.M., Van schuilkerk tot zuilkerk. Geschiedenis van de Mozes en Aäronkerk te Amsterdam (Amsterdam I94I).

Heerickx O.F.M., J., 'Baptiste Varani', in: DS I (I937) 1240-1241.

Hensen, A.H.L., 'Musius (Comelis)', in: NNBW VI, I046-105I.

Herpoel, S., "Nosce te ipsum", of schrijven op bevel in Spanje. Over autobiografieën van vrouwen in de Spaanse zeventiende eeuw', in: A.-J. Gelderblom en H. Hendrix (ed.), De vrouw in de Renaissance (Amsterdam 1994) 42-57.

Hesse O.F.M., G., De minderbroeders te Amsterdam. Historische herinneringen naar aanleiding van het jubilée der Mozes en Aäronkerk (z.p. 1916).

Heyden, L.J. van der, 'Schoen (Wilhelmus)', in: NNBW III (1914) II43.

Heijst, A. van en M. Derks (ed.), Terra incognita. Historisch onderzoek naar katholicisme en vrouwelijkheid (Kampen 1994).

Heijst, A. van en M. Derks, 'Godsvrucht en gender: naar een geschiedschrijving in meervoud', in: idem (ed.), Terra incognita, 7-38.

Hieber, W., Legende, protestantische Bekennerhistorie, Legendenhistorie. Studien zurliterarischen 
Gestaltung der Heiligenthematik im Zeitalter der Glaubenskāmpfe (Würzburg 1970).

Hildebrand O.C.M., P., 'Een vergeten ascetische schrijver en apostel der veelvuldige communie: P. Albertus van den Bosch († 1740)', OGE 2 (1928) 176-188 en 245-275. Hilhorst, G., 'Het kerkelijk Gooiland na de Hervorming', $A A U$ I (1874) 268-306.

Hobby, E., Virtue of necessity: English women's writings r649-I688 (Londen 1988).

Hoeck S.J., F. van, De jezuïeten te Nijmegen ('s-Hertogenbosch/Antwerpen I92I).

Hoeck S.J., F. van, 'De jezuïeten-statie te Culemborg', $A A U 57$ (I933) 62-94.

Hoeck S.J., F. van, Schets van de geschiedenis der jezuïeten in Nederland (Nijmegen I940).

Hofman, F., 'Bediening', in: LW I, 227-229.

Hofman, F., 'Gebeden der stervenden', in: $L W \mathrm{I}, 792-794$.

Hofman, J., 'Allerlei betreffende de stad Utrecht', $A A U 5$ (1878) 180-239.

Hofman, J.H., 'Imsum', $A A U$ 20 (I893) II4-285.

Hoogland O.P., A.J.J., 'Drie klopjes voor het gerecht te Leiden', $B B H 6$ (1878) 69-76.

Hoogland O.P., A.A.J., 'Descriptio status, in quo anno 1638 erat religio catholica in Hollandia et in conterminis Belgii proviniciis sub Ill ${ }^{\text {mo }} \mathrm{D}$. Philippo Rovenio Archiepiscopo Philippensi (....)', $A A U 12$ (1884) 189-213.

Houben S.J., A.H., 'Analecta van het oude bisdom Roermond', in: Venner (ed.), Roermond, 103-II5.

Houtman-Desmedt, H., 'De eindfase van de oorlog in het Zuiden I633-1648', in: $A G N$ $6,385-395$.

Huizinga, J., Herfsttij der Middeleeurven (Haarlem 19354).

Hullu, J. de, 'Aantekeningen betreffende de katholieken in Twente en op het platteland in de ronde van Deventer (1583-1629)', $A A U 40$ (1914) 1-92.

Hullu, J. de, 'De katholieken te Stompwijk in 1655', BBH 37 (1917) 146-148.

Huysmans, J., 'Bijdragen tot de geschiedenis der katholieken te Gorcum sedert I592', $A A U$ 43 (1917) 193-322.

Hunt, L., The new cultural history (Berkeley/Los Angeles/New York 1989).

Hunt, L., 'Introduction: history, culture, and text', in: idem (ed.), The new cultural history I-22.

Ignatius van Loyola, Geestelijke oefeningen, vertaald en bezorgd door J. Tesser S.J. ('sHertogenbosch 1953).

Isaac, M.-T., 'Documents inédits sur une communauté de dames enseignantes au XVIIe siècle: les “jésuitesses” de Valenciennes, I630-I63I', Lias 14,I (I987) 4I-59.

Iserloh, E., J. Glazik en H. Jedin, Reformation, Katholische Reform und Gegenreformation. Handbuch für Kirchengeschichte IV (Freiburg/Bazel/Wenen 1967).

J., E. [E. Janssen] C.ss.R., Inventaris der handschriften van de eerbiedwaardige foanna van Randenraedt, geb. te Brussel I8 october 16ro, overh te Roermond 26 juli I684 (Roermond 1937). Jacobs, J.Y.H.A., foan Christian van Erckel (1654-1734). Pleitbezorger voor een locale kerk (Amsterdam/Maarssen I98I).

Jacques, E., 'Les Voeller. Une famille de notables jansénistes à Bruxelles à la fin du XVIIe siècle', in: Cahiers Bruxellois 12 (1967) I53-193.

Jadin, L., Le cardinal Thomas Philippe d'Alsace archevèque de Malines et le Saint Siège. Correspondance (Brussel 1958).

Jansen, W., 'De vele gezichten van genus. Een agenda voor onderzoek naar de culturele constructies van vrouwelijkheid en mannelijkheid', in: M. Brügmann (ed.), Vrouven in 
opspraak. Vrouwenstudies als cultuurkritiek (Nijmegen 1987) 46-62.

Jansen, W., Women without men. Gender and marginality in an Algerian town (Leiden 1987). Jansen, W., 'Het offensief tegen de zusters van de broederschap. Vrouwen in de Algerijnse islam', Amsterdams Sociologisch Tijdschrift 15,3 (1988) 507-527.

Janssen, A.E.M., 'Toewijding, vakkundigheid en bezieling. De beoefening van de geschiedenis van het Nederlands katholicisme in vogelvlucht', in: Monteiro, Rooijakkers en Rosendaal (ed.), De dynamiek, 302-320.

Janssens C.ss.R., M., 'Geestelijke dochters in het Waasland', OGE 40 (I966) 306-342. Janssens, $P$., 'De landvoogdij van Isabella', in: $A G N$ 6, 372-384.

Jappe Alberts, W., Geschiedenis van beide Limburgen (2 dln.; Assen 1974).

Jedin, H., 'Religiöse Triebleäfte und geistiger Gehalt der katholischen Erneuerung', in: Iserloh, Glazik en Jedin, Reformation IV, 561-604.

Jedin, H., 'Ursprung und Durchbruch der Katholischen Reform bis 1563', in: Iserloh, Glazik en Jedin, Reformation IV, 45I-516.

Jerrell, L.M., The development of legal structures for women religious between 1500 and 1900: a study of selected institutes of religious life for women (Washington D.C. 1984; dissertation Catholic University of America).

Jobse, J., Eenvoudig maar voedzaam. Cultuurgeschiedenis van de dagelijkse maaltijd in Nederland (Nijmegen 1995).

Jong, O.J. de, De Reformatie in Culemborg (Assen 1957).

[Juana de la Cruz], $A$ woman of genius. The intellectual biography of Sor fuana Inès de la Cruz, translation and introduction by M. Sayers Peden (Salisbury (Conn.) 1982).

Kerkelijk kunstbezit. Handleiding voor het beheer. Inventarislijst O.L.V. Tenhemelopneming (Kapel in 't Zand) Rectoraat en klooster C.ss. R. te Roermond. Geïnventariseerd door J.M.A. van Cauteren (1986; uitgave Stichting Kerkelijk Kunstbezit in Nederland).

Kessel-Schulte, E. van, 'Wenina en Agatha van Heussen, de Klopjes van "De Liefde"', $A G K K N$ Io (1968) 248-280 (ook verschenen in Up Ponciaens Outaer. Kerkhistorische opstellen aangeboden aan Pater Poncianus Polman O.F.M. naar aanleiding van zïn zeventigste verjaardag (Utrecht/Antwerpen 1968) 248-280).

Kingma, E., De mooiste onder de vrouwen. Een onderzoek naar religieuze idealen in twaalfdeeeuwse commentaren op het Hooglied (Hilversum 1993).

Kingma, E., 'Gender-bending in twaalfde-eeuwse commentaren op het Hooglied', in: Van Heijst en Derks (ed.), Terra incognita, 39-56.

Kloek, E., 'De Reformatie als thema van vrouwengeschiedenis. Een histories debat over goed en kwaad', in: idem e.a. (ed.), Vrouzven in de geschiedenis van het christendom. Jaarboek voor vrouwengeschiedenis 4 (Nijmegen 1983) ro6-149.

Kloek, E., Wie hij zij, man of wijf. Vrourvengeschiedenis en de vroegmoderne tijd: drie Leidse studies (Hilversum 1990).

Kloek, E., N. Teeuwen en M. Huisman (ed.), Women of the Golden Age. An international debate on women in seventeenth-cetury Holland, England and Italy (Hilversum I994).

Kloek, E., 'Introduction', in: idem, Teeuwen en Huisman (ed.), Women of the Golden Age, 9-18.

Knipping O.F.M., B., De iconografie van de Contra-Reformatie in de Nederlanden (2 dln.; Hilversum 1939-1940).

Knuttel, W.P.C., De toestand der Nederlandsche katholieken ten tijde der Republiek (2 dln.; 
's-Gravenhage 1892-1894).

Kok O.F.M., J.A. de, Nederland op de breuklïn Rome-Reformatie. Numerieke aspecten van protestantisering en katholieke herleving in de Noordelijke Nederlanden 1580-1880 (Assen 1964).

Koorn, F., 'Elisabeth Strouven. La donna religiosa', in: G. Calvi (ed.), Barocco al femminile (Rome/Bari 1992) 127-I52.

Koom, F., 'Een charismatische anti-heilige: Elisabeth Strouven (1660-1661)', in: $M$. Cornelis e.a. (ed.), Vrome vrouwen. Betekenissen van geloof voor vrouwen in de geschiedenis (Hilversum 1996; ter perse).

Kronenburg C.ss.R., J.A.F., Maria's heerlijkheid in Nederland. Geschiedkundige schets van de verering der $H$. Maagd in ons vaderland, van de eerste tijden tot onze dagen (8 dln.; Amsterdam 1904-1914).

Laarhoven, J, van, 'Een geschiedenis van de biechtvader', Tijdschrift voor Theologie 7 (1967) 375-422.

Lagerwey, E., 'De Oud-katholieke begraafplaats', in: Jaarboekje Oud-Utrecht (1929) 5I-99.

Lambermond O.P., C.H., recensie van E. Theissing, Over klopjes en kwezels, Studia Catholica 12 (1936) 351-352.

Langer, O., 'Geistliche Sinnlichkeit. Zur Frage der Gotteserfahrung in der Frauenmystik des Mittelalters', Jahrbuch für Volkskunde (nieuwe reeks) 14 (1991) 143-155.

Laqueur, T., Making sex. Body and gender from the Greeks to Freud (Cambridge (Mass.)/ Londen 1990).

Le Bras, G., 'Les confréries chrétiennes. Problèmes et propositions' [1940/r941] in: idem, Études de sociologie religieuse (2 dln.; Parijs 1955-1956) II, 423-462.

Le Brun, J., 'Die geistliche Biographie im Frankreich des 17. Jahrhunderts. Weibliches Schreiben? Mystisches Schreiben?', fahrbuch für Volkskunde (nieuwe reeks) 14 (1991) 156-165.

Lemoine O.S.B., Dom R., Le droit des religieux du Concile de Trente aux instituts séculiers (Parijs 1955).

Lemoine O.S.B., Dom R., Le monde des religieux. L'époque moderne (1563-1789) (Parijs 1976).

Liebergen, L. van, "Waer een paradis". Kloosterleven in Brabant na de Reformatie (Uden 1987).

Liebowitz, R.P., 'Virgins in the service of Christ: the dispute over an active apostolate for women during the Counter-Reformation', in: R.R. Ruether (ed.), Women of spirit. Female leadership in the jewish and christian traditions (New York 1979) 131-152.

Lieburg, F.A. van, 'De receptie van de Nadere Reformatie in Utrecht', De Zeventiende Eeuw 5,1 (1989) 120-128.

Lieburg, F.A. van, Levens van vromen. Gereformeerd piëtisme in de achtriende eeuw (Kampen 1991).

Lindeman, R., Y. Scherf en R. Dekker, Egodocumenten van Noord-Nederlanders uit de zestiende tot begin negentiende eeuw. Een chronologische lijst (Rotterdam 1993).

Linssen, J.H.F.H., 'Instellingen van weldadigheid', in: Gedenkboek Roermond, 244-263.

Lommel S.J., A. van, 'Pastoors der statie Oud-Ade c.a.', $B B H_{4}$ (1876) 297-329.

Lommel S.J., A. van, 'Relatio visitationis reverendi patris Thomae Dekens provincialis provinciae Flandro-Belgicae S.J., $\mathrm{A}^{\circ} \mathrm{I}_{656}, A_{A U} 3$ (1876) 45-90.

Lommel S.J., A. van, 'Bouwstoffen voor de kerkelijke geschiedenis van verschillende parochiën thans behoorende tot het Bisdom Haarlem', $B B H 6$ (1878) I46-209. 
Lommel S.J., A. van, 'Relatio visitationis Missionis S.J. in Hollandia a Pe Guilelmo Bauters, Jussu R' P' Jacobi Stratii Provincialis Flandro-Belgicae Provinciae (...)', AAU 6 (1879) 222-256.

Lommel S.J., A. van, 'Bouwstoffen voor de kerkelijke geschiedenis van de verschillende parochiën thans behoorende tot het Bisdom van Haarlem', $B B H 7$ (1879) 340-391.

Lommel S.J., A. van, 'Joh. Matthias van de Velde S.J., "Narratio Historica seu descriptio status romano-catholicorum civitatis Groningensis necnon agri circumjacentis sive Ommelandiae et provinciae Drenthiae I620-I64I"', $A A U 6$ (1879) I-99.

Loos, J.C. van der, 'Jansenistica: 174I', $A A U 44$ (1919) too-104.

Loos, J.C. van der, 'Kerkelijk Uitgeest', $B B H 43$ (1925) 192-272.

Loos, J.C. van der, Vaderlandsche kerkgeschiedenis uit de zeven noordelijke provinciën sinds het concilie van Trente (5 dln.; Amsterdam 1946-1953).

Longny, J. de, A l'ombre des grands ordres. Histoire, spiritualité, constitution des huit principaux tiers-ordres (Parijs 1937).

Mack, Ph., Visionary women. Ecstatic prophecy in seventeenth-century England (Berkeley/Los Angeles/Oxford 1992).

Maio, R. de, Donne e Rinascimento (Milaan 1987).

Majkowski, J., 'Lectio divina et lecture spirituelle', in: DS IX (1976) 470-510.

Marshall, S., The Dutch gentry I500-1650: family, faith, and fortune (Westport (Conn.) 1987).

Marshall, S., (ed.), Women in reformation and counter-reformation Europe. Public and private worlds (Bloomington/Indianapolis 1989).

Matter, E.A., 'Discourses of desire: sexuality and christian women's visionary narratives', in: foumal of Homosexuality I8, 3/4 (1990) (themanummer Homosexuality and Religion) II9-I3I.

Matter, E.A., 'The personal and the paradigm: the Book of Maria Domitilla Galluzzi', in: Monson (ed.), The crannied wall, 87-103.

Matter, E.A. en J. Coakley (ed.), Creative women in medieval and early modern Italy. $A$ religious and artistic renaissance (Philadelphia 1994).

Matter, E.A., 'The commentary on the rule of Clare of Assisi by Maria Domitilla Galluzzi', in: idem en Coakley (ed.), Creative women, 20I-2II.

Megens, I., 'Zicht op een vrouwelijk verleden. Ontwikkelingen binnen vrouwengeschiedenis in Nederland', in: Met andere ogen. Vrouwengeschiedenis in Nederland 1975-1985 (Groningen I985).

Meijer O.P., G.A., Dominikaner klooster en statie te Nijmegen (Nijmegen I892).

Meijer O.P., G.A., 'De Dominicanen-statie te Leeuwarden', $A A U$ 35 (1909) 78-159.

Meijer O.P., G.A., Gedenkboek van de Dominicanen in Nederland 1803-1910 (Nijmegen 1912).

Meijer O.P., G.A., 'Nopende het aartspriesterschap van Swolle naer de beroerten deser Nederlanden mitsgaders van eenige gedenckweerdige voorvallen van Amold Waeijer', $A A U 45$ (1920) I-193.

Mendelson, S. Heller, 'Stuart women's diaries and occasional memoirs', in: Prior (ed.) Women in English Society, 181-210.

Menologium van de Sociëteit van fezus voor de Nederlandsche provincie (2 dln.; Leiden z.j. [1913]).

Mensinck, B.A., Fan Baptist Stalpart van der Wiele. Advocaat, priester en zielzorger 1579-1630 (Bussum z.j.). 
Merlin O.E.S.A., N., 'Tiers-ordre Augustinien', in: Longny, A L'Ombre, I43-1 79.

Meulmeester-Jacobs, D., 'Het wereldlijk recht inzake verloving en huwelijk', in: P. van Boheemen (ed.), 'Kent, en versint, Eer datje mint. Vrijen en trouwen 1500-1800 (Zwolle 1989) I2I-137.

Mierlo S.J., J. van, recensie van E. Theissing, Over klopjes en kwezels, OGE Io (1936) 253254.

Miert S.J., L.J. van, 'Over het veelvuldig communiceren in vroeger eeuwen in de Nederlanden', Studiën: godsdienst, wetenschap en letteren 53,96 (1921) 18-33.

Misch, G., Geschichte der Autobiographie (4 dln.; Frankfurt a/M 19493-1969).

Monson, C.A. (ed.), The crannied wall. Women, religion, and the arts in early modem Europe (Ann Arbor 1992).

Monteiro, M., 'Een maagd zonder regel is als een schip zonder stuurman. Richtlijnen voor geestelijke maagden in de Noordelijke Nederlanden in de zeventiende eeuw', Trajecta I (1992) 332-35I.

Monteiro, M., G. Rooijakkers en J. Rosendaal (ed.), De dynamiek van religie en cultuur. Geschiedenis van het Nederlands katholicisme (Kampen 1993).

Monteiro, M., G. Rooijakkers en J. Rosendaal, 'Van hoogaltaar tot tochtportaal. Sociaalculturele aspecten van religieus gedrag', in: idem (ed.), De dynamiek, 9-20.

Monteiro, M., 'Den middelen staet. Waarom vrouwen in de vroegmoderne tijd kozen voor een semi-religieus bestaan', in: idem, Rooijakkers en Rosendaal (ed.), De dynamiek, r38161.

Monteiro, M., “"Ick ben gekomen inde werelt om vuur te brenghen." Inspiratie, ambitie en strategie van katholieke geestelijke maagden in de vroegmoderne tijd', in: Van Heijst en Derks (ed.), Terra incognita, 57-86.

Moore, C. Niekus The maiden's mirror. Reading material for German girls in the sixteenth and seventeenth centuries (Wiesbaden 1987).

Moore, C. Niekus, 'Erbauungsliteratur als Gebrauchsliteratur für Frauen im 17. Jahrhundert: Leichenpredigten als Quelle weiblicher Lesegewohnheiten', in: Bödeker, Chaix en Veit (ed.), Le livre religieux, 291-315.

Mosmans C.ss.R., H., 'Uit het leven van de waardige Joanna van Randeraedt', Maasgouw $7 / 8$ (I926) 37-40.

Mosmans C.ss.R., H., 'Een Limburgsche magistraatsfamilie (Bijdrage over de Randenraedts)', PSHAL 66 (1930) 69-96.

Mossink, M., 'Naar het leven: een inleiding', in: M. Aerts e.a. (ed.), Naar het leven. Feminisme en biografisch onderzoek (Amsterdam 1988) 9-27.

Nahmer, D. von der, Die lateinische Heiligenvita. Eine Einführung in die lateinische Hagiographie (Darmstadt 1994).

Nijenhuis, W., 'De publieke kerk veelkleurig en verdeeld, bevoorrecht en onvrij', in: $A G N$ 6, 325-343.

Nijenhuis, W., 'Religiegeschiedenis 162I-1648: kerk in het meervoud', in: $A G N 6$, 397-4I1.

Nispen, C.A.I.L. van, 'De Hoevense parochie van Sint Jan de Doper (1310-1989)', in: Ter kerke op de Halderberg. Zeven eeuwen kerkelijk leven in Hoeven (Hoeven 1989) 23-216.

Norberg, K., 'The Counter Reformation and women: religious and lay', in: J.W. O'Malley S.J. (ed.), Catholicism in early modern history. A guide to research (St. Louis 1988) 133-I46. Nouwens M.S.C., Jac., De veelvuldige H. Communie in de geestelijke literatuur der Nederlanden 
vanaf het midden van de I6e eeuw tot in de eerste helft van de 18e eeuw (Bilthoven/Antwerpen I952).

Noye, I., 'Examen de conscience (Moyen Age et temps modernes)', in: DS IV (I96I) 1807I831.

Noye, I., 'Girard de Vilthierry (Jean)', DS VI (1967) 400-402.

'Numerieke aspecten van de protestantisering in Noord-Nederland tussen 1656 en 1726.

Debat van A.M. van der Woude, J.A. Faber en H.K. Roessingh met J.A. de Kok O.F.M.', $A A G$ Bijdragen 13 (1965) 149-180.

Nübel, O., Mitrelalterliche Beginen - und Sozialsiedlungen in den Niederlanden. Ein Beitrag zur Vorgeschichte der Fuggerei (Tübingen 1970).

Ochsenbein, P., 'Leidensmystik in dominikanischen Frauenklöstern des I4. Jahrhunderts am Beispiel der Elsbeth von Oyen', in: Dinzelbacher en Bauer (ed.), Religiöse Frauenbewegung, 353-372.

O'Malley S.J., J.W., The first fesuits (Cambridge (Mass.)/Londen I993).

Opitz, C., 'Hunger nach Unberührbarkeit? Jungfräulichkeitsideal und weibliche Libido im spāten Mittelalter', Feministische Studien 5 (1986) 59-75.

Ortega Costa, M., 'Spanish women in the Reformation', in: Marshall (ed.), Women in reformation and counter-reformation Europe, 89-II9.

Perry, M.E., Gender and disorder in early modern Seville (Princeton (N.J.) 1990).

Petroff, E.A., Medieval women's visionary literature (New York/Oxford I986).

Petrus a Matre Dei, Clara Relatio missionis Hollandicae et Provinciarum Confoederatarum ad instructionem eorum quae in hac Missione geruntur, spectantque ad religiones catholicam (...) Anno 1658 (Rotterdam I891).

Pey, E.F.B., Een prosopografisch onderzoek naar de klopjes van 'De Hoek'te Haarlem van 1583I65I (ongepubliceerde doctoraal bijvak-scriptie Geschiedenis van het Nederlands Katholicisme, KU Nijmegen 1983).

Pey, E.F.B., 'De manuscripten van Tryn Jans Oly als bron voor een prosopografisch onderzoek naar de klopjes van "De Hoek" te Haarlem', $A G K K N 28$ (1986) 138-160.

Philippen, L.J.M., 'Begijnhoven en spiritualiteit', $O G E_{3}$ (1929) 165-196.

Pol, L. van de, recensie van E. Kloek, Wie hij zij, man of wijf. Vrouwengeschiedenis van de vroegmoderne tijd: Drie Leidse studies, TvV 12, I (1991) 144-146.

Pol, L. van de, 'Prostitutie en de Amsterdamse burgerij: eerbegrippen in een vroegmodeme stedelijke samenleving', in: Te Boekhorst, Burke en Frijhoff (ed.), Cultuur en maatschappij, 179-218.

Polman O.F.M., P., 'Roomse en anti-roomse strijdliteratuur uit de dagen der Republiek', Studia Catholica XII (1936) 89-104.

Polman O.F.M., P., 'Het geestelijk leven der katholieken in Nederland onder de apostolische vikarissen', OGE 20 (1946) 2 I5-235.

Polman O.F.M., P. (ed.), Romeinsche Bronnen voor de kerkelijke toestand der Nederlanden onder de apostolische vicarissen 1592-1727 III ('s-Gravenhage 1952) (RGP 94).

Polman O.F.M., P., Katholiek Nederland in de achttiende eeuw (3 dln.; Hilversum I968).

Pomata, G., 'De geschiedenis van vrouwen: een kwestie van grenzen', Socialisties-feministiese teksten Io (1987) 6I-II3.

Poncelet S.J, A., Histoire de la Compagnie de fésus dans les anciens Pays-Bas (2 dln.; Brussel 1926). 
Post, R.R., 'Zes verslagen over de werkzaamheden van de jezü̈eten der Holandsche Missie verricht', $A A U 59$ (I935) 79-I96.

Post, R.R., 'Overzicht der literatuur omtrent het Aartsbisdom Utrecht', $A A U 60$ (1936) [16]-[19].

Post, R.R. (ed.), Romeinsche bronnen voor den kerkelijken toestand der Nederlanden onder de apostolische vicarissen 1592-1727 II ('s-Gravenhage 1941) (RGP 84).

Post, R.R., 'Inleiding', $A A U 75$ (1957).

Prior, M. (ed.), Women in English society 1500-1800 (Londen/New York 1985).

Put, E., m.m.v. B. Pauwels, "'Het fundament van een welregeerde republique." De Antwerpse zondagsscholen in de I7e eeuw', De Zeventiende Eeuw 5, I (1989) I I-20.

Put, E. en M. Wynants (ed.), De jezuieten in de Nederlanden en het Prinsbisdom Luik (1542I773) (Brussel I99r).

Put, E., 'Het onderwijs in de colleges', in: idem en Wynants (ed.) De jezuïeten in de Nederlanden, 35-48.

Put, E., 'Een nieuw pastoraal model', in: idem en Wynants (ed.), De jezuieten in de Nederlanden, 49-6o.

Putmans, J., 'Bijdragen voor de kerkelijke geschiedenis van Oudewater uit de $18 \mathrm{e}$ eeuw, in het stedelijk archief verzameld', $B B H 12$ (1886) 228-252.

Pyls, C., 'Roermonds kloosterleven', in: Gedenkboek Roermond, 188-220.

Ranft, P., 'A key to counter reformation women's activism: the confessor-spiritual director', fournal of Feminist Studies in Religion 10,2 (1994) 7-26.

Ranke-Heinemann, U., Eunuchen voor het hemelnijk. De rooms-katholieke kerk en seksualiteit (Baarn 1990).

Rapley, E. The dévotes. Women and Church in seventeenth-century France (Montreal etc., 1990).

Reypens S.J., L., 'Pelgrum Pullen (1550-1608). Zijn geschriften', $O G E_{3}$ (1929) 125-143.

Rombauts, E., Leven en werken van pater Adrianus Poirters S.f. (1605-1674) (Ledeberg/Gent z.j. [1930]).

Roemers, Tesselschade, De gedichten van Tesselschade Roemers, uitgegeven door A.A. Sneller en O. van Marion, m.m.v. N. v. Megen (Hilversum 1994).

Rogier, J.A.A., 'Bijdragen tot de geschiedenis van Schieland', $B B H 42$ (1926) 282-308; $\mathrm{BBH}_{43}$ (1927) 103-12I.

Rogier, L.J., 'De cultus van Sint Willibrord bij de apostolische vicarissen der Hollandse Zending in de zeventiende eeuw', Historisch Tijdschrift 18 (1939) 246-274.

Rogier, L.J., Geschiedenis van het katholicisme in Noord-Nederland in de I6e en de I7e eeuw [1946] (3 dln.; Amsterdam 1947²).

Rogier, L.J., 'Over de beoefening van de geschiedenis van de katholieke kerk in Nederland sedert omstreeks I870', $A G K K N$ I (I959) I-25.

Roldanus, C.W., Zeventiende-eeuwse geestesbloei [1938](Utrecht/Antwerpen $196 \mathrm{I}^{2}$ ).

Rooijakkers. G. en Th. van der Zee (ed.), Religieuze volkscultuur. De spanning tussen de voorgeschreven orde en de geleefde praktijk (Nijmegen 1986).

Rooijakkers. G. en Th. van der Zee, 'Ten geleide. Van volksgeloof naar religieuze volkscultuur', in: idem (ed.), Religieuze volkscultuur, 7-1 I.

Rooijakkers. G., 'Opereren op het snijpunt van culturen: middelaars en media in ZuidNederland', in: Te Boekhorst, Burke en Frijhoff (ed.), Cultuur en maatschappij, 245-283. 
Rooijakkers, G., 'De brede en de smalle weg. Vermaak en zaligheid in Noord-Brabant: een problematisch duo', in: J.A.F.M. van Oudheusden e.a. (ed.), Ziel en zaligheid in Noord-Brabant. Vijfde verzameling bijdragen van de Vereniging voor de Nederlandse Kerkgeschiedenis (Delft 1993) 18-39.

Rooijakkers, G., Rituele repertoires. Volkscultuur in oostelijk Noord-Brabant 1559-1853 (Nijmegen 1994).

Roper, L., The holy household. Religion, morals and order in reformation Augsburg (Oxford 1989).

Roper, L., "Wille" und "Ehre": Sexualität, Sprache und Macht in Augsburger Kriminalprozessen', in: Wunder en Vanja (ed.), Wandel der Geschlechterbeziehungen, 180-197.

Rosen, L., 'The negotiation of reality: male-female relations in Sefrou, Morocco', in: L. Beck en N. Keddie (ed.), Women in the muslim world (Cambridge (Mass.)/Londen 1978) $56 \mathrm{I}-584$.

Rosen, L., Bargaining for reality. The construction of social relations in a muslim community (Chicago/Londen I984).

Rosier O.Carm., I., Biografisch en bibliografisch overzicht van de vroomheid in de Nederlandse Carmel van 1235 tot het midden der achttiende eeuw (Tielt 1950).

Rotsaert, K., Tussen Eva en Maria. De vrouw volgens de predikanten van de 17de en I8de eeuw (Aartrijke 1992).

Rowlands, M.B., 'Recusant women I560-1640', in: Prior (ed.), Women in English society, 149-180.

Rubin, G.,'De handel in vrouwen', Socialities-Feministiese Teksten 4 (1980) 196-252.

Ruether, R. Radford, 'Misogynism and virginal feminism in the Fathers of the Church', in: idem (ed.), Religion and sexism: images of women in the jewish and christian traditions (New York 1974) 150-183.

Sasse van Ysselt, A. van, 'Wie viel oudtijds onder de benaming "klopje"', Taxandria 29 (1922) 138-142.

Sasse van Ysselt, A.F.O. van, De voorname huizen en gebouwen van 's-Hertogenbosch, alsmede hun eigenaars of bervoners in vroeger eeuwen (3 dln.; 's-Hertogenbosch 1910).

Schama, S., The embarrassment of richess. An interpretation of Dutch culture in the Golden Age [1987] (z.p. $1988^{2}$ ).

Scheijndel O.F.M., R. en A. van Hesse O.F.M., De parochie Woerden 1566-1928 (2.p. 1930).

Schillebeeclox, H., 'Priesterschap', in: ThW III, 3960-4003.

Schöffer, I., recensie van E. Schulte van Kessel, Geest en vlees in godsdienst en wezenschap. Vijf opstellen over gezagsconflicten in de I7de eeuw, BMGN 98 (1983) 232-233.

E. Showalter, 'Florence Nightingale's feminist complaint: women, religion, and suggestions for thought', Signs. Fournal of women in culture and society 6 (I981) 395-4I 2.

Schulte van Kessel, E., 'Le vergini devote nella Missione Olandese al tempo di Neercassel', in: Actes du Colloque sur le Yansénisme (Rome 1973) (Leuven 1977) 187-203.

Schulte van Kessel, E., Geest en vlees in godsdienst en wetenschap. Opstellen over gezagsconflicten in de zeventiende eeurv ('s-Gravenhage 1980).

Schulte van Kessel, E., 'Vis noch vlees. Geestelijke maagden in de Gouden Eeuw', in: J. Blok e.a. (ed.), Tweede Jaarboek voor vrouwengeschiedenis (Nijmegen 198I) 167-192.

Schulte van Kessel, E., 'Gender and spirit, pietas et contemptus mundi', in: idem (ed.), Women and men in spiritual culture. XIV-XVII Centuries ('s-Gravenhage 1986) 47-68. 
Schulte van Kessel, E., 'Maagden en moeders tussen hemel en aarde: vrouwen in het vroegmoderne christendom', in: Farge en Davis (ed.), Geschiedenis van de vrouw, 123-156.

Schutte, A. Jacobson, 'Inquisition and female autobiography: the case of Cecilia Ferrazzi', in: Monson (ed.), The crannied wall, I05-118.

Schutte, A. Jacobson, 'Per speculum in enigmate: failed saints, artists, and self-construction of the female body in early modem Italy', in: Matter en Coakley (ed.), Creative women, 185-200.

Schwegman, M., 'Vrouwengeschiedenis kritisch bekeken', BMGN 107 (1992) 500-507.

Scott, J. Wallach, Gender and the politics of history (New York I988).

Scott, J. Wallach, 'Women's history' [1983], in: idem, Gender and the politics of history, 1527.

Scott, J. Wallach, 'Gender: a useful category of historical analysis' [1986], in: idem, Gender and the politics of history, 28-50.

Scott, J. Wallach, 'Deconstructie van gelijkheid-versus-verschil. De bruikbaarheid van de post-structuralistische theorie voor het ferninisme' [r988], in: F. de Haan e.a. (ed.), Het raadsel vrouwengeschiedenis. Tiende jaarboek voor vrouwengeschiedenis (Nijmegen 1989) 96II 2

Scott, J. Wallach, 'The evidence of experience', Critical Inquiry 17 (199I) 773-797.

Second de Turin O.F.M. Cap., 'L'Emprise de l'idéal monastique sur le spiritualité des laïcs au XVIIe siècle', Revue des Sciences Religieuses 40 (I966) 209-239 en 353-383.

Sleegers, F., 'Maagdelijkheid in de beleving van twintig vrouwelijke religieuzen', in: $\mathbf{C}$. Halkes, V. Poels en D. de Beijer (ed.), Boeiende beelden. Feministische en christelijke visies op de mens als vrourv en man (Nijmegen/Baam 1992) 97-I I8.

Sloots O.F.M., P.C., 'De minderbroeders te Leiden', in: Bijdragen tot de geschiedenis van de paters Minderbroeders 3 (1947) 465-68o.

Smit, F., Het hofje van Buytenwech te Gouda, in de jaren 1684-1713. Bijdrage tot de katholieke armenzorg in de I7e en I8e eeuw (Amersfoort 1983)(Publicatieserie Stichting Oud-Katholiek Seminarie I2).

Smit, F., 'Klopjes en klopbroeders binnen de Clerezie' [1980], in: idem, Batavia Sacra (Amersfoort 1992)(Publicatieserie Stichting Oud-Katholiek Seminarie 24) 39-62.

Smit, F. en J. Jacobs, Van den Hogenheuvel gekomen. Bijdrage tot de geschiedenis van de priesteropleiding in de kerk van Utrecht 1683-1723 (Nijmegen 1994).

Smith, S., A poetics of women's autobiography. Marginality and the fictions of self-representation (Bloomington/Indianapolis 1987 ).

Spiertz, F.X., De katholieke liturgie in de Noordelijke Nederlanden in de zeventiende en achttiende eeuw (2 dln.; Nijmegen 1992).

Spiert, M.G., Ambtelijk onbegrip. Kanttekeningen bij de breuk Utrecht-Rome (Nijmegen 1972).

Spiertz, M.G., L'Église Catholique des Provinces-Unies et le Saint-Siège pendant la deuxième moitié du XVIIe siècle (Leuven 1975).

Spiertz, M.G., 'Het aandeel van de katholieken in de Friese bevolking tussen I663 en 1796', $A G K K N$ I9 (1977) 147-I69.

Spiertz, M.G., 'De ontwikkelingsgang van de katholieke missie in Friesland 1609-1689', $A G K K N$ 2I (1979) 262-292.

Spiertz, M.G., 'Achtergronden van het Breve Memoriale, een geruchtmakend anti-jansenistisch geschrift', $A G K K N 26$ (1984) 180-207. 
Spiertz, M.G., 'Godsdienstig leven van de katholieken in de zeventiende eeuw', in: $A G N$ 8, 344-357.

Spiertz, M.G., 'Johannes van Neercassel, pasteur et polémiste', in: Van Bavel en Schrama (ed.), Fansénius et le fansénisme, 54-65.

Spiertz, M.G., 'Succes en falen van de katholieke reformatie', in: H.L.M. Defoer e.a., Ketters en papen onder Filips II. Het godsdienstig leven in de tweede helft van de IGe eeuw ('sGravenhage ig86) 58-74.

Spiertz, M.G., 'Pastorale praktijk in de Hollandse Zending. Jezuïeten in de Republiek der Zeven Provinciën (1592-1773)', in: Put en Wynants (ed.), De jezuieten in de Nederlanden, 87-99.

Spiertz, M.G., 'Jansenisme in en rond de Nederlanden I640-I690', Trajecta I (I992) I44167.

Spiertz, M.G., 'Anti-jansenisme en jansenisme in de Nederlanden in de achttiende en negentiende eeuw', Trajecta I (I992) 233-244.

Spiertz, M.G., 'Heumen, Joannes van', in: DHGE 24 (1993) 313-3I4.

Spiertz, M.G., 'De katholieke geestelijke leiders en de wereldlijke overheid in de Republiek der Zeven Provinciën', Trajecta 2 (1993) 3-20.

Stichtende leven en deugden van de waardige foanna van Randenraedt. Geestelijke dochter onder de Bestiering van het genootschap van fesus door eenen priester van hetzelfde genootschap (Doornik 1857).

Storme, H., Die trouwen wilt voorsichtelijck. Predikanten en moralisten over de voorbereiding op het huwelijk in de Vlaamse bisdommen (I7e-18e eeuw) (Leuven 1992).

Tans, J.A.G., 'Van maagden en engelen', in: Jaarboek Oud-Utrecht (198I) 263-275.

Teeuwen O.E.S.A., N., 'P. Fulgentius Stevins en de augustijnse klopjes in de Hollandse Missie', Anima Una. Mededelingenblad van de Belgische Augustijnenprovincie I (1954) 10-17.

Teeuwen O.E.S.A., N., 'Stevins, Fulgentius', in: Nationaal Biagrafisch Woordenboek 3 (Brussel 1968) 857-858.

Teresa van Avila, Innerlijke burcht [1577] (Gent 1982).

Theissing, E.E.A.J.M., Over klopjes en kwezels (Nijmegen/Utrecht 1935).

Therry, M., De religieuze beleving bij de leken in het I7de-eeuwse bisdom Brugge (I609-1706) (Brussel 1988).

Thijm S.J., J.C. Alberdingk, "Uit het “Cost Boeck” der zoogenaamde kloppenschool te Culemborg', $A A U 37$ (I9II) 326-343.

Thijs, A.K.L., 'Notities voor een studie van de Antwerpse I7de-eeuwse suffragia', De Gulden Passer (1983-1985) 561-593.

Thijs, A.K.L., Van geuzenstad tot katholiek bolwerk. Maatschappelijke betekenis van de kerk in contrareformatorisch Antwerpen (Turnhout 1990).

Thomas a Kempis, De navolging Christi, uit het Latijn vertaald door F. Erens (Amsterdam 1907).

Tomizza, F., Heavenly Supper: The story of Maria fanis, translated by A. Jacobson Schutte (Chicago I99I).

Troeyer, O.F.M., B. de, 'Frans Vervoort', in: idem, Bio-bibliographia Franciscana Neerlandica Saeculi XVI (2 dln.; Nieuwkoop 1969-1970) I, 21 I-230.

Troeyer O.F.M., B. de, Bio-bibliographia Franciscana Neerlandica ante saeculum XVI 3 dln.; Nieuwkoop 1974). 
Vanden Bosch, G., Hemel, hel en vagevuur. Preken over het hiernamaals in de Zuidelijke Nederlanden tijdens de I7de en I8de eeuw (Leuven 199I).

Vanden Bosch, G., 'Satan op de kansel. Preken over “den boosen vyant” in de Zuidelijke Nederlanden (zestiende-achttiende eeuw)', in: G. Rooijakkers, L. Dresen-Coenders en M. Geerdes (ed.), Duivelsbeelden. Een cultuurhistorische speurtocht door de Lage Landen (Baarn 1994) 310-328.

Vandenbroeck P. (ed.), Hooglied. De beeldwereld van religieuze vrouwen in de Zuidelijke Nederlanden, vanaf de 13de eeurw (Brussel 1994).

Vanderhaeghen, F., Bibliographie gantoise. Recherches sur la vie et les travaux des imprimeurs de Gand (1483-1850) (7 dln.; Gent 1858-1869).

Velthuysen, B.P., 'De invoering der Hervorming en de wederopleving van het katholicisme te Kampen', $A A U 25$ (1898) 134-206.

Ven, A.J. van de, 'De driehoek van St. Marie te Utrecht', in: Faarboekje van Oud-Utrecht (1955) 33-80.

Venner, G.H.A. (ed.), Roermond. Stad met een verleden. Negen hoofdstukken over Roermondse geschiedenis (Roermond 1985 ).

Venner, G.H.A, 'De schepenen, raadsverwanten en burgemeesters van Roermond sedert 1637', PSHAL 124 (1988) 145-200.

Venner, J.G.C., 'De stadsbranden in Roermond (1554-1665). Brand, overheidsmaatregelen en herstel', in: Venner (ed.), Roermond, r I6-r4I.

Vergote, A., 'Psychologische interpretatie van visioenen', in: R.E.V. Stuip en C. Vellekoop (ed.), Visioenen (Utrecht 1986) 226-239.

Vernet, F., 'Brigitte de Suède', in: DS I (1937) 1943-1958.

Verreyt, Ch.C.V. en W.J.F. Juten, 'Noord-Brabantsche schepenzegels', Taxandria 7 (I900) 254-262.

Verreyt, Ch.C.V., 'Leden der Lieve-Vrouwe-broederschap te 's-Hertogenbosch van I3I8I642', Taxandria I6 (1909) 53-59.

Verschueren O.F.M., Luc., 'De boeken eener geestelijke dochter', $O G E_{13}$ (r939) 185-209.

Viaene, A., 'Het stichtelijk vertaalwerk van Adriaan van Loo', Annales de la Société d'Émulation de Bruges 73 (1930) IOI-118.

Visser, J., Rovenius und seine Werke. Beitrag zur Geschichte der Nordniederländischen Frömmigkeit in der ersten Hälfte des 17. Jahrhunderts (Assen 1966).

Visser, J., 'De mogelijke invloed van de Moderne Devotie op de spiritualiteit van de Nederlandse seculiere clerus aan het begin van de zeventiende eeuw', in: P. Bange e.a. (ed.), De doorwerking van de Moderne Devotie. Windesheim 1387-1987 (Hilversum 1988) 209-216.

Voorvelt, C.P., De Amor Poenitens van foannes van Neercassel (1626-1686). Ontstaansgeschiedenis en lotgevallen van een verhandeling over de strenge biechtpraktijk (Zeist 1984).

Vovelle, M., 'Culturele tussenpersonen', in: idem, Mentaliteitsgeschiedenis. Essays over leefen beeldwereld (Nijmegen 1985) I 26-141.

Vregt, J.F., 'Over katechismussen in de Hollandse Missie in gebruik', $B B H 6$ (1878) 337368.

Vries, J. de en A. van der Woude, Nederland I500-1850. De eerste ronde van moderne economische groei (Amsterdam 1995).

Vroede, M. de, 'Kwezels' en 'zusters'. De geestelijke dochters in de Zuidelijke Nederlanden, I7de en r8de eeuw (Brussel 1994). 
Waardt, H. de en W. de Blécourt, 'Aantekeningen over de rol van het Gelderse Hof bij de procesvoering inzake toverij, 1543-1620', Bijdragen en Mededelingen betreffende de Geschiedenis van Gelre 80 (1989) 24-50.

Wamer, M., De enige onder de vrouwen. De Maagd Maria: mythe en cultus (Amsterdam 1990).

Weber, A., Teresa of Avila and the rhetoric of femininity (Princeton (N.J.) 1990).

Weber, A., 'Between ecstacy and exorcism: religious negotiation in sixteenth-century Spain',

The foumal of Medieval and Renaissance Studies 23,2 (1993) 221-234.

Weet uw weg ('s-Gravenhage 1933)(Sleutelbos-brochure I).

Weiler, A.G., 'Over de geestelijke praktijk van de Moderne Devotie', in: P. Bange e.a. (ed.), De doorwerking van de Moderne Devotie. Windesheim 1387-1987 (Hilversum 1988) 29-45.

Weiler, A.G., 'De betekenis van de Modeme Devotie voor de Europese cultuur', Trajecto I (1992) 33-48.

Wereld, H. van der, Geschiedenis van de Parochie Sint Bavo te Oud Ade (z.p. 1979).

Wiesner, M.E., Women and gender in early modern Europe (Cambridge 1993).

Wijnhoven O.Praem., G. H., 'Kerkgang', in: LWII, 13 I I-13I2.

Willaert, F., M.M. Kors en H. Vekeman, 'De betekenis van de Nederlandse en vooral de Brabantse mystiek voor de Europese spiritualiteit', Trajecta I (1992) 5-32.

Willeumier-Schalij, J.M., 'Maria van Houts gehoorzame ongehoorzaamheid', $O G E 66,1 / 2$ (1992) r24-I44.

Wingens, M., Over de grens. De bedevaart van katholieke Nederlanders in de zeventiende en achtiende eeuw (Nijmegen 1994).

Wiseman, S., 'Unsilent instruments and the devil's cushions: authority in seventeenthcentury women's prophetic discourse', in: I. Armstrong (ed.), New feminist discourses. Critical essays on theories and texts (Londen/New York 1992) 176-196.

Wittert van Hoogland, E.B.F.F., 'Geslacht De Witte uten Limminghe', De wapenheraut 6 (1902) 257-271.

Worp, J.A., Een onwaerdeerlycke vrouw. Brieven en verzen van en aan Maria Tesselschade [1918] (Utrecht 1976).

Woude, A.M. van der, 'Demografische ontwikkeling van de Noordelijke Nederlanden $1500-$ I800', in: $A G N$ 5, 102-168.

Wunder, H., 'Von der "frumkeit" zur "Frömmigkeit". Ein Beitrag zur Genese bürgerlicher Weiblichkeit (I5.-17. Jahrhundert)', in: U.A.J. Becher en J. Rüsen (ed.), Weiblichkeit in geschichtlicher Perspektive. Fallstudien und Reflexionen zu Grundproblemen der historischen Frauenforschung (Frankfurt a/M 1988) 174-188.

Wunder, H. en Ch. Vanja (ed.), Wandel der Geschlechterbeziehungen zu Beginn der Neuzeit (Frankfurt a/M 199I).

Zarri, G., 'Ursula and Catherine: the marriage of virgins in the sixteenth century', in: Matter en Coakley (ed.), Creative women, 236-278.

Ziegler, J., Sculpture of compassion. The pieta and the beguines in the Southem Low Countries, c. 1300-c. 1600 (Brussel/Rome 1992).

Zwijsen, C.J., 'Een jaar kapelaan te Helmond I773-1774' BB 2 (1918-1919) 79-1or. 


\section{Herkomst van de afbeeldingen}

I. Titelblad uit Willem Schoenius, De weg der Suyverheyt van d'Hollantsche Maegden (Antwerpen: voor Philippus van Eyck [Amsterdam] 1676). Bibliotheek van de Katholieke Universiteit Nijmegen.

2. Gravure door C. Philips / Jacobsz naar gewassen pentekening door H. Keun uit 1769. Museum Catharijneconvent, Utrecht (sign. BMH g810.02) / foto Ruben de Heer.

3. Speldekussen met Christusmonogram (IHS) en Mariamonogram (MAR), afkomstig van de maagden van De Hoek, Haarlem (1625-1650). Museum Catharijneconvent, Utrecht (sign. BMH t927).

4. Gravure van Salomon Saverij naar Adriaen van de Venne, 1655. Uit Alle de wercken van den heere facob Cats / [met een voorberigt van f.J. Schipper; met gedichten van foannes Arserius ... et al.J - Laatste druk, waar in het twee-en-tachtig jaarig leeven des dichters beneffens desselfs slaapeloose nachten, met printverbeeldingen fijn verrijkt: nooit voor deesen soo gedrukt (Amsterdam: Nicolaas ten Hoom [etc.] 1712). Bibliotheek van de Katholieke Universiteit Nijmegen.

5. Gravure van J.E. Grave, eind 18e eeuw, uit D. van Heel O.F.M. en B. Knipping O.F.M., Van schuilkerk tot zuilkerk. Geschiedenis van de Mozes en Aäronkerk te Amsterdam (Amsterdam 194I).

6. Titelblad uit Martinus de Roa S.J., Op-rechte Af-beeldinghe van den maeghdelijcken staet: betrocken op het leven van de Edele en godtvruchtige Sancia Carillo eerst beschreven in de Spaensche tale, Ende nu in het Neder-landtsch overgheset (Antwerpen: weduwe van Jan Cnobbaert 1639). Bibliotheek van de Katholieke Universiteit Nijmegen.

7. Titelblad uit Joannes Lindeborn, De Leeder facobs. De Maegden, die Godt met opzet van eeuwige Reinigheit in de Wereld dienen, toegepast (Antwerpen: Michiel Cnobbaert voor Joachim van Metelen [Amsterdam] 1670). Bibliotheek van de Katholieke Universiteit Nijmegen.

8. Bidprentje, perkament, vermoedelijk tweede helft $18 \mathrm{e}$ eeuw. Museum Catharijneconvent, Utrecht (sign. OKM dp9or8) / foto Ruben de Heer.

9. Bidprentje, waterverf op perkament met applicatie van kopergravure en textiel vermoedelijk I8e-eeuws. Breda's Museum (sign. ST 3500).

10. Gravure van Hieronymus Wierx, uit A. Gerardi S.J., Den Spiegel van Philotea, ende der Godtvruchtighen zielen (Antwerpen: weduwe van Jan Cnobbaert 1646). Bibliotheek van de Rijksuniversiteit Limburg.

I I. Bidprentje, inkt op perkament, ca. I 700. Museum Catharijneconvent, Utrecht (sign. OKM dproo42) / foto Ruben de Heer.

12. Frontispice in [Daniël Huysmans S.J.,], Leven ende deughden vande weerdighe Agnes van Heilsbagh gheestelycke dochter onder de bestieringhe der Societeyt Iesu (Antwerpen: Michiel Cnobbaert I691). Bibliotheek van de Katholieke Universiteit Nijmegen. 
13. Gravure van A. le Poutre; frontispice in [Daniël Huysmans S.J.,], Kort Begryp des levens ende der deughden van de weerdighe foanna van Randenraedt geestelycke dochter onder de Bestieringhe der Societeyt Iesu (Antwerpen: Augustinus Graet 1690). Bibliotheek van de Katholieke Universiteit Nijmegen.

I4. Gemeentearchief Roermond, Fotoverzameling nr. 170403.

15. Koninklijke Bibliotheek Albert I, Brussel, Afdeling Handschriften, inv.nr. 20422, gewetensrekeningen Agnes van Heilsbach, 86; ibidem, inv.nr. r9070, gewetensrekeningen Joanna van Randenraedt, i82vo.

16. Gravure van J. le Poutre; frontispice in Wercken vande H. Moeder Theresia van Jesus fondatersse vande Ongeschoende Carmeliten ende Carmelitersen, In Twee Deelen gescheyden. Over-gheset uyt het Spaens, Frans, ende Latyn, door den eerw. P. Servatius vanden $H$. Petrus Religieus van't selve Order, deel I (Gent: Michiel Maes I697). Bibliotheek van de Rijksuniversiteit Limburg.

17. Tekening van Herman Janssens (omstreeks 167I), ingekleurd. Gemeentearchief Roermond, Fotoverzameling nr. F 351-369.

I8. Aquarel, eind I8e eeuw, maker onbekend. Gemeentearchief Roermond, Topografische Verzameling nr. F 304 .

19. Gravure uit A. Gerardi S.J., Den Spiegel van Philotea, ende der Godtvruchtighen zielen (Antwerpen: weduwe van Jan Cnobbaert 1646). Bibliotheek van de Rijksuniversiteit Limburg.

20. Tekening, vermoedelijk I8e-eeuws, maker onbekend. Gemeentearchief Roermond, Fotoverzameling nr. I73II3

21. Gravure van Hieronymus Wierx, uit A. Gerardi S.J., Den Spiegel van Philotea, ende der Godturuchtighen zielen (Antwerpen: weduwe van Jan Cnobbaert I646). Bibliotheek van de Rijksuniversiteit Limburg. 


\section{Summary}

\section{Spiritual virgins}

Life between convent and the world in the Netherlands

in the seventeenth century

This study deals with the development of the religious identity of spiritual virgins, as well as with the significance of this specific way of life for the women concerned and the clergy. Spiritual virgins were unmarried or widowed Catholic women who devoted themselves to a sober, religious life in the world and applied themselves to all kinds of good works. In Dutch they were commonly referred to as 'kloppen' or 'klopjes'. Although they let themselves be guided in their existence by the evangelical counsels of poverty, obedience, and chastity, they were not bound by solemn vows nor subject to monastic seclusion as women religious were. The contemporary characterization 'middelen staet' (medial state), an equivalent for what is currently called a semi-religious or quasi-religious existence, aptly expresses the position of spiritual virgins between the laity on the one hand and the clergy and religious on the other hand. Canonically, their mode of existence was not recognized as a state in life; their contemporaries - clergy as wel as laity, protestants as well as catholics - were often in the dark as far as the actual status of spiritual virgins was concerned.

In the historiography of Dutch catholicism the origin of the way of life led by spiritual virgins, briefly described in Dutch as the 'kloppenstaat' (the state in life of 'kloppen'), is generally attributed to the Reformation. After 1581 Catholic worship was officially prohibited in the provinces of the Northern Netherlands. Churches and church property were appropriated and put to use for the new public church, the Dutch Reformed Church. Monasteries and convents were closed or threatened with extinction since no new novices were admitted. Within the boundaries of the Dutch Republic monastic life came to an end. Contemporary observers sometimes considered the way of life of spiritual virgins to be a substitute for those who desired a religious life but could no longer enter a convent. Some historians also subscribed to this explanation. Others held, however, that the religious lifestyle and the ecclesiastical commitment of spiritual virgins resulted from the pressure the clergy exerted upon them. Internally, the Church in the Dutch Republic suffered from a deficient infrastructure, lacking churches, a system of poor relief, and schools. Until about 1640 there had been a chronic shortage of priests trained in the spirit of the Counter Reformation. Instead of appointing new bishops to episcopal sees that had become vacant, the Holy See appointed a 'vicar apostolic', who was to supervise the provinces where 
Calvinism was dominant. In the absence of clerical structures the Church had become largely dependent on the laity. Dedicated core members, like many of the spiritual virgins, not only financially supported the Church and priests who carried out the ambulant mission, but they opened their houses to clandestine services, were engaged in sick and poor relief, and took confirmation classes.

The historians Eugenie Theissing and Elisja Schulte van Kessel have already questioned the one-sided correlation between the development of the 'kloppenstaat' and the Reformation. A chaste, pious life dedicated to spiritual care and (semi-)pastoral activities probably met the wishes of many a devout woman in the seventeenth century, even though such a more active religious lifestyle was not in keeping with the conception the Church held of the religious state for women. After all, the Council of Trent (1545-1563) had consolidated the notion that women religious needed to be bound by monastic vows and confined to convents. The causal connection between the Reformation and the origins of semireligious or quasi-religious modes of existence has been eroded even further by recent studies which have established that some women in predominantly Catholic regions preferred such a way of life to the contemplative convent life. Moreover, these studies indicate that self-conception or self-understanding serves as a fundamental category for the analysis of women who nominally were no religious, but who nevertheless considered themselves as such.

In the first chapter the theoretical framework, main sources, temporal and geographical demarcation of this study are brought forward. Following on a relatively new analytical approach in church history, the so-called "histoire religieuse', the inspiration of spiritual virgins and priests is chosen as a point of departure. It is argued that neither form nor status of the specific way of life led by spiritual virgins were fixed during the seventeenth century. Instead they were the subject of negotiation among clerics and 'kloppen'. For a clear understanding of the positions they held in these negotiations, the analytical category 'gender' is introduced. Gender refers to social and cultural constructions of masculinity and femininity. It is contended that during the early modern era gender functioned as a fundamental aspect of identity, on which social structures were largely founded. As such it is considered an essential variable for the analysis of the acceptation and adaptation of forms of culture, including religion. In order to trace the development and the meaning of the new, confessionally oriented identity of spiritual virgins, two types of sources have mainly been analysed: edifying books of conduct for spiritual virgins written by secular and regular priests on the one hand, and writings by two 'kloppen' on the other hand. The study focusses on those spiritual virgins who lived outside the few communities that existed, but instead lived with relatives, in small groups or independently. Although the study concentrates on the seventeenth century, events or developments are sometimes traced either to the end of the sixteenth century or the beginning of the eighteenth 
century. The geographic boundaries of the study are formed by the territory of the present Netherlands. According to seventeenth-century standards this included the Republic of the United Provinces, as well as parts of the current provinces of Zeeland, Noord-Brabant and Limburg that then belonged to the southern Dutch or Spanish Dutch dioceses Bruges, Gent, Antwerp, 's-Hertogenbosch, Roermond and the prince bishopric Liège.

The second chapter offers a survey of the number, housing, and activities of spiritual virgins. It is estimated that the majority of the approximately over five thousand Catholic women who led a religious life in the world, lived independent$l y$, in very small groups of like-minded women, or with relatives. The membership of brotherhoods or the worldly third order provided a suitable framework for their piety as well as for their works of charity. The organization of their existence as 'klop' also depended on their financial position and housing arrangements. Furthermore, their father confessor's opinions affected their way of life and charitable responsibilities. In spite of the change of status - from a common lay woman to a spiritual virgin and as such a bride of Christ - spiritual virgins could still rely upon existing social networks of family and friends. Thanks to this embedment in the local Catholic community, 'kloppen' could effectively act as intermediary between clergy and laity. Their material and immaterial contributions were of existential importance to the Catholic Church, which, due to the process of Calvinization, was at a disadvantage in the process of 'confessionalization'. Generous gifts and loans, as well as an unflagging zeal in good works ensured, to a certain extent, the emanation of the Church on a local level. Due to their particular attire, which usually consisted of simple, dark clothes with a white collar and a simple form of headgear, spiritual virgins had an unmistakably religious aura. In a way they served as living signposts in the missionary Church, in which different strategies of 'recatholization' among secular and regular clergy gradually took shape. Spiritual virgins needed a great deal of mental flexibility in order to hold their own in the midst of the internal tension from which the Dutch missionary Church suffered. Considering their informal religious position, they already had to shift skilfully between worldly and ecclesiastical circuits. Material and immaterial dependence on spiritual virgins brought about some ambivalence among secular and regular priests. For spiritual virgins occasionally demanded a say in ecclesiastical matters because of the fact that they were benefactresses or assistants in spiritual care. Existing hierarchical relations between laity, to which 'kloppen' belonged, and clergy were in danger of being disrupted or even inverted. This imminent inversion explains the ambivalent attitude of clerics towards spiritual virgins.

This ambivalence is poignantly reflected in the idealized images the clergy created of the 'kloppenstaat', which are analysed in the third chapter. Since there was no general rule for spiritual virgins, several pious books of conduct with a 
prescriptive character came into being. These books, which I refer to as 'kloppenboeken' (books for spiritual virgins), were written by clerics and may be regarded as a specific genre of devotional literature. They illustrate how the clergy defined the mode of living of spiritual virgins, depicted their identity and described desirable authority relations between these women and the priests who acted as their confessors and spiritual directors. In the debate on the question whether a religious existence outside a convent should be considered a state in life comparable to the religious state, basically all authors who wrote on the subject between 1570 and 1730 , agreed that spiritual virgins were not women religious. However, not only the regular priests, but also a number of secular priests among the authors emphasize that the lifestyle of 'kloppen' was as dignified as the ecclesiastically approved religious state and favoured the salvation they aspired to just as well. Their pleas for a spiritual life outside convent walls may be read as an explicitly formulated alternative for the religious state. The preference for 'spiritual' in characterizations of 'kloppen' and their way of life exemplifies how the authors attempted to create a new category in addition to the religious and the laity. Through their ingenious defence of the 'kloppenstaat' these authors questioned the primacy of the convent life as the only approved religious existence for women. Their arguments show that within the seventeenth-century Dutch Catholic Church different views were taken of the status of a holy life in the world without solemn vows or monastic seclusion.

An important objective on the part of the clerical authors was to regulate the day-to-day life of spiritual virgins. Clearly outlined instructions, inspired by monastic rules, structured the entire existence of the spiritual virgin and were meant to assure its religious character. The intended outcome of this regulation was twofold. On the one hand the authors wanted to discipline spiritual virgins, so that they would become shining examples for the Catholic community; on the other hand the state in life of spiritual virgins took on form and substance thanks to these rules and thus became identifiable for others. Through this system of plain clothing, modest behaviour, intense devotional practices, and works of charity women could make their inner virtuousness and the holy status of their life known to others. The evangelical counsels of poverty, obedience, and chastity were put into practice through a regime of piety. This not only expressed an order prescribed by the clergy, but offered a frame of action as well, from which spiritual virgins could derive their identity. Conceived as a complex of social, devotional and ritual acts, piety offered spiritual virgins an opportunity to express their faith in a way that was open to women. By observing the outlined regime of piety, unmarried women and widows could confirm the religious, honourable nature of their lifestyle, which was not embedded in canon law.

According to the authors of 'kloppenboeken', it was a God-given order that women were subordinate to men in church and society. To a certain extent the 
privileged state of virginity freed women from this inferior position. In theory spiritual virgins merely had to obey God and their heavenly Bridegroom, Christ. In practice this was translated as obedience to Their earthly deputy, a priest who acted as confessor and spiritual director. The hierarchical organization of the relations between the sexes did not necessarily impede the religious development of women. Some 'kloppenboeken', especially vitae of spiritual virgins, exemplify their bond with God, expressed for example in mystical trances, visions or dreams. As 'experts by experience' these women were granted a certain authority. The majority of their spiritual sisters, however, could attain an honourable and even influential position within their local community in a different way. By a public, recognizable display of piety they could propagate their religious conviction at home and in the Church, thereby contributing to the preservation and the dissemination of what they considered to be the true faith.

The following two chapters deal with the contribution of spiritual virgins themselves to the forming of the 'kloppenstaat', as well as with the way they perceived this mode of living. Writings by spiritual virgins are extremely scarce, as are writings by women in the early modem period in general. Agnes van Heilsbach (1597-I640) and Joanna van Randenraedt (1610-I684) left over four thousand pages of notes (autographs and contemporary copies). They lived in Roermond, a town just outside the territory of the Dutch Republic that - institutionally came under the Southern or Spanish Netherlands. Among the spiritual virgins under the guidance of the local Jesuits they rose to prominence, chiefly because of divine revelations transmitted by dreams, visions and voices. Reports of these extraordinary occurrences were noted down, among other things, in so-called accounts of conscience, intended for their father confessor. These sources illustrate the tension inherent to their ambition to serve God outside the convent; tension other spiritual virgins perhaps also had to deal with.

The fourth chapter explores how Van Heilsbach en Van Randenraedt negotiated their position, status, tasks, and authority by means of their accounts of conscience. Writing by order of their confessor granted them a limited means of expression, yet confronted them with various dilemmas as well. It is argued that form and content of their accounts can only be appreciated in the context of the confessorspiritual daughter relationship. Each had different interests, that sometimes converged. The confessor was expected to gain profound knowledge of the inner life of his penitents and to establish whether possible extraordinary experiences originated in God or the devil. In addition to this professional concern, several Jesuits who acted as confessors to Van Heilsbach and Van Randenraedt may have had a more personal interest, because through these exceptional penitents they perhaps gained a better insight into God's will, their own spiritual welfare or their own performance as priests. For their part both women benefitted from the 
supervision of the confessor through the accounts of conscience. They testify that he was able to help them accomplish their aspiration after a perfectly religious existence in the world. His support, in the form of instructions and control, meant an implicit acknowledgement of their informal, ecclesiastically unauthenticated state in life. Above all, they could employ their writings to negotiate, not merely the meaning of dreams or other exceptional occurrences that supported their informal authority, but also the regime of piety that would ensure the religious character of their existence and their identity as spiritual virgins.

It is argued that in describing their (religious) experiences Van Heilsbach and Van Randenraedt were restricted by the operative frame of reference they shared to a certain extent with their confessors. This referential framework was engendered: the parameters of self-awareness and self-presentation were partly determined by social and cultural constructions of femininity and masculinity. Although both women subscribed to dominant ideas of female inferiority in their accounts, they also tried to evade and even undermine these by setting themselves apart from the other members of their sex, Van Heilsbach as a manly maiden, and Van Randenraedt as a womanly bride. On the basis of a conflict over the veracity of the experiences described by Agnes van Heilsbach that arose a few years after her death, the power relations between spiritual virgins and their confessors are analysed from a gender perspective. Writing on order confronted these spiritual virgins with several mutually exclusive demands, which constitute a double bind. Silence and humility behooved them as women. They could in fact not write about the origin, meaning or veracity of their own religious experiences without breaking this gendered code of conduct or infringing upon the privilege of interpretation held by their theologically trained confessors and intended readers. Consciously or unconsciously Van Heilsbach and Van Randenraedt employed rhetorical strategies of concession and humility in order to maintain a certain balance between what their confessor wanted to know and what they themselves wished to disclose. Conceding to existing notions about the female sex actually offered an opportunity for claiming authority.

The opinions Van Heilsbach en Van Randenraedt held on the status of their way of life, as well as on the authority relations with their spiritual directors and other spiritual virgins, are discussed in the fifth chapter. Neither of them counted herself among the laity, as would have been appropriate according to church law; instead they regarded themselves as 'spiritual' persons. Before all they considered themselves daughters of the founder of the Order of Jesuits, Ignatius of Loyola, and consequently 'sisters' of their confessors. On this self-image, which may be defined as 'jesuitic', their claim for equality towards their spiritual directors is founded. Joanna van Randenraedt's accounts of conscience in particular testify to a certain insecurity, however, that emanated from the question whether the chosen religious life outside the convent would in fact result in the aspired salva- 
tion. Pastoral ambitions, which both women decidedly had, were partly satisfied by the informal function of 'spiritual mother', which put them in charge of the other virgins under the guidance of the Jesuits in Roermond. As spiritual mothers both Van Heilsbach and Van Randenraedt needed to bargain for their authority, since the distribution of power between themselves and the confessor on whose authority they acted, was by no means clear. Van Heilsbach made heavy demands on her spiritual daughters and occasionally used stringent, even unorthodox methods in their training. Van Randenraedt, on the other hand, had a less authoritarian style of leadership. Under her authority the Roermond virgins developed into a relatively close-knit group. Apart from the ambition to lead a chaste, religious life in the world, these women had in common their social backgrounds. Since they could hardly back out of their familial and social obligations, the combination of prayer and (charitable) activity entailed extra tension for these women.

Spiritual virgins such as Van Heilsbach and Van Randenraedt had a multiple identity with gender at its core, an identity which corresponds with the definition offered by the 'kloppenboeken'. As spiritual daughters they were subordinate to their father confessor. However, as spiritual mothers they presided over other virgins and felt authorized to talk to other members of the laity about their religious life and practice. And as brides of Christ they felt invigorated by His power, which they sometimes used against His earthly deputy. They were convinced that they were endowed with divine grace which granted them, as much as their confessors, the spiritual authority to lead others to God. Still, their longing for an active apostolate was not fully satisfied by the 'kloppenstaat', precisely because of their gender. Van Heilsbach's interpretation of some of her dreams in which she distributes food, which, according to her, represents the host, indicates that she strove for priestly dignity and privileges. Van Randenraedt, in fact, occasionally complained that had she been born a man, she might have become a priest and would have served God better than she now could as a woman. Both women partly tried to break away from the gender-specific restrictions imposed on their activities by (selfinflicted) physical suffering. It is argued that various dimensions may be distinguished in their yearning for suffering, which point to intricate connections between religion, identity and gender. Through suffering with their heavenly Bridegroom, both women confirmed their identity as His brides and experienced an actual union with Him, as they also did by means of the communion.

The impressions conveyed by the accounts of conscience of Agnes van Heilsbach and Joanna van Randenraedt are infinitely more complex than historiographical depictions of the life-style and identity of spiritual virgins have thus far intimated. Clearly - and in contrast to the regulations offered by the 'kloppenboeken' - the relationship between a spiritual father and his 'daughter' was marked by mutual 
dependence. Since there was no general rule, women themselves could have a say in designing their way of life as a spiritual virgin. Thanks to the relatively free disposal of their time, energy and financial means, they could carve out a religious career for themselves in the world. Their virtue, always a weak spot for unmarried or widowed women, was ensured by the religious character of their state in life. In the case of spiritual virgins, obedience to male authority was arranged and formalized differently than in matrimonial union. They were bound to obey the earthly deputy of God and their heavenly Bridegroom. Within this binding relationship, however, spiritual virgins were at a disadvantage. In local communities the position of religious women without any formal ecclesiastical approval depended heavily on the support from priests who acted as their spiritual directors. It was up to a spiritual virgin to round up the necessary clerical support in order to safeguard a certain measure of personal and material autonomy. The writings of the two Roermond virgins illustrate that self-determination was best warranted by submission, not to earthly authority, but to the supreme reign of God over their lives. In the daily association with their confessor, the combination of humility and obligingness proved to be an effective course of action.

Van Heilsbach and Van Randenraedt opted for a life as spiritual virgins because they were convinced that they could serve God and their fellow human beings better in the world than behind convent walls. Presumably, this motive was not exceptional among Dutch spiritual virgins. Naturally, some of the over five thousand 'kloppen' really longed for the convent life, whereas others were led by priests to chose this way of life. Some women, however, aspired on their own accord to a more active religious lifestyle than the Church approved of for the members of their sex. The changed status and appearance of the Catholic Church in the Netherlands in part enabled them to realize this and to contribute to the preservation and reform of their Church. In this respect, spiritual virgins found their likes elsewhere in Europe: e.g. the disciples of Mary Ward, the sisters of the Visitation of Annecy or the 'Filles de la Charité'; women who were all deeply affected by the ideals of reform of the Counter Reformation.

Unlike any other group within the seventeenth-century Catholic community spiritual virgins exemplify and personify the paradox of submission and personal development: whereas the doctrinal authority of the Catholic Church allotted them a position subordinate to men and treated them as minors, they themselves took their faith as a foundation for life fulfilment, identity, and activity. Religion served as motive and justification for doing what they actually were not allowed to do on the grounds of contemporary gendered restrictions. Through religion, women in the early modern era, deprived as they were of many possibilities for expression and development, were offered a language in which they could define and comprehend their place in the world. On the basis of the analysed accounts of conscience, as well as the 'kloppenboeken', it is contended that this language not merely pre- 
sented the jargon of endurance and obedience, that was already partially imposed by prevailing opinions about women. The devotional books for their part also incited their intended female readership to action and contained examples of what the energy of religiously inspired women could bring about with God and among their fellow humans. The writings of Van Heilsbach and Van Randenraedt indicate that some women were indeed susceptible to this kind of encouragement. 


\section{Personenregister}

(Deze lijst bevat de namen van personen uit de tekst van hoofdstuk I tot en met VI en bijlage III. Namen van auteurs zijn opgenomen voor zover zij in de tekst genoemd worden. Historische personen, die vermeld worden in voetnoten, zijn in dit register opgenomen onder vermelding van paginanummer met toevoeging $n t$ )

Adolfs, Clara 13

Aerts S.J., Norbertus II6

Agatha de la Croix I4Int

Agnes, heilige 158

Agolla O.E.S.A., Matthias 366

Alfons de Vadaterra $246 \mathrm{nt}$

Alvarez, Balthasar 142

Ambrosius 150, 161, 175, 244

Angela de Foligno 246

Angoumois, Philippe d' I58nt-159

Anna Theodora de la Croix Mongarde

O.Carm. 222nt

Antonius, heilige, 239nt

Aquaviva, Claudius 35, 318

Ariaens, Trijntje 139

Arias S.J., Franciscus 242

Arienbroeck, Maeijken $\mathbf{8 7}$

Aristoteles 168

Athanasius 175, 183, 239nt

Augustinus I13, 135, 137, 175, 196, 244nt, 257-258

Baptiste Varani 246

Bartholomeus, Maria 97

Basilius 154, 178nt, 244nt

Beckaff O.P., Petrus 81

Beeck, Margriet 28ont

Beecom, Joannes van 59

Beijers, Geertruid 84

Bellarminus S.J., Robert 136

Belle S.J., Philippus van $56 n t$

Benedictus van Nursia $178 n t$
Bennekom, Joannes van Ioont

Bernardus van Clairvaux 135nt, I36-137, 244nt, 335

Bileam, profeet $18 \mathrm{Int}$

Birgitta van Zweden 246

Bisschop S.J., Valentinus 79, 90, 132, 135139, 143, I45, 146nt, I5I-I52, I56, 166, 170, 186, 188, 193-195, 196nt, 197-198, $200,220,240-243,267,282,338,36$ I

Blaes, Jacobus 30, 31nt

Bloemert, Augustinus Alstenius 59

Boede, Maria I3

Bollandus S.J., Joannes 365

Bonifatius VIII 26nt

Borgia, Franciscus van 66

Bosch O.C.M., Albertus van den 132, I5I, I55nt, 362

Bosman S.J., Theodorus 229nt

Botter, Everard 213-214

Botter, Matthias 214

Botters, Ida (geb. Van Mierlo), weduwe van Everard Botter 213-215, 241, 267, 274, 296, 303, 308-310, 316, 328

Bouchout O.P., Alanus 36I-362

Bourignon, Antoinette 247, 249, 253nt, 295

Braak, Hendrick van de(n) $76 n t$

Braak, Maria Catharina van de 76

Braau, Nicolaas $137 n t$

Brakman, Petrus 83

Breekevelt S.J., Franciscus 98

Breevliet, Claertje Pieters 85-86

Breevliet, Pieter 85nt 
Brekelmans, Joanna 67

Brienen, Abraham van 61, 125, 146, 171

Broeck, Catharina van den I4Ont, I4Int, 222, 236, 299, 310, 313

Broedersen, Nicolaas 83

Bruggen, Martine van 252nt

Brugman O.F.M., Jan 36Int, 364

Bruyn, Hendrick de 130

Buggenum, Maria 282nt

Buijs, Godefrida 143, 228

Burch, Francisus van der 34

Busenbaum S.J., Herman 145, I46nt

Bynum, Caroline Walker 254

Calvijn, Johannes 100, 150

Campen, Ancilla van 182

Carillo, Sancia 131, 139, 140, 142-143, I49, 172, 197-199, 365

Carlini, Benedetta 260nt

Cassianus $178 n t$

Castro, Jacobus a 211 , 319

Catharina van Siena 137, 253 $\mathrm{nt}$

Cathuis S.J., Amoldus 219nt-220

Cats, Jacob (priester te Utrecht) 56

Cats, Jacob (raadpensionaris) IOI

Cats, Boudewijn 84

Caussin S.J., Nicolas 151, 152, 156-158, I79, 362

Cecilia, heilige 138

Cesarius, Maria $76 n t$

Chantal, Joanna van 29, 227nt

Chigi, Fabio I7I

Christina, heilige 142

Cicero 244nt

Claessens, Aeltien $93^{n t}$

Claessens, Catharina Teresia $282 n t$

Claessens, Griettien $93 n t$

Clara van Assisi 17, 248

Clemens, Theo 129

Clerc, Alix le 255, 284-285

Clerck S.J., Livinus 143, 221, 233, 259, 261, 263-264, 292, 300-301, 328

Clerikus S.J., Walter 219-220, 296, 301

Cliffius O.F.M., Franciscus 92nt

Cloots, Geertruijd Maria 282nt
Cloppenborch, Joanna 83

Cnobbaert, Michiel 130

Cock, Theodorus de III

Codde, Petrus 53, III, II4-I15, II7

Codt S.J., Jacobus de I52nt

Collaert, Adriaan 248nt

Conrad, Anne 28, $4^{\circ}$

Cools, Reginald 225

Courten S.J., Adrianus 82-83

Craenhals, Maria 84-85

'Cremers Wyfken' 252nt

Cuykius, Hendrikus 211

Cyprianus 154, 175, 244nt

Dael, Elisabeth van 216

Dalenoort, Willem van I16, I54nt

Dammes, Merritge 64-65

Davia, Giovanni Antonio 114-115

Davis, Natalie Zemon 250

Demetrias, heilige 158

Derks, Marjet 37

Deventer, Maria van 112

Dienbergh, juffrouw 308nt

Dierout, Agatha 6I

Dingnum, Lucia I5

Dirks (Dirix), Ida 280nt

Dirks, Jannetje 139

Donckers, Adriana Elisabeth 90

Doppegieter, Cornelis $143^{n t}$

Dotecum, juffrouw Van 83

Dresen, Grietje 332-333

Dunghen, Joannes Baptist van 226nt

Dunghen, Rutger Jozef van 226

Ebbius, Henricus 112

Eck, Maria van 83, 112

Eeckhout O.E.S.A., Joannes Uuten 13, 69, 149

Elsbeth von Oyen $327^{n t}$

Elshout, Anna Woltera van 217nt

Elshout, Catharina van (geb. Maes) 216, $217^{n t}, 308$

Elshout, Gilles van 216, 217nt

Escobar, Marina de $227 \mathrm{nt}$

Essche, Nicolaas van 365 
Fell, Margaret Iog

Fierlinx O.F.M., Adrianus 73

Filips II 216

Foppens, Willem 56, I16

Fourier, Pierre 255

Fox, George 109

Franciscus van Sales 29, 33, 86, 124, 135nt, $136,155,180,227 n t, 238,362$

Franciscus Xaverius 170, 329

Francken, Sebastiaen 81

Frans, Jannetje $\mathbf{8 4}$

Frederik Hendrik 224

Freriks, Giertgen I36

Fulgentius I6o

Gabriël a S. Joanne Baptista O.Carm. 362

Gael, Hugo 182

Galle, Comelis $248 n t$

Galluzzi, Maria Domitilla 228nt, 247-248

Ganda, Eligius I4I

Geertruid van Helfta 139, I4I

Geffen, Anna van 8I

Gerardi (Gheeraerdts) S.J., Egidius 163nt, I78, I84, I94, 239, 362

Gerrets, Dieuwer 58

Gerrets, Machtelt 58

Gestel, Catharina van 215-216, $217 n t, 223$, $227,236,261,291,296,304,308,310-$ 312, 323

Gestel, Pieter van $217 n t$

Gijsje de Clop 96

Girard de Vilthierry, Jean I62nt, 197, 363

Godefridus (priester te Utrecht) 6I

Goetbloets, Josinne 139

Graaf, J.J., 20

Graft, Henricus van der 6I, I45

Gramay, Ido 2 I I

Grave, Johan van 56

Gregorius XIII 26nt

Grimminck, Karel-Lodewijk I8ont

Groeninghen, Rudolf Franciscus van 95

Gryspere, Willem de 63nt

Gryspere, Charles de 63nt

Hadewych I4I
Haegen, Cathrien van der 3II

Haelen, Maria Catharina van 282nt

Hagen O.P., Servatius van der 112

Hartman, Maria 13

Hasselholt, Everard van $224 n t$

Hazart S.J., Comelius 130-131, 136, 146nt,

$149-155,158,160,363$

Heeren, Jacobus Antonius 129nt-13̣o

Heijst, Annelies van 37

Heilsbach, Agnes van 46-48, 9r, I27, I4I, I 5 , I 76-I77, I79, I8I, I85-I86, I97-I98, 20r, 204;

hoofdstuk IV passim;

hoofdstuk V passim; 346-350

Hellin S.J., Andreas 220, 263, 272

Hennepin O.F.M., Louis 116

Herkinge, Volkert $\mathbf{8 2 - 8 3}$

Hermite S.J., François l' 105, 22I, 235nt, 26I-264, 266, 268, 272, 302, 320-32I

Herp, Hendrik 141

Heumen, Joannes van 14, 91, 125, 130, I 47 $n t$, I 50-I II, I63, I95, 282, 363

Heussen, Agatha van 22-23

Heussen, Wenina van 22-23

Hieronymus $138,143,145,244 n t$

Hiessche S.J., Balduinus 220

Hoeck S.J., F. van 2 I

Honsem O.F.M., Franciscus van $92 n t$

Hooch, Pieter de 5int

Hoogewerff, Bernard 9I

Horenbeek, Aldegonda van 222, 301, 313

Hout, Maria van 273nt

Hove S.J., Simon van den 214, 220, 232233, 235nt, 24I, 259, 26I, 263, 272, 275, 287-288, 296, 298, 301-303, 308-310, 328329,337

Hoynck, Adriana 135, 138, 154nt

Hulshoudt S.J., Melchior 142

Huygens, Constantijn I00

Huysingh, Catharina 81

Huysmans S.J., Daniël 132, 176, 179, I86, I94, 208-210, 21 Int, 212-214, 216, 218, 22I-222, 224, 226, 228-229, 23I-232, 234-235, 242, 245-247, 259, 265, 276-277, $317,325,327,331-332,334,363-364$ 
Idserd, Euphemia van den 80-8I

Ignatius van Loyola 30nt, II4, 137, I43, $239,242-243,285,288,338,346$

Ingen, Sybilla van 112

Ingoli, Francesco 3 Int

Innocentius IV 185

Isabella van Frankrijk 152, I56, $178-179$, 185, 201,364

Isbrants, Maritgen 136

Isenbaert S.J., Carolus 264

Jacobi S.J., Ludovicus 361nt, 364

Jacobus van Vitry 294

Jans, Aeltgen 73

Jans, Aletha $70 n t$

Jans, Anna 97

Jans, Maertje 84

Jansenius, Cornelius 113

Johannes Chrysostomus 244nt

Johannes van het Kruis $317 n t$

Jovinianus 150

Juan de Avila 365nt

Juana Inès de la Cruz 249

Jutte Costersdochter 105

Kalckhoven, Christina 106

Kemp, Willibrord 59-60, 87, 133, 364

Kerckhoven, Anna van 215, 237, 309-310

Kernkamp, G.W. I9

Kessenich, Johan Walraven van $224 \mathrm{nt}$

Kessenich, Margaretha van 221-222, 224nt

Kistemaeker O.F.M., Josephus 56

Kloek, Els 40

Klops, juffrouw 313

Klut, Catharina van 71

Kool, Cornelis Dircksz 85nt

Kool, Hendrickje (Hendrina) $85-86$, r30

Lacqueur, Thomas 40

Lambrechts S.J., Jacobus 82

Lambroek, Gervasia Grouwers van 2I6nt

Laure, Anthonetta Adriaanse de $77 n t$

Laure, Jan Adriaanse de $77^{n t}$

Laure, Jan Casparsse de $77^{n t}$

Laurentius S.J., Petrus I06, II
Lely, Juliana van der 73, 77

Lent O.F.M., Godefridus van 56

Leroy, Guillaume 132, 160nt, I76-177,361nt

Lessius S.J., Leonardus 30, 113, 146, 152nt, I55nt, 165nt, 242, 26I

Lichthert, Comelis Arents 58, 95

Lidwina van Schiedam 137, 185, 194, 198, 201, $361 \mathrm{nt}, 364$

Lindanus, Wilhelmus $2 \mathrm{II}$

Lindeborn, Joannes 56, 61, 65-66, I14-115, 125, I30, 135, 138, I45-149, I 52, I54-155, 158-159, 164, 171, 178, 180-181, 184nt, 192I93, I94nt, I95-I97, 200nt, 282, 364-365

Linden O.E.S.A., Hyacinthus van der II2

Lodewijckx O.F.M., Mathias 68

Lodewijk IX van Frankrijk 152

Lodewijk XIII van Frankrijk 283nt, 362

Lodewijk XIV van Frankrijk 224

Loo, Adriaan van 363

Loon, Anna van (uit Amsterdam) 88

Loon, Anna van (ujt Delft) $\mathbf{8 3 - 8 4}$

Loon, Jacob van 72

Loon, Margareta van 83

Loyens, Maria (geb. Van Loon) 72

Loyens, Pieter 72

Lumnius, Joannes Fredericus 132, 162, $169,196,365$

Luther, Maarten 25, 150

Maes, Catharina, zie Elshout, Catharina van

Maes, Esther 216nt

Maes, Thomas $217^{n t}$

Makeblijde S.J., Lodewijk 95nt, 97, 136, 139, 150

Maren, Johanna van 76

Maria Magdalena de Pàzzi 246

Maria van Oignies 294

Marquemont, Denis-Simon de 29

Masius, Gijsbertus 95nt, $217 n t$

Meeren, Carel (Charles) van der 216

Meeren, Livina van der $63,78,216,222-$ 223, 316, 322

Meeren, Wilhelma (Wilhelmina) van der $63 n t$

Meerendonk, weduwe 6 I 
Meerhout, Anna 97

Meerhouts S.J., Antonius 221nt, 336nt

Melchiors, Catharina $282 n t$

Meldert S.J., Ignatius van 92-94

Melick, Johan van 252nt

Mendoza, Luisa de Carvajal y 127, 132,

134-135, 139, 156, 167, 194, 197-198, 365

'Merricken in den Raef' 302

Merven O.P., Henricus van II2

Metelen, Joachim van 130, 137nt

Methodius 173

Metz, Zacharias de I7ont, I7I

Meyers, Hendrik 252nt

Milliert, Anna Margaretha 73

Minnen O.P., pater De 56

Molina S.J., Luis II3

Moock, Joanna van 143

Moor S.J., Cornelis de 221, 299, 302, 31031 I, 328-329

Morrenhoven, Margareta 70

Muller, Jan $85 n t$

Muller, Liesbeth 85nt

Muller, Maritge 85nt

Munnos (Muñoz), Ludovicus 132, 156, 365

Munster S.J., Ignatius van $229 n t$

Murens, Geertgen 252nt

Musius, Comelius $36 \mathrm{Int}$

Nassau-Siegen, Johan Frans Désiré van 224

Neercassel, Joannes van 62, 70-7I, II3-II4, 116, 134-135, 137-138, 145-147, 148 $\mathrm{nt}$, 153-154, 158, 170nt, 171, 173nt, I81 nt, 182-183, 192-193, 197, 202, 363

Nelisken, moeder van Wenckeler 252nt

Noortdijck, Dina 64, 106

Noortdijck, Joost 64

Oly, Catharina (Trijn) Jans 20, 56-58, 85, 136

Ool, Hendrickje van $282 n t$

Ommen, Geertruijt van 64

Oostendorp, Johanna van, weduwe Van Vilsteren 82-83

Ortigosa, Catharina di 215, 219, 289, 299, 309
Parmentier O.E.S.A., Petrus II2

Paula, heilige 145,158

Paulus, apostel 27, 108-109, 167, 317, 331

Pauwels (Paulessen), Agnes 304

Paz S.J., Jacobus Alvarez de 242-243

Peelen, Antonius 304nt

Peeters, Hendrick 252nt

Peter van Luxemburg 239nt

Petraea, Margareta 154

Petrus a Matre Dei 89-92, 108, 167, 169

Petrus Canisius 94

Petrus Olavi van Alvastra 246nt

Petrus Olavi van Skänningen 246nt

Pijl, Maria 77nt

Plaat, Antonius van der 84

Poirters S.J., Adriaan 131, I53, I6I, 174, I96, 221, 264-265, 292

Polman O.F.M., Pontianus 22

Portmans, Theodora 142-143

Post O.E.S.A., Ferdinand de 69

Potcamp, Gerard 8I

Pottere S.J., Roeland de 97

Puente S.J., Luis de la 136, 242

Pullen, Pelgrim 14I

Purmerent, Petrus 78, 110

Putkamer, Joannes 6r, 364nt-365

Putte, Joachim van den I28nt

Quesnel, Pasquier 17

Quispel, Grietje Jans 139, I4I

Randenraedt, Comelis van $63 n t, 78,140 n t$, $216,221,322,328 n t$

Randenraedt, Comelis Georgius van 223nt

Randenraedt, Everardus Ignatius van 22 I $n t$

Randenraedt, Ignatius Carolus van $223 n t$

Randenraedt, Joanna van $46-48,63,78,80$, 86, 91-92, 127, 130, 132, 136, 139-143, I5I, I64, I76-1 77, 179, I84-186, I94, I97199, 201, 204; hoofdstuk IV passim; hoofdstuk V passim; 346-350, 363

Randenraedt, Livina van, zie Meeren, Livina van der

Randenraedt, Maria Catharina van $22 \mathrm{I} n t$, 223 
Randenraedt, Philip Jacob van 223

Randenraedt, Wilhelmus van 223nt

Randenraedt, Willem van 63, I40-I4I, 216, 229nt

Randenraedt, Willem Hendrik van 78 , 140nt, 216, 222-223, 252

Rapley, Elizabeth 27, 40

Rau, juffrouw De 304

Raymond van Capua 253nt

Ring, Anna Theresa van 73

Roa S.J., Martinus de I49, 172, 365

Rode S.J., Joannes van 56

Rodriguez S.J., Alphonsus 137nt, 143, 242, 364

Roemers, Maria Tesselschade I00

Rogier, L.J. 21-22, 47, 67

Roldanus, Comelia W. 2 I

Rosweydus S.J., Heribertus I27, 131, 136139, 142-143, 173, 197-198, 365

Rovenius, Philippus 45, 49, 66-67, 75-79, 8Int, 84, 86-87, 94-95nt, I04, I06, III, 142, 144-146, 149, I53-I56, I58, 170nt, 17I, I8Int, 186, 202, 242-243, 275

Ruusbroec, Jan I4I

Ruyven, Jacobmina van Ioont

Santhorst, Hendrina van 6I-62

Santhorst, Hester van 6I-62

Santhorst, Machtelt van 61-62

Schaijk, Elizabeth van II4-II5

Schenckel S.J., Dominicus 334

Schep, Willem 85, 112

Schnabels, Ida 35

Schoenius, Willem 51, 75, 79, 86, I25-126, 130, 137, 154-155, 168, I80, 194, 366

Schoonhoven, Comelis Adamsz van (pseud. Bellacuria) 146-147, 171

Schulte van Kessel, Elisja 22-24, 44, 52-53

Schurman, Anna Maria van 249nt

Scott, Joan 41-42

Seneca 244nt

Seyses S.J., Robertus 84

Simpernel O.F.M., Gregorius 81

Smabers, Geertruijt Catharina $282 n t$

Smidt S.J., Franciscus de 124, 132, 158, 366
Stakenburg, Cornelis 56, II6

Stalpart van der Wiele, Jan Baptist 59

Staveren, Anna van 329

Steenbicker O.F.M., pater 56

Steur O.P., Amoldus 244, 366

Stevins O.E.S.A, Fulgentius 133, 137, 149, I51, 166, 245, 366

Stichter, Johannes I37nt

Stockheim zu Vollenhoven, Jan Willem van $224 n t$

Stockem, Jenneken van $282 n t$

Stoel, Anna Maria van der $77 n t$

Straeten S.J., Philippus van der 56nt

Strazeele S.J., Petrus 56nt

Strouven, Elisabeth 206, 294-295, 324nt

Sucquet S.J., Antonius 180nt, I8I $n t, 242$

Surmont, Claude Louis de, heer van Vlooswyck $\quad 117$

Swaen, Willem de 8r

Tanara, Sebastiano Antonio di 114

Tauler, Johannes I4I

Teresa van Avila 17, 137, 142-143, 243, 246-250, 262-263, 266-270, 276

Terlou, Adrianus 17-18, 364

Tertullianus 173

Thecla, heilige 158

Theissing, Eugenie $18-23,43,46,144,181$, I86-r 87

Theophila 138

Thijm, Catharina Alberdingk 3I Int

Thomas a Kempis 86, $136 n t$, 137, 243

Thomas van Aquino 135, 168

Thomas Philippe d'Alsace 117

Thomassen, Ida $\mathbf{2 8 2 n t}$

Tirza, Matthias 98

Tits, Elisabeth (Liesbeth) van 215, 238, 309

Tits, Geertruid (Geertien) van 215, 309

Torre, Jacobus de la 53nt-54, 55nt, r7ont, I7I

Torres, Anna de 149, 164, 173nt, 197-198, $324 n t$

Trijntje Cornelisdr. II7

Tyras O.F.M. , Jacob 73 
Urbanus VIII Ir3

Uwens S.J., Joannes Bapt. 2Ignt

Val de Dampierre, Maria Anna du 14-15, 132, 134, 157, 159-160, I64nt, I76-177, 193,198

Veen, Geertruyt van Ioont

Veen, Pieter van Ioont

Veen, Appolonia van der $77^{n t}$

Velst, Francisca van der II

Verbiest S.J., Franciscus II5

Vervoort O.F.M., Frans I39

Verwel, Sebastianus 8I

Vincentius a Paulo 32-33, I35nt

$V$ is, Adewina II2

Vis S.J., Herman II2

Vis, Maria II2

Vitelleschi S.J., Mutius 288, 337

Voeller, Jean-Herman 62,83

Voeller, Léonard $\mathbf{8 3}$

Voeller, Marie-Anne 62, 83, I I4, 134, 137, 182

Vos, Henricus 107

Vosmeer, Sasbout 17, 45nt, 65, 103-104, I05nt, I10, 170

Vosmeer, Tilman 170
Vries, Simon de 14, 283nt

Vroede, $M$. de 32-34

Waels, Margariet 282nt

Waldeck, Henrick Wolraet van, graaf van Culemborg 98

Walvis, Ignatius $\mathbf{8 2}$

Wannaer, Willem 8r

Ward, Mary 30-32, 34, 37, I 52nt, 254-255, 284-285, 349

Weber, Alison 262, 266, 268

Werimont, Lucia de 216, 222-223, 228, $234,236,238,290,299-300,310-311$, 313, 320-32 I, 329, 363

Werimont, Martinus de (sr.) 216

Werimont, Martinus de (jr.) 216nt, 290

Westerhout, Johanna 81-82

Weyden O.C.S., F. van de $132 n t, 36 \mathrm{I} n t$

Wij, Trijn Dircx 139

Wijbinga, Martinus 87

Wijns S.J., Jacob 219nt-220, 22I-222, $235 n t, 260-264,266,268,272,277,287$, 296, 301-302, 3II, 313, 337

Willemart O.E.S.A., Jacobus 69

Witzenburgh, Theodorus $8 \mathrm{I}$

Zuurhuys, J. 54 


\section{Over de auteur}

Marit Monteiro (1964) deed in 1982 eindexamen VWO aan de toenmalige rijksscholengemeenschap Hamaland te Winterswijk. Het studiejaar 1982-1983 bracht zij in het kader van een intercultureel uitwisselingsprogramma door in Mariemont (Ohio) in de Verenigde Staten. In 1983 begon zij met de studie geschiedenis aan de Katholieke Universiteit Nijmegen (KUN). Na de afronding hiervan in 1989 verzorgde zij als free-lance historica biografische en algemene lemmata op het gebied van vrouwengeschiedenis en ferninisme voor de negende editie van de Grote Winkler Prins. Van 1989 tot 1992 was zij coördinator en secretaris-penningmeester van de Stichting Vrouwengeschiedenis van de vroegmoderne tijd. In 1990 trad zij als assistent in opleiding in dienst van de KUN en was vier jaar lang werkzaam bij de vakgroep geschiedenis. Sinds 1995 is zij bestuurslid van de stichting 'Echo historisch onderzoek naar religie en sekse'.

$\mathrm{Zij}$ is co-auteur van het deel Vrouwengeschiedenis in de reeks Cahiers voor lokale en regionale geschiedenis. Daarnaast maakte zij deel uit van de redactie van enkele boeken, waaronder De dynamiek van religie en cultuur. Geschiedenis van het Nederlands katholicisme en Anna Maria van Schurman (1607-1678): een uitzonderlijk geleerde vrouw, waarvan in 1996 de Engelse vertaling is verschenen. 
STELLINGEN

behorend bij het proefschrift

\section{Geestelijke maagden}

Leven tussen klooster en wereld in Noord-Nederland

gedurende de zeventiende eeuw

van

MARIT MONTEIRO

I De hedendaagse omschrijving 'semi-religieus', waar de canonieke definitie van 'religieus' aan ten grondslag ligt, doet onvoldoende recht aan die geestelijke maagden in de vroegmoderne tijd die zich niet achter kloostermuren terug wilden trekken en voor wie actief apostolaat een wezenlijk bestanddeel vormde van hun bestaan en zelfverstaan dat eerder als geestelijk dan als religieus bestempeld moet worden.

II Historici die in de bestaanswijzen van religieus bewogen vrouwen zonder officieel erkende status in kerk of maatschappij in de vroegmoderne tijd een beweging zien, miskennen het vaak amorfe en a-institutionele karakter van deze leefwijzen en hebben bovendien geen oog voor het gegeven dat juist in dit karakter de aantrekkelijkheid school voor vrouwen, omdat zij de vormgeving van hun religieus ingekaderde existentie konden aanpassen aan persoonlijke sociale en materiële omstandigheden.

(Vgl. Caroline Walker Bynum, Holy feast and holy fast. The religious significance of food to medieval women (Berkeley/Los Angeles/Londen 1987, 24.)

III Hoewel in historisch onderzoek vooral het repressieve karakter van de biecht beklemtoond wordt, verdienen biechtvaders ook als ondersteunende instantie in vrouwenlevens aandacht.

IV 'Kloppenboeken' dienen niet enkel geanalyseerd te worden op hun stichtelijke strekking, maar ook op hun functie in het zeventiende-eeuwse debat over religieuze identiteit.

$\mathrm{V}$ De omgang met alsook de rol en de functie van stichtelijke lectuur in de levens van gelovende vrouwen dient voor de Lage Landen nader onderzocht te worden. 
VI Onderzoek naar de verwevenheid van religie en sekse bij identiteitsvorming en identiteitsopvattingen zal zich in de toekomst vooral op mannen als object van onderzoek moeten richten.

VII Het aloude onlosmakelijke verband tussen denken en schrijven lijdt onder het gebruik van moderne tekstverwerkingsapparatuur.

VIII Dat de gehistoriseerde dramaserie 'Tijd van leven', waarin de rode draad gevormd wordt door de lotgevallen van een Achterhoekse aannemersvrouw, door een recensent afgedaan is met de zinsnede 'het zeurt maar deur', illustreert behalve zeker 'Randstad-centrisme' van de dagbladjournalistiek ook treffend dat levens van vrouwen nog steeds geen bijster interessant onderwerp vormen in de ogen van (sommige) mannen.

IX Een wettelijke regeling van het recht op deeltijdarbeid zal weinig bijdragen tot een herverdeling van (zorg)arbeid tussen vrouwen en mannen, zolang werkgevers en werknemers loopbaanplanningen (impliciet) blijven baseren op werkweken van meer dan veertig uur.

$\mathrm{X}$ Het bekostigen van dure trainingen voor het middel- en hoger management binnen bedrijfsleven en (semi-)overheidsinstellingen beoogt niet zozeer in een eventueel gebrek aan kennis en vaardigheden in deze echelons te voorzien, maar kan veeleer worden opgevat als een poging om meer structurele problemen binnen een organisatie te verdoezelen.

XI Retorische strategieën van concessie en nederigheid, zoals die in de zeventiende eeuw met succes door vrouwen in het kerkelijk domein zijn beproefd, lijken aan het einde van de twintigste eeuw nog altijd onontbeerlijk voor vrouwen in het door mannen beheerde wetenschappclijk domein. 
Geestelijke maagden waren geen kloosterlingen, maar ook geen 'echte' leken. Zij leidden een religieus bestaan in de wereld en legden zich toe op , geloofsonderwijs, zieken- of armenzorg. Hun leefwijze werd door de katholieke kerk niet als religieuze staat erkend. Toch bepaalden deze zedig in zwart geklede vrouwen in belangrijke mate het aangezicht van de katholieke kerk in de zeventiende eeuw. Zij droegen bij aan de wederopbouw daarvan binnen de Republiek, waar de katholieke eredienst sinds 1581 van overheidswege was verboden. Mede dankzij hen konden priesters de zielzorg min of meer. clandestien voortzetten. Als intermediairs tussen clerus en leken vervulden geestelijke maagden bovendien een belangrijke rol in processen van confessionalisering.

Hoe er gedacht werd over de bestaanswijze van geestelijke maagden door geestelijken en de betrokken vrouwen zelf, wordt beschreven door Marit Monteiro. Uit stichtelijke werken die priesters voor geestelijke maagden schreven, destilleert zij de ideaalbeelden van de clerus ten aanzien van deze levenswijze. Deze idealen hingen nauw samen met de heersende opvattingen over vrouwelijkheid, vroomheid en de gezagsverhoudingen tussen de seksen. Aan de hand van egodocumenten van twee geestelijke maagden laat Monteiro zien hoe vrouwen zelf dergelijke denkbeelden deels beaamden, maar deels ook weerspraken, naar hun hand zetten en zo ruimte creëerden voor hun kerkelijk engagement.

Geestelijke maagden ontrafelt de verwevenheid van sekse, geloofsovertuiging en identiteit in de vroegmoderne tijd en vormt een belangrijke bijdrage aan de geschiedenis van de katholieke cultuur in Nederland. 